Writing in the Key of Life 


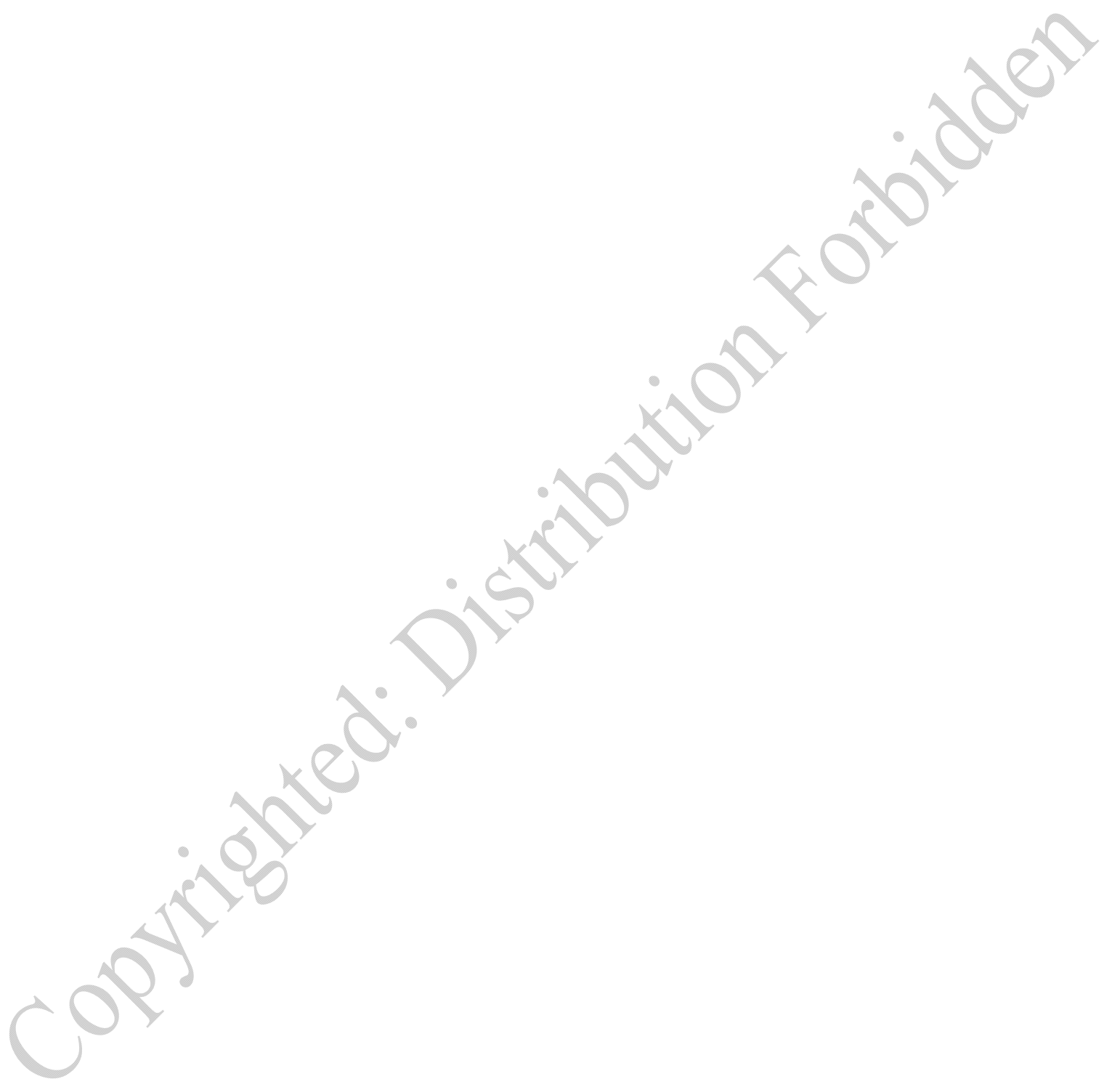




\section{Caryl Phillips \\ $*$}

Writing in the Key of Life

Edited by

Bénédicte Ledent \& Daria Tunca 


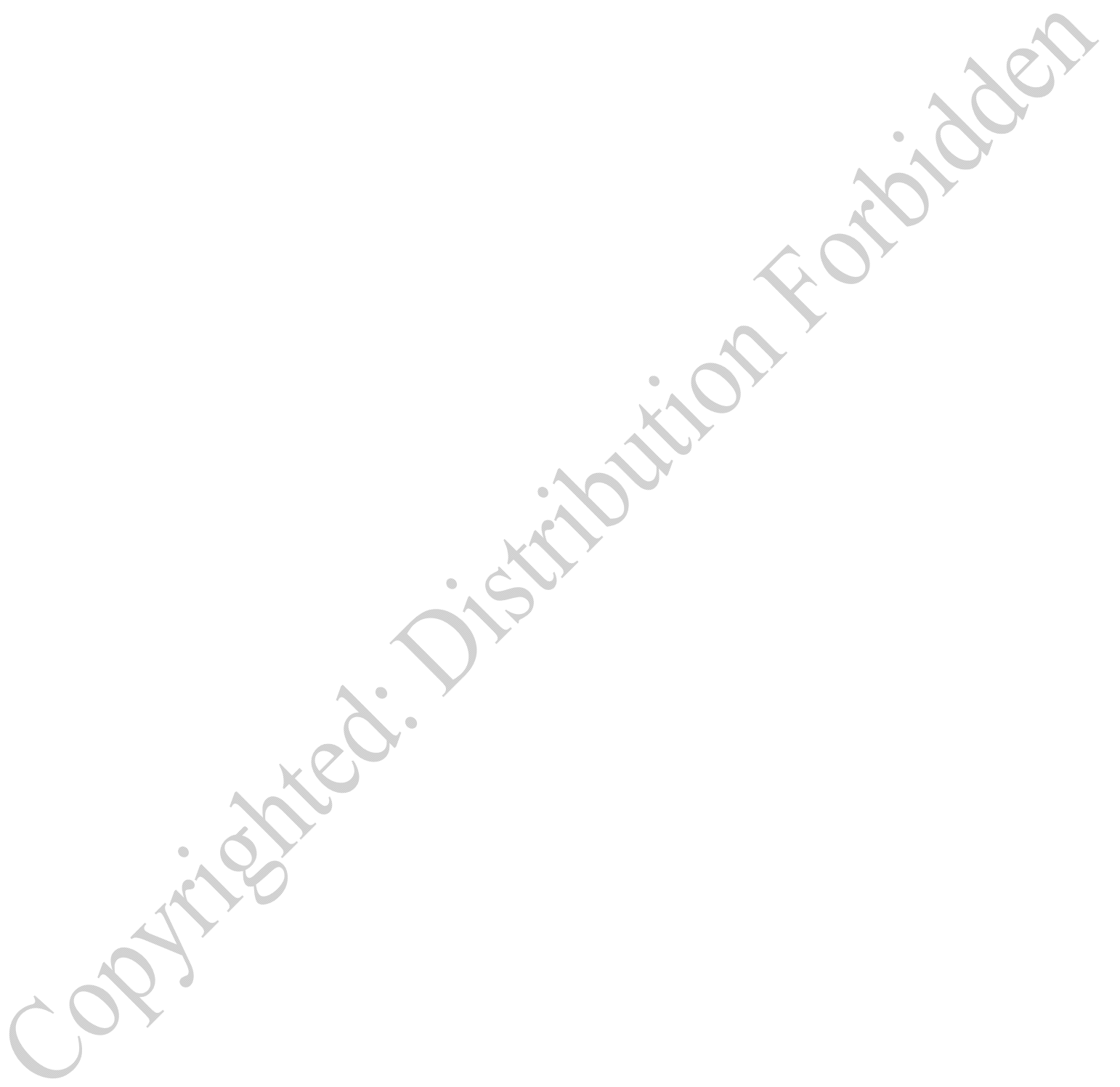




\section{Table of Contents}

Acknowledgements

Introduction

\section{CARYL Phillips: TWENTY-Five YeARS OF WRITING}

Oxford

Peter Marsden

Preamble

CARYL PHILLIPS

Colour Me English

CARYL PHillips

Caryl Phillips and the Question of

Political Identity:Wrestling with Prejudice

KIRPAL SINGH

II CRITICAL ESSAYS

\section{AUTOBIOGRAPHY, FACT, AND FICTION}

Conversations with Caryl Phillips:

Reflections upon an Intellectual Life

RENÉE SCHATTEMAN

Plural Selves: The Dispersion of the

Autobiographical Subject in the Essays of Caryl Phillips

LOUISE YELIN

"Look liberty in the face": Determinism and Free Will

in Caryl Phillips's Foreigners: Three English Lives

BÉNÉdicte LEDENT 
Hybrid Inventiveness: Caryl Phillips's Black Atlantic

Subjectivity - The European Tribe and The Atlantic Sound

Joan Miller Powell

CARYl PhILlips and the Other Writers

Vido, not Sir Vidia: Caryl

Phillips's Encounters with V.S. Naipaul

JOHN MCLEOD

A New World's Twilight: Ethics of the Caribbean Writer in Caryl Phillips's and Derek Walcott's Essays

MALIK FERDINAND

Caryl Phillips's "Heartland" and Conrad's Heart

of Darkness: Revisiting Fear - An Intertextual Approach

IMEN NAJAR

DIASPORAS

Linking Legacies of Loss: Traumatic Histories

and Cross-Cultural Empathy in Caryl Phillips's

Higher Ground and The Nature of Blood

STEF CRAPS

Bidirectional Revision: The Connection between

Past and Present in Caryl Phillips's Crossing the River

FAtim Boutros

"The cloud of ambivalence": Exploring Diasporan Identity in Caryl Phillips's The Atlantic Sound and A New World Order ABIGAIL WARD

Caryl Phillips's Seascapes of the Imaginary

WENDY KNEPPER

The Dis-ease of Multiple Identities: The Nature of

Diasporan Identity in Caryl Phillips's Strange Fruit

CHIKA UNIGWE

BRITAIN AND ITS 'OTHERS'

A New World Tribe in Caryl Phillips's A Distant Shore

Alessandra Di Maio 
Dorothy's Heart of Darkness: How

Europe Meets Africa in A Distant Shore

SANDRA COURTMAN

Negotiating Inclusion in Caryl Phillips's A Distant Shore

THOMAS BONNICI

Strange Encounters: Nationhood and the

Stranger in Caryl Phillips's A Distant Shore

Petra Tournay-Theodotou

The Civilized Pretence: Caryl

Phillips and $A$ Distant Shore

Cindy Gabrielle

\section{RACE AND MASKS}

Omnipresent and Everlasting Imperialism: Race and Gender

Oppression in Caryl Phillips's Cambridge and A Distant Shore

Lucie Gillet

The Dilemma of a Black Entertainer: A Contextualized

Reading of Caryl Phillips's Dancing in the Dark

TSUNEHIKO KATO

The Mask and the Unheimlich in Caryl

Phillips's Dancing in the Dark

ITALA VIVAN

Concentric and Centripetal Narratives of Race: Caryl

Phillips's Dancing in the Dark and Percival Everett's Erasure

DAvE GunNing

The Dynamic of Revelation and Concealment: In the Falling Snow and the Narrational Architecture of Blighted Existences

GORDON COLLIER

Notes on Contributors $\quad 407$

Index 


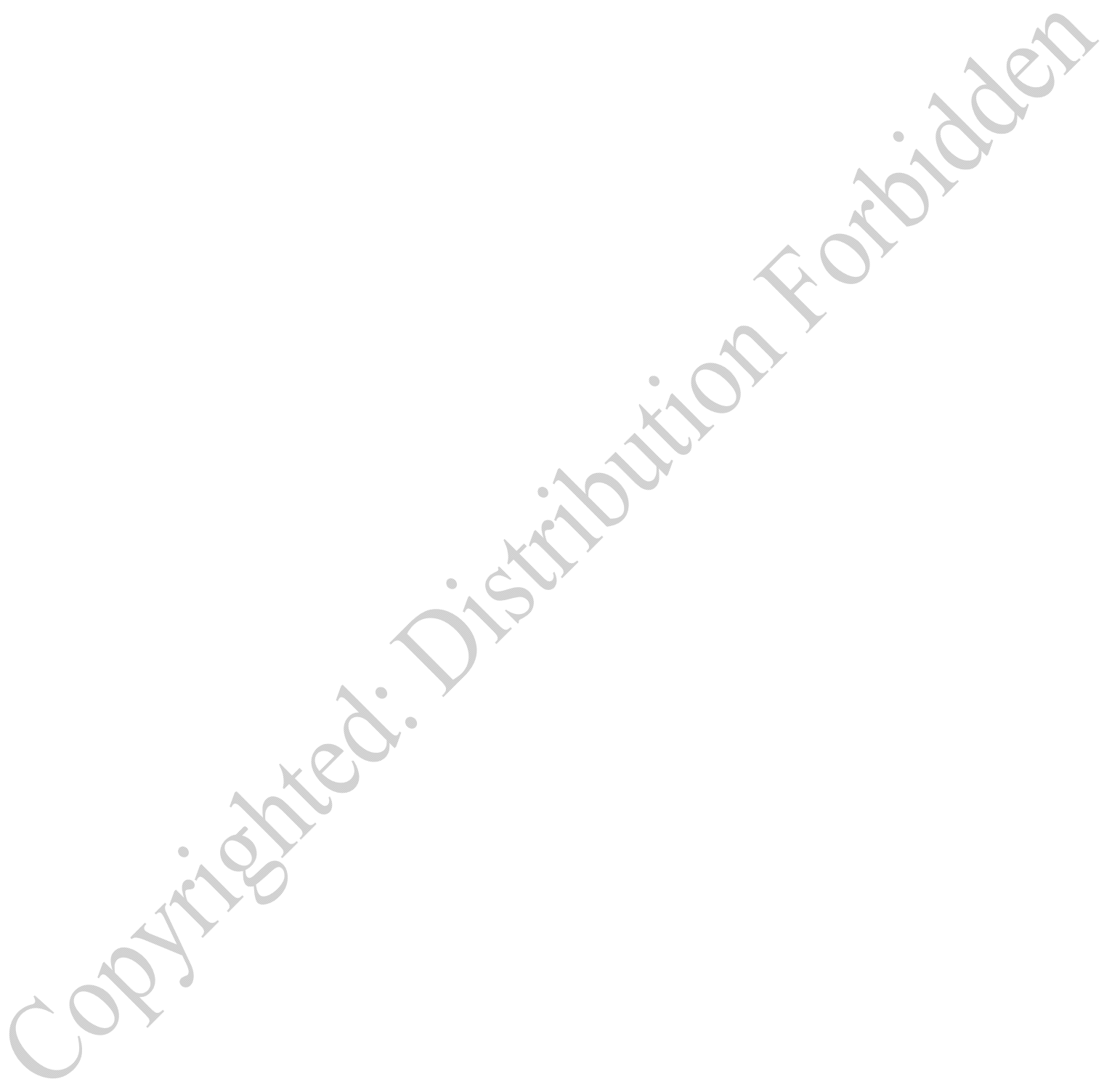




\section{Acknowledgements}

Our thanks for their generous financial support go to: the "Patrimoine" of the University of Liège, the Faculty of Philosophy and Letters of the University of Liège; and the "Fonds de la Recherche Scientifique - FNRS."

The following appear here in revised form:

Stef Craps, "Linking Legacies of Loss: Traumatic Histories and CrossCultural Empathy in Caryl Phillips's Higher Ground and The Nature of Blood," Studies in the Novel 40.1-2 (Spring-Summer 2008): 191-202.

Renée T. Schatteman, "Introduction" to Conversations with Caryl Phillips, ed. Renée T. Schatteman (Jackson: UP of Mississippi, 2009): ix-xviii. 


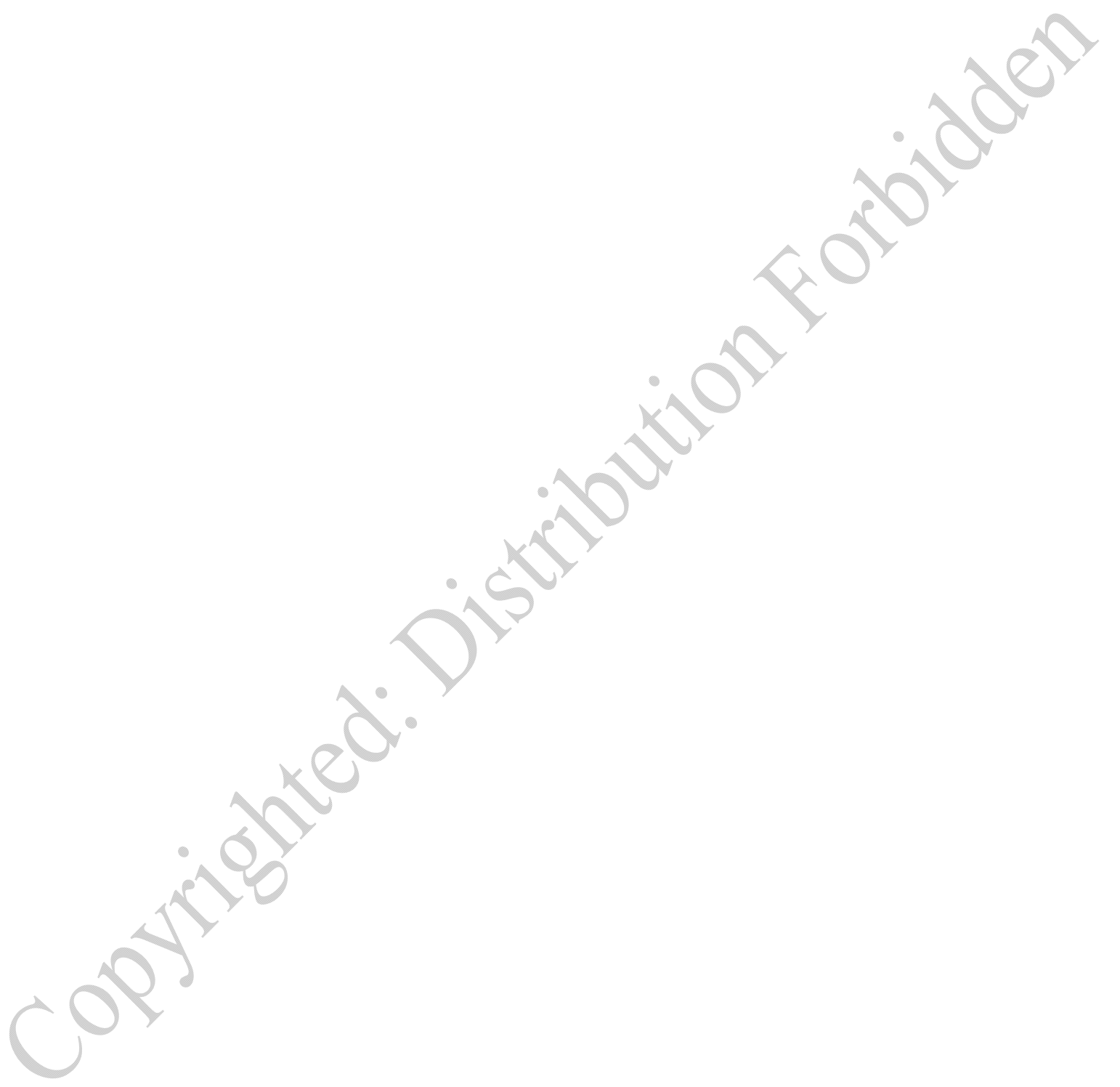




\section{Introduction}

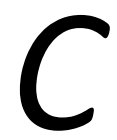

aryl PHILlips: Writing in the KEY OF LIFE began with a conference held on 1-2 December 2006 at the University of Liège in Belgium to celebrate the silver jubilee of Caryl Phillips's writing career.

The idea of an event on this author had been in the air for quite a while. Since the early 2000s, many were those who believed that the time had come to pay homage to a writer who, by virtue of his creative vigour and political depth, had become one of the major literary voices at the turn of the twenty-first century. The year 2006 seemed to provide the ideal opportunity to carry out this long-standing project, as it marked the twenty-fifth year of a remarkable literary journey which had begun in 1981 with the publication of Phillips's first play, Strange Fruit. The call for papers for "Caryl Phillips: 25 Years of Writing" met with an enthusiastic response, so that more than fifty participants from all over the world, either confirmed critics or younger scholars, gathered in Liège over two days to discuss Phillips's work, both formally and informally. They also had the chance to hear the writer deliver what appeared to the audience on that day to be one of his most beautiful texts, "Colour Me English," which is included in the present publication. ${ }^{1}$

Our aim in putting this book together is at least twofold. On the one hand, this volume is meant to commemorate the event held in Liège, not only for those who attended but also for those who were unable to be present. On the other, it also aims at providing wide-ranging, though not exhaustive, coverage of Phillips's multi-faceted work, testifying to its impressive scope, to the moving resonance of its themes, and to its formal inventiveness. The texts collected here, it is hoped, signal more than the sum of their parts: they also constitute a tribute to a versatile and prolific artist who in thirty years has published four stage plays, five works of non-fiction, ten novels, as well as innumerable scripts and articles on a wide variety of topics. Phillips is a writer

\footnotetext{
1 "Colour Me English" is the title essay in Caryl Phillips's eponymous collection (London: Harvill Secker, 2011).
} 
who has kept bringing newness to his work while remaining true to a vision of the world that combines profound emotional authenticity with sharp social awareness.

One gets an idea of the remarkable consistency of Phillips's work, but also of its development, if one briefly compares his first novel, The Final Passage, published in 1985, with his latest, In the Falling Snow, released in 2009. The former addresses West Indian migration to England in the 1950s through the experience of a young woman named Leila, while the latter focuses on contemporary England and the mid-life crisis of a Briton of Caribbean descent called Keith. Even if the books are set in different periods, they are thematically close. Like most other novels by Phillips, they engage with such topics as identity, exile, or loneliness and provide insight into what divides human beings, be it class, gender, or race. The novels also display a similar high degree of linguistic craftsmanship, a similar predilection for ambiguity, and similar care in their characterization and their examination of their protagonists' development, even if they apply their very own distinctive narrative strategies. Finally, both are also deeply fascinated with the past - what Phillips has called "the back story" - and how it shapes the present. As he explains, "To understand where you are now you have to understand the back story [...]. I've been playing with the idea of what constitutes the end and the beginning, how things keep coming back round, since my very first novel."

Clearly, The Final Passage and In the Falling Snow are part of an ongoing and subtle exploration of what makes us who we are, and how we came to be that way. What, then, separates the two books? One way of indicating this might be to recall Phillips's literary production between 1985 and 2009, and all the subject-matter that it covered over that time-span, whether slavery, the African and Jewish diasporas, or the black presence in Europe, to mention just a few. Quite significantly, in Phillips's latest novel, Keith's cultural and existential baggage seems much heavier and bulkier, and perhaps also less clearly labelled, than Leila's in The Final Passage. The family history of the young Caribbean woman who arrives in England with her husband Michael and her baby boy Calvin remains, until the end of the novel, much of a mystery to her; her identity is basically dual, shaped mainly by the Caribbean where she was born and spent much of her life and, to a lesser extent, by England, the disappointing 'mother country', where she has chosen to settle but which she might be about to leave at the end of the novel. Keith, by contrast, seems to

\footnotetext{
${ }^{2}$ Anita Sethi, "Home and Away," The Independent (22 May 2009), Arts and Books: 26.
} 
have a more complex, though also partly hidden, heritage. His composite genealogy, embodied to some extent in his own mixed-race son Laurie, includes England, the Caribbean, Europe, but also the African diaspora at large, a "black cultural heritage"3 which he indirectly explores by trying to write a book on black music. For all these differences, Phillips's characters in both novels fail to successfully communicate with others and they suffer from the same sense of forlornness. This is exemplified by comparable scenes where the characters are caught "in the falling snow,"4 an element symbolizing their displacement as well as the coldness, both real and metaphorical, that England represents. Through Leila and Keith, therefore, Phillips tackles the same universal themes, such as displacement and family relationships. Yet the increased complexity of Keith's background and experience is a measure of the way the writer's palette has expanded in the twenty-seven years that separates the two stories, and of the way he has become even more keenly aware of the convolutions of human life, which he expresses in each new book with increasing technical sophistication.

We hope that the title that we have chosen for this volume goes some way towards capturing the sense of "changing same" that can be regarded as one of the defining features of Phillips's oeuvre so far. "Writing in the key of life" encapsulates its comprehensiveness, the fact that it touches ceaselessly on major social issues and goes to the heart of the human condition, not just the postcolonial one. At the same time, as a reference to Stevie Wonder's 1976 masterpiece album Songs in the Key of Life, this title contains further allusions - which we will briefly explain at the risk of being accused of choosing a title that "signal[s] [our] cleverness before the piece has even begun," an annoying academic habit denounced by the protagonist of In the Falling Snow. ${ }^{6}$ The most obvious of these allusions is to Stevie Wonder himself, a major source of artistic inspiration for Phillips, as shown in the title of his fourth novel, Higher Ground, which is an echo of Wonder's 1973 song of the same title from the Innervisions album. Phillips has repeatedly said how influential

3 Caryl Phillips, In the Falling Snow (London: Harvill Secker, 2009): 95.

${ }^{4}$ See Caryl Phillips, The Final Passage (London: Faber \& Faber, 1985): 204; Phillips, In the Falling Snow, 320-21. Incidentally, Vivien, one of the characters in Strange Fruit, recalls a similar scene where she sees snow for the first time just after being victim of a racist attack. Caryl Phillips, Strange Fruit (Ambergate: Amber Lane, 1981): 52.

${ }^{5}$ See Deborah E. McDowell, "The Changing Same": Black Women's Literature, Criticism and Theory (Bloomington \& Indianapolis: Indiana U P, 1995).

${ }^{6}$ Phillips, In the Falling Snow, 106. 
Wonder - together with Marvin Gaye and Curtis Mayfield - had been on his own development as a black boy growing up in Britain, and later as an artist. ${ }^{7}$ In a 2002 interview with Charles Wilkin, for example, he declared:

[When I was] growing up in Britain during the seventies [...] I looked for people who could help me to understand what was happening amongst my generation, [...] what was happening on the streets. [...] I looked to the United States and to what was happening in black American society. And it seemed to me that the people who had the strongest narratives and the most profound insights were people like Stevie Wonder, Marvin Gaye and Curtis Mayfield, artists who were writing music that was not just passionate, but music that actually was incredibly socially engaged. ${ }^{8}$

But "Writing in the key of life" is also suggestive of music in general, a genre that has had a decisive impact on the form of Phillips's writing, as the writer himself acknowledges when he speaks of his almost obsessive relation to Beethoven's Sixth Symphony. ${ }^{9}$ And, indeed, the lyrical beauty, the almost choric arrangements and the symphonic structures of the author's fictional texts testify to the musical quality of his prose. This is an exciting aspect of Phillips's work which still needs to be fully explored. However, as this volume shows, his writing has otherwise given rise to a multiplicity of responses, which bodes well for the future of Phillips scholarship.

Caryl Phillips: Writing in the Key of Life is divided into three parts. The first, "Caryl Phillips: 25 Years of Writing," takes us back to the eponymous 2006 conference and contains contributions whose oral quality has in most cases been deliberately preserved to allow the reader to share in the unique atmosphere of convivial debate that prevailed during the symposium. "Oxford," PETER MARSDEN's brief introduction of Phillips, refers to the university attended by the writer in the 1970s, while also playfully alluding to his novel Cambridge (1991). Marsden's humorous subversion seems befitting here, for, shortly before the conference, Phillips's oeuvre, with its characteristic exploration of deep-seated racial and social prejudice, earned him an Honorary

\footnotetext{
${ }^{7}$ See Caryl Phillips, "Preamble," page 9 below.

${ }^{8}$ Caryl Phillips, "Interview with Caryl Phillips," by Charles Wilkin, WINN FM, 23 December 2002 (Basseterre, St Kitts), in Conversations with Caryl Phillips, ed. Renée T. Schatteman (Jackson: UP of Mississippi, 2009): 130-31.

${ }^{9}$ Caryl Phillips, "Other Voices: An Interview with Caryl Phillips" (October 2001), by Stephen Clingman, in Conversations with Caryl Phillips, 108-109.
} 
Fellowship from The Queen's College in Oxford. This recognition from the Establishment is greeted by Marsden with enthusiasm and a sense of lighthearted revenge. PHILLIPS's own response to his success has always been notoriously discreet. Well aware of the debate prompted by his circumspection, the writer decided to share extracts from his private notebooks as a prelude to his lecture. These diary entries convey his continued interest in identity, his love of music, and his attempts to cope with artistic fame. The keynote address that follows, "Colour Me English," starts with the recounting of a childhood memory which led the young Phillips to realize that not only race and class, but also culture and religion, serve as factors of exclusion in British society. His essay then develops into a thought-provoking critique of Europe's attitude towards its Muslim citizens, and concludes by highlighting the role of literature in the promotion of tolerance. The responsibility of the writer, a theme that runs implicitly through Phillips's entire essay, is precisely what lies at the heart of KIRPAL SINGH's address. Examining the Caribbean-British writer's long-standing ethical and political commitment, Singh emphasizes the potential of the author's work to initiate a process of healing in a world marked by violence and oppression. A salient point in this discussion is the understanding of history's intricacies that Phillips endeavours to convey to us all.

Such understanding is above all acquired through a careful interpretation of the author's rich opus, as shown in the second and largest part of the volume, which contains twenty-three critical essays and is divided into five sections. In the first, "Autobiography, Fact, and Fiction," Renée Schatteman's opening essay reminds us that interviews can be an invaluable source for gaining a fine appreciation of Phillips's artistic project. She underscores the remarkable consistency of the writer's reflections in conversations over the years, and presents a panorama of the themes that have been recurrently addressed in his exchanges with critics, journalists, and fellow artists. If interviews can be considered enlightening exercises in self-definition, LOUISE YELIN argues that Phillips's autobiographical pieces, which are dispersed throughout his work, conceal the writer's "plural selves." She offers an analysis of the versatility with which the author employs the autobiographical mode in his texts, among these being "Northern Lights," the final section of his volume of fictionalized biographies, Foreigners (2007). BÉNÉDICTE LEDENT tackles this book from a different angle, taking as a point of departure a question that has intrigued Phillips critics for years: namely, whether the writer has an optimistic or a pessimistic take on life - a discussion evoked 
both in Phillips's own piece and in Schatteman's essay, and mention of which will not have escaped the initiated reader. In her analysis of Foreigners, Ledent attempts to discern how the author's hopeful or fatalistic stance impinges on his representation of his three protagonists. The final essay in this section, by JOAN MILLER POWELL, concentrates on two other works in which Phillips skilfully combines fact and fiction: namely, The European Tribe (1987) and The Atlantic Sound (2000). Exploring the multiple formal strategies to be found in these books - most notably as they relate to the tradition of travel writing - Powell posits that the narratives partake of a type of "hybrid inventiveness" that reflects the writer's meandering exploration of issues such as displacement and identity. ${ }^{10}$

The next section, "Caryl Phillips and the Other Writers," probes Phillips's - sometimes or, indeed, often ambiguous - literary relationships with other authors and their work. Concerns with fact and fiction are not entirely left behind here, for JOHN MCLEOD's examination of Phillips's writerly connection to the Trinidadian V.S. Naipaul proceeds from the Kittitian author's struggle to reconcile Naipaul's talent as a novelist with the Nobel Prize laureate's far less admirable personality. McLeod sounds the nature of Phillips's ambivalent link with Naipaul, filtering the commonalities and divergences in the two men's approaches to writing through an analysis of Phillips's early novel A State of Independence (1986). The echoes between Phillips and another West Indian Nobel Prize-winner, Derek Walcott, constitute the subject of MAlik Ferdinand's piece. Putting the younger writer's A New World Order (2001) side by side with the older poet's What the Twilight Says (1998), Ferdinand considers both collections of essays as reflections of their respective authors' attempt to define Caribbeanness, and he concludes that, in spite of their individual traits, the two artists share strikingly similar visions. A marked resemblance also characterizes "Heartland," the first part of Phillips's novel Higher Ground (1989), and Joseph Conrad's Heart of Darkness (1902). IMEN NAJAR performs a close reading of these two narratives, emphasizing intertextual motifs relating to the representation of fear, and builds on her findings to delineate the terms of Phillips's nuanced response to the Polish-born novelist.

Interestingly, all three authors considered in the section on literary relationships - Naipaul, Walcott, and Conrad - are migrant writers. This further evi-

\footnotetext{
${ }^{10}$ The notion of 'meandering', with its connotation of fluid response to challenges, has a positive valency in Phillips's lexicon.
} 
dences, if need be, the pervasive influence of diasporic voices and themes on Phillips's work. Such topics are indeed addressed, if only obliquely, in all of the contributions to the volume so far, and the next section, devoted to "Diasporas," offers an even closer examination of Phillips's poetic of displacement. Echoing Kirpal Singh's earlier essay, STEF CRAPs points to the centrality of ethics in the writer's fiction, and further asserts that Phillips's repeated imaginative re-creation of the Jewish experience alongside that of the African diaspora makes his work challenging material in the context of trauma studies. Craps suggests that the establishment of such bold parallels between diasporic peoples could easily degenerate into an unethical appropriation of another people's suffering, but he demonstrates how Phillips avoids this pitfall in Higher Ground and The Nature of Blood (1997) through his use of specific textual devices. Representations across the boundaries of race are equally important in Crossing the River (1993), whose intricate workings F A TIM Boutros proposes to unravel in his essay. Introducing the concept of "bidirectional revision," Boutros successively tackles the different sections of the novel and argues that the narratives work both "retroactively," in that they invite the reader to reassess his or her prejudiced conceptions of the past, and "proactively," as they have a potential bearing on the future. The combination of journeying and remembrance found in Crossing the River is also present in The Atlantic Sound and A New World Order, two volumes of essays which provide the focus for ABIGAIL WARD's article. Ward first considers Phillips's pieces around his lifelong passion for football, and examines how conceptions of 'home' and British identity are articulated in these texts. She then pays attention to the writer's account of his travels on both sides of the Atlantic, and concludes by reflecting on the significance of crossings and crossroads in Phillips's perception of his own identity. The central position occupied by the Atlantic Ocean in the author's works leads WENDY KNEPPER to devise a "theory of seascapes." She first of all demonstrates the relevance of this marine metaphor to making sense of the intertwined geographical and historical networks that inform Phillips's The Atlantic Sound and some of his other books, and subsequently assesses the manner in which his fluid vision apprehends the global and local cultural formations of the contemporary world. The map of diasporic connections laid out by Phillips in his non-fictional works may be said to testify to his continual engagement with the migrant's predicament. Such is CHIKA UNIGWE's suggestion in her study of Strange Fruit (1981). Indeed, this essay detects in Phillips's first play, which records the responses of a Caribbean mother and her two sons to 
British society, many of the concerns that underlie the writer's later work, not least an uneasy sense of (un)belonging captured by Unigwe under the evocative designation "dis-ease."

The British setting of Strange Fruit was to reappear in different guises in Phillips's subsequent works - for instance, in the two novels briefly compared in the opening paragraphs of this introduction, The Final Passage and In the Falling Snow. Also featuring prominently among the narratives at least partly set in Britain is A Distant Shore, arguably one of Phillips's most convincing interrogations of "Britain and Its 'Others'," hence the title of the next section, which deals almost exclusively with this 2003 book. The first contribution, by ALESSANDRA Di MAio, draws the reader's attention to the novel's development of two relatively under-explored literary themes: namely, African civil wars and the black presence in Britain. Di Maio contends that, even though a large portion of Phillips's narrative is set in contemporary Europe, an informed reading of the text can only be achieved if its African components are also given due attention. The pertinence of this two-pronged approach is then demonstrated by means of an analysis of some of the novel's structural, metaphoric, and thematic patterns. The crucial importance of the interplay between Europe and Africa in A Distant Shore is also underscored by SANDRA COURTMAN, who deciphers the narrative through an examination of its intertextual connections with Conrad's Heart of Darkness, a text that has clearly exerted a key influence on Phillips, as already shown by Najar's discussion of Higher Ground. Courtman shows how he deconstructs the image of Africa as the 'dark continent' and how, through the unmasking of colonialist ideologies, he simultaneously contextualizes Africa's present struggles and sheds light on the mechanics of exclusion in contemporary Britain. This very sense of exclusion, experienced by the two main characters of the book, Dorothy and Solomon, provides the basis for THOMAS BonNICI's reading of the novel. His is a related yet slightly different view, since he argues that race works as a metonym for all types of rejection in $A$ Distant Shore, and that what ultimately binds the protagonists is their common sense of postmodern Unheimlichkeit. Petra Tournay-Theodotou also broaches the tension between inclusion and exclusion in the narrative, most notably by paying attention to Phillips's allegorical treatment of space. The possibility of such an interpretation is briefly touched on by some of the other contributors, but Tournay develops the idea into a detailed interpretative model around the figure of the stranger and of Benedict Anderson's notion of "imagined community." The framework thus established is then used to 
decode some of the novel's recurrent thematic motifs, including the integrity of the body and the obsessive concern with politeness. The latter theme is brought to the fore by CINDY GABRIELLE, who adopts a different stance towards the protagonists' demonstration of 'good manners'. Examining how the expression of decorum correlates with notions of so-called 'civilization', she exposes the deception that lies behind the mask of respectability worn by some of the novel's characters.

Other types of disguise are scrutinized in the next section, entitled "Race and Masks." Combining the themes of race and gender, LuCIE GILLET uncovers the remarkable continuity that exists between Cambridge and $A$ Distant Shore, despite the apparent rupture suggested by the novels' dissimilar settings and time-frames. Gillet analyzes Phillips's characters and use of language, thereby uncovering the subtle parallels that he establishes between nineteenth- and twenty-first-century forms of racial and gender oppression. Equally subtle is the writer's treatment of race and masks in Dancing in the Dark (2005), which the next three contributions in the volume all address in different ways. TSUNEHIKo KATO concentrates on the dilemma faced by Bert Williams, the historical figure whose life is fictionalized in the novel. Kato contextualizes the predicament of this black entertainer, who performed in so-called 'cork face' on Broadway at the turn of the twentieth century, and shows how Phillips depicts the man's attempt to come to terms with his unwilling perpetuation of a black stereotype. ITALA VIVAN examines Williams's plight from a Freudian perspective, viewing the character's disguise as a manifestation of the 'uncanny'. Her psychoanalytical reading underlines the many references to mirrors and 'doubleness' in the book, and reveals this ambiguity to be the source of Williams's anguish. Mirror images also feature in DAVE GUNNING's essay, although his analysis probes the performative aspects of Williams's transformation. Gunning compares Dancing in the Dark with another novel that foregrounds the performance of race, Percival Everett's Erasure (2001), and proposes to read the narratives as respectively "concentric" and "centripetal," metaphors which aptly capture the writers' divergent approaches to racial representation. Phillips's treatment of race, this time explored from a more expressly formal angle, is also central in GORDON COllier's examination of In the Falling Snow. Carefully unravelling the narrative's "textual architecture," Collier demonstrates how the strategic alternation between "revelation and concealment" crucially shapes the way in which the reader apprehends the characters' diverse backgrounds and relationships with each other in this complex and elusive novel. 
While the essays contained in this volume illuminate different facets of Phillips's versatile artistic production, it is almost inevitable that, in a book presenting such a large number of articles on the work of a single writer, the arguments developed by the authors independently of each other should occasionally overlap. These sporadic convergences hold their own interest, for they are indicative of the consensus that is currently emerging around some of the major issues in Phillips's writing. In this "many-tongued chorus"11 of critical voices, however, each individual follows his or her own score in an attempt to capture precisely what it means to be, like Phillips, writing in the key of life.

\section{WORKS CITED}

Conrad, Joseph. Heart of Darkness (1902), in Heart of Darkness and Selections from the Congo Diary, intro. Caryl Phillips (New York: Modern Library, 1999): 1-96.

Everett, Percival. Erasure (2001; London: Faber \& Faber, 2003).

McDowell, Deborah E. “The Changing Same”: Black Women's Literature, Criticism and Theory (Bloomington \& Indianapolis: Indiana U P, 1995.

Phillips, Caryl. The Atlantic Sound (London: Faber \& Faber, 2000).

—. Cambridge (London: Bloomsbury, 1991).

—. Colour Me English (London: Harvill Secker, 2011).

- Crossing the River (London: Bloomsbury, 1993).

—. Dancing in the Dark (London: Secker \& Warburg, 2005).

. A Distant Shore (London: Secker \& Warburg, 2003).

- The European Tribe (London: Faber and Faber, 1987).

The Final Passage (London: Faber \& Faber, 1985).

—. Foreigners: Three English Lives (London: Harvill Secker, 2007).

. Higher Ground (London: Viking 1989).

In the Falling Snow (London: Harvill Secker, 2009).

- "Interview with Caryl Phillips" (December 2002), by Charles Wilkin, in Con-

versations with Caryl Phillips, ed. Renée T. Schatteman (Jackson: UP of Mississip-

pi, 2009): 118-34.

. The Nature of Blood (London: Faber \& Faber, 1997).

. A New World Order: Selected Essays (London: Secker \& Warburg, 2001).

. “ “Other Voices': An Interview with Caryl Phillips” (October 2001), by Stephen

Clingman, in Conversations with Caryl Phillips, 95-117.

_. A State of Independence (London: Picador, 1986).

\footnotetext{
${ }^{11}$ Caryl Phillips, Crossing the River (London: Bloomsbury, 1993): 1.
} 
Strange Fruit (Ambergate: Amber Lane, 1981).

Sethi, Anita. "Home and Away," The Independent (22 May 2009), Arts and Books: 26.

Walcott, Derek. What the Twilight Says: Essays (London \& New York: Faber \& Faber, 1998).

Wonder, Stevie. "Higher Ground," Innervisions (Tamla Motown, 1973).

_. Songs in the Key of Life (Tamla Motown, 1976). 


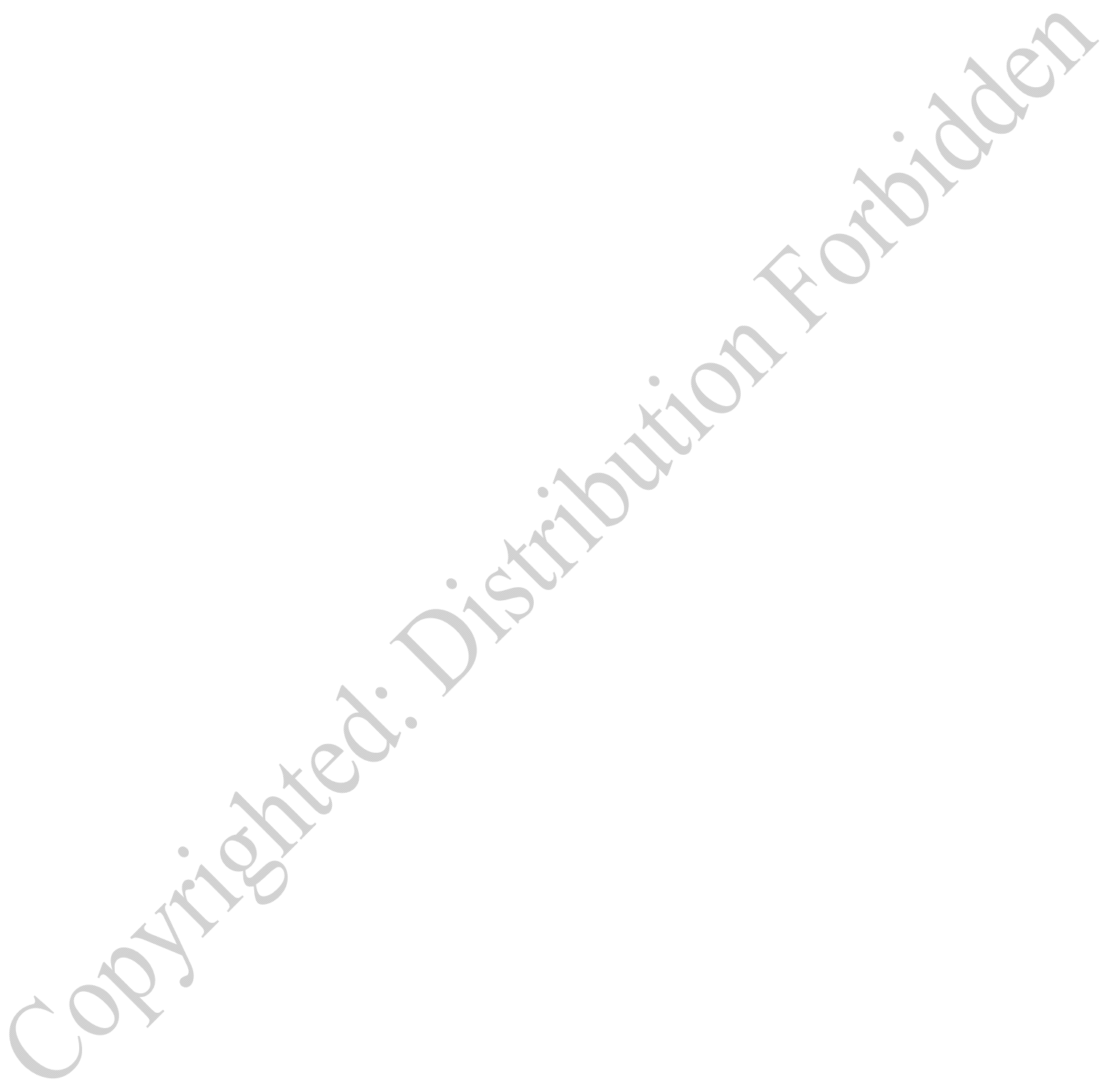




\section{CARYL PHILLIPS:}

TWENTY-FIVE YEARS OF WRITING 


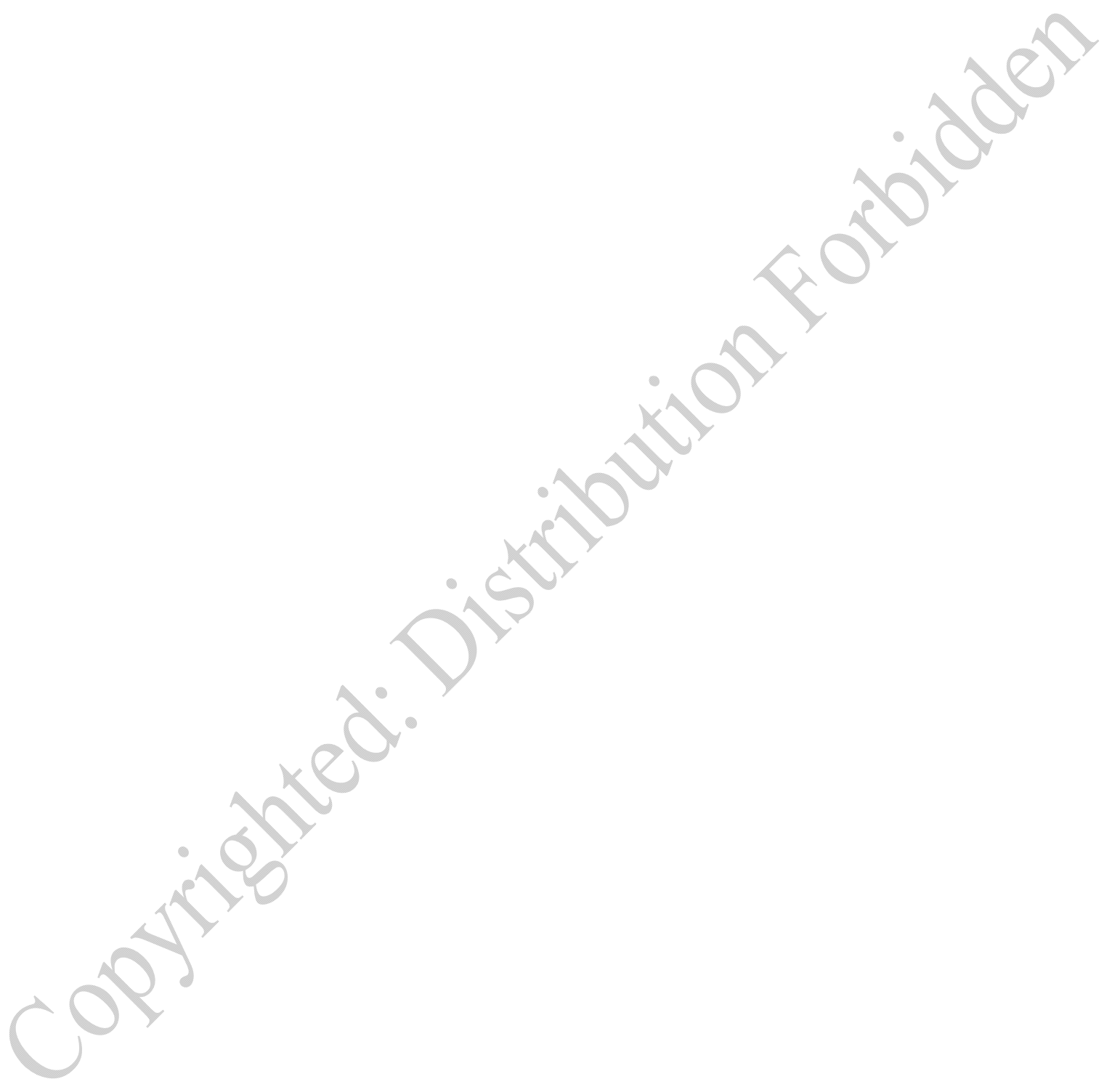




\section{Oxford $^{1}$}

\section{Peter Marsden}

AM NO PHILLIPS SCHOLAR, BUT I AM THRILLED to have the opportunity - and the platform - to say something in public about Caryl Phillips outside the confines of my own lectures and seminars, where I have frequently found myself referring to and quoting the man, his work, and his achievement. A personal, literary, and cultural achievement that I greatly admire and which has found recognition in a huge array of glittering prizes, awards, and honours, residencies and guest professorships at distinguished institutions running the gamut from Amherst to Yale.

The most recent such distinction could arguably be said to be in process, taking place right now - by which I mean the very fact that we are all gathered here today to spend a couple of days paying tribute to the work of one writer. The evidence is all around us - si monumentum requiris, circumspice.

But I would like to single out another distinction - the most recent one before the present one. Now, personally, I'm not actually a great name-dropper (in fact, I was saying so to Tony only the other day...). Nor have I ever been a prototypical college chauvinist, automatically proud of my alma mater. But recently something happened to change all that. No, I wasn't on the way to Damascus at the time. I just happened to read a little news item that converted me instantaneously and absolutely. Name-dropping has since become one of my favourite indulgences, and my old college (and it is, in fact, a very old college) has gone up enormously in my estimation. This little news item was in the columns of the The Queen's College Newsletter for Trinity Term 2006. There I read - only shortly before I heard that Bénédicte Ledent was going to

\footnotetext{
${ }^{1}$ This text was delivered as an introduction to Caryl Phillips's keynote address, entitled "Colour Me English," on the final day of the conference "Caryl Phillips: 25 Years of Writing," held at the University of Liège, 1-2 December 2006.
} 
put on this conference - under the heading "Honorary Fellows," that the College had recently elected a number of Old Members (charming Oxford dysphemism for 'graduate of the College'), including "the writer and academic Professor Caryl Phillips (1976, English)" to an Honorary Fellowship. Let me tell you: I felt truly proud - proud to be associated, however tenuously, with a venerable institution that has seen fit to thus honour the achievements of this man; that has had the sensitivity, the perspicacity, and the acumen to single him out for this signal distinction.

This felicitous 'election' strikes me as an act of poetic justice. This most exclusive of clubs has decided to include as a member a man who, when being interviewed for admission to the College as a student (or: undergraduate), had thought to himself that, being a working-class black boy with a Yorkshire accent he probably didn't have a hope in hell. Or, as he actually put it: "This isn't going to work." The man who, as a kid growing up in Leeds in the 1960s and 1970s, had to suffer the slings and arrows of outrageous racist slurs and insidious innuendoes, including constant injunctions to explain where he came from with a view to going back there forthwith, could now, if he so chose, say to his former tormentors: "Why don't you just stay where you come from? I've moved on." If they could see him now...!

Back in 1987, Caryl Phillips wrote, in The European Tribe: "I cannot write in Yoruba or Kikuyu, any more than a black youth born in Peckham or Middlesbrough can hope to feel at home in Addis Ababa or Kingston, Jamaica. His excellence, his ability is all that he has to offer British society, and any society should be grateful to receive it." ${ }^{2}$

Well, Caz, over the last twenty-five years - at least - you have offered ample proof of that excellence, that ability; you have offered it to British society (and not only to British society), and there are very, very many people who have been, and continue to be, grateful to receive it. And now it's you who are up there in the uppermost echelons of British society.

I am, of course, fully aware that the high anxiety of occupying a seat at High Table might be somewhat tempering of any incipient stirrings of euphoria in yourself. In fact, it can't be entirely ruled out that you might be feeling somewhat Grouchily Marxistic about the whole thing - maybe you didn't want to belong to a club that accepted you as a member. But, at least according to the article in The Queen's College Newsletter, you have accepted the honour. I don't think there's any danger of your succumbing to the be-capped

${ }^{2}$ Caryl Phillips, The European Tribe (London: Faber \& Faber, 1987): 126. 
and be-gowned [and be-gloved?] clutches of the Establishment and its blandishments, or of becoming an instance of what Tom Lehrer has memorably termed "ivy-covered professors in ivy-covered halls." 0 On the contrary, I can imagine you waking and shaking things up quite a bit in those grave groves of Isis and Cherwell.

I'm resisting the temptation to lead us all in a rousing chorus of "[For] he's a jolly good fellow!' I do have some inhibitions about stating the obvious we know he is, we know he will be - and so think all of us. Instead, from one Yorkshireman to another, I'll just grudgingly and laconically mumble: "Ee, lad - it's champion!" And you tell that to them folks back in Leeds, and they won't believe yer.

\section{WORKS CITED}

Lehrer, Tom. "Bright College Days," An Evening Wasted with Tom Lehrer (Lehrer Records, 1959).

Phillips, Caryl. The European Tribe (London: Faber \& Faber, 1987).

$*$

3 Tom Lehrer, "Bright College Days," An Evening Wasted with Tom Lehrer (Lehrer Records, 1959). 


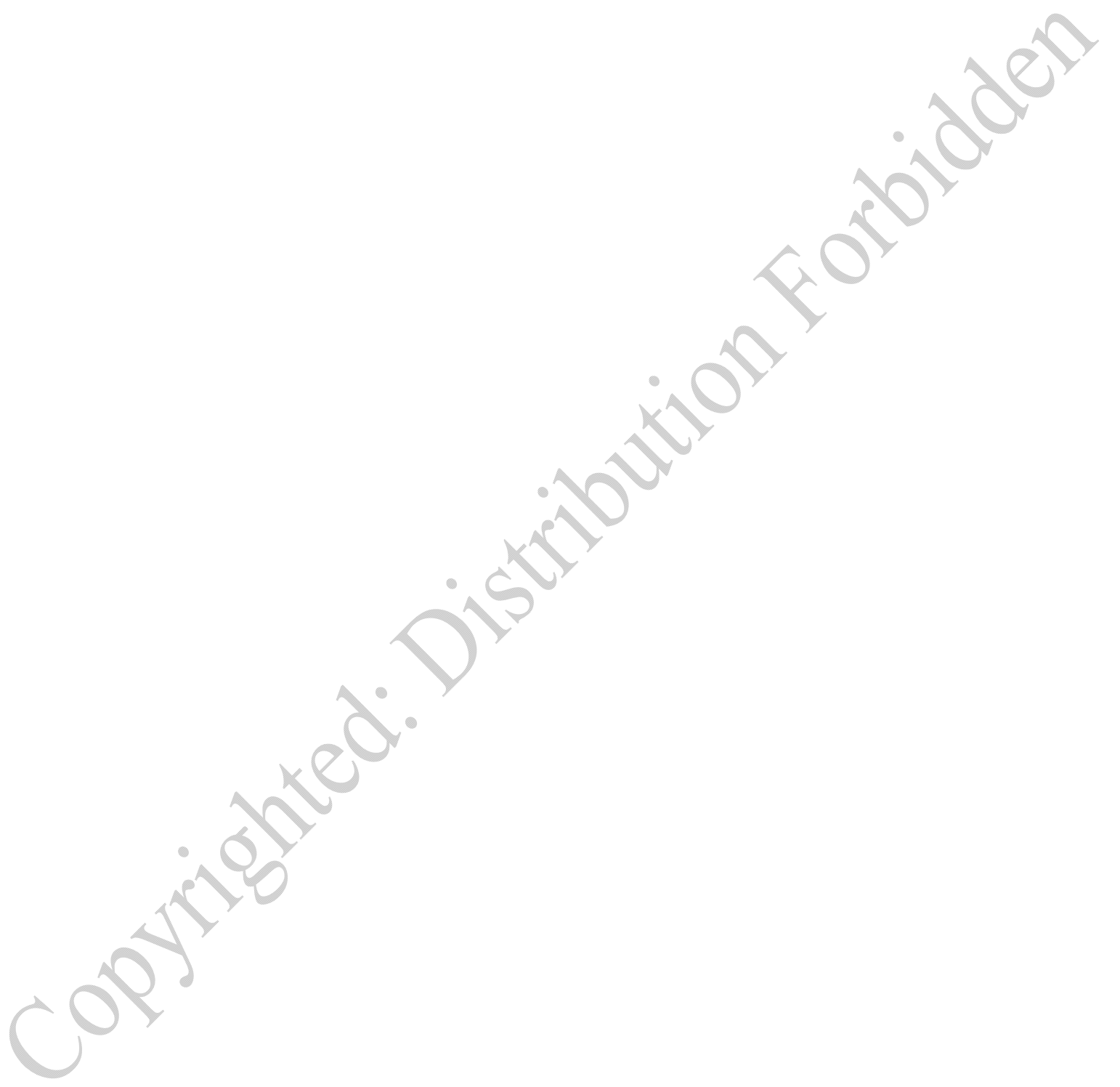




\title{
Preamble $^{1}$
}

\author{
CARYL PHILLIPS
}

'M GOING TO READ AN ESSAY, BUT BEFORE I DO SO... I was sitting in a facility across the street for the last hour, thinking: What do I do in this situation? Because - it goes without saying - this has never happened before, and maybe it will never happen again. I thought back to a sort of halfconversation I had with Renée [Schatteman] and with Louise [Yelin], which refers to the fact that I never really say much about myself. And what they don't know, and what nobody in this room knows - including Bénédicte [Ledent], who probably knows more about me than most - is that when I was twenty, I started to keep notebooks that looked like this. [Shows notebook.] And they are numbered now; this is number twenty-seven. The moment I decided I was going to be a writer, I started to write down what I really thought about things that happened to me. So, before I read the essay, I'm going to read you just a few extracts... and Renée, and Louise, this is as close as it's going to get.

Rome, 29 June 2005

I really don't think of events before I was twenty-one, and leaving college, as being anything other than preparation. Life only began when I became a writer.

Edinburgh, 27 August 2005

In 1979, I started to write because I had something to say. I had no desire to be either famous or to become a celebrity. I still have no desire to embrace

\footnotetext{
${ }^{1}$ The following is the transcript of what Caryl Phillips said before delivering his keynote, entitled "Colour Me English," on the final day of the conference "Caryl Phillips: 25 Years of Writing," held at the University of Liège, 1-2 December 2006.
} 
either fame or celebrity. These are terrible accidents that can destroy the privacy of a writer's life and impair his ability to see clearly.

St Louis, Missouri, 6 October 2005

I'm becoming extremely bored with my own company, my own routine, and my own rhythm. Things need to be shared. I think I also need some help.

Vancouver, 21 October 2005

I'm so depressed and tired and generally fed up. I've been writing for twentyfive years now, and writing novels for twenty years. I know I don't want another twenty years of this. I want to write of course, but I want something different.

San Francisco, 22 October 2005

There is an old Native American saying: 'Two dogs live inside of us. The one that grows the largest is the one that we feed'.

New York, 19 November 2005

"To those in their twenties and early thirties, the problems are not yet real. [...] What has happened to us [in middle age] is not only the first massive shake to human identity since adolescence, but probably the strongest that we receive after becoming adults - aside from individual calamities - until we suddenly find ourselves in old age. True, it can be deferred, if not avoided, provided we are able to distract ourselves and keep busy [...]."

Quotation from Doctor Samuel Johnson

Ghana, 1 December 2005

I will tell you that I belong. But at the same time, I will resist your embrace. I was not born in Europe. I was not born in Africa. I was not born in the United States. I was born on a small island, where I could breathe Europe, I could breathe America, and I could breathe Africa, in one draft, one deep, luxurious intake of breath, and then exhale knowledge of all of these worlds. Geography, in fact, made me who I am, and history presented me with a blank canvas upon which I could begin to describe an identity that resists the vulgarities of loyalty to nation or race. The embrace of welcome can quickly tighten into a life-threatening chokehold in which we breathlessly begin to accept other people's definitions of who we are.

Delray Beach, Florida, 1 April 2006

I've never felt it easy to belong. 
Las Vegas, 7 April 2006

America has no interest in you having a career. It merely wants you to be a success.

Puerto Rico, 24 May 2006

I learned how to combine the heart with politics from Stevie Wonder, from Marvin Gaye, and from Curtis Mayfield. Unfortunately, I learned about form from Emerson, Lake and Palmer, Rick Wakeman and Elton John.

And finally...

3 October 2006

Fame and recognition are not the same thing.

Thank you for recognizing me. 


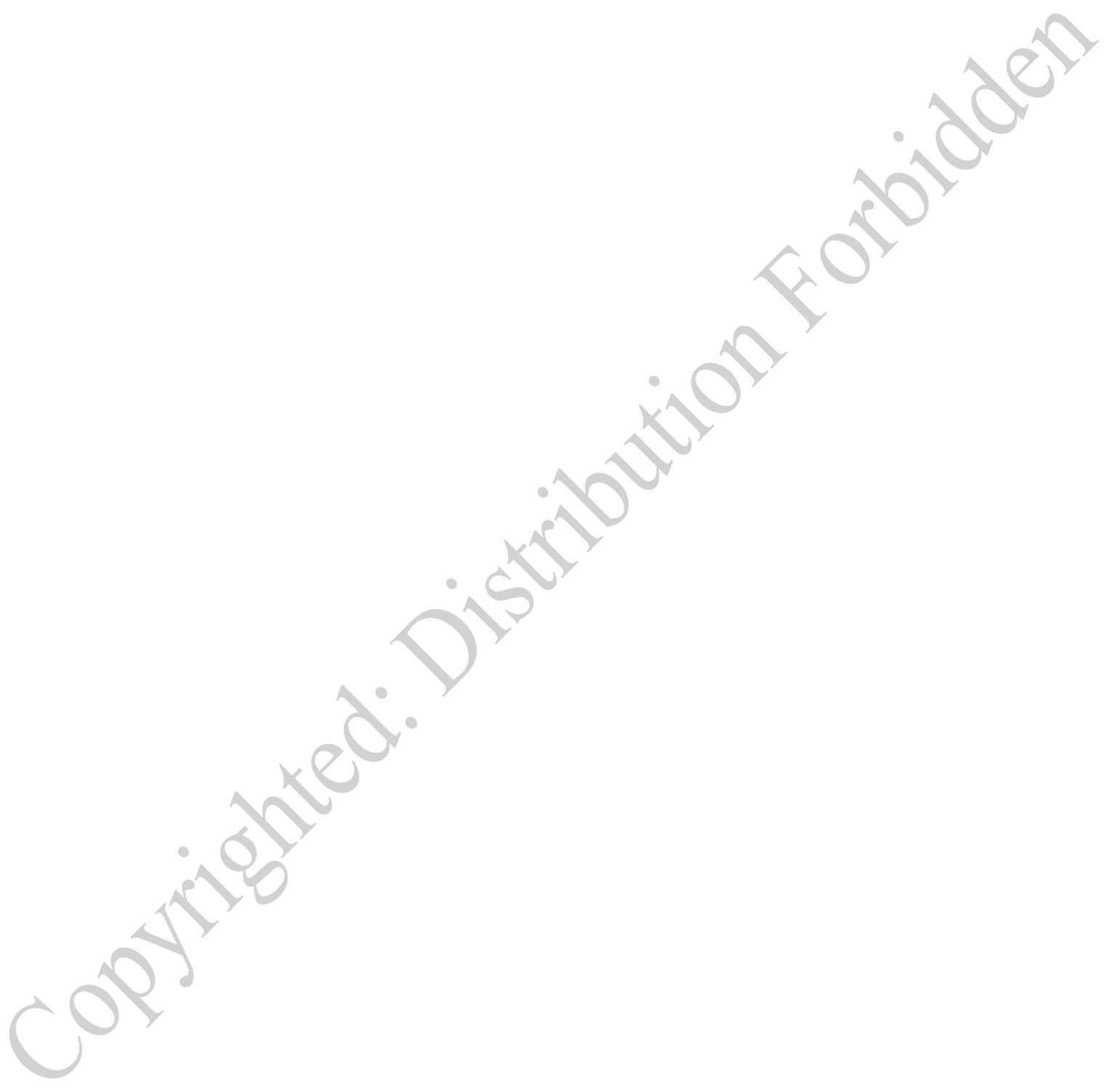




\title{
Colour Me English
}

\author{
CARYL PHILLIPS
}

WAS THIRTEEN AND ENTERING MY THIRD YEAR at Leeds Central High School, an all-boys grammar school in the centre of Leeds. This year marked a transition because for the first time I would no longer be the only black boy in the school. My brothers, Trevor and Malcolm, would be starting in the first year. Trevor was born at the start of September and Malcolm at the end of July, and so, by a matter of a few days, they were both grouped together in the same school year. I remember feeling that my 'freedom' was about to be traduced by the arrival of my younger brothers, but it never occurred to me to advise them on how to cope with the somewhat lonely racial situation at the school. We had been the only black children at our primary school, and we remained the only black family on a tough, North Leeds, all-white working-class estate. All three of us knew full well how to cope. We knew when to fight and we knew when to run. In fact, most of my childhood was spent either fighting or running, and my only refuge was reading, which I tried to conceal as a slightly shameful secret, for it did not square with the rough, aggressive, demeanour that I had to cultivate in order to survive. Naturally enough, both of my brothers knew full well how to fight and how to run, which meant that there was no need for a conversation on the topic of racial isolation. And so, as the black population of Leeds Central High School tripled, I settled down to the novelty of no longer being the only one in the school.

Two weeks into the term it happened. One morning as the teacher called out our names, there was an extra name, like an afterthought, tagged on the end of the register. "Ali." We all turned around and there, seated in the furthest corner, was a small moon-faced brown boy in a brand-new school blazer that was clearly too big for him, and which served only to accentuate his 
diminutive stature. Ali looked terrified. Thirty pairs of eyes took in this oriental apparition and he began to blink furiously, as though he might at any moment burst into tears. The teacher did not bother to introduce the new boy, or explain why he was joining us two weeks into the term. He simply closed the register with a dull thud as he did every morning, and then he barked, "Assembly." Chairs were scraped back, and desk lids were opened and slammed shut as we formed a noisy procession and filed out towards the school hall. I assume that on that first morning Ali stood up and joined us, but I really have no idea. He was the new boy and so he was effectively ignored.

During the next few weeks, Ali's palpable sense of isolation did not attenuate. As far as I could tell he had no friends, and nobody went out of their way to rescue him from his segregation. As a matter of daily routine, somebody in the classroom would throw a pencil, or a piece of chalk, and it would strike an unsuspecting boy on the back of the head. The boy who had been struck would turn angrily and try to discern who the assailant was. Fingers would quickly point towards Ali, and raucous cries of 'Hey, pack it in Ali' would fill the room, a supposedly clever play on his Pakistani origins. All the while, an increasingly shy and tormented Ali sat quietly at the back of the classroom visibly shrinking before our eyes. Boys can be merciless, and we certainly were, and because nobody told us to cease, this daily harassment of the newcomer in our midst continued unabated.

It almost doesn't need stating, but Ali was predictably bad at games. You can imagine the scene. On Tuesday afternoons we were bussed to the outskirts of West Leeds, where the school playing fields were located. The school cross-country run was a brutal affair, featuring a near vertical ascent the so-called 'steep' hill - and untold laps of the football pitches. We were divided into four houses - all named after famous scientists. Faraday, Priestley, Newton, and Murray. Competition for house points was fierce, and we were all focused. Most of us had showered and changed back into school uniform by the time Ali rounded the final corner of the football pitch. He could be seen, through the late-afternoon gloom, making his painfully slow way towards the school pavilion, his baggy white shirt blowing in the breeze with barely a torso to give it any shape or substance. His spindly legs always appeared to be on the point of buckling, but his arms still pumped like little pistons, and his chin was angled upwards, for Ali was determined to cross the line. We all stood and laughed at him. "Come on, pack it in, Ali."

After games period was over there was no school bus to take us back to town, so we were expected to leave en masse and take public transport to 
wherever we lived. A few boys lived in West Leeds, but the majority of us took a bus back into the city, and then transferred to whatever bus would take us to north, or south, or east Leeds and back in the direction of home. One late Tuesday afternoon, I remember sitting upstairs on the top deck of a bus as it ferried the noisy schoolboys back towards the city centre. Ali was sitting by himself some few seats behind me, and then I heard the commotion and turned around. A group of boys had grabbed Ali's backpack and they were rifling through the bag and pulling out his text books, his exercise books, his pencil case, everything that was in there. I saw terror on Ali's face, and immediately understood that he could not afford to lose these things. I knew how hard my own mother was working to make sure that her sons had uniforms and books and sports kit, and I assumed that Ali's family were in the same predicament. One simply could not afford to be frivolous when it came to the practical aspects of getting on in England as a non-white child. And then I saw the bullies open the small top window of the bus that was there to evacuate cigarette smoke, and I watched as they threw all of Ali's books, one by one, out of the window of the speeding bus and into the middle of Headingley Road. They then handed him an empty backpack, their stupid faces flushed with success. I turned back around in my seat and faced the front, knowing that something inside of me had changed.

When the bus stopped outside of Leeds Central High School, I got up and spoke to Ali for the first time. "Come with me," I said. Ali followed me down the stairs of the bus and onto the pavement. "We're going to report this, okay?" He nodded and then traipsed after me, as I walked up the flight of stone steps and into Leeds Central High School. Once there, I made my way towards the school office, where I was all too familiar with the sour-faced woman whose head poked out of the little hatch. She was the gatekeeper to the headmaster's office, and I had been summoned before him on numerous occasions for various disciplinary reasons. In fact, only the previous week he had bestowed six strokes of the cane upon me for some alleged form of insubordination. As far as his secretary was concerned, I was not just a troublemaker, I was the troublemaker. "Yes," she said, eyeing the two thirteen-yearold immigrant boys standing before her. I explained what had happened to Ali's books, and I named names. She listened and then with a triumphant smirk simply said, "so what do you want me to do about it?" Was she serious? These hooligans had thrown Ali's books out of the window of a public bus. "Well?" she said. I stared at her and then decided that it was probably politic for me to say nothing further. I turned and walked away in disgust, and 
Ali shuffled after me. Once outside the school, I turned to face him. "You can try and report it again tomorrow." Ali looked at his champion, and he slowly nodded. "Okay," he said. I've seldom felt more naive than I did at that moment. Poor Ali, who could neither run nor fight, but there was no need for me to feel too sorry for him, for the newcomer already understood how things were in England, and when tomorrow came he would not be reporting anything to anybody in the school office.

I don't remember ever having another conversation with Ali. The classroom teasing continued, but I made a conscious effort not to take part. However, I am somewhat ashamed to say that I don't think that I ever again spoke up in Ali's defence. He was the first Muslim that I ever knew, and the first South-East Asian, but although I felt some immigrant kinship with him, and had instinctively tried to help him, things between us went only so far, and no further. Although we might be enduring some of the same difficulties because of our pigmentation, there was a clear cultural difference which meant that while I was able to find a way to anxiously participate in British life, albeit in a manner that was hardly fulfilling, Ali was enduring the type of hostility that renders any thoughts of participation a distant, and decidedly unlikely, dream. My nominal acceptability to my classmates was in part related to the fact that I was bigger, stronger, and a good deal more outgoing than Ali, but was also related to my being, at least nominally, an Anglican church-goer who had the good manners not to be able to flaunt another language. Take race out of the equation and I had no place to hide from the English. Culturally, I was very much like them except, as a helpful teacher once told me, "You've just been left in the oven a bit longer, that's all love." I was exposed and the English could see me, and keep an eye on me, and even get to know me if they chose to. I could be useful, on the football team or on sports day, but I knew that at any moment the privilege of participation could be withdrawn and, depending on the mood of the person, or people, that I was with, I might have to suddenly fight or run. Ali, on the other hand, had the culturally essential worlds of religion and language into which he might retreat and hide from the English, which, of course, made him deeply untrustworthy.

For a large part of my life I grew up feeling that the real divisive factor in British, and by extension European, life was race; that it was race that was keeping us separate from each other, and that racism had made the greatest contribution to the inequity of opportunity in modern Britain. However, on 7 July 2005 I was reminded that something else is going on which contributes powerfully to divisiveness in British and European life. The cultural 'other- 
ing' of another people so that their national affiliation is attacked by pointing to their cultural practices is hardly a new European experience. However, the forceful response of those who feel that their cultural practices are being disrespected is something new. The four young men who met just outside of London at Luton train station on the morning of 7 July 2005 were as British as I am, and to all intents and purposes one might have believed that, aside from the casual and institutional racism, which they no doubt had to frequently endure, they were functioning reasonably well in British society. However, the fact that on that morning they chose to strap bomb-filled backpacks to themselves and enter buses and underground trains, where they detonated the bombs to murderous effect, killing themselves and scores of innocent people, speaks to a sense of European disaffection and culturally informed determination that is truly shocking.

Both before, and certainly since, the events of 7 July 2005, the British media have been replete with articles that have been hostile to Islam, portraying it as a backward faith whose fundamental principles are incompatible with the British way of life. The media would have us believe that this is a religion without any nuances of belief or practice, and they defend their belligerence on the grounds that they are taking a principled stance on behalf of women's rights, or they claim that theirs is a civilized response to a religion that sanctions a barbaric code of punishment, or they insist that they are adopting a necessary position in order that they might maintain our freedom and national security. Of course, most of the discourse is just plain, simple, old-fashioned malevolence towards the outsider, the person who not only looks different, but who dresses differently, or who worships in a place that is different from a church. It is an old European game and we have all seen and heard it before. But, of late, it is not just the media who have stepped up pressure on "these people."

The former British Foreign Secretary, Jack Straw, recently urged Muslim women to remove full facial veils when talking to him, claiming that the veil was "such a visible statement of separation and difference that it jeopardized British social harmony." Tony Blair, of course, echoed him, calling the veil "a mark of separation." Other European countries have already passed judgment on this and similar issues. In several German states, Muslim teachers are banned from wearing the hijab (or headscarf) in public schools. In France, nobody - Muslim teachers or students - can wear the headscarf in schools, for President Jacques Chirac claims that schools should be a "republican sanctuary." (Somewhat confusingly, Sikh boys are still allowed to wear their tur- 
bans, but presumably this will only be tolerated until somebody complains.) The Italian Prime Minister, Romano Prodi, agrees with his European colleagues. "You can't cover your face," he said, "you must be seen [...] It is important for our security." And some among the Dutch agree. Rita Verdonk, the Liberal Party immigration minister, plans to introduce legislation to ban Muslim women from wearing burquas in public places. There are one million Dutch Muslims, who make up six percent of the population of the country. Best estimates suggest that somewhere between thirty and fifty women in the whole country wear burquas, which essentially makes this a non-issue - one Muslim leader called it "a big law for a small problem." Indeed, it is a big law, for to pass this law would be to violate Dutch constitutional guarantees of religious freedom. However, Ms Verdonk proposes to circumvent this irritating fact by embracing the absurd and also making it illegal to wear full-size motor-bike helmets or ski masks. In other words, she intends to try and convince the Dutch population that this culturally biased piece of legislation is actually crucial for national security.

These days, on both sides of the Atlantic, many civil rights are being stripped away in the name of 'national security'. The fact is, the wearing of the burqua is becoming increasingly rare in the liberal Muslim world, including Pakistan, and it seems inevitable that European Muslim women will, as the generations turn over, also set it aside. In countries where more fundamental notions of Islam prevail, such as Uzbekistan, the question of women's attire remains a problem, for women are beaten and raped over this issue. And it is true that in Europe, there are Muslim women who are fed up with being called whores by their fathers and brothers, and freaks by other men, simply because of how they dress. But instead of condemning Muslims as separate and antisocial, we need to find ways to help those who want help. There is something unpleasant about the judgment of Western men being imposed upon Muslim women. In this sense, Jack Straw, Jacques Chirac, Romano Prodi, and others are in a long tradition of male patronage which found its most eloquent expression in the nineteenth century when the British occupation of Egypt was justified on the grounds that the British would "liberate women from their oppressive veils." And today, in Afghanistan and Iraq, both Britain and the USA have claimed that because of their intervention Muslim women will achieve greater freedom.

Clearly there are a significant number of Europeans who passionately dislike Muslims, and they point to Islamic cultural practices for evidence as to why "these people" cannot fully participate in European national life. Web- 
sites are increasingly filled with the righteous indignation of those who are thrilled that their governments are now legislating against "these Muslims." In liberal Holland, the November 2004 murder of the filmmaker Theo Van Gogh by a twenty-six-year-old Muslim obviously initiated a backlash of antiMuslim feeling, but the national tone had already been established by the late right-wing politician Pim Fortuyn. One recent posting on a Dutch website puts the anti-Muslim, anti-immigrant case very succinctly, claiming that immigrants "have forgotten that the responsibility and obligation of any immigrant is to conform to the society to which they have moved. They should move if that society is not appropriate for them [...] obviously they don't want to be French, Dutch, Canadian, American or a member of any Western culture because, despising Western culture, they invariably break the traditional immigrants pact with their host country. Instead of going as an immigrant, they are in fact going as an invader, the vanguard, the first wave."

To some extent it is "the responsibility and obligation of any immigrant $[\ldots]$ to conform to the society to which they have moved." They must, of course, be cognizant of the laws, and aware of the national traditions. Female circumcision is not tolerated in Holland, or in any part of Europe, nor should it be, and one should not expect to be able to practise it, any more than one should be able to anticipate public beheadings, or male-only drivers on the streets. But European Muslims are not stupid; they know this. The vast majority of Muslims in Europe have never subscribed to a rigid interpretation of sharia, and therefore have no problem at all marrying the practice of their faith to basic human rights as they are understood in the West. There are, in the world, those who do adhere to a strict interpretation of sharia, and without reform this form of Islam can probably not be reconciled to European cultural practice. But Islam is, like Christianity and Judaism, a flexible faith, which accommodates a multiplicity of differing orthodoxies, and is not a reactionary, monolithic, creed as some would have us believe.

And what is this "traditional pact with their host country" that immigrants are supposed to have? Presumably arrive, do nothing apart from the jobs that none of the locals want to do, make no criticism of the society, keep their heads down and out of sight, keep their hands off the women, and either die or leave in silence. This notion of migration, which I fear remains the model of how most Europeans think, of course removes any obligation for change from the host nation. Not only is it an ignorant misunderstanding of one's own history and how nations are formed, it is a potential recipe for disaster in the present climate. Integrating Muslims into European life is not just about 
colour; it is, as the current debates suggest, about a notion of identity that runs much deeper.

As a boy growing up in England, I knew that the main factor that was preventing my full participation in British life was the colour of my skin. If only they could somehow colour me English - in other words, white - then nobody would know the difference. The truth is, I did not want to be white, I just wanted to fit in, and I believed that colour was the issue. And then slowly things began to change. In November 1978, Viv Anderson, the Nottingham Forest full back, became the first black player to play for England. Within a few years there were black players on most of the first division football teams, and then there were other black faces in the English national team; soon after there were many black athletes on the Olympic track and field team, and black people on television reading the news. We were colouring England, and although problems remained, one sensed gates being unlocked, rusty bolts being drawn back, and barriers being frequently crossed. However, the shock that most felt on the morning of 7 July 2005, when it became clear that four non-white Britons had killed themselves and others, was a timely reminder of the superficial, and ultimately foolhardy, notion of thinking that race by itself is a barometer either of human disaffection or of social progress. It is a factor, but equality of opportunity, especially in housing, education, and employment, is determined by race and class and gender; and then there is something else.

This is what my young Muslim 'friend', Ali, knew when we stood outside of the school office. I had escorted him there in some kind of gesture of racial - outsider - solidarity, but he was culturally an outsider in a way that I never could be. Back then, I thought that Britain was narrating a harsh tale to me about who I was; however, I had no idea how caustic the narrative was that Ali was being forced to listen to. I was constantly being told to, literally, 'Go back to where where you came from', but in reality I did not have anywhere to go back to. Some among my generation did grow dreadlocks and try to retreat into a strangely essentialist black identity and they began to speak of Africa as 'home', but I knew that we were not going anywhere and that we would have to wrestle with Britain to make their story fit our lives. That's what all migrants do, as their plural selves develop, and concessions are made to the new nation while they decide, as time moves on, which of their cultural traditions to hold on to and which they can discard without brutalizing who they are. In other words, while they decide how, and at what pace, they will adapt. 
As England was colouring itself, Ali and his family were obviously hearing the same stories that I was subjected to regarding England's desire that we should all go back to where we came from, but Ali did have some essential place of identity to which he could, should he wish to, turn as an alternative to the perceived hostility of British life. On that July morning in 2005, four young British men felt it necessary to reach out and embrace an alternative place by seizing upon an extreme form of Islamic political identity and demonstrating its potency with a series of mindless acts of violence. In order to prevent this happening again, it is absolutely crucial that we think long and hard about what is happening in Europe. The colouring of Britain, and Europe, suggests a radical and permanent change in the appearance of the European continent that is as dramatic as the changes that came with the postColumbian settlement of the Americas, or the European settlement of Australasia. To imagine that one can successfully legislate the pace of this change is to fundamentally misunderstand the human desire to belong, and to dangerously misjudge the human capacity to feel slighted. There are those who are willing to pay the highest price imaginable to resist people who would police their identities. And there are those who will pay the highest price imaginable to secure an identity. The European response needs to be significantly more sophisticated than merely telling people that their traditions are barbaric and that they have to dress differently.

European borders are porous. European nations have been built, have grown, and have been developed by countless waves of people entering countries and slowly learning the language, adapting to the customs, and enriching the national life by eventually learning to consider themselves English, or Dutch, or French, or Belgian. In recent years, this process has been complicated and made more difficult by issues of race. How does one have a black face and be European? This has been one of the great essay questions of my life, and it continues to be a vexing issue at the heart of Europe, but I am an optimist. Despite the statement by Georges Frêche - a French socialist politician who only two weeks ago claimed that he is ashamed, for, according to him, the French football team does not represent France, because there are too many black faces - I remain convinced that this colouring of Europe, so that one can be both black and European, is not something that might happen, it has already happened. However, what if your blackness or brownness comes with a different set of cultural traditions? This is where we now seem to be, and on both sides of the fence the stand-off is filled with violence and distrust. Does it make sense to single out one group and berate them with scant regard 
for any nuances of difference among them, and then panic into legislating against them? Is this going to help smooth the transition in Europe? I think the so-called radicalizing of the man who killed Theo Van Gogh, and the radicalizing of the suicide bombers on 7 July in London, gives us some part of the answer. Of course, vigorously rooting out those who seek to commit random acts of violence against innocent people going about their daily business is part of our social contract. In Britain, we learned just how deadly and destructive this violence can be with the I.R.A. bombing campaign in the 1970 s and 1980s. But we also learned that being dogmatic, and passing restrictive legislation, and not understanding our own history, only slows down the movement towards peace and our ability to both tolerate and cherish diversity in all its manifestations.

My heart sank on the morning of 7 July 2005 when I realized that three of the four suicide bombers were from Leeds. They were people with Yorkshire accents, exactly like the people I had grown up with. Just what had gone wrong with these young British lives? And, of course, I thought of Ali. I thought of his face as his colleagues threw his books out of the bus window; I thought of his silent, dignified, hurt. I felt guilty that, over the years, I had made little effort to try to imagine how it felt to be both British and a Muslim, and I had never stopped to consider how it felt to be called a 'Paki' every day. I was safe in my world where eventually I could wait for coloured footballers, and musicians, and newscasters to emerge and ease my passage into the outer circle of belonging in a still defensive and racist Britain. However, at least for me, the journey was beginning. I was being coloured English, as opposed to my thirteen-year-old classmate Ali.

The truth is, Ali's journey had begun from a far more peripheral place than my own, and clearly the pace of his journey would be glacial compared with my own meandering. In the years that have passed, both of us have witnessed significant changes in English life; for instance, legislation has been put into place which outlaws the use of racist language in public discourse, but those on the right have simply replaced their 'paki-bashing' discourse with an antiMuslim rhetoric delivered with a wink and a nudge, for they know full well that they are still targeting non-white people. Nominally, at least, I am not affected by such anti-Muslim rhetoric, but Ali and his family remain in the front line of attack, and, this being the case, I am not sure how much real progress has been made. I often wonder what happened to Ali, and if he ever did complete the journey or if, like the three young Muslims from Leeds, the effort of trying to belong, and the pain of moving slowly into England, caused 
him to suffer from some sort of assimilation fatigue that eventually led him to simply abandon the whole enterprise. Did Ali get fed up with being called 'Paki', and being told that he and his family must dress like English people, and not speak their own language, and knock it off with that Mosque prayer stuff, and stop cooking their smelly food? Back then, as a thirteen-year-old, I instinctively knew that some part of me was Ali; I knew that in a time of crisis there is no 'us' and 'them', there is only 'we', and we must obey the moral directive to communicate with each other.

I hope that Ali, unlike the three Leeds Muslims who died on 7 July, has not given up on Britain. I hope that over the years he has learned to cultivate a temporary deafness to the knee-jerk proclamations of various politicians and the bitter hostility of thugs who understand neither what is, nor what is inevitable. Successful integration does mean that immigrants adapt to the new country, but it also means that the new country adapts to them. It demands that the residents cultivate the capacity - and courage - to change their ideas about who they are. For this to work, it is not just those who go to the mosque and who wear headscarves that have to look at themselves. Those who eat fish and chips and drink beer or wear clogs or berets have to look at themselves, too, they have to look into a mirror and realize that they live on a continent that is in the midst of radical change, and no amount of violence from right-wing racists, or fundamentalists of any stripe, or rhetoric from politicians, or cant from the media is going to halt this change. This transition is as inevitable as the sun rising in the morning and setting in the evening; the only question is, what kind of day are we going to have?

Europe is no longer white and never will be again. And Europe is no longer Judaeo-Christian and never will be again. There are already fifteen million Muslims in the European Union, and the figures will grow. All of us are faced with a stark choice. We have a choice; we can rail against European evolution, or we can help to smooth its process. And, if we choose the latter, the first thing we must remind ourselves of is the lesson that great fiction teaches us as we sink into character and plot and suspend our disbelief; for a moment, 'they' are 'us'. I believe passionately in the moral capacity of fiction to wrench us out of our ideological burrows and force us to engage with a world that is clumsily transforming itself, a world that is peopled with individuals we might otherwise never meet in our daily lives. As long as we have literature as a bulwark against intolerance, and as a force for change, then we have a chance. Europe needs writers to explicate this transition, for literature is plurality in action; it embraces and celebrates a place of no truths, it relishes 
ambiguity, and it deeply respects the place where everybody has the right to be understood, both the thirteen-year-old boy whose books are thrown out of a bus window and the boys who are throwing the books, and it judges neither party, in the hope that by some often painfully slow process of imaginative osmosis one might finally recognize what passed before one's eyes today, what occurred yesterday, and what will happen tomorrow, and it implores us to act with a compassion, born of familiarity, towards our fellow human beings, be they Christian, Jew, Muslim, black, brown, or white. This truly is my hope for Europe, and I know that the writer has a crucial part to play in this. I believe this. And this only. 


\title{
Caryl Phillips and the Question of Political Identity Wrestling with Prejudice
}

\author{
KIRPAL SINGH
}

WANT TO BEGIN BY SAYING THAT TO DELIVER A KEYNOTE on this wonderful writer whose work we are celebrating today is both an honour and a pleasure. But we cannot celebrate works without also having a sense of the vision behind these works. In what follows, I want to seek your indulgence as I try to journey through some of the very subtle and complex terrains which Caryl Phillips has himself traversed in the twenty-five and more years that provide the focal point for this conference. For, how does one even begin to locate when a writer's voice starts, and how does one negotiate around T.S. Eliot's famous statement "in my beginning is my end"? 1 Was Eliot just being poetic or simply provocative or very profound? These are questions which we may equally apply to Phillips's writings. As I journey along I will do so in my own peculiar fashion and you, my audience, must indulge me, because we are dealing with a writer whose honesty and moral courage are daunting. I'm going to say a few things which I think must be said if we are to come anywhere close to truly responding to Phillips's works with the kind of sensitive feeling and emotionality that I believe he fully deserves and demands. Thus, for example, I used the words 'honour' and 'pleasure' in my opening remarks. Although these terms are very often used in conjunction, what our author seems to suggest is that this combination is not necessarily appropriate in all cases. Louis Armstrong, for instance, might have considered it an honour to play and be invited to play here and there, but the pleasure he might have got from such invitations may provide very dif-

${ }^{1}$ T.S. Eliot, “East Coker,” Four Quartets (1945; London: Faber \& Faber, 1959): 23. 
ficult or, indeed, problematical spaces for us and especially for our author, because the conjunction of honour and pleasure depends on a host of factors which, Phillips reminds us, we definitely need to consider and even probe. Ours is an age that has learnt to collapse many different viewpoints and their implications into one over-arching perspective which is supposed to convey the utter complexity of dealing with these difficult and awkward aspects of our living and thinking, but in doing so, what truly takes place is a blurring of sensibilities. While I do not want to suggest, even for a moment, that such formulations spring directly from our inability to challenge and change the language of the corporate world, I do harbour a sneaking suspicion that this need to 'collapse', compress together, as it were, conflicting viewpoints is an aspect of the highly smooth manner in which the corporate world conducts its business. The works of our author singly and collectively document transactions which provide commercial success but which at the same time betray some dark recesses of our human inheritance. Most certainly, both of the keywords in my title - Identity and Prejudice - are frequently glossed over by those in positions of power, and sometimes these words are simply compromised. Given the high stakes involved, this should not surprise us. But an inner voice, that small but unending reminder that behind all our endeavours ought to be the knowledge that we are first and foremost human beings, constantly and consistently nags us and makes us feel guilty whenever such positions obtain and blight our perceptions.

In 1977 I attended a conference hosted by the English Department of the University of Queensland, in Australia, where the well-known Fijian writer Satendra Nandan was speaking. He was a young man then - we all were - but the title of his paper has always been in my mind, most of all these days, when the urgencies of the world beg for sanity and for all the help anyone can give to make sure we don't all kill ourselves. Nandan's title was "The Artist as Healer." I believe that healing is what Phillips wants us to do, but can there be healings without pain, without punishment, without opening up again those very wounds we are trying so desperately to heal? Phillips has said that violence is the first refuge of desperate men, and probably of women too, particularly in the sexual sphere, because it is a sphere that makes us uneasy and that, therefore, we are always afraid of discussing frankly. Every day we read about sexual violence and witness it on TV: what we don't often read about and watch is the perverse violence that enacts itself in sexual encounters between men and women of different ethnicities, even though it is sometimes represented in pornographic films as a pathetic demonstration of 'see what I 
can do to you which your men (women) can never dream of doing'. Unfortunately, in reality too, boys and girls, men and women sometimes try and act out such ugly sexual power-plays. A relative of mine living in England became the unwitting victim of such violence. Thinking that the Pakistani boy who wanted to sleep with her was well-intentioned, she secretly agreed to the encounter, only to realize that not just the boy alone but two of his friends also were to force themselves upon her. When the dastardly display of overt sexual prowess was over, the boy left, but not before telling her, "See what a great time we Pakis can give you stupid Sikh women." I don't have to tell you just how deep the scar of that incident has gone - and my relative cannot be the only victim of such ugliness. And it would be both totally silly and hugely wrong to think that the harm of such events only affects those most immediately present; these incidents have a way of travelling round the world and showing their horrific realities to all.

To go back to Satendra Nandan: what he was attempting to say in his paper was that it is not enough for the artist to narrate; he or she must make it his or her responsibility to narrate with kindness, compassion, and a desire to heal the sores and the wounds which some people would rather just lick. No matter how such 'licking' is done, Nandan says that wounds don't and won't heal unless a concerted attempt is made in that direction. A mere description of the hurts, scars, violence - no matter how accurate, how frighteningly or sensitively presented - is not going to suffice if we want and hope for art to make amends and attempt to create a better, more harmonious world.

The African diasporic worlds have formed the bedrock of the subjectmatter that Phillips has written about for more than twenty-five years. On the other side of the world, fellow author Nandan addresses comparable issues, but he, unlike Phillips, is writing about the Indian diasporic worlds and about the migration which brought thousands and thousands of indentured labourers to places such as Fiji, Mauritius or Malaya, so that the economy of Mother England might flourish. For me, personally, it has been a great blessing to watch how writers like Phillips and Nandan have attempted to educate us about these similar and yet vastly different inheritances. There is, of course, no way in which the Indians who were taken to islands like Fiji experienced the sufferings which the Africans experienced as they were transported to the Americas. But then, who is to measure suffering? And how can one empathize with human pain when everywhere there are allegations of fraudulent histories being manufactured? 
Even as I say this, my mind goes back to my own education, wherein I was taught that Jane Austen was one of the greatest writers who has ever walked this earth because she made this little square inch of ivory her very home in art. $^{2}$ Well, as I grew up and I read, I realized that Austen's small bit of ivory, so well perceived universally by almost everybody I knew and know, had precious little to say about the horrors of exploitation which were taking place as she was writing her six famous novels, especially Mansfield Park. This novel is particularly appropriate to our discussion of Phillips's work, for Austen's book is deeply concerned with money, yet hardly comments on the fact that the riches of the Price family come from the labour of the slaving thousands in the West Indies where the father, the gentleman of the family, had yast interests that sustained his economic wealth. It is to precisely such subtle irony, I want to suggest, that our author draws our attention, but he also does much more.

Because Caryl Phillips has made the east coast of the USA his home in recent years, I would like to share a small narrative which bears heavily and very sadly upon some of the themes he explores in his various works. As I was thinking about this keynote, I heard over the BBC a report that an African-American bridegroom-to-be was shot dead by several policemen in Queens in New York (fifty shots were fired) because he and his friends had behaved in a 'very suspicious' manner. Of course, these men tell no tales, because they are dead! When I was much younger, I used to hear people say that in the armed forces it is almost a given that if one is to use a gun it should be used to kill, because, precisely, dead men tell no tales. The New York incident took place, I believe, about a week ago. So, has much happened since our friend Rudy Williams was writing from his prison cell? ${ }^{3}$ Have the dogooders and all those other blessed ones who believed in the goodness of human nature to redeem evil been able to rescue the situation? Have we, the educated and perhaps the enlightened, been able to do much to redress the balance in favour of the downtrodden, the repressed, the suppressed, and the oppressed? Ours is an age given to counting its blessings, but such are these blessings that the very language we use is becoming debased, corroded, and corrupted by the interesting spins used by the strategists on the side of those

\footnotetext{
${ }^{2}$ This is a reference to Jane Austen's description of her writing as "the little bit (two Inches wide) of Ivory on which I work with so fine a Brush.” See Jane Austen, Selected Letters, ed. \& intro. Vivien Jones (Oxford World's Classics; Oxford: Oxford U P, 2004): 198.

${ }^{3}$ Rudy Williams is a character in Phillips's Higher Ground (London: Viking, 1989).
} 
in command. Against these spins, of course, comes the spinning of our writers, but because they transcend the popular imagination their spinning will take a long time to complete the work they embarked upon. And even then the real meanings may never be understood, as it is not the business of art, especially good, potent art, to make itself easily accessible and transparent. Not that creative artists deliberately want to block the common folks from understanding, but if art is to survive the simplistic onslaughts of basic, literal meanings, then it must, of necessity, demand educated readings - and, sadly, these are rare and getting rarer still.

In November 2006, Phillips gave a keynote address at the University of Münster, during an international conference discussing fundamentalism and literature. In this address he alluded to former President Bush's use of "bring 'em on" as one instance of what our writer considers to be the dangerous new rhetoric which language allows its abusers to employ, In the same lecture he also talked about people sitting in a circle, listening to the storyteller whose tale enchants but does not lead to any action, at least not any meaningful action that might change the course of events. Although Phillips obviously had scenarios such as the Iraq war in mind, I think the message is a much larger one. Are writers listened to for real education or for mere titillation and some entertainment? As the twenty-first century plunges us deeper into an age of confusion and anxiety and as we reel away from truth and shudder from the blistering realization that so much of the misery we see is caused by the direct misapplication of faith, we begin to get a sense, merely a sense, of the larger challenges our times are thrusting our way. And, yes, in case you have not really believed this so far, a writer like Phillips is trying his best to educate us so that we might yet save ourselves from a tyranny of our own making: that of interracial abuse.

The introduction to $A$ New World Order concludes with a scene where a meditating Phillips is left on his own by a hotel waiter, supposedly to allow the writer to grieve for his lost princess. ${ }^{5}$ Although the obvious princess of this anecdote is Princess Diana, we all grieve for each of our own individual princesses; beautiful lives dominated by the brutality of a world which has steadfastly refused to understand what it blatantly knows: the overpowering of the weak who also happen to be beautifully gifted and talented. I'm here

\footnotetext{
${ }^{4}$ Caryl Phillips, "American Stories, American Silence," Literary Encounters of Fundamentalism: A Casebook, ed. Klaus Stierstorfer \& Annette Kern-Stahler (Heidelberg: Winter, 2008): 13-21.

${ }^{5}$ Caryl Phillips, A New World Order (London: Secker \& Warburg, 2001): 6.
} 
thinking ruefully over the sad and the blighted existence of people like Rudy Williams in his prison cell, trying desperately to bring a sense of reality to those he loves and cares for, but on whom he has little influence. In this sense, Rudy is like our distinguished author, who writes searingly, knowing very well that so many out there would want him to say things, remember things, differently. For the world has come to a state in which those of us who feel committed to narrating and telling truths (whether collective or individual) often find ourselves at the feet of temptation. Be gentle, temptation says, compromise, tell your stories but embellish them a little so the reminders, the meanings, elude real defence: glory in exchange for a certain kind of silence.

In a revealing article published in the Guardian some years ago, Phillips recounts his experience of knowing Angela Carter and, via Carter, the Japanese writer Natsume Soseki. ${ }^{6}$ Phillips takes his own journey to Japan, experiences a different world, and raises issues about individual identity and nationalistic expectations - issues that continue to prove disturbingly haunting as we observe the tragedy taking place all around us. Phillips wonders if one possible solution for famed writers like himself, Carter, and Soseki is to reconcile the pain of exile with the pleasure of literature. But here, we might raise yet another of those curious but terrible questions which make any easy assessment of such complex phrases highly problematical: will this reconciliation result in our putting on masks? One is reminded of the lyrics sung by the black artiste Bert Williams, whose life Phillips re-imagines in Dancing in the Dark: "I ain't never got nothing from nobody, no time, / and until I get something from somebody sometime, / I don't intend to do nothing for nobody, no time." In other words, I will start caring and worrying about the world when the world starts to care and worry about me. A user-value proposition. I know that this is, indeed, the underlying agenda of many of today's generation. This agenda is alarming precisely because it might draw attention to the powerlessness of literature to teach and change attitudes. Our ingrained selfishness, it would appear, is here to stay.

The world has its uniquely attractive way of seducing men and women of talent by shifting their true energies from the substantive to the superficial, and this, says our author, belittles all of us, because it makes us realize that in willing the world's attention we lose yet another fundamental part of our

\footnotetext{
${ }^{6}$ Caryl Phillips, "Finding Oneself at Home," Guardian (21 January 2006): http://www .guardian.co.uk/books/2006/jan/21/fiction.angelacarter (accessed 15 December 2009).

${ }^{7}$ Bert Williams, "Nobody" (Attucks Music, 1906).
} 
humanity. Rudy's section in Higher Ground represents for me one of the numerous high points that Phillips skilfully shares with us by rendering so many of our assumptions suspect. And suspect precisely because language has been so manipulatively utilized to lead us to believe that all is well under God's beautiful pencil. The old Browning adage "God's in his heaven [and] All's right with the world" ${ }^{\prime 8}$ stares at us weakly today, mocking us as we tread our different paths without any genuine understanding of the stark realities around us: realities we would rather not acknowledge, because acknowledging means having to do something about the dismal state of affairs - and we have nothing, truly, to plot and chart a concerted action-plan.

Because everyone in this room has probably read most of Phillips's writings, I don't think I need to go into detail and dwell on the many instances where the intricate relationship between religion and money-making is subjected to critical scrutiny in a manner which disillusions anyone who seriously believes in the virtues of the one and the evil of the other. Religion and business always went hand in hand, perhaps still go hand in hand, Phillips reminds us. His telling narrative in The Atlantic Sound merely helps to anchor this intriguing nexus in a world which can't seem to eliminate corrupt practices. Indeed, again and again, the writer explores the ways in which religion both brought about a certain measure of good and, in its very wake, also a large measure of bad, as the entire history of slavery testifies. The bond, say, between Edward and Nash in Crossing the River is but one of the many instances when doing good, doing God's work, and doing business all get mixed up and messed up, with tragic consequences. Of course, attention has been drawn to the fact that Nash is like the Kurtz of Conrad's novella Heart of Darkness: ${ }^{9}$ both are men sent out with visions of grandeur and glorious change but who die with their ambitions and missions totally 'screwed up'. Approximations of such failures find their way into our media practically every day or week.

In talking about his meeting with Chinua Achebe, Phillips strikes a small ambivalent chord in terms of how he and Achebe view Conrad's Heart of Darkness. ${ }^{10}$ Such ambiguity also extends to other writers like George Orwell

\footnotetext{
${ }^{8}$ Robert Browning, "Pippa Passes" (1841), in The Poetical Works of Robert Browning (London: Humphrey Milford/Oxford U P, 1940): 171.

${ }^{9}$ Joseph Conrad, Heart of Darkness (1902), in Heart of Darkness and Selections from The Congo Diary (New York: Modern Library, 1999): 1-96.

${ }^{10}$ Caryl Phillips, "Out of Africa," Guardian (22 February 2003): http://www.guardian .co.uk/books/2003/feb/22/classics.chinuaachebe (accessed 15 December 2009).
} 
and Graham Greene. Phillips muses that Orwell, too, though British by citizenship and upbringing, was born outside of England. So the question of identity and race gets confused and confusing. At least Phillips and Achebe agree that Greene shows more respect for the Africans than Conrad because his hidden agendas are less prejudiced. We note in passing that Phillips's unease about Achebe's strong attack on Conrad does not diminish his admiration for this great African novelist, for whom colonization meant "things falling apart" so badly that no "man of the people" could successfully rescue the colonized without being severely punished and destroyed. It is also worth noting that, though the specific discussion of Achebe's attack on Conrad is now an historical classic, few scholars today seem to want to venture, as Phillips has done, into this blighted territory with its waters full of crocodiles.

I read and re-read J.M. Coetzee's essay on Caryl Phillips in preparation for this talk and I was myself reminded of the quotation from Frantz Fanon, who tells of a teacher warning him as a boy, "whenever you hear anyone abuse the Jews, pay attention, because he's talking about you." Incidentally, Coetzee's insightful essay concludes with the stronger assertion that all of Phillips's diverse works rotate around a single unifying theme: "remembering what the West would like to forget." ${ }^{, 12}$ Yet it is precisely this re-membering that hurts and scars. He was a wise man who said that those of us who forget our history are condemned to repeat it. And repeat our various histories we do, inevitably, because the world prefers to have us make the same mistakes than really learn from them. If we learn, so the world seems to be saying, then something gets taken away, as it were, which somehow takes the steam out of the shenanigans that keep us excited and enraged.

Phillips has stated that it was the writing of Higher Ground that made him think and meditate on the question of the writer's responsibility. ${ }^{13}$ We know that 'responsibility' is an old-fashioned word. And much of contemporary literary discourse, with its jargonizing and phrase-forming - I'm always bemused by phrases such as "the sites of contestation" - has little or no time for these kinds of inclusive larger perspectives on literature. But for this very

\footnotetext{
${ }^{11}$ Frantz Fanon, Black Skin, White Masks, tr. Charles Lam Markmann (Peau noire, masques blancs, 1952, tr. 1967; London, Pluto, 1982): 122.

${ }^{12}$ J.M. Coetzee, "What We Like to Forget," review of The Nature of Blood, by Caryl Phillips, New York Review of Books 44.17 (6 November 1997): 41.

${ }^{13}$ Caryl Phillips, Conversation with Kirpal Singh, Münster (November 2006).
} 
reason, it is important for us to fathom more deeply why our author is so agonizingly trying to tell us again and again the same refrain: if we do not get the courage to find out the truth of our own history, the truth of our own geography, the truth of our own inheritance, then the writer has to step in to help us. It then becomes his or her duty and responsibility to educate us. And this is not just being arrogant or taking on a role in order to justify one's occupation as a writer. No. The question is one of morality, not of a moral higher ground, pardon the allusion, but of moral courage to confront, face, engage, and, finally and hopefully, lighten and remove the burdens we all carry without fully knowing or understanding their significance in our day-to-day lives. If the KKK is revealed as an organization so tightly structured and organized that even a famous US president is said to have been in its frame, then we all start to recognize and realize just how tenaciously entrenched racist attitudes can be, and often are.

Phillips has told us that his grandfather was Jewish, and perhaps it is this connection running through the 'blood' that made him link the sufferings of the Jews with those of the Africans, and those of African descent. I do not here wish to belittle the complex way in which the four narratives in The Nature of Blood - 'blood' again, if you please - are linked but, more crucially, to note that in connecting the suffering of these two groups of people, Phillips has inevitably compelled us to understand that the two, because of major events in recent history, share a common platform: men's hatred for men, and men's gender-specific exploitation of the silence of women. The very moving stories of Eva Stern, in The Nature of Blood, and of Dorothy Jones, in A Distant Shore, represent, for me, Phillips's making reparation, as it were, to women, who have silently suffered so many different tyrannies. 'Suffering is real', Phillips seems to be saying, 'even when it appears to be casual'. Indeed, much of his writing belies the deepest roots of the issues he wants us to come to terms with. When I studied Othello at university and got to know that old rhyme about this "black ram [...] tupping [the] white ewe" (I.i.89), I realized that a good poetic sensibility of the old world will never be fully rewarded in Venice, because he, Othello of this old world, was trying too hard, and failed. Was it Kipling, another English citizen from outside of England, who told us that "East is East, and West is West, and never the twain shall meet"? ${ }^{14}$ Sure. I believe Phillips will know what exactly it is that I'm trying to communicate

\footnotetext{
${ }^{14}$ Rudyard Kipling, "The Ballad of East and West" (1889), in A Choice of Kipling's Verse, Made by T.S. Eliot (London: Faber \& Faber, 1963): 111.
} 
here, that there are writers whose sense of responsibility tilts in directions from which the world takes a very long time to recover because the signposts are not really clear. Many authors have taken on the aura of being ambivalent and ambiguous, knowing full well that such frames do not enhance the cause of any real sensibility, because they cloud the core of the problem and help to confuse the reader.

Some of this inability to appreciate fully the depth of felt pain is revealed by Phillips when he talks about the new Leeds. ${ }^{15}$ Yes, says our author, Leeds has changed, "England has changed"; ${ }^{16}$ indeed, the whole world has changed, but some things don't change so easily. The picture from the outside might be rosier, but from the inside it is just as sinister. That is quite a daring word to use, 'sinister'. Through much of his work, starting with Strange Fruit, Phillips takes us on several journeys which are marked by the constant presence of the sinister, whether in terms of people, in terms of place, or in terms of events. And it is this insight that serves to alert us to the nuances which characterize his best writing. He relentlessly pursues this theme - our sense of identity in a world which seems loath to acknowledge the real history that drives our attitudes and guides our behaviour. We are, says Phillips, if I understand him correctly, invariably trapped by our historical conditions, and unless and until we accept this, understand this, and learn from this, we will not be able to relate to and with each other with the dignity that each of us deserves. It is a hard and sobering message, but one that must be clearly recognized and understood.

I entitled my address "Caryl Phillips and the Question of Political Identity: Wrestling with Prejudice." Many readers have asked Phillips about his concerns with issues of race, and he has often said that he was more concerned about identity than race. And this is how it should be. Indeed, in recent years, it has become more obvious that political power continues to rationalize about race and identity because of the provisions for a multiracial society, a multicultural community, and so forth. You know, there is someone who said - and this someone knew a thing or two about both politics and race - that man is a political animal, ${ }^{17}$ but has also functions which provide the basis for ethics to enter human life and redeem some of our animal-like character. Yes, we do

\footnotetext{
${ }^{15}$ Caryl Phillips, "Northern Soul," Guardian (22 October 2005): http://www.guardian .co.uk/artanddesign/2005/oct/22/photography.communities (accessed 15 December 2009).

${ }^{16}$ Caryl Phillips, A Distant Shore (London: Secker \& Warburg, 2003): 3.

${ }^{17}$ Aristotle, Politics, tr. Ernest Barker; rev., ed. \& intro. R.F. Stalley (Oxford: Oxford UP, 1995): 10 (I.2, 1253a2).
} 
need an Aristotle to remind us that every gesture, every single thing we do, is political but also at the same time human, and therefore in need of being ethical. Today we continue to wrestle with the broader applications of this simple dictum: how we live as humans who are remembering our animal origins. Even in saying this, I need to qualify myself, for no animal kills for pleasure - perverse pleasure. Indeed, in the animal kingdom, I'm told, it is considered beneath contempt (and here I am anthropomorphizing ethics a little) for an animal to kill another of its kind that has surrendered. Only humans do this. Only humans kill, maim, and torture for the sheer pleasure of letting others know who is in charge and who controls. We do not choose when, how, to be born. Our skin colour is a given. And beneath the skin colour lies our blood. What is tragic is that after so many centuries, we still do not seem to appreciate the meaning embedded in the phrase 'race is only skin deep'. Perhaps now that scientific experiments that can change our skin colour are under way, there is hope that our children might begin to realize the shallowness of basing judgments on the colour of one's skin.

In the early 1980s, Phillips explored the plight of a family caught in a conflict of two cultures. That strange fruit has now ripened into a more mature exploration of a multi-layered conflict, brought about by various complex modalities which, Phillips cautions us, have yet to be fully studied with any degree of real honesty and courage. Why? Because, he says, the truth will hurt those who do not know how to handle guilt and have, indeed, very little inkling of just how terrible it was, or is, to have the supposedly wrong colour and origin. So much more needs to be done before the maturation process can really begin to make a difference. Books, honest articulations of the kind we find exemplified in Phillips, can help us accelerate our education in this respect - but even here we do need to proceed with sensitivity, for explosive possibilities are always lurking very close to the surface.

- How do we learn the fuller meanings of words such as 'belonging', 'home', identity', 'race', 'prejudice'? We may gain a partial answer by considering the case of V.S. Naipaul - Lord Vidia - with whom our author has been compared. Phillips, like the well-known Indian critic Narasimhiah, does not have much sympathy for Naipaul, and I think the reason is plain: behind the gifted writing of Naipaul seems to be a man who appears to have betrayed his origins and compromised much to belong to the Establishment. Perhaps not quite another Conrad, but one who nevertheless embraces, and has been embraced by, dominant presences. The wrestling continues, and, even as we gather to celebrate the genius of our author, Caryl Phillips, out there the dark 
shadows continue to fall on unsuspecting men and women, incapacitated by the ruins of progress and the lure of glittering consumerist cultures. For me, as a product of these currents, and as one belonging to a minority within a minority, the lessons Phillips has been trying to communicate to us through the sensitive lenses he has been blessed with, and through his complex and subtle use of language, are simply impressive. Here is an author who is still relatively young but whose every observation of the world is particularly profound. His work constantly reminds us that the act of writing and the consequent act of reading can, and does, help us to become better human beings.

\section{Afterword}

Since delivering the above keynote in December 2006, I have been even more vividly struck by how Phillips's work seems to speak to my own experience, and brings to mind the case of my five-year-old son, Christopher. He keeps telling me that he does not want to be known as Premshan (his full name as registered on his birth certificate is Premshan Christopher Singh) and that he does not like talking in Chinese. Now, his mother is Chinese (of a minor 'mixed' ancestry - her forebears being also those minority Chinese of South-East Asia known as the Peranakaans) and I, his father, am myself of mixed-race parents, as my father was Sikh and my mother is Scottish. Young Christopher's dawning awareness that he is not a simple this-or-that (of course, no one is - but that's another matter) with its attendant consequences has vast and critical implications for all of us, whether or not we are (in)directly related to him. All over the world there must, today, be millions and millions of Christophers - young, growing boys and girls all becoming conscious of their 'differences' in terms of names, colours, and inclinations. Gone are the days when an individual could easily define him- or herself as clearly being this or that. The very foundations of all our perceptions and sense of values are changing so rapidly and transforming our own conduct so dramatically that even Woody Allen's masterful film Whatever Works (2009), with its witty but powerful depiction of a world in which no one can tell what really is going on - fails to come anywhere near the reality we are all trying so hard to grasp and understand. For a writer such as Phillips, this must, in itself, be a cause both for exhilaration and for dismay. Our author, obsessed as he is and has been with questions of identity, must, surely, now feel these issues to be even more problematical as the world gets to be more 'mixedrace' or just simply mixed-up. In the fascinating essays of A New World Order, what becomes apparent is that Phillips does not seem to think that 
there can be any lasting and serious answers to the question 'where do I come from?' When H.G. Wells wrote The New World Order (1940), he probably didn't realize that his utopian optimism would remain precisely that: utopian. For Phillips, writing after all the events (including the Holocaust) that have taken place post-Wells, the new world order, if it means anything at all, means for human beings to learn preciously how to survive in the midst of racial mixtures and impurities and, more significantly, without any real promise or hope of harmony prevailing among the numerous and diverse human 'types' (a very inadequate word I am here using to describe the multitudes of racial possibilities).

Since 2006, I have also had the opportunity both of talking with Phillips more about the many questions raised by his books and his talks as well as reading Foreigners and In the Falling Snow, which were published in 2007 and 2009 respectively. ${ }^{18}$ There does now seem to be a slight shift in focus: from a frame rather centred on black-white differences, Phillips has now moved to a more complex and variegated frame, namely that of 'mixed-race'. The three compellingly told narratives in Foreigners must not only move many readers to tears of understanding, but one of the book's sections, which recounts the life of the boxer Randy Turpin, also demonstrates remarkably just what it means to be born of mixed race. The other two parts, devoted to Francis Barber (who attended to Dr Samuel Johnson's every need) and David Oluwale (who suffered untold injustice at the hands of racists), are no less memorable. Each, in its own way, invites us to both consider and to share in the complicated sagas that the major players of these stories dramatize. Because my own father was a boxer, I heard a lot about Randy Turpin, both from my father and from his eldest brother Bill, my uncle who really brought me up. And I recall both my uncle and my father telling me how glorious it was to know that the great Sugar Ray Robinson could be taken to task by someone who became a somebody from being a nobody. In somewhat hushed tones not meant for the hearing of a young boy like me, both my father and others would talk about Turpin's origins, occasionally making slight and even snide remarks about the nature of his mixed blood. Later on, I have often asked myself: How can blood be mixed if it is, indeed, red all around? The technicalities of this question notwithstanding, the main stress is on the word 'mixed': for some quaint reason, to be 'mixed' is not a badge of honour - at

\footnotetext{
${ }^{18}$ Caryl Phillips, Foreigners: Three English Lives (London: Harvill Secker, 2007), and In the Falling Snow (London: Harvill Secker, 2009).
} 
least, not for most of Phillips's characters and not for the likes of me. The world, generally, seems to rest easier with directly identifiable types, rather than hybrids, even if we, the hybrids, seem better suited, better qualified, and sometimes even more talented than those who are seen to be 'pure'. We are seen to be 'neither-this-nor-that', existing and wandering around those extremely sensitive nerve-ends of boundaries that preclude rational discourse.

Hence the majesty of In the Falling Snow - for me almost certainly Phillips's best book to date. Here are present not only the recurring themes of much of the writer's work but also an underlying sensitivity, almost surreal and sublime (sometimes even sublimated by the unique characterization), which leaves at least me in awe. For, how does one begin to talk about the likes of Keith and Annabelle and their children and all the traumas of race and identity that they go through, either singly or collectively? Here is the novel's opening sentence: "He is walking in one of those leafy suburbs of London where the presence of a man like him still attracts curious half-glances.",19 And the last sentence of the terse opening paragraph reads: "It is painfully clear that, as far as some people are concerned, he simply doesn't belong in this part of the city. ${ }^{, 20}$ The novel is a moving testimony to the plights of individuals condemned by their race and/or by their refusal to recognize race: both types suffer, and it is this anguish, this inner suffering, that, at the core of the novel, informs us of the author's uneasiness about the future of us mixedup human beings. Phillips has not stopped his quest to calm the demons demanding that he search for that inner peace befitting the individuals who are prepared to travel out of their comfort zones in order to assert, or even just find, their real selves. There are no simple solutions either to Phillips's quest or to the riddles the quest invariably puts across to us. As I re-read this beautiful biography, almost, of one man and his journey towards self-realization, I feel a sense of identification, because I could be Keith. In today's globalized world it matters little if the cosmopolitan city we are discussing is London or New York or Frankfurt or Shanghai or Singapore: what matters is how each of these great cities enables mixed types to feel at home. And our children, too. Because it is generational and historical - this theme of identity being affirmed and confirmed for us through our race, essentially through our skin colour. In a long essay written for the New Republic some years ago, Phillips underlined the observation that our skin colour is something we are just born

\footnotetext{
${ }^{19}$ Phillips, In the Falling Snow, 3.

${ }^{20}$ In the Falling Snow, 3.
} 
with, something that we just have to live with, something that is beyond us, something given which we cannot change and therefore something for which we should not be held responsible or punished. ${ }^{21}$ Notwithstanding the late Michael Jackson's slow but certain transmogrification, even if we could change our skin colour, would we be fully integrated? I am afraid that, so long as human memory remains what it is, the honest answer to this question must be only, at best, a very small and even then tentative, yes. For our birth and context seem determined to follow us everywhere. Admittedly, there is real progress here - more and more of our young are intermarrying and, like Keith and Annabelle, trying their damnest to solve and resolve differences. But the task is huge and the journey precarious, teeming with shocks and horrific experiences.

So I need to end my text here with the not-so-happy conclusion that for Caryl Phillips the same question about which he has been writing these past twenty-eight years or so remains very much at the centre of his explorations. This, while sustaining his creative energies, does not say much about human progress, for it means that we humans are stubborn creatures who find it hard to be generous, kind, sensitive, compassionate, no matter how much education we have received and no matter how much we try and rationalize our actions and attitudes. The very stuff of our relationships seems to be corrosive, slowly but surely gnawing away at the precise emotionalities wherein could reside our salvation. Phillips is not sentimental, and few, if any, of his major characters indulge in commonplace sentimentality. But, as a reader, deeply impressed by what I read and by what my reading tells me, I crave some sentimentality - at least it provides me with the illusory but necessary sense of escape. If this seems contradictory, since 'escapism' is never a real answer and our author would baulk at such a naive suggestion, it is necessary and important to conclude by reminding ourselves of the urgency with which Phillips addresses all the multi-layered questions we have been discussing. For Phillips, as for us, if we do not check our impulses and irrational actions, such as hurting those who are simply different from us by virtue of their skin colour (as witness the recent attacks on Indian students in Melbourne, Australia), or those who prefer to exercise a different faith in terms that some of us may find objectionable (as witness the attacks on churches in Malaysia because of

\footnotetext{
${ }^{21}$ Caryl Phillips, "The Enigma of Denial," review of Between Father and Son: Family Letters by V.S. Naipaul and Reading and Writing: A Personal Account, by V.S. Naipaul, New Republic 222 (29 May 2000): 43-49.
} 
the use of the word 'Allah' by Christians to refer to God), then humanity will have an extremely heavy price to pay. There is still hope; but precious time is running out.

\section{WORKS CITED}

Aristotle, Politics, tr. Ernest Barker; rev., ed. \& intro. R.F. Stalley (Oxford: Oxford UP, 1995).

Austen, Jane. Mansfield Park (1814; London: Oxford U P, 1970).

- Selected Letters, ed. \& intro. Vivien Jones (Oxford World's Classics; Oxford: Oxford UP, 2004).

Browning, Robert. "Pippa Passes" (1841), in The Poetical Works of Robert Browning (London: Humphrey Milford/Oxford U P, 1940): 165-85.

Coetzee, J.M. "What We Like to Forget," review of The Nature of Blood, by Caryl Phillips, New York Review of Books 44.17 (6 November 1997): 38-41.

Conrad, Joseph. Heart of Darkness (1902), in Heart of Darkness and Selections from The Congo Diary (New York: Modern Library, 1999): 1-96.

Eliot, T.S. "East Coker," Four Quartets (1945; London: Faber \& Faber, 1959): 23-32.

Fanon, Frantz. Black Skin, White Masks, tr. Charles Lam Markmann (Peau noire, masques blancs, 1952, tr. 1967; London, Pluto, 1982).

Kipling, Rudyard. "The Ballad of East and West" (1889), in A Choice of Kipling's Verse, Made by T.S. Eliot (London: Faber \& Faber, 1963): 111.

Phillips, Caryl. "American Stories, American Silence," in Literary Encounters of Fundamentalism: A Casebook, ed. Klaus Stierstorfer \& Annette Kern-Stahler (Heidelberg: Winter, 2008): 13-21.

. The Atlantic Sound (London: Faber \& Faber, 2000).

—. Conversation with Kirpal Singh, Münster (November 2006).

. Crossing the River (London: Bloomsbury, 1993).

. Dancing in the Dark (London: Secker \& Warburg, 2005).

- A Distant Shore (London: Secker \& Warburg, 2003).

"The Enigma of Denial," review of Between Father and Son: Family Letters by

V.S. Naipaul and Reading and Writing: A Personal Account, by V.S. Naipaul, New Republic 222 (29 May 2000): 43-49.

. "Finding Oneself at Home," Guardian (21 January 2006): http://www.guardian .co.uk/books/2006/jan/21/fiction.angelacarter (accessed 15 December 2009). . Foreigners: Three English Lives (London: Harvill Secker, 2007).

Higher Ground (London: Viking, 1989).

—. In the Falling Snow (London: Harvill Secker, 2009).

- The Nature of Blood (London: Faber \& Faber, 1997).

—. A New World Order: Selected Essays (London: Secker \& Warburg, 2001). 
"Northern Soul," Guardian (22 October 2005): http://www.guardian.co.uk /artanddesign/2005/oct/22/photography.communities (accessed 15 December 2009).

. "Out of Africa," Guardian (22 February 2003): http://www.guardian.co.uk /books/2003/feb/22/classics.chinuaachebe (accessed 15 December 2009).

- Strange Fruit (Ambergate: Amber Lane, 1981).

Wells, H.G. The New World Order (London: Secker \& Warburg, 1940).

Whatever Works, dir. Woody Allen (Sony Pictures Classics, US A/France 2009; 92 min.).

Williams, Bert. "Nobody" (Attucks Music, 1906). 


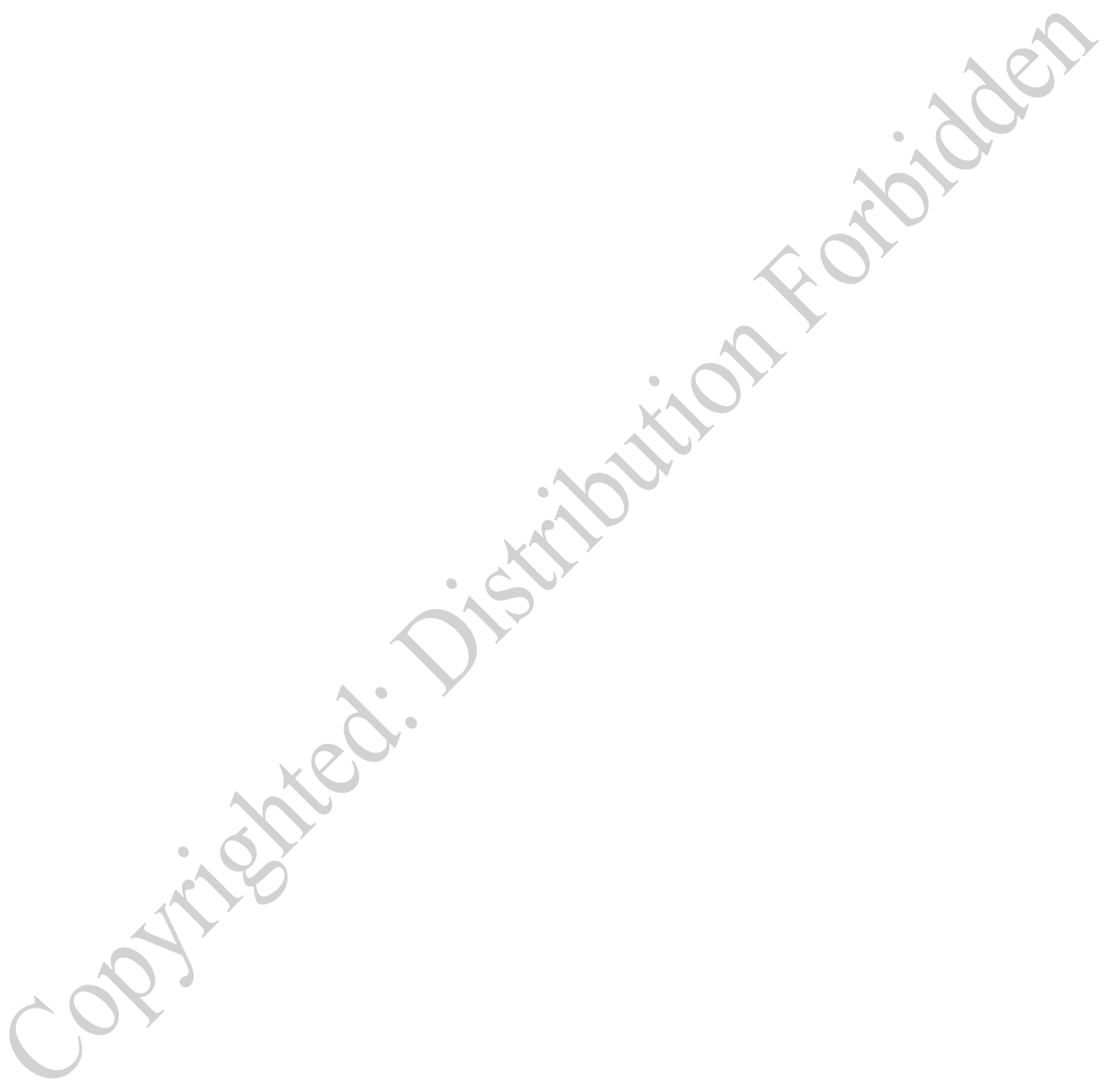


CRITICAL ESSAYS 


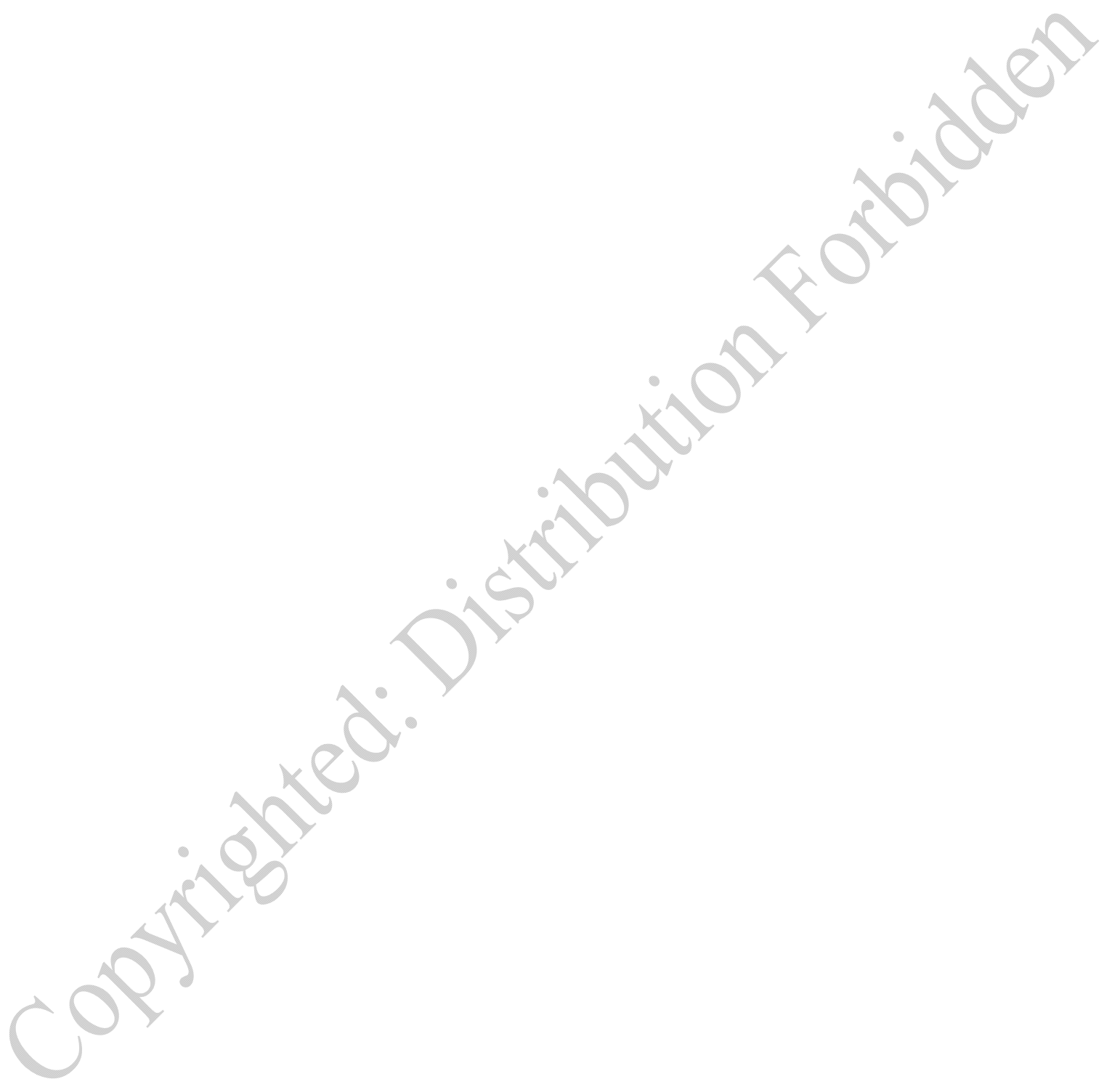


AUtobiography, FACT, AND FICTION 


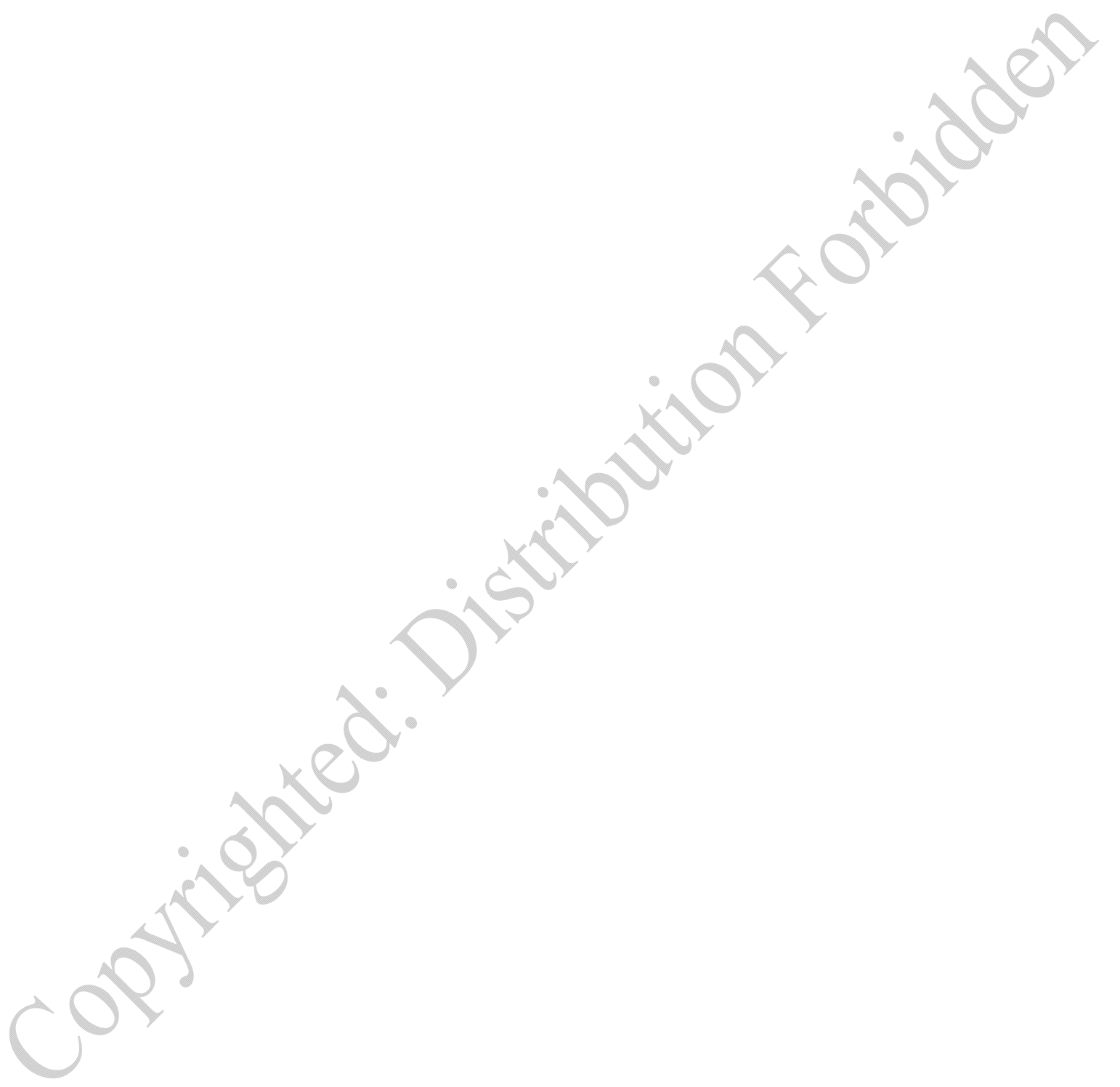




\title{
Conversations with Caryl Phillips Reflections upon an Intellectual Life ${ }^{1}$
}

\author{
Renée Schatteman
}

$\mathrm{T}$

HE NEW YORK TIMES has described CARYL PHILlips as one of the great literary giants of our time, ${ }^{2}$ an appraisal supported by the sheer number of novels, plays, screenplays, anthologies, radio and television drama and documentaries, and essays he has produced in his more than twenty-five years as a writer and by the broad scope of his interest in issues concerning belonging, identity, and dislocation as they are manifested in multiple points of the African diaspora. Born in St Kitts in the West Indies, raised in England, and currently residing in New York City, Phillips has a history that makes him uniquely positioned to address these concerns. Having experienced the 'unbelonging' that was imposed on Caribbean immigrants in England in his early years and having devoted his later years to the exploration of dislocation and homelessness, Phillips uses both his fiction and his non-fiction to imagine the lives of people least represented in history, even though they are often the most adversely affected by historical circumstances. His resulting works, in particular the nine novels and four works of non-fiction he has written to date, have firmly established him as one of the most important and talented writers of the late-twentieth and early-twenty-first century.

Since 1987, Phillips has given some fifty interviews that have appeared in a wide range of scholarly journals, newspapers, magazines, online sites, and increasingly - the popular media. He is an ideal interviewee: articulate, col-

\footnotetext{
${ }^{1}$ This is a slightly revised version of the introduction to Renée T. Schatteman, Conversations with Caryl Phillips (Jackson: UP of Mississippi, 2009): ix-xviii.

2 George Garrett, "Separate Prisons," New York Times Book Review (16 February 1992): 25.
} 
legial, sincere, charming, and witty. A social being who appreciates the camaraderie of others, he has an easy informality about him that causes many of the interviews to resemble a good conversation between friends at a pub, and, in fact, a number of the shorter ones actually were conducted in such a setting. At the same time, Phillips is always completely serious about his writing, answering each question he is asked with a precision and intelligence that speak to his deep knowledge about and commitment to his subject-matter. When I asked him why he is so willing to answer questions about his work, he responded that he appreciates the clarifications that can emerge about the purpose and direction of his writing from a conversation that consists of tough, far-reaching questions. He explains:

it gives you an opportunity to think about what you really think about [a] subject, about an author, about a particular book, about yourself, about your own development - questions that I never ask myself when I'm sitting at my desk. ${ }^{3}$

The resulting interviews and profiles can be viewed as Phillips thinking aloud and can be used as important supplements to his writing, for they contain his insights into the factors that have motivated his career and inspired particular texts as well as his understanding of the aesthetic and thematic concerns that make up his writing. As such, the interviews open up new interpretative spaces for understanding the many writings that make up his oeuvre while providing illuminating connections between Caryl Phillips the writer and Caryl Phillips the man.

This willingness to speak so freely about his work may seem out of character for a writer who, by his own admission, remains largely inconspicuous in his writing. As he comments to Louise Yelin when asked about where he positions himself in his novels, "I' $m$ not present, the characters are totally in the fore, I' $m$ invisible. [...] I hide behind the characters and let them have the issues." Phillips has offered multiple reasons for ceding centre stage to his characters and refraining from authorial commentary: to avoid polemic, to seek out understanding rather than judgment, to provide room for his readers to dwell in the gray areas, and to let his characters have a voice, since they are so frequently excluded from other, more official narratives. This tendency to

\footnotetext{
${ }^{3}$ Caryl Phillips, "Caryl Phillips: Reflections on the Past Twenty-Five Years," by Renée Schatteman, Conversations with Caryl Phillips, 169-70.

${ }^{4}$ Caryl Phillips, "An Interview with Caryl Phillips," by Louise Yelin, Culturefront 7.2 (1998): 80.
} 
stand in the wings is in keeping with certain elements of Phillips's public persona, for, while he is strikingly open about this intellectual life, he carefully guards his personal life and avoids anything that smacks of celebrity. As he tells Charles Wilkin,

people are always very interested in the lives of artists, of painters, musicians, writers, poets; they want to know the man or the woman behind the work. I'm quite reluctant to let things drift in that direction. ${ }^{5}$

When considering an entire body of interviews given over a period of more than twenty years, one might expect that the shifts over time would prove the most interesting, but that is not the case with Phillips. What is most striking is the consistency of his reflections and the particular points that are repeated, albeit in a variety of forms. This consistency is most obvious in his recollections of his personal history. Phillips holds no cloak of privacy over his past as he does his present; instead, he is particularly forthcoming, especially about those touchstone moments that were critical to his identity-formation. His recollections, which work their way into nearly all of his interviews to some degree, are focused on three specific times in his life: his early years as a black youth growing up in a white working-class neighbourhood in Leeds, his university years when he was a student at Oxford and made his first trip to the USA, and his return to the Caribbean in his twenties, especially his first visit there since his original departure at only three months of age. The fact that memories from his past have had such resonance gives credence to Stephen Clingman's point about the striking degree "to which the personal, the biographical, and [the] writing are interlinked" in this author's work. ${ }^{6}$

Phillips has never softened the recounting of his childhood. As he tells Maya Jaggi,

objectively, my childhood was massively dysfunctional and traumatic. I have

no happy memories of it. But I never felt deprived; I played with the cards I

was dealt. ${ }^{7}$

The causes of his trauma were multiple. Being from the only black family in a white community, he suffered the verbal and physical abuse of being chased

\footnotetext{
${ }^{5}$ Caryl Phillips, "Interview with Caryl Phillips," by Charles Wilkin, WINN FM, 23 December 2002 (Basseterre, St Kitts), in Conversations with Caryl Phillips, 119.

${ }^{6}$ Caryl Phillips, "Other Voices: An Interview with Caryl Phillips" (October 2001), by Stephen Clingman, Salmagundi 143 (2004): 113.

${ }^{7}$ Maya Jaggi, "Rites of Passage," Guardian (3 November 2001): 6.
} 
down the street by other boys, the emotional turmoil of being best friends with someone one day and ignored the next - an event he says that "was often tinged with racial overtones"8 - and the discomfort of being torn between a British and West Indian culture. He also faced challenges in his home setting that added to the precariousness he felt as the child of immigrants in the outside world. He felt confusion about his Caribbean heritage because his parents, who were of the pioneer generation, were anxious to root themselves in England and consequently did not talk about back home. This was particularly difficult, he tells Pico Iyer, because Leeds was

a very kind of rooted part of England, very working class, extended family.

A place where everybody is going to see their mam, their gran, or their aunt

[...]. I had my mother, and my father, and my brothers, and that's it. So, the primary displacement I felt was growing up in such a tight community without a sense of extended family. ${ }^{9}$

Home was made even more elusive for Phillips when his parents divorced and afterwards when his mother struggled with serious illness. For a period of time, he and his brothers had to be fostered out, or, as he expressed it, "cargoed around between white families in the north of England,"10 and later he lived with his father from the ages of fourteen to eighteen, also due to his mother's health problems.

Phillips's childhood was also one in which gender and class figured prominently. Growing up working-class in England determined his identity as much as did his race, and living primarily in a female-ruled household made him especially sensitive to the struggles of his female characters. Various interviewers have commented on Phillips's ability to successfully capture female voices, and he himself admits to being drawn to women's viewpoints because they are often more honest, impassioned, and complex than men's and because gender issues are so inextricably tied to issues of race and class. Describing his childhood as a time of profound silence about his identity, he suggests that this deprivation led him to use his writing to give voiceless people a chance to tell their own stories and consequently write themselves into history. Additionally, he often makes note of the importance of his learning

\footnotetext{
${ }^{8}$ Caryl Phillips, "Disrupting the Master Narrative: An Interview with Caryl Phillips," by Renée Schatteman, Commonwealth: Essays and Studies 23.2 (2001): 100.

${ }^{9}$ Caryl Phillips, "Caryl Phillips," interview with Pico Iyer, Lannan Foundation, Director Dan Griggs, 1995, in Conversations with Caryl Phillips, 38.

${ }^{10}$ Jaggi, "Rites of Passage," 6.
} 
about antisemitism and the Holocaust as a teenager because he could finally relate the hardships of his own life to a people's story, even if it was not his own people or his own story. His first short fiction, in fact, was about a Dutch Jewish boy and was written in 1973 after watching a TV documentary about the German occupation of the Netherlands.

Phillips's early years are critical to his writing because it is during this period that he gained the experiential knowledge of themes that would later infuse his fiction; the other touchstone moments from his past reflect periods when he began to understand the causes of the crucible he had had to endure. During his university years, he began to demythologize the concept of class when he learned that students who came from supposedly better stock were no more intelligent or sophisticated than he. He experienced racism anew, even though he was one of the more outgoing and socially active students on campus, but now he could contextualize the racial slurs against him in relation to the race riots that were taking place in Notting Hill in 1976. He also gained a heightened identification with blackness when he yisited the USA during the summer before his last year at university and learned of the AfricanAmerican literary tradition. As he recounts in many interviews, during this trip he purchased a copy of Richard Wright's Native Son while visiting Laguna Beach, California, and began reading it one morning. He did not rise from the chair until he had finished the novel as the sun was setting in the ocean, and he did so with the newly discovered intention of becoming a writer himself. The importance of his identification with African-American identity issues in the absence of a well-articulated black British identity cannot be overestimated. When he returned from his journey, he intended to do thesis work on African-American literature, as "a not too subtle way of trying to synthesize Laguna Beach with Oxford," 11 but he discovered that the university library did not have any of the resources needed, even though American fiction was supposedly an available option. His frustration at this under-representation of minority voices would give him the determination to make sure that his own books would one day be found in the stacks of the Bodleian.

Phillips started writing plays after university, but it was his trip to St Kitts in 1980 that gave him distance from England and attachment to his place of origin, both of which he needed to begin to write fiction that could contain his own story. As he tells Maya Jaggi, "the trip liberated me. It kicked my brain out of a British perspective; I realised the narrative didn't begin in Leeds or

\footnotetext{
${ }^{11}$ Phillips, "Interview with Pico Iyer," 42.
} 
Brixton." ${ }^{.12} \mathrm{He}$ returned repeatedly to the Caribbean and established a home there for a period of time. This location would serve to launch his career as a novelist, as his first two novels, The Final Passage and A State of Independence, are set at least in part in the West Indies and present narratives about the first Caribbean immigrants to England, the Windrush Generation, and their relationship with their homes and families back on the islands.

Phillips's interviews also give considerable attention to his aesthetic choices, particularly in discussions about his use of characterization and form, both elements that are unique enough in his work to warrant investigation. As early as 1991, only six years after the publication of his first novel, he identified form as the most important aspect of a writer's work. As he said to Graham Swift,

it seems to me that the real test of a writer's ability is the degree to which that writer applies himself or herself to the conundrum of form, to the task of imposing a form upon these undisciplined stories. ${ }^{13}$

What distinguishes Phillips's form in the majority of his works is, of course, his fragmented style and the resulting leaps he makes across his various narratives. It is often assumed that he did not begin splicing together stories from different times and spaces until the 1989 publication of Higher Ground, his third novel, but Phillips clarifies, in his interview with Carol Margaret Davison, that it was in the 1983 play entitled The Shelter that he actually began "exploring the way of writing and connecting across centuries." ${ }^{14} \mathrm{He}$ speaks eloquently about the logic and relevance of this form, which he invented for himself, as he had no models to work from, and which he has used to varying degrees in all of his fiction, with perhaps the exception of $A$ State of Independence. In the Pico Iyer interview, he states:

I keep trying to write a book with a beginning, a middle, and an end, and then

failing spectacularly. Something happens during the process where the linear

structure seems to break down. It's almost like I've crafted this wonderful

ceramic fruit bowl, and I'm two pages from the end of the book just doing

\footnotetext{
${ }^{12}$ Jaggi, "Rites of Passage," 6.

${ }^{13}$ Caryl Phillips, "Caryl Phillips Interviewed by Graham Swift," Kunapipi 13.3 (1991): 100.

${ }^{14}$ Caryl Phillips, "Crisscrossing the River: An Interview with Caryl Phillips," by Carol Margaret Davison, ARIEL: A Review of International English Literature 25.4 (October 1994): 93.
} 
the final glazing, and I deliberately drop it, and it shatters, and then I have to start again." $" 15$

He fragments his narratives so dramatically, he explains to many interviewers, because his characters' lives have been deeply disrupted by the forces of history, forces such as slavery and migration. "It hasn't seemed right to write a novel about people whose lives are fractured and ruptured," he notes, "without trying to reflect some of that fracture and rupture in the narrative." 16

Phillips is equally emphatic and reflective in his interviews about his characterization, which is not surprising, given that he began his career directing and then writing plays. As with his drama, his fiction writing starts with character, and he often speaks of how he views his characters as real individuals, people he must wait upon and who continually surprise him despite his efforts to control their actions. What has drawn readers' attention and interviewers' questions about Phillips's characterization is his tendency to depict individuals who are highly ambiguous and deeply flawed in at least one regard - the African translator in Higher Ground, Emily Cartwright in Cambridge, the father that sells his own children in Crossing the River, and Bert Williams in Dancing in the Dark being obvious examples - at the same time as he depicts individuals who are mere victims of the historical and cultural forces beyond their control - such as Irene and even Rudi in Higher Ground, Eva in The Nature of Blood, and Solomon in A Distant Shore. Phillips has argued that characterization automatically introduces ambivalence into fiction because characters resist the easy reduction of history and contemporary events to sloganeering; the writer capitalizes on the potential for ambiguity by often including individuals whose views he doesn't share so that he can, as he tells Jenny Sharpe, "transgress such artificial boundaries as good and evil, black and white - I mean black and white in a broader sense - right and wrong, in fiction." 17 To bring out these voices, he draws on historical accounts of people who embraced offensive belief-systems, and he fictionalizes their stories in a way that explores the "self-serving nature behind [their] narratives." 18 Despite his characters' shortcomings, though, Phillips is unwavering in his refusal to judge them. "Part of the magic of writing," he stresses to Graham Swift, "is

${ }^{15}$ Phillips, "Interview with Pico Iyer," 43.

${ }^{16}$ Phillips, "Disrupting the Master Narrative: An Interview with Caryl Phillips," 96.

${ }^{17}$ Caryl Phillips, "Of This Time, of That Place: A Conversation with Caryl Phillips," by Jenny Sharpe, Transition 68 (1995): 160.

${ }^{18}$ Phillips, "Of This Time, of That Place: A Conversation with Caryl Phillips," 158. 
that you cannot be too judgmental about a character. You have to find some kind of trust, some form of engagement. You attempt to breathe life into these people and if you're lucky they breathe life into you."19

The interviews also cover common ground in their discussions of the interrelated themes that are pervasive in Phillips's work: those of displacement, home/homelessness, race and identity, eurocentrism, victimization and complicity. Whether he is depicting slavery, migration, the Holocaust, or genocide, whether his narratives are set in England, the Caribbean, the USA, or Africa, whether he is writing about the contemporary moment or centuries ago, he is always seeking out the stories of people who have been displaced and are misunderstood and who do not have the security of belonging to a particular history. Keenly aware that the powerful desire to be rooted carries with it the violent potential for exclusion, Phillips has adopted a pluralist notion of home and advocates for a more fluid sense of human identity in his writing. His engagement with the world, as evidenced, for example, in the major reading tours he has given in twenty-one different countries in the past twenty-odd years, suggests that Phillips has moved beyond the need for affiliation as configured in conventional terms. In so doing, he has joined the ranks of other transnational authors who write across borders and who identify with a sense of belonging that emerges from the movement between spaces rather than from any particular locale. He names as his colleagues those writers who cannot be easily identified with one particular national tradition, such as J.M. Coetzee, Salman Rushdie, Michael Ondaatje, Pico Iyer, Edwidge Danticat, Jhumpa Lahiri, and Rohinton Mistry. It is also significant that Phillips repeatedly identifies James Baldwin as a person who exerted a great influence on his early writing, since Baldwin, whose interest lay in matters involving race consciousness, also declared a transatlantic identity for himself.

One final thread that runs through his interviews has to do with Phillips's insistence on remaining true to his artistic convictions even in the face of criticism from various directions. A telling anecdote he recounts to Stephen Clingman involves an African-American woman who was extremely angry at him for including the white woman Joyce as one of the children claimed by the African father in Crossing the River. ${ }^{20}$ Phillips refuses to invest in notions of racial solidarity, and a number of his works - particularly Cambridge and The

\footnotetext{
${ }^{19}$ Phillips, "Caryl Phillips Interviewed by Graham Swift," 100.

${ }^{20}$ Phillips, "Other Voices," 133.
} 
Nature of Blood - demonstrate his interest in examining the way that history has affected white people as well as black. Other unpopular views that he has willingly voiced throughout his career include an unflattering representation of Caribbean men in The Final Passage, the suggestion of a corrupt government in St Kitts in A State of Independence, the accusation of European tribalism in The European Tribe, the indictment of African involvement in the slave trade in Higher Ground, the critique of the African Americans' idealization of Africa in The Atlantic Sound, and the acknowledgement of a vexed relationship between African Americans and Caribbean immigrants in Dancing in the Dark. J.M. Coetzee has commented that Phillips's fiction has a single aim - "remembering what the West would like to forget"; ${ }^{21}$ clearly, Phillips's recollecting proves challenging for many different audiences, given the complicated dynamics of race, class, and power in the diaspora as a whole.

Phillips's interviews also reflect shifts in his perspective that occur naturally over time as he moves from England to other locations, as he advances from one academic position to another, as he develops a stronger sense of himself as a writer, and as he gains a fuller sense of relationship and the interrelationship between his fiction and his non-fiction. But, as argued earlier, it is the consistencies of his reflections over the past two decades that are more prominent, and they indicate that he likely had a general vision of his purposes from early on. When I asked him if he intended his texts to build on one another, he said:

I'm increasingly aware of the territory that I'm trying to cross and re-cross. In that sense, inevitably the texts do speak to each other. Or maybe I should put it this way: they will eventually all speak to each other. But right now it's pretty much a matter of just staying on the scent of whatever it is that is pulling me forward. ${ }^{22}$

The driving forces behind Phillips's writing seem to be his commitment to the reworking of history to reveal new layers of analysis about the past and his ethic of empathy and concern for those who have been overtaken by historical injustices. In a number of interviews, he is asked whether he thinks he sees himself as an optimist or a pessimist. While his answers vary, he more frequently suggests that some degree of hope does emerge from a heightened

${ }^{21}$ J.M. Coetzee, "What We Like to Forget," New York Review of Books 44.17 (6 November 1997): 41.

${ }^{22}$ Phillips, "Caryl Phillips: Reflections on the Past Twenty-Five Years," 161. 
understanding of the causes of suffering, even if that understanding cannot yet offer immediate or practical remedies. As Jenny Sharpe notes,

he is skeptical of facile solutions to the deep and pervasive problems left by history, but he holds out the possibility that, even beset by tragedy, one can and should meet these challenges open-eyed and with courage. ${ }^{23}$

Phillips's works ultimately affirm those things that people cling to as they struggle to survive - love, faith, family - even as they call for the need of alternative social systems that do not impose unnecessary suffering on the marginalized. His is a moral imperative based on understanding and analysis which implicitly calls for reform, even if the means of transformation are never outlined in the texts themselves.

Phillips's overall uniqueness as a writer is confirmed by the way in which he represents himself and his literary purposes in his many interviews. He is always challenging boundaries, whether in terms of racial divisions, distinctions of genre, or geographical identities. He resists pigeon-holing by wearing many labels at once, as seen, for example, in the way he allows himself to be identified as a black British writer, a Caribbean writer, or a postcolonial writer without feeling the need to rank his affiliations in a particular hierarchical order. He epitomizes a sense of cosmopolitanism which is based on a sense of homelessness that has over time transformed into an affiliation with multiple homes at once. The resulting complexity of Phillips's writing and life has clearly made a significant impression upon his readers, for he has received considerable critical attention for his overarching project throughout his career. He has been given honorary degrees from Amherst College (1995), Leeds Metropolitan University (1997), the University of York (2003), Leeds University (2003), and Yale University (2006); he has received numerous literary fellowships, including the Guggenheim Foundation Fellowship in 1992; his novel Crossing the River was short-listed for the Booker Prize in 1993; his fiction has been translated into eleven languages; he has been honoured at the international conference, "Caryl Phillips: 25 Years of Writing," held at the University of Liège, Belgium, in 2006, which was the impetus behind the present collection of essays; and he has been the recipient of many prestigious prizes, ranging from the Malcolm X Prize for Literature, which he received in 1987, to the PEN / Beyond Margins Award, which he was given in 2006. Finally, a collection of his interviews entitled Conversa-

\footnotetext{
${ }^{23}$ Phillips, "Of This Time, of That Place: A Conversation with Caryl Phillips," 155.
} 
tions with Caryl Phillips, which was published in 2009 by the University Press of Mississippi in their Literary Conversations series, indicates not just the current assessment of Phillips as a writer of considerable significance but also the realization that his reflections on his intellectual life contained in the various interviews are critical supplements that aid in understanding and appreciating the magnitude of his work.

\section{Works Cited}

Coetzee, J.M. "What We Like to Forget," New York Review of Books 44.17 (6 November 1997): 38-41.

Garrett, George. "Separate Prisons," New York Times Book Review (16 February 1992): 1, 24-25.

Jaggi, Maya. "Rites of Passage," Guardian (3 November 2001): 6-7.

Phillips, Caryl. The Atlantic Sound (London: Faber \& Faber, 2000).

- Cambridge (London: Bloomsbury, 1991).

. "Caryl Phillips" (1995), interview with Pico Iyer, in Conversations with Caryl Phillips, ed. Schatteman, 36-45.

. "Caryl Phillips Interviewed by Graham Swift," Kunapipi 13.3 (1991): 96-103.

. "Caryl Phillips: Reflections on the Past Twenty-Five Years," by Renée Schatteman, in Conversations with Caryl Phillips, ed. Schatteman, 160-72.

- "Crisscrossing the River: An Interview with Caryl Phillips," by Carol Margaret Davison, ARIEL: A Review of International English Literature 25.4 (October 1994): 91-99.

- Crossing the River (London: Bloomsbury, 1993).

. Dancing in the Dark (London: Secker \& Warburg, 2005).

. "Disrupting the Master Narrative: An Interview with Caryl Phillips," by Renée

Schatteman, Commonwealth: Essays and Studies 23.2 (2001): 93-106. . A Distant Shore (London: Secker \& Warburg, 2003).

The European Tribe (London: Faber \& Faber, 1987).

The Final Passage (London: Faber \& Faber, 1985).

Higher Ground (London: Viking 1989).

"Interview with Caryl Phillips" (December 2002), by Charles Wilkin, in Conversations with Caryl Phillips, ed. Schatteman, 118-34.

. "An Interview with Caryl Phillips," by Louise Yelin, Culturefront 7.2 (1998):

$52,53 \& 80$.

. The Nature of Blood (London: Faber \& Faber, 1997).

"Of This Time, of That Place: A Conversation with Caryl Phillips," by Jenny

Sharpe, Transition 68 (1995): 154-61. 
"Other Voices: An Interview with Caryl Phillips" (October 2001), by Stephen Clingman, Salmagundi 143 (2004): 113-40.

The Shelter (Oxford: Amber Lane, 1984).

. A State of Independence (London: Faber \& Faber, 1986).

Schatteman, Renée T., ed. Conversations with Caryl Phillips (Jackson: UP of Mississippi, 2009).

. "Introduction" to Conversations with Caryl Phillips, ed. Schatteman, ix-xviii.

Wright, Richard. Native Son (1940; New York: New American Library, 1964). 


\title{
Plural Selves
}

\section{The Dispersion of the Autobiographical Subject in the Essays of Caryl Phillips}

\author{
LOUISE YELIN
}

I n an essay titled "Necessary Journeys" (2004), Caryl Phillips reflects on what propelled him, twenty years earlier, to travel around Europe and, later, record his travels in The European Tribe (1987). "Like any black child in Britain who grew up in the 60s and 70s," Phillips observes, "it had long been clear to me that the full complexity of who I am - my plural self, if you like - was never going to be nourished in a country that seemed to revel in its ability to reduce identity to easily repeatable clichés." In this essay, I explore the 'plural selves' dispersed in Phillips's autobiographical writings. A note on terminology: I do not like the term 'non-fiction'; I refer to Phillips's autobiographical writings as 'essays' for the sake of simplicity and also to distinguish them from his novels and plays, even though the latter might also be read as sites in which his life is rendered or, in the terms set out by Georges Gusdorf in a now-classic study of canonical autobiography, "reassembled" or "recapitulated." ${ }^{2}$ This article is part of a longer project, a book titled British Lives which examines self-portraiture, self-representation, and self-fashioning in writing, painting, sculpture, photography, cinema, and performance since the 1950s. In the longer project, I will set Phillips's essays in

\footnotetext{
${ }^{1}$ Caryl Phillips, "Necessary Journeys," Guardian (11 December 2004): http://www .guardian.co.uk/books/2004/dec/11/society2 (accessed 4 August 2009); The European Tribe (1987; New York: Vintage, 2000).

${ }^{2}$ Georges Gusdorf, "Conditions and Limits of Autobiography" ("Conditions et limites de l'autobiographie," 1956), tr. James Olney, in Autobiography: Essays Theoretical and Critical, ed. James Olney (Princeton N J : Princeton U P, 1988): 31, 38.
} 
the context of a large body of work - life-writing and self-portraiture, broadly construed - that registers changes in Britain and, concomitantly, in notions of British identity over the past fifty years.

Caryl Phillips has not published a full-scale autobiography or memoir. Rather, his autobiography is diffused in a diverse, eclectic array of travel narratives, written documentaries, journalistic and literary essays, occasional pieces, and interviews, some collected in books, some appearing in periodicals, and many now available on the web. ${ }^{3}$ Recent studies of life writing help to situate Phillips's work - essays and interviews in particular - in this hybrid genre.

Phillips's essays - like, say, the self-portraits of Lucian Freud and David Hockney, made over the course of a lifetime, or the diaries of Alan Bennett, which appear at intervals in the London Review of Books - might be seen as a version of what Leigh Gilmore identifies in an essay on Jamaica Kincaid as "serial autobiography.," Phillips's serial autobiography is a discontinuous narrative of self-fashioning in which, to extrapolate from Gilmore's discussion of Kincaid, 'Caryl Phillips' is represented as a figure "capable of crossing all kinds of boundaries, including the boundaries of discrete texts." In many of Phillips's essays and in interviews as well, narrative, or "storytelling," is what Sidonie Smith and Julia Watson term a "performative act." Discrete narratives and the larger corpus these narratives comprise unfold in a "scene" that is, as Smith explains, "at once a literal place, a location, and also a moment in history, a (sociopolitical) space in culture [...]. The autobiographical subject finds him-/herself on multiple stages simultaneously, called to heterogeneous recitations of identity.",

\footnotetext{
${ }^{3}$ See, for example, Phillips's personal web site, Caryl Phillips: Official Web Site: http: //www.carylphillips.com (accessed 4 August 2009); The Caryl Phillips Bibliography, ed. Bénédicte Ledent: http://www.l3.ulg.ac.be/phillips (accessed 4 August 2009); Conversations with Caryl Phillips, ed. Renée T. Schatteman (Jackson: U of Mississippi P, 2009).

${ }^{4}$ Leigh Gilmore, "Endless Autobiography? Jamaica Kincaid and Serial Autobiography," in Postcolonialism and Autobiography: Michelle Cliff, David Dabydeen, Opal Palmer Adisa, ed. Alfred Hornung \& Ernstpeter Ruhe (Amsterdam \& Atlanta G A: Rodopi, 1998): 211.

5 Gilmore, "Endless Autobiography," 211.

${ }^{6}$ Sidonie Smith \& Julia Watson, Reading Autobiography: A Guide for Interpreting Life Narratives (Minneapolis: U of Minnesota P, 2001): 47; see also Anthony Bond, "Performing the Self?," in Anthony Bond \& Joanna Woodall, Self-Portrait: Renaissance to Contemporary (exh. cat.; London: National Portrait Gallery, 2005): 31-39.

${ }^{7}$ Sidonie Smith, "Performativity, Autobiographical Practice, Resistance," in Women, Autobiography, Theory: A Reader, ed. Sidonie Smith \& Julia Watson (Madison: U of Wisconsin P, 1998): 110 .
} 
Moreover, several of Phillips's essays are instances of what Philippe Lejeune calls "autobiography in the third person." Lejeune uses this term to distinguish works explicitly written in the third person - e.g., The Education of Henry Adams or Roland Barthes par Roland Barthes - from first-person narratives in which the autobiographical I "conceals [...] a secret third person" - that is, the self as written about. ${ }^{8}$ Phillips's "Growing Pains" (2005), for example, appeared in The Observer as "an autobiographical story" about an unnamed "boy" whose life resembles that of the author. ${ }^{9}$ Often, though, Phillips turns Lejeune's definition of third-person autobiography inside-out: he represents himself by writing about others, whether well-known figures or persons unknown except in his work.

In what follows, I examine the adumbration in Phillips's essays of what Gilmore, Smith and Watson, and Lejeune, among others, identify as features of contemporary life-writing. I begin by discussing the essay titled "Necessary Journeys," in which Phillips comments on his "plural self," then go on to consider texts that develop the conception of the autobiographical subject and autobiographical writing - elaborated in this article.

"Necessary Journeys" is a reflection on what Gusdorf calls the "conditions and limits" of autobiography, an autogenealogy and an autoethnography, a manifesto as well as an exemplary instance of Phillips's autobiographical practice. Here, Phillips offers a template for his autobiographical project as he revisits his struggle, twenty years earlier, to "become a writer [and] to recognise and protect my own identity": to "express," as he puts it in The European Tribe, "the conundrum of my own existence." ${ }^{, 10}$ In the process, he delineates his own genealogy. He affiliates himself with a "robust literary history," a long tradition of travel writing whose exemplars - he mentions Walter Raleigh and Robert Louis Stevenson, among others - "moved out beyond the horizon and produced books that $[\ldots]$ grappled with [the] vexing issues of British identity and belonging." At the same time, he identifies himself with writers of the African diaspora - among them, Langston Hughes in Moscow and Phillis Wheatley in London - for whom "travel [...] has provided [...] a means of clarifying their own unique position in the world." Finally, he aligns himself with authors of Caribbean origin - Jean Rhys and Samuel Selvon, to

\footnotetext{
${ }^{8}$ Philippe Lejeune, "Autobiography in the Third Person" (tr. 1977), On Autobiography, ed. Paul John Eakin; tr. Katherine Leary (Minneapolis: U of Minnesota P, 1989): 35.

${ }^{9}$ Caryl Phillips, "Growing Pains," Observer (20 August 2005): http://www.guardian.co .uk/books/2005/aug/20/featuresreviews.guardianreview18 (accessed 4 August 2009).

${ }^{10}$ Phillips, The European Tribe, 8.
} 
take just two examples - who were enabled by "migration, forced or voluntary," to make "their own sense of themselves in the world." Phillips observes that his "triple heritage of journeying; British, African diasporan, Caribbean," validates - at least in retrospect - his decision, in 1984, to leave Britain, which offered him "only unpalatable, and racially determined, stereotypes as models for my own identity." Rhys and Wheatley, Stevenson and Selvon, Phillips perforce represents himself as a diasporic, cosmopolitan subject.

Autogenealogy is for Phillips a close cousin to autoethnography. The heterogeneous lineages into which he inserts himself signal his rejection of categories of belonging - race and nationality most prominent among them and his resistance to confinement in straitjackets of identity. As he observes in a 2004 interview, this resistance underwrites his identification with contemporary writers - among them, Michael Ondaatje, Edwidge Danticat, and J.M. Coetzee - who "don't fit comfortably into a national tradition [and] [...] would resist being grouped around race." ${ }^{\prime 12}$ In associating himself with writers who cross traditional - racial, national, and ethnic - boundaries, Phillips constructs an autoethnography that takes as a point of departure the interrogation of identity in general and black British identities in particular that preoccupied Stuart Hall et al. in the 1980 s and early 1990s: that is, in a postcolonial moment that predates what Phillips characterizes as the "post-postcolonial" period we now inhabit. ${ }^{13}$

Hall notes in "New Ethnicities" (1989) that the "extraordinary diversity of subjective positions, social experiences, and cultural identities which compose the category "black'" calls into question the effectiveness of 'race' as a category of social and cultural analysis. ${ }^{14}$ In "Necessary Journeys," Phillips, too, rejects the idea of "blackness as a form of essential identity." His critique of identity is not presented as an intervention in a theoretical debate - although it can certainly be read in this way - but, rather, as a conceptual frame for his reconstruction of his quest, twenty years earlier, to "recognise and protect [his] identity in all its intricacy"; for, he adds, "to use any element of oneself as

\footnotetext{
${ }^{11}$ Phillips, "Necessary Journeys."

${ }^{12}$ Caryl Phillips, "Other Voices: An Interview with Caryl Phillips" (October 2001), by Stephen Clingman, Salmagundi 143 (2004): 122.

${ }^{13}$ Phillips, "Other Voices," 122.

${ }^{14}$ Stuart Hall, "New Ethnicities" (1989), excerpt in The Post-Colonial Studies Reader, ed. Bill Ashcroft, Gareth Griffiths \& Helen Tiffin (London \& New York: Routledge, 1995): 225 .
} 
either a weapon or a shield is restrictive." 15 What Phillips says here about the young writer he once was recalls his description of James Baldwin's reluctance to be labelled as a "negro author" " and his assessment of Richard Wright's decision to leave the USA as an attempt to "slip the [...] noose of the label 'negro' artist."16

Travel is central in Phillips's account of himself - as might be expected of a man who comments on his "compulsive itinerancy." 17 What the writer calls "the narrative of self," which recounts an "interior personal journey," is derailed in a society in which, as he puts it, "it is difficult to exercise any authority over one's own identity." The political and social climate of the 1970 s and 1980 s - the decline of empire, anxiety about participation in the European Economic Community, "racial and cultural confusion," and a difficult transition from " 'West Indian' to 'Black British' as the acceptable [...] term with which to describe non-white citizens" - produced in Britain a "profound 'identity crisis", and compromised Phillips's sense of himself. ${ }^{18}$ His conception of his predicament is echoed in Hanif Kureishi's "London and Karachi," written at about the same time as Phillips embarked on his journey around Europe. In this essay, Kureishi recounts the "little identity crisis" induced by his inability to feel at home either in England or Pakistan, the two places to which he ostensibly belonged. ${ }^{19}$

Like Kureishi, who observes that he acquired in Karachi "some kind of identification with England" and found in the "intermix" a "new way of being British," 20 Phillips notes that his own history of migration - from the Caribbean to Britain, from Yorkshire to Oxford - "bequeathed" him a "multifarious sense of self $[\ldots]$ that resisted easy classification." Travel to the Caribbean and Europe and later across and around the globe, Phillips says, gave him a way to "look inwards and explore a personal identity that is rooted both in and beyond Britain." 21 Towards the end of "Necessary Journeys," Phillips asks:

15 Phillips, "Necessary Journeys."

${ }^{16}$ Caryl Phillips, "Giovanni's Room by James Baldwin," in A New World Order: Essays (2001; New York: Vintage, 2002): 30; "Native Son by Richard Wright," in A New World Order, 21.

${ }^{17}$ Caryl Phillips, "Conclusion: The 'High Anxiety' of Belonging," in A New World Order, 305

18 Phillips, "Necessary Journeys."

${ }^{19}$ Hanif Kureishi, "London and Karachi," in Patriotism: The Making and Unmaking of British Identity, vol. 2, ed. Raphael Samuel (London: Routledge, 1989): 276.

${ }^{20}$ Kureishi, "London and Karachi," 284, 286.

${ }^{21}$ Phillips, "Necessary Journeys." 
"what would have happened to me if I had not left Britain in 1984 and begun a process of border crossings that I've continued to this day?" He reasserts his connection with others who, in moving around the world, "reaffirm $[\ldots]$ the fact that dual and multiple affiliations feed our constantly fluid sense of self." ${ }^{22}$ Phillips includes among his kindred spirits not only those like Baldwin and Wright, Ondaatje and Coetzee who resist classification by race or nationality, but also Angela Carter and the early-twentieth-century Japanese writer Natsume Soseki who, as he puts it in a 2006 essay, were freed by travel and self-imposed, if temporary, literary exile to "reinvent [themselves] without having to wrestle with the multiple anxieties of belonging.,"23

Running throughout Phillips's writings is a meditation on home and exile, identity and belonging that resonates not only in his description of Carter and Soseki but also in the way he characterizes himself as "of and not of" the places he traverses. ${ }^{24}$ This phrase first appears in the Preface to The European Tribe, which presents this text as a notebook containing Phillips's "thoughts about a Europe I feel both of and not of, ${ }^{, 25}$ and which indeed began as a notebook, now lodged in Phillips's papers at Yale's Beinecke Rare Book Library. ${ }^{26}$ The published text radically pares down the original notebook entries and, in part through the phrase "of and not of," hones both the sense of self and the sense of place that the writings convey. The phrase is reiterated in the title essay and introduction to A New World Order, a book named as an homage to Curtis Mayfield. Here, "of and not of" defines Phillips's relationship to the US A, Africa, the Caribbean, Britain, the settings of the essays collected in the book and sites of his formation as a cosmopolitan, hybrid, diasporic, anglophone subject and citizen of a multilingual, transnational world of letters: "I recognise the place," he says; "I feel at home here, but I don't belong. I am of, and not of, this place." ${ }^{27}$ Toward the end of "A New World Order," Phillips links the narrating 'I' to a nomadic, global 'we', in an attempt, once more, to

${ }^{22}$ Phillips, "Necessary Journeys."

${ }^{23}$ Caryl Phillips, "Finding Oneself at Home," Guardian (21 January 2006): http://www .guardian.co.uk/books/2006/jan/21/fiction.angelacarter (accessed 4 August 2009).

${ }^{24}$ Bénédicte Ledent, " 'Of, and not of, this Place': Attachment and Detachment in Caryl Phillips' A Distant Shore," Kunapipi 26.1 (2004): 155-69; Louise Yelin, "Caryl Phillips," in British Writers Supplement V, ed. George Stade \& Sarah Hannah Goldstein (New York: Scribner's, 1999): 384 .

${ }^{25}$ Phillips, The European Tribe, ix.

${ }^{26}$ Caryl Phillips Papers, Uncat MSS 15, Beinecke Rare Book and Manuscript Library, Yale University.

${ }^{27}$ Phillips, "Introduction: A New World Order," A New World Order, 1. 
come to terms with what he calls the "conundrum of my existence": "These days," he says, "we are all unmoored. Our identities are fluid. Belonging is a contested state. Home is a place riddled with vexing questions." 28 I read "unmoored" as a pun that announces the end of what Phillips once called his "unfinished business with Othello" even as it suggests that the plural selves his essays trace are, to use another word that recurs in his work, 'marooned' in the contested state of belonging. ${ }^{29}$

The fluid identities Phillips outlines in his autobiographical writing emerge in an equally fluid sense of place whose spatial and temporal coordinates are defined by dislocation. Many of Phillips's essays might loosely be classified as travel writing; most of these, however, play havoc with the distinction between here and there that structures classic instances of the genre. The European Tribe, for example, begins with Phillips's description of a journey across the USA that culminates in his reading of Native Son and his decision to become a writer - an experience that figures in several accounts of his life as the foundation of his career. ${ }^{30}$ The Atlantic Sound finds Phillips in three cities that played key roles in the triangular trade, Charleston, Elmina, and Liverpool. ${ }^{31}$ But, as I have argued elsewhere, the three locales interrupt each other in ways that point to the rupture of time and space alike by the Middle Passage and its legacies. ${ }^{32}$ Phillips rejects standard-issue, colonial constructions of travel as the adventure of an imperial self who seeks dominion over an objectified - exotic, erotic - other. ${ }^{33}$ Rather, he describes journeying which always, he says, involves loss, as an occasion for reinvention. ${ }^{34}$

Like the first-person plural, here rendered as an authorial "we," the third person looms large in Phillips's essays, which offer several different versions of third-person autobiography. First, as his observations about travel as a

${ }^{28}$ Phillips, "A New World Order," 6.

${ }^{29}$ Caryl Phillips, conversation with Louise Yelin, New York City (January 1998).

Phillips, The European Tribe, 7; "Growing Pains"; and "Native Son," 18.

Caryl Phillips, The Atlantic Sound (London: Faber \& Faber, 2000).

${ }^{2}$ Louise Yelin, “'Living Stateside': Caryl Phillips and the United States," Moving Worlds 7.1 (2007): 87-88.

${ }^{33}$ On the colonial/imperial construction of travel, see, for example, Mary Louise Pratt, who argues that "travel books by Europeans about non-European parts of the world went (and go) about creating the 'domestic subject' of Euroimperialism." Imperial Eyes: Travel Writing and Transculturation (London \& New York: Routledge, 1992): 4; and Gayatri Spivak, who comments on the "domesticated other that consolidates the imperialist self." "Three Women's Texts and a Critique of Imperialism," in 'Race,' Writing, and Difference, ed. Henry Louis Gates, Jr. (Chicago: U of Chicago P, 1986): 272.

${ }^{34}$ Phillips, "Other Voices," 117. 
meeting place suggest, he delineates what Smith and Watson call a relational self: i.e. a subject that unfolds in the text in relation to others. ${ }^{35}$ 'Caryl Phillips' takes shape in essays about historical and cultural figures, among them writers and musicians of African origin - James Baldwin and W.E.B. Du Bois, Marvin Gaye and Curtis Mayfield - presented as surrogate fathers or substitute selves, role models or roads not taken, cautionary images of the legacies of the Middle Passage or theorists and exemplars of eclectic configurations of race, nationality, and belonging. Next, he writes about those identified by T.S. Eliot in the passage from Four Quartets used as the epigraph to The Final Passage (1985) as the "people without history." ${ }^{, 36}$ He gives a voice to those who have not yet told their own stories - for example, black immigrants and especially Nigerian prostitutes in Antwerp, where the ultraracist Vlaams Blok won thirty-three percent of the vote. ${ }^{37} \mathrm{He}$ records the experience of asylum-seekers waiting in Sangatte to cross the Channel or settle in France ${ }^{38} \mathrm{He}$ describes the writers and aspiring writers he meets in Freetown in the aftermath of the civil war in Sierra Leone. These writers, he says, are thwarted not only by the lingering traumas of wartime but also by the lack of even the rudiments of a literary culture: bookshops, publishers, newspapers and readers. ${ }^{39}$ The autobiographical subject appears in these pieces in the guise of an observer, a witness whose dispatches are energized by his empathy and by his interest in the quirky and the tragic alike.

In addition, as noted above, Phillips translates his own experiences into the "growing pains" of the boy in a story that exemplifies (at least on the surface) Lejeune's definition of third-person autobiography. Phillips remarks in "A New World Order" that his own life has been "lived along the twin rails of reading and writing." ${ }^{40}$ In "Growing Pains," similarly, he focuses on the central importance of reading and writing in the life course of the unnamed protagonist. In this portrait of the artist as a young black man, the phases of the character's life are marked out by what he is reading or writing - Little Black

${ }^{35}$ Smith \& Watson, Reading Autobiography, 64-69.

${ }^{36}$ Caryl Phillips, The Final Passage (1985; New York: Vintage, 1995): 3.

${ }^{37}$ Caryl Phillips, "The Silenced Minority," Guardian (15 May 2004): http://www .guardian .co.uk/books/2004/may/15/society.politics (accessed 4 August 2009).

${ }^{38}$ Caryl Phillips, "Strangers in a Strange Land," Guardian (17 November 2001): http: //www.guardian.co.uk/uk/2001/nov/17/immigration.books (accessed 4 August 2009).

39 “Distant Voices," Guardian (19 July 2003): http://www.guardian.co.uk/books /2003 /jul/19/sierraleone.shopping (accessed 4 August 2009).

${ }^{40}$ Phillips, "A New World Order," 5. 
Sambo, Enid Blyton, Anna Karenina, Blues for Mr Charlie - and by the ways his writing has been read, misread, or not read at all. (The story ends with the protagonist's realization that his great-grandmother, who doted on him and to whom he has been sending the books he wrote, has not read them, because she cannot read.)

"Growing Pains" is one of several essays that take Phillips back to Leeds. In "United We Stand," he revisits his conflicted history as a Leeds United fan and reflects on the rift between the club and the black population of the city. ${ }^{41}$ In "Do You Come Here Often," he honours the South African football star Lucas Radebe on the occasion of Radebe's retirement from Leeds United. ${ }^{42}$ In "Northern Soul," he describes a visit to a city that is not exactly the provincial place he left years before because it is now populated by a "multicultural medley of people" who hail - or whose parents hail - from around the globe. ${ }^{43}$ Leeds, here, is not 'home' but a node in the trajectory of border crossings that define Phillips's life and work. He notes that three of the four suicide bombers who attacked London in July of that year came from the Leeds area. They were second- or third-generation citizens whose "disaffection with Britain," he says, "ran deep."

The events of July 2005 and the suicide bombers' connection with Leeds loom large in "Colour Me English," the keynote address, printed in this volume, that Phillips delivered at the conference held in his honour in Liège, Belgium, in December 2006. ${ }^{45}$ Unlike much of Phillips's autobiographical writing, "Colour Me English," written in the first person, records a kind of conversion experience. In this respect, it is a companion piece or sequel to the Preface to The European Tribe, in which Phillips represents his reading of Native Son as the genesis of his vocation as a writer - that is, as a secular variation on the theme of conversion. In seeing himself, as if in a mirror, in the work of Wright and Ellison and Baldwin, Phillips explains, he found a way of negotiating his situation as a young black Briton. Race, then, is central to the account of self-discovery and the narrative of vocation presented in The

${ }^{41}$ Caryl Phillips, "United We Stand," Guardian (22 June 2002), http://www.guardian.co .uk/world/2002/jun/22/race.football (accessed 4 August 2009).

${ }^{42}$ Caryl Phillips, "Do You Come Here Often?" Observer (8 May 2005): http: //www .guardian.co.uk/sport/2005/may/o8/africannationscup2002.africannationscup (accessed 4 August 2009).

${ }^{43}$ Caryl Phillips, "Northern Soul," Guardian (22 October 2005): http://www .guardian .co.uk/artanddesign/2005/oct/22/photography.communities (accessed 4 August 2009).

${ }^{44}$ Phillips, "Northern Soul."

${ }^{45}$ Caryl Phillips, "Colour Me English," this volume, 11-22. 
European Tribe, although, even here, in worrying or juggling the identitycategories black/British, black/European, black/American, Phillips eschews essentialist or monocausal explanations of who he is or was: As he puts it in the introduction to the US section of $A$ New World Order, "Race matters. Sure it does, but not that much." ${ }^{46}$

In "Colour Me English," however, Phillips transforms the conversion narrative outlined in the Preface to The European Tribe by revisiting his childhood, reaccentuating his account of his early life, and rethinking the importance of race. The beginning of the essay finds the thirteen-year-old Caryl Phillips, formerly the only black boy at Leeds Central High School, at a moment of "transition." 47 The black population of the school, Phillips says, tripled when two of his brothers enrolled in the same year. Race, it seems in the first few sentences of the essay, will once again occupy the foreground of the narrative. But Phillips quickly changes direction. All three brothers, he says, had learned how to cope with the "lonely racial situation" ${ }^{\text {"48 }}$ at the school and on the all-white housing estate where they lived - they knew, that is, "how to fight and how to run" - so there was "no need for a conversation on the topic of racial isolation." ${ }^{, 49}$ Then something happened that radically affected the young boy's sense of himself and the world around him, the arrival at the school of a Pakistani Muslim immigrant named Ali. This "small moonfaced brown boy" who experienced a "palpable sense of isolation",50 quickly became the object of vicious bullying by his thuggish classmates.

Phillips recalls a particularly sordid episode, in which a group of boys on a schoolbus grabbed Ali's backpack and threw his schoolbooks out of the bus window. Unable, at the time, to protect Ali from their classmates or convince the school authorities to do so, Phillips now asserts that "something inside of me had changed." 51 What changed, perhaps, was his sense of his own position as a black Briton and, more broadly, his sense of the significance of race; the change - like the conversions of Malcolm X and St Augustine, to take just two examples - is registered retrospectively in a past-tense, first-person confessional narrative:

\footnotetext{
${ }^{46}$ Caryl Phillips, "Introduction: The Burden of Race," in A New World Order, 17.

${ }^{47}$ Phillips, "Colour Me English," 11.

48 "Colour Me English," 11.

49 "Colour Me English," 11.

50 "Colour Me English," 12.

51 “Colour Me English," 13.
} 
He was the first Muslim that I ever knew, and the first south-east Asian, but although I felt some immigrant kinship with him, and had instinctively tried to help him, things between us went only so far, and no further. Although we might be enduring some of the same difficulties because of our pigmentation, there was a clear cultural difference which meant that while I was able to find a way to anxiously participate in British life, albeit in a manner that was hardly fulfilling, Ali was enduring the type of hostility that renders any thoughts of participation a distant, and decidedly unlikely, dream. [...] Take race out of the equation and I had no place to hide from the English. Culturally, I was very much like them. [...] Ali, on the other hand, had the culturally essential worlds of religion into which he might retreat and hide from the English which, of course, made him deeply untrustworthy. ${ }^{52}$

In the rest of the essay, Phillips moves back and forth between past and present, the personal and the collective, the local (Leeds) and the translocal (Britain, Europe, the rest of the world). He juxtaposes his own story and those of other black Britons with that of Ali, which he sets in the larger narrative of Britain's Muslims - immigrants and their children and grandchildren - and the "cultural 'othering", to which they were subjected. This narrative, he suggests, supplies a context, but not an explanation, for the actions of the July 2005 suicide bombers. What is new, Phillips says, is not the pervasive "European disaffection and culturally informed determination" experienced by Muslims in Britain and elsewhere in Europe, but the "forceful response" of a few of their number, a response that race (or racism) alone cannot explain. Returning to his own situation, he remarks that as a child he wanted to fit in, and he goes on to note that in the years since he left Leeds, black Britons have been "colouring England," 54 even if only gradually. Unlike Ali, who "was culturally an outsider in a way that I could never be" and unlike some in his own generation who tried to "retreat into an essential black identity," Phillips recognized that "we would have to wrestle with Britain to make their story fit our lives. That's what all migrants do, as their plural selves develop." $55 \mathrm{He}$ goes on to assert: "The colouring of Britain, and Europe, suggests a radical and permanent change in the appearance of the European continent that is as

\footnotetext{
${ }^{52}$ Phillips, "Colour Me English,” 14.

53 "Colour Me English," 15.

54 “Colour Me English," 18.

55 “Colour Me English," 18.
} 
dramatic as the changes that came with the post-Columbian settlement of the Americas, or the European settlement of Australasia.",56

In a sense, what Phillips presents in "Colour Me English" is the conversion narrative of the developing, plural self of the migrant. This essay revises earlier accounts of his life by reconsidering the articulation of race and identity and reassessing the competing claims of past and present. In this respect, Phillips's writings elaborate what Gusdorf identifies as the constitutive features of autobiography: the "testimony of a man about himself, the contest of a being in dialogue with itself., ${ }^{, 57}$ If in "Colour Me English" and "Northern Soul" it is the events of July 2005 that prompt Phillips to continue his dialogue with himself, in "Northern Lights" he turns or returns to an earlier episode in the history of Leeds, the harassment, beating, and death by drowning in 1969 of David Oluwale, a homeless immigrant who had left Nigeria twenty years earlier, by two police officers who were convicted in 1971 of multiple counts of assault. ${ }^{58}$ (The charge of manslaughter was dropped because there were no witnesses who could testify to having seen Oluwale's death.) Once again, Phillips frames a narrative in which race plays a central part, yet "Northern Lights" neither supersedes nor cancels but, rather, complements "Colour Me English," and the different weight he gives to race in these recent works may be as much a matter of emphasis or context as of chronology: "Northern Lights" was published in autumn 2007, after the appearance of "Northern Soul" (2005) and "Colour Me English" (first presented in 2006), but Phillips began writing "Northern Lights" in 2001-2 and gave a lecture about Oluwale in Leeds in March 2005. His awareness of Oluwale dates back to the late 1960 s and the events surrounding the trial in the early 1970s - around the time when his brothers and Ali entered Leeds Central High School. ${ }^{59}$

"Northern Lights" reprises the narrative strategies of many of Phillips's writings, fiction and essays alike, but also departs significantly from his cus-

Phillips, "Colour Me English," 19.

${ }^{57}$ Gusdorf, "Conditions and Limits," 43.

${ }^{8}$ Caryl Phillips, "Northern Lights," in Foreigners (New York: Alfred A. Knopf, 2007): 149-235. Phillips's Foreigners was marketed as a novel and used to be listed under 'fiction' on his website, but the work has now been relocated to the webpage's 'non-fiction' section. The book is described - both on its dust jacket and on the website - as a "hybrid of reportage, fiction, and historical fact." See Caryl Phillips: Official Web Site: http://www .carylphillips.com (accessed 4 August 2009).

${ }^{59}$ Leeds Metropolitan University, "The Life and Death of David Oluwale: A Citizen of Leeds": http://www.leedsmet.ac.uk/as/sss/carylphillips.htm (accessed 4 August 2009). Caryl Phillips, e-mail to Louise Yelin (11 May 2007). 
tomary textual practice. In "Northern Lights" as in much of his work, Phillips eschews omniscient narration, juxtaposes discrete narratives, and calls narrative authority into question. While, in many essays, he represents himself as a witness, observer, or traveller, in "Northern Lights," Phillips or 'Phillips' is not manifestly represented at all, although a reader might find traces of the author - for example, in the reflections of a visitor to the house where Oluwale once lived or to the prison where Oluwale was incarcerated. Rather, 'Caryl Phillips' is diffused in "Northern Lights" as a scholar-writer who recovers the history of Oluwale and collects and orchestrates (or invents in some cases) the reflections and reminiscences of friends, acquaintances, coworkers, and others Oluwale encountered over the years; fragments of dossiers compiled in prisons, hospitals, mental asylums, and hostels; and testimony taken at trial.

What Phillips does not do in "Northern Lights" is bring David Oluwale to life by inhabiting Oluwale's voice or consciousness. Unlike the novels and many of the essays, which fully realize the voices of persons who are decidedly not the author, "Northern Lights" circles around the silence - or silencing of Oluwale, who is described, in the third person, or addressed, in the second. Running like a refrain through the text is the slogan "REMEMBER OLU WALE," scrawled on walls in Leeds in the 1970s. The reader, here, is asked to remember a man whose absence from what should be his own story is emblematic, on the one hand, of his resistance to inscription in the British social text and, on the other, of the refusal of Leeds in particular and British society in general to acknowledge him. As in novels such as Cambridge and Crossing the River, Phillips seeks in "Northern Lights" to rectify the acts of forgetting that 'disappeared' his protagonist from public view: indeed, the essay begins with the sentence "I remember" - itself a refrain that recurs throughout his writing - uttered by a fourteen-year-old girl who knew Oluwale as the man who greeted her when they passed each other in the street. But because Phillips does not allow us to hear Oluwale's voice - except through others' reports of the words that Oluwale spoke - or to gain access to Oluwale's interior monologue, he underscores the man's isolation and points both to the urgency and the limits of the empathy that plays a crucial role in his writing.

What Phillips does, instead, is to set Oluwale in context. He interweaves Oluwale's life with the history of Leeds from Roman times to the present. The central characters in this history are the river that runs through the city and the waves of invaders, conquerors, and immigrants who settled there, transformed the landscape by building bridges, canals, railroads, and factories, and made 
Leeds a centre of commerce and industry. David Oluwale was one such immigrant, although neither an invader nor a conqueror. He left Nigeria in 1949 with the ambition of becoming an engineer. He stowed away on a ship and on arriving in England was briefly imprisoned in Hull before he settled in Leeds, where he worked as a labourer and frequented pubs where he danced more than he drank. For several years in the 1950s and 1960s, Oluwale was confined in prisons and mental asylums. As one informant reports, "The problem with David was he didn't understand the colour-bar situation and he would get very wound up. 'I'm from a British colony and I'm British,' he would say. 'So why do they call me "nigger"?' [...] He wasn't crazy, he just didn't understand the system, that's all." ${ }^{\circ 0}$

Oluwale resurfaced in the late 1960 s as a man 'living rough' in the centre of Leeds, where he was brutalized by two particularly sadistic policemen who repeatedly tried, in Phillips's Dickensian phrase, to "move him on." ${ }^{, 61}$ Oluwale as Phillips portrays him was the object of racism at once unthinking, malicious, pervasive, arbitrary, and systematic: "There you were, David, working in the white hot heat of the foundry $[\ldots]$ and then, at the end of the day, out again, away from the filthy black river, out onto the windswept streets lined with redbrick factories. 'Hey you, nigger boy. Did you come out of your mam's arse?' ." 62 If Phillips places Oluwale in and against the postwar material and ideological ensemble - race, class, migration - that defined Leeds's black population in the 1950s and 1960s, he also insistently conveys Oluwale's refusal to accommodate himself to the prevailing structures of feeling or accepted patterns of behaviour, Oluwale's inassimilable, unknowable particularity. "Northern Lights," which begins with the sentence "I remember," ends with the words "You are still in Leeds. Forever in Leeds," uttered by an unidentified second-person narrator who addresses Oluwale after visiting the grave he shares with nine others. ${ }^{63}$

- Like Phillips's essays about Wright and Baldwin - and like "Colour Me English," for that matter - "Northern Lights" is a version of what I call the autobiography of the other, its protagonist a figure who, Phillips says, "has been ever present in my life." "Northern Lights" participates, too, in the project of autoethnography and autogenealogy that animates Phillips's entire

\footnotetext{
${ }^{60}$ Phillips, "Northern Lights," 172.

61 "Northern Lights," 153.

62 "Northern Lights," 171.

63 "Northern Lights," 235.

${ }^{64}$ Phillips, email to Louise Yelin (11 May 2007).
} 
autobiographical corpus. The history into which Phillips inserts David Oluwale is the history of Phillips's own formation, the history of black Britons and black Britain that he has been writing at least since the 1980 .

In "Northern Lights" as in the other essays that take Phillips back to the city where he grew up, he comes to no conclusion about Leeds, avoiding nostalgia for a lost past, despair about a bleak present, and facile notions of progress. The lack of closure in these essays befits their status as episodes in a serial autobiography that is still unfolding and that, like A Distant Shore (2003) among other texts, describes the condition of England today. I look forward to instalments of Phillips's autobiography as yet unwritten and to the ongoing work of others - Gary Younge, Mark Wallinger, Yinka Shonibare, and Sam Taylor-Wood, to take just a few examples - who are limning plural selves and inventing versions of Britishness that join what Phillips identifies as a "global conversation." Entering this conversation in which no one, as Phillips puts it, is "fully at home," - Caryl Phillips not least among them - are composing their life stories and in the process fashioning new notions of identity that remain to be imagined.

\section{WORKS CITED}

Adams, Henry. The Education of Henry Adams: An Autobiography (1918; Ithaca NY: Cornell UP, 2009).

Barthes, Roland. Roland Barthes par Roland Barthes (Paris: Seuil, 1975).

Bond, Anthony. "Performing the Self?" in Anthony Bond \& Joanna Woodall, SelfPortrait: Renaissance to Contemporary (exh. cat., National Portrait Gallery, London and Art Gallery of New South Wales, Sydney; London: National Portrait Gallery, 2005): 31-39.

Caryl Phillips: Official Web Site: http://www.carylphillips.com (accessed 4 August 2009).

Eliot, T.S. Four Quartets (1945), in The Complete Poems and Plays 1909-1950 (New York: Harcourt, 1962).

Gilmore, Leigh. "Endless Autobiography? Jamaica Kincaid and Serial Autobiography," in Postcolonialism and Autobiography: Michelle Cliff, David Dabydeen, Opal Palmer Adisa, ed. Alfred Hornung \& Ernstpeter Ruhe (Amsterdam \& Atlanta GA: Rodopi, 1998): 211-31.

Gusdorf, Georges. "Conditions and Limits of Autobiography," tr. James Olney, in Autobiography: Essays Theoretical and Critical, ed. James Olney (Princeton NJ:

\footnotetext{
${ }^{65}$ Phillips, “A New World Order,” 5.
} 
Princeton UP, 1988): 28-48. Originally as "Conditions et limites de l'autobiographie," in Formen der Selbstdarstellung: Analekten zu einer Geschichte des literarischen Selbstportraits: Festgabe für Fritz Neubert, ed. Günter Reichenkron \& Erich Haase (Berlin: Duncker \& Humblot, 1956): 105-23.

Hall, Stuart. "New Ethnicities" (1989), excerpt in The Post-Colonial Studies Reader, ed. Bill Ashcroft, Gareth Griffiths \& Helen Tiffin (London \& New York: Routledge, 1995): 223-27.

Kureishi, Hanif. "London and Karachi," in Patriotism: The Making and Unmaking of British Identity vol. 2, ed. Raphael Samuel (London: Routledge, 1989): 270-87.

Ledent, Bénédicte, ed. The Caryl Phillips Bibliography: http://www.l3.ulg.ac.be /phillips (accessed 4 August 2009).

—. " 'Of, and not of, this Place': Attachment and Detachment in Caryl Phillips' $A$ Distant Shore," Kunapipi 26.1 (2004): 155-69.

Leeds Metropolitan University. "The Life and Death of David Oluwale: A Citizen of Leeds": http://www.leedsmet.ac.uk/as/sss/carylphillips.htm (accessed 4 August 2009).

Lejeune, Philippe. "Autobiography in the Third Person," On Autobiography, ed. Paul John Eakin; tr. Katherine Leary (Minneapolis: U of Minnesota P, 1989): 31-51. Tr. Annette \& Edward Tomarken from "Récit à la troisième personne" and originally published in New Literary History 9.1 (Autumn 1977): 27-50.

Phillips, Caryl. The Atlantic Sound (London: Faber \& Faber, 2000).

-. Cambridge (London: Bloomsbury, 1991).

. Caryl Phillips Papers, Uncat MSS 15, Beinecke Rare Book and Manuscript Library, Yale University.

. "Colour Me English," this volume, 11-22.

_. "Conclusion: The 'High Anxiety' of Belonging," in A New World Order, 303309.

. Conversation with Louise Yelin, New York City (January 1998).

Crossing the River (London: Bloomsbury, 1993).

A Distant Shore (New York: Alfred A. Knopf, 2003).

. "Distant Voices," Guardian (19 July 2003): http://www.guardian.co.uk/books /2003/jul/19/sierraleone.shopping (accessed 4 August 2009).

. "Do You Come Here Often?" Observer (8 May 2005): http://www.guardian.co .uk/sport/2005/may/o8/africannationscup2002.africannationscup (accessed $4 \mathrm{Au}$ gust 2009).

. Email to Louise Yelin (11 May 2007).

. The European Tribe (1987; New York: Vintage, 2000).

. The Final Passage (1985; New York: Vintage, 1995).

. "Finding Oneself at Home," Guardian (21 January 2006): http://www.guardian .co.uk/books/2006/jan/21/fiction.angelacarter (accessed 4 August 2009).

—. "Giovanni's Room by James Baldwin," A New World Order, 28-34. 
. "Growing Pains," Observer (20 August 2005): http://www.guardian.co.uk /books/2005/aug/20/featuresreviews.guardianreview18 (accessed 4 August 2009).

. "Introduction: A New World Order," A New World Order, 1-6.

"Introduction: The Burden of Race," A New World Order, 9-17.

"Native Son by Richard Wright," A New World Order, 18-27.

"Necessary Journeys," Guardian (11 December 2004): http://www.guardian.co .uk/books/2004/dec/11/society2 (accessed 4 August 2009).

. A New World Order: Essays (2001; New York: Vintage, 2002).

"Northern Lights," Foreigners (New York: Alfred A. Knopf, 2007): 149-235.

"Northern Soul," Guardian (22 October 2005): http://www.guardian.co.uk /artanddesign/2005/oct/22/photography.communities (accessed 4 August 2009).

."Other Voices: An Interview with Caryl Phillips" (October 2001), by Stephen Clingman, Salmagundi 143 (2004): 113-40.

."The Silenced Minority," Guardian (15 May 2004): http://www.guardian.co.uk /books/2004/may/15/society.politics (accessed 4 August 2009).

—. "Strangers in a Strange Land," Guardian (17 November 2001): http://www .guardian.co.uk/uk/2001/nov/17/immigration.books (accessed 4 August 2009).

—. "United We Stand," Guardian (22 June 2002): http://www.guardian.co.uk /world/2002/jun/22/race.football (accessed 4 August 2009).

Pratt, Mary Louise. Imperial Eyes: Travel Writing and Transculturation (London \& New York: Routledge, 1992).

Schatteman, Renée T., ed. Conversations with Caryl Phillips (Jackson: U of Mississippi $P$, 2009).

Smith, Sidonie. "Performativity, Autobiographical Practice, Resistance," in Women, Autobiography, Theory: A Reader, ed. Smith \& Watson, 108-15.

_, \& Julia Watson. Reading Autobiography: A Guide for Interpreting Life Narratives (Minneapolis: $\mathrm{U}$ of Minnesota P, 2001).

Spivak, Gayatri Chakravorty. "Three Women's Texts and a Critique of Imperialism," in 'Race,' Writing, and Difference, ed. Henry Louis Gates, Jr. (Chicago: U of Chicago P, 1986): 262-80.

Wright, Richard. Native Son (1940), in Richard Wright, Lawd Today!; Uncle Tom's Children; Native Son (New York: The Library of America, 1991): 443-850.

Yelin, Louise. "Caryl Phillips," in British Writers Supplement V, ed. George Stade \& Sarah Hannah Goldstein (New York: Scribner's, 1999): 379-94.

. " 'Living Stateside': Caryl Phillips and the United States," Moving Worlds 7.1 (2007): 85-102. 


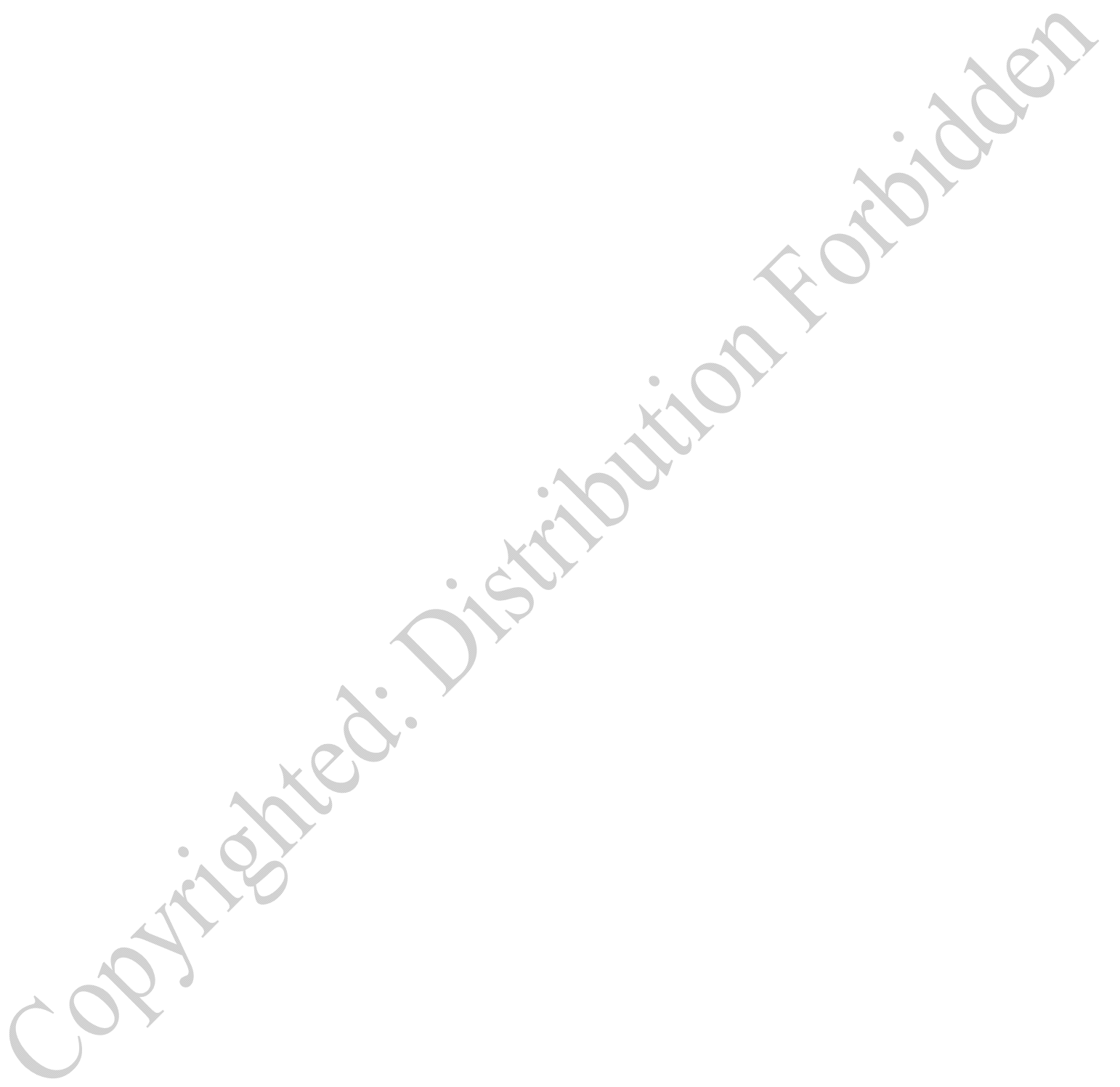




\title{
"Look liberty in the face" Determinism and Free Will in Caryl Phillips's Foreigners: Three English Lives
}

\author{
BÉNÉDICTE LEDENT
}

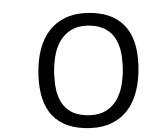

NE OF THE MAJOR POINTS OF CONTENTION among scholars working on Caryl Phillips's writing is the extent to which his world-view should be regarded as optimistic or pessimistic. Some critics seem to focus on the glimmer of hope that for them marks many of his novels, if only tenuously. They find it, for example, in the final chorus that brings together the descendants of the victims of the slave trade in Crossing the River or in the ephemeral relation of trust established between Dorothy and Solomon in A Distant Shore. Others concentrate on the bleakness of Phillips's vision, conveyed, in their eyes, by the madness that eventually takes possession of many of his female characters or by the tragic death that strikes several of his male protagonists. This divergence of opinion is particularly marked in relation to a specific aspect of Phillips's fiction: namely, the determinism that pervades most of his narratives and which implies that history is meant to repeat itself, particularly when it comes to oppression and discrimination. While the proponents of Phillips's pessimism see a confirmation of their interpretation in the predicaments that his characters from the African and Jewish diasporas seem to inherit from the past, those who conclude that he is optimistic look beyond this almost atavistic suffering to perceive some redemption in his ability to interweave the lives of individuals separated by time, space, race, or gender, but bound by a common sense of otherness and exclusion. These critics also argue that Phillips's protagonists are not wholly deprived of free will, even if the characters' bids for freedom often fail in the face of racial and social pressures that they cannot control. 
In what follows, I would like to take a closer look at Phillips's idiosyncratic take on determinism, a contested notion which has been at the heart of many philosophical debates. I shall use it in its most general acceptance here: i.e. as the belief that events and actions are entirely determined by what happened previously, which means that there is no real freedom of choice. By means of introduction, I will first briefly consider Phillips's fiction in general. Then I will focus on Foreigners: Three English Lives, which came out in 2007. A discussion of this book will, I trust, help us to reflect further on the nature of Phillips's philosophy and establish whether he is more an optimist than a pessimist, although I suspect that in view of the writer's well-known penchant for ambiguity it will not be easy to come to a clear-cut conclusion.

Phillips's fiction may be said to have been shaped from the start by some form of determinism. Clearly, the circularity of the unnamed Caribbean island at the centre of his first novel The Final Passage is synonymous with an existential predictability which his migrant characters try to escape by leaving for the so-called Mother Country, where they get caught up in their colonial past. In his second novel, $A$ State of Independence, Phillips suggests that the newly independent island on which the novel takes place cannot achieve real freedom, and he presents its economic and cultural submission to the USA as the almost inevitable consequence of centuries of oppression at the hands of the mostly British colonizers. Although depicting rather bleak situations, both novels are actually open-ended, suggesting that the protagonists might eventually manage to exercise some control - however limited - over their future, or at least find some reprieve, notably through personal relationships (even if they are still presented at the end as isolated individuals). Phillips's approach to determinism seems slightly less sombre in much of his later fiction, since this body of work often combines an acknowledgement of the recurrence of human misery with a sense of shared distress, which alleviates, in a way, the inescapability of evil. This is particularly the case in Higher Ground, Crossing the River, and The Nature of Blood, three books which bring together the doomed fate of human beings scattered in time and space. These novels, to borrow the words of Jonathan P.A. Sell, "trace back into the past the genetic and historical bonds from which the present is regarded as unable to shake itself free"1 while they also "universalize the human condition." ${ }^{2}$ Sell views

\footnotetext{
${ }^{1}$ Jonathan P.A. Sell, "Chance and Gesture in Zadie Smith's White Teeth and The Autograph Man: A Model for Multicultural Identity?" Journal of Commonwealth Literature 41.3 (September 2006): 31. Sell's focus in this article is Zadie Smith's work; his discussion of Phillips's position is meant to provide a contrast.
} 
this as an "idealist project" which, for him, "loses contact with the here and now and effaces the individuality of [...] fictional characters." 3 Admittedly, Phillips's decision to give these novels a panoramic dimension makes it less easy to lend weight to his characters' failed attempts to exercise their free will, since the focus in these fragmented books is very much on the transspatial and trans-temporal: in other words, on the global dimension of human suffering, essentially linked in these narratives to transatlantic slavery and the Holocaust. Still, it seems to me that instead of distancing the reader, as Sell seems to suggest in his brief treatment of The Nature of Blood, Phillips's narrative method in Higher Ground, Crossing the River, and The Nature of Blood obliges him/her to adopt an empathic attitude towards the characters, which to some extent helps counterbalance the gloom of their common destiny. Phillips's other four novels, Cambridge, A Distant Shore, Dancing in the Dark, and, to some extent, his latest fiction, In the Falling Snow, also share the sense of an almost pre-ordained fate, but their determinism might be even less tinged with fatalism. Indeed, as these novels are relatively more linear and focus on a single set of characters, they tend to give more prominence to the protagonists' individual aspirations and their attempts to be autonomous, even if their efforts often prove unsuccessful and, in many cases, their lives are still doomed by circumstances beyond their control. In Cambridge, for example, Cambridge and Emily are eventually defeated by the larger order that surrounds them - mainly white and male - but they are shown to make choices, if sometimes the wrong ones, which confers a certain grandeur on their struggle. The same could be said of Dorothy and Solomon in A Distant Shore and of Bert in Dancing in the Dark. As for Keith, the protagonist of In the Falling Snow, he is at the beginning of the novel under the deceptive impression that he is fully in control of his life, until he becomes acquainted with the details of his father Earl's painful experience as a West Indian immigrant in England. He only then realizes that the past is a burden that he, and his own mixed-race son, might find it difficult wholly to escape.

My intention in the rest of this essay is to show how this paradoxical combination of defeat and dignity, this tension between determinism and free will, is also crucially at the heart of Phillips's last book but one, Foreigners: Three English Lives, which retraces the tragic lives of three black men who actually

\footnotetext{
${ }^{2}$ Sell, "Chance and Gesture in Zadie Smith's White Teeth and The Autograph Man," 32.

${ }^{3}$ Sell, "Chance and Gesture in Zadie Smith's White Teeth and The Autograph Man," 32. Sell mentions the namelessness of the Othello character in The Nature of Blood. Many characters of "Heartland" in Higher Ground are equally nameless.
} 
lived in England at different periods, yet all saw their liberty to decide curtailed by racial prejudice and paternalism, but also by their own human weaknesses. In Foreigners, Phillips's take on determinism seems to combine the two approaches present in his later fiction. On the one hand, its tripartite structure seems to imply, as in Higher Ground, for example, that things have not really changed between the eighteenth and the twentieth century, and that slavery, and the racism that it left in its wake, has had a lasting effect on human relationships in English society. On the other hand, like Dancing in the Dark, for instance, Foreigners focuses very much on the personal struggle of its protagonists, who are all located very precisely (not only in London but in the Midlands, in Wales and in Yorkshire) and whose plight is presented above all as individual, while also having more general ramifications. It might be argued that the determinism at work in Foreigners is of the softer kind, presented as permanent, but not universal, and regarded as compatible with a limited exercise of free will. I will first attempt to explain how determinism and free will coexist in this book by examining separately the life stories told in each of its three sections. I will further briefly focus on its formal features and will try to explain that its bold mix of fiction and non-fiction - which goes beyond another form of determinism, generic this time - partakes of its overall statement about human freedom, or the lack thereof. It might be read as an indirect assertion of the free will of Phillips's characters but also of his own as a writer.

The first section of Foreigners, entitled "Dr Johnson's Watch," evokes the life of Francis Barber, who was born in Jamaica, arrived in England as a young boy in 1750, and spent most of his life in the service of Samuel Johnson, the famous man of letters. Barber's life is told by an anonymous narrator who several years after Johnson's death decides to publish a profile of the latter's famous black servant. In his account, the narrator concentrates on the "unique relationship"4 that bound Dr Johnson and Francis Barber, who were almost like father and son; he also describes how Barber, who had inherited handsomely from Johnson, ended up a pauper. What is most interesting in the perspective adopted here is to see how the narrator accounts for what he calls Barber's "fall from grace" $(21,53)$. For him, this is to be blamed on Barber's own ineptitude, his drinking and spending habits, and other people's dishonesty. He also suggests that the Jamaican's downfall might be linked to his

\footnotetext{
${ }^{4}$ Caryl Phillips, Foreigners: Three English Lives (London: Harvill Secker, 2007): 23. Further page references are in the main text.
} 
personality, "such as one might reasonably anticipate from a member of his race" (6), as if Barber's ruin were somehow a fatality caused by his complexion. However, he hardly relates Barber's predicament to the latter's situation as a black outsider and as a man who was sold, transported, given as a present to Johnson - in other words, a man who was acted upon rather than acting. The narrator's presentation of Johnson is not without interest, either: the famous author is shown as someone who not only escaped the "modest circumstances" (4) he was born into, but who also steers clear of implementing racial determinism. Indeed, the famous doctor is opposed to slavery, which, for him, "could never be considered the natural condition of man" (6), and he educates his black servant at a time when black men in England "were prohibited by law from learning a trade" (32). In spite of his perception of Johnson's progressive nature, it seems, however, that the narrator is unaware of the complexities of the Johnson-Barber relationship and fails to see how the doctor's well-meaning decisions on behalf of his servant actually impinge on the latter's freedom to decide for himself. At one stage, for example, Barber arranges to go to sea - a resolution clearly associated with his desire for independence - but Johnson manages to have him discharged because he is worried about his protégé's welfare.

It is only when the narrator finally meets Barber on his death-bed, in a miserable infirmary in Lichfield (also Johnson's birthplace), that Barber's own voice is heard and that the reader gets another, more nuanced perspective:

I lack dignity. [He says] Even coming to Lichfield was a fulfilment of my master's wishes. [...] I sincerely wish that he had used me differently. [...] Perhaps it would have been more profitable for me to have established for myself the limits of my abilities rather than having them blurred by kindness, dependence, and my own indolence. (58)

This is the only time that one of the three protagonists is given a chance to actually express himself in the novel. And, significantly, Barber's final words are "Look liberty in the face" (58), a sentence, as we will see, that could have been uttered by the other two "foreigners" portrayed by Phillips. Be that as it may, the narrator of the first section interprets this statement as "pitiful" (59), but fails again to understand its irony. Indeed, for all his relative open-mindedness, the narrator is blinded by a rigid sense of race and class, which was by no means unusual for the time. This transpires most visibly in his own choice of words - for example, all the race-related adjectives (such as "sable," 
"sooty," and "negro," 5-6) that he uses whenever he speaks of Barber, but also in the many remarks which convey his rather inflexible but also naive view of the "natural order" (33) that should preside over society. Of Barber, he concludes for instance that "this negro had most likely been destroyed by the unnatural good fortune of many years of keeping company with those of a superior rank, thus depriving him of any understanding of his own true status in the world" (59). He further declares that "English air is clearly not suitable for negro lungs and soon reduces these creatures to a state of childish helplessness" (59). In view of this, it is not surprising that his present to Barber's widow should be a watch, an object that used to belong to Dr Johnson but also one which can be associated with determinism. The title of the section has therefore a double meaning: it refers to this clockwork, a mechanism that regulates time, but it can also be understood as Dr Johnson's watchful protection, which was for Barber a blessing of sorts but also a curse, as it got in the way of his autonomy.

The second section of the book is devoted to Randolph Turpin, an Englishborn, mixed-race man with roots in Guyana who became Britain's first black world champion boxer in 1951. Two hundred years after Francis Barber, Turpin also experiences a spectacular "fall from grace" $(144,150)$ and dies destitute in spite of a career that made him at one point one of the most famous black Britons. Like Barber, Turpin is 'protected' by white men, his manager and his trainer, who are presented at once as father figures of sorts and as the authors of the part that the boxer is supposed to play - i.e. "the script" (70) of his professional life.

Turpin's story is first told as a factual account of the boxer's rise and fall, written in a rather dry and journalistic style, including occasional clichés, such as "shot in the arm" (73). It ends on a more personal note, with an 'I' narrator - obviously Caryl Phillips himself - discussing the boxer's life with two of Turpin's now adult daughters, as if the author had wanted to allow his readers the freedom to first make up their minds about Turpin before decoding his life story and approaching it from a more intimate angle. ${ }^{6}$ The conversation with Annette and Charmaine Turpin confirms that their father "felt betrayed" (164)

${ }^{5}$ The narrator seems to support Granville Sharp's project of resettling blacks on the West Coast of Africa. This is also the topic of Caryl Phillips's latest play, Rough Crossings (2007).

${ }^{6}$ Turpin's daughters tell the 'I' narrator that this is the model of behaviour their parents passed down to them: by letting them make up their minds about things, as opposed to a predetermined view of the world $(160,165)$. 
by British society, which temporarily forgot about his race and his workingclass background when he was successful, but failed to recognize him otherwise. Their father was, indeed, adulated when he was at the height of his fame in a sport that until 1947 treated "black boxers, even if they were, like Randolph Turpin, born and bred in Britain, [...] as foreigners and excluded [them] from fighting for their own national championship" $(78)^{7}$

From Phillips's account, it is clear that Turpin was a man torn between his private and his public image. Privately, he was a very complex character: sensitive and "emotionally vulnerable" (100), he was also "headstrong and capricious" (92), always making sure that things went "exactly the way he wanted" (133), perhaps as a way of coping with his daily experience of humiliation as a member of "the only coloured family in town" (94). His eventual suicide (and an attempted suicide when he was younger) may be viewed as the ultimate expression of this self-will - although this "controlling personality" (115) also leads to less respectable actions such as his domestic violence against his first wife or his failed attempt to kill his own baby daughter, Carmen. Publicly, however, Turpin is expected to play a predetermined role as "a coloured bully" (109), a womanizer, or as a sports celebrity who signs autographs and performs for the public. At one point in his career, he is shown as "doing little more than shadow-boxing alongside singing and dancing acts, clowns, and even pet acts" (122), and later, as a black wrestler, he becomes "little more than novelty ring-fodder to be thrown around for the comic entertainment of the masses" (144-45), a degradation that is similar to that of Bert Williams in Dancing in the Dark. Turpin's double personality, at once responsible for his behaviour yet influenced by circumstances over which he has no control, is reflected in the ambivalent title of the chapter, "Made in Wales," which signals both dignity and humiliation. It first refers to the influence of Wales, his wife's birthplace, on Turpin's character. Indeed, it is in Wales that he "could temporarily escape his upbringing, his past" (71), that he "could just be himself" (162), and was not made to feel a foreigner. But

7 In a sense, boxing could be interpreted as a metaphor for the black British condition, as black British people have had to constantly retaliate or fight back to assert themselves and keep their dignity. The narrator of Turpin's story evokes the cases of several black boxers in Britain (76-77). Black prize-fighters are also mentioned in Peter Fryer's Staying Power: The History of Black People in Britain (London: Pluto, 1984): 227-28, 445-54. I would like to thank Dave Gunning for pointing out this reference to me. See also Caryl Phillips, "Only Connect: An Interview with Caryl Phillips on Foreigners," by Bénédicte Ledent, in Conversations with Caryl Phillips, ed. Renée T. Schatteman (Jackson: UP of Mississippi, 2009): 186. 
Wales is also the place where his celebrity was literally manufactured by Leslie Thomas Salt, an unscrupulous white businessman, making of Turpin a mere product to be marketed and thus commodified as slaves once were.

Other allusions to slavery, and indirectly to its impact on contemporary English society, can be found in the last section, "Northern Lights," where the protagonist, the Nigerian David Oluwale, is referred to as "Yoruba cargo" (175). Oluwale arrives as a teenager in Leeds, "the heart of England" (175), at the end of the 1940s. His story is told in a wholly unpredictable way through a medley of voices with many different tones. Included in Oluwale's narrative are several witnesses, official documents, and extracts from books, as well as the interventions of a narrator addressing him in the second person. This creates a sense of intimacy that contrasts with Oluwale's bleak fate as an isolated individual. If there is a sense of unexpectedness in the form, however, the content of Oluwale's life is quite predictable in its horror, part of a long chain of suffering, following the path of those who, like him, came illegally to the UK from Africa and were crushed by the institutional racism rife in what is supposed to be the land of justice and liberty (210-11). Oluwale's misfortune also has much in common with the experience of all the immigrants, whether Jewish or Irish, who arrived in Leeds before him and had to face the city's infamous hostile attitude to "perceived 'outsiders" (213). This fact is mentioned in historical snippets that are included in the narrative itself and remind the reader that Leeds's wealth in the nineteenth century depended "upon the labour of the poor and the young" (210). Nothing much seems to have changed in the twentieth century, the narrator bitterly suggests (218).

Oluwale arrives from his native Nigeria as a stowaway, in circumstances reminiscent of the Middle Passage, with the difference that he thinks he has his "whole life in front of him" (174) and that he believes he is travelling to freedom, with the dream of becoming an engineer. Yet his is a journey to utter loneliness and to confinement, not only in prison but also for several years in a mental asylum, a place where, it is well-known, one "[loses] control of [one's] life" (202) and where Oluwale was presumably "[sedated] into submission" (194). After this, much of his time is spent as a vagrant on the streets of Leeds, chased by the police, who are all the more determined to harass, beat, arrest or torment him, since "he [isn't] prepared to be anybody's victim" (207) and has proudly made up his mind that he has a right to belong. In other words, Oluwale stubbornly refuses to "be invisible" (219), knowing full well what his defiance will earn him at the hands of the police - a strange combination of fatalism and determination. Oluwale is eventually found dead in 
the river Aire, an end which resembles that of Solomon in A Distant Shore and ironically ensures that he is now "forever in Leeds" (260) as he wanted to be. His dignity is preserved, even if the two policemen suspected of his death are convicted only of assault, and not of manslaughter.

Nothing much seems to have changed between Barber and Oluwale. Yet, far from testifying to Phillips's pessimism, Foreigners could be read as evidence of his optimism, qualified as it may be. Clearly, the book makes a convincing case in bringing these three blighted lives together. Put side by side, the three of them show, with both nuance and strength, how preconceived ideas and bigotry can restrict, even annihilate, individual freedom of action and deprive men of responsibility. Foreigners thus restores some of these men's lost self-esteem by providing a rendering - both objective and moving, factual and emotional - of their singular life stories, which had so far largely remained untold. ${ }^{8}$ If they are cast as 'Foreigners' by English society, they are nonetheless shown to live very English lives, as the subtitle to the novel indicates. They are seen not only as victims of racial and social determinism but preeminently as human beings with aspirations, dreams, and shortcomings, who have been thwarted in their endeavours but nevertheless "refused to compromise their own value system." As one of the people who knew David Oluwale says, "To me, David was a fighter for freedom. He was not another victim" (226).

The impressive unity that exists on the thematic level is nevertheless absent on the formal one. Each story is, indeed, told in its own peculiar style and uses different narrative strategies, resulting in "portraits as hard to pigeonhole as are its protagonists." 10 Phillips has explained in an interview that this "[stylistic] choice was intuitive," but that "as [he] entered further into each section, [he] tried, very deliberately, to develop a formal tone that was diffe-

\footnotetext{
${ }^{8}$ On Francis Barber, see Dave Randle, A Troublesome Disorder (New Romney: Bank House, 2002); on David Oluwale, see Jeremy Sandford, Smiling David: The Story of David Oluwale (London: Calder \& Boyars, 1974), Linton Kwesi Johnson, "The Night of the Head," in his Dread Beat and Blood (London: Bogle-L'Ouverture, 1975): 34-35, and Kester Aspden, Nationality: Wog: The Hounding of David Oluwale (London: Jonathan Cape, 2007).

9 David Lammy, "It's Cold Outside," review of Foreigners: Three English Lives, by Caryl Phillips, Guardian (25 August 2007): http://www.guardian.co.uk/books/2007/aug /25/society (accessed 8 January 2010).

${ }^{10}$ Margaret Busby, "Three Hundred Years of Solitude," review of Foreigners: Three English Lives, by Caryl Phillips, Independent on Sunday (21 September 2007): http://www .independent.co.uk/arts-entertainment/books/reviews/foreigners-three-english-lives-by-carylphillips-464497.html (accessed 9 January 2010).
} 
rent from the other two sections." ${ }^{, 11}$ While this formal diversity might be linked to the type of documentary material that Phillips had at his disposal for each individual character, it also offers an intriguing riposte to the regrettable Western tendency to cast all black people in identical moulds, judging all black people by the colour of their skin as if they were similar and, as a consequence, behaved in the same way. Phillips's narrative individualization may thus be read as a way of paying respect to the singularity of Francis Barber, Randolph Turpin, and David Oluwale, whose lives, like those of many others, were constrained by preconceived notions hindering their personal emancipation. Foreigners also goes against the deterministic grain in another way: by freely combining fact and fiction, and by producing a text which is eventually generically unpindownable, midway between an essay and a novel. A quick look at the reviews published when Foreigners appeared confirms that its hybrid quality did not leave critics indifferent, but prompted them to produce widely divergent analyses, the book being a source of satisfaction to some and of irritation to others. By making it difficult to stick labels on it, Foreigners has contributed to challenging the validity of over-determined categories, whether social, racial, or literary.

\section{WORKS CITED}

Aspden, Kester. Nationality: Wog. The Hounding of David Oluwale (London: Jonathan Cape, 2007).

Busby, Margaret. "Three Hundred Years of Solitude," review of Foreigners: Three English Lives, by Caryl Phillips, Independent on Sunday (21 September 2007): http://www.independent.co.uk/arts-entertainment/books/reviews/foreigners-threeenglish-lives-by-caryl-phillips-464497.html (accessed 9 January 2010).

Fryer, Peter. Staying Power: The History of Black People in Britain (London: Pluto, 1984).

Johnson, Linton Kwesi. "The Night of the Head," in his Dread Beat and Blood (London: Bogle-L'Ouverture, 1975): 34-35.

Lammy, David. "It's Cold Outside," rev. of Foreigners: Three English Lives, by Caryl Phillips, Guardian (25 August 2007): http://www.guardian.co.uk/books/2007/aug /25/society (accessed 8 January 2010).

Phillips, Caryl. Cambridge (London: Bloomsbury, 1991).

- Crossing the River (London: Bloomsbury, 1993).

. Dancing in the Dark (London: Secker \& Warburg, 2005).

\footnotetext{
${ }^{11}$ Phillips, "Only Connect: An Interview with Caryl Phillips on Foreigners," 189.
} 
. A Distant Shore (London: Secker \& Warburg, 2003).

The Final Passage (London: Faber \& Faber, 1985).

—. Foreigners: Three English Lives (London: Harvill Secker, 2007).

. Higher Ground (London: Viking 1989).

. In the Falling Snow (London: Harvill Secker, 2009).

. The Nature of Blood (London: Faber \& Faber, 1997).

"Only Connect: An Interview with Caryl Phillips on Foreigners," by Bénédicte Ledent, in Conversations with Caryl Phillips, ed. Renée T. Schatteman (Jackson: UP of Mississippi, 2009): 184-91.

- Rough Crossings (London: Oberon, 2007).

- A State of Independence (London: Faber \& Faber, 1986).

Randle, Dave. A Troublesome Disorder (New Romney: Bank House, 2002).

Sandford, Jeremy. Smiling David: The Story of David Oluwale (London: Calder \& Boyars, 1974).

Sell, Jonathan P.A. "Chance and Gesture in Zadie Smith's White Teeth and The Autograph Man: A Model for Multicultural Identity?" Journal of Commonwealth Literature 41.3 (September 2006): 27-44. 


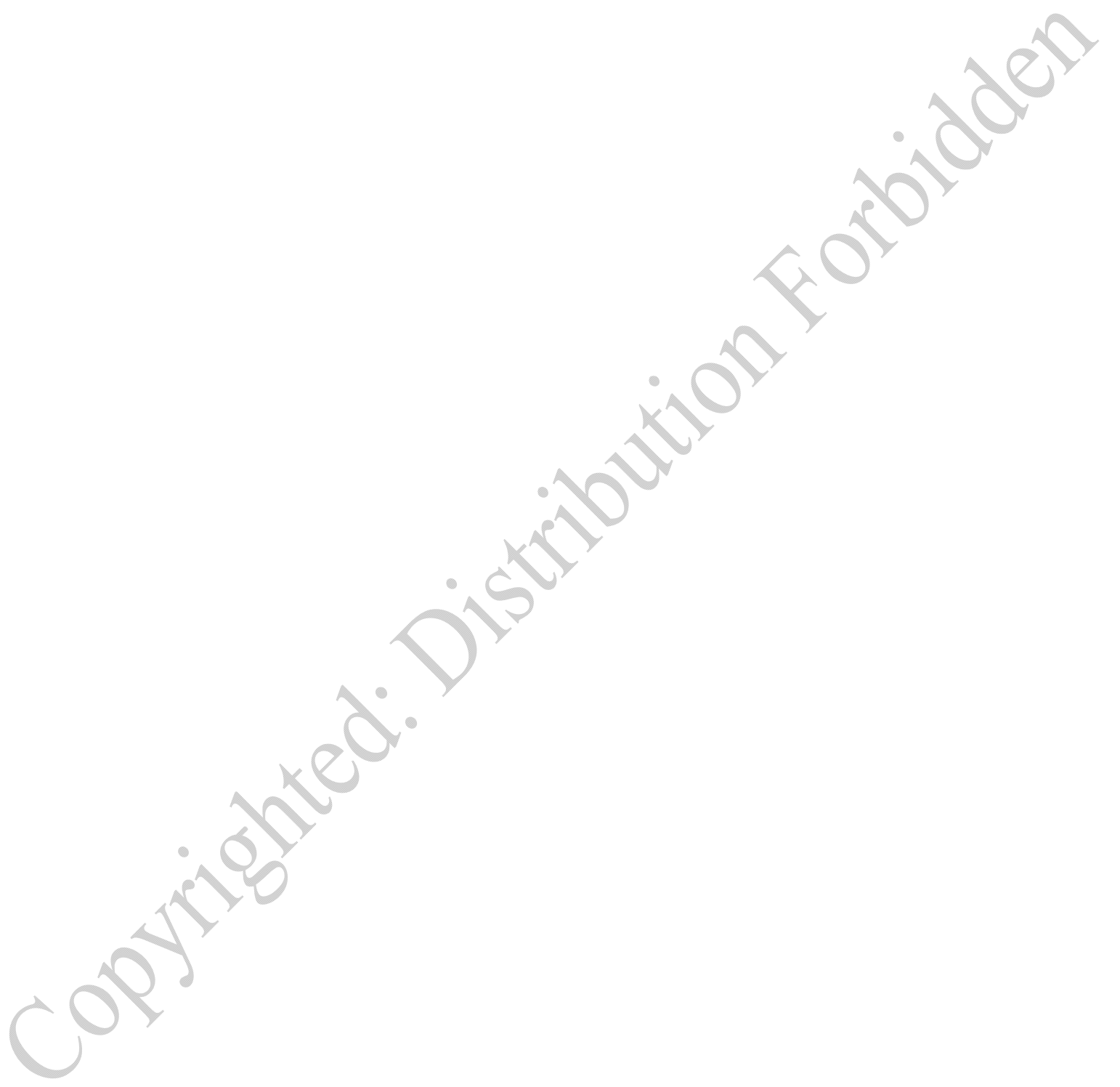




\title{
Hybrid Inventiveness
}

\section{Caryl Phillips's Black Atlantic Subjectivity:} The European Tribe and The Atlantic Sound

\author{
JOAN MilLER POWELL
}

N an interview With Stephen Clingman, Caryl Phillips states that from his very first book he knew he had to "disrupt form [...] because the stories I was going to tell, the people that I was talking about, seemed to me to be people whose lives had been disrupted and didn't have a clear narrative continuity, because of various forms of displacement." In other words, Phillips is concerned with formal disruption because it is the structural analogue of the historical, socio-cultural, and psychological disruption of the diasporic subjects who inhabit the world of his texts. Although present from the very beginning, Phillips's poetic of displacement has undergone substantial evolution, in that it has moved from the seemingly social realism and largely linear narration of his first two novels to the more experimental and disruptive postmodernist forms of his later works. These formal strategies have become characteristic of his novels and show Phillips to be self-consciously innovative as well as being explicitly metafictional in his appropriation and rewriting of a variety of texts. His non-fiction work is no different. His two travel narratives, The European Tribe and The Atlantic Sound, which constitute the focus of this enquiry, demonstrate that Phillips's tendency to experiment with form is shared across genres.

In tracing the transgressive practices of his work generally, and his travel writing in particular, I wish to argue that Phillips has a propensity for metafictional narrative modes, pastiche, polyphony, intertextuality, and related forms

\footnotetext{
${ }^{1}$ Caryl Phillips, "Other Voices: An Interview with Caryl Phillips" (October 2001), by Stephen Clingman, Salmagundi 143 (2004): 128.
} 
that enable the inquisitorial revision and articulation of the literary and historical representations of black and Jewish diasporic subjects. The writer's structural oscillations undermine generic conventions, fixed categories of race, nation, place, identity and, ultimately, history itself. Consequently, his work effects a 'hybrid inventiveness' or repertoire of formal strategies that draws on the travel narrative and on various types of life-writing to imaginatively represent the diasporic condition in terms of nomadism, ontological instability, and serial transformations. This 'hybrid inventiveness', in other words, means the renewal of genres by reworking, reframing, and recontextualizing their dominant conventions; as such, this phrase speaks to the architectonics of Phillips's representation of displacement in his fiction and nonfiction alike. Displacement in the two early novels, The Final Passage and $A$ State of Independence, is figured particularly in terms of spatial binaries (metropole and island/colony, here and elsewhere). In the subsequent works, by contrast, it is represented in terms of rhizomatic relationships across diasporic sites, which are also formally linked to Phillips's troping of orphanage and familial dysfunctionality as key markers of displacement. This is exemplified, in Crossing the River and The Nature of Blood, through filial disruption and paternal betrayal, orphanhood, and states of psychic abandonment, as well as interracial relationships that expand the notion of kin.

Phillips's two travelogues, The European Tribe and The Atlantic Sound, which are equally representative of his repertoire of formal strategies, position his writing as a need to "express the conundrum of [his] own existence." They chart the problematics of black British diasporic angst from the "halflife which is the predicament of the outsider" ${ }^{\prime 3}$ to the development of a consciousness effectively represented in Paul Gilroy's The Black Atlantic as a consequence of the massive dispersal of Africans to the Americas and Europe. In this scenario, the Atlantic Ocean becomes the nodal position, subtended by continental Africa, from which radiates a profoundly variant geocultural matrix of systems with multiple intersections and interactions. The Black-Atlantic consciousness that arises from this 'supranational formulation' is a collective one, fashioned from and informed by the lived realities of colonial and postcolonial histories haunted by the ghosts of imperial subjugation, slavery, and racism. Constituted heterogeneously, Black-Atlantic conscious-

\footnotetext{
${ }^{2}$ Caryl Phillips, The European Tribe (London: Vintage, 200o): 8. Further page referrences are in the main text after " $E T$."

${ }^{3}$ Michael Hanchard, "Afro-Modernity, Temporality, Politics and the African Diaspora," Public Culture 11.1 (Winter 1999): 245-68.
} 
ness is a matrix of various racial, ethnic, national, and cultural configurations, re-alignments, and re-formations which, in turn, give rise to certain forms of cultural and artistic expression.

Both The European Tribe and The Atlantic Sound serve to chronicle Phillips's slippages between traveller and immigrant and his emergence into some kind of Black-Atlantic persona. As such, both texts map his move from the "contradiction of feeling British" $(E T, 9)$ and the attendant sense of unbelonging, to the point where he is able to acknowledge, albeit with much struggle, that he is Caribbean ${ }^{4}$ and that he can also "[travel] towards Britain with a sense of knowledge and propriety" $(A S, 22)$. The texts are marked by the particular anxieties and ambiguities of black British identities which Gilroy describes in this way:

The black experience in England is increasingly revealed to possess a certain uniqueness - a particularity and peculiarity that distinguish it from the history of black populations elsewhere in the diaspora. ${ }^{5}$

For Gilroy, migrancy and postcoloniality "rather than the memory of slavery" are the constitutive experiences of contemporary black Britain. Phillips, by contrast, while fully concerned with the contemporary issues mentioned by Gilroy, is also haunted by the memory of slavery and the persistence of the imperial past in the present.

This pervasive angst is first evoked in The European Tribe, in Phillips's account of his journey initially, though rather briefly, to the Caribbean of his birth, then later to North Africa and eventually to Europe. The journey is a quest to define himself as well as to understand a continent, Europe, that he "feel[s] both of and not of" (ET, ix). Phillips's wanderings last over a year and as he travels he views different places through different lenses, some cinematic, others literary or historical. The journey starts in Casablanca, Morocco, supposedly Africa's nearest city to Europe, where Phillips is unable to reconcile the suggested opulence and romance of the movie Casablanca - as he remembers it - with the poverty confronting him. Travelling through to Gibraltar and Spain, he eventually arrives in southern France, where he meets and spends a few days with James Baldwin and Miles Davis. Leaving Nice,

\footnotetext{
${ }^{4}$ Caryl Phillips, The Atlantic Sound (New York: Alfred A. Knopf, 2000): 210. Further page references are in the main text after " $A S$."

${ }_{5}^{5}$ Paul Gilroy, "The Peculiarities of the Black English," in Small Acts: Thoughts on the Politics of Black Cultures (London: Serpent's Tail, 1993): 54.

${ }^{6}$ Gilroy, "The Peculiarities of the Black English," 54.
} 
he arrives in Venice, where he reflects on Shakespeare's Shylock, and makes a personally metaphoric and psychological connection with another Shakespearean character, Othello. Phillips subsequently visits Paris and Amsterdam, where he tours the Anne Frank House. Then he leaves for Ireland, where he interviews the Archbishop of Ireland, a former missionary to the Ibo peoples, who relates an interesting anecdote about the origins of Nigeria's name. Continuing his journey, Phillips visits several German cities, as well as Poland and Norway. After visiting Moscow, he leaves, finally, for England.

Whereas The European Tribe narrates a largely intra-continental experience, The Atlantic Sound takes Phillips across four continents (the Americas, Europe, Africa, and Asia), incorporating for the first time in his non-fiction the cartography and socio-economic, psychological, and political transactions that have resulted in the cultural heterogeneity of the Black Atlantic. The Atlantic Sound records Phillips's attempt to retrace the ports involved in the infamous triangular trade of slavery and to also experience the journey later undertaken by his own family in the wake of HMS Empire Windrush. His journeying begins with his arrival by air in Guadeloupe, then onwards by banana boat on a somewhat tedious and claustrophobic voyage to Dover, from where he travels to Liverpool, once the European hub of the slave trade. In Liverpool, he reflects on the way in which the city drew its grandeur from human sacrifice and he is struck by how seemingly oblivious its citizenry is to its past. From there, Phillips goes to Accra, Ghana, where he attends Panafest, a black cultural festival, and visits several places including Elmina Castle, the fort from which hundreds of thousands of Africans left as slaves for the Americas. He then goes to Charleston, South Carolina, the representative third angle of the triangular slave trade. After that, he travels to the Negev Desert, where he meets a community of African Americans, the African Hebrew Israelites, who have set up their Kingdom of God on Earth and who believe themselves to be descendants of the ancient Israelites who were punished by God for disobeying his commandments. Three other stories are woven into the main narrative of The Atlantic Sound. The first one is that of John Ocansey, who, with much trepidation, journeys to Liverpool and successfully retrieves money of which his father had been defrauded. There is also the story of Philip Quaque, a black missionary in Ghana for the Londonbased Society for the Propagation of the Gospel in Foreign Parts, as well as the story of the white American Judge Waring, ostracized both for his second marriage and for his role in the civil-rights struggle against segregation in the American South. 
In The European Tribe, Phillips's formal strategies, his engagement with the essay, allow him to represent his efforts to determine his place in the world and to open up for discussion European exclusionary and divisive practices. The Atlantic Sound, by way of its fluvial-marine metaphor, underscores a confluence of cultures through plural perspectives. The trope of multiple and intersecting journeys is the principal formal device in both narratives, but ironic appropriation and inversion are important technical strategies as well. In The European Tribe, travel and its associated topoi are used to underscore and undermine the monolithic whiteness of Europe's self-construction, whereas in The Atlantic Sound they chart the differentiated complexities and cartographies of the Black Atlantic.

Despite the varied stylistic strategies and tropes employed in The European Tribe and The Atlantic Sound, it is the travelogue, or travel writing as a genre, that defines the narrative structure of these two works. Travel writing is pliable and receptive. As Jonathan Raban remarks, it "accommodates the private diary, the essay, the short story, the prose poem, the rough note and polished table talk with indiscriminate hospitality."7 Mary Louise Pratt agrees. In describing the narration-description duality of travel writing, she makes the point that

it was conventional for travel accounts to consist of a combination of firstperson narration, recounting one's trip, and description of the flora and fauna of regions passed through and the manners and customs of the inhabitants. ${ }^{8}$

At once dynamic and subtle, the travel narrative proves a shape-shifting genre that grasps multiplicities even as it potentially unsettles polarities. It courts anomaly even as it conforms. It is transgressive and disruptive even while it seeks order. Known for prevarication, it seeks to maintain integrity. It engages in temporal layerings and oscillations and even where it detours it still moves from journey's beginning to journey's end. In its syncretic relationship with fact and fiction, it occupies the gap between anthropology and history. Nevertheless, the traditional travel narrative, often associated with colonialism, is synonymous with equivocation, with a penchant for exaggeration, embellishment, and inventing, as well as with a predilection for disseminating and justi-

\footnotetext{
${ }^{7}$ Quoted by Steve Clark in his "Introduction" to Travel Writing and Empire: Postcolonial Theory in Transit, ed. Steve Clark (New York: Zed, 1999): 1.

${ }^{8}$ Mary Louise Pratt, "Fieldwork in Common Places," in Writing Culture: The Poetics and Politics of Ethnography, ed. James Clifford \& George E. Marcus (Berkeley: U of California P, 1986): 33 .
} 
fying Europe's essentialist epistemologies and racist ideologies. Paradoxically, however, the genre's propensity for the polyvalent imbues it with the capacity to destabilize monolithic understandings and fixed binaries. In its heterogeneity of form and content, the travel narrative covers a broad spectrum which, in Phillips's application, underscores the pluralism, hybridities, and discontinuities at the heart of The European Tribe and The Atlantic Sound.

Not surprisingly, the labile quality of the travel narrative renders it generically elusive and enables it to engage in a tantalizingly ludic relationship with definitions. Patrick Holland and Graham Huggan, while acknowledging the genre's indeterminacy and its problematic relationship to ethnography, tentatively define it as "self-consciously autobiographical, intentionally anecdotal and (in some cases) deliberately ethnocentric." In turn, they quote Rob Nixon - "who identifies travel literature as a polyvalent genre that alternates between 'a semi-ethnographic, distanced, analytic mode' and 'an autobiographical, emotionally tangled mode" $" 10$ - and Paul Fussell, who speaks of

"a sub-species of memoir in which the autobiographical narrative arises from the speaker's encounter with distant or unfamiliar data, and in which the narrative - unlike that in a novel or a romance - claims literal validity by constant reference to actuality."11

Phillips's practice of this type of narrative overlaps with all of these definitions, but it also constantly subverts the conventional relationship between the strange and the familiar, the literal and the metaphorical, the ethnographic and the autobiographical.

In The European Tribe and The Atlantic Sound, the author's stylistic and thematic strategies exploit the ductility of the travel narrative in an effort to re-frame and revise the genre. From the very outset, therefore, Phillips announces his intention to undermine or, indeed, appropriate, certain conventions of the travelogue, with the aim of subverting the discourses of colonialism. Primarily, he readjusts the dominant paradigm of the white male traveller as speaking voice in the travelogue. In a discussion of the function of race and

\footnotetext{
${ }^{9}$ Patrick Holland \& Graham Huggan, Tourists with Typewriters: Critical Reflections on Contemporary Travel Writing (Ann Arbor: U of Michigan P, 2000): 11.

${ }^{10}$ Holland \& Huggan, Tourists with Typewriters, 11, quoting Nixon, London Calling: V.S. Naipaul, Postcolonial Mandarin (Oxford: Oxford U P, 1992): 15.

${ }^{11}$ Holland \& Huggan, Tourists with Typewriters, 10, quoting Fussell, Abroad: British Literary Travelling Between the Wars (Oxford \& New York: Oxford U P, 1980): 203.
} 
class in the discourse of travel, James Clifford makes the point that "in the dominant discourses of travel, a non-white person cannot figure as a heroic explorer, aesthetic interpreter, or scientific authority."12 From his personal position as a black author, Phillips asserts his refashioning of this conventional presentation of the travel writer. In addition, by using epigraphs from works by Claude McKay, Richard Wright, and James Baldwin, he locates himself in the tradition of black writers who have written about Europe.

In both travelogues, Phillips arrogates to himself the right to be a traveller and the right to appropriate colonialist discourse. In this transgressive act, he inserts himself as a self-willed black, educated traveller of class, managing in the process to challenge the colonial proposition. Thus, in The European Tribe, as Europe's own Other, Phillips presents the continent in all its fallibility to itself and to its peripheries. In this case, it is Europe that becomes the focus of the gaze, placed as it is under the ethnographic and anthropological microscope. In The Atlantic Sound, the third-person narratives of Philip Quaque and John Ocansey, as well as Mansour's story, tell of journeys by Africans - journeys that terminate in their encounters with Europe. Ocansey, Quaque and Mansour are presented as voluntary travellers rather than as transportees, and as such are established as subjects rather than as objects, in contradistinction to imperial ideology. In this way, Phillips once again disrupts the imperialist imperatives of the traditional travel narrative by inverting the subject/object position, by inscribing the right of the Other to be a traveller and by utilizing the genre to demystify empire. Hence, in The European Tribe and The Atlantic Sound, he posits the travelogue as documentary evidence of transculturation, to neutralize imperialist perceptions and allow new perspectives.

In The European Tribe, Phillips subverts the notion of imperial expansion and colonialism by presenting instead a decentred Europe, its old colonialist practices displaced by a new colonizer, the US A. He states unequivocally:

Britain's and Western Europe's days of imperialistic glory are history. [...]

America has conquered Europe economically, politically, and culturally. [...]

I have sat in Barbados sipping 7-Up through a 'Keep America Clean' straw -

a neo-colonial experience. $(E T, 120-21)$

Phillips achieves this representation of Europe by investing in a narrative strategy partial to fragmentation and repetition. Within the travelogue, Phillips

\footnotetext{
${ }^{12}$ James Clifford, Routes: Travel and Translation in the Late Twentieth Century (Cambridge M A: Harvard U P, 1997): 33.
} 
interweaves historical facts ("The Venetian ghetto was the original ghetto [...]. Legally created in 1516, it further isolated the Jews who had first come to Venice in 1373 to avoid mainland persecution": ET, 52) and contemporary data ("As a new member of the Common Market, Spain desperately needs access to the European labour pool": ET, 26). His contemplations of European canonical characters - Othello, Shylock, and Anna Karenina - are also interlaced within the text. Thus, in The European Tribe, Phillips's journey is fragmented by the insertion of diverse historical and literary material that creates heterogeneity, interrogates European identities, and articulates his concerns within a geographical, economic, historical and sociological framework. The writer splinters the text, excavating and scattering the shards of different histories and, by so doing, revealing a decaying and intransigent Europe. The textual potpourri effectively emblematizes the hybridization necessary to counter Europe's deteriorating monolithic heart of whiteness.

Such a strategy signals the rhetorical dismantling of European identitarian discourses even as it reveals the continent's exclusionary practices. As happens in The Atlantic Sound, Phillips's technique of juxtaposing the reality of his journey with statistical and historical data (in an effort to foreground 'truth') counteracts the genre's propensity to embellish by collapsing the documentary and the fantastic $(A S, 40-47,157-67)$. While the traditional travel narrative explored the dichotomy between the real and the imagined, between the Self and the perceived Other, Phillips's re-presentation of the genre facilitates a confrontation with colonialism and racism by repositioning Self and Other. At the same time, the author's insertion of documentary-type material into both travelogues allows a comparative analysis of the consequences of colonialist practices, including racism, cross-cultural exchange, and economic interdependence:

In the ten years between 1783 and 1793, 921 ships employed in the slave trade left Liverpool. Together they shipped to the Americas over 300,000 slaves, who were sold at a sterling value of $£ 15,186,850$. Which means that slaves were worth an average $£ 50$ 'per head', and although there remained expenses from the voyage, and a 5 per cent factor's commission to be deducted, the profits to the slave-traders of Liverpool were still, by anybody's estimates, simply enormous. (AS, 44-45)

The documentary mode intrudes on Phillips's narration of his travel in the same way as different national cultures intrude on each other to create an intra-hybridized Europe ("The Spanish newsagents are packed with British 
newspapers and magazines," ET, 34) that is also subject to non-European influences in the face of its dependency on migrant workers from its former colonies.

Phillips also resists earlier models of travel writing by the way he structures address in both narratives. It is a feature of the genre to embrace the reader in an affiliative way, but neither of Phillips's travelogues does so. In The European Tribe, he adopts the prosecutorial tone of Aimé Césaire's Discourse on Colonialism ${ }^{13}$ to address his European audience:

You justify your Empire, your actions, your thought with your 'civilization,' forgetting that in this century, in the Congo, Belgians chopped off black hands and feet as legal punishment for under-production. $(E T, 128)$

In The Atlantic Sound, he makes no attempt to address the reader directly and from the outset $(A S, 23)$ indicates, by way of the use of Free Indirect Discourse, that, from the moment he leaves home, his feelings will only be obliquely expressed.

The Atlantic Sound and The European Tribe reveal intertextual and discursive relationships - what John Hollander terms a "cave of resonant signification" lips's oeuvre. Structurally, The European Tribe and The Atlantic Sound resemble Phillips's novels. Indeed, the plural and heterogeneous nature of the travelogue as genre, as well as its reputation for accommodating the fictive, allows a platform for the stylistic manoeuvres the writer employs for his novels. The sequential, the episodic, and the parenthetical parallel coalesce and even clash in the travel narratives in the same way they do in his fiction. In both cases, Phillips's texts behave dialogically, interacting with each other to create various configurations of text, pre-text, and con/texts.

One is also able to detect a pointed resonance between both travel narratives themselves, with Liverpool's historical amnesia echoing Europe's amnesia regarding the source of its own "churches, art galleries, and architecture" $(E T, 128)$. Further, as already suggested, both travel narratives engage in an intertextual relationship with European canonical texts. There is interplay with the Shakespearean texts Othello and The Merchant of Venice in The European Tribe, as Phillips establishes metaphoric and thematic valencies

\footnotetext{
${ }^{13}$ Aimé Césaire, Discourse on Colonialism, tr. Joan Pinkham (Discours sur le colonialisme, 1950; New York: New York UP, 2000).

${ }^{14}$ John Hollander, The Figure of Echo: A Mode of Allusion in Milton and After (Berkeley: U of California P, 1981): 65 .
} 
with the Othello and Shylock characters. The European Tribe recalls Tolstoy's Anna Karenina, whereas, in The Atlantic Sound, Phillips alludes to Heathcliff in Emily Brontë's Wuthering Heights when contemplating Liverpool's slave past.

This literary filiation as well as the generic relationship between The European Tribe and The Atlantic Sound as travel narratives is undeniable, and, as indicated above, both texts combine to display the range and possibilities of the travelogue as a genre. However, the differences between the two texts are salient, too. The European Tribe and The Atlantic Sound are not structurally identical, as the former is a collection of essays while the latter is made up of a variety of narratives that include 'factional' re-creations of historical events as well as Phillips's contemporary accounts of his travels. In The European Tribe, there is a single, author-controlled voice projecting Phillips's perspectives and opinions. With this stance, he places himself in opposition to the Europe he is addressing. This is not the case in The Atlantic Sound. Here, the writer engages with the "chorus of a common memory." 15 Thus, in The Atlantic Sound, he splits his eye/I (i.e. his narrative gaze and his authorial subjectivity), thereby positioning himself in different temporal frames and even ideological positions and changing tense to announce perspectival shifts. In Liverpool, he is sometimes a tourist and sometimes an individual bemused by the matter-of-fact Liverpudlian attitude to the city's past. In Africa, the impression is one of unsentimental detachment. Significantly, too, The European Tribe is presented in the past-historic tense. According to Robert Fraser in his discussion of the poetics of postcolonial fiction, this technique "is a revolutionary device" which "renders events substantial." ${ }^{.16}$ In The Atlantic Sound, by contrast, Phillips combines tenses "to redress clichéd habits of historical perception,, 17 especially as this relates to the travel narrative as a genre and in terms of his own project of highlighting the ramifications of the transatlantic slave trade, as well as determining his place in the world.

However, the differences between the two travelogues reside not only in Phillips's manipulation of tenses but also, among other things, in the focus of each narrative on different geographical areas. Apart from the fact that the locations work to emphasize disconnection, they also emblematize the locus of out-of-placeness. The European Tribe mostly records Phillips's travelling

\footnotetext{
${ }^{15}$ Caryl Phillips, Crossing the River (London: Bloomsbury, 1993): 1.

${ }^{16}$ Robert Fraser, Lifting The Sentence: A Poetics of Postcolonial Fiction (Manchester: Manchester U P, 2000): 105-106.

${ }^{17}$ Fraser, Lifting the Sentence, 106.
} 
across and within Europe, and even though it notes an oblique connection with the points of the Atlantic triangular trade, it is in The Atlantic Sound that Phillips literally surveys the routes of that particular journey as he travels through the Americas, Europe, and Africa, and even on to Asia, by way of a visit to Israel. In The European Tribe, Phillips, conscious of marginalization and even oppression, is angry, sometimes acerbic, isolated, and alienated. In The Atlantic Sound, he is casual, at times snobbish, even arrogant, but still out of place in the countries he visits. Thematically, The European Tribe grapples with the virulence of racism and the insecurity of unconnectedness while The Atlantic Sound highlights a diasporic imagination, a Black-Atlanticist concern with transformative travel and displacement, and the questions of origins and belonging that resonate as legacies of the Middle Passage.

Phillips's preface to The European Tribe loosely describes it as a "narrative in the form of a notebook" ( $E T$, ix). It does have a notebook quality, in that one is able to sense with some immediacy the writer's anger and alienation, suggesting, as is characteristic of the genre, a lack of distance between the experiencing and the recording of feelings and events. But The European Tribe is perhaps best described as a compendium of ethno-literary travel essays. Technically, a narrative moves along by way of the actions of its characters. An essay, though, is a way to expeditiously disseminate facts and opinions. Here, the essay form provides an aesthetic and thematic portal for Phillips to relay historical and cultural information through comparative analysis, or through statistical or intertextual references regarding Europe; to relate racial confrontation even as he juxtaposes a colonizing past with it; to emblematize the compartmentalization that subtends Europe's exclusionary practices; and to signify his own feeling of unconnectedness and difference.

The flexibility of the essay as a genre is reflected in Clifford Geertz's claim that "for making detours and going by side roads, nothing is more convenient than the essay form." ${ }^{.18}$ The European Tribe very easily substantiates this claim. The travelogue also confirms George E. Marcus's assertion that the essay "legitimates fragmentation, rough edges, and the self-conscious aim of achieving an effect that disturbs the reader." ${ }^{19}$ Indeed, the text literally directs itself to the white European reader. Further, Phillips is at least etymologically

\footnotetext{
${ }^{18}$ Clifford Geertz, Local Knowledge: Further Essays in Interpretative Anthropology (New York: Basic Books, 1983): 6.

${ }^{19}$ George E. Marcus, "Contemporary Problems of Ethnography in the Modern World System," Writing Culture: The Poetics and Politics of Ethnography, ed. James Clifford \& George E. Marcus (Berkeley: U of California P, 1986): 191.
} 
incisive when he asserts that he "wrote The European Tribe in an attempt to solve the conundrum of what it felt like to be both of, and not of, Europe" ( $E T, 133$, emphasis mine), because it is the nature of the form to test, to try, to prove. The polemical and reflective attributes of the essay enable Phillips to incorporate these qualities into his travel narrative.

As well, the constant ending of one essay and beginning of another enacts Phillips's incessant arrival at and departure from one place or another, and the repetitions and interruptions express the writer's own conflicting wish to return 'home' even while he needs to wander. More significantly, the author asserts the personal nature of his work. From the beginning, The European Tribe affirms his autonomy and his effort to resist totalizing paradigms.

Phillips's organization and sequencing of the various essays offer palpable clues to the techniques used to foreground displacement. In setting up "Hollywood's Casablanca" as the opening chapter after the "Introduction," the writer gives notice that his European tour will be focalized through what Frances Bartkowski describes as the "theatrics of racism." ${ }^{, 20}$ Subsequently, as Phillips moves from one country to another, he conjures up European literary and historical personae who were themselves victims of racism, such as Othello, Shylock, and Anne Frank, as powerful cameos in the ongoing drama of Europe's relation to the Other. By embedding his contemplative gestures in fictional and historical characters, Phillips inflects his narratives with an intertextuality that, according to Tobias Döring in his general discussion of this literary technique, marks affiliation and maintains difference. As Döring succinctly puts it, intertextuality "both generates and retraces a web of tradition, both activates and reinscribes the recollections shared. ${ }^{.21}$ This statement can be incontrovertibly applied to The European Tribe. Phillips's fictive and historical characters perform a mnemonic function, in that they recall a European tradition of black and Jewish oppression. This memory, woven into the interstices of the travelogue, points to Europe's attempts to purge itself of difference, as well as to construct façades of racial and cultural purity.

The Atlantic Sound also has its own mnemonic metronome, coded in histories of Atlantic passages, the slave trade, and free-floating signifiers of home and belonging. Structurally, this is apparent in the book's five movements, including the framing Prologue and Epilogue. The Prologue and Epi-

\footnotetext{
${ }^{20}$ Frances Bartkowski, Travelers, Immigrants, Inmates: Essays in Estrangement (Minneapolis: U of Minnesota P, 1995): 64

${ }^{21}$ Tobias Döring, Caribbean-English Passages: Intertextuality in a Postcolonial Tradition (London: Routledge, 2002): 14.
} 
logue are entitled "Atlantic Crossing" and "Exodus," respectively. The intervening three chapters are entitled, in that order, "Leaving Home," "Homeward Bound," and "Home," and these reveal Phillips's well-known thematic interest in displacement and the ambiguities of home and belonging. The irony of the last chapter lies in the fact that the writer never really feels at home anywhere. Home is, rather, a fictitious place to which one returns only to find oneself in "exodus." These subtitles bring to the fore the polysemic nature of the travelogue's very title, The Atlantic Sound. The term "sound" has the flexibility of being noun, verb, and adjective, and its semantic possibilities are as fluid and multiform as the diasporic realities that it symbolizes. Technically, it is hardly an apt description for the vast body of water that is the Atlantic Ocean. This "sound" at once connects and fuses diametrically opposite cultures. As such, it is about encounter, inter-connectedness, and interaction, even as it is a divide. It is about multidirectional odysseys - journeys in and journeys out, journeys about and across, journeys back and forth. It is about cross-cultural affiliations, dislocation, and re-connection. But it is also about transgressions, violence, and contamination, deprivation and exploitation. Additionally, in terms of Phillips's imperatives, The Atlantic Sound sounds/measures the depth and range of the Black-Atlantic system in terms of its capaciousness, its hybrid personal, physical, and narrative geographies, its generation of tragedy, its reflections on conflict and loss, and yet, its regenerative capacities, its transcultural features - in other words, its hybrid inventiveness. It gives voice to, or sounds, those marginalized and excluded by History; it revises and refashions established perspectives and allows the author to sound/speak forcibly his opinions and perspectives; it sounds/tests/ probes his connectedness and in all of this allows him to 'sound'/pronounce that, even in the face of history, the world is still not sound/right.

In the interview with Clingman mentioned above, Phillips makes certain remarks that further illuminate his use of the Atlantic as a trope. He affirms water as a "constant," "something which binds us together" and which is "a pathway along which we continue to meet and encounter each other." ${ }^{, 22}$ It is in this oxymoronic position of being a binding fluidity that The Atlantic Sound reveals its paradoxical liminality as the medium of connection and agent of dislocation. As Clingman notes, this water entails a duality that combines connection with a "dismal history." ${ }^{, 23}$ On the one hand, as a vast expanse of

\footnotetext{
${ }^{22}$ Clingman, in Phillips, "Other Voices," 117.

${ }^{23}$ Clingman, in Phillips, "Other Voices," 117.
} 
sea it creates a distance which speaks to isolation and alienation, to incursions and violence, thereby confirming Derek Walcott's statement that "the sea is history." ${ }^{24}$ On the other hand, it facilitates mobility with its underwater connections by way of currents and flows, undersea networks that absorb even as they connect all cultures, enabling Kamau Brathwaite's perspective that the "unity is submarine." 25

It bears repeating that, in addition to its basic divisions, Phillips's travelogue contains documentary material, and three fictionalized narratives relating the individual histories of three men caught up in the effects of slavery. His use of the documentary is significant in terms of the relationship between authorial ideology and generic convention. When he inserts in the account of his travels already established documentary material, actual histories, and historical references, he is undermining the notion of history as linear, but, even as he does so, in his application of the documentary he is ascribing to his text the conventional, and normally incontrovertible, marker of authority and authentic truth, and effectively tethering his journey to Black-Atlantic historical reality. In short, he establishes the trustworthiness of his travelogue.

The three fictionalized narratives of Philip Quaque, John Ocansey, and Judge J. Waties Waring, spread across the three chapters, span the eighteenth, nineteenth, and twentieth centuries. These narratives evoke the developmental trajectory of Phillips's poetic - that movement from a seemingly linear narrative to the experimental and disruptive postmodernist forms of his later works. All three stories, told by a flatly assertive third-person narrator, feature fundamentally linear plots that serve to underscore the relentlessly controlling forces of colonialism and the rigid, implacable nature of racism. On the other hand, the interruptions within each narrative by way of such sub-generic material as extracts from letters and court documents re-create the disruptive worlds of these people, their dislocation and relocation. Ocansey's journey to Britain to right wrongs, Quaque's English education and his conversion to Christianity, as well as Judge Waring's social and professional demise, for example, symbolize the existential legacy of slavery manifested in the vicissitudes of inter-cultural encounters, alienation, ontological transformation, and loss.

\footnotetext{
${ }^{24}$ Derek Walcott, "The Sea is History" (1979), Collected Poems: 1948-1984 (London: Faber \& Faber, 1992): 364-66.

${ }^{25}$ Edward [Kamau] Brathwaite, Contradictory Omens: Cultural Diversity and Integration in the Caribbean (Mona, Jamaica: Savacou, 1974): 64.
} 
The stories of Ocansey, Quaque, and Waring also bear the common markers of movement. In fact, journeys constitute an important trope to emblematize rupture and dislocation, and many types of displacement converge in The Atlantic Sound. Geographically, the three narratives locate the trajectory of the slave trade. Consequently, although overtly all of the journeys are personally willed by the respective traveller, they are also focalized through the archetypal triangular voyage and specifically the Middle Passage. The Ocansey and Quaque narratives, in particular, recount actual physical crossings which, contextually, relate to England's relationship with Africa. These travels involve, in the case of Quaque, a quest for knowledge as he goes to England for education and, in the process, undertakes a possible journey from self. Ocansey's expedition works as a quest for justice. So does Waring's, with the additional complexity that his is also a psychological journey, during which he is displaced by his social environment. Waring's displacement is evident in Phillips's reconstruction of his life. Thus, as the writer moves through the South Carolina city of Charleston, interviewing and meeting with the judge's various acquaintances, he narrates and constructs a moving tableau depicting the coming into awareness and the resulting social alienation of the judge.

In The Atlantic Sound, the ship, aircraft, and the car are dominant motifs that denote modes of transport as well as tropes of the centrality of journeys in Black-Atlantic experience. The ship specifically becomes a core metaphor, as a reprise of one of Phillips's earliest experiences, literally generating his black British condition even as it is the "central organising symbol" lanticism. These motifs converge to form what Gail Low describes as "an alternative vision of cross-cultural fertilizations, hybridities, and diasporas."27 This vision valorizes movement, difference, and fluid indeterminacy, as is evident in The Atlantic Sound's repeated traversals across what Edward Said designates as "overlapping territories and intertwined histories." 28

Repetition in The Atlantic Sound also functions, inter alia, to illustrate the nature of oppression as brutal and unending:

${ }^{26}$ Paul Gilroy, The Black Atlantic: Modernity and Double-Consciousness (Cambridge M A: Harvard UP, 1993): 4.

${ }^{27}$ Gail Low, “' A Chorus of Common Memory': Slavery and Redemption in Caryl Phillips's Cambridge and Crossing the River," Research in African Literatures 29.4 (Winter 1998): 122.

${ }^{28}$ See Edward Said's Culture and Imperialism (London: Chatto \& Windus, 1993). "Overlapping Territories, Intertwined Histories" is the title of Chapter One. 
For many years the African has been respected. But now the white man has cheated him of nearly everything that he owns. Abandoning his Christian beliefs, he makes desperate sacrifices to native Gods. But they have forgotten him. His life is running aground. The African has dispatched money to the white man. And now his heart is heavy with grief. $(A S 23,80)$

Repetition in itself stifles - indeed, breaks - linearity and, combined with fragmentation, causes a sense of time as something other than a fixed moment. The combined techniques of starting at the beginning and then later moving backward in time simulate reiteration within the Ocansey story, and so they do across the different sections of the travelogue. Indeed, the Prologue sees Phillips leave the Caribbean, while the next chapter, "Leaving Home," is devoted to Ocansey's departure from Africa and suggests that this is how it all started. In the same way, stylistic strategies such as perspectival shifts, which, for example, occur in the switch from Phillips's first-person account of his journey $(A S, 3)$ to third-person narratives of individuals' stories $(A S, 23)$ or 'objective' recounting of the history of the founding of Liverpool $(A S, 37)$ make the writer both presenter and re-presenter, even while effecting movement from the individual to the general.

Phillips also incorporates dialogue that creates 'factional' moments, making the text informal and uniquely personal. As well, he constantly interrupts himself, ${ }^{29}$ not merely because he wants to alleviate the dominance of his own voice, but to insert other voices. In this sense, then, the shift in perspective enables a broader view, gives depth to the consequences of the slave trade and the development of the Black-Atlantic condition, and creates a dialectical text. In view of this polyphony, it is not surprising that he should employ the technique of Free Indirect Discourse, a fact already mentioned in passing above. According to Henry Louis Gates, Jr., quoting Zora Neale Hurston, this involves "words walking without masters" which, among other things, "evoke a 'voice' or presence" - a presence which, Gates further asserts, "supplements the narrator's." ${ }^{30}$ In The Atlantic Sound, this technique undergirds the Ocansey narrative with urgency and agency. Free Indirect Discourse works to reveal psychological discontent, as it foregrounds the elder Ocansey's sense of desperation and impending social and

\footnotetext{
${ }^{29}$ In The Atlantic Sound, the story on Elmina interrupts Phillips's account of his journey (157), and the Philip Quaque narrative interrupts the description of Phillips's visit to Panafest (175).

${ }^{30}$ Henry Louis Gates, Jr., The Signifying Monkey: A Theory of African-American Literary Criticism (New York: Oxford UP, 1988): 209.
} 
personal catastrophe in the face of betrayal. Moreover, it informs the younger man's need to successfully complete his business in order to return home. In other words, Phillips's multiple perspectives and use of Free Indirect Discourse validate Michael Ginsberg's definition of the latter technique as the "way of expression of a divided self." 31

As this essay has attempted to demonstrate, the textual manoeuvres and strategies at work in The European Tribe and The Atlantic Sound are not all about an alteration of existing aesthetics, or the subversion of traditionally held conventions, merely to describe a journey over land and thereby depict the individuality and idiosyncrasies of a continent or two. Shaped by the same revisionist imperatives as Phillips's fiction, these two travel narratives operate a decentering of eurocentrism by resorting to a politics of black literary filiation and reversing the conventions associated with the white traveller's gaze. They also foreground travel as transculturation and destabilize essentialist discourses of identity, while at the same time documenting colonial and imperial histories and legacies. Indeed, Phillips's travel narratives derive from the disjunctive moment that arises from the conjunction of his postcolonial and postmodern sensibilities and is full of complexities and incompatibilities. Not only does Phillips's very condition as a Caribbean-born British subject make it problematic for him to define himself in terms of a particular place, but the condition is itself forged in the crucible of the travel/journey from Columbus to the slave ships of the Middle Passage and the banana boats-cum-passenger ships to Europe. Travel is therefore a significant part of his life and the physical journey becomes a psychic movement to confront his own confusions. Thus, given its pliability, the travelogue becomes an apt vessel to accommodate and reflect Phillips's predicament. His travels, or his exploration of other countries, represent his examination of his own displacement, his search for an integrated self. The dialectic of being Caribbean and black British reveal Phillips in a psychological Sargasso Sea. Therefore, in an approach that recognizes not only his plurality but also the imbrications and problematics of identity, Phillips constructs his subjectivity textually, by way of the travelogue, and experientially by way of the consequences of his many journeyings.

${ }^{31}$ Quoted by Henry Louis Gates, Jr., The Signifying Monkey, 209. 


\section{WORKS CITED}

Bartkowski, Frances. Travelers, Immigrants, Inmates: Essays in Estrangement (Minneapolis: $U$ of Minnesota P, 1995).

Brathwaite, Edward [Kamau]. Contradictory Omens: Cultural Diversity and Integration in the Caribbean (Mona, Jamaica: Savacou, 1974).

Casablanca, dir. Michael Curtiz (Warner Bros, US A 1942; 102 min.).

Césaire, Aimé. Discourse on Colonialism, tr. Joan Pinkham (Discours sur le colonialisme, 1950; New York: New York UP, 2000).

Clark, Steve, "Introduction" to Travel Writing and Empire: Postcolonial Theory in Transit, ed. Steve Clark (New York: Zed, 1999): 1-28.

Clifford, James. Routes: Travel and Translation in the Late Twentieth Century (Cambridge MA: Harvard UP, 1997).

Döring, Tobias. Caribbean-English Passages: Intertextuality in a Postcolonial Tradition (London: Routledge, 2002).

Fraser, Robert. Lifting the Sentence: A Poetics of Postcolonial Fiction (Manchester: Manchester UP, 2000).

Fussell, Paul. Abroad: British Literary Travelling Between the Wars (Oxford \& New York: Oxford UP, 1980).

Gates, Henry Louis, Jr. The Signifying Monkey: A Theory of African-American Literary Criticism (New York: Oxford UP, 1988).

Geertz, Clifford. Local Knowledge Further Essays in Interpretative Anthropology (New York: Basic Books, 1985).

Gilroy, Paul. The Black Atlantic: Modernity and Double-Consciousness (Cambridge MA: Harvard UP, 1992).

. "The Peculiarities of the Black English," Small Acts: Thoughts on the Politics of Black Cultures (London: Serpent's Tail, 1993): 49-62.

Hanchard, Michael. "Afro-Modernity, Temporality, Politics and the African Diaspora," Public Culture 11.1 (Winter 1999): 245-68.

Holland, Patrick, \& Graham Huggan. Tourists With Typewriters: Critical Reflections on Contemporary Travel Writing (Ann Arbor: U of Michigan P, 2000).

Hollander, John. The Figure of Echo: A Mode of Allusion in Milton and After (Berkeley: U of California P, 1981).

Low, Gail. " “A Chorus of Common Memory': Slavery and Redemption in Caryl Phillips's Cambridge and Crossing the River," Research in African Literatures 29.4 (Winter 1998): 122-40.

Marcus, George E. "Contemporary Problems of Ethnography in the Modern World System," Writing Culture: The Poetics and Politics of Ethnography, ed. James Clifford \& George E. Marcus (Berkeley: U of California P, 1986): 161-93.

Nixon, Rob. London Calling: V.S. Naipaul, Postcolonial Mandarin (Oxford: Oxford UP, 1992).

Phillips, Caryl. The Atlantic Sound (New York: Alfred A. Knopf, 200o). 
- Cambridge (1991; London: Picador, 1992).

Crossing the River (1993; London: Picador, 1994).

The European Tribe (1987; New York: Vintage, 2000).

. The Final Passage (London: Faber \& Faber, 1985).

Higher Ground (1989; London: Picador, 1993).

The Nature of Blood (New York: Alfred A. Knopf, 1997).

"Other Voices: An Interview with Caryl Phillips" (October 2001), by Stephen Clingman, Salmagundi 143 (2004): 113-40.

—. A State of Independence (London: Faber \& Faber, 1986).

Pratt, Mary Louise. "Fieldwork in Common Places," Writing Culture: The Poetics and

Politics of Ethnography, ed. James Clifford \& George E. Marcus (Berkeley: U of

California P, 1986): 27-49.

Said, Edward W. Culture and Imperialism (London: Chatto \& Windus, 1993).

Walcott, Derek. "The Sea is History" (1979), in Walcott, Collected Poems: 1948-1984

(London: Faber \& Faber, 1992): 364-66. 


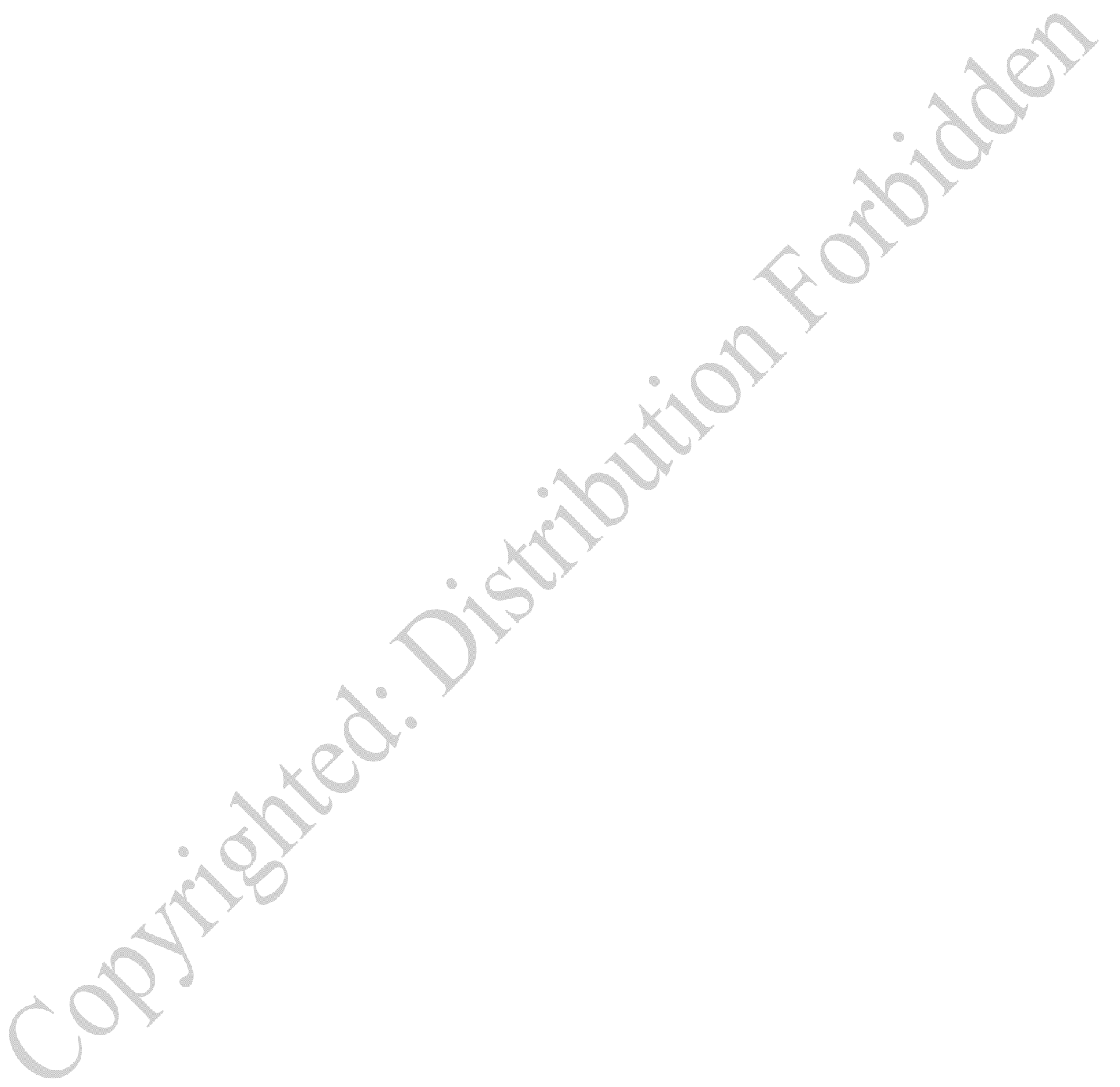


CARYL PHILLIPS AND THE OtheR WRITERS 


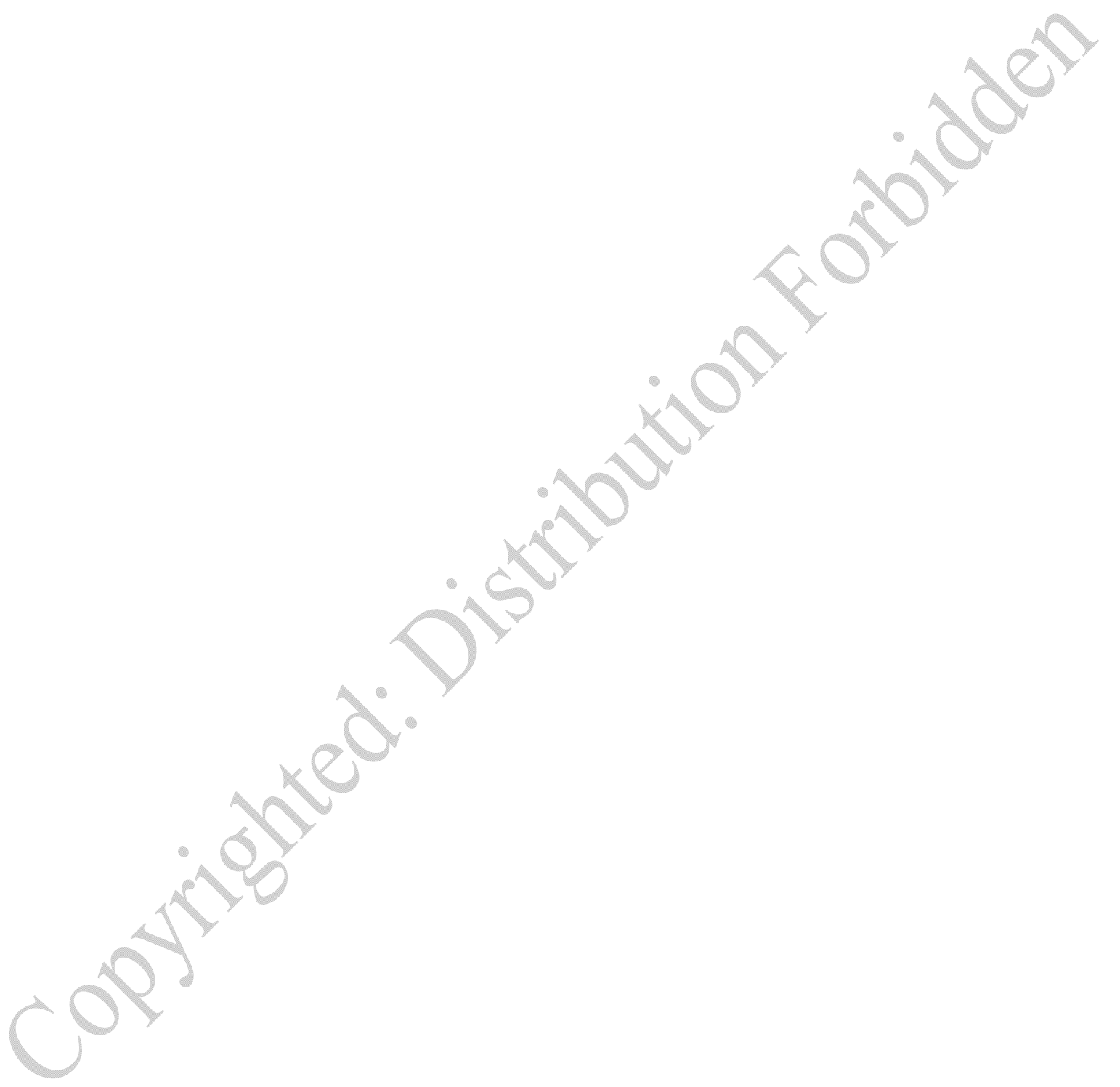




\title{
Vido, not Sir Vidia
}

\section{Caryl Phillips's Encounters with V.S. Naipaul}

\author{
JOHN MCLEOD
}

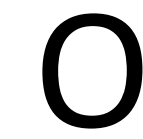

N 7 December 2001, When he received the Nobel Prize

for Literature, V.S. Naipaul delivered a lecture to the Swedish Academy in Stockholm called "Two Worlds.” He began by referring to Proust's remarks regarding the complicated matter of biography. Like Proust, Naipaul was wary of discerning a line of continuity between an author's life and his or her work. It was necessary to maintain a distinction between the two, and not to presume that an author's life could be readily discerned from their creative output. " "A book is the product of a different self from the self we manifest in our habits, in our social life, in our vices,", quoted Naipaul. And then, in his own words, he clinched his point:

All the details of the life and the quirks and the friendships can be laid out for us, but the mystery of the writing will remain. No amount of documentation, however fascinating, can take us there. ${ }^{1}$

A writer, it seemed, dwelt in two worlds, parallel yet distinct: the world of life's 'details' so beloved of the biographer, and the world of the page, where the act of writing emerged from, and perhaps engendered, another version of self.

A few weeks previous to this, Caryl Phillips called Derek Walcott from La Guardia airport, New York City, where he had just learned the news of Naipaul's Nobel Prize. A couple of days later he reflected on Naipaul's achievement in a British newspaper, the Guardian, and wrestled with his own re-

\footnotetext{
${ }^{1}$ V.S. Naipaul, “Two Worlds," in Naipaul, Literary Occasions: Essays, ed. Pankaj Mishra (London: Picador, 2003): 182.
} 
sponse to that year's award. In his article "Reluctant Hero," he recalls an occasion when he had spoken "respectfully but critically" about Naipaul's work at the University of the West Indies in Trinidad, and had been surprised by "the look of outrage and disbelief that marked the faces of those present":

I quickly understood. Naipaul may be an ungenerous bastard, but he was their ungenerous bastard. Who the hell was I to talk about their son of the soil? ${ }^{2}$

But if Phillips was not averse to representing Naipaul's 'vices' in public, his view of the older writer was complicated by his enduring admiration for Naipaul's work. In his article he praises Naipaul's "ability to synthesise, in almost equal part, his fiction and non-fiction - the one genre informing the other both structurally and thematically - [which] has been both original in construction and fascinating to witness."3 Phillips clearly had little time for the distempered 'biographical' Naipaul, yet the mystery and majesty of Naipaul's writing were not to be dismissed.

Significantly, whereas Naipaul demanded a distinction between writers and their writing, Phillips seemed unwilling to let Naipaul and his work reside separately in 'two worlds'. Indeed, in his Guardian article Phillips goes so far as to attempt to uncover a very different version of Naipaul, more virtuous than malevolent, and a dissimilar individual from the "ungenerous bastard" whom Phillips had discussed at the University of the West in Indies in Trinidad. Here highlights a fleeting moment in Naipaul's Letters between a Father and Son (1999) when the twenty-year-old Naipaul - known as Vido - writes to his father about his nostalgia for Trinidad. "I miss this Vido," remarks Phillips; and he concludes his article by imagining Trinidadians telling each other the news of Naipaul's Nobel success: "Not so much, 'Well done Sir Vidia,' but 'You hear about Vido? Naipaul's boy. He done good, eh?' ."4 It is as if Phillips wants to resurrect the tender, kindly 'self' of Vido, enamoured of vernacular Trinidad, and have him replace the garrulous, unforgiving figure of Sir Vidia who did not even mention the Caribbean in his first response to the Nobel award. Naipaul's writing, it seems, deserves a better writer: Vido, not Sir Vidia. It is a remarkable investment on the part of Phillips. We should wonder why.

\footnotetext{
${ }^{2}$ Caryl Phillips, "Reluctant Hero," Guardian (12 October 2001): http://www .guardian.co .uk/books/2001/oct/12/fiction.vsnaipaul (accessed 15 August 2008).

${ }^{3}$ Phillips, "Reluctant Hero."

4 "Reluctant Hero."
} 
In trying to resurrect the figure of Vido, Phillips attempts to align the allegedly different 'selves' which animate an author's life and work, and appears uncomfortable with the tension between Naipaul as a contemptible person - the "ungenerous bastard" - and the creator of original and fascinating literature. These 'two worlds' are not allowed to exist out of synch. It is worth noting, and pausing to think about, the fact that Phillips's Guardian article was merely the latest round in his career-long encounter with the legacy and achievement of Trinidad's most famous writer. In Phillips's review of Naipaul's Letters, collected as part of the essay titled "V.S. Naipaul" in A New World Order (2001), he is similarly caught between a dismissal of Naipaul's personality and an admiration for his work which confounds the distinction between the writer and his creative output. Once again, Phillips's response to this unhappy state of affairs involves an attempt to beckon forth the benign figure of "Vido" from out of Sir Vidia's authorial shadow and install him as the ideal author of Naipaul's Caribbean writing. Phillips argues that Naipaul's letters, written in the 1950s while he was a young man at Oxford University, reveal an alternative future for Naipaul:

a close reading of these letters allows us also to espy something else: the possibility of a subject, a subject that Naipaul wilfully spurned, a subject that, had Naipaul grasped it, would not have necessarily made him into a better writer, but would almost certainly have made him into a more likeable one. ${ }^{5}$

This subject might be thought of as the Caribbean in all of its wonder, richness, and complexity, as Phillips already suggested in a 1992 article that appeared in the Caribbean Review of Books. ${ }^{6}$

With this in mind, it is indeed interesting to note Phillips's suggestion that, in the case of Naipaul, the likeability of a writer may be as important as their creative abilities. This wished-for correspondence or alignment between the 'social life' of a writer and their work reveals, I think, the deep level of Phillips's investment in and admiration for Naipaul's achievement which is expressed here revealingly in terms of disappointment with, even anger at, the uncharitable and aloof figure who has nonetheless accomplished so much on the page. Phillips dearly wants Naipaul to be something other than an "ungenerous bastard." At a moment such as this, it is clear that Naipaul matters to

\footnotetext{
${ }^{5}$ Caryl Phillips, "V.S. Naipaul," A New World Order: Selected Essays (London: Secker \& Warburg, 2001): 204.

${ }^{6}$ See Caryl Phillips, "West Indian Writing Abroad: Naipaul and the New Generation," Caribbean Review of Books 3 (1992): 16, 19, 24, 25-27.
} 
Phillips in a way which is different from, and perhaps more meaningful than, other older literary figures from the Caribbean.

Significantly, Phillips's engagement with Naipaul is prolonged in A New World Order. His Naipaul essay is the longest in the book (thirty-two pages), much longer than the pieces on C.L.R. James, Derek Walcott, George Lamming, and Sam Selvon - writers whom Phillips has often acknowledged as major influences. The measure of his interest can be discerned as his discussion of the Letters proceeds. Phillips writes warmly of Naipaul's early work, culminating in A House for Mr Biswas (1961), and praises it for its representation of vernacular East Indian Trinidad life. On this point, Phillips twice makes mention of compassion in his praise of the novel - a key term in his writings on Naipaul, and one worth recognizing and pondering. For Phillips, Biswas "suggests the existence of a compassionate Naipaul"7 - more "Vido" than "Sir Vidia," as I am terming it. But Phillips also knows that such a figure remains fleeting and temporary. When discussing Naipaul's ungenerous denigration of his cousins in a letter to his sister, Phillips writes: "One begins to wonder where, in all this, is the compassion that is necessary if one is going to write with real understanding." 8 Naipaul's severe persona can already be glimpsed in embryo in the Letters and goes some way to explaining why a benign Naipaul never eventually materialized. And as Vido recedes, so too is the persistence of compassion thwarted, causing serious damage to Naipaul's creative output. Phillips's disappointment, I would suggest, is palpable.

Naipaul matters so much to Phillips, we might hazard, because his writing perhaps serves as a fundamentally important model - in terms of style and content - of how Phillips might formulate his own writerly relationship with the world. As he reflected in 1992,

Every young writer needs to have writers whom they wish to emulate, writers whom they can look up to, writers whose very existence helps them to understand that the journey they are about to embark upon might be something more than a self-deceiving peasant's pilgrimage. ${ }^{9}$

For Phillips, Naipaul is both an inspiration and a warning, and his ambivalent example enables Phillips to discern and fix the very different bearing of his own moral compass as a writer. As we shall see, Phillips's endeavours as an author often attempt to broker compassion, often in the bleakest of circum-

\footnotetext{
${ }^{7}$ Phillips, "V.S. Naipaul," 208.

${ }^{8}$ Phillips, "V.S. Naipaul," 208.

${ }^{9}$ Phillips, "West Indian Writing Abroad," 16.
} 
stances. Writing affords a chance to create sympathetic understanding across divides; in Phillips's hands it becomes a way of engaging exploratively with the lives of others. As I have argued elsewhere, Phillips's writing is driven by an ethics based on looking and listening, and demands that we try to reimagine the lives and losses of seemingly different people as a way of breaking down the barriers of race, gender, culture, and generation. ${ }^{10}$ These are rather un-Naipaulian pursuits, perhaps; but so often Phillips's writerly task is distinctly indebted to Naipaul's example. In other words, Naipaul's example shows Phillips in equal measure how to be, and not to be, a writer; this is why he struggles so persistently with Naipaul's life and work. It is a literary relationship which continues to be creatively fertile - perhaps even necessary. However, as Phillips has explained, while he has always valued the "simple existence" of Naipaul as a major writer from the Caribbean, he has come to understand that "our outlook on most things, literary or otherwise, differs quite radically.",

Let me attempt to clarify my point through a further example, by turning to Naipaul's comments on his significant literary antecedents. In his 1974 essay "Conrad's Darkness and Mine," Naipaul writes of his changing attitude to Joseph Conrad's work. As a younger man, Naipaul had found Conrad bewildering: "I felt with Conrad I wasn't getting the point. Stories, simple in themselves, always seemed at some stage to elude me."12 Such frustration with an earlier writer gives way, eventually, to a different kind of reading of Conrad, born out of Naipaul's experience of travelling through the Caribbean, India, Africa, and South America, and what he thought he saw when living away in the world:

The new politics, the curious reliance of men on institutions they were yet working to undermine, the simplicity of beliefs and the hideous simplicity of actions, the corruption of causes, half-made societies that seemed doomed to remain half-made: these were the things that began to preoccupy me. They were not things from which I could detach myself. And I found that Conrad sixty years before me, in the time of a great peace - had been everywhere before me. Not as a man with a cause, but a man offering, as in Nostromo, a

\footnotetext{
${ }^{10}$ See John McLeod, “'Between two waves': Caryl Phillips and Black Britain,” Moving Worlds 7.1 (2007): 9-19.

${ }^{11}$ Phillips, "West Indian Writing Abroad," 16.

${ }^{12}$ V.S. Naipaul, “Conrad's Darkness and Mine” (1974), in Literary Occasions, 166.
} 
vision of the world's half-made societies as places which continuously made and unmade themselves $[\ldots]$. $^{13}$

In writing about a world distinct from, yet thematically related to, Naipaul's, Conrad offers a vital literary example of how Naipaul might, as a writer, engage with a series of coincident locations and preoccupations. His representation of Conrad's "vision," of course, tells us much more about his particular perspective on so-called "half-made" societies, and perhaps misrepresents Conrad's literary endeavours and visions. My point, however, is that in Naipaul's eyes - accurately or not - Conrad becomes an inspirational example of framing, conceptualizing, and ultimately writing about the "new world."14 Importantly, Naipaul has had to struggle with his relationship to Conrad, as revealed by that contest between admiration and frustration, clarity of vision and obfuscation, which characterizes Naipaul's discussion of Conrad in his essay. From out of this vexed, prolonged encounter, Naipaul has discovered a written style very different from Conrad's: whereas Conrad's writing is often characterized by the complexity, adventurousness, and artful convolution of his sentences, Naipaul's graceful prose is a model of control, discipline, and elegance, unmatched in contemporary writing in English. Naipaul does not write like Conrad; but his style and vision have been enabled to an extent by his long-standing encounter with Conrad's work.

In a similar (but, of course, not identical) manner, we might approach Phillips's writing as also enabled in part by his troubled perceptions of Naipaul. It is one that has also allowed Phillips to shape a literary voice quite distinct from, and at times at odds with, Naipaul's achievement. As someone who has travelled in and written about the Caribbean, Africa, the USA, and Europe, Phillips might regard Naipaul - more than any other writer from the Caribbean - as someone who has also been everywhere before him. These two writers' visions of the world may appear ultimately incompatible, but each faces the parallel challenge of how to write about a world in which they consider themselves to be unmoored. In the Enigma of Arrival (1987), the narrator admits to feeling "unanchored and strange" in his Wiltshire environs, certainly not "part of the view." 15 Such a sense of unbelonging also inhabits Naipaul's visions of Trinidad, the wider Caribbean region, Africa, India, and elsewhere. In A New World Order, Phillips remembers being a seven-year-old

\footnotetext{
${ }^{13}$ Naipaul, "Conrad's Darkness and Mine," 170.

14 "Conrad's Darkness and Mine," 170.

${ }^{15}$ V.S. Naipaul, The Enigma of Arrival (Harmondsworth: Penguin, 1987): 19.
} 
in 1960s Leeds, "too late to be coloured, but too soon to be British. [...] I am of, and not of, this place. ${ }^{\prime 16} \mathrm{He}$ repeats the latter part of this phrase when discussing Africa, the USA, and St. Kitts. These two authors' lives are distinct and unique, to be sure, and their separate senses of displacement from the Caribbean and other significant locations should not be conflated or synchronized. But each has turned to writing as a way of shaping a response to such displacements, and both have looked to other writers to help them contend with the sober task of writing of, and out of, their particular itinerant, unanchored ways in the world. For Naipaul, it was Conrad; for Phillips, I would hazard, it has often been Naipaul.

In pursuing a consideration of Phillips's work in relation to Naipaul's in these terms, it is tempting to identify correspondences of theme, style, and content as evidence of writerly 'influence'. But this takes us only so far. In moving now to a consideration of Phillips's early fiction, I wish to maintain a focus on inspiration as functioning as a point of departure and divergence, rather than as a circuit of mere correspondence, and keep in mind Phillips's task to open a mode of sympathetic insight which he believes is missing from Naipaul's writing. Coincidences of detail, if taken at face value, imply mimicry or homage; but in this particular instance they mark the coordinates of a divergent creative encounter between a younger writer and a significant predecessor. As Bénédicte Ledent points out, while Naipaul and Phillips admittedly "have a few things in common, [...] their visions of the world and of literature are as widely apart as can be, a divergence that cannot be explained by the fact that the two writers belong to different generations." ${ }^{17}$ Although we might resist the stark polarization of these writers' "visions" suggested here, Ledent reminds us that we need to account for any such divergences on the level of the writing, rather, by turning to biographical realities.

Phillips's first two novels have interesting Naipaulian connections. The Final Passage (1985) echoes the title of Naipaul's account of his travels in the Caribbean in 1961, The Middle Passage (1962). A State of Independence (1986) dovetails two distinctly Naipaulian themes of the 1950s and 1960s: the returning Caribbean exile, in the figure of Bertram Francis, at a moment of independence; and the critique of a neocolonial Caribbean state. Ledent has argued that this novel attempts to open "a resolutely critical approach towards

\footnotetext{
${ }^{16}$ Caryl Phillips, "Introduction: A New World Order," in A New World Order, 4.

${ }^{17}$ Bénédicte Ledent, "The Same, Yet Different: Caryl Phillips's Screen Adaptation of V.S. Naipaul's The Mystic Masseur," in V.S. Naipaul: A World in Tension, ed. Judith Misrahi-Barak (Montpellier: University of Montpellier III, 2003): 156.
} 
the society in which [Phillips] was born, pointing out the pitfalls of neo-colonialism and human greed," but at the same time it "clearly marks the writer's sympathetic engagement with the Caribbean. ${ }^{, 18}$ Phillips, then, attempts a typically Naipaulian task if we consider the novel's political subtext; that said, elsewhere he seeks to prolong something which Naipaul allegedly only fleetingly achieves in his early fictions of Trinidadian life: an empathetic representation of Caribbean matters. Naipaul's early writings on the Caribbean, from The Mystic Masseur (1957) - a novel which Phillips has adapted for the cinema - to The Mimic Men (1967), offer Phillips an important achievement which his own early work both learns from and moves beyond. As Phillips has stated, "the early novels of V.S. Naipaul [...] had always held a special appeal for me as they seemed to depict a Trinidad that the author had some affection for." ${ }^{, 19}$ In $A$ State of Independence, Phillips draws on Naipaul's early work in order to offer a critical vision of a Caribbean location while attempting to free its representation from containment within what I shall call Naipaul's 'expatriate' mode of mediation.

If The Final Passage revisits the historical experiences of the Windrush migrants which preoccupied George Lamming, Sam Selvon, and Andrew Salkey, A State of Independence enters terrain which is familiar in Naipaul's work: namely, life in a Caribbean country prior to political autonomy. Just as Gail Low suggests that The Final Passage is a revision of those 1950s novels of arrival, I would suggest that $A$ State of Independence offers a deliberately revisionary encounter with early Naipaul. ${ }^{20}$ The returning figure of Bertram Francis, the novel's central character, to his childhood island home after several years in England has distinct Naipaulian overtones. Like Naipaul, Bertram left the island on a scholarship to study in England, and comes back at the moment of independence. Naipaul returned to Trinidad at the behest of the new Trinidadian Government just prior to independence in 1962, after twelve years in England, and his upsetting return as an expatriate is depicted in The Middle Passage. Bertram's expatriate status also recalls the young narrator of Miguel Street (1959) whom we spy at the end of that book leaving for Eng-

\footnotetext{
${ }^{18}$ Bénédicte Ledent, Caryl Phillips (Contemporary World Writers; Manchester: Manchester UP, 2002): 53 .

${ }^{19}$ Caryl Phillips, "Foreword to The Mystic Masseur - the Screenplay," Moving Worlds 2.1 (2002): 39 .

${ }^{20}$ See Gail Low, "Separate Spheres? Representing London through Women in Some Recent Black British Fiction,” Kunapipi 21.2 (1999): 26.
} 
land, as well as the unnamed narrator of The Mystic Masseur who eventually leaves Trinidad to study at Oxford.

In fashioning a distinctly Naipaulian literary location and dramatic situation, Phillips makes some important decisions regarding form in A State of Independence, which go some way towards moving the novel away from the imperiousness and Olympian vantage of Naipaul's early fiction and travel writing. Most important is the creation of a third-person narrator whose point of view seems primarily, but not entirely, limited to Bertram's subjective consciousness. Naipaul's early fictional narrators and travelling persona explicitly stand above and to one side of the scenarios they describe, and the views of the Caribbean people they depict are never allowed to dislodge the authority and control of the narrator's all-seeing, promontory vista. Until The Mimic Men, Naipaul's narrators - anonymous or named - frequently install a distinct distance between themselves and the scenes they witness, marked by the divergence between their use of standard English and the characters' Trinidadian vernacular dialogue. In A State of Independence, by contrast, the narrator's limited point of view articulates expatriate consciousness by anchoring the novel's narratorial perspective to this point of view, but it does not surrender narrative authority entirely to it. Bertram exists somewhere between the positions of narrator and narratee: his consciousness is not in full control of the narrative. As I will show, although Bertram's perspective is the prevailing one in the novel, Phillips is able to acknowledge the existence and agency of the contrasting perspectives of the islanders, without subjugating them to the expatriate mediation in which Naipaul's Caribbean figures are ensnared. Indeed, it is Bertram's expatriate perspective that is ultimately subject to critique.

Bertram's return to the island is a painful one, and evokes troubling memories. He arrives from England in a Naipaulian frame of mind, and many of his first impressions of his old childhood home assume a distinctly Naipaulian register. On his journey from the airport to Sandy Bay, he surveys a derelict and poverty-stricken landscape, hellish and polluted. Leaves from the canestalks are being burned, and the cindered canetrash makes a group of schoolchildren's eyes water. A bus "shuddered and belched before disappearing behind a greyish mist of spent fuel.", Bertram watches "as a mother furiously beat a piece of rope across the back of a child's legs, the child silent, his face

\footnotetext{
${ }^{21}$ Caryl Phillips, A State of Independence (London: Faber \& Faber, 1986): 20. Further page references are in the main text.
} 
twisted in concentration" (18) - we recall, perhaps, Naipaul's infamous assertion that nowhere are children beaten as savagely as they are in the Caribbean. As Bertram re-acquaints himself with the island, the novel quite deliberately installs a Naipaulian environment within which Bertram moves with unease. For example, the fly-infested foodstuffs and the glass case in Leslie Carter's shop recall Ramlogan's shop in The Mystic Masseur. And perhaps the most overt Naipaulian reflex in the novel concerns its ending: A State of Independence is the only one of Phillips's books that ends with a date, 20 June 1985 a typically Naipaulian trait, of course.

Phillips's creation of Bertram's island draws on Naipaul as part of a commitment to critique the island's neocolonial existence and future, and in order to offer a muted and critical vision of a Caribbean location at a moment of dubious 'independence' which recalls Naipaul's sceptical vision of Caribbean politics and society in The Middle Passage. A State of Independence strives to bear witness to the suffering of the islanders, as well as attempts to assess the extent to which they are responsible for the neocolonial subjugation to the USA, signified by the television cables that are being strung at the end of the novel, or by the enthusiasm that Livingstone, Bertram's putative son, feels for American pop culture and consumer goods. Furthermore, Phillips's particular choice of narrative perspective also functions to critique the damning dismissal of Caribbean people, and he attempts to forge a compassionate encounter with the islanders which does not hold them responsible for the neocolonial conditions in which they live. Indeed, the novel's politics are grounded much more in the vernacular life of the island's folk than they are in a critical representation of Government and economics in the Caribbean - a rendering which appears at times synoptic, unsubtle, and perhaps a little clichéd. But depicting Caribbean folks as characters, especially in a Naipaulian fictional environment, presents certain challenges. As a writer who lived away from the Caribbean in his younger years, Phillips is perhaps conscious that he cannot articulate the islanders' lives and perspectives on their terms, or assume to access with ease their points of view. Like Naipaul and Bertram, he is inevitably "of, and not of," this place. Phillips acknowledges his position by making questionable the expatriate perspective of the island as articulated by Bertram. He therefore challenges the authority of expatriate mediation and opens a space where he might prize the fact that the islanders answer back to, or even refuse, the returnee's displaced, limited view. In A State of Independence, it is not the case that, in Homi K. Bhabha's infamous mantra, "the truest eye may now 
belong to the migrant's double vision." 22 Phillips demonstrates that there is a great deal which Bertram cannot see clearly, and that his expatriate vista is worryingly limited. In contrast to Naipaul's writing, the islanders are not entirely subjugated to the narrator's control.

In Naipaul's early work, Caribbean folks are presented as fatally philistine, terminally deluded, and belittled by their own petty rivalries, which, as in The Suffrage of Elvira (1958), constitute only a grotesque parody of politics. They are also deliberately, disgustingly comic. One thinks of The Great Belcher and Beharry in The Mystic Masseur: the one belching and rubbing her breasts indecorously, the other constantly nibbling like a rodent. As well as eschewing such unwholesome representations of Caribbean figures, Phillips problematizes the Naipaulian expatriate optic that makes possible such haughty modes of representation in the first place, by pointing to and valuing the agency of the islanders' perspectives in challenging the authority of Bertram's view. The Naipaulian expatriate gaze is not so much relinquished - Phillips draws on Naipaul for important resources, as we have seen - as confronted with its limits. Just as Phillips was brought up short by the "look of outrage" from his audience that greeted his critique of Naipaul at the University of the West Indies, as the novel proceeds so, too, is Bertram invited to re-assess himself and his assumptions through a series of visual encounters.

Bertram's mother, his ex-partner Patsy, and his one-time friend Jackson Clayton, now a Minister, either refuse Bertram's attempt to look at them or challenge his vision with some confrontational looks of their own. Indeed, his first awkward encounter with Jackson is marked by the silence of their meal, as well as Bertram's uneasy sense that he is being watched by his friend:

At one point Bertram looked up, feeling sure that his friend's eyes were upon him, but he was mistaken. Bertram watched and noticed that Jackson's temples undulated as he ate. Then Jackson looked up and smiled at Bertram, who smiled back. Then they both continued their meal as though strangers. (68)

The jousting of perspectives at this moment is subtle but revealing. Bertram's feelings of uncertainty and unease are underscored by his sense of himself as both observer and observed. Jackson confounds his friend's sense of being in control - Bertram feels as if he is being looked at - and also confronts Bertram's look with one of his own, refusing to be subjected to an expatriate

\footnotetext{
${ }^{22}$ Homi K. Bhabha, The Location of Culture (London \& New York: Routledge, 1994): 5.
} 
gaze. Furthermore, the emphasis on such silent moments of looking marks the confines of Bertram's, and the novel's, perspective, and reminds us to doubt the range of Bertram's point of view. Significantly, Bertram is ultimately looked at as much as he looks out in the novel. Whereas he spends the beginning of the narrative looking at the island and islanders from a Naipaulian vantage, by the end others have challenged his vision with their own critical acts of looking, initiating, perhaps, a process of self-questioning.

One such moment occurs when Bertram's mother effectively dismisses him from the family home after their difficult and (for her) unexpected reunion. In this scene, situated just over half-way through the novel, Bertram is depicted as losing a distinctly optical battle:

"You don't want me in the house?" [said Bertram.]

His mother fixed a hard and resolute glare upon him. "You can stay here the night, in fact you can stay here a few more days, then either you must go back to wherever it is you come from, or if you must stay on the island and mess up my life with your nonsense, you must find a next place to live, you understand?"

Bertram looked at her, unsure that she was speaking from her heart. He said nothing in the hope that she might change her mind, but as she stared at him her anger seemed to grow. (86)

Bertram's mother's "hard, resolute glare" is an index of her dissatisfaction with her son's previous conduct and uninvited return, while her refusal to submit to the authority of his "unsure" act of looking indicates Bertram's precariousness and relative powerlessness. As in the earlier scene between Bertram and Jackson, Bertram's mother subjects her son to her own act of looking. Significantly, his mother concludes their unhappy exchange by rolling over on her bed, "present[ing] her son with the back of her head" (86) and disrupting Bertram's line of vision. Her refusal to meet her son's eyes underlines the extent to which she ultimately escapes being subjected to Bertram's gaze, while her silence which accompanies this moment - her banishment is "[her] last word on this or any other topic" (86) - also marks a threshold of knowing which the novel's limited expatriate point of view deliberately will not cross. It is interesting that, when Bertram retires to bed, we are told that "it was dark outside, a night of hidden eyes and strange noises" (86). This detail emphasizes Bertram's transition from superior observer to the subject of others' observation, as hinted at by the reference to the island's unnerving "hidden eyes," which recalls his earlier peculiar feeling of being watched by Jackson. 
Bertram's transition as a character, forced to re-assess himself and the island, is highlighted in the third example I wish to look at, concerning his fragile relationship with his youthful sweetheart, Patsy, near the novel's end. The final depiction of these two characters suggests the slim possibility of an emotional and practical future for Bertram, despite primarily calling attention to the identitarian difficulties which he has experienced since his return. This slim possibility is signalled by the ultimate relinquishment of Bertram's authoritative eyes, and the creation of a more considerate way of regarding him which is forged by, and identified with, the islander Patsy. As Bertram leaves Patsy's house to attend the Independence celebrations, she follows him with her eyes:

Bertram kissed [Patsy] and turned to leave. Patsy stood and followed him out into the yard. Then she watched as he passed through the gate and down the small alley towards Whitehall. (153)

Previous to this moment, Patsy invites Bertram back to the house to spend the evening, and there is a sense that their relationship, long dormant, just might rekindle itself. Patsy's offer of accommodation contrasts with his mother's banishing of him from her house. The fact that Patsy continues to look at Bertram as he leaves (she does not turn her head) indicates the creation of a less hostile and more democratic and compassionate encounter between islander and expatriate.

By this late stage of the novel, Bertram has been made to endure a difficult process of self-questioning which has altered his prior vision of being able to return and set up a business, as well as his relationship with England. As he leaves Patsy's house to head for the Independence celebrations, Bertram has shifted significantly from his initial Naipaulian expatriate position. Indeed, he spends the last few pages of the novel in silence, thinking analytically and seriously about the past and the future, as well as confronting self-critically his troubled place in the world: "He tried hard to imagine how he might cope, were he to make peace with his own mediocrity and settle back on the island" (157). In looking to learn, Bertram's troubling experiences have helped deliver him up to a more subjective, self-questioning, and potentially humane situation, suggested by his admittance to Patsy's endearing and affectionate gaze. This situation is by no means devoid of pain or difficulties: just prior to leaving, Bertram tells Patsy that he feels adrift between an England he "[does not] care much for" (152) and the island of his birth where he no longer "feel[s] at home" (152). But it is hinted by the end of the novel that Bertram's 
redemption may lie in his beginning to learn to look again - at himself, at others, and at the country to which he has returned - so as to usher in for him the possibility of achieving a state of emotional independence from his own immiserating loneliness and pain. Indeed, his last gesture is a selfless one suggesting reconnection: the novel ends with Bertram "wonder[ing] if later this same day he should ask Mrs Sutton how he might help his mother" (158).

A State of Independence indexes a recurring concern throughout Phillips's work: the attempt to look critically, but with emotional and moral insight, at the difficult lives of others. In very much a Naipaulian vein, the novel opens a space where the integrity of the political elite is rendered suspicious, while casting doubt on the substance of the island's 'independence' as it readies itself for American tourism. While the novel's point of view is grounded in the returning expatriate's perspective, Phillips potentially delegitimates this position by exposing its limitations, prejudices, and blindnesses - perhaps this is why Bertram spends a lot of the novel falling asleep. While Bertram is often exposed to the steadfast evaluative gaze of others, and his faults are coolly catalogued, he is by no means a condemned or loathed figure - there is no simple inversion of, or contempt for, a Naipaulian expatriate perspective. Phillips continues to care for Bertram's "mediocrity." As Patsy's vista in particular demonstrates, some compassion remains for Bertram's difficult position, and he is not wholly rejected by the island of his birth. Phillips invites us to look critically yet benevolently at his central character, beckoning us to enter into the vital process of sympathetic engagement that makes impossible quick or prejudicial judgments, just as Bertram must learn to look both critically and compassionately at the island and its folk on his return. This significant departure from the narrative aloofness of a Naipaulian optic enables an ethical investment in the characters' fortunes and Bertram's troubled position. Each of the protagonists has faults in A State of Independence, and there is no attempt to eulogize the islanders' lives while condemning Bertram's arrogant assumptions regarding his return. The attempt to deal thoughtfully with each character by staying alert to their qualities and shortcomings is part of Phillips's moral and democratic commitment to the lives of all, one that (in contrast to Naipaul) does not seem to take sides. It is this concerned commitment that pushes Phillips beyond the Naipaulian expatriate optic I have discussed, and installs a crucial ethical quality in $A$ State of Independence, unlike anything we find in Naipaul's early writing of and on the Caribbean. 
Let me conclude by returning our attention to the 'two worlds' of which Naipaul spoke. Whereas Naipaul demanded a distinction between the world of habits and vices and the world of "the mystery of the writing," Phillips's long-standing literary engagement with Naipaul is much less willing to uncouple the writer from his work. It is, perhaps, another example of compassion. It is a measure of the remarkable moral integrity of Phillips that he will complain about, but never dismiss, Naipaul's labours as a writer. Indeed, we would do well to follow Phillips's example in our own approach to Naipaul, so that we do not become quickly antipathetic towards or dismissive of his painful predicament - just as A State of Independence seeks to understand, rather than swiftly condemn, the high anxieties of Bertram's unbelonging. Writing, we should recall, was a struggle for the young Naipaul, not least because as a colonial he found it a profound challenge to write about the colonial world in a metropolitan literary form:

The English or French writer of my age had grown up in a world that was more or less explained. He wrote against a background of knowledge. I couldn't be a writer in the same way, because to be a colonial, as I was, was to be spared knowledge. ${ }^{23}$

Writing has become his means to articulate his sense of the pain of growing up as a colonial: living in an environment without a tradition of literary explanation, doubly displaced from ancestral India, coping with the death of his father, which occurred when Naipaul was an undergraduate student. Somewhere along the way, this has meant that Vido has given way to Sir Vidia but Phillips will not allow the ungenerous Sir Vidia to obscure fully the presence of another, more 'likeable' figure whose affectionate relationship with the Caribbean is worth saving, treasuring, and taking inspiration from.

Contrastingly, Phillips has grown up with a literary explanation of the Caribbean and black Britain derived from Selvon, Lamming, Naipaul, and others. There is 'knowledge', to be sure, but it has its problems. Naipaul has gifted Phillips a legacy of how to write from something like his position, and about the once-colonized world; as Conrad did before him, Naipaul points to a path which Phillips travels in his work, if only to depart from it in discovering his own literary voice, one which grapples with and transforms the pain of his early life in 1960s Leeds, where he suffered racism and prejudice - both verbally and physically - on a frighteningly regular basis.

\footnotetext{
${ }^{23}$ V.S. Naipaul, "Prologue to an Autobiography" (1984), in Literary Occasions, 66.
} 
Phillips's writing has always striven for an ethical location where one looks through the divisions of race and gender in an attempt to understand the position and pain of others as a way of breaking down barriers. Ultimately, this ambition also informs his reflections on Naipaul. Phillips may declare his unhappiness and disappointment with Naipaul's often corrosive representation of the Caribbean and its folk, but he still attempts to look with care beyond this vision and engage with the value of those earlier Naipaulian views of the region. Phillips has little time for Sir Vidia; but as a writer he will not give up on Vido, whose example he continues to look for and learn from, in shaping his own unique literary voice.

\section{WORKS CITED}

Bhabha, Homi K. The Location of Culture (London \& New York: Routledge, 1994).

Ledent, Bénédicte. Caryl Phillips (Contemporary World Writers; Manchester: Manchester UP, 2002).

— . "The Same, Yet Different: Caryl Phillips's Screen Adaptation of V.S. Naipaul's The Mystic Masseur," in V.S. Naipaul: A World in Tension, ed. Judith MisrahiBarak (Montpellier: University of Montpellier III, 2003): 155-69.

Low, Gail. "Separate Spheres? Representing London through Women in Some Recent Black British Fiction," Kunapipi 21.2 (1999): 23-31.

McLeod, John. “'Between two waves': Caryl Phillips and Black Britain,” Moving Worlds 7.1 (2007): 9-19.

Naipaul, V.S. “Conrad's Darkness and Mine," in Naipaul, Literary Occasions: Essays, ed. Pankaj Mishra (London: Picador, 2003): 162-80. Originally as "Conrad's Darkness," New York Review of Books 21.16 (17 October 1974): 16-21, repr. in The Return of Eva Perón (1980: Harmondsworth: Penguin, 1981): 197-218.

. The Enigma of Arrival (Harmondsworth: Penguin, 1987).

. A House for Mr Biswas (London: André Deutsch, 1961).

- Letters between a Father and Son (London: Little, Brown, 1999).

- The Middle Passage (London: André Deutsch, 1962).

Miguel Street (London: André Deutsch, 1959).

. The Mimic Men (London: André Deutsch, 1967).

. The Mystic Masseur (London: André Deutsch, 1957).

. "Prologue to an Autobiography," in Literary Occasions: Essays, ed. Pankaj Mishra (London: Picador, 2003): 53-111. Originally in Finding the Centre: Two Narratives (London: André Deutsch, 1984): 15-86.

- The Suffrage of Elvira (London: André Deutsch, 1958).

. "Two Worlds" (2001), in Literary Occasions: Essays, ed. Pankaj Mishra (London: Picador, 2003): 181-96. 
Phillips, Caryl. The Final Passage (London: Faber \& Faber, 1985).

—. "Foreword to The Mystic Masseur - the Screenplay," Moving Worlds 2.1 (2002): $38-41$

. "Introduction: A New World Order," in A New World Order: Selected Essays (London: Secker \& Warburg, 2001): 1-6.

. "Reluctant Hero," Guardian (12 October 2001): http://www.guardian.co.uk /books/2001/oct/12/fiction.vsnaipaul (accessed 15 August 2008).

. A State of Independence (London: Picador, 1986).

"V.S. Naipaul," in A New World Order: Selected Essays (London: Secker \& Warburg, 2001): 187-219.

"West Indian Writing Abroad: Naipaul and the New Generation," Caribbean Review of Books 3 (1992): 16, 19, 24, 25-27. 


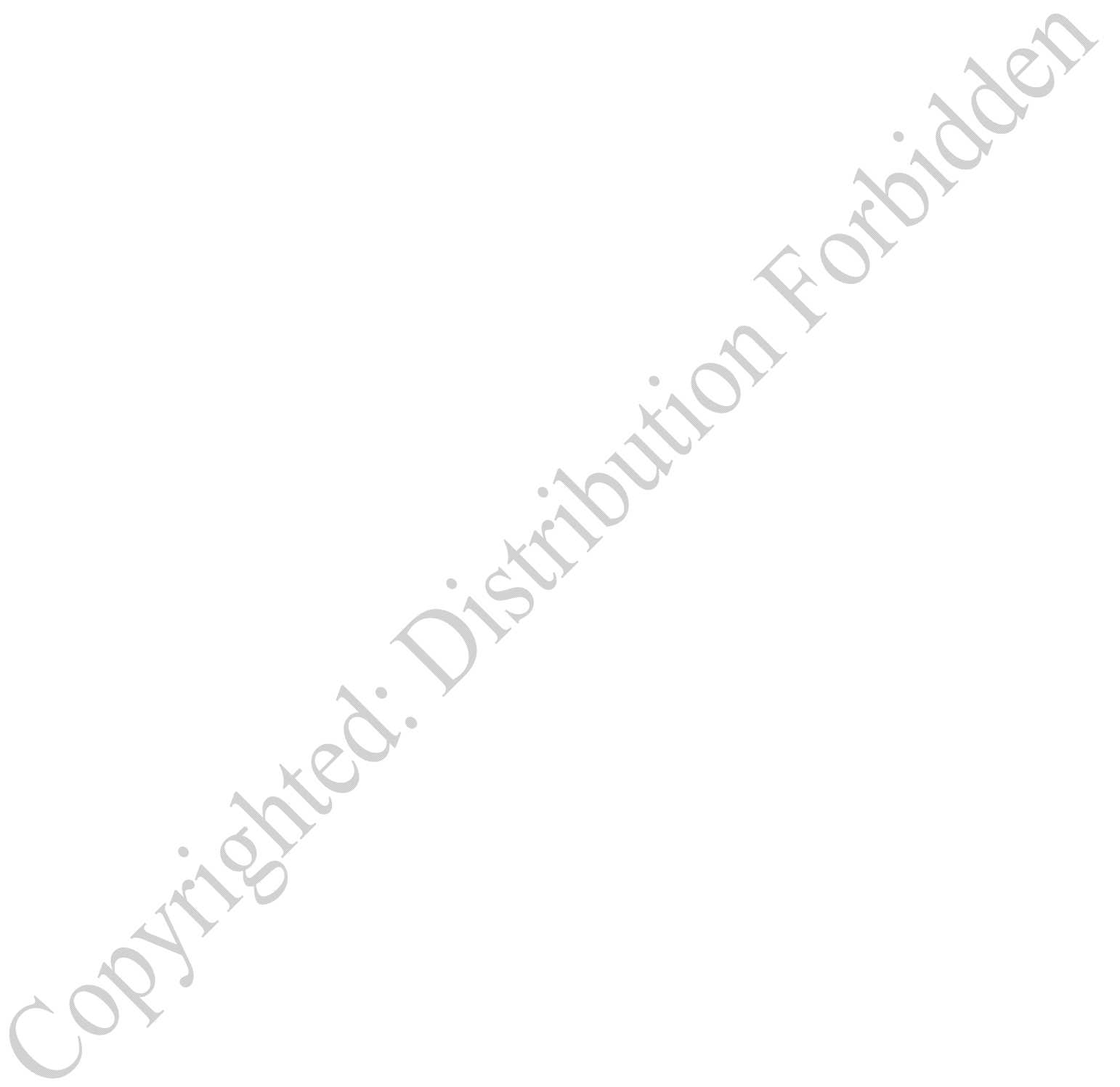




\title{
A New World's Twilight \\ _ Ethics of the Caribbean Writer in Caryl Phillips's and Derek Walcott's Essays
}

\author{
MALIK FERDINAND
}

\footnotetext{
C
} aryl Phillips and Derek Walcott published two major collections of essays at about the same time, respectively entitled $A$ New World Order (2001) ${ }^{1}$ and What the Twilight Says (1998). ${ }^{2}$ These contain critical commentaries written over several years (or decades in the case of the St Lucian poet) on contemporary writers from various regions of the world and deal with the act of writing in general. Not only do these volumes explain their authors' birth as writers, but they also discuss what is meant by writing the Caribbean. Phillips and Walcott analyze the works of the same authors: namely, C.L.R. James, V.S. Naipaul, and Patrick Chamoiseau, among other artists from the area. With their common rejection of the race factor and their particular perceptions of history, Phillips and Walcott repeatedly ask themselves the same question: how does a writer bring his Caribbean experience into his art? While thought-provoking and informative in their own right, these two books should also be regarded as specimens of literary craftsmanship. Indeed, in organizing their arguments, the authors employ formal strategies that seem as relevant to the understanding of the texts as the content of the works itself does. The writers' conceptions of literature thus

\footnotetext{
${ }^{1}$ Caryl Phillips, A New World Order: Selected Essays (London: Secker \& Warburg, 2001). Further page references are in the main text after " $N W O$."

${ }^{2}$ Derek Walcott, What the Twilight Says: Essays (London \& New York: Faber \& Faber, 1998). Further page references are in the main text after "WTS." Note that the title is taken from the essay prefacing Walcott's Dream on Monkey Mountain and Other Plays (New York: Farrar, Straus \& Giroux/Noonday, 1970).
} 
seem to lie in the spaces between what French theorists call 'énoncé'- i.e. roughly speaking the 'utterance', or the arguments obviously developed in the books - and 'énonciation' - i.e. the 'uttering', or the way these ideas are presented. This essay will therefore focus at the same time on Phillips's and Walcott's explicit analyses and on the form of their writing, in the hope that such an examination will lead to some critical insights into the Caribbean philosophical tradition.

\section{Essays as attempts}

The titles of Phillips's and Walcott's collections at once immerse the reader in the spirit of Caribbean thought. Indeed, both volumes are subtitled "Essays": A New World Order: Selected Essays and What the Twilight Says: Essays. In both cases, the subtitle is linked to the title on the level of the signified. Walcott is a poet, and the euphony of his long title sets the tone by stressing the sweetness and swiftness of the Antillean twilight. As the term "what" embraces the chiaroscuro colour of the twilight, the phrase "what the twilight says" reveals the tenor of Walcott's main thesis and suggests that no argument is perfectly clear-cut. In fact, what we discover in Walcott's book is the very meaning of the word 'essay': his articles and the conceptions they develop are only 'attempts'. For a colonial writer, to 'attempt' means to find his own voice between the beats of the Empire's grammatical rhythm and those of his own environmental rhythm. The repetition of "says" in "Essays" is striking, and might be evocative of Walcott's artistic doubt, in that it reflects the tension between stating and trying. In other words, writing becomes the site of a struggle for self-definition. In articulating his personal quest along with that of other West Indians writers, Walcott gives the reader a vantage point from which to observe a Caribbean mind in action.

A New World Order is made up of four major sections, "The United States," "Africa," "The Caribbean," and "Britain." The subtitle "Essays" reinforces the idea that no place is a final destination and that each site is just an attempt to become rooted. This endless quest for a home is the central theme of the introduction to the book. Each paragraph of this opening section lays emphasis on a particular time and place central to Phillips's life. And so he describes his journeys in different parts of the world: Phillips is in West Africa, he is in New York, he is in St Kitts, he is in England. He is thirty-two, he is twenty, he is twenty-two, he is seven. And each paragraph of each journey ends with the line: "I recognise the place, I feel at home here, but I don't belong. I am of, and not of, this place" (NWO, 1, 2, 3, 4). This absence of an 
immutable place perhaps embodies the exilic condition of writing: all of the countries described and all of the writers discussed constitute 'essays' for the writer, part of what Patrick Chamoiseau calls a 'Sentimenthèque' or library of feelings. ${ }^{3}$ This is in line with Walcott's statement that in the West Indies "there is no history, only the history of emotion" $(W T S, 5)$.

One immediately associates Phillips's sentimental library with the emotional falsetto of Curtis Mayfield's New World Order. ${ }^{4}$ Interestingly, in this civil-rights icon's album, there is a song entitled "Here but I'm Gone" in which the chorus says "Where do I belong / And where in the world did I ever go wrong / [...] I still feel as if I'm here but I'm gone." These lyrics are a comment on the African-American condition in the USA, while being also a source of inspiration for the writer:

Their [Stevie Wonder, Curtis Mayfield, Marvin Gaye's] ability to transform pain into art, and to create incisive narratives that spoke to both blacks and whites with clarity and passion, excited the young writer in me. $(N W O, 36)$

The lexical resemblance between Mayfield's chorus and Phillips's introduction is based on two different situations, but in both cases the artist feels uncomfortable in one single place. We can imagine that it is this uneasiness that Phillips relates to in Curtis Mayfield's song. At the same time, however, Phillips's paradox - feeling at home and at the same time not belonging - can be interpreted as the freedom to move away from a given place, while being moved by it. At the conclusion of A New World Order, Phillips explains that this capacity for movement is linked to the story of his own life:

Most people live secure lives in a place that they recognise as their own. [...] But then most people did not grow up in Leeds in the sixties and seventies having to endure a daily chorus of 'Why don't you fuck off back to where you come from?' (NWO, 309)

Like Phillips's connection with Curtis Mayfield, Walcott's metaphor of twilight heralding the end of the Empire testifies to the worldly commitment of his essays. The combination of "Says" and "Essays" in his title echoes the Caribbean word say-say, which means 'gossip' and reminds one of the lyrics of Bob Marley's song, "Rat Race": "Don't involve Rasta in your say-say /

\footnotetext{
${ }^{3}$ Patrick Chamoiseau, Écrire en pays dominé (Paris: Gallimard, 1997). The word Sentimenthèque is used throughout the book-length essay.

${ }^{4}$ Curtis Mayfield, New World Order (Warner Brothers, 1996).
} 
Rasta no work for no C.I.A." ${ }^{5}$ Like the Jamaican singer, Walcott constantly tries to sing the archipelago without the expected lyrical tone:

What is the earthly paradise for our visitors? Two weeks without rain and a mahogany tan, and, at sunset, local troubadours in straw hats and floral shirts beating 'Yellow Bird' and 'Banana Boat Song' to death. (WTS, 81-82)

In sum, Walcott's and Phillips's essays explore the Caribbean philosophy of writing in relation to their emotional and environmental background.

\section{Cultural hybridity: hovering between two shores?}

Who is a Caribbean writer? What is Caribbean literature? Is it defined by the subject treated, the artist's origin or the artistic form? Or is it just a question of marketing strategy: sea, text and sun, white sand and blue colours nurturing a Caribbean plural texture? In the inner lightning of Walcott's twilight, the West Indians write against the grain, because their very origins suggest hybridity:

I see the word "Ashanti" as with the word "Warwickshire," both separately intimating my grandfathers' roots, both baptizing this neither proud nor ashamed bastard, this hybrid, this West Indian. (WTS , 9)

This sentence encompasses the Caribbean writer's questioning. By examining evocative words like "Ashanti" and "Warwickshire," Walcott foregrounds their common consonance, embodied in the sound 'sh', which may be suggestive of waves scratching against the Caribbean sand. The binary structure "neither proud nor ashamed" follows the same ambivalent pattern. The Caribbean artist is always between two shores, the western side, that of the Caribbean Sea, and the eastern part, that of the Atlantic Ocean. In fact, the string of phrases "this neither proud nor ashamed bastard, this hybrid, this West Indian" reminds us that the denomination 'West Indian' is an oxymoron. With India representing the East, 'West Indian' is itself an instance of hybridization. This expression involves geographical directions, but also points to displacement in its construction. Indeed, 'West Indian' does not merely contain the opposition of signifiers, east versus west. What we literally notice is not the absence of a clear single direction, but the existence of both - east and west in the same phrase. Beyond this opposition, we predict an opening on two horizons and a bridging of the infinite space between them.

\footnotetext{
${ }^{5}$ Bob Marley and The Wailers, "Rat Race," on Rastaman Vibration (Tuff Gong \& Island, 1976).
} 
It is no surprise, therefore, that in the introduction to the Caribbean part of A New World Order entitled "The Gift of Displacement," Phillips defines Caribbean authors as having a very special "migratory condition" (NWO, 131). For him, the cultural hybridity of the Caribbean heritage allows the writer to create narratives away from the simplistic divisions of race or national identity. To support this argument, Phillips tells his own story as a writer. And this story starts with two books by Frantz Fanon: "Black Skin, White Masks and The Wretched of the Earth became my Old Testament and my New Testament" (NWO, 129). In Fanon's humanism, Phillips found a means to depart from African-American authors' focus on race: "The shadow of purity does not extend far south beyond the Florida Keys" (NWO, 133). As Phillips himself explains, he was inspired by African-American writing but, when encountering Black Skin, White Masks and The Wretched of the Earth, he was able to link his Caribbean heritage to his writing. The comparison with the Old and the New Testament evokes the image of Moses opening a passage between the Florida Keys and the Caribbean Sea. Phillips also uses Fanon's personal story as a motif. Fanon was born in Martinique, lived a part of his life in Europe and North Africa, died in the US A, and was buried in Algeria. Even after death, Fanon's body was displaced. This idea relates to Phillips's own wish to have his ashes scattered in the middle of the Atlantic Ocean $(N W O, 304)$, and also reminds one of Walcott's comment on Antillean people's relationship with death: "we have not wholly sunk into our own landscapes, as one gets the feeling at funerals that our bodies make only light, unlasting impressions on our earth" (WTS, 18). Clearly, Fanon's story, as viewed by Phillips, brings to light the Caribbean sense of displacement, but using someone else's personal story to describe one's own journey represents yet another form of displacement: Fanon's biography and his dead body signify on Phillips's own life. In addition, displacement is suggested, on the formal level, by Phillips's rhetorical choices in the "The Gift of Displacement": this essay does not feature a unique grammatical subject. Predictably, Phillips uses the first-person singular, "I," to refer to himself, and the third-person singular, "he," for Fanon; but he also employs some phrases referring to Caribbean artists - such as "the Caribbean artist," "Caribbean writers," "a Caribbean voice" - and the first-person plural, as in the question "How do we explain our new hybrid selves without recourse to the simplistic discourse of race?" $(N W O, 132)$. In this multiplicity of grammatical subjects, hence of perspectives, the reader gets a sense of grammatical displacement akin to the geographical dislocation experienced by Phillips. 
Walcott also had to face a sense of displacement. For him, the archipelago is synonymous with a journey, a life journey, starting with the childhood of twin brothers who had to deal with the colonial experience:

Yet, like the long, applauded note, joy soared farther from two pale children staring from their upstairs window, wanting to march with that ragged, barefooted crowd, but who could not because they were not black and poor [...]. $(W T S, 19)$

In these autobiographical and meditative sections of What the Twilight Says, Walcott employs the third person, the singular for himself, and the plural for himself and his twin brother, Roderick. He-intertwines his own perception with that of his sibling. This splitting of the autobiographical subject displaces the reader's focus, for, according to Philippe Lejeune, using the third person enables self-distantiation and irony. ${ }^{6}$ But here, distance is not only established between a speaker and an autobiographical subject; it also suggests the colonial condition. In this passage, the Walcott brothers observe the marching of a patrol, "the black faces of men in white, martial uniforms" (WTS, 19). The split identity of the colonial subject is highlighted by this ironical remark, a variant of black skins wearing white-mask uniforms. And the distance is not only physical - upstairs from the backyards - it also refers to skin colour: upstairs are the spectators, pale and not poor, and in the yards are the poor, the blacks, the barefooted. These "were the shadows of his first theatre [...], and the rhythms of the street itself were entering the pulse beat of the wrist" (20). The crowd is in the yard, the writer and his brother stand upstairs behind a window, so the writer's gesture is to cross the distance between the two groups, and this process involves a metamorphosis. Walcott begins by using the third-person plural to describe his brother and himself. Then, in becoming a playwright, he uses the third-person singular. At the same time, the beat of the streets and the numerous shadows of the crowd direct his wrist and therefore his writing. Thus the St Lucian artist finds his personal voice by trying to incorporate his fellows' sounds and rhythms. His birth as a writer in this case seems to be going from 'twinphony' to polyphony, from uncertain identity to the embracing of many identities, from a window in a house to an entire environment.

\footnotetext{
${ }^{6}$ Philippe Lejeune, Le pacte autobiographique (Paris: Seuil, 1996): 17.
} 


\section{An unmarooned Caribbean writer in the mangrove swamp}

Both Phillips and Walcott consider Caribbean literature to have strong political relevance. This awareness is particularly clear in their respective reviews of Chamoiseau's novel Texaco. Walcott entitles his essay "A Letter to Chamoiseau" and Phillips chooses to characterize the Martinican author's ethics by using the title "Patrick Chamoiseau: Unmarooned." Surprisingly, in creating the neologism "unmarooned" Phillips seems more poetical than Walcott, whose letter takes the form of a short story. Despite this contrast, both readings of Chamoiseau's novel underline the political importance of literature produced in the West Indies.

For Phillips, Chamoiseau is "an accomplished literary petit marron" ( NWO, 231). In French, the figure of the 'petit marron' refers to a strategy adopted by the slaves on the small islands of the Caribbean. In these islands, no extended maroon community succeeded in settling in the bush as in Jamaica or Haiti: the 'petit marron', literally 'the little maroon', escaped from the plantation but still had relationships with the other slaves; he still lived near the plantation. So, the one Phillips calls a "small-island rebel" ( $N W O$, $226)^{7}$ occupied an ambiguous position. By escaping, he denied the slave system; but by his continuing reliance on the plantation - for food, for example he benefited from slavery. Phillips compares this particularity to Chamoiseau's linguistic strategies, especially his use of creole features. For Phillips, Chamoiseau's ability to create an idiosyncratic language reminds one of the attitude of the small-island rebel, in the sense that the writer escapes from French language rules with creole grammar, only to come back with French vocabulary. Reading Texaco is disturbing because one doesn't know whether it is written in French or creole, or both. By blurring the linguistic demarcations between French and creole, Chamoiseau makes a strong political statement. Like his ancestors, the writer is confronted with a regime he disapproves of, one that maintains Martinique under French rule. As Phillips argues, Martinicans "do not need to see themselves in the context of Europe, for there is already the ready-made illusion that they are Europe" ( $N W O$, 221). In other words, Martinique's link with Europe is politically institutionalized; consequently the influence of the 'foreign' power (France) is pervasive and considered normal. However, when reading Texaco one cannot pretend that one is reading an exclusively French novel, nor can one pretend that Mar-

\footnotetext{
${ }^{7}$ Incidentally, this denomination could also apply to the Kittitian Phillips and the St Lucian Walcott, both of whom are from small islands.
} 
tinique is an exclusively French territory. Phillips views the example set by Chamoiseau as useful, for the commitment of the Martinican author illustrates the duty of all Caribbean writers: "the writer should always create himself and his people before somebody else creates them" $(N W O, 231)$.

What is relevant in Phillips's practice of the essay in this particular case is the fact that he creates the neologism 'unmarooned' to express this necessity of self-creation. To maroon is to escape from the plantation and gain freedom: this is an active decision. In the context of Caribbean post-slavery societies, the adjective, 'marooned', introduces a contradictory connotation. Indeed, one can choose to be a maroon, but how can one be marooned? The signification of 'maroon' is not in accordance with the lack of freedom connoted by its verbal adjective form, 'marooned'. This tension can also be found in the negative form used by Phillips. Does to be 'unmarooned' mean to abandon one's maroon condition - that is to say, to come back to the plantation? Or, if one has been marooned, does being 'unmarooned' mean that one recovers one's own autonomy? 'Maroon' originates in the French marron, which in turn is from the Spanish cimarrón, which means 'wild' or 'untamed'. 'Cimarron' in Spanish is related to cima, summit, which indicates the original characteristic of the maroons: they were runaway slaves who used to live in the high mountains of Jamaica and Haiti. It was noted above that no similar phenomenon took place in the case of Martinique. So Phillips's unstable neologism relates both to the specific nature of the small-island marron and to Chamoiseau's aesthetics. Neither mountain rebel nor gentle slave, Chamoiseau does not abandon French for creole, he maroons within the French linguistic system. From this perspective, Phillips intimates that this subtle strategy provides a sense of the creolized and unstable nature of the Martinican narrative tradition: this is exactly what the reader feels in trying to read 'unmarooned'.

In his comments on the same novel by Chamoiseau, Walcott chooses to address the Martinican author directly, as in a personal letter. Yet this form is the pretext for Walcott to describe his own journey with Texaco. And Walcott's encounter with the book soon becomes the starting point of a fantasy: he creates characters for a play or a short story. The St Lucian poet argues that he would sell Chamoiseau's novel to every West Indian in every market, and would even stop traffic in so doing: "I would press your book into the hands of every West Indian as if it were a lost heirloom, even on those who cannot read" (WTS, 215). Walcott creates a character, a reader so impressed by the book that he becomes a bookseller. He also imagines the author: "And I know you, Chamoiseau. You were one of those urchins with the artificial anger of 
boys running on a beach" (WTS, 214). One can once again sense the richness of Walcott's vision: the author is a Caribbean boy, Walcott imagines selling Texaco in market places, even to illiterate people. Considering Texaco as an "organic, fragrant novel" (WTS, 214), Walcott reveals his secret desire: the book should become organic. Like fruit and vegetables, books should be displayed on market stalls. In a way, the ethic of the Caribbean writer is to plant an organic work in the lives of Caribbean people. It may be an exaggeration to speak of sustainable development but, it is suggested, the Caribbean writer should produce works in close relationship to his ecosystem. In so doing, he or she counters the imposition of a European or an American environment. For Walcott, Chamoiseau's book fulfils this duty brilliantly: its prose is like a "mangue, that reflecting lagoon where mangroves anchor their branches" (WTS, 215). It is significant that Walcott should compare Texaco's prose to a mangue, a Spanish or Portuguese word of Carib or Arawak origin denoting 'a reflecting lagoon' surrounded by 'mangroves'. Indeed, the eponymous shantytown in Chamoiseau's novel is called "urban mangrove swamp" by the different characters. On a metaphorical level, too, the image of the mangroves' interlaced branches evokes Texaco's prose and its code-mixing, and is a further reference to the link between Chamoiseau's language and the Caribbean landscape.

\section{The Caribbean writer: a double portrait}

To conclude, one could underline the sense of displacement shared by both authors at the dawn of their writing experience. For the young Walcott, who grew up in a colony, this displacement is a result of the imperial social and racial orders, of the immobility and manichaeism of the colonial divisions. For Phillips, the exilic condition seems to be more geographical than social, even if the geographical divisions of the world, in Europe or in the US A, are also reflections of racial divides in society. In claiming a multiple identity, he rejects the idea that an area should belong to a single and homogeneous people. In short, what both writers find in Caribbean hybridity is a path, a way to escape imperial perceptions and conceptions. For Phillips and Walcott, to be a Caribbean writer is to move freely into the uncertain archipelagic frontier. Far away from the official or traditional narratives of a single nation or race, Caribbean writers need to embrace the entire world. This is the reason why Phillips is impressed by Walcott's "Arkansas Testament": "it is a poem about writing, about a man's struggle to bear his soul and talent in an environment other than that which nurtured it" $(N W O, 151)$. 
How do Phillips and Walcott portray the Caribbean writer? Their respective discussions of two major figures of the Trinidadian literary tradition, C.L.R. James and V.S. Naipaul, reach rather similar conclusions. Both Phillips and Walcott comment on Beyond a Boundary, James's memoir, which focuses on West Indian cricket. The St Lucian describes James's hybrid ethic as follows: "Mr. James's ancestors are African; why does he find mimesis in Periclean and not African sculpture when he describes the grace of his cricketers?" (WTS, 118). However, for Walcott, James's legacy is also subversive because the Trinidadian "does not try to make marble from ebony" (WTS, 117). Phillips has read Walcott's comment on James's work ${ }^{8}$ and shares the same admiration. Comparing James to Arthur Lewis, Derek Walcott, Aimé Césaire, and Alejo Carpentier, the Kittitian author considers the Trinidian intellectual to be the most "outstanding Caribbean mind of the twentieth century" (NWO, 152). Phillips is also fascinated by James's nomadic experience and his worldwide political involvement, and believes that the hybridity of Beyond a Boundary epitomizes Caribbean achievement: "The great triumph of the book is its ability to rise above genre and in its form explore the complex nature of colonial West Indian society" $(N W O, 167)$.

If Phillips and Walcott agree in their assessment of James, they are similarly concerned by V.S Naipaul's scorn for Caribbean people. They both denounce Naipaul's legendary tale of absolute uniqueness: "The myth of Naipaul as a phenomenon, as a singular, contradictory genius who survived the cane fields and the bush at great cost, has long been a farce" $(W T S, 128)$. For Walcott, Naipaul followed in the footsteps of C.L.R. James, Samuel Selvon, Jean Rhys or George Lamming. Phillips agrees, and considers the Trinidadborn writer's experience to be no more or less remarkable than that of other exilic writers such as Wole Soyinka, Guillermo Cabrera Infante or Joseph Brodsky: "there is nothing at all unique about Naipaul's journey" (NWO, 212). Despite Naipaul's proclaimed disregard for the Caribbean, Phillips anchors him to the archipelago: "It [Naipaul's subject-matter] is called Caribbean life - the people, the music, the heat, the flora, the fauna, the sunrise, the sunset, the history" ( $N W O, 214)$. Like Phillips, Walcott deplores Naipaul's disdain: "Why is this heat magical in Greece or in the desert, and just heat in Trinidad?" (WTS, 127). Thus Walcott invents another Naipaul, the Caribbean writer he would have liked to portray: "not as an enigmatic English squire

\footnotetext{
${ }^{8}$ Walcott commented on Beyond a Boundary in 1984. The review was later reprinted in What the Twilight Says.
} 
who has finally arrived, but as the sadhu that he might have become" (WTS, 132-133). Phillips does the same by reminding us that Naipaul's father had encouraged his son to write with empathy for his fellow Trinidadians, and concludes regretfully, "If only the son had listened" $(N W O, 219)$. In trying to imagine a more human V.S. Naipaul, the essayists reveal their pain and confess that their ideal Caribbean writer should be a humanist - or not be at all.

\section{WORKS CITED}

Chamoiseau, Patrick. Écrire en pays dominé (Paris: Gallimard, 1997).

—. Texaco, tr. Rose-Myriam Rejouis \& Val Vinokurov (Texaco, Paris: Gallimard, 1992; tr. New York: Vintage, 1998).

Fanon, Frantz. Black Skin, White Masks, tr. Charles Lam Markmann (Peau noire, masques blancs, 1952, tr. 1967; London, Pluto, 1982).

- The Wretched of the Earth, tr. Constance Farrington, preface by Jean-Paul Sartre (Les damnés de la terre, 1961; tr. 1965; Harmondsworth: Penguin, 2001).

James, C.L.R. Beyond a Boundary (London: Stanley Paul, 1963).

Lejeune, Philippe. Le pacte autobiographique (Paris: Seuil, 1996).

Marley, Bob \& The Wailers, "Rat Race," Rastaman Vibration (Tuff Gong \& Island, 1976).

Mayfield, Curtis. New World Order (Warner Bros, 1996).

Phillips, Caryl. A New World Order: Selected Essays (London: Secker \& Warburg, 2001).

Walcott, Derek. Dream on Monkey Mountain and Other Plays (New York: Farrar, Straus \& Giroux/Noonday, 1970).

. What the Twilight Says: Essays (London: Faber \& Faber, 1998). 


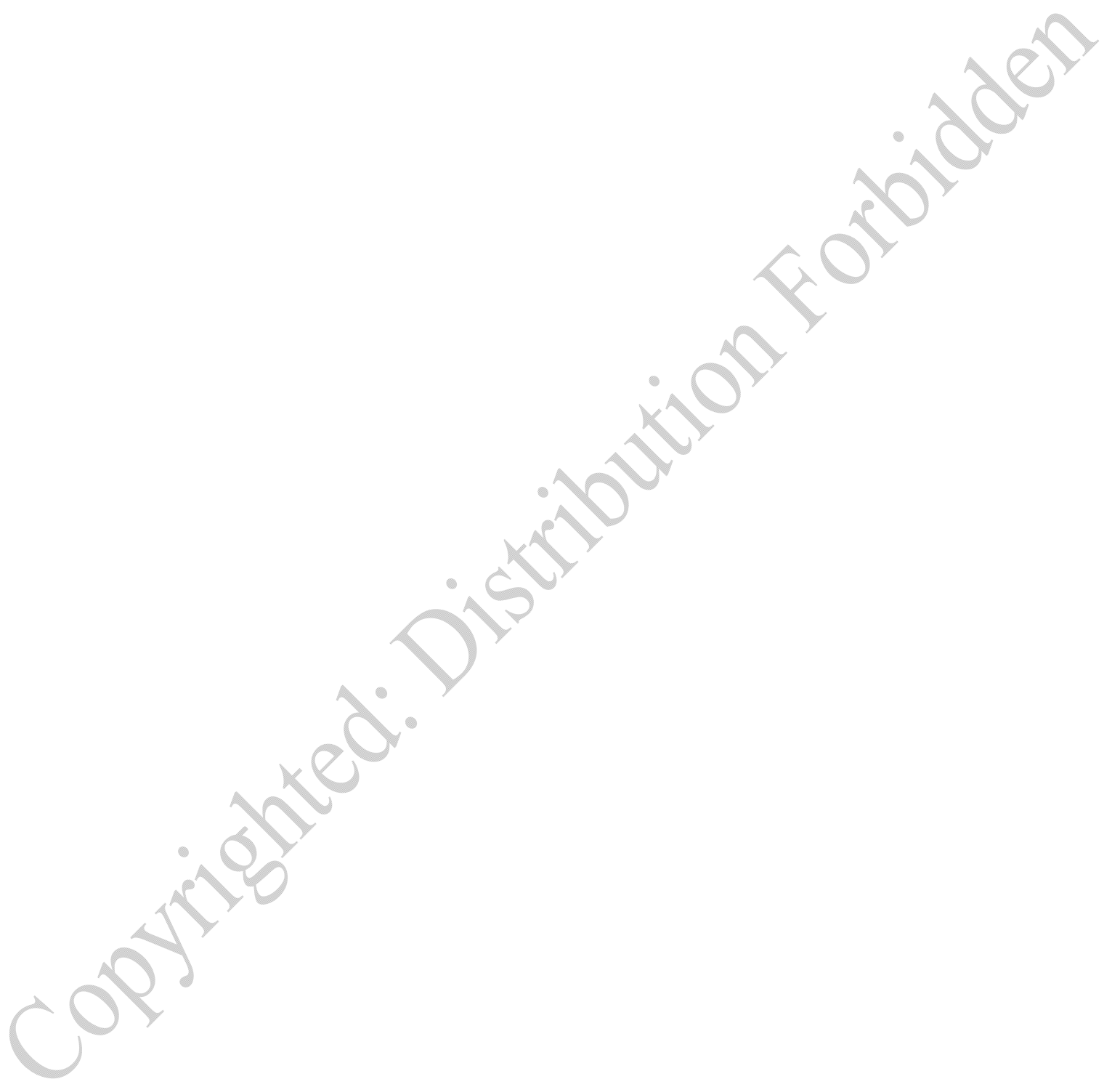




\title{
Caryl Phillips's "Heartland" and Conrad's Heart of Darkness
}

\section{Revisiting Fear: An Intertextual Approach to Phillips's and Derek Walcott's Essays}

\author{
IMEN NAJAR
}

A S A LITERARY MOTIF, THE JOURNEY PLAYED AN IMPORTANT ROLE in European colonial literature. It was exploited by many Western writers, who generously answered their readers' need to leave their familiar surroundings and embark on a tour around mysterious and alien worlds. Among these writers, Joseph Conrad seems to have best captured the idea of the unknown, which he develops in Heart of Darkness through Marlow's journey to the 'black continent'. Conrad's depiction of the African world has long been a source of inspiration for both writers and film directors. T.S. Eliot, for example, clearly had the Conradian novella in mind when he wrote The Waste Land. Francis Ford Coppola adapted it into his film Apocalypse Now. And, more recently, Alex Garland used Conrad's setting and shadowy atmosphere in his novel The Beach, filmed by Danny Boyle under the same title. Heart of Darkness has indeed led a successful life, enchanting, disenchanting, and above all fertilizing the soil of postcolonial writing. In this regard, and as his various novels testify, Caryl Phillips has always been fascinated by Conrad's tale, which, as he explains in his introduction to the novella, should not be considered as a political "pamphlet." In an article about his encounter with the Nigerian writer Chinua Achebe, Phillips clearly relates to the novella, unlike the African author, and considers it a reference work proposing "no programme for dismantling European racism or imperial-

\footnotetext{
${ }^{1}$ Caryl Phillips, "Introduction" to Heart of Darkness and Selections from the Congo Diary, by Joseph Conrad (New York: Modern Library, 1999): xv.
} 
istic exploitation;", the only "programme" of Conrad's tale, Phillips says, is "doubt." It is thus not surprising if Heart of Darkness is a work from which he garners techniques, and situations that he eventually utilizes in a no less productive and ingenious way. His novel Higher Ground (1989) obviously echoes Conrad's earlier story, first serialized in 1899. Phillips's work, as we shall see, and without being exclusively confrontational, is full of intertextual allusions to Heart of Darkness, exemplifying his own novel's "revisionary strategy.", In what follows, I shall comment only on "Heartland," the opening section of Higher Ground, which offers, among other things, an interesting representation of colonialism and slavery.

Heart of Darkness voices Marlow's obscure and mostly inconclusive seaman's narrative recalling his voyage along the African coast in the late-nineteenth century. The journey takes the form of a quest for Mr Kurtz, the European chief of an interior station and a collector of ivory, whose "nerves [...] went wrong, and caused him to preside at certain midnight dances ending with unspeakable rites," as Marlow reports. ${ }^{5}$

Phillips's "Heartland" is similarly located on an African coast with a trading fort under Western management. The narrative focuses on an African collaborationist, who works as an interpreter for the slave traders of the colonial settlement. His life is conditioned by his fear of his countrymen, who despise his involvement in the slave trade, and his terror of his white employers, who tolerate his presence as long as his human claims are silent. When the narrator wants to assert his love for a local woman, he is decreed a piece of 'Cargo', and shipped to the New World as a slave.

Just like Marlow's travel account in Heart of Darkness, the native collaborator's narrative in "Heartland" offers a vista on the dealings of Western colonialism in Africa and its implications for the everyday life of both colonizer and colonized. Each in his own tragic way seems a victim and a prisoner of his fear of the Other. Terror of the enemy - the local's terror of the colonialist

${ }^{2}$ Caryl Phillips, "Out of Africa," Guardian (22 February 2003): http://www .guardian.co .uk/books/2003/feb/22/classics.chinuaachebe (accessed 1 August 2009).

${ }^{3}$ Caryl Phillips, "Out of Africa."

${ }^{4}$ Bénédicte Ledent, "Is Counter-Discursive Criticism Obsolescent? Intertextuality in Caryl Phillips's Higher Ground," in A Talent(ed) Digger: Creations, Cameos, and Essays in Honour of Anna Rutherford, ed. Hena Maes-Jelinek, Gordon Collier \& Geoffrey V. Davis (Cross/Cultures 20; Amsterdam \& Atlanta G A: Rodopi, 1996): 302.

${ }^{5}$ Joseph Conrad, Heart of Darkness (1902), in Heart of Darkness and Selections from the Congo Diary (New York: Modern Library, 1999): 61. Further page references are in the main text after " $H D . "$ 
and the colonialist's terror of the local - becomes a space of painful connectedness confirming Aimé Césaire's belief that "between colonizer and colonized there is room only for $[\ldots]$ intimidation, pressure, $[\ldots]$ contempt, mistrust, arrogance" ${ }^{\prime 6}$ and fear. Taking my cue from these general observations, I would like to explore the perennial state of apprehension that binds the African and Western characters in "Heartland" and Heart of Darkness. I shall first examine the status of collaborators in both texts and then discuss the situation of Westerners in Africa as seen respectively by Phillips and Conrad.

In Higher Ground, the narrator and protagonist of "Heartland" shares the life of some white soldiers, who are mobilized in Africa. Interestingly, despite his pledged allegiance to the imperial undertaking, the native interpreter is totally excluded from the society of the colonial garrison, and obviously relegated to a peripheral existence, where he seems to be besieged and almost completely defeated by his fear of the foreign employer. In an autobiographical mode, the local's life is depicted as a tragic reptilian strategy of survival. Almost like a snake preferring the security of the shade to the exposure of daylight, Phillips's collaborator creeps to "darkly shadowed cloisters," sneaks "into a pool of shadows" $(H G, 13)$, slithers "on to the ramparts" $(H G$, $16)$, and "[coaxes] open the doors" $(H G, 14)$ to avoid the white traders' suspicious gaze. That he has been "purged [...] of Negro habits" in the vein of Dabydeen's protagonist in A Harlot's Progress or Conrad's "reclaimed, the product of the new forces at work" in Heart of Darkness $(H D, 18)$ does not entitle the collaborator of "Heartland" to live as freely as the other white agents in the fort. His racial affiliation to the allegedly 'inferior' and 'savage' world of the African is his scarlet letter; it excludes him from the fortress, and condemns him to a life of fear and effacement that he himself judges as "low and often unbearable" $(H G, 19)$.

To illustrate the notion of fear that corrodes the life of the interpreter, it is interesting to examine the character's interaction with the other residents of the fort. Out of loneliness, Lewis, a low-ranking member of the Western group, tries to befriend the local. Yet his friendship seems "too easily proffered for the interpreter's own comfort" $(H G, 17)$, putting him immediately on his guard. In a similar way, the new governor's attempt to make friends with

\footnotetext{
${ }^{6}$ Aimé Césaire, Discourse on Colonialism, tr. Joan Pinkham (Discours sur le colonialisme, 1950; tr. New York: Monthly Review Press, 1972): 21.

${ }^{7}$ Caryl Phillips, Higher Ground (1989; London: Viking, 1999): 11. Further page referrences are in the main text after " $H G$."

${ }^{8}$ David Dabydeen, A Harlot's Progress (1999; London: Vintage, 2000): 164.
} 
him fills him with an acknowledged "inner alarm" $(H G, 12)$, which leads to his commenting twice on the scrutinizing presence of soldiers: "I am aware of idling soldiers looking down upon us," and "men staring at us" $(H G, 13)$. Being the focal interest of the Westerners' eyes is dreadful for the narrator. The imperatives of his effacement are so deeply rooted in the survival codes of his existence that he rejects any Western sign of mere interest. I would tentatively add here that the hierarchical structure of the fort, which has relegated the collaborator to its periphery, is rigidly and strictly guarded both by the native interpreter and the Western soldiers, who, in their watchful caution, resemble Conrad's black knitters guarding the door of the company headquarters in Brussels.

The anonymity of the local agent in Higher Ground is a further sign that sustains the character's erasure - what Bénédicte Ledent describes as his "existential vacuum." The native interpreter is not given a name by his Western chiefs. His existence is not labelled, and he has therefore no claim to inscribe his personal experience on the map of communal knowledge and history. His nominal excision acts, in this regard, like one of Conrad's impenetrable hazes, which makes the character's social, historical, and even physical presence completely imperceptible. One has to concede, however, that the condition of anonymity benefits, in some way, the collaborator's strategy of survival. It makes him nominally undetectable to his employers, thereby guaranteeing his lapse into a state of eternal camouflage.

This situation doubtlessly questions the reasons behind the collaborator's motives in tolerating such a debasing process of existential obliteration. Why not rebel, why not escape and seek refuge in the interior of the country as many African 'tribes' generally did to avoid the colonial invasion? The narrator does not leave these questions unattended and proficiently substantiates the idea of an ever-hovering danger of mistrust and punishment that binds him not only to his white masters but also to his people. In fact, the interpreter's plight is even more tragic in view of the local population's undisguised "disdain" $(H G, 22)$ for his association with the white enslavers. Any attempt at escaping would in fact be fatal, since most locals would readily avenge their human losses on him. This leads one to conclude that a consuming state of apprehension clearly presides over the collaborator's marronnage between his white employers on the one hand and his own people on the other. It causes

\footnotetext{
${ }^{9}$ Bénédicte Ledent, Caryl Phillips (Contemporary World Writers; Manchester: Manchester UP, 2002): 61.
} 
him, in Ledent's terms, to "act most unnaturally," to lose himself in his "fear of the Other." 10

In terms of intertextual echoes, Phillips's nameless protagonist is obviously reminiscent of the native soldier guarding the ghastly manacled African slaves in the name of colonialism in Heart of Darkness. Just like the interpreter in "Heartland," the Conradian guard joins the imperial institution after "he [has] been instructed," and rendered "useful" $(H D, 45)$ to the trading mission. He is guarding his countrymen, whose "deathlike indifference" excludes him, just like Marlow in this episode, as part of the "insoluble mystery" $(H D, 18)$ that had come to them from a still unknown world. The guard's fear of the colonial establishment, shared by Phillips's narrator in "Heartland," is more or less hinted at in Heart of Darkness during the encounter with Marlow on the latter's arrival on the African coast. As Marlow reports,

seeing a white man on the path, [the native soldier] hoisted his weapon to his shoulder with alacrity. This was simple prudence, white men being so much alike at a distance that he could not tell who I might be. He was speedily reassured, and with a large, white, rascally grin, and a glance at his charge, seemed to take me into partnership in his exalted trust. $(H D, 18)$

I would say that Conrad's collaborator's initially panicky attitude, hastily replaced by a show of assurance, is the expression of two conflicting feelings, which submerge him in an immeasurable terror. Interestingly, when he first sees Marlow, the native soldier seems to be unconsciously and involuntarily reclaimed by his belonging to the African community, which regards Westerners as potential enemies. He is afraid, alarmed at the sight of the white invader. Yet, on second thought, the native soldier remembers his new position as a colonial agent, and puts on a large grin to make up for his previous expression of fear. The "rascally grin" $(H D, 18)$, a fiendish smile, is a sign of the local's recovered alliance with the white man. It is also the symptom of the fear that he has to smother in the presence of the ruling invader.

Another epitome of Conrad's "reclaimed" $(H D, 18)$, whose total abandonment to colonial rule might have largely inspired Phillips in his creation of the interpreter in "Heartland," is Marlow's helmsman, who shares his anonymity with other members of "the new forces at work" $(H D, 18)$, such as the poleman, the fireman, and the local guard. They are all "improved specimen[s]"

${ }^{10}$ Ledent, Caryl Phillips, 62. 
(HD, 45), who were, at some stage, educated by the "civilizational Other," to quote Aijaz Ahmad. ${ }^{11}$

While the attitude of the native soldier guarding the chain-gang might evoke, as discussed above, a local agent's dread of Western authority, the helmsman's conduct, during the attack that Marlow's crew face in the upriver journey, suggests a collaborator's fear of his own African people. In the general confusion of the assault, the helmsman's terror of the local tribe makes him behave in a most inexplicable and strange way. His body seems to be reduced to pure sensation, bereft of self-control and traversed by violent forces: "He held his head rigid, face forward; but his eyes rolled, he kept on, lifting and setting down his feet gently, his mouth foamed a little" $(H D, 55)$. The helmsman's body here enacts the character's fear of his own people. It is suddenly seized by uncontrollable convulsions, which develop into a last movement of energy that brings about the character's death. In fact, before passing away, the native agent deserts his post, fires at the shore, shakes the empty rifle at the invisible enemy, and yells at the coast before he falls down dead, a martyr of what Marlow reads as the native's foolishness, madness, and lack of "restraint" $(H D, 63)$.

Despite Marlow's attempts, throughout the narrative, to evade, mask, and deride any possible logic in the natives' reactions, it is more or less clear in this episode that the helmsman's uncontrollable alarm is triggered by his apprehensiveness of the African. As might be expected, the local agent has deeply internalized his employers' fear of the native population, a fear which combines here with his own choking dread of the African community on account of his collaboration. The lethally intoxicating blend of terrors brings about the convulsions, and then comes the unspeakable silence of death: "he died without uttering a sound" $(H D, 57)$.

My discussion so far has highlighted the state of fear that yokes Conrad's local agents to the interpreter of "Heartland" in view of their shared existential isolation. My aim now is to show how Phillips goes beyond a simplistic recuperation of Conrad's "reclaimed." Indeed, the Phillipsian interpreter of "Heartland" evokes the local agents of Heart of Darkness, but this does not mean that the author of Higher Ground duplicates their limitations.

\footnotetext{
${ }^{11}$ Aijaz Ahmad, "Jameson's Rhetoric of Otherness and the 'National Allegory'” (1987), excerpt in The Post-Colonial Studies Reader, ed. Bill Ashcroft, Gareth Griffiths \& Helen Tiffin (London \& New York: Routledge, 1995): 77.
} 
First, Phillips builds up the characterization of his local agent as a kind of synthesis of Conrad's main collaborators: namely, the soldier and the helmsman. In Heart of Darkness, each of these characters typifies one facet of fear: there is the dread of the colonial authority and the terror of the local population, which are distinctly epitomized by two different natives. What Phillips does in "Heartland" is to encapsulate the two terrors in the one native narrator of his story. His interpreter simply accumulates fears. Phillips manages thus to render, in a more explicit way, the overwhelming hopelessness of a collaborator's survival under the imperial authority.

Yet Phillips's most significant achievement in the web of connections that he establishes with Conrad's novella lies mainly in his choice of the narrative voice. In Heart of Darkness, all native subjects, including the helmsman, the poleman, the fireman, and the soldier of the chain-gang, are denied explicit voices. They exist solely within the bounds of Marlow's dominant discourse, while their own voices lie low, buried in their supposedly inarticulate experiences, which are definitely lost to the reader. Most probably, it is this intentional erasure of the natives' speech in Marlow's account of his African journey and in most travel narratives and journals of the colonial and even postcolonial era that triggered Phillips's concern with the indigenous population in this case, the local agent - and its still unrelated human experience. As Phillips himself explains in an interview, his main consideration is to

look at that history from a different angle - through the prism of people who have nominally been written out of it, or have been viewed as the losers or victims in a particular historical storm. ${ }^{12}$

It is clear from this statement that his choice of a local narrator is intentional. "Heartland" unseals the lips of Conrad's silent natives, and attests to Phillips's gestures towards an assertion of unknown identities, whose inscrutability to the Western gaze obliterates them from historical and fictional records. From this perspective, the Phillipsian text arises as an overt verbalization of a so far expunged native discourse that Marlow could not, or simply refused to, decipher. It can be assumed, then, that the helmsman's unuttered address in Conrad's Heart of Darkness ultimately regains articulation in Phillips's Higher Ground to present the reader with the standpoint of the imperially subjectified local.

\footnotetext{
${ }^{12}$ Caryl Phillips, "Crossing the River: Caryl Phillips talks to Maya Jaggi," Wasafiri 20 (1994): 26.
} 
That the native agents are caught in the global machinations of colonialism is clear, but what seems to be equally relevant both in "Heartland" and in Heart of Darkness is that Western colonizers experience the same malaise in Africa. Their lives are so deeply conditioned by their fear of the native that they seem to duplicate the misery of the local community. This idea partly ties in with Homi Bhabha's concept of mimicry, whereby colonialists either perceive the colonial Other as a source of repugnance and fear, or unconsciously adopt him in a universalist mode as a potential reflection of the self. Bhabha makes the point that in his relationship with the colonized, the colonialist aims at a moulding of the colonial subject into "a reformed, recognizable Other, as a subject of a difference that is almost the same, but not quite." "Bhabha argues that the Other is "Anglicized" but not "English"14 and "almost the same but not white." 15

In keeping with the idea of imperial malaise experienced by the colonial protagonist, I propose to focus on the character of Lewis and some of the other Western soldiers in "Heartland." Just like Conrad's Kayerts and Carlier, the incompetent colonial administrators of a desolate trading post in the Congo in "An Outpost of Progress," "young Lewis, who came to Africa with dreams of adventures, tarries in the fort waiting for future action. In a retrospective mode, he likens his life within "the high stone walls" $(H G, 17)$ of the garrison to "sweating like a rotting apple," which is to him "a waste of time" $(H G, 19)$, and he further compares his existence to an imposed process of decomposition, whereby he simply "sits around waiting to get old" $(H G, 19)$. The narrator of "Heartland" presents this condition of confinement and aimlessness as a wide-ranging state affecting not only Lewis but most agents in the trading fort. Many soldiers, we are told, resort to "the taunting and torturing of creatures - particularly lizards - [as an] occupation that helps [them] pass time" $(H G, 17)$. What these examples and others make clear is the stifling condition of incarceration that colonialists have to endure on the 'black continent.' They find themselves in a state of siege because of their acceptance of the propaganda developed by most colonial countries, which sought to depict the African world as a coliseum of murder and lust. Just like the

\footnotetext{
${ }^{13}$ Homi Bhabha, "Of Mimicry and Man: The Ambivalence of Colonial Discourse," October 28 (Spring 1984): 126. Emphasis in original.

${ }^{14}$ Bhabha, "Of Mimicry and Man," 128.

15 "Of Mimicry and Man," 130. Emphasis in original.

${ }^{16}$ Joseph Conrad, "An Outpost of Progress" (1897), in Tales of Unrest (1898; Harmondsworth: Penguin, 1977): 83-110.
} 
native in pain, the imperial capturer suddenly becomes a captive, caught in the trap of his own beliefs. However, beyond this image of the trapped Western invader who is condemned to live within the boundaries of the fort and, by extension, of his own assumptions, one must keep in mind that the conquest of Africa was also a military expedition, which implies that soldiers were expected to remain in the garrison in wait for action.

In "Heartland," Mr Price, a leading figure of the trading post, further illustrates the pervasive state of fear which, in Phillips's text, seems to dominate the experiences of most representatives of the colonial institution in Africa. When placed within the familiar boundaries of the fort and among the members of the Western community, this character's demeanour is extremely brutal and arrogant. Yet Mr Price becomes suddenly terrified when faced with the African bush. He adopts "a look of worry" when he approaches the native village and "relaxes his pace until [the interpreter is] in the lead" $(H G, 22)$ to use his body as a human shield against any aggression. Mr Price even resorts to a paranoid interrogation of his guide about the friendliness of the locals, and this in spite of his belief "that any hostile act [on the locals' part] would almost certainly bring about the destruction of this village" ( $H G, 23)$. My point is that the colonial leader, who impudently imposes his rule upon everybody in the fort, gradually shrinks to a frail shadow of himself when placed in the foreign environment of the African Other. Nevertheless, Mr Price can still be regarded as a model of bravura of sorts, in view of the fact that he is the only character in "Heartland" who leaves the fort without the support of a whole detachment. Unlike Price, most soldiers are exclusively fort-bound. Their role on the 'black continent' allows only for limited excursions in the framework of expeditions, which have the propensity of being a great "mobilization" $(H G, 35)$, that is, a massive demonstration of imperial power and prestige.

Interestingly, Phillips's colonizers, Mr Price and Lewis, are hardly distinguishable from Conrad's Europeans in Heart of Darkness. In Marlow's account, the white man's fear of the natives is similarly described as an indisputable aspect of the Western experience and psyche in Africa. I shall examine the character of the chief accountant and his fellow agents to show how Conrad's missionaries, just like Phillips's soldiers, each in their own way, try to control their unspoken dread of the local.

In Heart of Darkness, the chief accountant of the company station is hailed by Marlow as a "vision" and a "miracle" $(H D, 21)$ on account of his remarkable appearance. Living amid the general muddle of the trading post, the 
agent obsessively cultivates his elegance as a way of safeguarding himself from the danger of 'going native'. The imperial understanding of Africa as a demonic place of primitive rites, "devoid of all recognizable humanity, into which the wandering European enters at his peril," induces Conrad's accountant to cling to the accessories of the Western world, his "starched collar, white cuffs, a light alpaca jacket, snowy trousers $[\ldots]$ and varnished boots" $(H D, 21)$ as his only way to salvation. Marlow's caricature of the chief accountant as a model of sophistication and aesthetic luxury is revealing, in that it shows how the white man's fear of the native transcends the conventional realm of physical terror, which might remind us of $\mathrm{Mr}$ Price's dread of a bodily aggression in "Heartland," or Marlow's fear of attack during the up-river journey. Indeed, the accountant's horror at his black counterpart goes beyond the mere fear of physical aggression: it is of a mental sort. A blemish in his appearance would, in his understanding, bring him into a state of lethal kinship with the native African, and thus banish all his convictions of both superiority and purity.

The fear of the local population is further illustrated in Heart of Darkness through the general attitude of European envoys, more commonly referred to in Marlow's narrative as "pilgrims" $(H D, 27)$. These obsessively carry their staves as if these were extensions of their bodies. The staves, unimpressive hand-made weapons improvised to ward off intruders or to inflict physical punishment on the native attendants, are recurrently singled out by Marlow as the pilgrims' most distinguishing feature: "they wandered here and there with their absurd long staves in their hands" ( $H D, 27)$, "white men with long staves [...] strolling up" $(H D, 24)$, and "pilgrims with their staves - all complete" $(H D, 43)$. So, just as the Company brick-maker amasses a trophylike "collection of spears, assegais, shields, [and] knives" $(H D, 28)$, Conrad's pilgrims seem to value their arsenal of rods as a potential warrant for security and obedience in Africa.

However, the rudimentary weapons of the Western agents are quickly replaced by "Winchesters" $(H D, 55)$ when the natives' spears prove too difficult to handle. This happens during the up-river journey, when Marlow's crew is attacked in the fog. On this occasion, the European members of the group abandon their rods and readily brandish their guns to counter the natives'

\footnotetext{
${ }^{17}$ Chinua Achebe, "An Image of Africa: Racism in Conrad's Heart of Darkness," in Hopes and Impediments: Selected Essays (1988; Garden City NY: Doubleday Anchor, 1990): 12.
} 
assault. Such a strategy of defence, which consists in alternating exposed batons and secreted rifles, testifies to the pilgrims' chronic fear of the African population; the same colonial terror that handicaps Phillips's colonizers in "Heartland," keeping them fort-bound. In the light of this, one might add that, when the local becomes the enemy as a result of colonial subjugation and his chosen field of action is confrontation, there is definitely something to fear for white colonizers.

Clearly, whether colonized or colonizers, Phillips's characters in "Heartland" largely evoke Conrad's figures in Heart of Darkness. Yet, as already mentioned, the British-Caribbean writer is not interested in a mere reproduction of the Conradian types. He is, among other things, concerned with a counter-response to Marlow's colonial discourse. Nevertheless, Phillips's narrative can in no way be reduced to a single discursive strategy that would impose a unique reading-practice, "ignoring whole layers of meaning," for, as Ledent explains, "the counter-discursive paradigm can be reductive if used as the only method of approach."18

Keeping this idea of plurality in mind, I would now like to go back to both texts and try to show how Phillips addresses Marlow's deliberate omission of the native in pain in Heart of Darkness. Marlow constantly hints at the general sense of fear that is shared by most pilgrims towards the colonial subject. However, neither Conrad nor Marlow gives us a full view of the reactions and emotions that mount above the imperial attitudes of either fear or greed. The terror that brands the displaced local population and the native collaborationists as a consequence of colonialism is clearly jettisoned. It is conspicuously absent from the narrative, enigmatically evading Marlow's partial gaze, which sees nothing in the locals outside incomprehensible "grin[s]" $(H D, 18)$, "filed teeth," and "ornamental scars" $(H D, 45)$. The reader is left with a jigsaw puzzle of hints and clues, and very often fails to detect anything beyond Marlow's narrative. Edward W. Said highlights the biased perspective of the Conradian narrator:

If we must $[\ldots]$ depend upon the assertive authority of the sort of power that Kurtz wields as a white man in the jungle or that Marlow, another white man, wields as narrator, there is no use looking for other, non-imperialist alternatives; the system has simply eliminated them and made them unthinkable. ${ }^{19}$

\footnotetext{
${ }^{18}$ Ledent, "Is Counter-Discursive Criticism Obsolescent?" 301.

${ }^{19}$ Edward W. Said, Culture and Imperialism (1993; London: Vintage, 1994): 26.
} 
As Said's comment clearly conveys, Marlow's account of his African journey functions within the general framework of colonial perspectives, which exclude Otherness and confine it to a realm of sub-humanity. This, as Said explains, clearly accounts for what seems to be Marlow's intentional erasure of all possible references to the locals' share in the colonial experience of fear and terror. It is probably this provocative exclusion of the native in pain from Heart of Darkness that Phillips answers in Higher Ground, as if "Heartland" were a corrective to Marlow's prejudiced account of his voyage. For the narrator of Phillips's story, even when self-focused, the discursive field is not discriminately selective. On the contrary, it is an all-encompassing space of expression, used to display both the natives' dread of colonizers and the colonizers' deep fear of the locals. The cases of Lewis and Mr Price, as discussed above, largely attest to the narrator's insistence on the cross-ethnic malaise triggered by colonialism. In other words, in Phillips's "Heartland," the narrative presents a panoramic view of a human experience that takes into account both sides of the colonial limbo, colonizers and colonized. It gestures towards a wider and sometimes corrective understanding of colonial reality that most narratives of that period, ike Heart of Darkness, describe only in part.

In conclusion, I would say that one of Phillips's major accomplishments in "Heartland" is to evoke Conrad's novella, rely on its textual echoes to address some of the issues that make Marlow's travel account in Heart of Darkness an essentially colonial narrative. Crucially, Phillips engages with Conrad's tale. In fact, the former explains in his article about Chinua Achebe that, although he can understand the Nigerian writer's dismissal of Conrad's novella as an essentially racist story, he himself does not fully identify with Achebe's rejection of Heart of Darkness, on account of his own personal history, which, of course, is different from Achebe's and consequently permits other readings. After all, Phillips "[is] not an African," as he himself says. ${ }^{20} \mathrm{He}$ is thus left with the different entities that make up his own identity, and must find his own answers to Conrad's story, as he indeed endeavours to do in the first section of Higher Ground. The result is a work too complex to fit into a reductive counter-discursive framework such as that presented in The Empire Writes Back. "Heartland" may be read as Phillips's response to Heart of Darkness, but this is only one possible reading among others.

\footnotetext{
${ }^{20}$ Caryl Phillips, "Out of Africa."

${ }^{21}$ Bill Ashcroft, Gareth Griffiths \& Helen Tiffin, The Empire Writes Back: Theory and Practice in Post-Colonial Literatures (1989; London \& New York: Routledge, 2002).
} 


\section{WORKS CITED}

Achebe, Chinua. "An Image of Africa: Racism in Conrad's Heart of Darkness" (1975), in Hopes and Impediments: Selected Essays (1988; Garden City N Y: Anchor, 1990): 1-20. Originally in Research in African Literatures 9.1 (Spring 1978): 1-15.

Apocalypse Now, dir. Francis Ford Coppola (United Artists, US A 1979; 153 min).

Ahmad, Aijaz. "Jameson's Rhetoric of Otherness and the 'National Allegory'” (1987), excerpt in The Post-Colonial Studies Reader, ed. Bill Ashcroft, Gareth Griffiths \& Helen Tiffin (London \& New York: Routledge, 1995): 77-82.

Ashcroft, Bill, Gareth Griffiths \& Helen Tiffin. The Empire Writes Back: Theory and Practice in Post-Colonial Literatures (1989; London \& New York: Routledge, 2002).

The Beach, dir. Danny Boyle (Twentieth-Century-Fox, U S A/U K 2000; 119 min.).

Bhabha, Homi. "Of Mimicry and Man: The Ambivalence of Colonial Discourse," October 28 (Spring 1984): 125-33.

Césaire, Aimé. Discourse on Colonialism, tr. Joan Pinkham (Discours sur le colonialisme, 1950; New York: Monthly Review, 1972).

Conrad, Joseph. Heart of Darkness (1902), in Heart of Darkness and Selections from The Congo Diary (New York: Modern Library, 1999): 1-96.

_. "An Outpost of Progress" (1897), in Tales of Unrest (1898; Harmondsworth: Penguin, 1977): 83-110.

Dabydeen, David. A Harlot's Progress (1999; London: Vintage, 2000).

Eliot, T.S. The Waste Land (New York: Boni \& Liveright, 1922).

Garland, Alex. The Beach (London: Viking, 1996).

Ledent, Bénédicte. Caryl Phillips (Contemporary World Writers; Manchester: Manchester UP, 2002).

—. "Is Counter-Discursive Criticism Obsolescent? Intertextuality in Caryl Phillips's Higher Ground," in A Talent(ed) Digger: Creations, Cameos, and Essays in Honour of Anna Rutherford, ed. Hena Maes-Jelinek, Gordon Collier \& Geoffrey V. Davis (Cross /Cultures 20; Amsterdam \& Atlanta G A: Rodopi, 1996): 301-308.

Phillips, Caryl. "Crossing the River: Caryl Phillips talks to Maya Jaggi," Wasafiri 20 (1994): 25-29.

- Higher Ground (1989; London: Viking, 1999).

."Introduction" to Heart of Darkness and Selections from The Congo Diary, by Joseph Conrad (New York: Modern Library, 1999): xi-xviii.

_. "Out of Africa," Guardian (22 February 2003): http://www.guardian.co.uk /books/2003/feb/22/classics.chinuaachebe (accessed 1 August 2009).

Said, Edward W. Culture and Imperialism (1993; London: Vintage, 1994). 


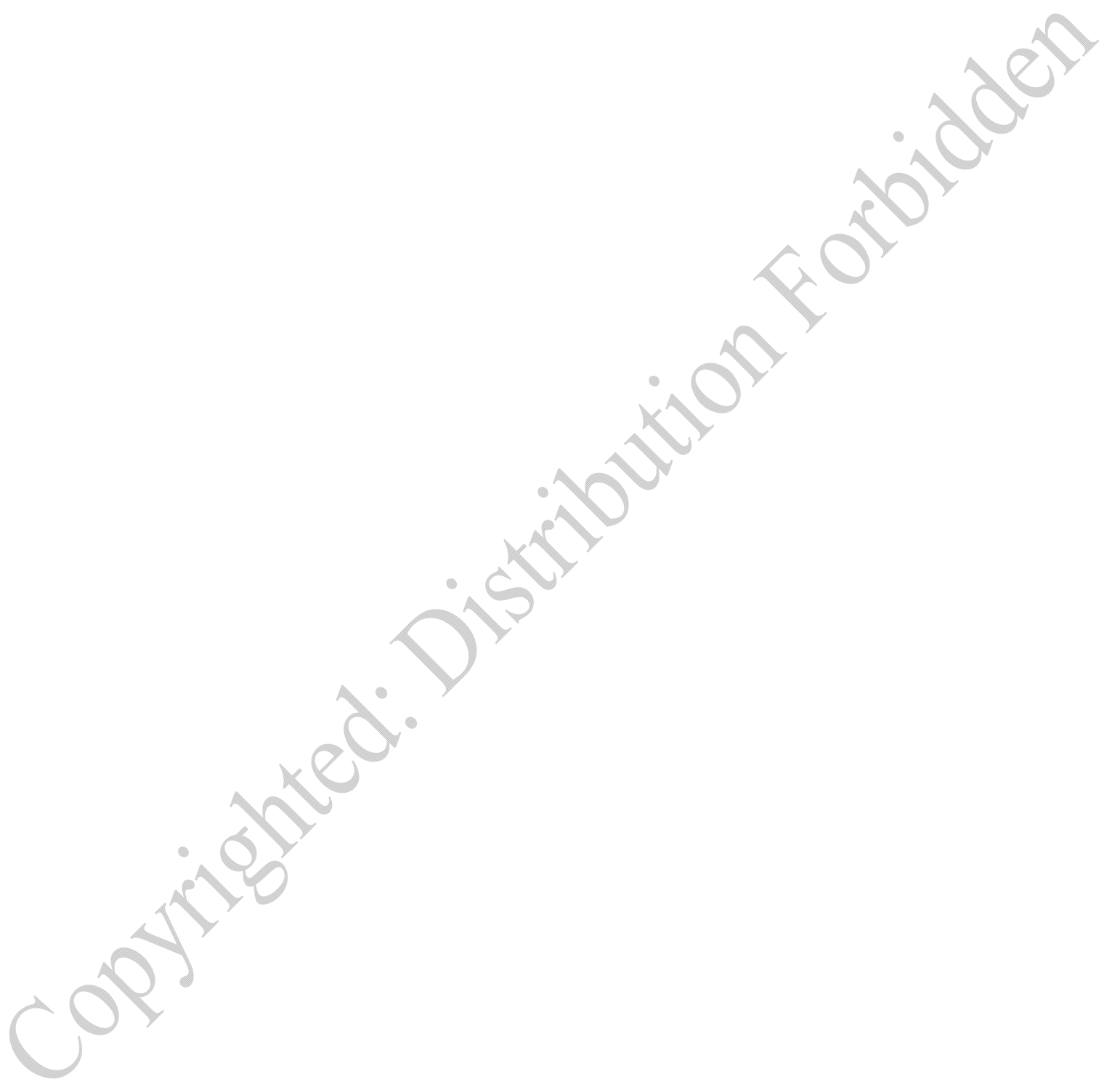




\section{DIASPORAS}




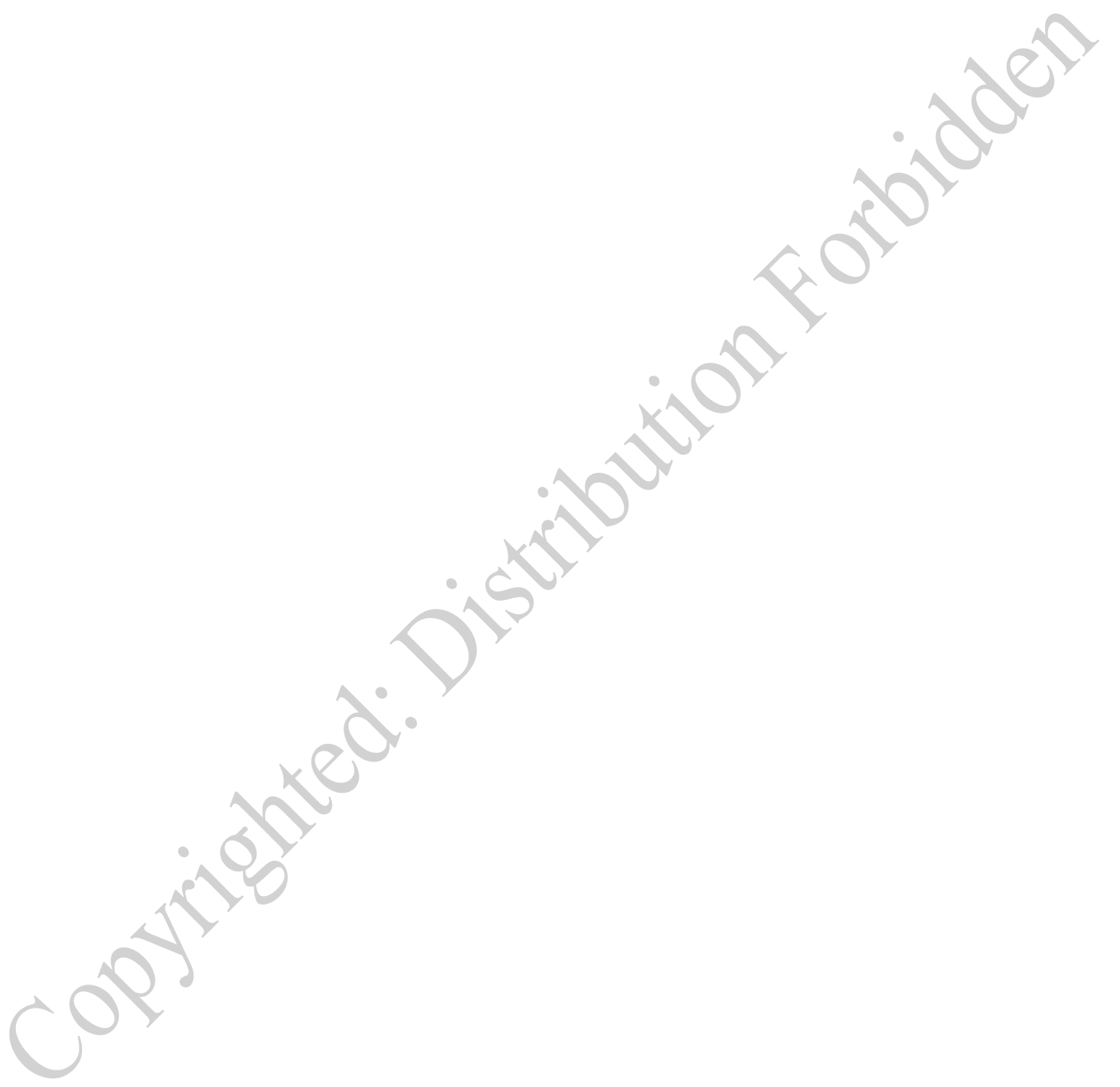




\title{
Linking Legacies of Loss \\ Traumatic Histories and Cross-Cultural Empathy in Caryl Phillips's Higher Ground and The Nature of Blood
}

\author{
SteF CRAPS
}

$\mathrm{T}$

rauma studies, an area of cultural investigation that came to prominence in the early- to mid-1990s, prides itself on its explicit commitment to ethics, which sets it apart from the poststructuralist and deconstructive criticism of the 1970 and early 1980 s in which it has its roots. Standing accused of irrelevance or indifference to 'real-world' issues such as history, politics, and ethics because of its predominantly epistemological focus, this earlier 'textualist' paradigm was largely eclipsed around the mid-1980s by overtly historicist or culturalist approaches, including the New Historicism, cultural materialism, cultural studies, and various types of advocacy criticism (feminist, lesbian and gay, Marxist, and postcolonial). Trauma studies can with some justification be regarded as the reinvention in an ethical guise of this much maligned textualism.

Cathy Caruth, one of the leading figures in trauma studies (along with Shoshana Felman, Geoffrey Hartman, and Dominick LaCapra), counters the oftheard critique of deconstruction and poststructuralism outlined above by arguing that, rather than leading us away from history and into "political and ethical paralysis,", a textualist approach can afford us unique access to history. Indeed, it makes possible a "rethinking of reference" which aims not at

\footnotetext{
${ }^{1}$ This is a revised version of an essay published under the same title in Studies in the Novel 40.1-2 (Spring-Summer 2008): 191-202.

${ }^{2}$ Cathy Caruth, Unclaimed Experience: Trauma, Narrative, and History (Baltimore MD: Johns Hopkins U P, 1996): 10.
} 
"eliminating history" but at "resituating it in our understanding, that is, at [...] permitting history to arise where immediate understanding may not." By bringing the insights of deconstructive and psychoanalytic scholarship to the analysis of cultural artefacts that bear witness to traumatic histories, critics can gain access to extreme events and experiences that defy understanding and representation. Caruth insists on the ethical significance of this critical practice. She claims that "the language of trauma, and the silence of its mute repetition of suffering, profoundly and imperatively demand" a "new mode of reading and of listening", which would allow us to escape the isolation imposed on both individuals and cultures by traumatic experience. In "a catastrophic age" such as ours, according to Caruth, "trauma itself may provide the $[\ldots]$ link between cultures." ${ }^{, 5}$ With trauma forming a bridge between disparate historical experiences, so the argument goes, listening to the trauma of another can contribute to cross-cultural solidarity and to the creation of new forms of community.

Remarkably, however, trauma studies' stated commitment to the promotion of cross-cultural ethical engagement is not borne out by the founding texts of the field (including Caruth's own work), which tend to marginalize or ignore traumatic experiences of currently subordinate groups both inside and outside Western society. Instead of promoting solidarity between different cultures, trauma theory risks assisting in the perpetuation of the very beliefs, practices, and structures that maintain existing injustices and inequalities as a result of this one-sided focus. For trauma studies to have any hope of redeeming its promise of ethical effectiveness, traumatic metropolitan or FirstWorld histories must be seen to be tied up with histories of colonial trauma. Attempts to give the suffering engendered by colonial oppression its 'traumatic due' have been made in recent years by several postcolonial critics, who have suggested theorizing colonization in terms of the infliction of a collective trauma and reconceptualizing postcolonialism as a post-traumatic cultural formation, ${ }^{6}$ as well as by historians working in the fledgling field of

3 Caruth, Unclaimed Experience, 11.

${ }^{4}$ Unclaimed Experience, 9.

${ }^{5}$ Cathy Caruth, "Trauma and Experience: Introduction," in Trauma: Explorations in Memory, ed. \& intro. Cathy Caruth (Baltimore MD: Johns Hopkins U P, 1995): 11.

${ }^{6}$ See, for example: Linda Hutcheon, "Postcolonial Witnessing - and Beyond: Rethinking Literary History Today," Neohelicon 30.1 (2003): 13-30; Leela Gandhi, Postcolonial Theory: A Critical Introduction (New York: Columbia U P, 1998); and David Lloyd, "Colonial Trauma/Postcolonial Recovery?" Interventions: International Journal of Postcolonial Studies 2.2 (2000): 212-28. 
comparative genocide studies, who have challenged the notion of Holocaust uniqueness by situating other - mainly colonial - atrocities in relation to the Holocaust. $^{7}$

In the field of literature, the work of Caryl Phillips deserves special mention in this connection. In his novels Higher Ground (1989) and The Nature of Blood (1997), Phillips excavates histories of both black and Jewish suffering: all of his protagonists are struggling with traumatic memories of racist or antisemitic violence and oppression. However, Phillips does not treat these individual histories in isolation but lets them address one another. As a result, his work resonates with Caruth's understanding of history and trauma as inherently relational: "history, like trauma, is never simply one's own, [...] history is precisely the way we are implicated in each other's traumas." ${ }^{8}$ In this essay, I will probe the nature of this implication by focusing on the aforementioned novels' management of empathy, a concept that plays a crucial role in much recent work on trauma and witnessing.

Many theorists agree that an appropriate response to accounts of trauma must involve empathic identification with the witness, but they also insist that this empathy must be checked. Dominick LaCapra has coined the phrase "empathic unsettlement" " to denote the desired type of affective involvement, which he distinguishes from "self-sufficient, projective or incorporative identification." "Empathic unsettlement means feeling for another without losing sight of the distinction between one's own experience and the experience of the other: "it involves virtual not vicarious experience - that is to say, experience in which one puts oneself in the other's position without taking the place of - or speaking for - the other or becoming a surrogate victim who appropropiates [sic] the victim's voice or suffering."11

\footnotetext{
7 See, for example: A. Dirk Moses, "Conceptual Blockages and Definitional Dilemmas in the 'Racial Century': Genocides of Indigenous Peoples and the Holocaust," Patterns of Prejudice 36.4 (October 2002): 7-36; David Moshman, "Conceptual Constraints on Thinking about Genocide," Journal of Genocide Research 3.3 (November 2001): 431-50; Dan Stone, "The Historiography of Genocide: Beyond 'Uniqueness' and Ethnic Competition," Rethinking History 8.1 (March 2004): 127-42; and Jürgen Zimmerer, "The Birth of the Ostland out of the Spirit of Colonialism: A Postcolonial Perspective on the Nazi Policy of Conquest and Extermination," Patterns of Prejudice 39.2 (2005): 197-219.

${ }^{8}$ Caruth, Unclaimed Experience, 24.

${ }^{9}$ Dominick LaCapra, Writing History, Writing Trauma (Baltimore MD: Johns Hopkins UP, 2001): 41.

${ }^{10}$ Dominick LaCapra, History in Transit: Experience, Identity, Critical Theory (Ithaca NY : Cornell U P, 2004): 135.

${ }^{11}$ LaCapra, History in Transit, 135.
} 
Jill Bennett relates LaCapra's notion of empathic unsettlement to Bertolt Brecht's critique of identification, specifically of art that induces what Brecht termed "crude empathy": i.e. "a feeling for another based on the assimilation of the other's experience to the self."12 Bennett analyzes contemporary trauma art which in Brechtian fashion seeks to negotiate a balance between encouraging audience identification and thwarting it through the deployment of strategies of estrangement. The empathic connections engendered by these works are seen to combine affect with critical awareness, resulting in encounters of an expropriative kind, in which the space between self and other is not eradicated but "inhabited."13 I argue that Higher Ground and The Nature of Blood go some way towards redeeming the ethical promise of trauma studies by promoting such a critical and self-reflexive empathy as conducive to the establishment of a truly inclusive post-traumatic community marked by openness to and respect for otherness.

I will proceed by briefly analyzing some of the textual strategies Phillips adopts for 'managing' empathy - in the double sense of succeeding in eliciting an empathic response and of controlling or limiting empathy. I will focus mainly on the latter aspect - the attempt to rein in empathy - as that part of the equation seems to me to have been relatively underexplored in the existing criticism. I want to start with a quotation from a survey article on Phillips's work up to Higher Ground which was published in World Literature Today in 1991. The authors of the article, Charles Sarvan and Hasan Marhama, conclude their detailed analysis of Higher Ground by praising the imaginative feat performed by Phillips in this - his then latest - novel, which

shift[s] from the days of slavery somewhere on the coast of black Africa to a contemporary maximum-security prison cell in the US A and then to a Polish Jewish woman suffering incomprehension, loneliness, and a breakdown in Britain during World War II. ${ }^{14}$

Crediting him with achieving "a wonderful broadening out of understanding and sympathy," Sarvan and Marhama describe Phillips thus:

\footnotetext{
${ }^{12}$ Jill Bennett, Empathic Vision: Affect, Trauma, and Contemporary Art (Stanford C A : Stanford UP, 2005): 10.

${ }^{13}$ Bennett, Empathic Vision, 105.

${ }^{14}$ Charles P. Sarvan \& Hasan Marhama, "The Fictional Works of Caryl Phillips: An Introduction," World Literature Today 65.1 (Winter 1991): 40.
} 
a writer who can penetrate the inner being of people vastly different from himself in time, place, and gender, yet people very much like us all in the common and eternal human inheritance of pain and suffering. ${ }^{15}$

In their humanist-universalist view, Higher Ground represents a triumph of the sympathetic imagination, which is seen to successfully extend the writer's and the reader's ethical horizon to include racial and gendered others that may previously have been beyond it. What the novel allows us to understand, according to Sarvan and Marhama, is the essential sameness underlying superficial differences between 'them' and 'us': we are invited to recognize their pain and suffering as "very much like" our own, as part of our common human destiny.

It is easy to see what gave rise to this reading of the ethical dimension of Phillips's work - a reading which I hope to expose as ultimately flawed. In both Higher Ground and The Nature of Blood, Phillips records the experiences of a wide range of characters who are all victims of racism or antisemitism. The former novel is aptly described on the book's dust-jacket as "a haunting triptych of the dispossessed and the abandoned - of those whose very humanity is being stripped away." It features the story of an unnamed African who works as an agent and interpreter in a British slave-trading fort on the west coast of Africa in the late-eighteenth century ("Heartland"); the story of Rudy Williams, a young black American detained in a high-security prison for armed robbery during the 1960 ("The Cargo Rap"); and the story of Irina, a Jewish refugee from Poland who escaped the Nazis on a children's transport to England, and Louis, a West Indian man Irina meets hours before he is to return from London to the Caribbean, disillusioned with British society ("Higher Ground"). The Nature of Blood follows an even more winding path through space and time, exploring the Nazi persecution of the Jews of Europe through the story of Eva Stern, a young German Holocaust survivor; retelling the story of Othello, the Moorish general brought to Venice to wage war against the Turks; recounting the story of a blood libel and the ensuing public execution of three Jews in a town near Venice in the late-fifteenth century; and following the life of Stephan Stern, Eva's uncle, who left Germany in the 1930 s to help found the state of Israel, where in his old age he has a brief encounter with Malka, an Ethiopian Jew suffering racism at the hands of her white co-religionists.

\footnotetext{
${ }^{15}$ Sarvan \& Marhama, "The Fictional Works of Caryl Phillips," 40.
} 
Both novels invite the reader to detect thematic connections between the discrete narratives about disparate characters in different times and places which they juxtapose. In the case of Higher Ground, which consists of three clearly demarcated, ostensibly self-contained novellas, the book's subtitle, $A$ Novel in Three Parts, encourages the reader to read the three sections together and to uncover parallels between the lives of the individual protagonists. In The Nature of Blood, which has no subtitle, it is the extremely fragmented structure of the text that prompts the reader to look for connections between the different stories. The narrative strands that make up the novel are not divided into clearly marked sections or chapters, as in Higher Ground, but merge and mingle at an ever-accelerating pace. In the process of disentangling these closely interwoven story-lines, the reader cannot help but reflect on what it is that unites them.

The numerous words, phrases, motifs, and themes that echo from one narrative to another in both Higher Ground and The Nature of Blood have been discussed at length by other critics. Rather than rehearsing them here, I will content myself with giving just a few examples of links between black and Jewish experience from the two novels. In Higher Ground, one of the themes connecting the enslavement of Africans recounted in the first section, the plight of black convicts in 1960s America explored in the second section, and the Holocaust and its aftermath examined in the third section is that of physical and/or psychological captivity. The connection is made explicit by the protagonist of the second section, who, in letters to his relatives and would-be legal representatives, constantly filters his own situation through the prisms of both the Holocaust and African American slavery. Rudy repeatedly uses Holocaust terminology to describe his own experience of incarceration, calling the prison in which he is kept "Belsen," 16 referring to the wardens as "the Gestapo Police,"17 and wondering, while being held in solitary confinement with twenty-four-hour light, whether "in Nazi Germany they used to keep the lights on as a form of torture." ${ }^{, 18}$ He also employs images of slavery to depict his detention, and black US citizenship in general, as similar states of imprisonment. For example, he regards the USA as a "plantation society"19 in which emancipation is yet to happen. Having been released from the maxi-

\footnotetext{
${ }^{16}$ Caryl Phillips, Higher Ground: A Novel in Three Parts (New York: Viking Penguin, 1989): 69, 84, 145.

${ }^{17}$ Phillips, Higher Ground, 127.

${ }^{18}$ Higher Ground, 72.

${ }^{19}$ Higher Ground, 67. The word "plantation" also appears on page 90.
} 
mum-security wing into the main prison population, he writes: "Restrictions still apply, but to me they are as welcome and as liberal as the emancipation proclamation that we have yet to hear." ${ }^{, 20}$ Rudy's current predicament and the past experience of slavery are linked most memorably in the deranged letter to his dead mother with which this section ends, which brings prison life and plantation atrocities together in an hallucinatory fusion.

In The Nature of Blood, the parallels suggested between different characters are even more numerous and conspicuous. For example, the experience of the black Ethiopian Jew Malka in the 1980s is subtly connected with that of the white German Jew Eva in the 1930s. Their departure from their respective homelands is described in strikingly similar terms. Malka speaks of being "herded [...] on to buses" and being "stored like thinning cattle" on the Israeli embassy compound, where she and the other Ethiopian Jews were left to "graz[e] on concrete" before being air-lifted to Israel. ${ }^{21}$ This image of people treated like cattle uncannily recalls Eva's description of the crowded boxcar trains in which she and her parents had been forced to travel, like animals, to the concentration camp. ${ }^{22}$ Moreover, Malka and Eva both meet with prejudice and suspicion in the foreign country - Israel in the case of the former, England in the case of the latter - in which they try to rebuild their lives after their respective ordeals. Two other characters whose life stories closely parallel each other are Stephan Stern and the African general whom we recognize as Othello, though he is not actually named as such in the text. Both characters leave behind their homeland, a wife, and a child to start a new life in a different country. Each passes through the island of Cyprus, on the border between the East and the West, and forms a romantic attachment across the colour line. Moreover, each is deluded by a naive idealism: Stephan is disappointed to find that the new homeland for which he had fought as a young man and which he had imagined as a haven for "the displaced and the dispossessed"23 is not free from exclusionary practices, and Othello similarly underestimates the forces of nationalism and racism militating against his dream of being accepted into Venetian society and beginning a "new life of peace,"24 although he, unlike Stephan, does not quite seem to have realized this yet when his narrative suddenly breaks off.

\footnotetext{
${ }^{20}$ Phillips, Higher Ground, 147.

${ }^{21}$ Caryl Phillips, The Nature of Blood (London: Faber \& Faber, 1997): 200.

${ }^{22}$ Phillips, The Nature of Blood, 156-57, 161-62.

${ }^{23}$ The Nature of Blood, 5 .

${ }^{24}$ The Nature of Blood, 174.
} 
In establishing links among the narratives, Higher Ground and The Nature of Blood appear to invite the reader to recognize a common human essence which persists across space and time. Differences between people which may seem profound are revealed to be only skin-deep. The equation between different historical experiences which the novels appear to put forward can be interpreted as evidence of Phillips's adherence to the confident humanist universalism attributed to him by Sarvan and Marhama. Further evidence may be found in the apparent ease with which the author inhabits the minds and voices of his characters, often using first-person narration and internal focalization. It seems as if neither chronological or spatial distance nor race or gender difference are allowed to set limits to the power of the sympathetic imagination, which enables Phillips to go inside the characters, no matter how deeply they may be traumatized, without meeting any obstacles. Yet, the inaccessibility of one's innermost experience to outsiders is repeatedly remarked upon by the characters themselves. Eva, for example, reflects, with reference to Gerry and the other British soldiers who have liberated her: "But he can never understand somebody like me. None of them can." 25 And similarly, with reference to the people who pass her by in the village square near the newly liberated concentration camp: "They cannot know what I know. They can never know what I know." 26 Fearing that communicating her experience to others cannot but result in distortion and trivialization, Eva reverts to silence in an effort to keep her inner reality inviolate from the world. The medical expert who treats Eva in the British hospital, and whose voice interrupts her narrative on three occasions, regrets his lack of knowledge of his patient's closely guarded interiority. Having only outward symptoms to go on, he did not consider her to be "a serious problem" and failed to identify her as a suicide risk. ${ }^{27}$ Eva's insistence on the need to protect her secret inner world against uncomprehending outsiders resonates with the conviction voiced by one of the Jewish money-lenders about to be put to death in late-fifteenthcentury Venice that "they [the Christian majority population] will capture only the outside of our people, but not their souls."28 Remarkably, however, literature apparently manages to bridge the divide between the outside and the inside and to penetrate the souls of people who have lived through various

\footnotetext{
${ }^{25}$ Phillips, The Nature of Blood, 43.

${ }^{26}$ The Nature of Blood, 46.

27 The Nature of Blood, 187.

${ }^{28}$ The Nature of Blood, 182.
} 
historical catastrophes. After all, Phillips's novels allow the reader to enter the minds of the characters, offering him or her a glimpse of what otherwise remains "secret and inaccessible." 29 Again, the suggestion is that it is possible, through the imagination, to feel one's way into others and to recognize a basic continuity of human experience.

Read in this way, Higher Ground and The Nature of Blood lay themselves open to the kind of criticism that LaCapra, Bennett, and other trauma theorists have levelled at unreflective attempts to empathize with victims of trauma. Rather than leading to an ethical encounter, they argue, uncritical or crude empathy leads away from it insofar as it appropriates the experience of the other, reduces it to familiar frames of reference, and thereby violates its singularity. Phillips has, in fact, been accused of doing exactly that in a rare scathing review of The Nature of Blood by the English writer and critic Hilary Mantel. Mantel finds it objectionable that a black male British writer should assume the voice of a white female Jewish victim of the Holocaust, in a novel, moreover, that juxtaposes and thereby supposedly equates black and Jewish suffering:

This is the devil's sentimentality: it is demented cosiness, that denies the differences between people, denies how easily the interests of human beings become divided. It is indecent to lay claim to other people's suffering: it is a colonial impulse, dressed up as altruism. The heart may be pure, but more than heart is needed; good motives sometimes paralyse thought. ${ }^{30}$

Other critics, including Bénédicte Ledent, Wendy Zierler, Anne Whitehead, Helge Nowak, and Stephen Clingman, have explicitly or implicitly sought to refute Mantel's accusation in their work. Ledent points out that, by taking on the voices of Jewish, female, and/or white characters, Phillips denounces what she calls the artistic ghetto of authenticity. ${ }^{31}$ She quotes from a review of The Nature of Blood in the New York Times which commends the author for his refusal to conform to the dictates of identity-politics:

in taking the Holocaust as his subject, and in writing much of the novel in the voice of a white Jewish woman, Mr. Phillips also challenges the current literary tribalism, pervasive in this age of identity politics, that would mark off

\footnotetext{
${ }^{29}$ Phillips, The Nature of Blood, 73 .

${ }^{30}$ Hilary Mantel, "Black Is Not Jewish," review of The Nature of Blood, by Caryl Phillips, Literary Review (1 February 1997): 40.

${ }^{31}$ Bénédicte Ledent, Caryl Phillips (Contemporary World Writers; Manchester: Manchester UP, 2002): 150.
} 
black experience as the domain of blacks, restrict the telling of women's lives to other women, and leave the Holocaust to the Jews. ${ }^{32}$

Ledent considers Mantel's criticism of Phillips's assault on literary tribalism to be evidence of the critic's narrow-mindedness and obliviousness to artistic freedom. Having traced the origins of the accusation to the doctrine of political correctness, Ledent voices her suspicion that "it could well be fuelled by racial bias too": after all, a black writer receives censure for conduct which is considered acceptable when displayed by white writers like Thomas Hardy, Tolstoy, or Shakespeare. ${ }^{33}$ Anne Whitehead similarly finds an insistence in Phillips's work that "authorial identity places no restrictions on the fictional or historical imagination." 34 Citing Salman Rushdie's claim that "literature is not in the business of copyrighting certain themes for certain groups," she also interprets Phillips's literary ventriloquism as a salutary and unproblematic attempt to move beyond identity politics. ${ }^{35}$

While I agree that Mantel misses the mark in her review, it seems to me that she does express a legitimate concern, albeit one that does not actually apply to Phillips's work. ${ }^{36}$ As I see it, her fatal flaw is not a dubious attachment to old-fashioned identity-politics but, rather, a failure to fully appreciate the self-reflexiveness of the text she reviews, causing her to misdirect her criticism. I argue that, for all their impressive ventriloquizing, Phillips's novels do, in fact, acknowledge limits to empathy. In this respect, my rebuttal differs from that offered by Stephen Clingman, though he, too, questions Mantel's reading skills rather than her politics. Clingman paraphrases Mantel's accusation, which he uses as the point of departure for his thoughtful reading of The Nature of Blood, as follows:

\footnotetext{
32 James Shapiro, quoted in Ledent, Caryl Phillips, 150.

${ }^{33}$ Ledent, Caryl Phillips, 151.

${ }^{34}$ Anne Whitehead, Trauma Fiction (Edinburgh: Edinburgh UP, 2004): 105.

35 Whitehead, Trauma Fiction, 105, quoting Salman Rushdie, "Imaginary Homelands" (1982), in Rushdie, Imaginary Homelands: Essays and Criticism 1981-1991 (London: Granta/Penguin, 1991): 15.

${ }^{36}$ Nowak similarly claims that Mantel's caveat "has to be taken seriously" and that her reproach is "misdirected in the case of The Nature of Blood and its author"; Helge Nowak, " "Naturally, Their Suffering Is Deeply Connected to Memory': Caryl Phillips's The Nature of Blood as a Grand Narrative of Racism and Xenophobia," in Xenophobic Memories: Otherness in Postcolonial Constructions of the Past, ed. Monika Gomille \& Klaus Stierstorfer (Heidelberg: Winter, 2003): 128. However, it seems to me that Nowak's defence, which proceeds mainly by invoking Phillips's credentials as a long-time critic of colonialism and antisemitism in the tradition of Jean-Paul Sartre and Frantz Fanon, sidesteps a key issue Mantel raises: namely, that noble and altruistic intentions can backfire.
} 
there is an intellectual slackness in The Nature of Blood, she claims, which generally she ties to a stylistic slackness - a lack of fully imagined reality or voicing in the novel. ${ }^{37}$

Clingman sets out to prove this claim wrong by performing a sophisticated close reading of the novel, which is meant to show that this supposed "lack of fully imagined reality or voicing" is in fact non-existent. The reality and the voices which Phillips presents, so Clingman argues, are a lot more "fully imagined" than Mantel gives the author credit for, which is why her criticism is unfounded. In my opinion, however, this reading overemphasizes Phillips's devotion to perfecting the art of narrative polyphony at the expense of textual signs which complicate the pursuit of imaginative identification, inviting critical reflection on the potentially harmful consequences of the drive to fully imagine another's reality or voice.

As I do not have enough space here to develop a detailed reading of either Higher Ground or The Nature of Blood (let alone both novels) which would bear out this claim, I will limit myself to a few moments in the texts where what I have called the 'management' of empathy is particularly evident, in the hope that this cursory sketch will give some indication of the direction in which a more full-blown reading might go. While I will mainly focus here on Phillips's representation of Jewish characters, I should make it clear that I do not regard the challenges faced by a contemporary black writer in representing black victims of slavery or racism as being categorically different from those he or she faces in representing Jewish victims of persecution. Indeed, I agree with Clingman that we should guard against the notion that there is "some simple and undifferentiated continuity of 'blackness' or of the black experience across the ages" which a black writer would have immediate access to by virtue of being black. ${ }^{38}$ With this caveat in mind, let us return now to the story of Rudy Williams, and particularly to the conception of history implicit in his account, which appears to be fundamentally metaphorical in nature. As we have seen, Rudy understands his own situation in terms of the historical experiences of Holocaust victims and African-American slaves. He regards history as a hall of mirrors, a walk through which affords one endless possibilities for self-recognition. Rudy's connection to the Holocaust and slavery clearly involves incorporative identification or crude empathy, as he is

\footnotetext{
${ }^{37}$ Stephen Clingman, "Forms of History and Identity in The Nature of Blood," Salmagundi 143 (Summer 2004): 147.

${ }^{38}$ Clingman, "Forms of History and Identity in The Nature of Blood," 149.
} 
far less interested in entering into an ethical relationship with historical others than in appropriating their experience to bolster his own claim to victimhood. His epistolary interactions with his relatives and sympathizers, all of whom he manages to alienate by self-righteously castigating them for their failure to live up to the radical political ideals which he himself has espoused, also betray a measure of ruthlessness. In a rare moment of self-criticism and humility, Rudy admits lacking the strength to love and to be kind, which, as he points out, involves "giving up not acquiring, opening doors not closing them, reaching out not holding back." 39 Through his life-long endeavour to shape both the past and the present in his own image, he has closed himself off from encounters with modes of existence and experience different from and irreducible to his own.

As if to rebuke Rudy's self-serving and exploitative analogizing, Phillips follows his story with that of a Polish Jewish refugee who is haunted by memories of her family members who died in the Holocaust. It can be (and has been) argued that by placing stories of black and Jewish suffering alongside one another, Phillips is in fact taking a metonymic rather than a metaphoric view of history. While the latter conflates distinct historical experiences, substituting one for the other, ${ }^{40}$ the former preserves the distance between them. The similarities between the narratives which Phillips juxtaposes in his novels should not blind us to the differences between them, both formal and thematic. As Clingman writes, with reference to The Nature of Blood,

the echoes between the stories are suggestive rather than symmetrical, [...] there are waves of connection but also of refraction, interference and shift. We might say therefore that there is a kind of oscillation and vibration among these stories - a displacement back and forth between the metonymic and metaphoric, in which the principle of recognition is at work, but not of simple reproduction or repetition. ${ }^{41}$

It seems to me that this dynamic is at work, not only between individual narratives, as several critics have pointed out, but also in the relationship between the author and the reader, on the one hand, and the characters, on the other. To

\footnotetext{
${ }^{39}$ Phillips, Higher Ground, 169.

${ }^{40}$ As Bennett points out, the notion of metaphor has "proved contentious in the context of trauma imagery precisely because it implies the appropriation of another's, quite distinct experience" (Empathic Vision, 147).

${ }^{41}$ Clingman, "Forms of History and Identity in The Nature of Blood," 160.
} 
my knowledge, the nature of these empathic connections - the primary target of Mantel's accusation - has received rather less critical scrutiny. ${ }^{42}$

As far as Irina's story in Higher Ground is concerned, it is worth noting the hesitant, indirect manner in which Phillips tackles the subject of the Holocaust. The first two stories, which are written in the first person and use simultaneous or epistolary narration, are characterized by a sense of intimacy and immediacy that is absent in the third story, which uses third-person retrospective narration. Moreover, as Wendy Zierler has observed, the Jewish narrative stands out, in that

it demonstrates a marked reticence about its very subject. Throughout

"Higher Ground," Phillips shies away from directly depicting the Holocaust, enshrouding Irene's story in so much hazy description that one never really gets the same sense of her character and realness as one does for the protagonists of the first two parts. ${ }^{43}$

While Zierler calls Irina's story "the weakest" of the three pieces on account of its oblique and circumspect treatment of the Holocaust, ${ }^{44}$ I subscribe to a more generous reading which regards its not being "fully imagined" not as proof of writerly failure, but as an implicit acknowledgement on the part of the writer of - indeed - the limits which one's subject-position places on the imagination. The remarkable restraint which the author shows in dealing with the Holocaust stands in stark contrast - and serves as a corrective - to Rudy's arrogation of imaginative control over this traumatic history.

In fact, it also marks a departure from Phillips's own previous relationship to the Holocaust, which bears some resemblance to Rudy's. As the author

\footnotetext{
${ }^{42}$ Critics who fail to take this metatextual dimension into account can offer only a partial rebuttal of Mantel's accusation. An example of this tendency is Wendy Zierler:

- In a scathing review of The Nature of Blood, the critic Hillary [sic] Mantel castigates Phillips for attempting to "lay claim to other people's suffering" by fusing black and Jewish experience. However, by maintaining a pattern of asymmetry, Phillips brings together black and Jewish history, but also safeguards their respective integrity and specificity. He creates contiguity without direct correspondence, effecting comparison without displacement.

- Wendy Zierler, “' My Holocaust Is Not Your Holocaust': 'Facing' Black and Jewish Experience in The Pawnbroker, Higher Ground, and The Nature of Blood," Holocaust and Genocide Studies 18.1 (Spring 2004): 62-63. While the points Zierler makes are all valid, it seems to me that she fails to address the heart of the matter by disregarding the imaginative links between the author, the reader, and the characters.

${ }^{43}$ Zierler, "“My Holocaust Is Not Your Holocaust'," 61.

44 “' My Holocaust Is Not Your Holocaust'," 61.
} 
notes in his essay collection The European Tribe (1987), his interest in the persecution of the Jews can be traced back to his experience of growing up black in Britain:

As a child, in what seemed to me a hostile country, the Jews were the only minority group discussed with reference to exploitation and racialism, and for that reason, I naturally identified with them. ${ }^{45}$

Having no access to any representations of colonialism or slavery, Phillips tried to make sense of his own history through the prism of Jewish suffering:

The bloody excesses of colonialism, the pillage and rape of modern Africa, the transportation of 11 million black people to the Americas, and their subsequent bondage were not on the curriculum, and certainly not on the television screen. As a result I vicariously channelled a part of my hurt and frustration through the Jewish experience. ${ }^{46}$

Phillips's earliest response to the Holocaust, then, was one of substitution: there being no public reference points for the black experience in Britain, the Holocaust was made to fill that void. This metaphoric logic also informs Phillips's earliest literary production. As he reveals elsewhere in The European Tribe, the first piece of fiction he ever wrote, at age fifteen or so, was "[a] short story about a fifteen-year-old Jewish boy in Amsterdam" ${ }^{\text {,47 }}$ who manages to escape transportation to a concentration camp and is saved by a farmer. When Phillips later revisits the Holocaust in Higher Ground, he implicitly criticizes and checks his initial impulse to directly analogize black with Jewish suffering.

At first sight, Phillips abandons all restraint again in The Nature of Blood, which broaches the subject of the Holocaust head-on. In this novel, the central consciousness through which he represents the Nazi persecution of the Jews is not that of a refugee who has escaped the worst atrocities, hence has no firsthand experience of them, but that of a concentration camp inmate who turns out to have been a member of the Sonderkommando and thus a key witness of the horror. The Nature of Blood draws a psychologically convincing and deeply moving portrait of a Holocaust survivor, of which no less a writer than J.M. Coetzee has remarked: "pages of Eva's story seem to come straight from

\footnotetext{
${ }^{45}$ Caryl Phillips, The European Tribe (London: Faber \& Faber, 1987): 54.

${ }^{46}$ Phillips, The European Tribe, 54.

${ }^{47}$ The European Tribe, 67.
} 
hell, striking one with appalling power."48 This power derives at least in part from the experimental modes of representation which Phillips employs in these sections of the novel, which register the shocking and unassimilable nature of the traumatic historical events they depict in formal terms.

Yet, while the novel appears to put the reader in close contact with the reality of the Holocaust, it continually reminds him or her of his or her, and the author's, own distance from Eva's experience through the use of intertextuality. The representation of the Holocaust that we are offered is filtered through a number of well-known literary sources, most prominently Anne Frank's Diary of a Young Girl, allowing Phillips to self-consciously signal his historical and cultural remove from, and his inevitably mediated mode of access to, the reality he represents. ${ }^{49}$ The author manages to estrange and unsettle the reader by departing very markedly from his source texts. In his version of the Anne Frank story, the protagonist does not die of typhus in Bergen-Belsen but survives the Holocaust, only to commit suicide in an English hospital a short time later. Eva's older sister, who, like Anne's, is called Margot, turns out to resemble the Anne we know from the diary much more closely than Eva herself. However, sent into hiding by her parents, Phillips's Margot is raped by the man who is sheltering her - clearly a very different character from the individuals who assisted the Frank family while they were in hiding. She is subsequently arrested, and dies "on a cold grey morning in a country that was not her own." ${ }^{, 50}$ As Whitehead points out, the alternative versions of the Anne Frank story which the author provides in Eva and Margot are "both aimed at revising and challenging popular myths and misconceptions" of Anne Frank's story "which highlight a consistently optimistic voice." If Eva's fate shows that "survival is not necessarily a happy ending," Margot's fate demonstrates that "not all of those who sheltered Jews were as

\footnotetext{
48 J.M. Coetzee, "What We Like to Forget," review of The Nature of Blood, by Caryl Phillips, New York Review of Books 44.17 (6 November 1997): 39.

${ }^{49}$ The Holocaust narrative in The Nature of Blood hardly stands alone in Phillips's oeuvre in using intertextuality to signal distance or difference. One could also point, in The Nature of Blood, to the Othello narrative, which rewrites Shakespeare's play, and to the story of the Jews of Portobuffole, which is based on historical accounts explicitly mentioned in the acknowledgements. In Higher Ground, "Heartland" echoes Joseph Conrad's Heart of Darkness, J.M. Coetzee's Waiting for the Barbarians, and Wilson Harris's Heartland; “The Cargo Rap" has its roots in George Jackson's prison memoir Soledad Brother; and "Higher Ground" appears to be indebted to Jean Rhys's Voyage in the Dark (Ledent, Caryl Phillips, 76-77).

${ }^{50}$ Phillips, The Nature of Blood, 174.

${ }^{51}$ Whitehead, Trauma Fiction, 107.
} 
selfless in their motivations as the helpers of the Secret Annexe." ${ }^{, 52}$ Phillips also undermines redemptive, 'feel-good' readings of the diary by radically revising its much-abused most famous line: "I still believe, in spite of everything, that people are truly good at heart. ${ }^{, 53}$ He recasts Anne Frank's hopeful words to convey a message of utter despair which leaves no room for recuperation: "You see, Eva, in spite of everything that we have lost, they still hate us, and they will always hate us." ${ }^{, 54}$ Such conspicuous departures from the original story puncture the reader's complacency and invite him or her to confront his or her own appropriative tendencies.

Another way in which Phillips challenges popularized versions of the Anne Frank story is through his refusal to portray Eva as a saintly innocent. In the course of the novel, Eva is shown not to be above small-mindedness and is presented as capable of duplicity: she is prejudiced against Eastern European fellow prisoners - "the dirty, uncultivated people from the east" forges a letter from an English soldier to get permission to travel to England after the war. While it is true to say that these imperfections make Eva an "all the more human" ${ }^{, 56}$ and "less anodyne" ${ }^{, 57}$ figure than the Anne Frank of popular memory, I would add that they also complicate the reader's involvement with her. At these moments in the text, and - a fortiori - when Eva reveals her membership of the Sonderkommando ("I burn bodies"58), the reader's sympathies, which she quickly engaged, become confused. By depicting Eva as a morally ambivalent character, an inhabitant, even, of Primo Levi's "grey zone," ${ }^{, 59}$ Phillips subverts easy identification and forces the reader to renegotiate his or her relationship with her. ${ }^{60}$

${ }^{52}$ Whitehead, Trauma Fiction, 107.

${ }^{53}$ Anne Frank, The Diary of a Young Girl, tr. Susan Massotty, intro. Elie Wiesel (1947; Harmondsworth: Penguin, 2000): 329-30. See Ledent, Caryl Phillips, 157.

${ }^{54}$ Phillips, The Nature of Blood, 88.

The Nature of Blood, 170.

${ }^{56}$ Ledent, Caryl Phillips, 157.

${ }^{57}$ Whitehead, Trauma Fiction, 106.

${ }^{58}$ Phillips, The Nature of Blood, 171.

${ }^{59}$ Primo Levi, "The Grey Zone," in The Drowned and the Saved, tr. Raymond Rosenthal (Sommersi e i Salvati, 1986; London: Abacus, 1989): 22-51.

${ }^{60}$ Phillips often employs morally compromised protagonists - characters who defy simple categorization as either victims or victimizers - in his work. Two clear examples from Higher Ground, to stay with the novels under discussion, are the protagonist of "Heartland," an African interpreter who facilitates the slave trade, and Rudy Williams, a victim of institutional racism who inflicts suffering on his family through his dogmatic 
In both engendering affect and promoting critical inquiry, Phillips's treatment of the Anne Frank story exemplifies the notion of empathic unsettlement as described by LaCapra:

At the very least, empathic unsettlement poses a barrier to closure in discourse and places in jeopardy harmonizing or spiritually uplifting accounts of extreme events from which we attempt to derive reassurance or a benefit (for example, unearned confidence about the ability of the human spirit to endure any adversity with dignity and nobility). ${ }^{61}$

In fact, LaCapra specifically mentions Anne Frank in this context as "a recent figure who has been subjected to representation that attempts to bring to the reader or viewer unearned and incongruous spiritual uplift." 62 The Nature of Blood, as we have seen, effectively counters this tendency by thwarting uncritical involvement with the characters through the introduction of reflexive distance into the text.

In conclusion, what I hope to have demonstrated is that, by enacting a kind of empathy which combines affect and critical awareness, both Higher Ground and The Nature of Blood open up a space for cross-cultural encounters in which differences are not eradicated but inhabited. Over and against the tribalisms of racism, nationalism, and separatism, Phillips's novels propose an ethic of cross-cultural engagement that works against and moves beyond the isolation imposed by trauma. Fostering attunement to multiple histories of suffering, they allow us to envisage the formation of a transnational memory culture which could contribute to building the solidarity needed to prevent future violence.

\section{WORKS CITED}

Bennett, Jill. Empathic Vision: Affect, Trauma, and Contemporary Art (Stanford C A: Stanford UP, 2005).

Caruth, Cathy. "Trauma and Experience: Introduction," in Trauma: Explorations in Memory, ed. \& intro. Cathy Caruth (Baltimore MD: Johns Hopkins U P, 1995): 3-12.

Unclaimed Experience: Trauma, Narrative, and History (Baltimore MD: Johns

Hopkins UP, 1996).

intransigence. In all such cases, the effect on the reader can be described in terms of estrangement, confusion, and disorientation.

${ }^{61}$ LaCapra, Writing History, Writing Trauma, 41-42.

${ }^{62}$ Writing History, Writing Trauma, 42 n.51. 
Clingman, Stephen. "Forms of History and Identity in The Nature of Blood," Salmagundi 143 (Summer 2004): 141-66.

Coetzee, J.M. Waiting for the Barbarians (London: Secker \& Warburg, 1980).

"What We Like to Forget," review of The Nature of Blood, by Caryl Phillips, New York Review of Books 44.17 (6 November 1997): 38-41.

Conrad, Joseph. Heart of Darkness (1902), in Heart of Darkness and Selections from The Congo Diary (New York: Modern Library, 1999): 1-96.

Craps, Stef. "Linking Legacies of Loss: Traumatic Histories and Cross-Cultural Empathy in Caryl Phillips's Higher Ground and The Nature of Blood," Studies in the Novel 40.1-2 (Spring-Summer 2008): 191-202.

Frank, Anne. The Diary of a Young Girl, tr. Susan Massotty, intro. Elie Wiesel (1947; Harmondsworth: Penguin, 2000).

Gandhi, Leela. Postcolonial Theory: A Critical Introduction (New York: Columbia UP, 1998).

Harris, Wilson. Heartland (London: Faber \& Faber, 1964).

Hutcheon, Linda. "Postcolonial Witnessing - and Beyond: Rethinking Literary History Today," Neohelicon 30.1 (2003): 13-30.

Jackson, George. Soledad Brother: The Prison Letters of George Jackson (1970; Chicago: Chicago Review Press, 1994)

LaCapra, Dominick. History in Transit: Experience, Identity, Critical Theory (Ithaca NY: Cornell UP, 2004).

Writing History, Writing Trauma (Baltimore MD: Johns Hopkins UP, 2001).

Ledent, Bénédicte. Caryl Phillips (Contemporary World Writers; Manchester: Manchester UP, 2002).

Levi, Primo. "The Grey Zone," The Drowned and the Saved, tr. Raymond Rosenthal (Sommersi e i Salvati, 1986; London: Abacus, 1989): 22-51.

Lloyd, David. "Colonial Trauma/Postcolonial Recovery?" Interventions: International Journal of Postcolonial Studies 2.2 (2000): 212-28.

Mantel, Hilary. "Black Is Not Jewish," review of The Nature of Blood, by Caryl Phillips, Literary Review (1 February 1997): 39.

Moses, A. Dirk. "Conceptual Blockages and Definitional Dilemmas in the "Racial Century": Genocides of Indigenous Peoples and the Holocaust," Patterns of Prejudice 36.4 (October 2002): 7-36.

Moshman, David. "Conceptual Constraints on Thinking about Genocide," Journal of Genocide Research 3.3 (November 2001): 431-50.

Nowak, Helge. “ “Naturally, Their Suffering Is Deeply Connected to Memory': Caryl Phillips's The Nature of Blood as a Grand Narrative of Racism and Xenophobia," in Xenophobic Memories: Otherness in Postcolonial Constructions of the Past, ed. Monika Gomille \& Klaus Stierstorfer (Heidelberg: Winter, 2003): 115-33.

Phillips, Caryl. The European Tribe (London: Faber \& Faber, 1987).

-. Higher Ground: A Novel in Three Parts (New York: Viking Penguin, 1989). 
The Nature of Blood (London: Faber \& Faber, 1997).

Rhys, Jean. Voyage in the Dark (1934; London: André Deutsch, 1967).

Rushdie, Salman. "Imaginary Homelands" (1982), in Rushdie, Imaginary Homelands: Essays and Criticism 1981-1991 (London: Granta/Penguin, 1991): 9-21.

Sarvan, Charles P., \& Hasan Marhama. "The Fictional Works of Caryl Phillips: An Introduction," World Literature Today 65.1 (Winter 1991): 35-40.

Stone, Dan. "The Historiography of Genocide: Beyond 'Uniqueness' and Ethnic Competition," Rethinking History 8.1 (March 2004): 127-42.

Whitehead, Anne. Trauma Fiction (Edinburgh: Edinburgh UP, 2004).

Zierler, Wendy. " 'My Holocaust Is Not Your Holocaust': 'Facing' Black and Jewish Experience in The Pawnbroker, Higher Ground, and The Nature of Blood," Holocaust and Genocide Studies 18.1 (Spring 2004): 46-67.

Zimmerer, Jürgen. "The Birth of the Ostland out of the Spirit of Colonialism: A Postcolonial Perspective on the Nazi Policy of Conquest and Extermination," Patterns of Prejudice 39.2 (2005): 197-219. 


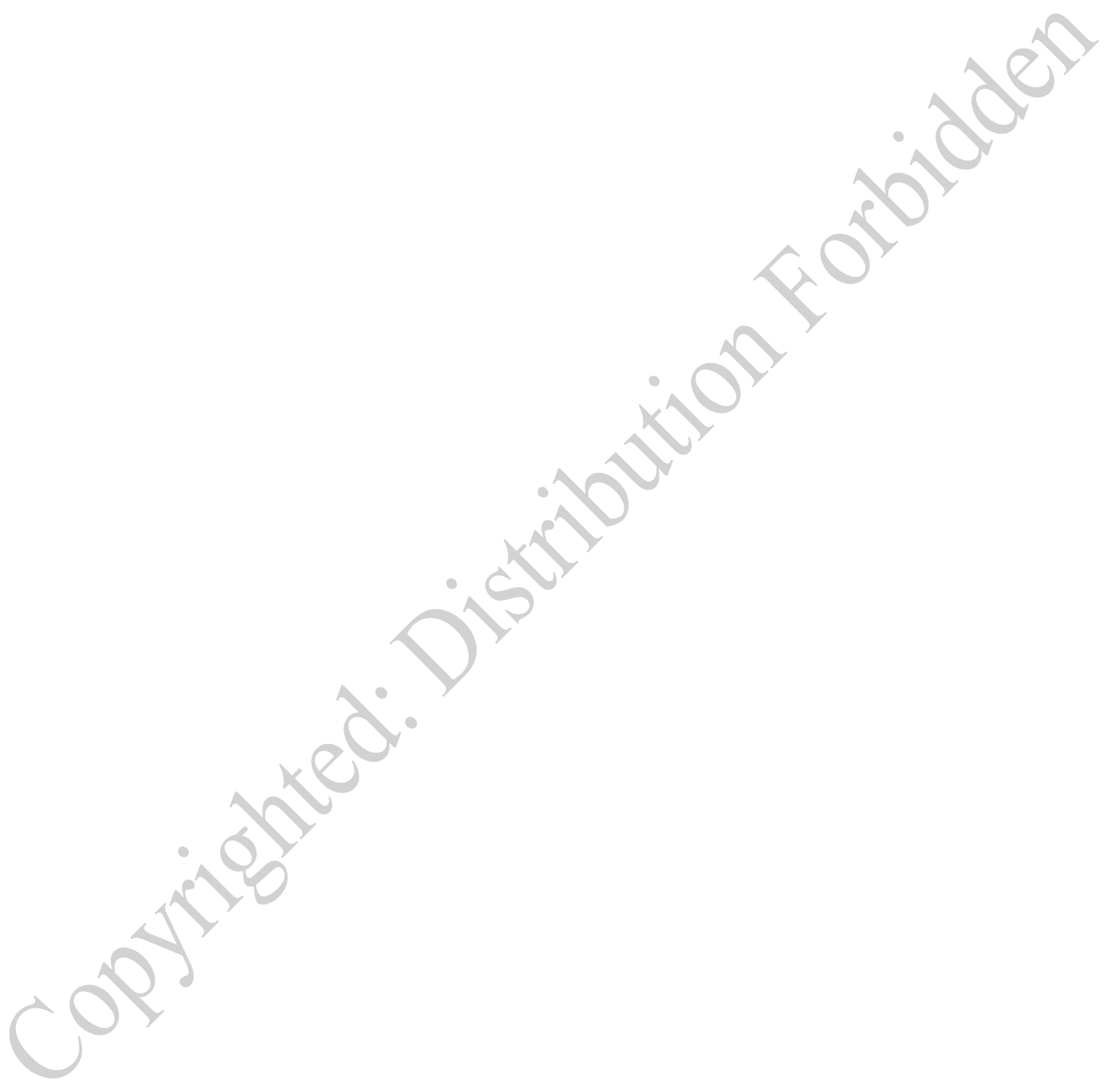




\section{Bidirectional Revision \\ The Connection between Past and Present in Caryl Phillips's Crossing the River}

\section{FATIM BOUTROS}

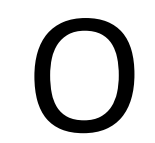

ne of the central features of Caryl Phillips's work is the clear connection the writer establishes between the history of the African diaspora - above all the founding experience of slavery and contemporary phenomena within the diasporic community. While most of Phillips's critics agree that the exploration of this transhistorical dimension is central to his narrative arrangements, there is much less consensus about the meaning that can be attributed to these fictional bridges between past and present. This is, I believe, mainly due to the fact that research on the political influence of literary discourses faces some serious structural problems. Apart from the fact that scholars in the field of literature usually lack the methodological apparatus to undertake empirical research, it seems very difficult to find convincing categories, especially for quantitative investigations into the socio-cultural impact of creative writing. Consequently, the exploration of counter-discursive agency, particularly in postcolonial studies, has to rely on traditional methods of interpretation. My analysis of the revisionary potential of fictional counter-history in Phillips's novel Crossing the River can therefore only be described in tentative terms.

Phillips himself has always been firmly convinced of the emancipatory influence of the fictional rearticulation of underexplored aspects of the colonial past, as evidenced by the following statement, made early in his career but still programmatic for his subsequent writings:

I had learnt that in a situation in which history is distorted, the literature of a people often becomes its history, its writers the keepers of the past, present, 
and future. In this situation a writer can infuse a people with a sense of their own unique identity and spiritually kindle the fire of resistance. ${ }^{1}$

This early credo seems to be symptomatic of the political drive behind the author's artistic ambition and resonates in the keynote address that he gave at the "Caryl Phillips: 25 Years of Writing" conference in Liège, Belgium, in December 2006. In almost three decades, Phillips has not lost any of his determination to use his art as a platform to provide identificatory impulses for people from the diaspora.

In this essay, I introduce the notion of bidirectional revision as a conceptual tool for the description of the complex interrelations between the negotiation of contemporary cultural identities and the literary representations of the past. Taking Crossing the River as an instance of Phillips's techniques of artistic expression, I focus on the way in which the plight of the protagonists introduces a paradigmatic shared experience, despite the fact that these characters are separated by time and space. I argue that their trauma appears as a strong unifying transhistorical feature and transcends the individual psyche.

\section{Bidirectional revision}

The revisionary potential of Phillips's literary work is twofold: it has a retroactive dimension, mainly aiming at a reinterpretation of the past through the introduction of fictional voices, and a proactive one, calling for a reinterpretation of the present through an increased awareness of the historical foundations of contemporary phenomena within the diaspora. Whereas the former dimension has been frequently analyzed in postcolonial studies, the latter deserves to be investigated in more detail. In what follows, I shall first sketch how spatiality influences culture in diasporic communities, and then focus on the way in which the reinterpretation of the past influences present processes of cultural positioning.

Arguably, the Middle Passage as an instance of traumatic deterritorialization constitutes the founding episode of the African presence in the New World. The cultural uprooting by violent force created a sense of community in an otherwise highly heterogeneous group of enslaved Africans. Several literary depictions of the Middle Passage suggest that a new sense of identity emerged already on board the slave ships, fed by an imaginary representation

\footnotetext{
${ }^{1}$ Caryl Phillips, The European Tribe (London: Faber \& Faber, 1987): 99.
} 
of Africa which changed with the distance from its referential source. ${ }^{2}$ In the everyday life of the colonial slave societies, Africa remained an important imagined homeland, helping the severely traumatized Africans to endure the hardships of their existences in the New World. The fact that the dissociation of culture and territory - which today is regarded as one of the defining parameters of globalization - already occurred in early modern times in African diasporic communities had massive consequences for the importance of narrative representations of the shared history. Discursive self-articulation partly compensated for the loss of the habitual emplacement in a material African environment. Thus, from the time of the very beginning of the African presence in the New World, the perpetuation of African traditions, which Stuart Hall described as a "vector of [...] continuity,", depended on shared ways of thinking. ${ }^{4}$ I would argue that the crucial importance that Phillips attributes to the role of the storyteller in communities which were founded on traumatic dislocations, and whose voices were systematically written out of dominant history, can at least partly be explained by the specificities of diasporic spatiality.

In order to gain a more complete understanding of the effects of the violent dissociation of African diasporic identity from its territorial anchorage, it is helpful to look at the descriptive categories used in transnational theory. The groundbreaking work of Akhil Gupta and James Ferguson is an important example of a radical reinterpretation of culturality in the light of contemporary global developments:

'Multiculturalism' is both a feeble recognition of the fact that cultures have lost their moorings in definite places and an attempt to subsume this plurality of cultures within the framework of a national identity. Similarly, the idea of 'subcultures' attempts to preserve the idea of distinct 'cultures' while acknowledging the relation of different cultures to a dominant culture within the same geographical and territorial space. Conventional accounts of ethnicity, even when used to describe cultural differences in settings where people from different regions live side by side, rely on an unproblematic link

2 Interesting examples are John Hearne, The Sure Salvation (London: Faber \& Faber, 1981), Caryl Phillips, Cambridge (London: Bloomsbury, 1991), and Fred D’Aguiar, Feeding the Ghosts (London: Chatto \& Windus, 1997).

${ }^{3}$ Stuart Hall, "Cultural Identity and Diaspora" (1990), in Colonial Discourse and PostColonial Theory, ed. Patrick Williams \& Laura Chrisman (New York: Columbia UP, 1994): 395.

${ }^{4}$ See Benedict Anderson, Imagined Communities: Reflections on the Origin and Spread of Nationalism (London \& New York: Verso, 1983). 
between identity and place. While such concepts are suggestive because they endeavor to stretch the naturalized association of culture with place, they fail to interrogate this assumption in a truly fundamental manner. We need to ask how to deal with cultural difference, while abandoning received ideas of (localized) culture. ${ }^{5}$

Their convincing approach succeeds in dissolving the apparent paradox behind the rise of nationalism that accompanies the increasingly obvious collapse of territorially anchored nation-states. Their thesis that imagined spatiality functions as a crucial surrogate for the loss of naturalized placedness in material space provides a basis for my interpretation of diasporic identities:

But the irony of these times is that as actual places and localities become ever more blurred and indeterminate, ideas of culturally and ethnically distinct places become perhaps even more salient. It is here that it becomes most visible how imagined communities (Anderson 1983) come to be attached to imagined places, as displaced peoples cluster around remembered or imagined homelands, places, or communities in a world that seems increasingly to deny such firm territorialized anchors in their actuality. In such a world it becomes ever more important to train an anthropological eye on processes of construction of place and homeland by mobile and displaced people. ${ }^{6}$

I wish to argue that the importance of imagined homelands discussed by Gupta and Ferguson is echoed in the literary representations of the NewWorld African community's colonial past and current postcolonial predicament. More specifically, I shall attempt to demonstrate that the literary images introduced in Crossing the River highlight the importance of spatiality in the negotiation of cultural identities within the African diaspora.

\section{Crossing the River}

Phillips's novel Crossing the River suggests a transhistorical continuity in African diasporic communities, centred on the traumatic experiences of cultural uprooting and slavery in the New World. Each of the book's four sections focuses on a crucial period in the history of the African diaspora. The protagonists are linked through the common frame of the desperate father figure present in the Prologue, who follows the fate of his children scattered

\footnotetext{
${ }^{5}$ Akhil Gupta \& James Ferguson, "Beyond 'Culture': Space, Identity, and the Politics of Difference," in Culture, Power, Place: Explorations in Critical Anthropology, ed. Akhil Gupta \& James Ferguson (Durham NC \& London: Duke UP, 1997): 35.

${ }^{6}$ Gupta \& Ferguson, "Beyond Culture," 39.
} 
all over the globe. The reason for their traumatic dislocation was his own readiness to sell them into slavery:

A desperate foolishness. The crops failed. I sold my children. I remember. I led them (two boys and a girl) along weary paths, until we reached the place where the mud flats are populated with crabs and gulls. ${ }^{7}$

The narrator is overwhelmed by his sense of guilt at having betrayed his own children: "I soiled my hands with cold goods in exchange for their warm flesh. A shameful intercourse. I could feel their eyes upon me. Wondering, why?" (1).

From the start of the novel, there is an obvious tension between the shared belonging to an imagined community and the unbridgeable separation caused by the spatial distance between the dislocated members of this group:

My Nash. My Martha. My Travis. Their lives fractured. Sinking hopeful roots into difficult soil. For two hundred and fifty years I have longed to tell them: Children, I am your father. I love you. But understand. There are no paths in water. No signposts. There is no return. [...] You are beyond. Broken-off, like limbs from a tree. But not lost, for you carry within your bodies the seeds of new trees. Sinking your hopeful roots into difficult soil. (1-2)

It is an integral part of Phillips's diasporic vision that there is no return to shared African roots; trying to recover the lost homeland would thus be futile. Put differently, the author's fictional negotiation of the contradictions at the heart of the globally dispersed community reflects his personal scepticism about all forms of pan-African nostalgia. ${ }^{8}$ The image of the broken-off limbs suggests the illusory nature of any attempt to bridge the chasms that divide the African diaspora into localized parts which have adapted to the practices of the places where they have settled. This importance of emplacement in new environments is also a significant aspect of Stuart Hall's approach to (diasporic) Caribbean identity. ${ }^{9}$ The paradigmatic triangulation which, according to his model, defines the Afro-Caribbean predicament includes not only the African and the European presences, which mutually influenced each other throughout the centuries of colonial history, but also the New World presence, which had its own impact on the emerging cultural formations.

\footnotetext{
${ }^{7}$ Caryl Phillips, Crossing the River (London: Bloomsbury, 1993): 1. Further page referrences are in the main text.

${ }^{8}$ This scepticism is most emphatically expressed in his non-fictional work The Atlantic Sound (London: Faber \& Faber, 2000).

${ }^{9}$ See Stuart Hall, "Cultural Identity and Diaspora," 392-403.
} 


\section{"The Pagan Coast"}

The first section of Crossing the River relates the story of the former slave Nash Williams, who, after his manumission, is sent to a Christian mission in Liberia. His life in West Africa, however, develops in a manner that stands in stark contrast to the intentions of his former owner Edward Williams, who only set Nash free after pressuresfrom his jealous wife. Instead of proselytizing the indigenous population, Nash is increasingly fascinated by their way of life and starts to copy elements of their customs, even if these cannot be reconciled with the Christian norms that Edward has forced upon him. Simultaneously, he starts to distance himself from the cultural dogmas he had absorbed in America and begins to be critical of the entire enterprise of the 'American Civilization Society'. The behaviour of his fellow missionaries, indeed, demonstrates that there are no clear-cut boundaries between the dissemination of Christian beliefs and the exploitation of native labour:

In our neighboring settlement, a Mr Charles, an American, his money grown short due to the ruin of his smallholding near Monrovia, borrowed two native boys, informing their fathers that he was going to teach them English. Instead he cruelly carried them to a slave factory and sold them for the equivalent of twelve dollars. ${ }^{10}$

Nash is appalled by such behaviour and voluntarily adopts the local way of life. The influence of the environment becomes obvious and his letters testify to the increasing divide that separates him from the ideological system he had learnt to accept during his life in the USA. His state of mind thus reveals contradictory loyalties. The elements of the dominant Western culture that he had adopted relatively uncritically cannot be reconciled with the heritage of continental Africa with which he is confronted in Liberia. His perspective on American 'civilization' changes just as much as his views about African cultural practices. He finds himself confronted simultaneously with an increasing disillusionment about present Western realities and an overwhelming fascination with the African past that he had up to that point repressed as an identificatory influence. The mysterious circumstances of his death, however, show that his attempt to 'go native' is as problematical as his earlier integration in Western patterns of thought. During his own voyage to Liberia, Edward tries to investigate Nash's enigmatic death. The cultural shock he has to endure there is a reversal of the usual role divisions attached to slavery. In Liberia, it

\footnotetext{
${ }^{10}$ Phillips, Crossing the River, $3{ }^{-}-32$.
} 
is the Westerner who is marginalized and who is unable to adapt to an unfamiliar environment. His irrational attempt to gain new confidence by singing a hymn - hence, a piece of music that is strongly associated with religious and, by extension, cultural traditions - reflects his loss of territorial moorings:

He decided that he would sing a hymn, in order that he might calm his beleaguered mind. The natives stared at him, and watched as the white man's lips formed the words, but no sound was heard. Still, Edward continued to sing his hymn. (69)

In the African environment, he is silenced and loses his voice, despite his ridiculous attempt to assert his religious and cultural sovereignty.

\section{"West"}

Martha's traumatic life experiences are hauntingly narrated in brief flashbacks which appear to her as she is about to die. This second section starts with the suggestive image of an unknown woman who stretches out her hand to Martha. However, this help comes too late; despite the woman's (sometimes too controlling) efforts, Martha dies. These two female figures could be interpreted as allegories of the collective experience of the African-American and the white American population. Martha's death in such a reading signifies the impossibility of bridging the abyss opened up by centuries of slavery. The suggestive title "West" links Martha's plight to one of the central ideological foundations of American society. In her attempt to find her lost daughter, which echoes the despair of the father figure in the Prologue, her imagined California appears as an African-American version of the American Dream through its association with the trek of white settlers. The bleak suggestion, however, seems to be that, for a community so severely traumatized, there is no chance of joining in the pursuit of happiness that the white population can at least attempt. Even if the journey of the white settlers might be inspired by illusory hopes of material wealth, their situation differs drastically from Martha's struggle. Apart from all the other historical differences that distinguish her community from that of the white trekkers, the absence of hope is a crucial aspect of the post-traumatic state in which she lingers. She even lacks the energy to attempt to join the gold-rush, and all she can do at the end of her life is to dream one last time of reunion with her family.

Ultimately, Martha's only remaining hope is frustrated, for, in the last vision before she dies, she does meet her daughter, but she is shocked by how she has developed and by the attitude that she has adopted to secure her integration in US society: 
Martha dreamed she had traveled on west to California, by herself, and clutching her bundle of clothing. Once there she was met by Eliza Mae, who was now a tall, sturdy colored woman of some social standing. Together, they tip-toed their way through the mire of the streets to Eliza Mae's residence, which stood on a fine, broad avenue. They were greeted by Eliza Mae's schoolteacher husband and the three children, who were all dressed in their Sunday best, even though this was not Sunday. A dumbstruck Martha touched their faces. Eliza Mae insisted that her mother should stay and live with them, but Martha was reluctant. All was not right. [...] Eliza Mae now called herself Cleo. Martha refused to call her daughter by this name, and insisted on calling her a name that her children and husband found puzzling. Soon it was time for Martha to leave, but her daughter simply forbade her mother to return east. Martha, feeling old and tired, sat down and wept openly, and in front of her grandchildren. (93-94)

The passage is worth quoting at length, since, in the light of the whole narrative arrangement, it suggests a depressing assessment of the current situation of the African diaspora, particularly that of black America. Given the importance of naming in Phillips's fiction, the fact that Martha's daughter has changed her name has to be read as a voluntary rupture with her origins. Her material wellbeing, which appears excessive to Martha, was purchased by an equally offensive ignorance of the fate of her predecessors. Implicitly, the African-American community, which appears to have been corrupted by Western capitalism, is thus confronted with a devastating judgment on their current materialistic orientation, and this can only be sustained by betraying the roots of the community.

After Martha dies, her unknown benefactor is left with the black woman's body. It is deeply ironic that it should only be at the moment of Martha's death that the supposedly white woman develops at least a superficial concern for her fate: "the woman wondered who or what this woman was. They would have to choose a name for her if she was going to receive a Christian burial" (94). However, even this final act of courtesy can at the same time be regarded as an instance of violent cultural appropriation. The integration of the corpse in the accustomed Western categories of thinking via Christian burial can be read as a kind of anthropological interest in the conservation of the incommensurable Other. Attributing a special heterotopic space ${ }^{11}$ to the Afri-

\footnotetext{
${ }^{11}$ The notion of heterotopia was introduced by Michel Foucault. For the purposes of this essay, the following definition will suffice:
} 
can presence - in this case, the graveyard - for her seems to be more important than the fact that she faces a dead person. ${ }^{12}$ This ignorance of the dominant culture about the hardships of the African diaspora builds a thematic link to the third section, which lends the novel its title and thus has a prominent function in the narrative, despite the latter's fragmentary nature.

\section{"Crossing the River"}

This third section depicts the Middle Passage through the prism of different voices, which all follow their specific generic conventions. Interestingly, the events on board the slave ship Duke of York are mainly represented through the eyes of the dominant culture. Captain Hamilton's chilling logbook is juxtaposed with the ardent love letters he writes to his wife in England: the brutality and simultaneous casualness of his reports on the treatment of the slaves form a stark contrast to the sentimental tone of his letters, which seem to be written by somebody with a wholly different personality. Instead of reading this discrepancy as betraying the hypocrisy of the English culture of that time, as Günther Lenz does, ${ }^{13}$ I would, rather, argue that Hamilton's contrasting texts reveal the cognitive dissonance into which the subjects of the

There are also, probably in every culture, in every civilization, real places - places that do exist and that are formed in the very founding of society - which are something like counter-sites, a kind of effectively enacted utopia in which the real sites, all the other real sites that can be found within the culture, are simultaneously represented, contested, and inverted. Places of this kind are outside of all places, even though it may be possible to indicate their location in reality. Because these places are absolutely different from all the sites that they reflect and speak about, I shall call them, by way of contrast to utopias, heterotopias.

— Foucault, "Of Other Spaces" ("Des Espaces Autres," 1984, tr. Jay Miskowiec) in The Visual Culture Reader, ed. Nicholas Mirzoeff (London \& New York: Routledge, 2001): 231.

${ }^{12}$ Michel Foucault, in his definition of heterotopic spaces, introduces the graveyard as one of the prototypical examples. See Foucault, "Of Other Spaces," 229-36.

${ }^{13}$ See Günter H. Lenz, "Middle Passages: Histories, Re-Memories, and Black Diasporas in Novels by Toni Morrison, Charles Johnson, and Caryl Phillips," in Crabtracks: Progress and Process in Teaching the New Literatures in English, Essays in Honour of Dieter Riemenschneider, ed. Gordon Collier \& Frank Schulze-Engler (Cross/Cultures 59; Amsterdam \& New York: Rodopi, 2002): 247-68. Lenz writes:

Phillips reveals the interrelatedness of two seemingly separate and oppositional discourses, exposing eighteenth-century sentimentalism and celebration of the bonds of the middle-class family as the reverse side of the spirit of capitalism, of the economic rationalism of the time, and of colonial contempt for the black 'primitive natives' in Africa, whom the white Christian slave-trader does not recognize as human beings. (262) 
dominant culture were forced in their everyday confrontation with the slaves' plight. In the presence of his crew, Hamilton deliberately tries to appear as cold-blooded as possible, particularly when he is faced with a lack of respect. Thus, much of his behaviour is to be interpreted as an attempt to live up to what is expected of a captain, which conflicts with his private character. The fact that he is simultaneously a man guilty of heinous crimes and a victim of his environment points to the highly ambivalent nature of colonial interaction. The reader is left with an ethical aporia in which it becomes disturbingly difficult to make any definitive moral judgments about Hamilton's situation. His case demonstrates the specific socio-cultural dynamic of slave societies. Different role expectations clash and the perpetrators suffer from mental strain caused by the nature of their everyday business. The subjection of individuals to ideological systems radically limits their agency and predetermines their behavioural patterns. ${ }^{14}$ Without offering any excuses for their crimes, this view of the perpetrators makes their decisions appear less arbitrary and thus places them in a perspective that allows for a more nuanced understanding of their social position.

If, as this essay contends, the representations of the past significantly influence contemporary cultural identities, Phillips's focus on aspects of the history of slavery that have to this day remained largely unexplored can have a considerable impact on diasporic realities. Of special importance is the representation of everyday life situations not mentioned in any of the official documents of the time. Edward's desire for his black slave, the well-meaning but dirigistic interest of the white woman who tries to help Martha, Captain Hamilton's sense of inadequacy - these provide images of the past that complicate stereotypical views of victims and perpetrators. I suggest that such representations can help us to develop in the present a more complex and less moralistic perspective on the past - in short, these sections work retroactively. In my reading of the last part of Crossing the River, I focus on the proactive aspect of Phillips's revisionary strategy.

\footnotetext{
${ }^{14}$ The notion of interpellation as a form of involuntary and mostly unconscious integration into ideological systems is most prominently discussed in the work of Louis Althusser. See his "Ideology and Ideological State Apparatuses," Lenin and Philosophy and Other Essays, tr. Ben Brewster (Lénine et la philosophie, 1969; New York \& London: Monthly Review Press, 1971): 121-76.
} 


\section{"Somewhere in England"}

The last section of Crossing the River establishes a transhistorical link between the fate of the slaves on board the Duke of York and the traumatic experiences of Travis, a black American GI who serves in England during the Second World War and suffers from discrimination and violence at the hands of British and American soldiers as well as the local population. The xenophobic resentment he faces from the people around him suggests a considerable degree of historical continuity in terms of racial discrimination. Even though his situation may not seem as obviously oppressive as that of the slaves, it is nonetheless deeply traumatic and leads to his inability to become accustomed to his surroundings. His case demonstrates that specific aspects of historical experience continue to influence the everyday realities of the African diaspora.

Considering the ideology prevailing in her Yorkshire village, Joyce, Travis's white English partner, is an exceptional character for her time. Not only is she open-minded enough to embark on a relationship with a black American soldier, but she also defies the war propaganda distributed through the British media:

I wandered back and sat with Len, who told me that we always start badly.

That we English lose every battle but the last. He'd believed the official story

behind the looks on those lads' faces. I was getting good at learning the dif-

ference between the official stories and the evidence before my eyes. (165)

The fact that Joyce's critical attitude about her political environment started to develop through her extensive reading is a meta-narrative hint about the importance of literature as a counter-discursive instrument. More specifically, this might be read as an allusion to the revisionary potential of Crossing the River itself. Just as Joyce's perspective has changed through her exposure to literary texts, so the reader's understanding of the chorus of diasporic history is supposed to broaden through the reading of Phillips's novel. For instance, by alluding to a plethora of other comparable stories, the "Epilogue" blurs the protagonists' fates into the multi-voiced discursive stream that forms the basis of present-day cultural interaction:

I wait. And then listen as the many-tongued chorus of the common memory begins again to swell, and insist that I acknowledge greetings from those who lever pints of ale in the pubs of London. Receive salutations from those who submit to (what the French call) neurotic inter-racial urges in the boulevards of Paris. (235) 
Worldwide links become obvious between people who share the trauma of uprooting and the resulting contradictory cultural affiliations. Their common heritage of colonial exploitation by Western nations up to the present day keeps influencing their perception of reality and their socio-cultural environment. The chorus of common memory thus resonates above all with a shared historical experience:

Survivors all. In Brooklyn a helplessly addicted mother waits for the mist to clear from her eyes. They have stopped her benefit. She lives now without the comfort of religion, electricity, or money. A barefoot boy in São Paulo is rooted to his piece of the earth, which he knows will never swell up, pregnant, and become a vantage point from which he will be able to see beyond his dying favela. In Santo Domingo, a child suffers the hateful hot comb, the dark half-moons of history heavy beneath each eye. A mother watches. Her eleven-year-old daughter is preparing herself for yet another night of premature prostitution. Survivors. In their diasporan souls a dream like steel. $\left(235^{-} 36\right)$

\section{The revisionary potential of Crossing the River}

Even if the revisionary potential of specific literary works defies direct assessment, I shall now attempt to address more explicitly the claim made at the beginning of this piece, and highlight some of the literary strategies found in Crossing the River that help to establish a special relation between the fate of its fictional characters and contemporary cultural realities within the diaspora.

So far, my analysis has shown that the novel's arrangement of fragments produces a mosaic that suggests certain parallels between the plights of the fictional characters, even if these links are never explicitly addressed and remain to be unearthed by the reader. Although the protagonists are significantly distanced from each other in time and space, certain aspects of their lives are highly similar. All of them face unwelcoming and hostile people whose behaviour is charged with xenophobic resentment. The multiple perspectives prevent facile judgment and leave the reader with the discomfort of unresolved moral dilemmas. Whether in the case of Edward's desperate struggle to find Nash, the unnamed woman's well-meaning effort to help Martha, Captain Hamilton's contradictory loyalties or Joyce's attempts to live with Travis in a heavily racist climate, the inability to move beyond racial ideologies is the reflection of serious intercultural tensions. Importantly, in all of those cases, the image of stereotypical perpetrators is subverted by a literary exploration of the complexity of historical constellations. The individualized 
perspective of the fictional characters allows the author to examine aspects of diasporic history which have remained largely unexplored in historiography, because of historical silencing and ideological distortions.

At the beginning of this essay, I stated that the revisionary potential of Crossing the River was twofold, and that the novel's impact had both a retroactive and a proactive dimension. I would now like to demonstrate how my analysis of the narrative can help me to buttress this claim.

\section{Retroactive dimension}

One of the most important aspects of retroactive revision is that a countermomentum to traditional historiography is provided by the fictionally reconstructed voices of marginalized members of the African diaspora. The relativity of historical truth is revealed by the discrepancies between representations of events depending on the perspective from which stories are told. Clearly, the selection of events that have been passed down by the dominant culture is shaped by a eurocentric view. Thus, for instance, Martha's despair and the hardships faced by Travis in his racist environment are dimensions of history that have not found their way into school books, despite their fundamental impact on diasporic identities. The novel demonstrates how written sources, like the Captain's log, convey historical events in a pseudo-objective manner, while individual tragedies are completely left out of the version of reality represented in History with a capital ' $\mathrm{H}$ '. Importantly, in Crossing the River, 'official' accounts such as Hamilton's diary are set against - and therefore contrasted with - the stories of introspective fictional characters, thereby giving the reader access to the affective dimension of slavery. The characters' most private and intimate sorrows make the debasing conditions of slavery appear much less remote and allow for an empathic identification with the victims of European cultural hegemony.

Just as important as the narrative perspective, and perhaps even more fertile for literary analysis, is the symbolic dimension of the literary discourse. The new images introduced into the narrative have a major iconographic function. For instance, Crossing the River establishes an analogy between the African diaspora and African space, on the one hand, and a tree and its broken limbs, on the other. Even if the branches have lost their direct connection to the tree, their shared history remains inscribed in the wood. Through these codifications of the experience of slavery, powerful founding myths can be introduced. As Aleida Assmann has put it, 
Vivid, somatic, and preverbal memories retain isolated scenes without a before or after. In their fragmentary character, they may be considered as proto-narrative kernels. Memories charged with an affect hold a middle position between the active encoding of a symbol and the passive encrypting of trauma. $^{15}$

Assmann's argument underscores the need for the encoding of affectively charged memories. In contrast to traumatic memories that remain lingering beneath the surface as an undercurrent inhibiting individual and collective agency, she suggests, occurrences that become codified symbols can have a healing function in that they work as active reminders of the past. Due to the experiences of the Middle Passage and enslavement, important images that had constituted the centre of cultural perception on the African continent became incompatible with the new situation. These radically different spatial environments are captured by Stuart Hall in his use of the term Présence americaine. ${ }^{16}$ The profound difference of the dislocated Africans' new physical environment rendered the translation of the new informational stimuli impossible and led to massive psychological disorders, as Phillips's literary representations repeatedly depict. Thus, up to the present day, there remains a large number of such suppressed memories that need to be symbolically encoded in order to tear them out of their unexpressed state - a latent condition in which they inhibit the community's agency. Literature, along with other forms of artistic expression such as the visual arts and, of course, music, plays a crucial role in the struggle for such an encoding.

\section{Proactive dimension}

Simultaneous with the retroactive revision of the past, literary representations of diasporic history may also lead to a revision of the present through an increased awareness of the ramifications of the communities' traumatic experience. Phillips reveals the extent to which racist thinking has diffused through all fields of cultural life ever since early colonial times, and thereby increases his readers' ability to critically assess social interaction in the contemporary world. The backward glance is thus not sustained for its own sake but is directly related to readers' perception of present-day phenomena.

\footnotetext{
${ }^{15}$ Aleida Assmann, "Three Stabilizers of Memory: Affect - Symbol - Trauma," in Sites of Memory in American Literatures and Cultures, ed. Udo J. Hebel (Heidelberg: Winter, 2003): 29.

${ }^{16}$ Hall, "Cultural Identity and Diaspora," 401.
} 
Judging from his public statements on the role of the writer, Phillips regards this aspect as politically more important than the correction of our knowledge of history for its own sake. In Crossing the River, he depicts episodes set in colonial times alongside the experiences of twentieth-century characters. The novel provides the readers with new insights into everyday life in slave societies and gives them access to the psychological introspection of both black and white protagonists. The emotional ties that are introduced through the experience of trauma shared by all of the characters suggests an interpretation of cultural belonging that is based on a diasporic consciousness. This, in turn, emerges primarily in reaction to the devastating dislocation from which all of the spatially dispersed members of the community suffer. The founding deterritorialization at the heart of the imagined community in Phillips's novel takes the place of the racial identifications that used to form the core of early identity-politics of the African diaspora. Avoiding all kinds of counter-essentialism, it appears as a collective shaped above all by the burden of its past.

\section{WORKS CITED}

Althusser, Louis. "Ideology and Ideological State Apparatuses," Lenin and Philosophy and Other Essays, tr. Ben Brewster (Lénine et la philosophie, 1969; New York \& London: Monthly Review Press, 1971): 121-76.

Anderson, Benedict. Imagined Communities: Reflections on the Origin and Spread of Nationalism (London \& New York: Verso, 1983).

Assmann, Aleida. "Three Stabilizers of Memory: Affect - Symbol - Trauma," in Sites of Memory in American Literatures and Cultures, ed. Udo J. Hebel (Heidelberg: Winter, 2003): 15-30.

D’Aguiar, Fred. Feeding the Ghosts (London: Chatto \& Windus, 1997).

Foucault, Michel. "Of Other Spaces" ("Des Espaces Autres," 1984, tr. Jay Miskowiec), in The Visual Culture Reader, ed. Nicholas Mirzoeff (London \& New York: Routledge, 2001): 229-36.

Gupta, Akhil, \& James Ferguson. "Beyond 'Culture': Space, Identity, and the Politics of Difference," in Culture, Power, Place: Explorations in Critical Anthropology, ed. Akhil Gupta \& James Ferguson (Durham NC \& London: Duke UP, 1997): 31-51.

Hall, Stuart. "Cultural Identity and Diaspora" (1990), in Colonial Discourse and PostColonial Theory, ed. Patrick Williams \& Laura Chrisman (New York: Columbia UP, 1994): 392-403.

Hearne, John. The Sure Salvation (London: Faber \& Faber, 1981). 
Lenz, Günter H., "Middle Passages: Histories, Re-Memories, and Black Diasporas in Novels by Toni Morrison, Charles Johnson, and Caryl Phillips," in Crabtracks: Progress and Process in Teaching the New Literatures in English, Essays in Honour of Dieter Riemenschneider, ed. Gordon Collier \& Frank Schulze-Engler (Cross/Cultures 59; Amsterdam \& New York: Rodopi, 2002): 247-68.

Phillips, Caryl. The Atlantic Sound (London: Faber \& Faber, 2000).

—. Cambridge (London: Bloomsbury, 1991).

Crossing the River (London: Bloomsbury, 1993).

—. The European Tribe (London: Faber \& Faber, 1987). 


\title{
"The cloud of ambivalence" Exploring Diasporan Identity in Caryl Phillips's The Atlantic Sound and A New World Order
}

\author{
ABIGAIL WARD
}

Culture has to be seen as not only excluding but also exported; there is this tradition which you are required to understand and learn and so on, but you cannot really be of it. And that to me is a deeply interesting question and needs more study because no exclusionary practice can maintain itself for very long. Then you get the crossings over [...] and then of course the whole problematic of exile and immigration enters into it, the people who simply don't belong in any culture. ${ }^{1}$

$\mathrm{T}$ his essay focuses on two of Caryl Phillips's non-fictional works: the historical travelogue The Atlantic Sound (2000) and the collection of essays A New World Order (2001). Edward Said's focus on "crossings over," within the context of migration and diaspora, is vital to my exploration of these texts, as crossing is a central motion in Phillips's fictional and non-fictional works. Said provides a theoretical vocabulary for this idea of crossing as an unfinished or incomplete state where, even when migrants physically cross over to another place, they find that they "simply don't belong in any culture." Further, the relevance of Said's comment about culture's "exclusionary practice" is evident in its link to what Phillips has, in Extravagant Strangers (1997), called the British "mythology of homogeneity" and the fierce policing of postwar British boundaries and identities in attempts

\footnotetext{
${ }^{1}$ Edward Said, "Appendix: Media, Margins and Modernity" (1986), in Raymond Williams, The Politics of Modernism: Against the New Conformists, ed. Tony Pinkney (London \& New York: Verso, 1989): 196.
} 
to control immigration from non-white citizens. ${ }^{2}$ This apparently exclusionary practice is instrumental in engendering feelings of unbelonging for those who are unable to "participate fully in the main narrative of British life."

Phillips's non-fictional works have received little critical commentary in comparison to his novels. Reviewers have struggled, particularly, to position The Atlantic Sound in a specific literary category, being as it is part fiction, part travelogue, and part historical journey, in which Phillips attempts to unpick the tangled web of diasporan identities. In my examination of $A$ New World Order, I will be concentrating on those essays that deal with concepts of identity, belonging, and diaspora, also central themes in The Atlantic Sound. Both books are divided into geographical sections; in A New World Order, these are the four zones of transatlantic slavery: "The United States," "Africa," "The Caribbean," and "Britain" - the latter section will be my primary concern. In The Atlantic Sound, while there is a similar geographical split, the labelling differs. It begins with the "Atlantic Crossing," where Phillips travels by banana boat from the Caribbean to Britain, retracing the journey he had undertaken as an infant with his parents as they emigrated from St Kitts. This is followed by a chapter about Liverpool, "Leaving Home," the first part of which examines the story of John Ocansey who, in 1881, came to Liverpool from Africa to investigate his father's missing money, owed for goods sent to a Liverpool merchant. In the second part, Phillips returns to Liverpool, where he meets up with a "Liverpool Born Black" (thus designated by members of this ethnic community) called Stephen. The next chapter, "Homeward Bound," sees Phillips travel to Ghana, where he attends Panafest and explores the politics and pitfalls of pan-Africanism. He then travels, in "Home," to Charleston in the US A, and delves into the life of Judge Waring, who campaigned to ensure the vote for black men and women in South Carolina. Finally, in the Epilogue, entitled "Exodus," Phillips visits a group of African Americans who have decided to live in the Negev desert in Israel, returning to the land of their biblical ancestors.

I begin by examining what is, for Phillips, the difficult issue of 'home'. Interestingly, it is through writing about football that Phillips tackles his ambiguous relationship with British national identity and interrogates the notion of belonging, where support for his team can only ever offer a temporary, and

\footnotetext{
${ }^{2}$ Caryl Phillips, Extravagant Strangers: A Literature of Belonging (1997; London: Faber \& Faber, 1998): xiv.

${ }^{3}$ Phillips, Extravagant Strangers, xiii.
} 
complicated, form of kinship. He also suggests in The Atlantic Sound and A New World Order that the problems experienced by non-white British citizens with a national identity may be seen as a legacy of slavery, and are arguably maintained by the widespread forgetting of this past. In order to illustrate this point, I shall explore how slavery is remembered or forgotten in Liverpool, Charleston, and Ghana. It is precisely this under-explored relationship between the anxieties of contemporary Britain, in particular, and the past of slavery that motivates Phillips's imaginative return to slavery in his fiction. This essay will be informed by some key critical ideas: Homi Bhabha's concepts of the pedagogical and the performative will be important in exploring the workings of British national identity, and Paul Gilroy provides a way of thinking about the relationship between nationalism and racism, specifically in relation to football. Finally, via Gilroy's rejection of 'roots' in favour of the idea of 'routes', I will demonstrate how Phillips traces the trajectories of slavery in positing an oceanic identity; however, as we shall see, ultimately I argue that this is not a viable solution to the exclusionary mechanics of national identity-formation.

The Atlantic Sound is, by its very nature, fragmentary - reflecting the fragmentation which is integral to diasporan identity. Edward Said has quite simply stated that "no one today is purely one thing,"4 and for Phillips - who was born in St Kitts, raised in Britain, and now resides mainly in the USA identity is necessarily composite. As Phillips states in his conclusion to A New World Order, "I realize that for me - [...] born elsewhere - there will never be any closure to this conundrum of "home'., This "conundrum" may be seen as a focal point of both his fictional and non-fictional works, including, as is evident from just the titles of the chapters, The Atlantic Sound. In this book, Phillips explores the multifarious understandings of home, not only from his own perspective, but from the viewpoints of people he encounters, or whose lives he explores, along the way. His uneasy position as a black child in postwar Britain is articulated in his introduction to $A$ New World Order:

I am seven years old in the north of England; too late to be coloured, but too soon to be British. I recognise the place, I feel at home here, but I don't

\footnotetext{
${ }^{4}$ Edward W. Said, Culture and Imperialism (1993; London: Chatto \& Windus, 1994): 407.

${ }^{5}$ Caryl Phillips, "Conclusion: The 'High Anxiety' of Belonging." in Philllips, A New World Order: Selected Essays (London: Secker \& Warburg, 2001): 308. Further page references are in the main text after "HA."
} 
belong. I am of, and not of, this place. History dealt me four cards; an ambiguous hand. 6

Unlike the first generation of Caribbean migrants to Britain, Phillips reflects a slowly changing country, and an identity that therefore falls between the labels 'coloured' and 'British'. Furthermore, he finds himself caught between the four "cards" of Africa, Britain, the Caribbean, and the US A. Regardless of his constantly changing location, the refrain remains the same: "I recognise the place, I feel at home here, but I don't belong. I am of, and not of, this place." Phillips's identity is one that is, to use Bhabha's vocabulary, "interstitial" or "liminal"7 - reflected most succinctly in the phrase "of, and not of, this place." The writer also makes the distinction between feeling at home and belonging, implying that while somewhere may be 'home', it can still be a place where one does not fully belong. ${ }^{8}$ This notion, as we shall see, is particularly pertinent to The Atlantic Sound, where Judge Waring ultimately finds he does not belong in what has been his home town of Charleston.

As I have mentioned, British identity has arguably been predicated on exclusions which, in the postwar period, were enforced by the passing of legislation designed specifically to exclude non-white people. As Phillips has also stated,

across the centuries British identity has been primarily a racially constructed concept. [...] Race and ethnicity are the bricks and mortar with which the British have traditionally built a wall around the perimeter of their island nation and created fixity.

This defensive wall is, furthermore, fiercely policed, as Rosemary Marangoly George writes in her book The Politics of Home (1996):

One distinguishing feature of places called home is that they are built on select inclusions. The inclusions are grounded in a learned (or taught) sense of a kinship that is extended to those who are perceived as sharing the same

${ }^{6}$ Caryl Phillips, "Introduction: A New World Order," in Phillips, A New World Order: Selected Essays (London: Secker \& Warburg, 2001): 4.

${ }^{7}$ See, for example, Homi K. Bhabha, The Location of Culture (London \& New York: Routledge, 2000).

${ }^{8}$ In The World, the Text, and the Critic, Said also writes of the "nuances, principally of reassurance, fitness, belonging, association, and community, entailed in the phrase at home or in place" (1984; London: Vintage, 1991): 8.

${ }^{9}$ Caryl Phillips, "The Pioneers: Fifty Years of Migration to Britain," in Phillips, A New World Order: Selected Essays (London: Secker \& Warburg, 2001): 272-73. 
blood, race, class, gender, or religion. Membership is maintained by bonds of love, fear, power, desire and control. ${ }^{10}$

This idea of an enforced kinship links up with the notion identified by Gilroy of "cultural insiderism." Gilroy writes that its identifying feature is "an absolute sense of ethnic difference. This is maximised so that it [...] acquires an incontestable priority over all other dimensions of [people's] social and historical experience, cultures, and identities," and is utilized in order to "construct the nation as an ethnically homogeneous object." 12 The importance of ethnic difference as signifier of nationality, and the twinned conception of the nation as "an ethnically homogeneous object," in turn anticipates Phillips's comments in Extravagant Strangers about the "mythology of homogeneity." The persistent attempt to deny black Britons full participation in Britain's "main narrative" may be seen as one of the continuing legacies of slavery. The "mythology of homogeneity" relies on the false, but persistent, notion that the docking of the Windrush was the primary moment of black arrival in Britain. This, in turn, depends on denying an earlier, and continuous, history of black habitation in Britain - an important part of which is the suppression of Britain's role in the slave trade. Significantly, Phillips's conclusion to A New World Order is subtitled "The 'High Anxiety' of Belonging," and in this he writes:

I grew up in Leeds in the sixties and seventies, in a world in which everybody, from teachers to policemen, felt it appropriate to ask me $[\ldots]$ for an explanation of where I was from. The answer "Leeds," or "Yorkshire," was never going to satisfy them. Of course, as a result, it was never going to satisfy me either. ("HA," 303)

As I have suggested, essential to identity-formation is the notion of home. Even dictionary definitions are confusing; 'home' is both "the place where one lives" and "the native land of a person or a person's ancestors," which allows for some considerable contradiction, especially for diasporan people. ${ }^{13}$

${ }^{10}$ Rosemary Marangoly George, The Politics of Home: Postcolonial Relocations and Twentieth-Century Fiction (Cambridge, New York \& Melbourne: Cambridge UP, 1996): 9.

${ }^{11}$ Paul Gilroy, The Black Atlantic: Modernity and Double-Consciousness (1993; London \& New York: Verso, 1999): 3. Gilroy borrows this notion from Werner Sollors; see Sollors, Beyond Ethnicity: Consent and Descent in American Culture (New York \& Oxford: Oxford UP, 1986).

${ }^{12}$ Gilroy, The Black Atlantic, 3.

${ }^{13}$ The Oxford English Reference Dictionary, ed. Judy Pearsall \& Bill Trumble (1995; Oxford \& New York: Oxford U P, 1996): 676. 
The word is therefore complex and something Phillips wrestles with throughout his work. We might, for instance, think of his novel Crossing the River (1993), in which Joyce, a white British woman who gave up her son, Greer, following the death of his black GI father, receives an unexpected visit from her now adult son. This arrival cannot, in any terms, be described as a return home for Greer, but it signals the possibility of a new relationship between Greer and Joyce. An understanding of what home means, and where it lies, is intimately connected to one's sense of identity, self, and belonging and, in The Atlantic Sound, Phillips makes various suggestions as to the meaning of this word. One of the most significant, and characteristic of Phillips, is in connection to football: "back at the hotel I lie full-length on my bed and watch images of 'home.' Everton versus Manchester United." " Here, football becomes emblematic of British identity; an idea that is also central to the essay in A New World Order entitled "Leeds United, Life and Me." In this piece, the racism that is interlaced in the game of football is evinced not only in the behaviour of hostile fans of opponent teams, who showered Phillips with "torrents of abuse [and] sharpened pennies," 15 but also in the utter duplicity of white Leeds football fans: "the same people who would hug you when Leeds scored [...] would also shout 'nigger' and 'coon' should the opposing team have the temerity to field a player of the darker hue" ("LU," 299). In some ways, Phillips's uneasy relationship with football would seem to echo his relationship with Britain. While he is, of course, entitled to go to matches, he is made uncomfortable by the number of racist fans that, in his experience, are in attendance; in a related way, his dissatisfaction with a British identity is in part due to the racism he has encountered over many years. Furthermore, as Phillips's comment suggests, football affiliations are, like British identity, also predicated on exclusions and are reinforced by maintaining a strong sense of the 'Other.'

However, football provides Phillips with a temporary, and not uncomplicated, sense of belonging:

Leeds United reminds me of who I am. All together now, "We are Leeds, We are Leeds, We are Leeds." Somewhere, thirty-five years ago, a small black boy in the company of his white teenage babysitter stood on the terraces at

\footnotetext{
${ }^{14}$ Caryl Phillips, The Atlantic Sound (London: Faber \& Faber, 2000): 122-23. Further page references are in the main text after " $A S$. ."

${ }^{15}$ Caryl Phillips, "Leeds United, Life and Me," in Phillips, A New World Order: Selected Essays (London: Secker \& Warburg, 2001): 299. Further page references are in the main text after "LU."
} 
Elland Road and muttered those words for the first time. And I say back to that child today, "And you will always be Leeds, for they are a mirror in which you will see reflected the complexity that is your life." (“LU," 301)

A momentary unity ("All together now") is created as the fans assume a collective identity, repeating their football-chant mantra. Belonging, it seems, needs to be continually asserted in order to become believable. Like the difficult representation of slavery in Phillips's novels, in which he refuses to reduce the complexity of this past to a simple, manichaean, politics of accusation and innocence, his depiction of the legacies of this past, such as belonging and identity for non-white Britons, is also complicated. Leeds United may remind Phillips of who he is but, as we shall see, this reminder is arguably of his difference; it is not an easy affiliation with the white football fans. I would contend that the above passage also indicates that identities are performative, suggesting Bhabha's notion of the pedagogical and the performative, on which I shall now elaborate.

In his essay "DissemiNation: Time, Narrative and the Margins of the Modern Nation" (1990), Bhabha writes of the heterogeneity of the nation - the numerous histories and points of cultural difference that preclude the establishment of a homogeneous national identity. There occurs, he suggests,

a split between the continuist, accumulative temporality of the pedagogical, and the repetitious, recursive strategy of the performative. It is through this process of splitting that the conceptual ambivalence of modern society becomes the site of writing the nation. ${ }^{16}$

For Bhabha, therefore, the pedagogical is a continuous history, a linear movement through time, whereas the performative is continually repeating and non-progressive. In A New World Order, we can see that, by donning a football shirt, the fans perform an identity as supporters of a certain team and, in so doing, also as British citizens. Against this performative, and repetitive, aspect of British identity runs the pedagogical. The belief in the uninterrupted continuity of British history is expressed in George Orwell's essay "England Your England," explored by Phillips in A New World Order. Completely ignoring centuries of migration to Britain and, of course, the involuntary arrival of slaves from Africa, Orwell is confident in claiming that

\footnotetext{
${ }^{16}$ Bhabha, The Location of Culture: 145-46.
} 
British people had no desire to view themselves as a nation of immigrants, and that a sense of continuity with the past was a crucial determinant of national identity. ${ }^{17}$

This idea of the unbroken continuity of British history has also been used by Enoch Powell, and has a far-reaching historical basis. As Ian Baucom states,

the strategy of disavowing blackness in order to negatively invoke a racially pure English identity draws on a long history of the reading of Englishness as primarily a racial category. ${ }^{18}$

The persistent belief in the coalition of race and nationality, which prompts the exclusionary tactics deployed against Phillips by fans of opposing teams, is clearly not a late-twentieth- or early-twenty-first-century phenomenon.

While a temporary solidarity may be introduced by assuming an identity as a Leeds United supporter, for fans like Phillips this identity remains volatile and uneasy. The mirror in this case is provided by his football team; in Phillips's works, mirrors can be found in different, often unexpected places. A mirror is a crucial tool in terms of identity-construction and, importantly, is not connected with how you are perceived by others but, rather, with how you perceive yourself. $^{19}$ If, as Phillips argues, he is often perceived by other Britons as not belonging in Britain, his affiliation with Leeds United provides him with a mirror in which he sees the confirmation that his identity is complex and that he does not, to use his terminology, easily "belong."

Phillips suggests, therefore, that moments of belonging are always temporary. When he travelled to France during the World Cup to watch England play against Colombia, he admits that he rose to sing the national anthem, "with a vigour that shocked [him]":

For a moment the cloud of ambivalence was lifted. I belonged. Why not, I wondered, submit to the moment and cease struggling? After all, what is wrong with a tee-shirt emblazoned with the Union Jack? The sixties and

${ }^{7}$ Caryl Phillips, "The Pioneers: Fifty Years of Migration to Britain," 266. Orwell's essay is entitled "England Your England," but his focus is on Britain, rather than England.

${ }^{18}$ Ian Baucom, Out of Place: Englishness, Empire and the Locations of Identity (Princeton N J: Princeton UP, 1999): 15. Again, while Baucom refers to England, his comments are fully applicable to Britain.

${ }^{19}$ Though, of course, the two versions of identity (self-identification and identification by others) are inextricably linked, as Phillips has stated: "Growing up in England in [...] that heavy time of Enoch Powell and the Notting Hill riots, created an anxiety in me and others about how we fitted into Britain. When I looked in the mirror I saw someone who was told to go back where he came from." See Harry Eyres, "Home Is Where the Art Is," The Times (London; 11 May 1993): 33. 
seventies are over [...]. However, for me, the unequivocal answer to such private urgings is contained in the one word; 'vigilance'. History has taught me that for people such as myself the rules will change. The goalposts will be moved. A new nationality act will be passed. And another. ("H A," 308-3)

For Phillips, British identity remains, it seems, locked into a position in which it works by exclusions, and the ever-moving "goalposts" of British legislation ensure that, for non-white citizens, a Union Jack tee-shirt will continue to be uncomfortably worn. It is worth stating here what may easily be overlooked: namely, that as a non-white citizen, belonging is so rare for Phillips that he has to attend a football match in order to experience it momentarily. This is also an instance of belonging based on assimilation; he can briefly belong, but only if he wears the appropriate tee-shirt and chants the correct words. This is a complicated and anxious moment for Phillips, and if his affinity to a football team affords him a sense of belonging, it remains an impermanent condition it is not long before the "cloud of ambivalence" once more descends. In After Empire, Gilroy also discusses "Britain's odd culture of sports spectatorship and its relationship to xenophobia, racism, and war," focusing on football in particular. ${ }^{20}$ As Gilroy writes,

Those of us who have had to run for our lives from vicious drunken crowds intent on a different, bloodier sport than the one they paid to see on the terraces have always been able to know where nationalist sentiments were wired in to the raciological circuitry of the British nation and where Brit racisms and nationalisms were fused together as something like a single ethnic gestalt. ${ }^{21}$

Gilroy emphasizes the integration of race and nationality, which, he suggests, we can see enacted in the drunken, racist behaviour of football supporters, especially. Like Phillips, he reveals the dangers of being lured into a temporary identification with white football fans. For Gilroy, football affiliations cannot be divorced from the wider and non-separable issues of nationality and race: "The knot of ideas around sport demonstrates that we cannot sanction the luxury of believing that 'race', nation, and ethnicity will be readily or easily disentangled from each other."22 Like Phillips's urged "vigilance," Gilroy suggests that the British coalition of race and nationality continues to ex-

\footnotetext{
${ }^{20}$ Paul Gilroy, After Empire: Melancholia or Convivial Culture? (Abingdon: Routledge, 2004): 116

${ }^{21}$ Gilroy, After Empire, 121.

${ }^{22}$ After Empire, 121.
} 
clude non-white people. Perhaps more emphatically than Phillips, however, Gilroy intimates that nowhere is this clearer than on the football terraces.

Any related ambivalence surrounding a black British identity arguably stems not only from repressive postwar legislation but also from the persistent denial of a history of black habitation in Britain that pre-dates 1948. Instrumental in these attempts to deny black Britons a pre-Windrush history has been Britain's drive to 'forget' slavery. The city of Liverpool was for some time at the forefront of Britain's slaving industry - as Ramsay Muir has candidly written in A History of Liverpool (1907), "beyond a doubt it was the slave trade which raised Liverpool from a struggling port to be one of the richest and most prosperous trading centres in the world."23 It was also in Liverpool in 1779 that the last sale of a slave on British soil took place. ${ }^{24}$ Phillips opens the postscript to the "Leaving Home" section of The Atlantic Sound with an epigraph about Liverpool from Richard Wright's Black Power: "Along the sidewalks men and women moved unhurriedly. Did they ever think of their city's history?" $(A S, 94) .{ }^{25}$ This question frames the section and, while Phillips comes face to face with ghosts of the past, Liverpool's history remains as silent as its river:

I walk up to the Cunard building and can see that carved into its façade are the names of the major ports in the world that this huge shipping company has done business with over the years. The word 'Africa' leaps out at me. Ships to Africa. [...] Behind me the Mersey lies silent. $(A S, 80-81)$

Reminders of Liverpool's role in the slave trade are, quite literally, carved into the city's buildings, yet the past is still extensively silenced and ignored:

It is disquieting to be in a place where history is so physically present, yet so glaringly absent from people's consciousness. But where is it any different? $(A S, 93)^{26}$

6

${ }^{23}$ Ramsay Muir, A History of Liverpool (London: Williams \& Norgate, 1907): 195.

${ }^{24}$ Hugh Thomas, The Slave Trade: The History of the Atlantic Slave Trade, 1440-1870 (1997; London, Basingstoke \& Oxford: Macmillan/Papermac, 1998): 483.

${ }^{25}$ Richard Wright, "Part I: Approaching Africa," in Wright, Black Power (1954), in Black Power - Three Books from Exile: Black Power; The Color Curtain; and White Man, Listen!, intro. Cornel West (New York: HarperCollins, 2008): 23.

${ }^{26}$ For a recent publication which still ignores the role of slavery in enabling the creation of Liverpool's buildings and sculptures, see Terry Cavanagh, Public Sculpture of Liverpool (Liverpool: Liverpool U P, 1997). 
A close precursor to Phillips's text is Ferdinand Dennis's "travelogue about black Britain," Behind the Frontlines. ${ }^{27}$ Dennis also visits Liverpool and comments on the silence surrounding the slave trade:

The city's museum has only a minor exhibition on the slave trade. Situated to the right of the entrance, it is easily overlooked by visitors. Its size and location hint at a desire to sanitise Liverpool's history, to purge the records. ${ }^{28}$

Dennis implies that the exhibition, apparently created in order to remember the slave trade, may actually enable a wilful forgetting, or 'purging' of this past. Similarly, in Making the Black Atlantic (2000), James Walvin comments on the apparent ease with which slavery, as something that happened overseas, was conveniently forgotten in Britain's slaving ports:

What lay behind the rise of Bristol and Liverpool? [...] Despite periodic reminders - returning slave ships, planters coming 'home' awash with their slave-based wealth, the occasional black servant/slave in London or Bristol - the slave system was out of sight and, too often, out of mind. ${ }^{29}$

Again, we should note Walvin's caution in employing the term 'home', suggesting, like Phillips, that black people have not been the only ones liable to hesitate before referring to Britain as their home. Phillips also sees firsthand that Liverpool's wealth is quite literally "out of sight"; on entering the Town Hall, for example, he encounters the utter excesses of its interior:

I discover the building to be a truly spectacular repository of marble, crystal, oil paintings and gilt. I pad my way from one room to the next, feeling increasingly glutted with the visual evidence of excess, until I finally succumb to a strange feeling of disgust. $(A S, 83)$

This wealth is something Phillips had written about in The European Tribe (1987), declaring: "Your eyesight is defective. Europe is blinded by her past, and does not understant [sic] the high price of her churches, art galleries, and architecture." 30 The necessity of understanding the past is arguably a key point for Phillips; in particular, comprehending how Britain's ostentatious architectural displays have been funded. As he states in A New World Order,

\footnotetext{
${ }^{27}$ Ferdinand Dennis, Behind the Frontlines: Journey into Afro-Britain (London: Victor Gollancz, 1988): ix.

${ }^{28}$ Dennis, Behind the Frontlines, 17.

${ }^{29}$ James Walvin, Making the Black Atlantic: Britain and the African Diaspora (London $\&$ New York: Cassell, 2000): $x$.

${ }^{30}$ Caryl Phillips, The European Tribe (London: Faber \& Faber, 1987): 128.
} 
History is contained in buildings. Their names mean something. We have clues to our past, our present and even some idea of our future if we study buildings and their origins. ("HA," 306-307)

It would seem, however, that the dominant view encountered by Phillips in Liverpool is a drive to look away from evidence of the slaving past. His local guide, Stephen, tells him that a city councillor wanted to rename one of Liverpool's streets, "The Goree," as "Lottery Way," feeling that the name was " "embarrassing' because it referred to the infamous island off the coast of Senegal where a slave fort $[\ldots]$ was located" $(A S, 78) .{ }^{31}$ The attempt to erase, or rewrite, Liverpool's “embarrassing" slaving past links to the proposed "renovation" of slave "castles" in Ghana, which Phillips discusses with the "renowned Ghanaian Pan-Africanist" ( $A S, 113)$ Dr Mohammed Ben Abdallah. Phillips proffers that this may be "seen as a process of literally and metaphorically whitewashing history" $(A S, 118)$, and also suggests that "by calling them 'castles' and equating them with kings and queens and the Eurocentric tradition, the African is not facing the reality of what these places really mean" $(A S, 121)$. In a related way, by proposing to rename "The Goree," Liverpudlians can also be seen as not facing the reality of their city's history and the source of its prosperity. Again, connections are traced by Phillips in seemingly unlikely places, though in this case, Liverpool and Ghana are linked by their involvement at two separate, but connected, points of the triangular trade.

While in Liverpool, Phillips also encounters reminders of the city's connection through the slave trade to Charleston in the USA, which assumes its place at the third point of the triangle. Like Liverpool and Ghana, Charleston is a place that may try to ignore, but cannot entirely erase, the prominence of slavery in its past. ${ }^{32}$ Not far from Charleston is Sullivan's Island,

${ }^{31}$ A similar debate has taken place recently about proposals to rename the infamous Penny Lane, named after James Penny, an eighteenth-century slave trader. See Lee Glendinning, "Renaming Row Darkens Penny Lane's Blue Suburban Skies," Guardian (10 July 2006): http://www.guardian.co.uk/uk/2006/jul/10/arts.artsnews (accessed 5 August 2009).

${ }^{32}$ Liverpool and Charleston were also both pioneering towns; Liverpool was the first place in the world to have a passenger railway service $(A S, 93)$ and Charleston was also the first place in the US A to have a train and a museum. Furthermore, Charleston was also the place of "the first shot in the civil war" and the "first place to fly the Union flag" $(A S, 211)$. I would suggest that the money necessary to ensure the "pioneering' status of these places was generated from the slave trade. 
an eerie and troubled place. [...] Having crossed the Atlantic in the belly of a ship. An arrival. Here, in America. Step ashore, out of sight of Charleston. To be fed, watered, scrubbed, prepared. To be sold. $(A S, 207)$

Phillips searches for the "pest houses" which held arriving slaves; where, he tells us, "over 30 per cent of the African population first landed in the North American world" $(A S, 207)$. However, this proves a fruitless task:

Of the many people that I have asked, nobody seems to know exactly where the pest houses were located, and of course nobody has thought it necessary at least to speculate and mark a place with a monument or plaque. $(A S, 207)$

Phillips seems disappointed to find no fixed marker pinpointing the location of the pest houses; it would initially seem that in Charleston, as in Liverpool, the past of slavery is forgotten. However, although lacking a "monument or plaque," Charleston perhaps provides a glimmer of hope, as Phillips finds that here there is an attempt to remember:

in this city which 'processed' nearly one-third of the African population who arrived in the United States, a population who were encouraged to forget Africa, to forget their language, to forget their families, to forget their culture, to forget their dances, five young black women try to remember [...]. Their sinewy bodies weave invisible threads that connect them to the imagined old life. $(A S, 213)$

The past is unavailable, hence Phillips's care to mention that the "old life" is an "imagined" one, but this act of imaginative remembrance is clearly important in the face of enforced forgetting. Out of this act comes a vision of black and white people celebrating together:

White men and women dancing to the rhythms of Africa in the street behind the United States Customs House. History smiles. [...] Ghosts walking the streets of Charleston. Ghosts dancing in the streets of Charleston. $(A S, 213)$

The "ghosts" that walk and dance in the streets suggest, again, the continuing legacy of slavery and, rather like the diasporic chorus with which Phillips ends Crossing the River, here, too, we have a vision of a connection between black and white people, remembering and acknowledging a shared past. Perhaps Charleston, in its communal celebration, provides a tentative answer to the question posed earlier by Phillips. As mentioned above, he commented that Liverpool's history is "physically present, yet [...] glaringly absent from people's consciousness" and asked, "but where is it any different?" Phillips may feel that the citizens of Sullivan's Island have been neglectful in failing 
to mark the location of the "pest houses," but Charleston's street celebration offers an alternative means of acknowledging this past.

Charleston, it would seem, has come a long way from the time of Judge Waring, who was ostracized by the white people of the town for his determination to secure the vote for black men and women. Waring was ultimately forced to leave, realizing that "it was simply too burdensome to be among those who openly hated you in a place you called 'home"' $(A S, 205)$. It is, therefore, not only diasporan black people who experience alienation and unbelonging. In A New World Order, Phillips writes that his own "continued sense of alienation in a British context is hardly original. The roots are racially charged, but others have felt similarly excluded on grounds of class, gender or religion" ("HA," 308). As Siddhartha Deb quite rightly states in his review of the book, therefore, Phillips "is not interested in confining the experience of estrangement to just one racial group. [...] he makes the suggestion that the dialectic of familiarity and alienation has expanded to encompass all of humanity." 33 The Charleston section differs from those on Liverpool or Ghana, both of which concentrate on the black diasporan experience. In Charleston, Phillips examines alienation and the problematical term 'home' from a specifically white perspective; in so doing, he suggests that, just as slavery is a shared past, the complexities of the notions of 'home' and belonging are not confined to diasporan or non-white people.

Crossing the River cautions us that "there is no return"; ${ }^{34}$ similarly, in The Atlantic Sound, although Phillips retraces the journey his parents made from the Caribbean to Britain by boat when he was an infant, it is both the same and different: "For me this will be no Atlantic crossing into the unknown. I fully understand the world that will greet me at the end of the journey" ( $A S$, 4). His years of habitation in Britain ensure that, for Phillips, the journey is to a familiar place:

Beyond the captain is Britain. On this bleak late winter's morning, I am happy to be home. As I look at the white cliffs of Dover I realize that I do not feel the sense of nervous anticipation that almost forty years ago characterized my parents' arrival, and that of their entire generation. $(A S, 16)$

The time spent away from Britain seems to have created what is to be a rare moment in Phillips's writing: on returning to Britain, he admits that he is

\footnotetext{
${ }^{33}$ Siddhartha Deb, "On Belonging: From Leeds to Naipaul," review of $A$ New World Order, Financial Times (20-21 October 2001): 4.

${ }^{34}$ Caryl Phillips, Crossing the River (1993; New York: Vintage, 1995): 237.
} 
"happy to be home" $(A S, 16)$. There is, in this unembellished phrase, none of the usual hesitancy surrounding the word 'home', normally signalled by his use of inverted commas. While he attempts to revisit the past by taking the same physical journey as his parents, his understanding of Britain renders it utterly different.

The impossibility of returning to the past runs contrary, however, to the belief at the core of the pan-African movement in the necessity of returning 'home' to an idyllic past:

Not long after the first slave ships set sail from the West African coast, the idea that those of Africa, and those of African origin 'overseas' somehow constituted a family - albeit a family with a broken history - took hold. The idea was seized upon with a particular enthusiasm by those 'overseas' [...]. There was engendered in their souls a romantic yearning to return 'home'. $(A S, 113)$

This conception that all black diasporan people are part of a family is a problematical notion for Phillips; the Pan-African "family" is not available to all. Phillips is informed by Dr Abdallah that the responsibility for the slave forts is the diasporans': "For us, they do not mean the same thing as they do for you people." As Phillips responds, "So much for Pan-Africanism, I thought. 'You people'?" $(A S, 118)$. Far from a family, therefore, there is a clear distinction made by Dr Abdallah between Africans who reside in Africa, and people of the African diaspora, who live elsewhere. In calling this section of the book "Homeward Bound," Phillips's pun on the word "bound" suggests that a reliance on the notion of returning 'home' can be highly restrictive, or even enslaving. ${ }^{35}$

The "romantic yearning" for home may be thought of in relation to Avtar Brah, who claims in Cartographies of Diaspora (1996) that home is always, for diasporans, a place of the imagination, rather than a real entity:

on the one hand, 'home' is a mythic place of desire in the diasporic imagination. In this sense it is a place of no return, even if it is possible to visit the geographical territory that is seen as the place of 'origin'.

${ }^{35}$ The 'Homeward Bound Foundation' is also the name of the pan-Africanist group behind the middle passage monument, sunk 427 kilometres off New York harbour. See Johanna C. Kardux, "Monuments of the Black Atlantic: Slavery Memorials in the United States and the Netherlands," in Blackening Europe: The African American Presence, ed. Heike Raphael-Hernandez (New York \& London: Routledge, 2004): 89-90.

${ }^{36}$ Avtar Brah, Cartographies of Diaspora: Contesting Identities (London \& New York: Routledge, 1996): 192. 
Home, Brah suggests, may be desirable but, as an imaginary location, is forever inaccessible. Furthermore, in the attempt made by the pan-Africanists to "return home," they appear to 'forget' slavery. For example, Phillips mentions that the Panafest guide "omits to point out the two female dungeons, each of which could accommodate up to one hundred and fifty slaves, or the male dungeon which often held upwards of a thousand slaves" $(A S, 135)$. In a similar way, Gilroy writes about slavery as

the site of black victimage and thus of tradition's intended erasure. When the emphasis shifts towards the elements of invariant tradition that heroically survive slavery, any desire to remember slavery itself becomes something of an obstacle. ${ }^{37}$

I would suggest this notion corresponds to Bhabha's already mentioned claims of the "continuist, accumulative temporality of the pedagogical," and Gilroy identifies a danger in this type of behaviour:

slavery becomes a cluster of negative associations that are best left behind. [...] Blacks are urged, if not to forget the slave experience which appears as an aberration from the story of greatness told in African history, then to replace it at the centre of our thinking with a mystical and ruthlessly positive notion of Africa that is indifferent to intraracial variation and is frozen at the point where blacks boarded the ships that would carry them into the woes and horrors of the middle passage. ${ }^{38}$

This tendency to leaving slavery behind is evident at the Panafest but, as Phillips has suggested, there is a comparable desire in Liverpool to 'forget' its slaving past, provoking Stephen's comment: 'Liverpool people don't want to acknowledge their own history. They don't want you to know what built this town" $(A S, 79)$. In writing about Liverpool and Ghana, Phillips draws some interesting, and perhaps surprising, comparisons - most notably, between the British "mythology of homogeneity" and the pan-African movement's aligned emphasis on historical continuity and racial separation. At a ceremony for those only "obviously of African origin" $(A S, 177)$ at the Panafest, Phillips records:

Just in case the white people in the audience are not feeling alienated enough [the Jamaican poet] states the 'fact' that this is not a place for white people.

\footnotetext{
${ }^{37}$ Gilroy, The Black Atlantic, 189.

${ }^{38}$ The Black Atlantic, 189.
} 
The blonde woman flushes red and slowly leads her confused Ghanaian husband and even more confused son away from the scene. $(A S, 177)$

Once again, Phillips is tracing the "overlapping territories, intertwined histories" generated and perpetuated by slavery and, in so doing, demonstrates that Said's "crossings over" are not confined to people alone. Like Britain, it seems that identity in Ghana is predicated on exclusions; the white woman is made to feel uncomfortable, just as black people have been made to feel unwelcome in Britain - though, due to slavery and colonialism, the histories of the countries are, as I have suggested, inextricably entwined. Phillips is, however, careful to make no judgments upon the people he encounters; re-examining slavery is for him, as I have argued elsewhere, not only about blame or retribution. ${ }^{39}$ Nor is it about solely black history; slavery, he reminds us, has involved white and black people. The mixed-race son, like Greer, is the result of this intertwining of black and white people and histories. Where, Phillips seems to ask, do mixed-race people belong in a world that is based on rigid divisions? His non-fiction arguably aims to fragment a polarized vision of slavery as 'black history', in favour of a shared understanding which invites people of differing races to take responsibility for the past of slavery. In $A$ New World Order, Phillips writes about his initial reaction to Elmina Castle:

I was coming face to face with a part of my Atlantic history. It was disturbing, but I wished neither to look the other way, nor to romanticise the encounter. I wished simply to understand. ("H A," 307)

Unlike the Britons and pan-Africanists who "look the other way," Phillips refuses to ignore history, or to turn it into something else by 'romanticizing' it. Instead, as always, he cites the necessity of "simply" understanding the slave past, though - as his numerous works testify - this task is anything but simple.

The necessity is, it would seem, for a delicate balance between remembering and forgetting; Phillips writes that,

on coming face to face with our history the vexing questions of belonging and forgetting rise quickly to the surface. And near-cousin to the words 'belonging' and 'forgetting' is the single word, 'home.' (“H A," 307$)^{40}$

\footnotetext{
${ }^{39}$ See Abigail Ward, "An Outstretched Hand: Connection and Affiliation in Crossing the River," Moving Worlds 7.1 (2007): 20-32.

${ }^{40}$ George also states that "belonging in any one place requires a judicious balancing of remembrance and forgetting" (The Politics of Home, 197).
} 
In order for black Britons to feel 'at home' in the UK it is, he implies, essential to remember the past and to acknowledge the impact of slavery on Britain. This notion of remembering, however, runs contrary to the British amnesia that denies the history of habitation of black people in Britain in order to construct a racially homogeneous national identity. Bhabha's notion that forgetting is instrumental in "remembering the nation" is also relevant in relation to the attempts made by pan-Africanists to 'forget' the reality of slavery. ${ }^{41}$ For pan-Africanists, as for white Britons, forgetting, or distorting, the history of slavery and colonization enables the construction of a national history and identity as continuous, unbroken, and homogeneous. ${ }^{42}$

Although the desire to return home to retrace one's 'roots' is integral to the pan-Africanist movement, ultimately it is revealed by Phillips to be an inadequate metaphor when dealing with diasporan, hence plural and changing, identities. As indicated above, Gilroy has also claimed that the notion of roots is perhaps unfitted to people of the diaspora, and that 'routes' could be a more useful term:

Marked by its European origins, modern black political culture has always been more interested in the relationship of identity to roots and rootedness than in seeing identity as a process of movement and mediation that is more appropriately approached via the homonym routes. ${ }^{43}$

This is arguably a central motif in Phillips's writing - rather than embarking on a quest for static 'roots', in The Atlantic Sound he instead traces diasporan identities by outlining the routes of the slave trade. In following these watery paths across the Atlantic, one cannot overlook the centrality of the sea in Phillips's imaginings. While Gilroy's concept of the "Black Atlantic" differs considerably from Phillips's "Atlantic Sound," for reasons I shall explain in a moment, Gilroy remains useful here for examining the historical legacy of the Atlantic. He has written that the "history of the black Atlantic," which has been "continually crisscrossed by the movements of black people - not only

${ }^{41}$ Bhabha, The Location of Culture, 161. Bhabha draws on Ernest Renan's essay "What is a Nation?" (1882), reprinted in Nation and Narration, ed. Homi K. Bhabha (London \& New York: Routledge, 1990): 8-21.

${ }^{42}$ The Africentric movement relies on linearity, which colonialism and slavery interrupts; see Gilroy, The Black Atlantic, 190.

${ }^{43}$ Gilroy, The Black Atlantic, 19. In The European Tribe, Phillips begins the section on Britain with a quotation from Simone Weil: "to be rooted is perhaps the most important and least recognized need of the human soul," arguably suggesting a significant shift in his conceptualization of diasporan identity (119). 
as commodities but engaged in various struggles towards emancipation, autonomy, and citizenship - provides a means to reexamine the problems of nationality, location, identity, and historical memory." 44 Gilroy makes an important point in stressing that the Atlantic Ocean should not only be thought of in relation to the Middle Passage. It also has positive connotations for black diasporan people in enabling critical thinking about identity, belonging, and memory. Although Phillips differs from Gilroy, in that his "countless millions" include white as well as black people, they both employ the ocean as a "means to reexamine the problems of nationality, location, identity, and historical memory," and it is ultimately the centre of the Atlantic Ocean that Phillips cites as the crossing point, or intersection, of these interconnected ideas. ${ }^{45}$

In Phillips's play Where There Is Darkness (1982), his protagonist, Albert, who, like Phillips, was born in the Caribbean but migrated to Britain, asks: "Why is it that the sea always sounds so fucking guilty? Whispering like it knows something but is not going say nothing." 46 The guilt mentioned here could be seen as a testimony to the legacy of slavery; the silence attesting to the reluctance in Britain to acknowledge or discuss its slaving past. The significance of the sea in The Atlantic Sound is evident from its title but, if the sea sounds guilty to Albert, Phillips's "Atlantic Sound" is, I would argue, no longer a guilty whispering, nor is it the silence of the Mersey. Instead, in his exploration of a range of diasporan identities at key points across the Atlantic, the 'sound' Phillips hears as he journeys across the water is the polyphonic voices of the diasporic "many-tongued chorus of the common memory" heard at the close of Crossing the River. ${ }^{47}$

In A New World Order, Phillips takes the proposed significance of the Atlantic further in suggesting that, as an African/Caribbean/British diasporan subject, his true 'home', and the place where he wishes to have his ashes scattered, is in the middle of the Atlantic Ocean: "this watery crossroads lay at the centre of a place that had become my other 'home'; a place that, over the

${ }^{44}$ Gilroy, The Black Atlantic, 16.

${ }^{45}$ Hence, while Gilroy's book is called The Black Atlantic, Phillips's The Atlantic Sound has lost the racial specificity.

${ }^{46}$ Caryl Phillips, Where There Is Darkness (Ambergate: Amber Lane, 1982): 16 (Act I, 1. 23).

${ }^{47}$ Phillips, Crossing the River, 235. Bénédicte Ledent also suggests that 'sound' could mean to explore, or plumb the depths. See Ledent, "Ambiguous Visions of Home: The Paradoxes of Diasporic Belonging in Caryl Phillips's The Atlantic Sound," EnterText 1.1 (Winter 2000): 198-211, http://www.brunel.ac.uk/4042/entertext1.1/Ledent.pdf (accessed 5 August 2009). 
years, I have come to refer to as my Atlantic home" ("H A," 304). George begins her book with a quotation from bell hooks that seems appropriate at this point: "At times home is nowhere. At times one only knows extreme estrangement and alienation. Then home is no longer just one place. It is locations." Phillips's Atlantic home is also born of a reconciliation to the idea that home is "no longer just one place." Instead, he offers a plural version of home, which corresponds to his notion of diasporan identities as shifting and everchanging: "These days we are all unmoored. Our identities are fluid." 49 At the end of $A$ New World Order, he pauses to contemplate his destiny:

Whenever I stand on the ramparts of Elmina Castle and gaze out at the Atlantic Ocean, I know exactly where I come from. I can look to the north and to the west and see the different directions in which I have subsequently journeyed. And, on a clear day, I can peer into the distance and see where I will ultimately reside. ("H A," 309)

Phillips stands quite literally on his past and, as one of Said's "people who simply don't belong in any culture," also at the intersection or "crossings over" of journeys and identities. However, on a clear day - when the "cloud of ambivalence" surrounding identity has temporarily lifted - it is the future, and not the past, towards which he gazes. It is also, less optimistically, towards death that he looks. Phillips's crossroads emanates from a discussion about where his ashes should be scattered. By citing the middle of the ocean as his 'home', his is not a practical solution to the problems of diasporan identity. Slavery, he suggests, has created the difficulties of identity and belonging still experienced by non-white people in Britain in the new millennium, but he is unable to propose a workable or realistic alternative to British identity that might alleviate some of these difficulties. It would seem that identity for him is ever liminal; ultimately, a perpetual unbelonging thwarts his attempts to resolve the "conundrum of 'home'."

\section{WORKS CITED}

Baucom, Ian. Out of Place: Englishness, Empire and the Locations of Identity (Princeton N : Princeton UP, 1999).

Bhabha, Homi K. The Location of Culture (London \& New York: Routledge, 2000).

\footnotetext{
${ }^{48}$ George, The Politics of Home, 1.

${ }^{49}$ Caryl Phillips, "Introduction: A New World Order," 6.
} 
Brah, Avtar. Cartographies of Diaspora: Contesting Identities (London \& New York: Routledge, 1996).

Cavanagh, Terry. Public Sculpture of Liverpool (Liverpool: Liverpool UP, 1997).

Deb, Siddhartha. "On Belonging: From Leeds to Naipaul," review of A New World Order, Financial Times (20-21 October 2001): 4.

Dennis, Ferdinand. Behind the Frontlines: Journey into Afro-Britain (London: Victor Gollancz, 1988).

Eyres, Harry. "Home Is Where the Art Is," Times (11 May 1993): 33.

George, Rosemary Marangoly. The Politics of Home: Postcolonial Relocations and Twentieth-Century Fiction (Cambridge, New York \& Melbourne: Cambridge UP, 1996).

Gilroy, Paul. After Empire: Melancholia or Convivial Culture? (Abingdon: Routledge, 2004).

- The Black Atlantic: Modernity and Double-Consciousness (1993; London \& New York: Verso, 1999).

Glendinning, Lee. "Renaming Row Darkens Penny Lane's Blue Suburban Skies," Guardian (10 July 2006): http://www.guardian.co.uk/uk/2006/jul/10/arts.artsnews (accessed 5 August 2009).

Kardux, Johanna C. "Monuments of the Black Atlantic: Slavery Memorials in the United States and the Netherlands," in Blackening Europe: The African American Presence, ed. Heike Raphael-Hernandez (New York \& London: Routledge, 2004): 87-105.

Ledent, Bénédicte. "Ambiguous Visions of Home: The Paradoxes of Diasporic Belonging in Caryl Phillips's The Atlantic Sound," EnterText 1.1 (Winter 2000): 198211, http://www.brunel.ac.uk/4042/entertext1.1/Ledent.pdf (accessed 5 August 2009).

Muir, Ramsay. A History of Liverpool (London: Williams \& Norgate, 1907).

Orwell, George. "England Your England," in Orwell, The Collected Essays, Journalism and Letters of George Orwell, vol. 2: My Country Right or Left, 1940-1943, ed. Sonia Orwell \& Ian Angus (1968; Harmondsworth: Penguin, 1970): 74-99. First published as Part I of The Lion and the Unicorn: Socialism and the English Genius (Searchlight Books 1; London: Secker \& Warburg, 1941).

Pearsall, Judy, \& Bill Trumble, ed. The Oxford English Reference Dictionary (1995; Oxford \& New York: Oxford U P, 1996).

Phillips, Caryl. The Atlantic Sound (London: Faber \& Faber, 2000).

_. "Conclusion: The 'High Anxiety' of Belonging," in A New World Order, 30309.

. Crossing the River (1993; New York: Vintage, 1995).

. The European Tribe (1987; London: Faber \& Faber, 1999).

_. Extravagant Strangers: A Literature of Belonging (1997; London: Faber \& Faber, 1998). 
"Introduction: A New World Order," in A New World Order, 1-6.

"Leeds United, Life and Me in A New World Order, 298-301.

A New World Order: Selected Essays (London: Secker \& Warburg, 2001).

"The Pioneers: Fifty Years of Caribbean Migration to Britain," in A New World

Order, 264-82.

. Where There Is Darkness (Ambergate: Amber Lane, 1982).

Renan, Ernest. "What is a Nation?" (1882), in Nation and Narration, ed. Homi K. Bhabha (London \& New York: Routledge, 1990): 8-21.

Sollors, Werner. Beyond Ethnicity: Consent and Descent in American Culture (New York \& Oxford: Oxford UP, 1986).

Said, Edward W. "Appendix: Media, Margins and Modernity" (1986), in Raymond Williams, The Politics of Modernism: Against the New Conformists, ed. Tony Pinkney (London \& New York: Verso, 1989): 177-98.

- Culture and Imperialism (1993; London: Chatto \& Windus, 1994).

- The World, the Text, and the Critic (1984; London: Vintage, 1991).

Thomas, Hugh. The Slave Trade: The History of the Atlantic Slave Trade, 1440-1870 (1997; London, Basingstoke \& Oxford: Macmillan/Papermac, 1998).

Walvin, James. Making the Black Atlantic: Britain and the African Diaspora (London $\&$ New York: Cassell, 2000).

Ward, Abigail. "An Outstretched Hand: Connection and Affiliation in Crossing the River," Moving Worlds 7.1 (2007): 20-32.

Wright, Richard. Black Power (1954), in Black Power - Three Books from Exile: Black Power; The Color Curtain; and White Man, Listen!, intro. Cornel West (New York: HarperCollins, 2008): 1-428. 


\title{
Caryl Phillips's Seascapes of the Imaginary
}

\author{
WENDY KNEPPER
}

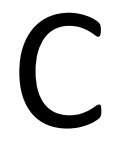

Aryl Phillips frequently takes the Caribbean experience of mobility and transcultural formation as a point of departure for a wide-ranging investigation into the global and local forces shaping today's increasingly permeable cultural imaginaries. The trans-Caribbean experience both prefigures and partakes in what Phillips defines as "a new world order" in which "it is impossible to resist the claims of the migrant, the asylum seeker, or the refugee."1 Neither colonial nor postcolonial, this is a world where there is "one global conversation with limited participation open to all, and full participation available to none." "It is a world where "nobody will feel fully at home." "This ambiguous situation, characterized by belonging and unbelonging, connectedness and isolation, affiliation and estrangement, is at the heart of Phillips's often ambivalent, always fluid narrative discourse. The titles of many of his works, including The Final Passage, Crossing the River, A Distant Shore, and The Atlantic Sound, evoke the historical, cultural, and metaphoric senses of water as it pertains to the legacies of the Middle Passage and the quest for home in a world order where myriad forms of mobility prevail. Traversing histories, geographies, and perspectives, in both his noyels and his non-fictional works, Phillips depicts and analyzes the ways in which protean, multiply-situated identities are constructed.

Not surprisingly, water and a fluid sense of self are recurring motifs for Phillips, often reflected in and through the manifold flows of his narrative

\footnotetext{
${ }^{1}$ Caryl Phillips, A New World Order: Selected Essays (London: Secker \& Warburg, 2001): 5 .

${ }^{2}$ Phillips, A New World Order, 5 .

${ }^{3}$ A New World Order, 5 .
} 
structures. Phillips sees water as an important motif in his fiction, describing it as a literal and symbolic pathway:

The one thing that is constant to me is water. Water seems to me to be something which binds us together. I wrote a piece, once, called "Water." [...] In the piece I make reference to the "ineluctable ribbons of water that bind us together." I'm interested in what brings us together and what allows us to meet each other, and water, to me, is a pathway along which we continue to meet and encounter each other. I'd rather be on the path than at 'home' at the beginning or at the end of the journey. ${ }^{4}$

For Phillips, water represents possibilities for connection and entanglement: his "ineluctable ribbons of water" take into account the journeys, pathways, and networks that bring peoples together. At the same time, the theme of fluidity is attractive because circuits of communication are continuously subject to change and transformation. Whether represented as subconscious relations or easily recognizable flows and forces, water plays a significant role in Phillips's transnational analysis of the communicative circuits that connect the world. His fluvial webs, diasporic narrative voices, and liquid narrative structures reflect a profound engagement with a uniquely Caribbean experience of mobility and migration. In analyzing his approach to writing, I propose a theory of seascapes as a way of thinking about how the Caribbean experience intersects with other mobility experiences, particularly in the context of a globalizing world. Highlighting some of the general tendencies and themes of Phillips's fiction and essays, I outline the ways in which a theory of seascapes serves to elucidate his creativity. Subsequently, I consider the role of a poetic of disorientation and the function of techniques of narrative navigation in The Atlantic Sound, paying close attention to the representation of transnational historical, cultural, economic, and social flows.

\section{The Caribbean experience of seascapes}

Arjun Appadurai introduced the use of the suffix '-scapes' as a means to talk about various flows in our modern global imaginary. In the modern world, Appadurai observes that "neither images nor viewers fit into circuits or audiences that are easily bound within local, national, or regional spaces."

\footnotetext{
${ }^{4}$ Caryl Phillips, "Other Voices: An Interview with Caryl Phillips" (October 2001), by Stephen Clingman, Salmagundi 143 (2004): 117.

${ }^{5}$ Arjun Appadurai, Modernity at Large: Cultural Dimensions of Globalization (Minneapolis: U of Minnesota P : 1996): 4.
} 
describe the effects of these uneven, disjunctive flows, he introduces the idea of '-scapes' - ethno-, media-, techno-, finance-, and ideoscapes. ${ }^{6}$ Appadurai notes that "the suffix -scape allows us to point to the fluid, irregular shapes of these landscapes":

These terms with the common suffix -scape also indicate that these are not objectively given relations that look the same from every angle of vision but, rather, that they are deeply perspectival constructs, inflected by the historical, linguistic, and political situatedness of different sorts of actors: nation-states, multinationals, diasporic communities, as well as subnational groupings and movements (whether religious, political, or economic), and even intimate face-to-face groups, such as villages, neighborhoods, and families.

My analysis builds on and critiques Appadurai's approach to '-scapes'. I introduce the term 'seascapes' to refer to the specific ways in which Caribbean authors, artists, and thinkers conceive of and represent the transformations taking place in the global order. Seascapes constitute the particular ways in which the Caribbean experiences of modernization prompt alternative accounts and articulations of the global imaginary. The product of mobility and cultural intermixtures, the Caribbean is already trans-Caribbean in its formation, shaped by a complex history of exchange with the wider world. I take this assumption as a starting point for a discussion of seascapes that follows four trajectories of analysis. Specifically, I examine (1) local experiences and expressions of modernity and globalization, (2) the underlying currents that produce mobility in the trans-Caribbean experience (such as economic, social, political, and transcultural exchanges and contexts), (3) the role of crosscultural and interracial contact in shaping fluid modes of thinking, and (4) the relevance of the trans-Caribbean perspective to an understanding of the global imaginary.

Seascapes constitute the historical and ongoing significance of mobilities and flows within and beyond the Caribbean: these fluidities continuously surface in the negotiation of relationships to time, place, and identity. From a cultural and literary perspective, a theory of seascapes is attentive to 'vernacular modernities ${ }^{8}$ or the processes of globalization that are not articulated solely

\footnotetext{
${ }^{6}$ Appadurai, Modernity at Large, 33.

${ }^{7}$ Modernity at Large, 33.

${ }^{8}$ In anthropology and the social sciences, the term 'vernacular modernities' refers to the myriad ways in which the interweaving of modernity and tradition takes place as well as to how this experience is construed at a local level. Some theorists prefer to refer to 'alternative modernities.' Stuart Hall, Arjun Appadurai, Bruce Knauft, Michel-Rolph Trouillot, and
} 
through capitalism, but through a commitment to local cultural practices and identities. In Stuart Hall's view, attentiveness to local-global exchanges enables a "new kind of 'localism' that is not self-sufficiently particular, but which arises within, without being simply a simulacrum of, the global." understand Hall's comment, it is useful to recall the ways in which the 'vernacular' has been (and continues to be) defined. Etymologically, 'vernacular' can be traced to vernaculus, a Latin term that refers to a slave born in a master's house. A second meaning of the vernacular is to express oneself in a local idiom, whether this is linguistic, architectural or cultural. When talking about the potential for trans-local formation, Hall notes that slavery played an important role in shaping local culture and disrupting a hegemonic concept of modernity. He observes:

Slavery itself, within capitalism, is not the older form of slavery, but it is an older, archaic, differentiated form, enclosed within and intimately linked to the development of the modern mode. It constitutes the possibility of a kind of modernity from below. ${ }^{10}$

He argues elsewhere:

This 'localism' is no mere residue of the past. It is something new - globalization's accompanying shadow; what is left aside in globalization's panoramic sweep, but returns to trouble and disturb globalization's cultural settlements. ${ }^{11}$

A critique of slavery and its legacies is a way of grappling with what has been exiled from the local in the sweep of globalization as a homogenizing force and thus needs to be reconstituted in the quest for an alternative, local account of modernity.

This mode of analysis takes into consideration the Caribbean histories of mobility and migration as well as the accompanying economic, social, political, and cultural flows. Paul Gilroy's image of the ship as a "living micro-

Ivan Karp are among the many scholars who discuss this concept. For more information, see the following volume of essays: Critically Modern: Alternatives, Alterities, Anthropologies, ed. Bruce Knauft (Bloomington: Indiana UP, 2002).

9 Stuart Hall, "Conclusion: The Multicultural Question," in Un/Settled Multiculturalisms: Diasporas, Entanglements, Transruptions, ed. Barnor Hesse (London \& New York: Zed, 2000): 216.

${ }^{10}$ Stuart Hall, "A Conversation with Stuart Hall," Journal of the International Institute 7.1 (1999): http://hdl.handle.net/2027/spo.4750978.0007.107 (accessed 31 July 2009).

${ }^{11}$ Hall, "Conclusion," 216. 
cultural, micro-political system in motion" ${ }^{\prime 12}$ exemplifies the importance of waters, seas, and oceans. Gilroy notes:

Ships immediately focus attention on the middle passage, on the various projects for redemptive return to an African homeland, on the circulation of ideas and activists as well as the movement of key cultural and political artefacts. $^{13}$

Fluvial routes introduce new economies of meaning and sometimes have the power to disrupt the contours of the prevailing social imaginary. For instance, the movement of Caribbean migrants outward from the Caribbean creates waves in the societies they enter, rocking landlocked ideologies of nationhood. This trajectory of investigation pays attention to colonial, postcolonial, and contemporary accounts of cultural contact and transcultural formation as well as to the related economic, social, and political forces that shape these exchanges. A theory of seascapes entails a keen awareness of the dynamics of trade and mobility and the complex interchanges between national, local, and global transformations that have shaped the specific practices of mobility and contact in the Caribbean.

Seascapes are evident in the ideological, poetic, cultural, and emotive effects of the Caribbean contact, migration, and mobility experience. Flows in and out of the region are linked to transformations of the local and global imaginaries. Creolization plays an especially important role in this context because it calls attention to the intermixtures of the Caribbean and the potential for cultural transformation through localization and globalization. Antonio Benítez-Rojo describes this fluid, mobile sensibility when he observes that "the Antilleans' insularity does not impel them toward isolation, but on the contrary, toward travel, toward exploration, toward the search for fluvial and marine routes. ${ }^{" 14}$ Similarly, following Édouard Glissant's theoretical lead, J. Michael Dash argues that the Caribbean Sea is not "an inland, centralizing body of water but one that explodes outward, thereby dissolving all systems of centering or totalizing thought." ${ }^{, 15}$ Caribbean seascapes prompt critics to

12 Paul Gilroy, The Black Atlantic: Modernity and Double-Consciousness (Cambridge MA: Harvard UP, 1993): 4.

${ }^{13}$ Gilroy, The Black Atlantic, 4.

${ }^{14}$ Antonio Benítez-Rojo, The Repeating Island: The Caribbean and the Postmodern Perspective, tr. James E. Maraniss (La isla que se repite: El Caribe y la perspectiva posmoderna, 1989; Durham NC \& London: Duke UP, 1992): 25.

${ }^{15}$ J. Michael Dash, The Other America: Caribbean Literature in a New World Context (Charlottesville \& London: U P of Virginia, 1998): 14. 
consider how the fluid relations of the Caribbean transcultural experience disrupt fixed concepts of identity. What forces shape(d) this attitude of open exploration? How are fluid relations constituted? In what ways do the histories and experiences of contact, creolization, and migration inform the contemporary understanding of the global imaginary?

A trans-Caribbean poetic offers alternative accounts of modernity, which stem from an attentiveness to mobility and migration, cross-cultural contact and mixing, a reconstruction of the history of slavery and local culture. In retracing the histories that shape the present, Caribbean writers often revise our understanding of the past, forward alternative interpretations of the present, and disclose new directions for the future. Local and popular forms of cultural expression (music, storytelling, sports, dance) play an important role in reflecting and reconstructing history and a sense of place. The transnational Caribbean with its rich and varied history of multiple flows in and out of the region sheds light on the transformations taking place in the world today. What do migration and mobility mean for the self and the concept of nation? How do communities reconstruct their identities when new cultures enter or when demographics shift? How might a reconstituted understanding of the present emerge from accounts of vernacular modernities? In my view, the trans-Caribbean concept of seascapes provides a way to theorize and understand the long history of transformations taking place in the world as well as in the global imaginary. Phillips is preoccupied by such questions and addresses issues of local-global exchanges in his writing. By tracing the pathways and exploring the waters of the trans-Caribbean imaginary, his work can be seen as embodying a poetic of seascapes.

\section{Trans-Caribbean flows in Phillips's writing}

Phillips's works, such as Strange Fruit and The Final Passage, trace Caribbean relations to the UK, showing how migration, exile, and (imagined) returns home transform individuals and societies. In Cambridge, Phillips examines the plantation experience, exploring various migratory perspectives and the workings of creolization from a multiplicity of vantage points. By undertaking the risky act of giving voice to a liberal yet racist narrative point of view, Phillips repeats discourses from the past, but offers contradictory and competing views that serve to foreground the often unreliable recounting of history. Crossing the River explores the African diasporic formation over centuries, across families and cultures, casting light on those who have been touched by the Middle Passage and other forms of displacement, whether 
chosen or coerced. In The Nature of Blood, Phillips rewrites European history and the canonical narrative of Othello, showcasing a Caribbean attentiveness to the effects of migration and the workings of global flows. In connecting or juxtaposing fragmentary experiences, Phillips implies that the global situation needs to be understood through a closer investigation of the histories of mobilities that connect and restructure relations.

With reference to the history of mobility, Elena Machado Sáez observes that Phillips's work involves a particular mode of historicity:

This historicity includes the remnants of the transatlantic slave trade, the migrations that followed the dismantling of the colonial system, and the shifts in global labor, which affected Phillips's parents. Contextualization is both the mission and curse of his travelling subject. ${ }^{16}$

While Machado Saéz sees the "two histories of slavery and globalization" as converging "to preclude the contemporary development of a coherent subjectivity or kinship and therefore the possibility of resistance via solidarity,"17 I propose a somewhat different interpretation. Phillips's seascape narratives foreground the often tragic or ironic consequences of isolation and lament the effects of rigid or racist identifications. Such is the case in A Distant Shore, where the growing intimacy between Dorothy and Solomon serves as an example of relationships that are not based on blood or marital ties, but unfold through a respectful, open, and caring attitude towards one's neighbour. This alternative account of social relations undergoes a dramatic foreclosure when racism prevails and local youths kill Solomon, but this incident serves to highlight the urgent need for new pathways and circuits of communication. Phillips shows the reader a world of missed connections, and he calls attention to solidarities that deserve recognition and can potentially serve to build new bridges and affiliations. The writer's work is deeply suggestive of the ignored, repressed or contentious points of solidarity that might yield an alternative, more cohesive social order.

Similarly, in Crossing the River, Phillips gives us a story of a fractured family that is torn apart when the crops fail and the father sells his children into slavery. Through the lives of the children and the father's lament, the reader apprehends the pathways of private loss across the seas and comes into contact with separate but related worlds. Fragmentation gives way to an

\footnotetext{
${ }^{16}$ Elena Machado Sáez, "Postcoloniality, Atlantic Orders, and the Migrant Male in the Writings of Caryl Phillips," Small Axe 17 (March 2005): 19.

${ }^{17}$ Machado Sáez, "Postcoloniality, Atlantic Orders," 22.
} 
expansive network of cross-cultural dialogues and interracial relations in various geographies (Liberia, the American West, Yorkshire) and contexts (mission work, pioneer settlement, the Second World War). In so doing, Phillips's work points to the profoundly alienating and schizophrenic experience of modernity while mapping the potentially positive transformations brought about when individuals acknowledge new forms of affiliation and kinship beyond blood lines. At the same time, the narrative foregrounds the devastation brought about when the circuits of communication break down: individuals are abandoned, left to die, and killed. This elegiac work dramatizes the reasons for communicative failures, fissures, and ruptures as well as disclosing the affiliations and lineages that bind the larger human family. Nonetheless, like Phillips's other works, this novel serves as a warning against facile attempts to create connections of solidarity based on race, nation, blood or a mythic concept of home. Instead, what we get is an expanded spatial and historical perspective in which the Africans' acts of crossing the river comes to stand for the marine traversals and other voyages that reconfigure human experience.

Phillips's works connect the unconnected, exploring alternative social formulations through the fluid interactions of history and migration; their grounding in a clinical, critical reinterpretation of story and history brings about a "return of the repressed." ${ }^{.18}$ For Phillips, "the Caribbean opens onto a multifaceted diasporic imaginary, which further complicates the web of his affiliations" and embraces the wider range of transplanted cultures in general. ${ }^{19}$ Similarly, Wendy Zierler notes that Phillips's resistance to master-narratives and his embracing of discontinuity allow disparate histories to come together in ways that highlight difference as well as contiguity. ${ }^{20}$ Phillips offers a

\footnotetext{
${ }^{18}$ Sigmund Freud speaks of "the return of the repressed" with respect to individual processes of socialization and the workings of the unconscious. Frantz Fanon opened the door to socio-political and postcolonial interpretations of this concept. Homi K. Bhabha's discussion of mimicry is likewise a fine example of the reworking of this Freudian psychoanalytic notion in postcolonial contexts (see Bhabha, The Location of Culture [London \& New York: Routledge, 1994]: 90, 91). In the case of Phillips, his narratives show how individuals, groups, communities, and nations repress certain memories or facts in order to constitute an imagined wholeness or shore up a sense of solidarity. By paying attention to what has been disavowed in order to attain a sense of belonging, Phillips calls attention to the often disjunctive dynamics at work in the constitution of identity, community, and nationhood.

${ }^{19}$ Bénédicte Ledent, Caryl Phillips (Contemporary World Writers; Manchester: Manchester UP, 2002): 172.

${ }^{20}$ Wendy Zierler, “' My Holocaust is not your Holocaust': 'Facing' Black and Jewish Experience in The Pawnbroker, Higher Ground, and The Nature of Blood," Holocaust and Genocide Studies 18.1 (Spring 2004): 57.
} 
recuperative viewpoint, in that he looks at history "from a different angle through the prism of people who have nominally been written out of it."21 Through a poetic of inclusivity that takes into account the perspectives of "the losers or victims in a particular historical storm," Phillips re-writes and puts under erasure History with a capital ' $\mathrm{H}$ '. ${ }^{22}$ Drawing on my notion of seascapes, I view Phillips's proclivity for multivalence and ambiguity as aspects of his attentiveness to the long histories of mobility and globalization. Phillips is sceptical of the ways in which identity is constructed as rooted or grounded; he questions the "mechanisms for shoring-up identity, most of which have an almost Shakespearean double-twist to them." ${ }^{, 23}$ At the same time, he traces the effects of dissolution, the changes in sensibility for those whose lives are transformed by local and global flows. He pays particular attention to those who fall victim to the desire to suppress the mobile, the varying routes of identity, and the ambiguous in favour of rooted identity and tribalism. Those who embrace or experience a dislocated sense of self are often subjects of cultural drowning, and Phillips transforms these tales of dissolution into acts of narrative submersion. Such is evident in, for example, The Nature of Blood, where the characters "don't have clear edges to their stories; they disappear into silence. That happens, for instance, to both Eva and Othello."24

Phillips's attentiveness to these moments of dissolution is tied to his own particular Caribbean perspective as well as to his personal migration choices. In "Necessary Journeys," he observes that

the gift of travel has been enabling for me in the same way that it has been enabling for those writers in the British tradition, those in the African diasporan tradition, and those in the Caribbean tradition, many of whom have found it necessary to move in order that they might reaffirm for themselves the fact that dual and multiple affiliations feed our constantly fluid sense of self. $^{25}$

Appropriately, this fluid sensibility is articulated in his travel writing or descriptions of travel, particularly in A New World Order, where he shares his multi-perspectival horizons of the imaginary with the reader:

${ }^{21}$ Caryl Phillips, "Crossing the River: Caryl Phillips Talks to Maya Jaggi," Wasafiri 20 (1994): 26

${ }^{22}$ Phillips, "Crossing the River: Caryl Phillips Talks to Maya Jaggi,” 26.

${ }^{23}$ Phillips, "Other Voices," 133.

${ }^{24}$ Phillips, "Other Voices," 134.

${ }^{25}$ Caryl Phillips, "Necessary Journeys," Guardian (11 September 2004): http://www .guardian.co.uk/books/2004/dec/11/society2 (accessed 31 July 2009). 
Whenever I stand on the ramparts of Elmina Castle and gaze out at the Atlantic Ocean, I know exactly where I come from. I can look to the north and to the west and see the different directions in which I have subsequently journeyed. And, on a clear day, I can peer into the distance and see where I will ultimately reside. ${ }^{26}$

He looks to an imaginative home that lies "in the middle of the Atlantic Ocean at a point equidistant between Britain, Africa and North America." ${ }^{27}$

Ambiguity and ambivalence are evident as Phillips seeks to describe the tensions of living in a world where a fluid sense of self is perceived as threatening and is threatened in return. Enoch Powell's infamous "rivers of blood" speech, which Phillips mentions at the beginning of The European Tribe ${ }^{28}$ is a dramatic example of the kind of hostility directed against multiracial imaginings of community and nationhood. Phillips attests to the pervasiveness of racism in British society and its effects on the individual when he recalls a childhood memory of school when the teacher of English literature attempted to deduce the origins of each child based on his or her last name. " 'Phillips,' he mused, 'you must be from Wales.' The whole class laughed [...]." Describing this as "one of the most painful episodes of my childhood," Phillips remarks: "The truth was I had no idea where I was from as I had been told that I was born in the Caribbean but came from England. ${ }^{, 29}$ Anxiety about the individual's place of origin and place in society are endemic in a nation that fears migration and racial intermixture. In A New World Order, Phillips defends the trope of ambiguity:

Most people live secure lives in a place that they recognise as their own. I understand that to such people my ambivalence will probably appear to be at best slightly cranky, at worst, paranoid. But then most people did not grow up in Leeds in the sixties and seventies having to endure a daily chorus of 'Why don't you fuck off back to where you come from? ${ }^{30}$

Feeling at home, then, is associated with a vigilant awareness of one's belonging in unbelonging. In the new world order, what might have once seemed paradoxical is no longer so: individuals are learning to come home to a peripheral, perennially unsettled condition. This fluid perception of past-present

\footnotetext{
${ }^{26}$ Phillips, A New World Order, 309.

${ }^{27}$ A New World Order, 304.

${ }^{28}$ Caryl Phillips, The European Tribe (London: Faber \& Faber, 1987): 1-2.

${ }^{29}$ Phillips, The European Tribe, 2.

${ }^{30}$ Phillips, A New World Order, 309.
} 
is the burden of history as well as a principle of self-preservation. Phillips suggests that this self-conscious ambivalence is an ethically responsible stance with regard to the past as well as to the realities of an increasingly flexible world of intermixtures, mobilities, and fragmented conversations.

\section{The Atlantic Sound: Navigating seascapes through a poetics of disorientation}

In The Atlantic Sound, Phillips takes a journey by banana boat from the Caribbean to Dover. During this ocean journey, the captain allows him to steer the vessel for five minutes. Phillips observes that the "sea is heavy" and imagines that he is not doing too badly under the circumstances - until the captain takes him on deck and he sees "the line of the wake meandering crazily as though scrawled by a drunk." "' "Such is the evidence of my navigational ability," he remarks (13). This episode is instructive, in that it gives us a sense of how the reader might navigate the poetic of disorientation at work in The Atlantic Sound, a text replete with continuously shifting perspectives and genres. Part memoir, part historical fiction, and part journalistic observation, The Atlantic Sound weaves poems, excerpts from the press, historical accounts, stories, and conversations into its textual fabric. Phillips adopts various strategies of dislocation, seemingly designed to force the reader to take a hand in navigating a course through the troubling seas of textuality. Some of these techniques include shifting narrative perspectives, divergent points of view, digressions, asides, and abrupt changes in time and place. Just as the captain asks Phillips to consider his navigational abilities by looking back at the ship's wake, in the same way Phillips asks the reader to reconsider what he or she has read, and thus reassess his or her interpretative orientation to the text and the world. The narrative moves forward in a certain direction, only to be interrupted by a change of view when Phillips looks back and reconsiders what has gone before. These techniques of textual disorientation and reorientation prompt the reader to pay close attention to the narrative journey and reflect on the relations among the many directions. The idea of seascapes helps explain how this navigational poetic operates in The Atlantic Sound. Structurally, the subtitles of the work reflect the themes of migration and mobility. The three main sections of the book are entitled "Leaving Home," "Homeward Bound," and "Home," and serve to orient the reader in this homeward-bound narrative. At

\footnotetext{
${ }^{31}$ Caryl Phillips, The Atlantic Sound (London: Faber \& Faber, 2000): 13. Further page references are in the main text.
} 
the same time, the Prologue, "Atlantic Crossing," and the Epilogue, "Exodus," undermine the assumption that it is possible to arrive at a place one might call home. Phillips begins with a symbolic journey of re-enactment, retracing the voyage he made as a child and immigrant to the UK. This personal account of mobility and migration serves as a point of departure for a series of journeys exploring the histories of Liverpool, Elmina, Charleston, and Israel. In all of these places, he encounters people who tell stories about mobility and migration past and present. Instead of a single-minded orientation, this shifting narrative offers multiple accounts of the quest for home.

Phillips begins with a sense of confidence, contrasting his certainty about where he is headed to the uncertainties experienced by a generation of West Indian emigrants before him for whom the Atlantic crossing was but the "prelude to a larger adventure - one which would change the nature of British society" (4). He notes that this is "no Atlantic crossing into the unknown," for he fully understands the world that will greet him at the end of the journey (4). Nonetheless, the voyage serves to open up a series of questions that reflect the changes and challenges for societies in and beyond the Caribbean in the current world order. Interrupting the narrative flow of contemporary experiences are a series of historical fictions that provide alternative accounts of modernity. The effect of the prologue is unsettling as Phillips narrates various traumas, tensions, and awkward encounters along the way. Changing planes in Puerto Rico, Phillips describes the nonchalance with which passengers step over the corpse of an old man who has died in transit (2). In Guadeloupe, he is struck by the prevalence of neocolonial attitudes; he notes that "the French Caribbean is the First World in tropical clothes" (2) and remarks on the ways in which the people "remain resolutely proud of the intimacy of their connection to Europe and Europeans" (1). Elsewhere, he sees contemporary ambiguities about global identity reflected in the banana boat that flies three flags as a means of asserting and negotiating the identities of where it comes from (Liberia), who it belongs to (the multinational firm Del Monte), and where it is going (Costa Rica) (6). Analyzing the treatment of the Burmese crew members, Phillips highlights residual colonial tensions as well as pointing to the dangers migrant workers face (11). Interchanges and dialogues among the passengers on the ship reflect hostility, cultural differences, and underlying socio-political conflicts (3). In Costa Rica, prostitutes approach him with racist pick-up lines (8) and he recounts the history of bigotry towards the Jamaican community of migrant workers in this country (7). This trans-Caribbean voyage serves to open up a more global analysis of movement and 
migration as Phillips presents a complex examination of economic, cultural, migratory, and other flows in and out of the Caribbean region.

Through the acts of journeying, reminiscing, and witnessing, Phillips reconstructs the meaning of symbolic spaces, such as the white cliffs of Dover. He observes that these not only served as symbols of Britain during the Second World War but also functioned as an historic landmark for Caribbean immigrants in the postwar period. Phillips provides a number of mediating contexts, reflecting on his parents' expectations when they migrated to Britain: "They travelled in the hope that the mother country would remain true to her promise that she would protect the children of her empire" (15). These expectations were soon disappointed when West Indian migrants of the 1950s and 1960 discovered that "the mother country had little, if any, desire to embrace her colonial offspring" (15). That this adverse situation has not changed much in the intervening years is evident from Phillips's account of his approach to Dover. Standing next to the captain and a fellow passenger named Kevin with whom he has formed a kind of alliance, Phillips recounts Kevin's comment to him: "'Look,' he says, 'it's black out there, just like your country'” (15). The racism and xenophobia underlying this remark are all the more disturbing because Kevin appeared throughout the journey to treat Phillips like a friend and fellow countryman. That he categorizes Phillips as belonging to a "black" country is suggestive of an inability to accept the multicultural realities of the UK as well as the particular citizenship of Phillips himself. This ambiguous reference to "your country" calls into question the relation between migration histories and a sense of belonging or being at home in the present. While Phillips does not counter Kevin's racist remarks, he makes the following observation for the benefit of the reader: "I have travelled towards Britain with a sense of knowledge and propriety, irrespective of what others, including my fellow passengers, might think" (16).

- This ambiguous encounter sets the stage for Phillips's subsequent critique of essentialist formulations of identity, community, and nationhood, particularly when these concepts are rooted in race-oriented ideologies and solidarities. In effect, this multivalent opening, replete with awkward moments, aborted dialogues, tensions, and traumas, produces a sense of unease that serves to reinforce the point that the issue of belonging is far from settled. In the final sentence of this opening chapter, Phillips subtly tenders implications of transcultural migration that he will explore in other ways throughout The Atlantic Sound: 
For one brief moment I imagine that a chapter in my own personal narrative has closed. I understand. I have arrived. I imagine - desire - closure. Finally I will be able to get the taxi that will whisk me towards the train station. Overhead, gulls wheel and circle as through inspecting this new arrivant; the ship, that is, not me. (16)

Phillips defies his desire for closure by introducing the image of the wheeling gulls. The birds circling the ship symbolize the pervasive circling around the question of arrivals and returns that informs the structure and poetic of The Atlantic Sound. Moreover, this incident orients the reader to the continuously whirling motions of the text as Phillips relates numerous tales of the anxieties and perils associated with the desire for a closed and unchanging sense of identity.

In "Leaving Home," Phillips creates a sense of disorientation as the narrative departs abruptly from present-day Dover and turns to nineteenth-century Africa. Switching genres and perspectives, Phillips's prose moves from firstperson observations to historical fiction as the discourse turns to the story of John Emmanuel Ocansey, a young man who travels from the shores of the River Volta in the British territory of the Gold Coast to Liverpool. This tale contains long digressions on the history of the city (28-30) and an analysis of the Middle Passage (30-36) which explore how the city's rising and falling fortunes are tied to the history of trade in persons and goods. Seeing Liverpool through Ocansey's eyes, Phillips offers an outsider's view of English society and provides a counter-hegemonic account of modernity. In the second part of "Leaving Home," the purpose of this historical fiction becomes clear as Phillips presents a parallel account of an outsider's visit to Liverpool, which takes the form of his current-day journey to the city. Reflecting on the dramatic transformation of football clubs in England, the treatment of black footballers serves as a benchmark for racism and bigotry in society. Phillips notes the hostility experienced by black footballers from the 1960 s to the 1980 , particularly so in the cases of West Ham United's Clyde Best and Liverpool's John Barnes. Although the 1990s saw a growing number of nonwhite players and even a black captain on the Liverpool team, Phillips probes the extent to which underlying racist attitudes have changed. The story of Liverpool's longstanding participation in the global economy and accompanying production of racist ideology sets the stage for a discussion of more recent events in the city's history of economic and race relations. Ultimately, Phillips diagnoses Liverpool as suffering from a dissonant sociopsychic condition characterized as "a cynical wit and a clinical depression in the souls of 
Liverpool's citizens" (93). Thus, the writer presents an alternative account of modernity retold through historical fiction as well as through a socio-political analysis of the vernacular of football. In connecting apparently unrelated local histories through time, the narrative discloses hidden connections between the past and present and shows the ways in which relations to the long history of globalization play a persistent role in shaping a sense of locality. In other words, Phillips's narrative provides the reader with a perspective on the past in order to navigate an interpretation of Liverpool's present course.

Vernacular culture plays an important role in reconstituting an understanding of history, particularly as Phillips explores the connections between football, social unrest in Liverpool, and the legacy of the slave trade. In an effort to learn more about the "suspiciously multiracial Liverpool" football club (77), Phillips describes an encounter with a young black activist named Stephen who belongs to a community referring to itself as Liverpool Born Blacks (LBBs). Phillips learns that LBB s pride themselves on their "long and continuous history in Liverpool as evidence of a certain authenticity" (87). Ironically, connections to the Black-Atlantic past and the slave trade are used to justify the politics of exclusion at work in attitudes towards other members of the black community. Refusing to recognize a shared history of migration, LBBs view the Windrush generation of migrants (88) and present-day African and Caribbean newcomers as "black outsiders" (87). For Phillips, the legacy of slavery is evident in the persistence of racist attitudes toward other ethnic groups. For instance, while Stephen distances himself from the LBBs' ideas to the extent that he criticizes the lack of solidarity with other black members of the community, he nonetheless shares their racist views concerning Jews, whom he sees as somehow responsible for the black slave trade (81). Stephen's hostility to a Jewish politician who supports solidarity among blacks and Jews is eventually situated in the context of his identity as an LBB, a community that forced the Jewish population out of its area of the city. Passing an abandoned synagogue in the LBB district, Stephen says to Phillips, "But then the Jews all moved out, if you know what I mean" (89). Phillips opposes entrenched concepts of identity and the 'us versus them' attitudes when he comments that Stephen's "undisguised glee" (89) at the ejection of the Jews is that of a Liverpool Born Black. Like Ocansey in the Liverpool of the nineteenth century, Phillips discovers that current-day attitudes about race in Liverpool are "at best uncomfortable, at worst insulting" (51).

Phillips's response to Liverpool is particularly noteworthy because it sets the stage for his critique of misguided yearnings for a sense of belonging or 
home, particularly as evidenced in the African diasporic communities of Ghana, Charleston, and the Negev desert. Of Liverpool, he concludes:

It is disquieting to be in a place where history is so physically present, yet so glaringly absent from people's consciousness. But where is it any different? Maybe this is the modern condition, and Liverpool is merely acting out this reality with an honest vigour. (93)

In "Homeward Bound," Phillips presents a number of stories about individuals whose quests for home, whether in Africa, the UK, the USA or elsewhere, bear an uneasy, divisive or forgetful relation to the historical past. For instance, Dr Ben Abdallah valorizes a pan-African theory of solidarity and defends the need to "look to the past" (115). Yet, at the same time, he contradicts this position by offering an oppositional account of African and African diasporic relations in the history of slavery. Abdallah divides the pan-African world into 'us' (Africans) and 'them' (those related to the history of slavery in the New World), arguing that members of the African diaspora should take responsibility for places related to the history of slavery because these sites do not mean the same thing for Ghanaians as they do for "you people" (118). Likewise, Phillips discovers contradictory, sometimes oppositional attitudes at work at Panafest, an event meant to celebrate solidarity but which induces a sense of "diasporan fatigue" (148). A series of uneasy episodes (such as the ungracious behaviour of the Jamaican guests in the hotel) serve to underscore divisions and cultural differences in the Black-Atlantic world. Often humorously, but sometimes despondently, Phillips describes various attempts to reclaim Africa as home. Ultimately, he is critical of people of the diaspora "who expect the continent to solve whatever psychological problems they possess" (172), who want Africa to cure them and make them feel whole. Likewise, he distances himself from those who "seem relieved to have been offered the opportunity to view history through the narrow prism of their own pigmentation" (178). The diasporan desire for belonging is seen as problematical when it is based on a solipsistic yearning for wholeness and affiliated with ways of thinking also found in racist societies "which define themselves by excluding others" $(98,176-77)$.

In response to these instances of exclusion, historical blindness, and wilful forgetfulness, Phillips introduces factual and fictional representations of the transcultural past, particularly through the genre of historical fiction, which he brings into dialogue with contemporary experiences of migration and racism. Through past-present dialogues, the text nudges the reader into an awareness 
of alternative ways of constituting modernity. For instance, in "Homeward Bound," he recounts the life of Philip Quaque, an African who was educated in the UK and returned to work in Elmina as a missionary. The author describes the man's letters as evidence of someone who has undergone loss: "The ambivalence, pain, and pathos of his letters signify loss. Loss of home, loss of language, loss of self, but never loss of dignity" (143). At the end of this section, Phillips pays homage to Quaque when he describes leaving Panafest and taking care to "step over, and not on, the tomb of Philip Quaque" (178). Similarly, in "Home," the life-history of J. Waties Waring offers a compelling example of someone who would rather feel homeless than be at home in a racially defined society. A white Southerner, Waring turned his back on his place in society and acted against the traditions of his community in order to uphold principles of integration. Consequently, he suffered "insults, $[\ldots]$ ostracization, and the mental anguish of being a pariah in the land that he loved" (205). Ultimately, he left the South because it was "simply too burdensome to be among those who openly hated you in a place you called 'home" (205). When Phillips visits Sullivan's Island, which he refers to as the "black Ellis Island" (207) - a remark that is ironic, considering that the former is a place of forced migration into slavery and the latter a site associated with voluntary citizenship - he reflects on the African experience of arrival in America. In contrast to this history of segregation and racism, he quotes from a transcript of Waring's 1951 speech to new citizens of America in which the judge presents a vision of the nation as a true cultural melting pot (207-209). The chapter ends with Phillips's account of the "Festival of African and Caribbean Art" in which he admires five young black women who "try to remember" (213). He notes that "history smiles" on this day when white men and women dance to the rhythms of Africa (213). Once more, the significance of the moment is refracted through historical memory, though this time through an awareness of "ghosts walking the streets" (213). The present is haunted by the past with all of the ambiguity this entails. On the one side, there is the vision of integration offered by Ellis Island as a place welcoming "your tired, your poor, your huddled masses yearning to breathe free" 32 and against this there is the memory of Sullivan's Island, where the tired and weary were welcomed by slavery. Accompanying the view of America as home to integration, democracy, and freedom (207-208), Phillips

\footnotetext{
${ }^{32}$ This quotation refers to the inscription found on a plaque inside the pedestal of the Statue of Liberty, which is located on Ellis Island in New York.
} 
offers us the ambivalent image of a world haunted by ghosts where the legacy of slavery is still palpable.

How does Phillips configure the relationship between home, migration, and history as a means of understanding our situation in the contemporary world? Far from providing any certain answers or solid ground, The Atlantic Sound ends, in "Exodus," with an image of people wandering in the desert, yearning to be free, longing to go home. Drawing on his trans-Caribbean history, Phillips recalls the motif of the voyage by ship, taking the reader on an imagined journey from the slavery of Israel to that of the New World. Recounting the story of his visit to Dimona, Israel, where an African-American community of residents "have come home" (216), Phillips rejects this vision of a "New World Order" (216). Rather, he refers to the past as surging like a mighty river that empties into the present, implying that it is futile to ignore or go against this downstream current (220). Drawing on the image of a vast journey across the waters where the ship's passengers bring their cultural baggage, he envisions a new kind of middle-passage voyage that does not come to a definitive end or offer closure. In response to a Minister's request urging him to admire this Israeli landscape of home, Phillips's response is one of outward silence and inner dissent. Gazing at the landscape of Israel, he remarks:

There is nothing I can say. You were transported in a wooden vessel across a broad expanse of water to a place which rendered your tongue silent. Look. Listen, Learn. [...] Remember? There were no round-trip tickets in your part of the ship. Exodus. It is futile to walk into the face of history. As futile as trying to keep the dust from one's eyes in the desert. (220-21)

For him, "Exodus" is not a reverse journey from slavery to the homeland but an ongoing movement of the people. ${ }^{33}$ Instead of Israel as home, Phillips reconfigures this landscape as a metaphor for the wilfully blind attempt to return home, walking with the sands of time blowing in one's eyes. The diasporic desire to return to a home that never existed is underpinned by a disavowal of past-present horizons. Instead of a rejection of the past, Phillips evokes the need for continuous investigation into the relations between past and present. He gestures toward an imaginative horizon where the space of continuous drifting and looking backwards becomes purposeful and serves as the 'source' for dialogue about the present and our future course. He revisits

\footnotetext{
${ }^{33}$ Bob Marley's song "Exodus" refers to the "movement of jah people," but Phillips offers a secular view of this theme.
} 
the lesson already repeated in Crossing the River: "There are no paths in water. No signposts. There is no return." 34

In a globalizing world where the processes of decolonization continue to unfold, Phillips's fluid narratives, poetic of (dis)orientation, and disjunctive textual manoeuvres reconfigure temporal and spatial relations through pastpresent dialogues. In taking up the themes of mobility, migration, and diasporic identity, Phillips is particularly attentive to the long history of transnational currents, interracial relations, and cross-cultural formations. More often than not, he highlights failures to connect and foregrounds the need to rethink the meaning of community and the workings of society. Rather than relying on the solidarities of race or rooted concepts of community, Phillips analyzes ways in which individuals come into contact with one another through trade and travel. He explores the past in search of alternative accounts of the local and discovers forgotten, lost, and overlooked relations in and to the world; he scrutinizes the ways in which individuals struggle to come to terms with migration and xenophobia. In short, he calls into question the meaning of 'home' and constructs of locality through time. Slavery and the Middle Passage are not remote incidents but are present and palpable in the lives of those who continue to grapple with legacies of the past. History emerges as a fluid entity that needs to be navigated anew. Mysterious, ambivalent, the past contains disturbing ghosts, secrets, and half-truths.

Through a shifting, disjunctive poetic, Phillips calls upon his readers to confront the spectral colonial presences that continue to haunt a transnational and globalizing world. He discloses numerous ways of configuring and reconstituting affiliations among phantasmagoric, imagined, and socio-politically constituted geographies through time. In the shifting marine interlacings of his narratives, there is no single map of the past or easy way of orienting oneself towards the future. Anxious dialogues, difficult conversations, and uneasy encounters heighten a sense of discomfort and ambiguity. All of these apprehensions contribute to the representation of a world where a sense of displacement and unbelonging is pervasive. Phillips demonstrates that it is futile and reactionary to yearn for a nation or a place in which one feels fully at home when that sensibility is informed by the politics of exclusion, race-oriented affiliations, disavowals of history or resistance to the constant transformations taking place in the global order. Instead, he opts for a purposeful, critical, and imaginative drifting in the world. His disquieting narrative interventions and

${ }^{34}$ Phillips, Crossing the River, 1-2, 237. 
interior monologues represent an often ironic, typically ambivalent, and multivocal response to the myriad visions of home he encounters on many voyages, imagined or real, in the long history that has shaped our new world order.

\section{WORKS CITED}

Appadurai, Arjun. Modernity at Large: Cultural Dimensions of Globalization (Minneapolis: U of Minnesota P, 1996).

Benitez-Rojo, Antonio. The Repeating Island: The Caribbean and the Postmodern Perspective, tr. James E. Maraniss (La isla que se repite: el Caribe y la perspectiva posmoderna, 1989; Durham NC \& London: Duke U P, 1992).

Bhabha, Homi K. The Location of Culture (London \& New York: Routledge, 1994).

Dash, J. Michael. The Other America: Caribbean Literature in a New World Context (Charlottesville \& London: UP of Virginia, 1998).

Gilroy, Paul. The Black Atlantic: Modernity and Double-Consciousness (Cambridge MA: Harvard UP, 1993).

Hall, Stuart. "Conclusion: The Multicultural Question," in Un/Settled Multiculturalisms: Diasporas, Entanglements, Transruptions, ed. Barnor Hesse (London \& New York: Zed, 2000): 209-41.

. "A Conversation with Stuart Hall," Journal of the International Institute 7.1 (1999): http://hdl.handle.net/2027/spo.4750978.0007.107 (accessed 31 July 2009).

Knauft, Bruce, ed. Critically Modern: Alternatives, Alterities, Anthropologies (Bloomington: Indiana UP, 2002).

Ledent, Bénédicte. Caryl Phillips (Contemporary World Writers; Manchester: Manchester UP, 2002).

Machado Sáez, Elena. "Postcoloniality, Atlantic Orders, and the Migrant Male in the Writings of Caryl Phillips," Small Axe 17 (March 2005): 17-39.

Marley, Bob. "Exodus," Exodus (Island/Tuff Gong, 1977).

Phillips, Caryl. The Atlantic Sound (London: Faber \& Faber, 2000).

- Cambridge (London: Bloomsbury, 1991).

Crossing the River (London: Bloomsbury, 1993).

" "Crossing the River: Caryl Phillips talks to Maya Jaggi," Wasafiri 20 (1994):

25-29.

. A Distant Shore (London: Secker \& Warburg, 2003).

. The European Tribe (London: Faber \& Faber, 1987).

The Final Passage (London: Faber \& Faber, 1985).

. The Nature of Blood (London: Faber \& Faber, 1997).

"Necessary Journeys," Guardian (11 September 2004): http://www.guardian .co.uk/books/2004/dec/11/society2 (accessed 31 July 2009). 
- A New World Order: Selected Essays (London: Secker \& Warburg, 2001).

"Other Voices: An Interview with Caryl Phillips" (October 2001), by Stephen Clingman, Salmagundi 143 (2004): 113-40.

. Strange Fruit (Ambergate: Amber Lane, 1981).

Zierler, Wendy. " 'My Holocaust is not your Holocaust': 'Facing' Black and Jewish Experience in The Pawnbroker, Higher Ground, and The Nature of Blood," Holocaust and Genocide Studies 18.1 (Spring 2004): 46-67. 


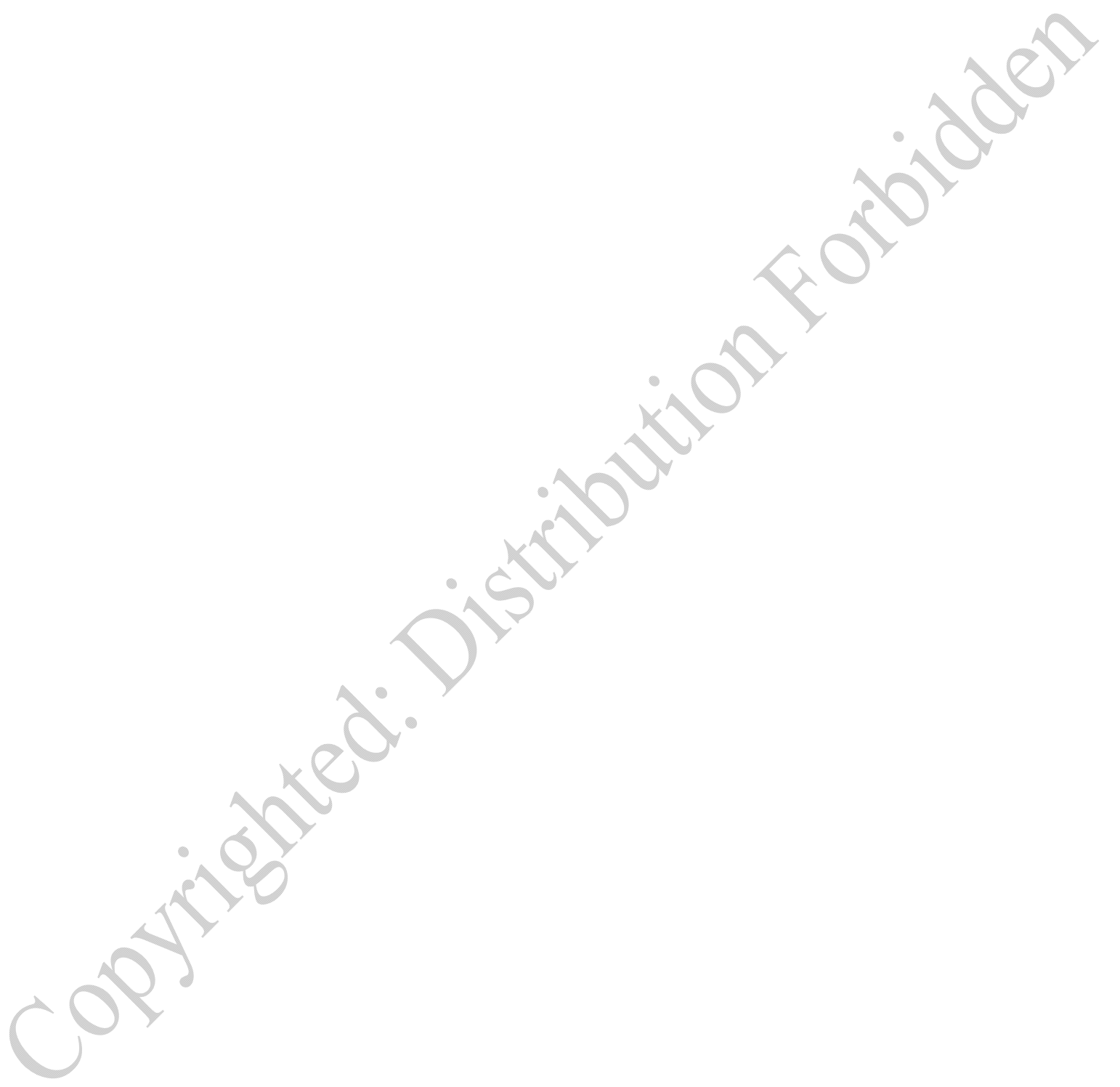




\title{
The Dis-ease of Multiple Identities The Nature of Diasporan Identity in Caryl Phillips's Strange Fruit
}

\section{CHIKA UNIGWE}

\author{
Southern trees bear a strange fruit \\ Blood on the leaves and blood at the root \\ Black bodies swinging in the southern breeze \\ Strange fruit hanging from the poplar trees. \\ Pastoral scene of the gallant south \\ The bulging eyes and the twisted mouth \\ Scent of magnolia, sweet and fresh \\ Then the sudden smell of burning flesh. \\ Here is a fruit for the crows to pluck \\ For the rain to gather, for the wind to suck \\ For the sun to rot, for the tree to drop \\ Here is a strange and bitter crop. ${ }^{1}$
}

ARYL PHILLIPS WAS BORN IN 1958, in the small village of St Paul's in the Caribbean Island of St Kitts. Between 1948 and 1958, one hundred and twenty-five thousand people migrated from the Caribbean to Britain, in search of a better life. Phillips's parents were part of that throng, along with their three-month-old baby, Caryl. The family moved to Leeds, where the parents would go on to have three more sons. In order to give their four sons the best possible chance in their new home, Phillips's parents chose to downplay their Caribbean origin. Like many immigrants of their generation, they tried to be as English as they could possibly be and

\footnotetext{
${ }^{1}$ Billie Holiday, "Strange Fruit," song by Lewis Allan (Commodore Records, 1939).
} 
encouraged their children to be so, too. Owing to a combination of his parents' divorce and his mother's illness, Phillips and his brothers were at some point fostered out to white families. In the light of this, it is not surprising that the most prevalent motif in all of the writer's works is displacement and the notion of home(lessness). His characters are constantly grappling with fitting in, with creating 'homes' even in their homelessness, and they are perennially plagued by marginalization in the communities they find themselves in. They are also constantly negotiating identity and their position as outsiders-insiders in their society. It is as if, in his works, Phillips were aiming at re-examining his Caribbean past and his multicultural present; a present which is fluid, defying the notion of a single fixed home, but which nevertheless does not make the yearning for a 'home' any less real. He carries the burden of both his past and his present, and seeks, as it were, to unburden that history in words. In a writing career that has so far spanned almost thirty years of active cross-genre writing, Phillips's works have mainly been steeped in the exploration (of issues) of identity, of isolation, of belonging and unbelonging, and, as mentioned above, of the notion of home(lessness). I agree with Bénédicte Ledent when she asserts that "his approach to literature is clearly [...] an attempt to come to terms with his own experience and use it as a catalyst for his imagination, even if the act of writing is hardly a panacea for the tensions faced by the exiled artist." ${ }^{2}$

I have chosen to examine one of Phillips's early works which deserves, but has not received, as much critical attention as his more recent pieces: Strange Fruit (1981), his first play. I am interested in this text because drama, as a genre, is the one that Phillips has concentrated on least, but also, and mainly, because Strange Fruit is his debut, coming four years before his first novel, The Final Passage (1985), and as such laying the foundation, as it were, for Phillips's recurring themes.

- Strange Fruit evokes quite consciously the title of the famed Billie Holiday signature song, "Strange Fruit," a protest song written by Lewis Allan (whose real name was Abel Meeropol) in 1938, and which was inspired by photographs he saw of the lynching of two African Americans, Thomas Shipp and Abram Smith. At the time his play was published, Phillips was unaware of the full history of Holiday's "Strange Fruit," as he admits in his 2007 essay "Blood at the Root." However, he knew that Holiday's song made reference

\footnotetext{
${ }^{2}$ Bénédicte Ledent, Caryl Phillips (Contemporary World Writers; Manchester: Manchester UP, 2002): 1.
} 
to racially motivated violence in America, and this was partly why he named his play after it. ${ }^{3}$

The title is indicative of the theme of the play. The phrase "strange fruit" is polysemous, referring at once to the figurative lynching of diasporan blacks in Britain and at the same time to the feeling of unease among black Britons who belong neither here nor there, and for whom home is not as easily identifiable, or definable, as may appear at first sight. These are people for whom, Phillips seems to suggest, Britain can become as dangerous as a lynching mob when they eventually confront it. In the play, these themes are explored through the story of a Caribbean woman, Vivien, who moves to Britain with secrets and dreams. Like many before her, she has made the journey to ensure a better life for her two sons.

The play is introduced with a 'warning' by the author on the mélange of voices:

a careful mixture of West Indian English [...], Standard English, and English working-class regional dialect. In the language one should be able to detect the socio-cultural confusion which undermines any immediate hopes of harmony within the body politic of the family. ${ }^{4}$

In the language(s), one can detect the fragmentation of the diasporan spirit, which does not augur well for any "immediate hopes of harmony." Appropriately, the play looks at the vast theme of black diaspora through the specific prism of five characters: Vivien; her sons Errol and Alvin; Shelley, Errol's white girlfriend; and Vernice, a family friend and fellow West Indian. The major players are the triumvirate of mother and two sons: it is chiefly through them that Phillips identifies and explores the effects of the diasporan condition on individuals. They each deal with their collective experiences in different ways. While leaving her native island was a conscious choice for the mother, her sons have immigration foisted on them. It is also through these three characters that I propose to read the play as an exploration of the disease of diasporan identity.

When the play starts, Alvin is away in the Caribbean. It is his first visit since the family moved to Britain while he was still a toddler. He is attending his maternal grandfather's burial, in place of his mother, who cannot (or will

\footnotetext{
${ }^{3}$ Caryl Phillips, "Blood at the Root," Guardian (18 August 2007): http://www.guardian .co.uk/books/2007/aug/18/jazz.urban (accessed 3 August 2009).

${ }^{4}$ Caryl Phillips, Strange Fruit (Ambergate: Amber Lane, 1981): 5. Further page references are in the main text.
} 
not) make it. It is implied that he has also, like many immigrants, gone in search of his roots. Feeling restless in a country he does not accept as his own, he hopes that a visit to the homeland will cure him. Errol, who feels as dislocated as his brother, stays back in Britain. He is depicted as an indecisive, volatile young man, given to illogical and impulsive acts of violence against his white girlfriend. He suffers from what I term 'diasporan dis-ease' and seeks ways of healing himself, one of which is by asserting an affinity with his mythic homeland, an amorphous, homogeneous Africa that has absolutely no bearing in reality. He is a member of a black brotherhood, but he does not always feel entirely comfortable there. We are told that "he will occasionally pin on a badge of protest only to remove it a few days later thinking that he's 'sold-out'. He can't decide whether or not to grow an Afro" (18-19). He is floundering in his search for an identity that entirely negates the world he lives in, and often comes across as simply spouting ideological cant that he neither fully understands nor, for that matter, appreciates. He is twenty-one, with a university degree in economics, but refuses to work. In one conversation with his mother, he talks about the "march [to] Africa" which prevents him from getting a job:

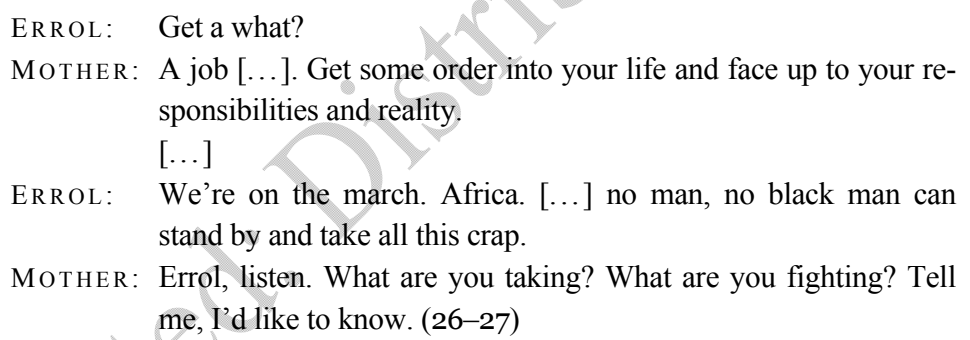

But Errol is unable to articulate his dis-ease and instead he just spews vitriolic ideology. In claiming that he lives in "a world of reality" (20), he fails to see how far removed from reality he actually is. He is cynical about the society he is growing up in, certain that the English are making fun of blacks but claiming that urban blacks are selling out. He sees conspiracy everywhere, and this is made even more evident when he ridicules a black newscaster:

"Today sixty-eight youths were sentenced for conspiring to stand on a street corner... All sixty-eight were black." It's only when you look up that you realise it's a bleeding black newscaster talking. Bloody Uncle Tom. (23)

It is obvious that he thinks that, by getting a decent job, he will become another "bloody Uncle Tom." He does not see the quandary he has created for 
himself: he complains about the white community systematically keeping the black "brothers" down, yet a black "brother" who makes it in the white world against all odds is a sell-out. He asks his mother:

I mean what do you want me to do? Go work for the CRE [Commission for Racial Equality]? Join the police? Stand for Parliament? Or perhaps you want me to make a bid for Trevor McDonald's job and spend the whole day talking shit on the television! (26)

Errol has trouble dealing with reality, especially with the fact that the Britain he lives in is heterogeneous. He does not believe in this diversity. He believes even less that this heterogeneity should be encouraged. As far as he is concerned, every white man is an enemy, his girlfriend Shelley's father is a "redneck" (35), and "mixed bands are a disgrace" (41): "What we want is black bands. Black producers and arrangers and black singers to do their own thing. Black businessmen means black music" (41). Errol advocates communities where there is no race-mixing - which is ironic, considering that his girlfriend, Shelley, is white. One possible explanation for this paradox is that, through Shelley, he exercises some sort of power over the white community that he seems to despise so much. After all, their relationship is less than ideal. Each time he is violent with her, each time he humiliates her, he is exacting revenge on the degradation that he and fellow black people have suffered at the hands of the whites. He refers to her as an "historical phenomenon" (39), some sort of synecdoche for the white race. She is the vicarious tool through which the colonial masters are subdued and beaten by the colonized 'native'. Errol uses his sexuality as a weapon of that domination. This, in a way, becomes his manner of 'striking back' at the empire. His lovemaking with Shelley is violent. They have sex, and after he reaches orgasm he literally throws her out, laughing at her suggestion that she come to Africa with him: "I don't need no white woman to dangle on a string to show I'm free" (44). Elsewhere, he also tells her

you don't control shit anymore. You don't control the land, the money or the mind. Now you're the tool and we're the craftsmen. Look around the world. Suddenly you're all frightened. There are more black Prime Ministers than white ones. There are more black people than white people. You're a minority - a sickening minority at that. (38)

Errol will use every means within his power to hang on to an illusion of power, and his hold over Shelley is the symbol of the power he has over her race. It is obvious, to judge by the way he talks of Alvin, that he admires his 
older brother. He shows off the latter's African, dashiki outfit to his girlfriend, and a pair of sunglasses he claims his brother got off a Black Panther:

You've never seen anyone wearing these, or any like 'em. These specs aren't for wearing. He got 'em off a Black American GI who knew Huey Newton. They're Huey Newton's dark glasses. Genuine Panther specs. (33)

However, when Alvin returns from his native island, he is no longer the man his brother remembers. It soon becomes clear that the trip has been his road to Damascus. He comes back a changed man, much to the chagrin of Errol; his hero has crumbled. Not only is Alvin refusing to "[talk] black" (62), but he is also unsure about the strike that the Black Front has got planned as part of its protest against the white community. Alvin thinks the plan to boycott everything British, refuse to go to work, stay off the transport, might provoke a backlash:

Well, think of this then, and just imagine it. Two old men sat on a park bench an hour ago, or in two hours time or any time tomorrow. One says to the other: "Just like old days, eh? Glad to be rid of the black bastards." Other one agrees, "Aye, pity we can't have this permanent. You know, all the time. No blacks in sight." They think for a while and then one says to the other: "I suppose we could, couldn't we?" "Yeah, we could," he says back. "Where do you find the number of the National Front? Oh I know. Let's look it up in the white pages." The pair of them get up and go off to fucking do something about it. (65-66)

He, more than his brother, realizes that

These two old men, what they don't know is [...] isn't it inconvenient that the buses and the tubes $[\ldots]$ are running a reduced service. What they don't think is $[.$.$] without the black doctors and nurses in this country the hospi-$ tals face a crisis $[\ldots]$. These aren't problems to worry about $[\ldots]$; they're a challenge. They can, and will, be solved as quickly as possible, even if it means bringing in the fucking army. (66)

Errol will not be pragmatic and ends up accusing his brother of inauthenticity and of "turn[ing] white en route" (65). He will not accept a Britain where blacks cannot live in an isolated community. He will much rather live with the exaggerated idea that Britain will grind to a halt if its black community boycotts the country for a day. There is no room in his vision for heterogeneity, which, whether he likes it or not, is the reality of the Britain he lives in. His brother's case is slightly different, for Alvin realizes that there is no simple 
solution - this, in my view, cannot be interpreted as a case of confusion, as Ulla Rahbek asserts, ${ }^{5}$ but, rather, as one of revelation. Indeed, Alvin is anything but confused; he simply becomes aware that the alternative reality he seeks is not possible.

It is only later that we discover that Alvin's Caribbean trip has not gone exactly as planned. It is not a place of spiritual rebirth, as he had anticipated, but a great disappointment. He does not receive the warm welcome he expected. The 'home' he has come to does not welcome him; it does not, in fact, recognize him, or regard him as one of its own. He has to feed himself, buy his own food. No one talks to him, and after the funeral, his uncle tells him quite matter-of-factly to get out and to tell his mother that her mother never wants to see her again. So, his mother, who is his direct link to the Island, is not even welcome there anymore. He has to accept that his roots are somewhere else. That home is not necessarily where the heart is:

And then when I tried to talk to them, our own relatives, not just any black people, you know how they treated me? Like a stranger in a very strange land, and that's how I felt. Alone, man. They don't see it like we do over here. (69)

His mother's family's rejection of him can be extrapolated into the island's rejection of him as well. The trip opens his eyes to the fact that his original vision of his parents' homeland was utopian. This is the revelation that many migrants who, having idealized the homeland they have never been to, experience when they eventually visit. In addition, the Island is riddled with corruption: "Smuggling at customs was so open and institutionalised, I couldn't believe it. I was too ashamed of my own people to write down what I found" (80). There is unemployment, inflation, poverty. Alvin is not accepted as a prodigal son returned, but perceived as a stranger, "a victim" (71). To deal with the rejection, he gives up on both family and the notion of a home being anywhere else but in Britain. He tells his brother:

[when] the shit hits the fan [...] you're going to have to run somewhere for cover, and if your own family won't give it to you, and there's no refuge in your place of birth, then where the fuck are you gonna go? Well? (70)

\footnotetext{
${ }^{5}$ Ulla Rahbek, “'I am 200 years old now, and getting older’: Blackness in Caryl Phillips's Plays from Strange Fruit to The Shelter," in Dialoguing on Genres: Essays in Honour of Andrew K. Kennedy on his 7oth Birthday, ed. Ulf Lie \& Anne Holden Rønning (Oslo: Novus, 2001): 114.
} 
He will much rather fight to gain respect in Britain than fight for a return to an idyllic homeland that does not exist. He believes that his future and that of those like him is in Britain, even while he realizes that this comes with its own problems: "This place, Britain, is full of shit, but where else is there?" (85). However, this is a vision that, like his brother's, ignores the possibility of his making a home elsewhere. He is reminiscent of the African-American Washington Post journalist, Keith Richburg, whose controversial book Out of America (written after he had spent three years in Kenya) Phillips quotes from in an essay in $A$ New World Order:

Talk to me about Africa and my black roots and my kinship with my

African-American brothers, and I'll turn it back in your face, and then I'll rub

your nose in the images of the rotting flesh. ${ }^{6}$

This seems to be what Alvin feels about the Caribbean and about any form of solidarity based on pigmentation. Errol has not left the house on the day of the supposed strike, and so Alvin tells him that black people on the streets are going on about their business as usual. The solidarity Errol had hoped for is non-existent; the plan to get all black people together for a massive strike was never going to work. Clearly, Errol's relationship to history, both personal and public, is problematical: he has inadequate knowledge of black history and a minimal knowledge of his own background. Up until when the story ends, he does not realize that everything he knows about his father is lies made up by their mother, who thinks she is protecting her children from a cruel truth. Like his vision of Africa, his vision of his father is an idealistic one that is hardly rooted in reality.

The brothers' different attitudes to the idea of a mythic homeland, on the one hand, and their relationship to Britain, on the other, are probably symptomatic of the difference in their personalities, but also, more pertinently, of their lived experiences. For Alvin, monoculturalism is not the answer; he realizes that, for the African in the diaspora, there is no simple solution. He states the quandary aptly when he tells his mother:

I can't live here, I can't live there. What am I supposed to do? What we supposed to do? Live on a raft in the middle of the Atlantic at a point equidistant between Africa, the Caribbean and Britain? [...] Lost between two waves, yet another black generation is dispossessed. (98-99)

\footnotetext{
${ }^{6}$ Keith B. Richburg, Out of America: A Black Man Confronts Africa (New York: Basic Books, 1997): xvi, quoted (with "turn" for Richburg's "throw") in Caryl Phillips, A New World Order: Selected Essays (London: Secker \& Warburg, 2001): 92.
} 
This passage finds striking echoes in Phillips's essay-collection A New World Order (2001). In the introduction to the book, the author writes eloquently of how "history dealt [him] four cards; an ambiguous hand"7 : homes from Leeds to America to Africa and to the Caribbean; homes he recognizes but does not feel at home in because he does not belong. This is the dilemma of the diasporan individual, which Alvin recognizes. There is no single 'home' for him, either, as each comes with its own problems of belonging. In A New World Order, the makeshift raft in the middle of the Atlantic mentioned in the early play has given way to a fluid "Atlantic home,", a watery crossroads between Britain, Africa, and North America where the writer would like his ashes to be scattered. Alvin's impossible 'home', in other words, can be said to have undergone symbolic re-articulation in Phillips's later work. However, even with this suggestion, the author's aim is not to provide a facile cure to the diasporan subject's dis-ease - most obviously, because the underwater home can actually be inhabited only in death.

If Alvin struggles to call Britain 'home', his mother initially sees the country as a safe haven, a sanctuary where she hopes to belong. In Phillips's more recent novel A Distant Shore (2003), the African, Solomon, also escapes to an England in which he expects to find refuge: he has been a witness to horrific wars, has watched his family being killed, and has also committed acts of violence himself. England is a chance for him to wipe the slate clean and begin a new life. However, there is a huge disparity between expectations and reality. Solomon feels marooned, unwelcome in England, the same way as Vivien does. She has turned her back voluntarily on the Caribbean and, regardless of how difficult it gets, she will try to make a living in Britain. She keeps in touch with her native island via her friends and the church but is determined never to go back there. However, Britain is not welcoming. She confesses this when she recounts to her friend, Vernice, the first time she sees snow:

I was lost. I opened a gate and knocked at a door. I saw the curtain move but I had to ask. A woman of my age opened the door except she was white. "Excuse me please, but which is the way back to town, please?" No answer. "Excuse me please, but..." She spat in my face and my stomach rushed into my mouth as I was sick. She screamed and a man ran out and punched me in the face. He dragged me out of the gate, onto the pavement, and threw me

\footnotetext{
${ }^{7}$ Phillips, $A$ New World Order, 4.

${ }^{8}$ A New World Order, 304.
} 
onto the grass verge. [...] Then it began to snow. I'd never seen snow before but I'd always thought that when it did snow - when I did get to England and see snow - it would be the happiest moment of my life. Nature's most beautiful costume and I'd never seen it. $\left(5^{1-52)}\right.$

It is only when Alvin gets back from the Caribbean that his mother tells him the real reason for her relocation to Britain: an escape from a miserable marriage; a marriage in which their father drank and bullied her. The man, seeing his chance of being a black cricket captain fall through, and witnessing his fellow players' betrayal (they went on tour without him, having accepted a bribe), turned to drink and took out his anger on his wife. However, Britain provides only a physical escape. It puts a spatial distance between her and the island where she was unhappy, but it does not bring the expected sense of fulfilment, as her friend, Vernice, reminds her: "Happy! Like when the hell the last time we both happy together? I mean the botha us really happy? Never in England, no" (90). Yet, Vivien fights to fit in. Like Phillips's parents, she chooses to downplay her Caribbeanness, causing Vernice to accuse her of "[thinking] too white" (31). She speaks 'proper' English and holds down a job. As Vernice reminds her,

in all the years you been here girl, you ain't get off your backside to go down the Caribbean Club, let alone get yerself on a boat or a plane to go and see yer own fockin' family. (30)

And when Vivien realizes how futile her efforts have been to fit in, and to have her children fit in, she gives up. She complains to Vernice:

I just work my damn fingers to the bone for twenty-five and odd years, doing everything from typist to teacher so they have two crusts of bread on their plate and clothes on their backs. I just take them to a country halfway round the world, where they can live and grow up, I just turn my back on my own family for them, I just love once, just once for them. (98)

The hopelessness of her sacrifice deprives her of the will to fight, and she allows Britain to kill her. She presumably dies from the drug overdose she takes at the end of the play when her children abandon her. Not only has England taken her dignity, it has swallowed the two people she cared for the most: Errol seeks solace in a mythic Africa he cannot go to - he does not even have a valid passport, because when he applied for one, he put down "The Dark Continent" as place of birth, and "African" as his nationality (99), thereby ironically echoing Western clichés of uniformity - while Alvin, being 
more pragmatic, grudgingly accepts, as he realizes that he must, Britain as his sole home, and it is implied that this will destroy him, too, because this is not a choice that he makes voluntarily. It is, like his migration, forced on him. It is the only option left to him, as he has no other home.

Strange Fruit suggests that the confrontation of the Caribbean (and, by extension, that of all the former colonies) with the old colonial power as 'home' can at best be ambivalent. It re-examines the notion of belonging and identity and provide no comforting solution. It sees displacement as a personal experience, questioning types of essentialist solidarity that are - like pan-Africanism - based on skin colour. It also explores the place of the African in the diaspora and cautions against the romanticization of history or of origins. The strength of Strange Fruit lies in its subtle advocacy for the diasporan soul of the notion of 'home' as something fluid, so that it does not become dyspeptic or even suffocating; migration should transform the migrant without annihilating him, so that he is able to carry his multiple identities with ease.

Significantly, none of the characters in the play achieves this awareness, and it is thus no surprise if Phillips returns both to this quest for identity and to the issue of blackness in his later novels and essays. His protagonists often struggle with the dis-ease of not having a homeland to call their own, on the one hand, and with the dis-ease of racism, on the other. This dual malaise is the underlying currency that binds Phillips's oeuvre, regardless of what century or continent his books are set in. Put differently, his work repeatedly displays a preoccupation with what Rahbek has called the "quest for illumination of the meaning of blackness and belonging." 9

Phillips creates characters who are confronted with indignities in Britain or America. Yet the writer does not advocate a mass return to the homelands; rather, he suggests that the imagining of 'home' as a fixed geographical location can at best be problematical. Thus, as Phillips seems to suggest repeatedly, the dis-ease which migration and relocation entail can perhaps only be salved by a realization that we carry our homes within us.

\section{WORKS CITED}

Holiday, Billie. "Strange Fruit," song by Lewis Allan (Commodore Records, 1939).

\footnotetext{
${ }^{9}$ Rahbek, "“I am 200 years old now, and getting older',” 123.
} 
Ledent, Bénédicte. Caryl Phillips (Contemporary World Writers; Manchester: Manchester UP, 2002).

Phillips, Caryl. "Blood at the Root," Guardian (18 August 2007): http://www.guardian .co.uk/books/2007/aug/18/jazz.urban (accessed 3 August 2009).

. A Distant Shore (London: Secker \& Warburg, 2003).

. The Final Passage (London: Faber \& Faber, 1985).

A New World Order: Selected Essays (London: Secker \& Warburg, 2001).

Strange Fruit (Ambergate: Amber Lane, 1981).

Rahbek, Ulla. “ 'I am 200 years old now, and getting older': Blackness in Caryl Phillips's Plays from Strange Fruit to The Shelter," in Dialoguing on Genres: Essays in Honour of Andrew K. Kennedy on his 7oth Birthday, ed. Ulf Lie \& Anne Holden Rønning (Oslo: Novus, 2001): 113-25.

Richburg, Keith B. Out of America: A Black Man Confronts Africa (NewYork: Basic Books, 1997). 
BRITAIN AND ITS 'OTHERS' 


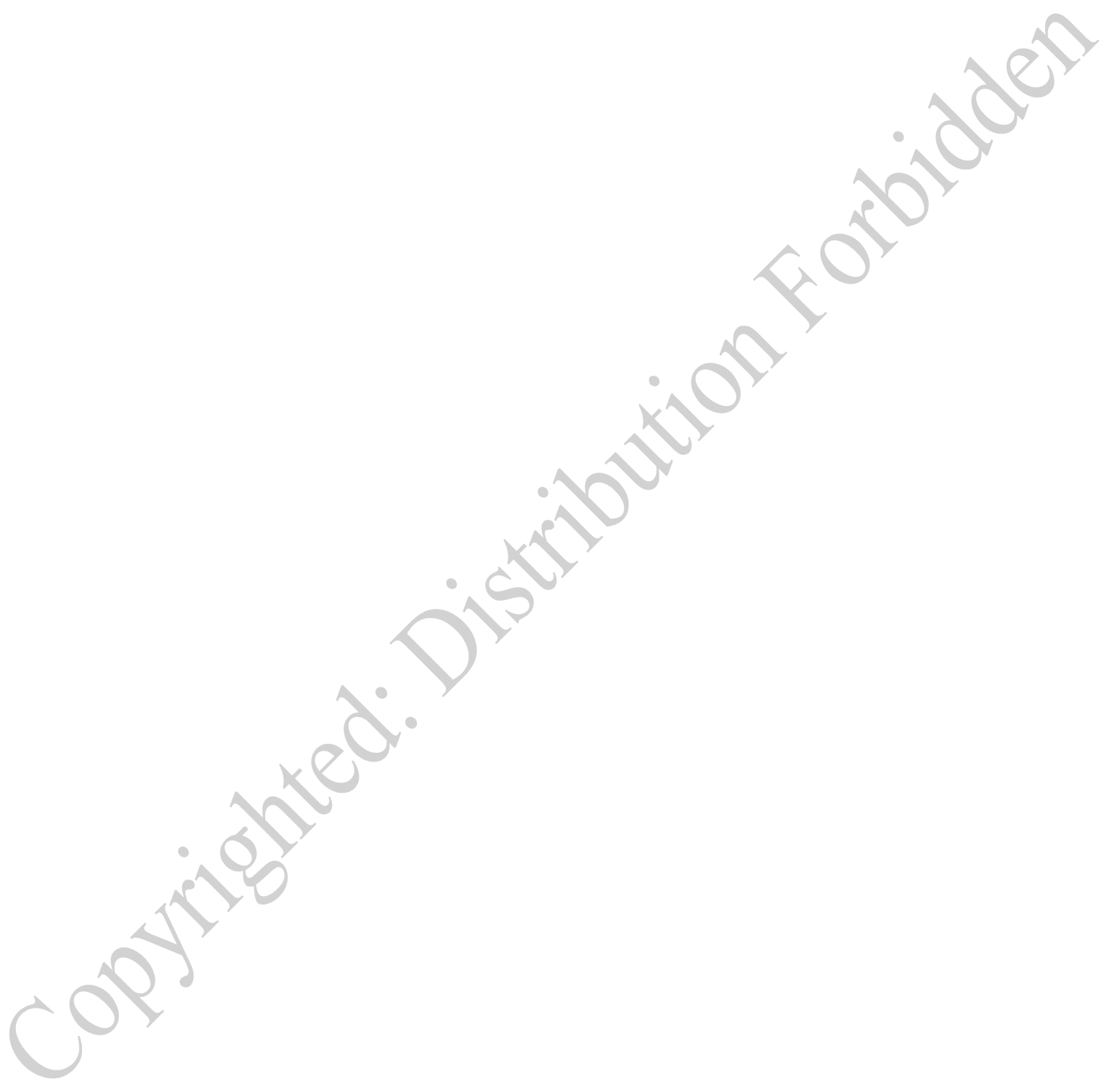




\title{
A New World Tribe in Caryl Phillips's A Distant Shore
}

\author{
AlessandRa DI MaIO
}

N MORE THAN ONE OCCASION, THE RENOWNED SOMALI AUTHOR

Nuruddin Farah has stated that writers from different times and places have one thing in common: their works occupy "territories" corresponding to human preoccupations. Farah has often lamented that the terrain of civil wars in Africa is among the still unexplored territories in the realm of fiction. ${ }^{1}$ Although a number of narratives have recently attempted to compensate for this deficiency - such as Chris Abani's Song for Night, Ishmael Beah's A Long Way Gone, Emmanuel Dongala's Johnny Mad Dog, Uzodinma Iweala's Beasts of No Nation, and Ahmadou Kourouma's Allah Is Not Obliged, all with child soldiers as protagonists - African civil war continues to be a largely uncharted field in literature. It would seem, however, that it is not the only one that remains to be mapped out.

Not long ago, in an article in the Guardian revealingly titled "Kingdom of the Blind," Caryl Phillips pointed out that white British writers have not appeared to pay much attention to the fact that their society had become increasingly multiracial since the fall of the Empire, in the 1950s. ${ }^{2}$ As he explains,

the 'colour problem' was debated in parliament, on television, in newspapers, magazines, on the radio. It was the big story of the 50s. Yet where is it represented in the literature? ${ }^{3}$

\footnotetext{
${ }^{1}$ Nuruddin Farah, keynote speech, African Literature Association Annual Conference, University of California at San Diego (2002).

${ }^{2}$ Caryl Phillips, "Kingdom of the Blind," Guardian (17 July 2004): 2-4.

${ }^{3}$ Phillips, "Kingdom of the Blind," 2.
} 
Among the few exceptions, Phillips quotes Colin MacInnes, the author of the well-known 'London trilogy ${ }^{4}$ portraying youth culture and social change in the years leading to the 'swinging Sixties', and of the collection of essays England, Half English (1961) - which is, as Bénédicte Ledent points out, indirectly referenced in Phillips's novel discussed in this essay. ${ }^{5}$

The situation seems not to have evolved significantly since the 1950 . "White writers have continued to write about Britain without seeing any black faces," remarks Phillips. ${ }^{6}$ Black characters, milieux, and concerns have been offered almost exclusively by "non-white writers" from the former colonies, or by their British-born children and grandchildren. "The lack of any reciprocal imagining on the part of white British writers is puzzling," Phillips continues. "The omission of black people from the literary landscape is so glaring it does beg questions about the politics of literary representation." ${ }^{.7}$ In sum, Phillips exposes another artistic 'territory' that calls for attention.

Why, we may wonder with Phillips, have white writers neglected to depict what has been happening on the streets of Britain, which have been visibly and increasingly teeming for over half a century with " ' dark strangers' who were both of, and not of," the country? ${ }^{8}$ Why have two sorts of "national literary canons' formed - one white, mostly blind to Britain's multiracial society, and a non-white one, challenging the traditional notion of a homogeneous British national literature?

\footnotetext{
${ }^{4}$ See Colin MacInnes's City of Spades (London: MacGibbon \& Kee, 1957), Absolute Beginners (London: MacGibbon \& Kee, 1959), and Mr Love and Justice (London: MacGibbon \& Kee, 1960).

${ }^{5}$ Via Billy Bragg's eponymous CD, whose track "Distant Shore," "spoken in the voice of an asylum seeker," in turn inspired Phillips's title. See Bénédicte Ledent, " 'Of, and not of, this Place': Attachment and Detachment in Caryl Phillips' A Distant Shore," Kunapipi 26.1 (2004): 152-60

"Phillips, "Kingdom of the Blind," $2-3$.

7 "Kingdom of the Blind," 3.

8 Besides being present in the article "Kingdom of the Blind," the phrase "of, and not of" recurs in A New World Order (2001), where Phillips, in the autobiographical reflections on his four 'homes'/cardinal points - Africa, the Caribbean, Britain, and the US A - remarks, "I recognise the place, I feel at home here, but I don't belong. I am of, and not of, this place." Caryl Phillips, A New World Order (London: Secker \& Warburg, 2001): 4. However, this phrase was first introduced in the Author's Foreword to the 1992 re-edition of The European Tribe, where it specifically refers to a contested sense of belonging to Britain and, in general, Europe: "I continue to travel extensively across this land that I feel both of and not of." Caryl Phillips, The European Tribe (1987; London: Faber \& Faber, 1992): xiii.
} 
Phillips answers some of these vexing questions with his novel $A$ Distant Shore (2003), ${ }^{9}$ his first to be set exclusively in the present. "It seems odd that it's taken me until now to set a novel in the present," he says. "The rest have been historical. I had to describe my own roots before I could deal with contemporary events."10

In fact, $A$ Distant Shore can be considered an historical novel from many perspectives, but with a peculiarity: it addresses contemporary history. "England has changed" (3) is the powerful, eloquent incipit of the novel, which is partly set in an historically defined, albeit geographically half-imagined, contemporary England - an England that has yet to come to terms with the fact that its million non-whites have contributed to the shaping of its national identity, and which is part of a larger Europe. But, I would like to argue, the story is set in 'changing' England only in part, not exclusively.

$A$ Distant Shore has been primarily read, reviewed, and marketed, particularly in Europe, as Phillips's only 'English' novel so far. This reading, I suggest, originates in, and perpetuates, a type of 'blindness' similar to that lamented by Phillips in his article "Kingdom of the Blind." For the "territory" of $A$ Distant Shore is modern-day, multicultural England - the one in which Phillips was raised and whose absence in traditional English letters he critiques as much as a present-day, decolonized Africa traumatized by brutal civil wars. Those wars, identified by Farah as a terra incognita in the realm of fiction, and described by the Somalian writer as the most devastating result of a disastrous historical process of Realpolitik that began with colonialism, have led to destruction in Africa while causing a diaspora of survivors seeking political asylum all over the globe, including Britain. ${ }^{11}$ These two worlds - Britain and Africa - would seem to converge in this contemporary historical novel for a reason. Dismissing one - either - of them, or turning a blind eye to their fundamental connection would mean missing the novel's historical significance, its very narrative foundations, and its main theme, which coincides with one of the central, crucial issues of our global society: that of mass migration from regions economically and politically challenged by past and present empires to the wealthier, supposedly more democratic West - often rhetorically referred to as the North. This migration is an exodus of enormous proportions

\footnotetext{
${ }^{9}$ Caryl Phillips, A Distant Shore (London: Secker \& Warburg, 2003). Further page references are in the main text.

${ }^{10}$ Caryl Phillips, in Donald Morrison, “A Writer of Wrongs," Time (19 May 2003): 63.

${ }^{11}$ See Nuruddin Farah, Yesterday, Tomorrow: Voices from the Somali Diaspora (London $\&$ New York: Cassell, 2000).
} 
involving the world as a whole. It is also a multidirectional movement that induces, although not always facilitating, contacts among people and cultures. It is, I would suggest, one of the most fundamental aspects in present-day world history. It comes as no surprise, then, that it should be central to Phillips's first 'contemporary historical' novel.

I wish to prove my argument by focusing on some of the novel's main narrative strategies and devices, which, in my view, aim at representing the inextricability of the two worlds depicted.

The encounter/clash between the African and the British worlds, and what they represent in this novel, is embodied by the short-lived, "tentative"12 friendship between the two protagonists, Solomon and Dorothy. Not only does their relationship characterize itself as ambiguous, but also the way they present and construct themselves to one another appears so. ${ }^{13}$ Their stories and their trajectories - the histories of their migrations - could not be more different. Yet their loneliness, their sense of displacement, their quest for new beginnings and renewed identities, and their search for a 'refuge' or a place to call 'home' could not be more alike. ${ }^{14}$ Solomon is a man in his early thirties, a refugee from a civil-war ravaged sub-Saharan African country, a man who, in his past life as Gabriel, has endured and sometimes inflicted atrocities of various kinds, and whose "every movement would appear to be an attempt to erase a past that he no longer wishes to be reminded of" (298). Dorothy, by contrast, is a middle-aged woman from Northern England who has travelled across, but never really left, her native country. Her life has been marked by a series of acts of abandonment, mostly suffered but at times also perpetrated upon others. They meet in Stoneleigh, the would-be posh development newly built for the emerging middle class on the edge of Weston, Dorothy's native home town, to which she returns after her retirement. In Stoneleigh, Solomon hopes to find a peaceful home where he can finally leave the past behind and recover from the series of traumatic experiences he was forced to endure,

${ }^{12}$ Caryl Phillips, "A Conversation with Caryl Phillips, Author of the Novel A Distant Shore," by Nathaniel Turner, ChickenBones: A Journal for Literary \& Artistic AfricanAmerican Themes (November 2003, updated 22 October 2007): http://www.nathaniel turner.com/distantshore2.htm (accessed 19 August 2009).

${ }^{13}$ See Maurizio Calbi, "Encounters on the Estate: Memory, Secrecy and Trauma in Caryl Phillips's A Distant Shore," in The Representation of Literary Landscapes, ed. Francesco Cattani \& Amanda Nadalini (Venice: Cafoscarina, 2006): 55-68.

${ }^{14}$ See Alessandra Di Maio, "The Mystery of Origins: Migratory Patterns in Caryl Phillips' A Distant Shore," in The Representation of Literary Landscapes, ed. Cattani \& Nadalini, 69-78. 
while Dorothy hopes to forget her own traumas, begin a new life, and find a long-lost home. She will find one in the end but, ironically, one with a slightly different, unanticipated connotation - one where she convalesces from her nervous breakdown - whereas Solomon will find death at the hands of a group of racist thugs.

The plot essentials, including Solomon's murder, are condensed in the initial pages of the first part of the novel, which is structurally as far removed as one might imagine from a 'murder mystery'. A Distant Shore is constructed contrapuntally, like "the patterns of music" that Dorothy, a piano teacher, recaptures in the final scene, when she is "once more able to make them [the keys] speak easily to each other" (312). Solomon's 'African' and Dorothy's 'English' stories speak to each other with equal authority, although to some extent Dorothy's first-person narrative structurally predominates, as it frames the entire novel by opening and closing it. This fictional choice seems to mirror the historical fact that Dorothy's Britain has dominated Solomon's African world for centuries. But what Dorothy comes to realize in the end is that her surviving voice has been made possible by that of her succumbing African friend: when he dies, she is left with a story to tell, which can be told only contrapuntally with Solomon's. Dorothy's and Solomon's stories are as inextricable from one another as the modern histories of their homelands.

In both the first and the fifth-and-last parts of the novel, Dorothy speaks in the first person, zigzagging back and forth through time and space. First-person narrative, Phillips tells Stephen Clingman, is one of his privileged "confessional modes," for it suggests "a deep necessity to speak, a deep necessity to communicate, which is born of a hurt, a displacement, a sense of exclusion." 15 The novel's central chapter, on the other hand, traces in the third person the main events in Dorothy's typically middle-class life - her relationship with her parents and her sister Sheila, her university years in Manchester, her marriage to Brian and their divorce, her decision to leave Birmingham and 'return home', her fleeting love affairs with Mahmood and Geoff, her forced retirement, her moving to Stoneleigh, her bus trips - in brief, all the vicissitudes and small-scale migrations she undergoes before her final encounter with Solomon. The point of view in this chapter, mainly in Free Indirect Discourse, is Dorothy's, whose life's narrative follows some sort of chronological order but is interspersed with flashbacks and flash-forwards.

\footnotetext{
${ }^{15}$ Caryl Phillips, "Other Voices: An Interview with Caryl Phillips" (October 2001), by Stephen Clingman, Salmagundi 143 (2004): 136.
} 
Contrapuntal to Dorothy's narrative, which corresponds to the first, central, and last chapters, are the two remaining sections of this symmetrically structured novel, the second and the fourth, recounting Solomon's story. The second and longest chapter tells Solomon's life in his unnamed African country, where he is Gabriel for his friends and family and Hawk to his soldiers, and from which he escapes after his family is massacred before his eyes. For the most part in the third person, omniscient narration and stream of consciousness alternate in this chapter, whose structural fragmentation is symbolic of its protagonist's profound displacement. Only one scene is told in the first-person singular: the one describing Gabriel/Solomon's frontline involvement in the war. Around this crucial mid-chapter scene, two fractured, apparently disjointed but finally linked sub-narratives in the third person intertwine in a vortex-like structure which is as convoluted as the central character's life. These two sub-narratives are, too, interlaced contrapuntally, mirroring the larger structure of the novel: to each fragment of the one proceeding forwards, a fragment of that going backwards follows, until they eventually merge in time and space in the scene of the protagonist's imprisonment. The narrative proceeding forwards at first tells the life and times of Gabriel in Africa, where he is an obedient son and a modest middle-class government clerk before joining the rebels under pressure from his father, and then his escape from what he can no longer conceive of as home - "I must leave. [...] This is not my home anymore" (88), he keeps repeating after the slaughter of his family. The various stages of his perilous journey to England follow, closely resembling those carried out by millions of political and economic migrants in today's real world. His is an illegal journey by different means of transportation which look rather like means of deportation: he first crosses the desert hiding under a tarpaulin in a truck, and then he is on a plane, on a ferry, in a train, in a French refugee camp, until finally he dives from a boat crossing the Channel and swims to England. Despite providing occasional references to specific locations, Phillips neither draws a geographically accurate map of the protagonist's route nor does reveals his nationality, thus making his story and journey resonate with those of the numerous refugees forced to flee their various African homelands in search of a new life in Europe, regardless of their specific origins and destinations. In similar fashion, Weston, the imaginary English village where the protagonist finally arrives, settles, and finds a racially motivated death, represents any provincial British town whose aspiration to upward mobility (the novel opens with a three-page description of Weston's partial gentrification) conceals a deeply conservative mentality hostile to any 
significant social transformation. The other sub-narrative in the chapter recounts backwards the protagonist's bleak days in the jail where he is imprisoned upon his arrival in Britain, and draws retrospectively on the events that lead him to being locked up: namely, the accusation of having raped Denise, the under-age girl who finds and feeds him, who confesses to being battered by her father and boyfriend, and who in fact is the first English character in the story for whom he feels some kind of empathy, albeit paired with suspicion. It is only after his acquittal and consequent release from prison that Gabriel changes his name to Solomon, which we learn at the very end of the chapter, more than halfway through the book. Until then, we follow the vicissitudes of Gabriel, whom we merely suspect might be Solomon.

It is a "one-year-old" Solomon who speaks in the first person in the fourth chapter of the novel (300). In his interior monologue, he talks about his friendship with Mike, the Irish lorry-driver who picks him up on the road after his release from jail and takes him north; about the Andersons, his surrogate British family, who offer him a human refuge while helping him apply for political asylum; about the racism that threatens and finally kills him; and, of course, about Dorothy, to whom he feels imponderably attracted. "This is a woman to whom I might tell my story," Solomon thinks:

If I do not share my story, then I have only this one year to my life. I am a one-year-old man who walks with heavy steps. I am a man burdened with hidden history. (300)

The chapter ends with his knocking on Dorothy's door, driven by the desire to get to know her and make himself known to her. ${ }^{16}$

In the structure of A Distant Shore there is no place for linearity of any kind. Within its external circularity, Dorothy's and Solomon's fractured stories are interwoven with one another as well as with those of minor characters - this is the case, for example, with Sheila's sub-plot, re-membered fragment by fragment by her sister Dorothy. "English history," Phillips declares during an interview, "is no longer as confidently sequential, either for people who look like they're traditionally English - confident, people of linearity nor for the people who arrive, for the newcomers, the immigrants." 17 The

\footnotetext{
${ }^{16}$ On the significance of the knocking on the door of the 'Other', see Maurizio Calbi, "Encounters on the Estate," 55-68.

${ }^{17}$ Caryl Phillips, in Jonathan Heawood, "Distance Learning," Observer (23 March 2003): http://www.guardian.co.uk/books/2003/mar/23/fiction.features (accessed 19 August 2009).
} 
plot-line of the novel seems to correspond to Dorothy's English non-linear history, on the one hand, and to Solomon's African history of displacement, on the other. Dorothy's tale follows the loop of her deranged mind, mixing voices, alive and dead, and stories, whereas Solomon's fragmented narrative, zigzagging northward in real life and meandering inward through his nightmares, seems to have neither end nor beginning - or, rather, multiple ends and beginnings, as suitable for a diasporic subject.

As Clingman suggests, Phillips is a "[disrupter] of [the] national form" of the novel. ${ }^{18}$ This seems to apply particularly to A Distant Shore. Asked to comment on this specific feature of his own fiction, Phillips - who was to publish A Distant Shore shortly after their interview - tells Clingman,

I knew I had to disrupt form. [...] Because the stories I was going to tell, the people I was talking about, seemed to me to be people whose lives had been disrupted and didn't have a clear narrative continuity, because of migration, because of various forms of displacement. The second reason was that I was seeing historical connections, which didn't make any sense genealogically. You couldn't hold them in one plot. So I knew that at some point I was going to have to introduce the reader to the difficulties, or the annoying demand from me that they think in a slightly different way than they might do if they just picked up a regular book. ${ }^{19}$

It is this very peculiar form that allows the author to create historical and personal connections in the novel through its protagonists' profound sense of displacement, resulting in what Louise Yelin describes as "an exemplary text of migrant fiction. ${ }^{20}$ By commenting on Slavoj Žižek's theory of the "parallax," which aims at replacing the traditional notion of "the polarity of opposites with the concept of the 'inherent' tension, gap, noncoincidence, of the One itself, ${ }^{21}$ Dave Gunning convincingly shows that in A Distant Shore Phillips succeeds in representing the concerns of the so-called First and Third Worlds while remaining faithful to the complexity of each, by pointing to their intersubjectivity. ${ }^{22}$ Gunning cogently underlines the necessity of tackling

${ }^{18}$ Clingman, in Phillips, "Other Voices," 128.

${ }^{19}$ Phillips, "Other Voices," 128-29.

${ }^{20}$ Louise Yelin, "Unsettling England: The Immigrant Fiction of Jean Rhys and Caryl Phillips" (MS).

${ }^{21}$ Slavoj Žižek, The Parallax View (Cambridge MA: MIT Press, 2006): 7; see also Žižek, "Parallax," London Review of Books 25.22 (20 November 2003): 24.

${ }^{22}$ Dave Gunning, "Anti-Racism, the Nation-State and Contemporary Black British Literature," Journal of Commonwealth Literature 39.2 (June 2004): 29-43. 
issues of nationality even in transnational texts engaging with anti-racist politics. Therefore, he argues, it is important to acknowledge that the novel tells "an international story" which is nonetheless "located in a fixed location with fixed codes and laws: the British nation." ${ }^{23}$ Gunning's point is that these texts can be understood only "when placed within the context of the actual discursive practices of the state and civil society of the nation at any given time."24 While agreeing with his point of view, I consider of fundamental importance the fact that the action in $A$ Distant Shore also and unequivocally takes place in an African country, which, although unnamed, is represented as "located" by "fixed codes and laws" just like "the British nation." In this perspective, the novel can indeed be regarded as a successful example of the application of a "parallax view": the continuous, contrapuntal shift of view from Dorothy's to Gabriel/Solomon's worlds, and vice versa, emphasizes their intersubjectivity, demonstrating that, rather than being polar opposites, they represent what Žižek refers to as the inner tension of the One itself.

It is certainly true that Britain in this novel is well-defined, as are its social codes and mores. As I argued earlier, the imaginary Weston might very well be any quiet, uneventful town in contemporary England: "Apparently, the biggest thing that had ever happened in Weston was Mrs. Thatcher closing the pits, and that was over twenty years ago" (4). Weston is depicted as an historically specific location with definite political, social, legal, and judiciary systems, and stands metonymically for England. Weston's social texture is rapidly changing, because of the rise of a larger middle class and, above all, because of immigration, two correlated aspects of present-day history: new wealth attracts new people, particularly from underprivileged regions. As a consequence, the town's community, symbolic of the nation, becomes increasingly multiethnic - several minor characters in the English section of the novel come from elsewhere. Yet, more often than not, this society perpetuates racism and classism instead of promoting social transformation. In this light, the incipit of the novel may be considered realistic as much as ironic, because it points to a demographic change which, however, does not correspond to one in mentality: "England has changed. These days it's difficult to tell who's from here and who's not. Who belongs and who's a stranger. It's disturbing. It doesn't feel right" (4). England in A Distant Shore is the contemporary

\footnotetext{
${ }^{23}$ Gunning, "Anti-Racism, the Nation-State and Contemporary Black British Literature," 39.

24 "Anti-Racism, the Nation-State and Contemporary Black British Literature," 29.
} 
nation afflicted by what Paul Gilroy refers to as "postcolonial melancholia," which is the ultimate consequence of its own inability to elaborate the loss of the empire, resulting in "the guilt-ridden loathing and depression that have come to characterize Britain's xenophobic responses to the strangers who have intruded upon it more recently"25 - in addition to being, presumably, the cause of the literary "blindness" lamented by Phillips in the Guardian. In this sense, Dorothy, loathing the homeless and gypsies, with her delusions and lingering depression resulting in a final breakdown and hospitalization, can be seen as an embodiment of England. Her crisis is symptomatic of that of the entire nation: repelled by the gypsies in town, she ends up having a fight with one of them; on the other hand, she is more than once attracted to non-white men, such as Mahmood, with whom she conducts a love affair, and Solomon, whom she sees as the object of a potential romantic involvement that nevertheless largely remains in her hallucinating mind. Dorothy's melancholia is central to her narrative, whose form and pace it shapes, though it only begins to be elaborated on towards the end. In the final scene at the asylum, when her doctor tells her "You don't appear to be getting any better, Dorothy," she responds in thought: "But he doesn't understand, there are good days and bad days" (307). Healing still is a long way away for Dorothy as well as for her melancholic, postcolonial England.

Gabriel/Solomon's unspecified African country, standing for all war-torn African nations, is finally as historically, socially, and politically defined as Dorothy's Britain. Its recent traumatic history is reconstructed in Gabriel/ Solomon's tortuous narrative, whose form reflects the disruption caused by civil war. His is a post-independence, "young country" (137) in which chaos reigns, where militias from the north and the south, mostly composed of child soldiers, wage a fratricidal war. Ferocious tribal assaults, drug abuse, mass murder, and rape are part of everyday life, and anarchy reigns. Human beings appear irreversibly debased. Bestial metaphors in this part of the text abound: whereas soldiers from the larger, northern faction roam the streets of the capital "in aimless packs like disturbed hounds" (137), those from the equally ruthless "smaller tribe" from the south are "dogs" let loose on the northern "chickens" (145). Gabriel/Solomon, aka Major "Hawk," is incited to continue the onslaught by his superior officer in these terms:

"How are the dogs?" By this I knew Colonel Bloodshed meant my troops.

"Sir, they are well."

\footnotetext{
${ }^{25}$ Paul Gilroy, Postcolonial Melancholia (New York: Columbia UP, 2005): 90.
} 
"It is hard for the dogs. If they are afraid, you must let them smoke the cannabis and mix it with gunpowder. Then they will have no fear of spilled blood coming back to haunt them. They will no longer see people, only chickens that have to be slaughtered. You must encourage them to harvest the chickens. It is time for the men of our country to reap the harvest and eat chicken." (145)

Even the influential men working in the equally corrupt "urine-stained" government headquarters "where rats played in the corners" look repugnant in their Western mimicry ("These fat men with greasy skin, who sweated underneath their tight western suits," 139). Similarly vulgar are the secretaries working for them, "ruby-lipped Madonna, or fat Baby, or Pleasure with her blond wig" (139), young women whose main concern is spending

their money on hot combs to make their stubborn hair smooth, and who wasted hours using skin-bleaching creams in the hope that they might render themselves more attractive to the men who promised these over-scented women a cosmetics shop of their own, or a half-dozen sewing machines, in exchange for their agreeing to lie back clumsily like upturned buses. (139)

Abusive sexism marks gender relationships in this postcolonial tower of power, where both men and women stand as commodities for one another, while constantly affecting Western ways, with grotesque results. On the other hand, in a time of chaos even gender markers appear to be blurred, and the very notion of virility is eventually distorted, if not denied. Gabriel, an introverted, unpretentious civil servant who is yet to join the rebels, experiences a sense of castration each time he is dismissed by one of these young women "with a flourish of her red nails" (139) and is sent back to roam the corridors of bureaucracy. A bestial metaphor of Kafkaesque memory describes how he feels:

These women did not consider me to be a man. A messenger clerk is not a man: I was a thing to be tolerated, a creature in a T-shirt and torn pants who was not much better than the cockroaches that skittered noisily across the floor. What did I know of Johnnie Walker Black Label? (139)

Even among his soldiers, when Gabriel's metaphorical animal identity rises from cockroach to Hawk, masculinity remains a vexed question. The child soldiers in the bush - not quite men yet - with their "painted nails, and the teddy bears that many clung to" (141), look as grotesque as the men and women in the capital city's government offices. Only when on drugs can they fight back their fear, ignore their childhood, and walk "with the authority of 
old men" in their boyish "plastic flip-flops" (141). Only weed can give them "a feeling of invincibility so that holding a stuffed toy, or wearing a Donald Duck mask, or daubing oneself with bright-pink lipstick, could never undermine their manhood" (141). And they are on all sorts of drugs when they rape the women of a recently captured village (146-47), which drives a disapproving Gabriel to desert his troops and walk north to reach his family, whose women eventually suffer the same fate. Rape becomes the ultimate warped manifestation of virility, in both the city and the bush, in a time when manhood itself is shattered.

Gabriel/Solomon's is a terminally sick society, one in which a father urges his only son to join the rebels ("'You must go now. You are my only son and it is my duty to send you to the liberation army'," 138 ), and the same son is forced to watch the women of his family being raped and murdered (131-32). It is an increasingly alienating place ("I continued to stare in disbelief. This was our city?," 140), which Gabriel/Solomon can no longer recognize as his own. If "England has changed" for Dorothy, similarly Gabriel/Solomon's African homeland has changed in his own eyes. After murdering his best friend Felix, he decides to join the mass of refugees who leave their lives and homes behind, searching for a safer place and a new name in an allegedly better world - Europe. The choice of the final destination is unavoidable: England. During his journey to Europe, Gabriel/Solomon befriends a fellow African refugee, Bright, whose life experiences resonate with his own, and whose words he quietly takes in:

'[But] I am an Englishman. Only the white man respects us, for we do not respect ourselves. If you cut my heart open you will find it stamped with the word "England". I speak the language, therefore I am going to England to claim my house and my stipend. [... I know we have all been afflicted, but I, this man, cannot go back ever. I hate it. I want to forget Africa and those people. I am an Englishman now. I am English and nobody will stop me from going home. Not you, not these people, nobody.' (134)

Migration is what connects Gabriel/Solomon's African world and that of his fellow refugees with Dorothy's England - as well as being, I argue, the keystone of A Distant Shore. However, as the sociologist Saskia Sassen suggests, migrations are never random: "Migrations do not simply happen. They are produced. And migrations do not involve just any possible combinations of countries. They are patterned. ${ }^{.26}$ Gabriel/Solomon's journey is that of a post-

\footnotetext{
${ }^{26}$ Saskia Sassen, Guests and Aliens (New York: New Press, 1999): 155.
} 
colonial refugee from a contemporary African country brutalized by a war that is the consequence of a ruinous historical process begun with colonialism. In this sense, his nation's civil war and Britain's postcolonial melancholia are the opposite, comparably traumatic sides of the very same coin. Trauma is omnipresent in this novel, in the lives of its protagonists and, by extension, in their societies, whose modern histories intertwine so profoundly that notions of home, homeland, and mother tongue call for a reassessment, as the passage above suggests. Dorothy and Solomon find some common ground because they share parallel painful life stories as well as a common traumatic history, and because they are both looking for a refuge to call home. Although Solomon is in every respect a political refugee seeking, and finally finding, asylum in England, and Dorothy is a British citizen, they both can be considered 'refugees' in the spirit of one of the many definitions of the term that Farah offers in Yesterday, Tomorrow, a highly political book concerning the diaspora of Somali refugees escaping the civil war:

A refugee [is] a person who has lost the ability to express the fullness of his or her nature, and who flees across borders if necessary in order to articulate the essence of his or her being, his or her human nature. ${ }^{27}$

Both Dorothy and Solomon in A Distant Shore go in search of a space of their own where they can heal, articulate their ever-changing identity, and discover the "essence" of their "human nature." By following different itineraries, they arrive in the same space, literally and metaphorically, and hesitantly begin to become friends. Even though Solomon's death does not allow them the time to explore the full potential of their friendship, the two protagonists connect through their stories, which remain to be largely reconstructed, like the histories of their countries. And they find refuge in one another.

Reassessing history by adding neglected fragments is crucial to a better understanding of the present. Creating transnational social structures able to provide individuals and communities, refugees, and citizens with a possibility of articulating the "essence of their humane nature" is of vital importance in an increasingly globalized world. Sassen remarks:

There is only one enlightened road to take for Europe today: that is to work with settled immigrants and refugees toward their full integration, and to do so through frameworks that ensure cultural and religious diversity will be part of civil society [...] part of what binds us rather than what segregates us. ${ }^{28}$

\footnotetext{
${ }^{27}$ Farah, Yesterday, Tomorrow: Voices from the Somali Diaspora, 50.

${ }^{28}$ Saskia Sassen, Guests and Aliens, 133.
} 
However, what does not as yet necessarily happen in public space can happen in private space. A refuge can be found in human connections, in personal relationships, in the desire to understand each other: this is what this novel ultimately seems to suggest. "My heart remains a desert, but I tried," Dorothy says at the end; and concludes, "I had a feeling that Solomon understood me" (312). Friendship, even when ambivalent, is celebrated in this otherwise bleak novel, which, despite Solomon's murder, closes with an unexpected turn of optimism: Dorothy's survival in the face of her friend's death.

Friendship allows one to cross borders and reach the essence of human nature, for it is about the human heart. Phillips points out elsewhere, "As we all discovered in the late $60 \mathrm{~s}$, when the first heart transplant operation took place in South Africa, the human heart has no colour." 29 In a resisting society, only the human heart can bridge gaps, and unite people, lands, and histories. This is what the two characters discover in the end, and their readers with them: that people, in spite of their different genders, ages, histories, and migratory patterns, in spite of the 'tribes' they originate in, are - ironically united by an identical destiny of death, insanity, and survival. They are all part of one new world tribe.

\section{WORKS CITED}

Abani, Chris. Song for Night (New York: Akashic, 2007).

Beah, Ishmael. A Long Way Gone: Memoirs of a Boy Soldier (New York: Farrar, Straus \& Giroux, 2007).

Bragg, Billy, \& the Blokes. "Distant Shore," England, Half English (Cooking Vinyl, 2002).

Calbi, Maurizio. "Encounters on the Estate: Memory, Secrecy and Trauma in Caryl Phillips's A Distant Shore," in The Representation of Literary Landscapes, ed. Francesco Cattani \& Amanda Nadalini (Venice: Cafoscarina, 2006): 55-68.

Di Maio, Alessandra. "The Mystery of Origins: Migratory Patterns in Caryl Phillips' $A$ Distant Shore," in The Representation of Literary Landscapes, ed. Francesco Cattani \& Amanda Nadalini (Venice: Cafoscarina, 2006): 69-78.

Dongala, Emmanuel. Johnny Mad Dog, tr. Maria Louise Ascher (Johnny chien méchant, 2002; New York: Farrar, Straus \& Giroux, 2005).

Farah, Nuruddin. Keynote Speech, African Literature Association Annual Conference, University of California at San Diego (2002).

\footnotetext{
${ }^{29}$ Caryl Phillips, "Necessary Journeys," Guardian (11 December 2004): http://www .guardian.co.uk/books/2004/dec/11/society2 (accessed 19 August 2009).
} 
Yesterday, Tomorrow: Voices from the Somali Diaspora (London \& New York: Cassell, 2000).

Gilroy, Paul. Postcolonial Melancholia (New York: Columbia UP, 2005).

Gunning, Dave. "Anti-Racism, the Nation-State and Contemporary Black British Literature," Journal of Commonwealth Literature 39.2 (June 2004): 29-43.

Heawood, Jonathan. "Distance Learning," Observer (23 March 2003), http://www .guardian.co.uk/books/2003/mar/23/fiction.features (accessed 19 August 2009).

Iweala, Uzodinma. Beasts of No Nation (New York: HarperCollins, 2005).

Kourouma, Ahmadou. Allah Is Not Obliged, tr. Frank Wynne (Allah n'est pas obligé, 2000; London: Heinemann, 2006).

Ledent, Bénedicte. " 'Of, and not of, this Place': Attachment and Detachment in Caryl Phillips' A Distant Shore,” Kunapipi 26.1 (2004): 152-60.

MacInnes, Colin. Absolute Beginners (London: MacGibbon \& Kee, 1959).

- City of Spades (London: MacGibbon \& Kee, 1957).

-. England, Half English (London: MacGibbon \& Kee, 1961).

-. Mr Love and Justice (London: MacGibbon \& Kee, 1960).

Morrison, Donald. "A Writer of Wrongs," Time (19 May 2003): 62-63.

Phillips, Caryl. "A Conversation with Caryl Phillips, Author of the Novel A Distant Shore," by Nathaniel Turner, ChickenBones: A Journal for Literary \& Artistic African-American Themes (November 2003, updated 22 October 2007), http://www .nathanielturner.com/distantshore2.htm (accessed 19 August 2009).

—. A Distant Shore (London: Secker \& Warburg, 2003).

- The European Tribe (1987; London: Faber \& Faber, 1992).

"Kingdom of the Blind," Guardian (17 July 2004): 2-4.

"Necessary Journeys," Guardian (11 December 2004), http://www.guardian .co.uk/books/2004/dec/11/society2 (accessed 19 August 2009).

- A New World Order (London: Secker \& Warburg, 2001).

- "Other Voices: An Interview with Caryl Phillips" (October 2001), by Stephen Clingman, Salmagundi 143 (2004): 113-40.

Sassen, Saskia. Guests and Aliens (New York: The New Press, 1999).

Yelin, Louise. "Unsettling England: The Immigrant Fiction of Jean Rhys and Caryl Phillips," unpublished essay.

Žižek, Slavoj. "Parallax," London Review of Books 25.22 (20 November 2003): 24.

. The Parallax View (Cambridge M A: MIT Press, 2006). 


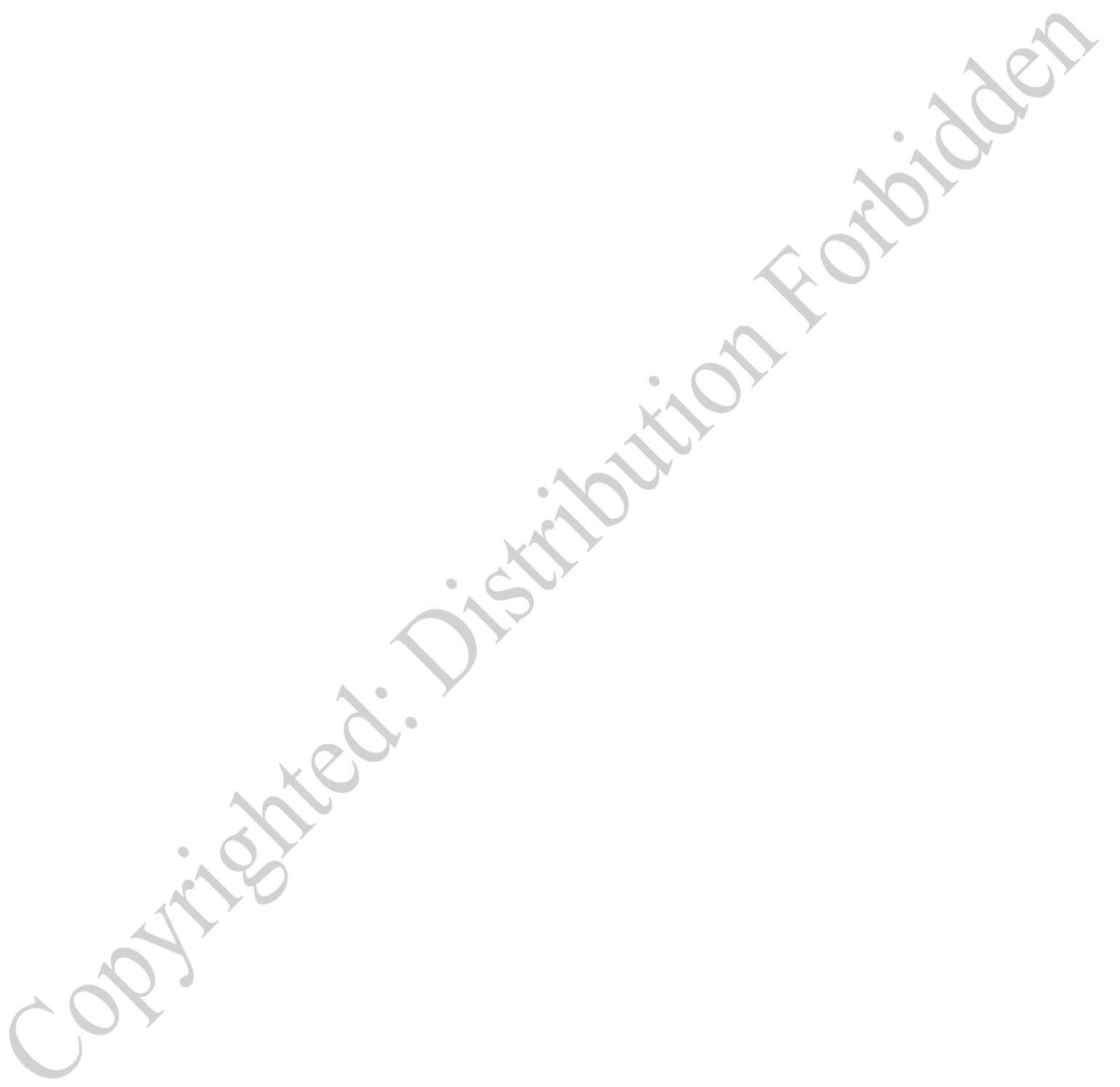




\title{
Dorothy's Heart of Darkness \\ How Europe Meets Africa in A Distant Shore
}

\author{
SANDRA COURTMAN
}

Before my breath, like blazing flax, Man and his marvels pass away;

And changing empires wane and wax, Are founded, flourish and decay ${ }^{1}$

It was a day that they never thought would arrive: not the handless and the one-legged victims of the brutal war in Sierra Leone, not the child soldiers who called him "Pappy", and certainly not the former warlord as he enjoyed his comfortable exile on the Nigerian coast. But on Monday in a Freetown courthouse lined with barbed wire and guarded by UN troops and local soldiers, international justice finally caught up with Charles Taylor. ${ }^{2}$

$A$

DISTANT SHORE IS PHILLIPS'S ONLY FICTION to be set exclusively in the contemporary period. A large part of the novel depicts crimes against humanity similar to those that led to the trial of the Liberian warlord Charles Taylor reported above in the Guardian. Phillips uses examples of actual war crimes, including murder, torture, rape, conscription of children, and enslavement to explain why young men like Gabriel/Solomon, one of the book's two main characters, seek sanctuary in Europe. A Distant Shore elicits the understanding of how material conditions

\footnotetext{
${ }^{1}$ Sir Walter Scott, from The Antiquary (1829), cited in Hector Bolitho, The British Empire (London: B.T. Batsford, 1947): 1.

2 Xan Rice, "As Mutilated Victims Look On, Liberian Warlord Enters Dock," Guardian (7 April 2006): http://www.guardian.co.uk/world/2006/apr/o7/sierraleone.warcrimes (accessed 7 July 2009).
} 
in countries like Sierra Leone have resulted in large numbers of Africans arriving in Britain. What we learn is the extent to which the European colonial project left Africa impoverished both materially and politically; and how the colonial methodology taught African warlords to survive by rifling the resources of their neighbours. A Distant Shore forces us to confront the fact that at the turn of the second millennium there is an historical continuum with Joseph Conrad's 1902 description of conquest in Heart of Darkness:

They grabbed what they could get for the sake of what was to be got. It was just robbery with violence, aggravated murder on a great scale, and men going at it blind - as is very proper for those who tackle a darkness. The conquest of the earth, which mostly means the taking it away from those who have a different complexion or slightly flatter noses than ourselves, is not a pretty thing when you look into it too much. ${ }^{3}$

A Distant Shore is intertextual in various ways. Phillips has made use of contemporary eyewitness accounts, news reports, and interviews with African writers with first-hand experience, such as Mike Butscher. ${ }^{4}$ And there are other literary intertexts available in contemporary African poetry and novels. For this essay, I am interested in the novel's relationship with one of the most studied literary representations of Africa, Conrad's Heart of Darkness, a novella with which Phillips has an ambivalent relationship. In Phillips's multi-layered fiction, such as the novels Cambridge and The Nature of Blood, historical documents and textual representations are overwritten to create a new text. The new work becomes, as Lars Eckstein explains in Re-Membering the Black Atlantic, a palimpsest. ${ }^{5}$ We might read A Distant Shore as having a metaphorical relationship to Joseph Conrad's Heart of Darkness in its reversal of the journey to, and encounter with, Africa. Indeed, Gabriel makes his difficult flight from Africa to what turns out to be "one of the dark places of the earth," Shore, the manichaean logic of European civilization and African barbarity implodes as Gabriel encounters a 'heart of darkness' in Africa and Europe. Neither does the black outsider/white insider binary hold as we learn how the

\footnotetext{
3 Joseph Conrad, Heart of Darkness (1902; Harmondsworth: Penguin, 1994): 10.

${ }^{4}$ Caryl Phillips, "Distant Voices," Guardian (19 July 2003): http://www.guardian.co .uk/books/2003/jul/19/sierraleone.shopping (accessed 7 July 2009).

${ }^{5}$ Lars Eckstein, Re-Membering the Black Atlantic: On the Poetics and Politics of Literary Memory (Cross/Cultures 84; Amsterdam \& New York: Rodopi, 2006).

${ }^{6}$ Conrad, Heart of Darkness, 7.
} 
villagers of Weston treat Dorothy, a white Englishwoman, and a Jewish woman doctor. This intertextual connection between Heart of Darkness and $A$ Distant Shore is encouraged by Phillips's creative affinity with Conrad's historical and aesthetic concerns:

The end of European colonisation has not rendered Heart of Darkness any less relevant, for Conrad was interested in the making of a modern world in which colonisation was simply one facet. The uprootedness of people and their often disquieting encounter with the 'other', is a constant theme in his work, and particularly so in this novel. Conrad's writing prepares us for a new world in which modern man has had to endure the psychic and physical pain of displacement, and all the concomitant confusion of watching imagined concrete standards become mutable. Modern descriptions of 20thcentury famines, war and genocide all seem to be eerily prefigured by Conrad, and Heart of Darkness abounds with passages that seem terrifyingly contemporary in their descriptive accuracy. ${ }^{7}$

Phillips's insight into the contemporaneity of Heart of Darkness makes itself felt in A Distant Shore, particularly in depictions of Dorothy's "concomitant confusion" and Gabriel's experience of genocide. It is clear from the above passage that Phillips is reading contemporary situations historiographically. Twenty-first-century atrocities in Africa and racist acts in rural Yorkshire are part of a "new world" connected to the imperial history that produced Conrad's textual ambivalence. Characters in Phillips's modern world share an uncertainty with Conrad's. Anthony Ilona explains this as a formal aesthetic device:

Uncertainty and irresolution percolate through Phillips's fiction. They precede the revelation of a connection between characters and they constitute the fabric of these characters' inner lives. They surface in Phillips's formal aesthetic as a counterpoint to the clear-cut classifications, continuities and foreclosures associated with the progressive logic of enlightened reasoning. ${ }^{8}$

We might assume that globalized, postcolonial societies had 'progressed' away from a fear of 'difference', but this is not reflected in a novel where Solomon and all of his family are murdered, Dorothy is alone in a mental institution, Mike, Solomon's friend, is killed in a lorry accident on his first trip

\footnotetext{
${ }^{7}$ Caryl Phillips, "Out of Africa," Guardian (22 February 2003): http://www.guardian .co.uk/books/2003/feb/22/classics.chinuaachebe (accessed 7 July 2009).

${ }^{8}$ Anthony Ilona, "The Purposeful Silence of the Artist in Full Flight: Review of $A$ Distant Shore and Dancing in the Dark," Wasafiri 47 (2006): 72.
} 
to continental Europe, and Dorothy's pupil, Carla, and her mum have to relocate. All of these very different characters are outsiders, and we only understand the connections between them by unravelling their individual stories. The book begins and ends with Dorothy, but in the pages between we begin to understand how her dispossession enables her to connect with Solomon without ever knowing his story. Even after his death, she is deeply troubled by the misapprehension that he must have family waiting for news of him. Ilona explains that uncertainty and irresolution are "embedded within the very structural composition of [Phillips's] work." structure inventively and in A Distant Shore the narrative flow of Solomon's exile and Dorothy's alienation is constantly disturbed by memories and dream sequences. The structure follows Phillips's characteristic interweaving of separate narrative threads to show their connectedness. As Stephen Clingman explains, the formal composition of the novel is inseparable from a prevailing concern with people who, in quite distinctive ways, are outsiders:

[There is] an interest rather in all those asymmetrically marginalized and excluded people of whatever origins whose paths cross in ways that shift from the complex and complementary to the jagged, tangential and disjunctive - in itself an underlying formal patterning in his work. ${ }^{10}$

In this novel, we must understand that Dorothy can have no idea what Solomon has been through before she meets him. Dorothy asks but never receives a direct answer to her question: " "But what about you, Solomon? I hardly know anything about you'."11 It is the structure that delivers their stories through interconnecting strands:

a) Dorothy's unreliable narration where she reflects on the formative events of her past including her relationship with her parents and her sister, her faltering career, her failed marriage and her self-destructive affairs with Geoff and Mahmood;

b) Gabriel's experience of war as Major Hawk, the witnessing of his parents' murder, his sisters' rape and his flight from Africa to Europe; and

\footnotetext{
${ }^{9}$ Ilona, "The Purposeful Silence of the Artist in Full Flight," 72.

${ }^{10}$ Stephen Clingman, “ “England has changed': Questions of National Form in A Distant Shore," Moving Worlds 7.1 (2007): 46.

${ }^{11}$ Caryl Phillips, A Distant Shore (London: Secker \& Warburg, 2003): 34. Further page references are in the main text.
} 
c) his incarceration in a UK detention centre and his interview with social worker Katherine where we learn about his dangerous encounter with Denise, followed by a recovery period with the Andersons, the family who take him in, and his settlement in Stoneleigh.

The temporal fragmentation of these narrative threads means that they cannot in actuality be ordered as a), b), and c). The novel spins backwards and forwards in time and shifts point of view to reveal how events happen. Phillips reinforces the idea that this technique, which produces textual uncertainty, also applies to the structure of Heart of Darkness: "In all three journeys, Conrad's restless narrative circles back on itself as though trapped in the complexity of the situation." 12 The structural logic of a circular narrative resists closure or coherent resolution. Thus, in A Distant Shore, there can be no promise of a happy ending for Dorothy and Solomon; their revelations can only offer the reader understanding.

The two characters are representative of Europe's most recent neocolonial encounter with African asylum-seekers and the often tragic stories associated with these encounters. In taking as his focus the plight of the asylum-seeker, Phillips promotes an understanding of the wider sweep of history with its transnational connections and global roots of intolerance. The novel also connects African and imperial history to a very particular, pluralized experience of alienation in postmodern Britain. A Distant Shore is part of a body of writing whose constant concern is to recover the histories of those 'others' that official histories would have us ignore. Phillips's fiction, in J.M. Coetzee's view, has a single aim: "remembering what the West would like to forget."13 He achieves this by finding a voice for the forgotten agents of history in portraits of complex, shifting, and multiple identities.

Phillips writes: "You subvert people's view of history by engaging them with character. I don't think you subvert it by arguing schematically about ideas." 14 The author engages the reader through characterization to explore how Africa and Europe connect historically and politically. A Distant Shore offers the reader a way of envisaging identities formed out of the contin-

\footnotetext{
${ }^{12}$ Phillips, "Out of Africa."

${ }^{13}$ J.M. Coetzee, "What We Like to Forget," review of The Nature of Blood, by Caryl Phillips, New York Review of Books 44.17 (6 November 1997): 41.

${ }^{14}$ Caryl Phillips, "Crossing the River: Caryl Phillips Talks to Maya Jaggi," Wasafiri 20 (1994): 26.
} 
gencies of civil war, resulting in migrations from Africa. As Bénédicte Ledent points out, A Distant Shore is the seventh in a series of novels that explore

the tension between attachment and detachment, between belonging and unbelonging that has been part of human life since the beginning of times, especially for the migrant. ${ }^{15}$

But the novel also juxtaposes the profound effects of Gabriel's trauma with Dorothy's dislocation to show how alienated a white female resident might also feel in a millennial Britain. In an interview, Phillips explains how important Dorothy's experience of displacement is in relation to Solomon's story:

I'm more concerned with 'identity' than with 'race.' The latter is just one component in the former, along with religion, gender, nationality, class, etc. This is obviously a novel about the challenged identity of two individuals, but it's also a novel about English - or national - identity. ${ }^{16}$

In A Distant Shore, as in Cambridge, the central relationship is that of a European woman and an African man. In both novels, the characters initially appear to represent the unequal power-relations between Africa and Europe, only for the relationship to become complicated by human interaction. For Solomon and Dorothy, their unlikely friendship develops out of physical proximity and a mutual loneliness but begins to attract the hostility of local racists fired by fears of miscegenation. Even Carla's mother warns Dorothy that 'people' are talking about her: "There are good people in the village that you can spend time with" (23). Although the relationship does not get the opportunity to develop, when Dorothy goes away she tells herself that Solomon might be "wanting me" (58), which testifies to the intensity of their friendship. And when we finally see Dorothy through Solomon's eyes, we learn that he thinks "she is very beautiful for her years" (293). He intuits that "this is a woman to whom I might tell my story" because she, too, is lonely and "burdened with a hidden history" (300).

Phillips's dialectic on the mixing of blood is of personal significance, since, as he explains, "my roots are in Madeira and Africa, and one of my grandmothers was Indian. But the idea that miscegenation means you go mad

\footnotetext{
${ }^{15}$ Bénédicte Ledent, " 'Of, and not of, this Place': Attachment and Detachment in Caryl Phillips' A Distant Shore," Kunapipi 26.1 (2004): 152.

${ }^{16}$ Caryl Phillips, "A Conversation with Caryl Phillips, Author of the Novel A Distant Shore," by Nathaniel Turner, ChickenBones: A Journal for Literary and Artistic AfricanAmerican Themes (November 2003, updated 22 October 2007): http://www.nathaniel turner.com/distantshore2.htm (accessed 7 July 2009).
} 
is deeply rooted in the British consciousness." ${ }^{17}$ Historically, degenerative insanity was assumed to be a potential consequence of the mixing of black and white blood and is a characteristic of many of the mad creoles in Caribbean literature. The narrative-therapeutic strategies employed by Phillips often challenge this motif. A Distant Shore offers a reverse discourse on the association between madness and miscegenation and another possible intertextual connection with Heart of Darkness. Indeed, the European Kurtz's physical and moral decline is assumed to be as a result of "the colossal scale of his vile desires": ${ }^{18}$ his degradation is achieved in part through sexual contamination with the "barbarous and superb" African woman. ${ }^{19}$ By contrast, the wholesomeness of Dorothy and Solomon's developing attraction promises a healing relationship - only to be thwarted by racism. The friendship exists long enough to illustrate how "England has changed" to the extent that this country is as untenable for Dorothy as Africa is for Gabriel. So that, by the end of the novel, with Solomon murdered, Dorothy seeks sanctuary in the literal asylum of a mental institution. In a sense, Dorothy and Gabriel are both refugees in unhealthy societies which prevent them from finding peace with each other.

Although A Distant Shore is set in the contemporary period, Phillips explains how the identity-politics are rooted in historical events:

The make-up of our modern, increasingly globalized, world has been to a large extent determined by the events which surrounded the Atlantic Slave Trade. [...] I suspect that the vast majority of what I have so far written has been an attempt to understand not just the actual details of the 'institution' of slavery but, more importantly, the continued, corrosive, troubling, and inescapable legacy of what happened on the coast of Africa, on the plantations in the Americas, and on the high and low streets of Europe. ${ }^{20}$

The Guyanese historian Walter Rodney forged a connection between historical exploitation and contemporary 'problems' in African countries. In his seminal analysis How Europe Underdeveloped Africa, he argued that the legacy of present-day Africa results from centuries of European interven-

\footnotetext{
${ }^{17}$ Maya Jaggi, "Rites of Passages," Guardian (3 November 2001): http://www.guardian .co.uk/books/2001/nov/o3/fiction.artsandhumanities (accessed 7 July 2009).

${ }^{18}$ Conrad, Heart of Darkness, 105.

${ }^{19}$ Conrad, Heart of Darkness, 97.

${ }^{20}$ Caryl Phillips, "Our Modern World," in Revisiting Slave Narratives/Les avatars contemporains des récits d'esclaves, ed. Judith Mishari-Barak (Montpellier: Université Montpellier III, 2005): 519-20.
} 
tion. ${ }^{21}$ The connection is central to our understanding of how countries like Sierra Leone have evolved into political turmoil with massive corruption, resulting in civil wars of the most brutal kind. On the face of it, Gabriel's flight from war-torn modern-day Africa would seem unconnected historically to Olaudah Equiano's eighteenth-century flight from slavery, but there is a link if we take Phillips's long view. Dorothy is inescapably connected to that history of economic exploitation even if she lacks understanding of the events described here that make up the political backdrop to the novel:

In 1990, 80,000 Liberian refugees flooded across the border into Sierra Leone in a bid to escape their own civil war. They were soon followed by a rebel army - the Revolutionary United Front (RUF) [...]. However, it was the tactics of the rebels that marked this out as a war of unspeakable brutality. They recruited criminals, drug addicts and thieves, but they also targeted impressionable and frightened children, some as young as seven. They forced these children to take drugs, and then maim their 'enemies' by crudely amputating legs, arms, hands, feet, even lips, ears and noses. These child soldiers also raped and killed. ${ }^{22}$

There is much of this historical detail in the novel, including a painful scene as Gabriel witnesses the murder of his family and the rape of his young sisters:

'Jacko' is the last to mount the younger sister, but by now 'Brutus' is losing patience. He claps his hands. 'Enough.' 'Jacko' clambers to his feet, and rearranges himself. His colleagues look on and laugh as 'Jacko' struggles to make himself appear decent. Gabriel can see that his youngest sister has a thin ribbon of blood running down the inside of her leg, which pools near her ankle. She also appears to have lost consciousness.

'Finish them off,' says 'Brutus', pointing to his sisters, 'but you can leave the old woman. She is no use to anybody.' (85)

Phillips has a petrified Gabriel witness his family's torture and this delivers the motivation for his flight from Africa: "For a moment Gabriel hesitates, and then he begins to run" (85). Phillips uses his considerable skill in characterization to explain how such unspeakable acts of brutality force many to risk their lives to reach safety. It is Gabriel's compelling narrative voice, weaving back and forth in the story to tell of his 'career' as Major Hawk in

\footnotetext{
${ }^{21}$ Walter Rodney, How Europe Underdeveloped Africa (London: Bogle-L'Ouverture, 1973).

${ }^{22}$ Caryl Phillips, "Distant Voices."
} 
command of the rebel army. The 'Hawk' section describes his shame as he becomes an accessory to the atrocities. The trauma of Africa represses and fragments his memories, which filter through as he is picked up as an illegal immigrant, charged with rape, and held in a UK detention centre. Through the emotional force of Gabriel's story, Phillips helps us to understand why it is that the immigration policies of 'fortress Europe' are still not enough to stop Africans from seeking asylum.

The scale of human disaster in Africa prompted the setting-up of a French Red Cross refugee camp at Sangatte. In addition to Phillips's extensive travels in sub-Saharan Africa, the author also writes about a covert mission to enter Sangatte in order to talk to the people sheltering there. ${ }^{23}$ Phillips takes an historical view of Sangatte when he observes that,

after a quarter of a century of migrant labour in Europe, this proud man in his late $40 \mathrm{Os}$, in stained jeans and a thin, inadequate, jacket, seems both lost and angry. $^{24}$

The Red Cross centre failed to cope with the number of asylum seekers but closure exacerbated the problem. As John Lichfield writes,

The closure of the refugee camp at Calais was designed to solve the problem of illegal immigration to Britain. But hundreds of asylum-seekers are returning to the port, desperate for passage across the Channel. ${ }^{25}$

We can understand how essential this research was to Phillips's project, enabling the First-World reader to engage with the African's traumatic encounter with Europe. Phillips forces us to read this modern condition with historical and political sensitivity. It is about shifting a perception of the African as a benefits-scrounger, rapist, and child molester. Gabriel is met as one of 'these people' whom the British tabloid press often constructs as criminals, intent on diverting resources from the social and criminal-justice system.

How 'they' are seen is a source of highly emotionalized conflict in contemporary England. Widespread protests across the country against asylumseekers have been described as moral panic. It is interesting that this moral panic shows no signs of abating. In 2007, Britain confronted the bicentenary

\footnotetext{
${ }^{23}$ Phillips, "A Conversation with Caryl Phillips."

${ }^{24}$ Caryl Phillips, "Strangers in a Strange Land," Guardian (17 November 2001): http: //www.guardian.co.uk/uk/2001/nov/17/immigration.books (accessed 7 July 2009).

${ }^{25}$ John Lichfield, "Sangatte Revisited," Independent (22 December 2005): http://www .independent.co.uk/news/world/europe/sangatte-revisited-520391.html (accessed 7 July 2009).
} 
of the abolition of the slave trade and, to this day, the asylum-seeker continues to serve as a visible reminder of the consequences of Europe's exploitative relationship with Africa. We need to understand and acknowledge the sources of fear and panic. In the small village of Saltdean on the British coast in Sussex, protesters held banners reading "Saltdean is not Sangatte," and "Homes for the elderly not for phoney asylum seekers. ${ }^{26}$ Significantly, it is not the large industrial cities with the 'problem' of assimilation, as in the 1950s; it is the small coastal towns in the privileged southern counties and the rural villages in isolated parts of northern England that are unfamiliar with the legacy of an underdeveloped Africa. Phillips makes Gabriel highly visible and highly vulnerable by placing him in a small Yorkshire village where there are no other black faces. This realization hits Dorothy when she is forced to confront the racist hate-mail he receives:

I haven't given it much thought, and perhaps this is my failing. In the town there are plenty of dark faces, but in this village he's alone. And maybe he feels alone. (45)

His story might have been very different had he settled among the many black and Asian faces in one of the multi-ethnic cities of the north.

Wherever they attempt to settle in Europe, Phillips explains that it is critical that Africans learn how 'they' are seen by 'us':

Solomon, the main character, has one thing in common with all Africans, who in the wake of the slave trade, left their continent for either Europe or the Americas. He has to learn to see again. Like Equiano before him, or the African who will arrive at Heathrow, or the port of Marseilles, tomorrow, he has to learn to negotiate this new world by understanding not only what he is seeing, but what 'they' are seeing when they look at him. ${ }^{27}$

Although Phillips tells much of Gabriel's story from the character's point of view, the polyphonic complexity of the narrative means that the protagonist is also seen through uncomprehending eyes, including Dorothy's, who first describes him as a "somewhat undernourished coloured man" (14). He has to negotiate these perceptions. Gabriel's European identity typically entails a change of name, and he becomes Solomon, who is exploited, feared, incar-

\footnotetext{
${ }^{26}$ Brighton Argus (27 January 2003), cited in Ralph Grillo, “'Saltdean can't cope': Protests against Asylum-Seekers in an English Seaside Suburb," Ethnic and Racial Studies 28.2 (2005): 236.

${ }^{27}$ Phillips, "Our Modern World," 521.
} 
cerated, and mistreated. He has to try to disappear in his new country, finding some sort of temporary sanctuary and friendship with the Andersons in Yorkshire. The novel is structured in such a way as to lull us into a false sense of resolution, since it begins with the end of his flight and we initially see him settled in Yorkshire, on a petit-bourgeois estate with a respectable job. Surely he is safe now, we might think. But the novel frustrates this assumption with Solomon's death, which occurs early in the novel (on page 46).

The collective trauma of civil wars in Africa have brutalized and maimed what should have been a group of healthy young nations, and we can only imagine what might have happened to Gabriel had he stayed in his unnamed homeland. However, we are forced to recognize very early in the story that he did not reach safety in England. It is ironic that, against considerable odds, he survives war in Africa, a near-fatal journey, and the detention centre, only to be murdered by racists in Yorkshire. The Britain and Africa depicted in $A$ Distant Shore are profoundly unhealthy societies. A 'heart of darkness' is omnipresent as Gabriel makes his long journey to England, an imagined place of safety, only to find it more subtly barbaric. A Distant Shore exposes the complexities of recent migrations to Britain, reversing the eurocentric racial discourse that supplies the textual ambivalence of Conrad's Heart of Darkness.

The connection between A Distant Shore and Heart of Darkness is characteristic of Phillips's use of other sources, as Lars Eckstein explores in some detail. Eckstein argues that Phillips uses textual sources to "cover" and "recover" a shared literary memory. Focusing specifically on the sources for Cambridge, Eckstein, as mentioned above, relates this creative strategy to the metaphor of the palimpsest:

The memory of literature, from this 'descriptive' point of view, is thus to be found in strategies of covering and re-covering other representations, strategies that can be identified and described by the reader.

The metaphor of the palimpsest expresses this idea quite clearly. A writer uses (materially, in the literal sense; in certain modes of dialogic reference, metaphorically) an older textual representation, on which he or she inscribes a new text. In the process of covering the material with a new layer of print he or she usually leaves marks and traces - signals of reference which allow the reader to un-cover the original material. ${ }^{28}$

It is relatively easy to trace the influence of earlier texts and historical documents on 're-covery' narratives such as Cambridge and The Nature of Blood,

\footnotetext{
${ }^{28}$ Eckstein, Re-Membering the Black Atlantic, 7.
} 
but in A Distant Shore, the contemporary setting does not lend itself so readily to such clear marks and traces of intertextuality. ${ }^{29}$ Conrad weaves a complex narrative in which Marlow tells the story of a journey down the Thames out of London to the river that will take him to the dying European Kurtz and the source of his African 'heart of darkness'. However, Gabriel's journey out of Africa into Europe reverses the direction of Marlow's journey, ending with the discovery of a 'dark place' in the heart of England. Thus, $A$ Distant Shore is a palimpsest if we apply Eckstein's idea of the metaphor - the journey from civilization to a 'dark' place - that invokes a dialogic reference to Heart of Darkness. Phillips published an account of an interview, significantly entitled "Out of Africa," he conducted with Chinua Achebe at Bard College, around the same time as the publication of $A$ Distant Shore. Phillips describes how Achebe sees the racial binary of Heart of Darkness:

Achebe sees Conrad mocking both the African landscape and the African people. The story begins on the 'good' River Thames, which, in the past, "has been one of the dark places of the earth." The story soon takes us to the 'bad' River Congo, presently one of those 'dark places. ${ }^{30}$

Phillips has a long-standing relationship both with Achebe's criticism of Heart of Darkness and Conrad's influential novella. Phillips explores Achebe's assertion that, for Conrad, Africa is "the antithesis of Europe and therefore of civilisation, a place where man's vaunted intelligence and refinement are finally mocked by triumphant bestiality." ${ }^{31}$ Conversely, it is Solomon the African who displays intelligence and refinement in the face of "triumphant bestiality" in Britain.

Phillips notes that, "according to Achebe, Conrad's long and famously hypnotically [sic] sentences are mere 'trickery', designed to induce a hypnotic stupor in the reader." 32 Correspondingly, there is something hypnotic in the series of repetitive sounds and short sentences that open A Distant Shore:

England has changed. These days it's difficult to tell who's from around here and who's not. Who belongs and who's a stranger. It's disturbing. It doesn't feel right. Three months ago, in early June, I moved out here to this new

\footnotetext{
${ }^{29}$ Even though the novel contains several passages taken from Olaudah Equiano's Interesting Narrative. See Bénédicte Ledent, "Family and Identity in Caryl Phillips's Fiction, in particular A Distant Shore," Commonwealth: Essays and Studies 29.2 (2007): 71.

${ }^{30}$ Phillips, "Out of Africa."

31 "Out of Africa."

32 "Out of Africa."
} 
development of Stoneleigh. None of the old villagers seem comfortable with the term 'new development.' They simply call Stoneleigh the 'new houses on the hill'. After all, our houses are set on the edge of Weston, a village that is hardly going to give up its name and identity because some developer has seen a way to make a quick buck by throwing up some semi-detached bungalows, slapping a carriage lamp on the front of them and calling them 'Stoneleigh'. If anybody asks me I just say I live in Weston. (3)

Here, Dorothy is alerting us to a primitive tribalism at work in the division between the old villagers and the incoming people of the new development. It is clear that taking ownership of territory can generate hostility and scratch the thin veneer of refinement laid over a Yorkshire village. Dorothy is a different kind of settler from Solomon, but she also attracts xenophobia because the working-class mining community have hitherto managed to avoid many migrant workers or 'foreigners'.

It is the immediacy of Dorothy's first-person narration that initially draws the reader in. Again there is an element of trickery, as the reader presupposes that this is a novel about a troubled middle-aged woman attempting to settle in a small Yorkshire village. If Conrad weaves his story into a multi-layered narrative, there is a complex polyphony at work in Phillips's storytelling, too. In spite of Achebe's charge of racism levelled at Conrad, ${ }^{33}$ Phillips sees him as conceding that "the novel is, in part, an attempt to examine what happens when Europeans come into contact with this particular form of economic and social exploitation." 34 This is precisely what Dorothy and all the inhabitants of Weston do, even though they will never understand how economic and social exploitation brought Gabriel/Solomon to Yorkshire. In Conrad's tale, Kurtz's dying words - "The horror! the horror!" - are left unexplained. ${ }^{35}$ Similarly, when the villagers encounter Solomon, they remain ignorant of the horrors that he has witnessed and been party to. He appears as an example of what F.R. Leavis describes as the "incomprehensible mystery" of Africa. ${ }^{36}$ As another black person of unknown origin - the "undernourished coloured man" (14) - his presence is inexplicable to those he meets. Phillips's novel fills in

\footnotetext{
${ }^{33}$ Chinua Achebe, "An Image of Africa: Racism in Conrad's Heart of Darkness" (1975), Research in African Literatures 9.1 (Spring 1978): 1-15.

${ }^{34}$ Phillips, "Out of Africa."

${ }^{35}$ Conrad, Heart of Darkness, 100.

${ }^{36}$ F.R. Leavis, "Joseph Conrad: Minor Works and Nostromo" (1941), in The Great Tradition: George Eliot, Henry James, Joseph Conrad (1948; Peregrine Books; Harmondsworth: Penguin/Chatto \& Windus, 1962): 197, quoted in Phillips, "Out of Africa."
} 
the political and historical gaps of this 'inexplicable' encounter just as Conrad did, racist or not, in his depiction of imperial Africa.

When Phillips reconsiders Heart of Darkness, one central question is:

What happens to this one individual who imagines himself to be released from the moral order of society and therefore free to behave as 'savagely' or as 'decently' as he deems fit? How does this man respond to chaos? ? $^{37}$

This question is also central to the characterization of Dorothy and Gabriel and their different ethical dilemmas in Africa and Europe. Both protagonists respond to the moral chaos of tribalism and racism and are highly sensitized by their exposure. When they each encounter man's capacity for evil, the self is destroyed, literally in Solomon's case and psychically in Dorothy's. She, like Kurtz, "sinks down through the many levels of the self to a place where [s] he discovers unlawful and repressed ambiguities of civilisation." $" 38$ After Solomon's murder, she realizes that "there's no way that I can live among these people" (59). The pub landlord tells Dorothy that he is sorry about Solomon's death because of " "what it's doing to our village'," since " " it makes us look bad, doesn't it?" " And he adds that there is " "nobody in Weston who would do anything like that" (48). These lies evade a much darker truth forcing Dorothy to confront the weight of hypocrisy - just as Marlow does when he makes the decision that "Mr Kurtz's reputation is safe with me."39

Phillips recognizes that how we understand this terrifying but contemporary 'heart of darkness' will depend on whether we are African or European. Faced with Achebe's Africanist response to Heart of Darkness, Phillips reappraises his own position. Phillips acknowledges that, while Achebe is unambiguously an African, he himself feels European:

The realisation hits me with force. I am not African. [...] I was raised in Europe, and although I have learned to reject the stereotypically reductive images of Africa and Africans, I am undeniably interested in the break-up of a European mind and the health of European civilisation. ${ }^{40}$

This explains why Dorothy and the "break-up of [her] European mind" is such an important part of the story. As a novelist, Phillips takes enormous risks with the setting and the characterization. Dorothy is very unpromising

\footnotetext{
${ }^{37}$ Phillips, "Out of Africa."

38 "Out of Africa."

${ }^{39}$ Conrad, Heart of Darkness, 90.

${ }^{40}$ Phillips, "Out of Africa."
} 
material for a major character - an unhinged, middle-aged, middle-class woman, and generically an invisible person. The village setting is equally downbeat and there is nothing urbane or gritty about Stoneleigh. But the risks are worthwhile because they reinforce the fact that while British cities might be unequivocally multicultural, racism prevails in all-white villages where inhabitants have avoided routine encounters with African, Asian, and Caribbean settlers. Tribal law and xenophobia go unchecked in such an enclave. As a British-born woman in her fifties, Dorothy is of a generation to be disturbed by the realization that, even in an all-white village, it has become difficult to "tell who's from around here and who's not. Who belongs and who's a stranger" (3). If anything causes the "break-up of [her] European mind," it is her own 'outsider' status and the loss of Solomon's friendship.

Suppressed grief and detachment render Dorothy an unreliable narrator of her own memories. She leads Solomon to believe that her sister is alive, leaving a letter supposedly written by her displayed on the mantelpiece: "After Sheila died I wrote to myself and pretended it was her doing the writing. It was all I had left of her. My imaginary Sheila who likes me and still needs my help"; here, in a moment of self-reflection, she grieves for the relationship that she avoided: "my cowardice had lost me my real sister" (71).

Dorothy is all alone in the world, having lost her parents, her husband, and her sister; we therefore understand how the loss of an esteem-building relationship with Solomon is devastating. Their mutual respect and restraint contrast sharply with the sexual degradation that she experiences with Geoff and Mahmood. She has been so diminished by serial abandonment that she tries to keep Mahmood by ensuring that

the dominant narrative is male. After all, his story involves passion, betrayal, migration, sacrifice and ultimately triumph. Mahmood is a success. Her story contains the single word, abandonment. Curiously enough, she realises that both stories seem unconcerned with the word 'love', but she keeps this thought to herself. (203)

Dorothy's perception of Mahmood is characteristically delusional, since he is clearly not the success that she imagines him to be. His ambitions remain unfulfilled and he is a lonely and unhappy man. Sex with Mahmood and Geoff is devoid of desire, sad and perfunctory. It is Dorothy's loneliness and abjection that lead her to offer them sex, and they use her friendship as a refuge without love. All the men betray her except Solomon, and this abandonment is part of what Ledent has identified more generally as "Phillips's pervasive 
preoccupation with the theme of the male desertion of women. ${ }^{, 41}$ By the end of the novel, the reader understands fully why they are both drawn to trust each other in a modern universe where the "intervening forces of dispossession and possession [...] are not subject to timetables or borders." ${ }^{, 42}$ They are both intensely lonely people in ailing societies. Dorothy should - theoretically - feel that she 'belongs' in Stoneleigh but she is as displaced as Solomon. Clingman explains this paradox:

Insiders can be outsiders, and the boundary is a matter of perpetual crossing and recrossing. Belonging may be flickering rather than fixed, dependent on ratios of power and recognition, voicing and silence. ${ }^{43}$

Dorothy has none of the traditional axes of power that a woman of her age might expect. She is without family and community, career and social status, friendship and love.

In conclusion, this exploration of Dorothy's powerlessness is how Phillips engenders empathy for this unprepossessing character. We can still feel Dorothy's confusion even if she takes for granted the safety, comfort, and citizenship that African asylum-seekers risk everything to attain. During his travels to Africa, Phillips inevitably witnessed the real pain of social and political meltdown, and this led him to question the role of the author in such an extreme situation:

Since my arrival in Sierra Leone I have been wondering about the relevance of writing in a nation whose social and economic infrastructure appears to be permanently close to collapse. ${ }^{44}$

Writing about his meeting with the Sierra Leonean author Mike Butscher, Phillips returns repeatedly to the question of how daily contact with the "horrors of [his] history" silences writers like his interlocutor. But, against considerable odds, Butscher has written about his first-hand experiences of civil war. He lends Phillips a copy of his war diary, and this no doubt provided a valuable source for Gabriel's story. Phillips is disturbed by the thought that even if we accept that writers are the social conscience of a country, they may be more usefully employed when their county is "barely functioning." Emer-

\footnotetext{
${ }^{41}$ Bénédicte Ledent, Caryl Phillips (Contemporary World Writers; Manchester: Manchester U P, 2002): 12.

${ }^{42}$ Ilona, "The Purposeful Silence of the Artist in Full Flight," 73.

${ }^{43}$ Clingman, " "England has changed'," 47.

${ }^{44}$ Phillips, "Distant Voices."
} 
gency aid, food, medicine, and shelter are not usually dispensed in book-form. However, he closes his article with a remark of Butscher's: "In a bad, bad situation like this," he says, "we need to hear from writers. It is writers who remind people who they are and where they come from." 45 This reinforces a commitment that Phillips has honoured throughout his career: the idea of the writer as someone who can help us understand the legacy of imperial history, fear of the outsider, and the restlessness of postmodern alienation. And, importantly, how these connect when Dorothy, grappling with her own 'heart of darkness', meets Solomon, and Europe once again encounters Africa.

\section{WORKS CITED}

Achebe, Chinua. "An Image of Africa: Racism in Conrad's Heart of Darkness" (1975), Research in African Literatures 9.1 (Spring 1978): 1-15.

Bolitho, Hector. The British Empire (London: B.T. Batsford, 1947).

Clingman, Stephen. “ 'England has changed': Questions of National Form in A Distant Shore," Moving Worlds 7.1 (2007): 46-58.

Coetzee, J.M. "What We Like to Forget," rev. of The Nature of Blood, by Caryl Phillips, New York Review of Books 44.17 (6 November 1997): 38-41.

Conrad, Joseph. Heart of Darkness (1902; Harmondsworth: Penguin, 1994).

Eckstein, Lars. Re-Membering the Black Atlantic: On the Poetics and Politics of Literary Memory (Cross/Cultures 84; Amsterdam \& New York: Rodopi, 2006).

Equiano, Olaudah. The Interesting Narrative of the Life of Olaudah Equiano, or Gustavus Vassa, The African, Written by Himself (1789), in The Interesting Narrative and Other Writings, ed. Vincent Carretta (New York: Penguin: 1995): 1-236.

Grillo, Ralph. “ 'Saltdean can't cope': Protests against Asylum-Seekers in an English Seaside Suburb," Ethnic and Racial Studies 28.2 (2005): 235-60.

Ilona, Anthony. "The Purposeful Silence of the Artist in Full Flight: Review of A Distant Shore and Dancing in the Dark," Wasafiri 47 (2006): 72-75.

Jaggi, Maya. "Rites of Passages," Guardian (3 November 2001): http://www.guardian co.uk/books/2001/nov/03/fiction.artsandhumanities (accessed 7 July 2009).

Leavis, F.R. "Joseph Conrad: Minor Works and Nostromo" (1941), in The Great Tradition: George Eliot, Henry James, Joseph Conrad (1948; Peregrine Books; Harmondsworth: Penguin/Chatto \& Windus, 1962): 192-222. Originally as part of "Revaluations (XIV): Joseph Conrad," Scrutiny 10 (1941-42): 22-50.

Ledent, Bénédicte. Caryl Phillips (Contemporary World Writers; Manchester: Manchester UP, 2002).

\footnotetext{
${ }^{45}$ Phillips, "Distant Voices."
} 
. "Family and Identity in Caryl Phillips's Fiction, in particular A Distant Shore," Commonwealth: Essays and Studies 29.2 (2007): 67-73.

" 'Of, and not of, this Place': Attachment and Detachment in Caryl Phillips' $A$ Distant Shore," Kunapipi 26.1 (2004): 152-60.

Lichfield, John. "Sangatte Revisited," Independent (22 December 2005): http://www .independent.co.uk/news/world/europe/sangatte-revisited-520391.html (accessed 7 July 2009).

Phillips, Caryl. Cambridge (London: Faber \& Faber, 1991).

_. "A Conversation with Caryl Phillips, Author of the Novel A Distant Shore," by Nathaniel Turner, ChickenBones: A Journal for Literary and Artistic AfricanAmerican Themes (November 2003; updated 22 October 2007): http://www .nathanielturner.com/distantshore2.htm (accessed 7 July 2009).

. "Crossing the River: Caryl Phillips Talks to Maya Jaggi," Wasafiri 20 (1994): 25-29.

—. A Distant Shore (London: Secker \& Warburg, 2003).

. "Distant Voices," Guardian (19 July 2003): http://www.guardian.co.uk/books /2003/jul/19/sierraleone.shopping (accessed 7 July 2009).

- The Nature of Blood (London: Faber \& Faber, 1997).

. "Our Modern World," in Revisiting Slave Narratives/Les avatars contemporains des récits d'esclaves, ed. Judith Mishari-Barak (Montpellier: Université Montpellier III, 2005): 519-26.

—. "Out of Africa," Guardian (22 February 2003): http://www.guardian.co.uk /books/2003/feb/22/classics.chinuaachebe (accessed 7 July 2009).

_. "Strangers in a Strange Land," Guardian (17 November 2001): http://www .guardian.co.uk/uk/2001/nov/17/immigration.books (accessed 7 July 2009).

Rice, Xan. "As Mutilated Victims Look On, Liberian Warlord Enters Dock," Guardian (7 April 2006): http://www.guardian.co.uk/world/2006/apr/o7/sierraleone .warcrimes (accessed 7 July 2009).

Rodney, Walter. How Europe Underdeveloped Africa (London: Bogle-L'Ouverture, 1973) 


\title{
Negotiating Inclusion in Caryl Phillips's A Distant Shore
}

\author{
THOMAS BONNICI
}

\section{Exclusion and inclusion}

W

hen Caryl Phillips's a Distant Shore was published in 2003, it gave rise to reviews which were generally celebratory but did not contain many original comments about the writer's work. Since then, however, several scholarly articles - by Warnes, Clingman, Ledent, and Gunning, ${ }^{1}$ among others - have hinted that the treatment of racism in the novel was likely to raise new questions about the issue of otherness.

In previous works, Phillips had more often than not represented blacks as colonized beings, whose persona was to a large extent determined by their race. A Distant Shore, by contrast, focuses perhaps more on identity viewed from a universal perspective: i.e. not narrowly defined by any one allegiance, be it ethnic, religious, class- or gender-related. In other words, the book deals with identity as something less associated with blackness or whiteness, and seems instead to concentrate first and foremost on the rootlessness of the postmodern human being, not only in England but also in the rest of the world.

By virtue of this focus, A Distant Shore is a novel that problematizes belonging and the expectations of reaching an imagined home, which, when it

${ }^{1}$ See the following articles: Andrew Warnes, "Enemies Within: Diaspora and Democracy in Crossing the River and A Distant Shore," Moving Worlds 7.1 (2007): 33-45; Stephen Clingman, " England has changed': Questions of National Form in A Distant Shore," Moving Worlds 7.1 (2007): 46-58; Bénédicte Ledent, “'Of, and not of, this Place': Attachment and Detachment in Caryl Phillips's A Distant Shore," Kunapipi 26.1 (2004): 152-60; David Gunning, "Anti-Racism, the Nation-State and Contemporary Black British Literature," Journal of Commonwealth Literature 39.2 (June 2004): 29-43. 
fails to materialize, results in a form of homelessness that Heidegger calls "Unheimlichkeit." This frustration produces loneliness and a feeling that nothing will ever change or, rather, that the sense of exclusion generated does not recede, let alone cease to exist. Nevertheless, even if the setting of the novel - rural England - is one of hypocrisy, deep-rooted prejudice, and discrimination, there are always 'ordinary' people who gesture towards welcoming the 'outsider.'

Building on these preliminary remarks, this essay will focus on the problem of exclusion and inclusion as represented by Phillips in A Distant Shore through the two main protagonists: Dorothy Jones, a native Englishwoman yet an outsider in her own country; and Solomon, an African immigrant who attempts to integrate into a covertly racist country.

\section{Not feeling at home}

Terms such as transnational diaspora, ${ }^{3}$ which are usually applied to the uprooting experiences of populations throughout history, ${ }^{4}$ seem insufficient to analyze the themes underlying $A$ Distant Shore. Admittedly, the novel focuses on an African character who has escaped his war-torn continent, which indirectly suggests that diaspora is a major consequence of colonialism - Solomon's presence in Europe is, after all, the ultimate result of the disruptions that European colonizers provoked through the grouping or dispersion of different African ethnic groups. However, deeper human needs lie beneath the postcolonial surface represented in the narrative, as reflected in the pervasive presence in the novel of exclusion and inclusion in different guises. Therefore, rather than 'diaspora', the term Unheimlichkeit mentioned above might be a more appropriate tool for analysis. Often used in postcolonial theory, ${ }^{5} \mathrm{Un}$ heimlichkeit connotes a feeling of displacement, uncanniness of space, homelessness, unbelonging, oppression, and marginalization. Such terms could be used to describe the predicament of both the illegal immigrant Solomon and the Englishwoman Dorothy. Even if their Unheimlichkeit is of a different sort,

2 Martin Heidegger, Being and Time, tr. Joan Stambaugh (Sein und Zeit, 1927; tr. Albany: State U of New York P, 1996).

${ }^{3}$ Gayatri Chakravorty Spivak, "Diasporas Old and New: Women in the Transnational World," Textual Practice 10.2 (Summer 1996): 245-69.

${ }^{4}$ William Safran, "Diasporas in Modern Societies: Myths of Homeland and Return," Diasporas 1.1 (Spring 1991): 83-89.

${ }^{5}$ See, for example, Bill Ashcroft, Gareth Griffiths \& Helen Tiffin, Key Concepts in PostColonial Studies (London: Routledge, 1998): 73. 
their sense of exclusion can be traced to Britain's development as a nation: if the country has not always been a haven for outsiders, especially those featuring the "racial epidermal schema,"6 a rejection of difference has also developed within the white community itself. Perhaps the meaning of the novel's introductory sentence "England has changed," if taken sarcastically, implies that Britain has not cured its racial sores but, rather, has intensified its exclusion of the Other in general.

It is my contention that unbelonging in A Distant Shore should not be regarded merely in exclusive relation to blackness, for it seems to insist on a conception of difference in which race is not the only defining element. In other words, 'difference' can, the novel seems to point out, be abstracted from 'race' or blackness, thereby becoming the condition shared by all who suffer exclusion from their respective social environments - whether they are females, blacks, or non-Europeans. This rejection is often paired with denigration, a term which, interestingly, is etymologically derived from 'blackening.' This testifies to the conflation of various types of marginalization: blackness is not only linked to racism, but might also be viewed as a metonym for all dispossessed subjects who experience unbelonging and exclusion.

The generalization of exclusionary practices beyond race does not only concern England. This is illustrated in the chapter devoted to Solomon's experience in Africa. Indeed, he belongs to a small ethnic group which wields economic and political power over the majority, and he lives in a system based on ethnic difference. However, discrimination is presented as even more insidious than this in his unnamed African country. For instance, Solomon - then called Gabriel - serves as a messenger clerk for "the type of men who drove large foreign cars and who travelled freely to Europe and even the United States." This suggests that inclusion in the government service is bound to the amount of corruption people indulge in, and to the level of crude westernization they are willing to undergo. In the same way, Solomon's 'exclusion' from his own country during the war and his participation in a contemporary version of the Middle Passage is not, strictly speaking, linked to skin colour, either. It is only when he arrives in England that the narrator reveals that race and shades of blackness differentiate the migrant.

\footnotetext{
${ }^{6}$ Frantz Fanon, Black Skin, White Masks, tr. Charles Lam Markmann (Peau noire, masques blancs, 1952, tr. 1967; London: Pluto, 1982): 112.

${ }^{7}$ Caryl Phillips, A Distant Shore (New York: Random House, 2003): 123. Further page references are in the main text.
} 
Unbelonging, the condition experienced by many immigrants and their descendants, is synonymous with in-betweenness and dislocation, and it is experienced not only by the African Solomon but by other immigrants, too. Indeed, Solomon is put in prison on a false charge, but such is also the case of his cellmate, the Iraqi illegal immigrant Said. The latter is not black as the term is usually understood; he is nevertheless also an outsider, at least in terms of culture, ethnicity, and nationality. Like Solomon, he is falsely accused of a crime - in his case, of stealing money from an Englishman and his wife who had asked him to take care of their luggage. He shares with Solomon a diasporic history of suffering: as a teacher in Iraq, he was, the novel implies, accused of being a dissenting voice in a dictatorship; he had to sell all his belongings and pay for his passage to England; he had to leave his family behind and undergo the hardships of the journey, only to end up in a detention centre. His hope of obtaining a job and working for a decent living, fostered by his high expectations of a country where "freedom is everything" and "British people are good" (70), is shattered when he is expelled from England: " "The light in England is very weak [he says]. It depresses me. They have taken the sun out of the sky" " $(71)$. In the end, neither the prison warden nor the doctor attends to him, and he dies miserably. In this instance, Phillips seems to highlight the dispossessed subject's condition as an outsider. Since Said does not belong to the place, he is fated to marginalization and, worse, early death.

Another example of exclusion is that of Bright - whose name ironically suggests optimism - an African who travels to England with Solomon. He is confident that he will be welcome in the country:

'I am an Englishman. Only the white man respects us, for we do not respect ourselves. If you cut my heart open you will find it stamped with the word 'England.' I speak the language, therefore I am going to England to claim my house and my stipend.' [...] 'I want to forget Africa and those people. I am an Englishman now. I am English and nobody will stop me from going home.' (119)

The narrator's silence around Bright seems to indicate that the latter's high hopes have eventually been shattered, too, and that he ends much like the other outsiders and disposable foreigners ${ }^{8}$ who are never considered as members of the British community but always as different Others.

\footnotetext{
${ }^{8}$ Jacques Derrida \& Anne Dufourmantelle, Of Hospitality (De l'hospitalité, 1997; Stanford CA: Stanford UP, 2000).
} 
But that rejection goes beyond the 'race' category is suggested most visibly through the character of Dorothy, a white Englishwoman, a former music teacher, who has never left the country. Estrangement from her parents and her cancer-stricken sister, their death, and her divorce and failed relationships have put on middle-aged Dorothy the accumulated stress of loneliness and dislocation. She feels marginalized in her own society - represented by her family circle, her neighbours, and her professional environment - and thus rootless in an England that has changed. ${ }^{9}$ Although the consequences are similar to those endured by the immigrants, the social transformation Dorothy complains about at the very beginning of the novel is somewhat different: she cannot feel at home in what is supposed to be her own country. Her displacement to different parts of England and finally to the newly built estate of Stoneleigh actually makes Dorothy a native of no place. In this Unheimlichkeit, her own mind revisits her harrowing past experiences of lovelessness, abandonment, and frustration. Moreover, her feeling of alienation is compounded by the comments that her parents and neighbours used to make, which reveal to her the unrelenting hegemony of whiteness in mainstream British culture. She perceives that Britain will not relinquish racial purity as the basis of the nation. Since she is neither black nor a foreigner, she embodies the existential dislocation of a person who is in her own home without feeling at home. In short, despite Solomon's and Dorothy's different circumstances, their existential situation is similar by virtue of its 'rootlessness'.

\section{Decentred subject}

Phillips's A Distant Shore epitomizes the situation of the decentred subject in today's globalized world. ${ }^{10}$ For Solomon and Dorothy, the country of birth, an erstwhile solid and stable place, is a mythical space, and the border or margin constitutes their habitation. For the former, the civil war becomes a watershed between the homeland, a space to be forgotten, and his English host country, a putative home in which he has to negotiate his identity.

These examples clearly demonstrate that, as suggested earlier, Solomon's plight is extended to all marginalized characters, particularly Dorothy, whose tragic identity, like his, is characterized by dislocation and unbelonging. As

\footnotetext{
${ }^{9}$ This is to some extent reminiscent of Joyce's situation in Crossing the River (London: Bloomsbury, 1993).

${ }^{10}$ Arjun Appadurai, "Disjuncture and Difference in the Global Cultural Economy," in Theorizing Diaspora, ed. Jana Evans Braziel \& Anita Mannur (Oxford: Blackwell, 2003): 25-48.
} 
she herself confesses, "abandonment is a state that is not alien to man" (208); rather, it is inherent to the human condition. The place-shifting and the tense relationship with her parents, her husband Brian, her sister Sheila, her pupils, her 'lovers', and other people met in the course of her life cause such alienation that she is oblivious to her own mental degradation, which the others perceive. No wonder, therefore, that one of her neighbours tells her:

'I think you need help, don't you? Carla likes you all right, but she says you shout, and then at other times you're nice, but most of the time you just stare out of the window and you don't hear anything that she's saying to you.' (20)

In other words, Dorothy's unbelonging may be suggested by the gap between her perception of the embarrassing situations in which she finds herself and the evaluation of others with regard to the same facts. For instance, the book presents, from Dorothy's perspective, her advances to a married colleague as a normal event and then surprises the reader with the unsavoury discordant comments of others who consider the affair from a different point of view. This, in addition, shows that people tend to judge by appearances: they see only Dorothy's existential uncanniness and fail to see in her anything beyond her psychological imbalance - just as they assess Solomon solely on the basis of the colour of his skin, a form of bigotry that eventually leads to his death at the hands of local youths.

\section{Multiculturalism and community formation}

The novel begins with Dorothy's statement that England has changed - an assertion which, at first sight, seems to bring to the fore Britain's contemporary multicultural makeup. However, as the narrative progresses, the country's apparent cultural diversity turns out to mask a far less desirable state of affairs. Half a century after the beginning of decolonization and in the current globalized era, modern multicultural Britain is revealed in the novel to harbour a network of dysfunctional relationships that leave no hope for either reconciliation or assimilation. To Solomon (still Gabriel), as he peers out of the window of a police van,

it is strange, but nobody is looking at anybody else, and it would appear that not only are these people all strangers to one another, but they seem determined to make sure that this situation will remain unchanged. (163) 
This perception of England as a country where people do not reach out to others, let alone to the Other, is echoed by Stuart Hall's comments on racism in Britain:

a culturally constructed sense of Englishness and a particularly closed, exclusive and regressive form of English national identity is one of the core characteristics of British racism today. [...] The politics of anti-racism has often constructed itself in terms of a contestation of 'multi-ethnicity' or 'multi-culturalism.'11

The exclusionary practices described by Hall also pervade $A$ Distant Shore. But some of Phillips's characters do display empathy with the in-betweenness experienced by marginalized people. Thus, racism is occasionally disrupted by a more discreet but nevertheless present community-building ${ }^{12}$ stance which, unlike empire-building, involves inclusion, support, multiplicity, and non-hierarchized relationships. Even in the direst circumstances there are, as bell hooks put it in another context,

sensibilities which are shared across the boundaries of class, gender, and race, and which could be fertile ground for the construction of empathy - ties that would promote recognition of common commitments and serve as a basis for solidarity and coalition. ${ }^{13}$

For instance, solidarity may be readily discerned in the meal brought by young Denise to the recently-arrived refugees Solomon and Bright, the encouragement offered by the social worker Katherine, the legal assistance provided by Stuart Lewis, the lawyer, the ride to freedom given by Mike the Irish truck driver, the hospitality extended by $\mathrm{Mr}$ and Mrs Anderson and their efforts to legalize Solomon's stay in Britain, and, less conspicuously but no less significantly, by Dorothy's efforts to reach to him.

Of all the characters, Dorothy perhaps most convincingly embodies this idea of community-building - and this, despite her occasionally intolerant behaviour - for she befriends Solomon even though their only tie may be an existence marked by exclusion in a country expected to be a haven of democracy and tolerance. Without any racial preconception, she approaches the

${ }^{11}$ Stuart Hall, "New Ethnicities" (1989), excerpt in The Post-Colonial Studies Reader, ed. Bill Ashcroft, Gareth Griffiths \& Helen Tiffin (London: Routledge, 1995): 226.

${ }^{12}$ Lois Kuznets, "Defining Full Human Potential: Communities of Women, An Idea in Fiction," Children's Literature Association Quarterly 7.4 (Winter 1982): 10.

${ }^{13}$ bell hooks, Yearning: Race, Gender and Cultural Politics (Boston MA: South End, 1990): 27. 
African watchman despite the fact that she had a family background featuring an aversion towards coloured people. Dorothy extends her hand to Solomon even within the highly charged environment in Stoneleigh, the microcosm for Britain, and in the context of the gender and racial marginalization they respectively endure. As for Solomon, his loneliness in a 'white' village and the increasingly explicit threats he receives - both of which are symptomatic of a colour-based and colour-biased Britain - make him knock on Dorothy's door. He does so not in self-pity, but just in order to encounter a space which provides "new and varied forms of bonding."

If, to go back to the argument advanced at the beginning of this essay, blackness is indeed to be considered a metonym for marginalization, and the act of negotiating a coexistence between blackness and whiteness stands for a broader strategy of inclusion and a re-forming of identity, then the outcome in Phillips's novel is, on the whole, bleak. The autodiegetic narrative of Solomon's stay with the Andersons shows that, even when the latter prove to be a non-racist couple, eager to promote his inclusion in British society, pressures from the local community against such integration are overwhelming. The rudeness of Solomon's workmates and the paint daubed on the wall of the Andersons' house bring things to a head. The dialogue that ensues between $\mathrm{Mr}$ Anderson and Solomon and between the latter and Mike on the racial issue in the local community demonstrates that even they are not wholly free from bias. In fact, when stereotypical arguments are put forward, such as the us/them distinction, the stealing of jobs by 'foreigners', or charges of dirtiness and laziness, Solomon realizes that the Andersons are euphemistically 'letting him go', now that he is 'free' and has a 'choice' to live where he likes in Britain. Then, having left the Andersons, Solomon soon finds out that prejudice is everywhere, including in Stoneleigh's new housing estate. The newness of the place is never a metaphor for a different and communitarian mentality, and people do not attempt to bring an end to the marginalization they think is Solomon's lot. Failure in negotiating co-living shows the continuation of a multicultural community still built on hardcore hierarchization.

\section{A possible meeting ground?}

The meeting ground between Solomon and Dorothy never materializes, or, more precisely, their relationship is shown to be doomed to failure. This reminds one of many other postcolonial novels in which the characters' past

\footnotetext{
${ }^{14}$ bell hooks, Yearning: Race, Gender and Cultural Politics, 31.
} 
history interferes with their present, nagging them either into reconciliation, or into rejection, or into an acceptance of differences in a multicultural space. Black British authors, for instance, have recently tried to address this issue. Whereas Zadie Smith experiments with a rather comical, yet ambivalent, approach to multi-ethnic characters in White Teeth (2000), Andrea Levy in Fruit of the Lemon (1999) and Small Island (2004) has insisted on the struggle for a truly multicultural society. More pessimistically perhaps, the sombre denouement of Phillips's novel seems to reveal that Britain, keeping up to its traditionally exclusionary 'ideals', still resists change and can therefore not become a viable multicultural society. This is all the more tragic as the types of exclusion described in the book - for example, those based on ethnicity may become the norm in a world that is paradoxically trying to be globalized. Perhaps Phillips wants to show that the encounter of Solomon and Dorothy, even though their friendship is nipped in the bud, somehow reveals that the concept of a territory-based society is outdated and that homelessness and dislocation have become the norm but may be negotiated by personal effort. The solution is neither the eradication of difference by excluding the odd man/woman nor assimilation into a global homogeneity. Rather, Phillips's $A$ Distant Shore offers a subtle questioning of the notion of 'home' in a country still pervaded by exclusion, whether racial, ethnic or social.

\section{WORKS CITED}

Appadurai, Arjun. "Disjuncture and Difference in the Global Cultural Economy," in Theorizing Diaspora, ed. Jana Evans Braziel \& Anita Mannur (Oxford: Blackwell, 2003): 25-48.

Ashcroft, Bill, Gareth Griffiths \& Helen Tiffin. Key Concepts in Post-Colonial Studies (London: Routledge, 1998).

Clingman, Stephen. “ 'England has changed': Questions of National Form in A Distant Shore," Moving Worlds 7.1 (2007): 46-58.

Derrida, Jacques, \& Anne Dufourmantelle. Of Hospitality (De l'hospitalité, 1997; Stanford CA: Stanford UP, 2000).

Fanon, Frantz. Black Skin, White Masks, tr. Charles Lam Markmann (Peau noire, masques blancs, 1952, tr. 1967; London: Pluto, 1982).

Gilroy, Paul. After Empire: Melancholia or Convivial Culture? (London: Routledge, 2004).

Gunning, David. "Anti-Racism, the Nation-State and Contemporary Black British Literature," Journal of Commonwealth Literature 39.2 (June 2004): 29-43. 
Hall, Stuart. "New Ethnicities" (1989), excerpt in The Post-Colonial Studies Reader, ed. Bill Ashcroft, Gareth Griffiths \& Helen Tiffin (London: Routledge, 1995): 223-27.

Heidegger, Martin. Being and Time, tr. Joan Stambaugh (Sein und Zeit, 1927; Albany: State U of New York P, 1996).

hooks, bell. Yearning: Race, Gender and Cultural Politics (Boston M A: South End, 1990).

Kuznets, Lois. "Defining Full Human Potential: Communities of Women, An Idea in Fiction," Children's Literature Association Quarterly 7.4 (Winter 1982): 10-33.

Ledent, Bénédicte. " 'Of, and not of, this Place': Attachment and Detachment in Caryl Phillips's A Distant Shore," Kunapipi 26.1 (2004): 152-60.

Levy, Andrea. Fruit of the Lemon (London: Review, 1999).

- Small Island (New York: Picador, 2004).

Phillips, Caryl. Crossing the River (London: Bloomsbury, 1993).

_. A Distant Shore (New York: Random House, 2003).

Safran, William. "Diasporas in Modern Societies: Myths of Homeland and Return," Diasporas 1.1 (Spring 1991): 83-89.

Smith, Zadie. White Teeth (New York: Random House, 2000).

Spivak, Gayatri Chakravorty. "Diasporas Old and New: Women in the Transnational World," Textual Practice 10.2 (Summer 1996): 245-69.

Warnes, Andrew. "Enemies Within: Diaspora and Democracy in Crossing the River and A Distant Shore," Moving Worlds 7.1 (2007): 33-45. 


\title{
Strange Encounters
}

\section{Nationhood and the Stranger in Caryl Phillips's A Distant Shore}

\author{
PETRA TOURNAY-THEODOTOU
}

Have you not observed that it is characteristic of a well-bred dog to behave with the utmost gentleness to those it is used to and knows, but to be savage to strangers $[\ldots]$ it is a trait that shows real discrimination and a truly philosophical nature [...] for the dog distinguishes the sight of a friend and foe simply by knowing one and not knowing the other. ${ }^{1}$

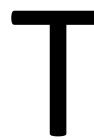
he contemporary Setting of A Distant Shore (2003) has been described as a change from Caryl Phillips's earlier work, which dealt almost exclusively with events set in the past. A closer look, however, shows that the themes addressed and the type of characters portrayed in the novel do not actually deviate from Phillips's earlier literary production. The setting might be contemporary, but the novel is still concerned with the same pressing issues of personal and social alienation, different kinds of (dis)placement, racial and gender discrimination, and the difficulties of interracial relationships.

In an interview about $A$ Distant Shore, Phillips himself draws parallels between the situation of asylum-seekers in contemporary England and the situation of the first immigrants in the Britain of the late 1950 s. $^{2}$ It is no

${ }^{1}$ Plato, The Republic, tr. Desmond Lee (Harmondsworth: Penguin, 1970): 111.

2 "One couldn't help but be aware of the debate about asylum seekers in Europe during the past few years. I noticed that a lot of the pejorative language used to describe them was similar to that applied to immigrants of my parents' generation. I've always felt that I would write a contemporary novel when the right subject-matter presented itself. And, of course, the right characters. I am still deeply committed to the notion of 'history' being the fundamental window through which we have to peer in order to see ourselves clearly." Caryl 
surprise, therefore, if the intertextual link between A Distant Shore and Phillips's first novel The Final Passage (1985) is more than obvious. However, the novel's meta-historical dimension becomes particularly evident in the description of Gabriel's/Solomon's flight from his war-torn country, which is strongly reminiscent of depictions of the Middle Passage. On several occasions, the discourse of slavery is employed: the men fleeing on the truck are referred to as "the cargo"; ${ }^{3}$ the refugees are crammed into the airplane like slaves on a slave ship and the interior of the airplane looks to Solomon like "a large tubular warehouse" (99). Furthermore, one cannot help but associate Solomon's crossing of the English Channel clutching on to the outside of a ship with the crossing of the Atlantic by slaves. The tragic fact that one of his companions falls overboard is yet another case in point. However subtle and rare these passages are in the novel, the intention of evoking a connection between the days of slavery and contemporary migration cannot be ignored. In other words, A Distant Shore is also a contemporary rewriting of the Middle Passage, a theme that has been of constant concern in Caryl Phillips's writing career.

In the interview quoted from above, Phillips was also asked about the decision to create a central white female character. ${ }^{4}$ Again this is not a new feature, since much of his work has represented black and white female protagonists and has also frequently opted for an escape into madness as a sign of their succumbing to the pressure exerted by alienating, oppressive, and violent surroundings. One need only think of Irina in Higher Ground, Leila in The Final Passage, and Eva in The Nature of Blood. The choice of an African refugee and a psychologically vulnerable, middle-aged white English woman as protagonists in A Distant Shore is indeed a clear sign of the writer's awareness of the connection between the equally oppressive sexual and (post)colonial politics, and of his wish to give a voice to those not represented in official or grand narratives and to provide an intimate view of their plight, as almost only literature can do. Phillips significantly has Dorothy say in the novel that "the dominant narrative is male" (203) and one may want to add: white Western heterosexual. As in his earlier books, in A Distant Shore the writer ex-

Phillips, "A Conversation with Caryl Phillips, Author of the Novel A Distant Shore," by Nathaniel Turner, ChickenBones: A Journal for Literary \& Artistic African-American Themes (2003): 1.

${ }^{3}$ Caryl Phillips, A Distant Shore (London: Vintage, 2003): 97. Further page references are in the main text.

${ }^{4}$ Phillips, "A Conversation with Caryl Phillips," 1. 
plores 'unlikely' relationships, crossing the boundaries of race, culture, and, in this case, also of generation. In short, the similarities in topic and choice of character outlined above suggest that he is still strongly committed to the same pressing issues, here clad in a contemporary guise. In view of the metahistoricity of the themes addressed, one could indeed say that he continues to weave the same narrative or, in other words, that he continues to write the same book.

This being the case, in what follows I wish to explore how Phillips adds to his ongoing narrative and approaches these 'same pressing issues' in A Distant Shore. More specifically, I will examine the novel's multiple constructions of the stranger based on race, gender, religion, and class, predominantly in the figures of the two protagonists, Dorothy, an ageing white English woman, and Solomon, an African refugee. This discussion will be linked to an analysis of the construction of places and spaces (the neighbourhood/the village) as miniature representations of the nation. The analysis will revolve around the various kinds of dis-placement - both spatial and psychological presented in the novel.

"England has changed. These days it's difficult to tell who's from around here and who's not. Who belongs and who's a stranger. It's disturbing. It doesn't feel right" (3). These opening sentences of A Distant Shore are of immediately programmatic value for the entire novel, introducing as they do several of its main concerns, such as England as a society in flux, the question of belonging and un-belonging, the use of the key term 'stranger', and the irritation these issues provoke in Dorothy. This incipit summarizes the destabilization of the experience of home undergone by contemporary societies. In her highly enlightening study Strange Encounters (2000), Sara Ahmed describes these changes to the once familiar space of home as follows:

there is always an encounter with strangerness at stake, even within the home $[. .$.$] homes do not stay the same as the space which is$ simply the familiar. There is movement and dislocation within the very forming of homes as complex and contingent spaces of inhabitance. $^{5}$

Dorothy's annoyance with the changes and her general mental instability aptly reflect the current 'disturbed' state of the British nation. In addition to

\footnotetext{
${ }^{5}$ Sara Ahmed, Strange Encounters: Embodied Others in Post-Coloniality (London \& New York: Routledge, 2000): 88.
} 
reading Dorothy as an allegory of Britain, as suggested by Bénédicte Ledent, ${ }^{6}$ I wish to argue that the depictions of the old village of Weston and the 'new development' of Stoneleigh likewise constitute miniature spatial allegories of the nation at large. In this reading, the village and/or neighbourhood functions on a small scale as a "tiny, underdeveloped nation."

To begin with, the contrastive use of the adjectives "old" and "new" suggests that the existing village represents the old England, with its old ways, whereas the 'new development' suggests change and a departure from the traditional ways. Furthermore, the location of the "new houses on the hill" and "on the edge of Weston" (3) captures a detached and marginal location on the periphery of the centre, Weston. I am here deliberately employing vocabulary used in colonial discourse, such as 'marginal' and 'periphery', as the village also comes to represent Britain's desperate effort to hold on to its glorious colonial past, which is illustrated by its unwillingness to "give up its name and identity" (3) and in the addition of "Weston" to "Stoneleigh" on letters "as though the former civilises the latter" (3). The spatial construction, together with the implied wealth of the inhabitants of the new development, suggests, moreover, its economic superiority, whereas the village with its high rate of unemployment represents the nation's general decline as an economic power. Class and an accompanying sense of inferiority on the part of the villagers thus also come to play an important role in the division of the two communities. This segregation becomes particularly evident when one of the female villagers refers to the new settlers as "the newcomers, or posh so-andsos" (5) and Dorothy in turn refers to the woman as "vulgar" (5), thus making the desire for social distinction a mutual one, as Dorothy registers: "So our village is divided into two" (4). In the context of my suggested allegorical reading of the village and the new development as representative of Britain, the division between the two communities thus encapsulates the tension between a conservative, essentialist Britain with its inability to accommodate change, on the one hand, and the demands of a society in flux, on the other. This division is further emphasized in the novel by the use of the us/them dichotomy, as much by Dorothy in her first-person narrative as by the owner of the pub, for example.

\footnotetext{
${ }^{6}$ Bénédicte Ledent, “ 'Of, and not of, this Place': Attachment and Detachment in Caryl Phillips' A Distant Shore," Kunapipi 26.1 (2004): 157.

${ }^{7}$ David J. Morris \& Karl Hess, Neigborhood Power: The New Localism (Boston MA: Beacon, 1975): 16.
} 
Apart from reading the village and the new development as powerful spatial images representing the current state of the nation, there is another 'space' recurrently mentioned in the novel that invites an allegorical reading: the pub. If Ledent interprets the constant consumption of tea by the English characters as "a quintessential symbol of Englishness," "I would like to add to this liquid allegory the spatial one of the pub, which appears to serve as a further emblem of home and Englishness. This construction of the alehouse seems to be the novel's most striking spatial image for conveying the dynamic of exclusion and inclusion. Dorothy's conservative father, for example, regarded pubs as a "place of refuge" and insisted that "they're about being yourself" (13) - or, as we may wish to add, about 'being English'. Considering that the history of the pub - or the public house - actually goes back to Roman times, this institution can be regarded as yet another "quintessential symbol of Englishness" in the novel. It is therefore not surprising that Dorothy doesn't feel comfortable with inviting Solomon to go to the pub with her (45) and that Solomon doesn't feel welcome there, as he keeps rejecting his Irish friend Mike's invitations to accompany him to " "his' pub" (286). It is also there that Dorothy's conflict of loyalties is played out when she resolves that she doesn't want Solomon to "become a problem in [her] life" (45). This is when she decides to leave without notifying Solomon and when, during her absence, he is tragically murdered by the village thugs. As a drifter between the two spaces, the inn and the new estate, Dorothy is assigned the role of mediator between the two worlds. If one may be tempted to read her strolls to the pub as an attempt at some kind of assertion of her Englishness, these visits eventually only exacerbate her rejection of the village community. During a conversation with the landlord following Solomon's murder, she stands by the African man when she openly declares: "Yes [...]. He was a friend of mine" (48). In this entire exchange, the publican shows no true compassion for Solomon's sad fate and is only eager to defend the purity of the village/ nation and the innocence of its inhabitants/citizens. Even though he does say in passing that he is sorry for Solomon, in the same sentence - that is, on the same level - he expresses his worry about the town's reputation (48) and is certain that it can only have been an accident, asserting further that in the village there live only " "decent folk committed to their families and their community. We don't have murderers here" (49). In response, Dorothy only nods, as she has "no desire to upset his sense of community" (49). The bar-

\footnotetext{
${ }^{8}$ Ledent, “' Of, and not of, this Place'," 157.
} 
keeper's concern for the village's reputation, his alliance with the rest of the villagers, together with the references to community above are, in fact, strongly reminiscent of Benedict Anderson's concept of the nation as an imagined community characterized by a "deep, horizontal comradeship."

In this context, it is interesting that Dorothy apparently thinks it more appropriate to take Solomon to the Somalian and Mediterranean Food Hall (18), a choice of place that is diametrically opposed to the English pub. Significantly, this ethnic restaurant is not located in the village but in the presumably more liberal nearby town. However, to read the existence of ethnic restaurants as a positive sign of successful multicultural integration is deceptive. According to Sara Ahmed,

a key aspect of multiculturalism as a policy for managing difference is food and eating. [...] difference is valued insofar as it can be incorporated into, not only the nation space, but also the individual body, the body-at-home. ${ }^{10}$

The quasi-cannibalistic act of the consumption of strangeness thus allows for a re-assertion of control on the part of the consuming native English self; or, again in the words of Sara Ahmed (in a discussion of bell hooks' article "Eating the Other"):

The white consuming subject is invited to eat the other: to take it in, digest it, and shit out the waste. The exotic and strange foods are incorporated into the bodies of Western consumers as that which is different, but assimilable. ${ }^{11}$

By extension, difference that cannot be incorporated, fully integrated, and assimilated into the nation or the body through consumption is not valued, hence becomes subject to rejection and, even worse, violence, in an effort to keep the nation's space pure, permitting only a certain dose of consumptive (manageable) exoticism to spice up one's life. In this connection, the description of the rude behaviour and abuse that Mahmood, Dorothy's married Indian lover, had to suffer at the hands of his white English customers when he was still running an Indian restaurant may serve as a further example (202). In fact, the entire episode strongly evokes the attitude of colonials taking over

\footnotetext{
${ }^{9}$ Benedict Anderson, Imagined Communities: Reflections on the Origin and Spread of Nationalism (1983; London \& New York: Verso, 1991): 7.

${ }^{10}$ Ahmed, Strange Encounters, 117.

${ }^{11}$ Strange Encounters, 117.
} 
the conquered space, defiling it and insulting the owner in an obvious effort to remind him who is still the master of the house/nation.

The division of the two communities is communicated to the reader mainly from Dorothy's perspective. Even though she is gradually revealed to be an unreliable narrator and many of her descriptions are coloured by her perception (indeed, willful construction of herself) as a stranger in her own homeland - she imagines herself to be stigmatized, with people staring at her as if she had the "mark of Cain on [her] forehead" (6) - there is nevertheless, from the very beginning, strong evidence that her neighbours cannot tolerate difference. ${ }^{12}$ On one particular occasion, Dorothy imagines that a man from the village

considers me and everybody else in the new development to be interlopers.

All of us, disturbing a pattern that has gone on for decade after decade until Stoneleigh came along to make them feel as though their shrinking lives, which were already blighted by closures and unemployment, were even less important than they had hitherto imagined. (29)

One may argue that this passage says possibly more about Dorothy than about the man himself. However, she conjures up this projection only after several encounters with some of the villagers reinforce such a construction of hostile opposition. One case that clearly illustrates the rejection of anybody who is perceived as different by the village dwellers is that of the presumably Jewish - female Dr Epstein and her family, who, according to the barman in the pub, would have been much happier had Stoneleigh already been finished: " Up there they might have fit in better, but living down here with us, well, it was difficult for them to mix"” (9). Thus, in the context of reading the neighbourhood as a miniature representation of the nation, one might speculate that the people in the "new development" following the 'us versus them' split - are similarly viewed as unwanted

${ }^{12}$ For example, Mrs Lawson, the mother of Dorothy's piano student, tells her straight: "you're behaving strangely" (23) and in what seems to be an effort to reach out to Dorothy - she is, after all, white and Anglo-Saxon - suggests that she should spend time with some of the "good people" (23) in the village.

${ }^{13}$ The use of the term "imagined" in Dorothy's comment yet again recalls Benedict Anderson's notion of the "imagined community." He refers to the nation as "imagined because $[\ldots]$ in the minds of each [member] lives the image of their communion" (Anderson, Imagined Communities, 6). The key terms "imagined," "mind," and "communion" clearly capture a state of mind which leads to a position of prejudice and of preconceptions about the other. 
intruders and outsiders on the level of the village, as asylum-seekers and immigrants are on the level of the nation, and again the village in nucleo mirrors the British nation at large.

As I have demonstrated so far, the 'other' characters in A Distant Shore are constructed as strangers on grounds of race, as in the case of Solomon, gender and religion, as in the case of Dr Epstein, and even of gender and class, as implied in the cases of Dorothy and Dr Epstein. As in many of his other narratives, Phillips has here skilfully interwoven race, gender, religion, and class into his narrative to lay bare the oppression still to be found in British - or for that matter European - society. It is noteworthy that already two years before the publication of A Distant Shore, Phillips expressed in a nutshell the concerns he was later to fictionalize in the novel. In his essay collection A New World Order (2001) he registered "a sharp increase in racial violence and acts of intolerance. The homogenisation of Europe opens the door not so much to immigrants, but to nationalists who lament the erosion of racially inscribed 'traditional' values.", 14

Yet there is more to be said about Dorothy's lucid comments on Weston's economic degeneration and on the effect this has on the self-esteem of its inhabitants. Sara Ahmed contends that

it is the very potential of the community to fail [or the suppressed certainty that they have already failed as in the case of Weston/Britain] which is required for the constitution of the community. It is the enforcement of the boundaries between those who are already recognised as out of place (even other fellow residents) that allows those boundaries to be established. ${ }^{15}$

That is, Weston's/Britain's security and well-being have been shaken with the closing down of the coal pits and the high rate of unemployment. Nevertheless, the community holds together, but is challenged beyond endurance when the posh neighbourhood is established, as it represents an alternative that holds up the mirror to their dire existence. In order to preserve itself, the neighbourhood/nation has to reject 'any/body' - including 'other' English people - who might threaten its perceived communal bond. This rejection, manifested in social exclusion - or in its most exacerbated form, violence - is thus ultimately motivated by a profound fear of failure or even of destruction,

\footnotetext{
${ }^{14}$ Caryl Phillips, A New World Order: Selected Essays (London: Secker \& Warburg, 2001): 245 .

${ }^{15}$ Ahmed, Strange Encounters, 26 (italics and parentheses in original, square brackets mine).
} 
of a veritable Götterdämmerung, so to speak. The novel furthermore captures this looming doom in the frequent pictorial references to the setting sun, a powerful image for the degenerate state of the nation. ${ }^{16}$ Ahmed's reference to boundaries above recalls recent expansions of the notion of the boundary or border as largely symbolic. According to Hastings Donnan and Thomas M. Wilson, for example,

what remains distinctive about locality and community $[\ldots]$ is $[\ldots]$ their [i.e. people's $]$ sense of difference and distinctiveness. Community difference and identity $[\ldots]$ reside $[\ldots]$ in the minds of the people who express them. ${ }^{17}$

In other words, the perceived difference and ensuing identity-formation are constructed, imagined, and thus symbolic. However, for the marginalized characters in A Distant Shore, these boundaries are no less real for not being physically marked, since they are clearly real in their consequences, resulting in Solomon's violent death and Dorothy's confinement in a mental asylum.

In the novel, Mr Anderson, "my benefactor" as Solomon comes to refer to him, is at some pains to explain to Solomon what goes on in people's minds:

'There's an awful lot of you, and the system's already creaking to breaking point. I mean, things are particularly bad if you want to get into one of our hospitals. People are upset. [...] People think [...] that you have too many children. [...] that you don't really want to work. It's in their heads and it makes them mad.' (289)

To this helpless attempt at explaining prejudice Solomon responds with a disarmingly wise innocence: "“Who put it there?"” (289). Even though $\mathrm{Mr}$ Anderson and his wife prove to be guardian angels for Solomon, in this particular exchange, Mr Anderson can't seem to help using the distancing device of the plural "you" when referring to Solomon and the implied masses of asylum-seekers. In this enumeration of the usual prejudices, those referring to the lack of hospital space and the fear of being outnumbered are especially noteworthy, as they both imply the threat of extinction, personal as well as national. Yet again, this passage evokes the concept of the imagined community, which needs to protect itself, its members and its space, against the

\footnotetext{
${ }^{16}$ See, for example, "As the sun began to set" (7), "The dying sun forms a halo around his [Solomon's] head" (32). The second quotation can in addition be read as a bad omen anticipating Solomon's violent death. The references to the setting sun furthermore recall the popular nineteenth-century phrase that 'the sun never sets on our [the British] Empire'.

${ }^{17}$ Hastings Donnan \& Thomas M. Wilson, Borders: Frontiers of Identity, Nation and State (Oxford \& New York: Berg, 1999): 24 (second set of italics mine).
} 
intrusion of others in order to secure its mere survival. The stranger is, as a result, constructed as a figure of danger who transgresses perceived boundaries and engenders fear in the 'native'. As a result, the enforcement of violence becomes 'justified'. Following Sara Ahmed, the discourse of the imperilling stranger "becomes a mechanism for the justification of acts of violence against those who are already recognised as strangers." 18 This justification applies with special force to the defence of Solomon's murderers offered by the owner of the pub in the scene discussed above. In keeping with the colonial reading previously suggested, Weston/Britain is thus constructed as the centre from which other beings - marginalized, strange bodies - have to be expelled, as they constitute a threat to identity and home.

If, in the construction of a body politic, Dorothy is an excluded body-athome, Solomon is an excluded body-out-of-place; as such, his exclusion functions both on the level of the neighbourhood and on that of the nation. As a black African, Solomon's position is especially precarious, as he embodies not only a cultural Other but primarily a racial Other. According to Fanon,

the real Other for the white man is and will continue to be the black man [...] for the white man The Other is perceived on the level of the body image, absolutely as not-self. ${ }^{19}$

In this racialized encounter, Solomon's - the black man's - subjectivity is reduced to the materiality of his body, with the skin serving as visual signifier of difference and as a clear boundary line. That is, the perceived threat that this 'strange body' poses to the bodily and social security is played out on the surface of the skin.

Maintaining the body image, in a study on neighbourhoods, Howard W. Hallman draws an interesting parallel between the ideal neighbourhood/ nation and a healthy body. ${ }^{20}$ This comparison suggests that a healthy and intact neighbourhood/nation is homogeneous and sealed, hence does not accommodate outsiders. It would have to reject them as foreign agents, as viruses, as something that needs to be expelled in order to secure or restore the neighbourhood's/nation's health.

\footnotetext{
${ }^{18}$ Ahmed, Strange Encounters, 37.

${ }^{19}$ Frantz Fanon, Black Skin, White Masks, tr. Charles Lam Markmann (Peau noire, masques blancs, 1952; tr. 1967; London: Paladin, 1975): 114.

${ }^{20}$ Howard W. Hallman, Neighborhoods: Their Place in Urban Life (Beverly Hills CA: Sage, 1984): 256.
} 
It is only shortly after setting foot on English soil that Solomon becomes acquainted with the dynamic of the imperilling stranger when he is accused of raping a young white English girl. If, according to studies of civil violence, the ultimate violent strangers are figured as either immigrants or men of colour, ${ }^{21}$ with cultural difference as the prime source responsible for the fear of crime, this allegation against an individual that is doubly stigmatized is not surprising. The case is, however, further complicated by the fact that the alleged victim is still almost a child. Again following Sara Ahmed:

the discourse of stranger danger also involves the figuring $[\ldots]$ of $[\ldots]$ the vulnerable body, the one who is most at risk. Here, 'the child' becomes a figure of vulnerability, the purified body that is most endangered by the contaminating desires of strangers. ${ }^{22}$

Based on this explanation, the episode begs to be also read as an allegory. Keeping in mind the traditional identification of the land/country/nation with the female body, it is not only the innocence and virginity of a girl child that is at risk from the proximity of strangers, but it is the moral purity of the nation space itself that is also under attack, that is violated by the uncontained sexual desires attributed to the black man.

Katherine, Solomon's assigned state defendant, summarizes this uncanny projection of danger onto a stranger when, in response to Solomon's assertion of his innocence, she says "I'm not disputing this [...]. It's just that people always assume that there's no smoke without fire. I know it's unfair, but that's how it is" (166). From the beginning of his new life in England, Solomon is thus confronted with people's prejudices and negative presumptions: "one knows again those whom one does not know by assuming they are the origin of danger.,"23

The 'strange encounter' that receives most of the attention in the novel is undoubtedly the relationship between Dorothy and Solomon. With its reversed chronology, the novel very cautiously develops this budding friendship between two people who "do not fit," ${ }^{24}$ whose common bond is chiefly based on the mutual recognition of their loneliness - "She appears lonely" (293) and their shared inability to deal with painful memories. When Dorothy watches Solomon washing his car she observes:

\footnotetext{
${ }^{21}$ Ahmed, Strange Encounters, 36.

${ }^{22}$ Strange Encounters, 34.

${ }^{23}$ Strange Encounters, 32 (italics in original).

${ }^{24}$ Strange Encounters, 24.
} 
this lonely man $[\ldots]$. His every movement would appear to be an attempt to erase a past that he no longer wishes to be reminded of. She looks at him and she understands. (268)

What draws these two individuals together is their common experience of alienation and "strangerness," ${ }^{25}$ which results in the creation of a "community of strangers," ${ }^{26}$ a common bond with another person who has shared a similar experience of (dis)placement - be it physical or psychological. It is, however, not only with Dorothy that Solomon has a close connection. When considering the cast of characters he encounters in Britain, in fact, almost every person who does him a good turn is strictly speaking a stranger and, as such, a member of the community of strangers. It is thus not surprising that Solomon strikes up a friendship with Mike, his "Good Samaritan" (293), who, as an Irishman, is himself a stranger in England. Upon first meeting Mike, Solomon registers that "Mike did not appear to be like the other English people" (272) and is puzzled and pleased to find out that they both come from another country (273). Even Mr and Mrs Anderson are not 'fully' English, for they retire to Scotland, the place where "Mum," as Solomon comes to affectionately call Mrs Anderson, is originally from. As Solomon's "sole desire was to be safe in England" (279), it is these 'other' strangers who provide him with a feeling of safety. In his first encounter with Mum, Solomon significantly realizes that "there was something about this small elderly woman that made me feel safe" (277). Phillips seems to have deliberately constructed a palette of characters that are not English but different in their own ways in order to show how a similarly marginalized position in society promotes a deeper understanding of and sympathy for the plight of another stranger.

A further characteristic that draws Solomon and Dorothy to each other is their common obsession with decorum and manners. In A Distant Shore the English are frequently portrayed as rude, uncivilized, and ill-mannered - or at least perceived as such by the novel's two protagonists, whereas they both appreciate the polite behaviour in each other. This need for courtesy and respectability seems at once to compensate for their estrangement from their surroundings and to provide them with a sense of dignity and self-esteem. This insistence on manners also serves to further emphasize how remote their fellow-citizens are from civilized or simply human behaviour. ${ }^{27}$ Dorothy sig-

\footnotetext{
${ }^{25}$ Ahmed, Strange Encounters, 88.

${ }^{26}$ Strange Encounters, 84.

${ }^{27}$ For example, Dorothy is not only annoyed at the hooligans and the homeless but also complains about ill manners in her pupils and her colleague Geoff, or about her neighbour's
} 
nificantly says to herself towards the end of the novel: "after all, without manners we're no better than animals" $(310-11) .^{28}$ As in many of Phillips's other narratives, this need for respectability goes together with an impeccable use of the English language. Solomon's refined diction in particular recalls several other black male characters in Phillips's previous work, especially Cambridge in the eponymous novel, Rudi in Higher Ground, and Othello in The Nature of Blood. For Phillips, proper use of language and personal refinement appear to be inextricably linked as a sign of the degree to which a person is civilized. He makes this very clear when in an interview he declares that "language is vital and precious. It dignifies us. ${ }^{, 29}$ Very much like the characters just mentioned, it appears that in terms of manners and eloquence Solomon finds himself on a reversed civilizing mission. This reversal becomes especially evident when, after having received several items of hate-mail, one day dog mess is introduced through his letter-box. In response, Solomon summarizes such conduct as "savage" (300), a term that applies even more forcefully to his later cowardly and brutal murder. In short, as a further illustration of the present condition of Britain, the novel unveils the allegedly civilized nation as its exact opposite and in contrast represents those who are commonly viewed as 'savage' as the ones who exhibit refined behaviour. It thus shows that those prejudices that are usually projected onto the unwanted 'others' are part of the nation's own "mental condition" (292).

Ultimately, A Distant Shore is another clear testimony to the author's political agenda of letting the subaltern speak. In an article on the power of the far right in Flanders, he offers the following mock-response to his critics:

Mr Phillips's multicultural society works only if there is a reciprocal exchange and, hopefully one day, a commingling, of narratives. [...] Having authority over our own story, and the means to tell it, is the most potent weapon that any of us are able to utilise against the corrupt vision of the far right. ${ }^{30}$

By taking on the task of the storyteller, giving Solomon and Dorothy a voice, Phillips saves their stories - which are representative of so many other 'small' lives - from oblivion. A Distant Shore can therefore also be described as a

banging on her door, "for it suggests bad manners" (20). She is also irritated by her student's sitting at the piano "without any sense of propriety" (21).

${ }^{28}$ For another discussion of 'polite behaviour' in A Distant Shore, see Cindy Gabrielle's article in the present volume, 309-18.

${ }^{29}$ Phillips, "A Conversation with Caryl Phillips," 3.

${ }^{30}$ Caryl Phillips, "The Silenced Minority," Guardian (15 May 2004): http://www .guardian.co.uk/books/2004/may/15/society.politics (accessed 1 August 2009). 
narrative of resurrection, talking from beyond the grave in Solomon's case and from beyond reason in Dorothy's, setting up a narrative monument in their memory.

With its close scrutiny of today's Britain, the novel provides a bleakly powerful commentary on the nation's condition. Equally do the fates of the text's two protagonists - death and mental collapse respectively - provide little hope for Phillips's vision of a functional, multicultural society. However, the two main characters have at least attempted what Sara Ahmed calls ethical communication:

a certain way of holding proximity and distance together: one gets close enough to others to be touched by that which cannot be simply got across. In such an encounter, 'one' does not stay in place, or one does not stay safely at a distance (there is no space which is not implicated in the encounter). It is through getting closer, rather than remaining at a distance, that the impossibility of pure proximity can be put to work, or made to work. ${ }^{31}$

Hence, the only glimpse of hope for the future of the nation, its accommodation of change and its acceptance of strangers, can be detected in the portrayal of the delicate friendship formed between Dorothy and Solomon, two vulnerable and - for the time being - sadly defeated individuals.

Yet, despite the tragic defeat suffered by his protagonists, Phillips himself demonstrates an undaunted determination to continue his fight against racism and nationalism - and on this note of resolve I would like to conclude my essay:

as long as there remain people who are incapable or unwilling to uncouple nationality from race, then my continued presence has virtue in so far as it might serve to confound, or perhaps even educate, such people."32

\section{WORKS CITED}

Ahmed, Sara. Strange Encounters: Embodied Others in Post-Coloniality (London \& New York: Routledge, 2000).

Anderson, Benedict. Imagined Communities: Reflections on the Origin and Spread of Nationalism (1983; London \& New York: Verso, 1991).

Donnan, Hastings, \& Thomas M. Wilson. Borders: Frontiers of Identity, Nation and State (Oxford \& New York: Berg, 1999).

\footnotetext{
31 Ahmed, Strange Encounters, 157.

${ }^{32}$ Phillips, A New World Order, 304-05.
} 
Fanon, Frantz. Black Skin, White Masks, tr. Charles Lam Markmann (Peau noire, masques blancs; Paris: Seuil, 1952; tr. 1967; London: Paladin, 1975).

Gabrielle, Cindy. "The Civilized Pretence: Caryl Phillips and A Distant Shore," present volume, 309-18.

Hallman, Howard W. Neighborhoods: Their Place in Urban Life (Beverley Hills C A: Sage, 1984).

hooks, bell. "Eating the Other: Desire and Resistance," in Black Looks: Race and Representation (London: Turnaround, 1992): 21-39.

Ledent, Bénédicte. " 'Of, and not of, this Place': Attachment and Detachment in Caryl Phillips' A Distant Shore," Kunapipi 26.1 (2004): 152-60.

Morris, David J., \& Karl Hess. Neighborhood Power: The New Localism (Boston M A : Beacon, 1975).

Phillips, Caryl. "A Conversation with Caryl Phillips, Author of the Novel A Distant Shore," by Nathaniel Turner, ChickenBones: A Journal for Literary \& Artistic African-American Themes (2003): 1-5.

. Cambridge (London: Bloomsbury, 1991).

- A Distant Shore (London: Vintage, 2003).

- The Final Passage (London: Faber \& Faber, 1985)

Higher Ground (London: Viking 1989).

The Nature of Blood (London: Faber \& Faber, 1997).

. A New World Order: Selected Essays (London: Secker \& Warburg, 2001).

. "The Silenced Minority," Guardian (15 May 2004), http://www.guardian.co .uk/books/2004/may/15/society.politics (accessed 1 August 2009).

Plato. The Republic, tr. Desmond Lee (Harmondsworth: Penguin, 1970). 


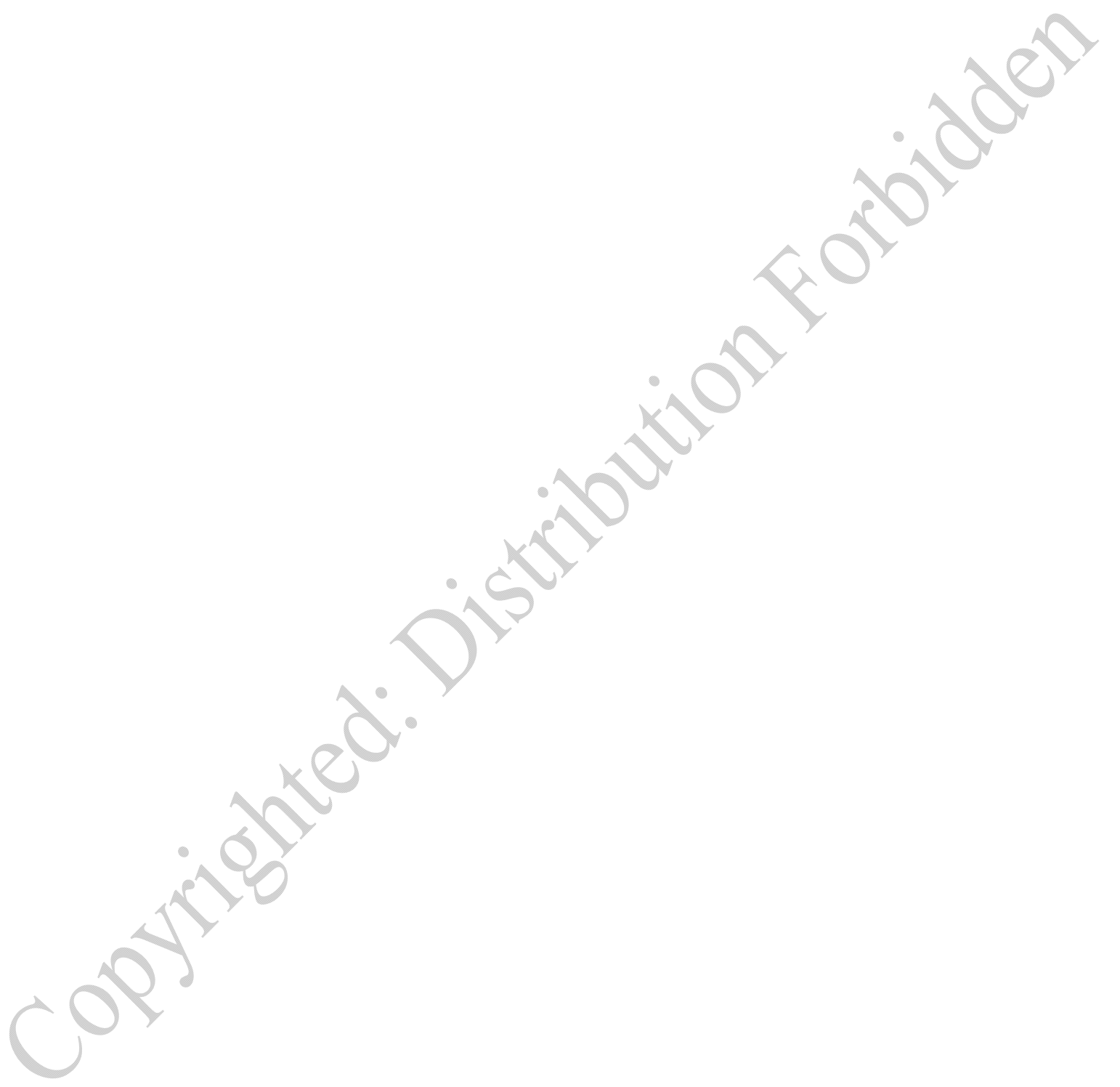




\title{
The Civilized Pretence Caryl Phillips and A Distant Shore
}

\author{
CINDY GABRIELLE
}

EAVING ENGLAND FOR AFRICA, MARLOW - THE MAIN CHARACTER of Heart of Darkness (1902) - cannot help thinking that England too "has been one of the dark places of the earth" where one can come across "utter savagery." Similarly, Caryl Phillips's A Distant Shore (2003) can be seen to dispute the spurious belief that England has been a civilized place ever since the Romans conquered it. What lies at the heart of Phillips's novel is the idea that neither imaginatively reaching back to England's primeval past nor actually travelling to 'uncivilized' places is a sine qua non condition to encounter darkness. To explore "man's capacity for evil,"2 it suffices to overturn the paradigm at the core of Heart of Darkness and, to paraphrase Phillips's comment on Conrad's novella, address the issue of what happens when a group of people, supposedly less human and less civilized than another, attempt to impose themselves upon their 'superiors'. ${ }^{3}$ What interests me is to try and look into the minute examination conducted by Phillips of the 'civilized pretence' maintained by English people and the falling apart of this deceitful posture in the face of immigration. Also, I shall analyze in greater detail the alienated others' response to the moral order oppressing them,

In $A$ Distant Shore, both the construction of posh bungalows in Weston and the arrival of black immigrants in England represent a challenge to English identity, as they are "disturbing a pattern that has gone on for decade after

\footnotetext{
${ }^{1}$ Joseph Conrad, Heart of Darkness (1902), in Heart of Darkness and Selections from the Congo Diary, intro. Caryl Phillips (New York: Modern Library, 1999): 5, 7.

${ }^{2}$ Caryl Phillips, "Introduction" to Joseph Conrad, Heart of Darkness, xvi.

${ }^{3}$ See Phillips, "Introduction," xvi.
} 
decade" and "creaking [the old system] to breaking point" (289). The villagers' first reaction is to deny the new housing development a separate name and thus an identity: the postman, for example, has been "instructed by the head office to scratch out the name "Stoneleigh" if it appears on any envelopes (4). Without an individual name, the new development becomes nominally indistinguishable from greater Weston. The hostility towards Stoneleigh should be understood in parallel with the general attitude towards yet another form of intrusion, immigration at large. One has the impression that immigration would be better tolerated if only the 'intruders' ceased to insist on their foreignness. This is, at least, the view adopted by some of the characters in the novel, including Mike:

'I'm an old traditionalist, Solomon. I want fish and chips, not curry and chips. I'm not prejudiced, but we'll soon be living in a foreign country unless somebody puts an end to all this immigration. These Indians, they still make their women trail after them, and they have their mosques and temples, and their butcher shops where they kill animals in the basement and do whatever they do with the blood. I mean, they're peasants. [...] There ought to be some training or they should go back.' (290)

As is often the case, the purpose of such attempts at assimilation is to nullify the threat that the intrusion represents for well-established identities. Yet the impulse towards assimilation goes hand in hand with what at first seems to be the opposite movement - the impulse to reject otherness. As emphasized a number of times in the novel, working-class people from Weston find it hard to accept (let alone identify with) the "posh so-and-sos" (5) not living "down here" with them but in the bungalows "up there" (9). As the village is said to be "divided into two" (4), the inhabitants of Stoneleigh are marginalized from the rest of the community, which is perhaps the reason why Dorothy feels she is wearing the "mark of Cain" (6) - the stigma of otherness and its subsequent rejection - in the eyes of the villagers. Thus, the breaking up of the 'old pattern' has not after all led to any societal change in A Distant Shore, since the threat of otherness is, as I have briefly shown, either rendered harmless (by assimilation or 'un-othering') or simply discarded. In view of this, it becomes clear that the pattern which the new development and black immigrants are disturbing is one of identification or, more accurately, of self-definition by

\footnotetext{
${ }^{4}$ Caryl Phillips, A Distant Shore (London: Vintage, 2003): 29. Further page references are in the main text.
} 
"strategies of exclusion." For white English people like Dorothy's father, "being English [indeed means] no coloureds" (42). Similarly, for the inhabitants of Weston, being a 'true' Westonian is equated with belonging to the working class. The fact that those who send threatening letters to Solomon insist on disclosing their names could then be seen not only as an identityassertion against the 'Other' but also as a refusal to accept that the old ways of identification are no longer valid in a society where, as Solomon's case exemplifies, one can be black but nonetheless a British citizen. These attempts to preserve a 'pure' English/working-class identity and traditional identification patterns at all costs are certainly at odds with the image of England as a nation of progress, but what the author underlines in A Distant Shore is the loss that this "closure" implies (29). Significantly, the disappearance of Mahmood and Solomon (those who represent 'otherness' in cultural terms) from Dorothy's life means that she loses a connection with "something that existed beyond the narrow scope of her own predictable world" (218) - which, incidentally, makes her realize how claustrophobic England is (see 64 and 266). It goes without saying that, on account of the more or less generalized endeavour to preserve the cultural and social status quo, England/Weston is anything but a place of new beginnings; rather, it is a dead end. ${ }^{6}$ How this is compatible with Dorothy's and Solomon's search for a safe haven should become clear in what follows.

The transformation of Solomon's future house - initially a storage hut into something "that blended in" (280) with the other bungalows of Stoneleigh is quite symptomatic of a society wanting no hybridization. Another obvious example is that of the Epstein family, who "didn't last long" (8) in Weston, probably because their Jewishness was too visible but also because their exoticism could not be 'reduced' to allow them to blend in - for, unlike huts, people can prove unadaptable. As the pub landlord explains,

'Nobody cares much [for Jews] in the town, but around here they don't blend in. I mean, Rachel and Jacob [the Epstein children]. They weren't even trying.' (9)

\footnotetext{
${ }^{5}$ Caryl Phillips, A New World Order: Selected Essays (London: Secker \& Warburg, 2001): 280.

${ }^{6}$ And, as Bénédicte Ledent says, "this absence of movement is also conveyed by the culde-sac in which Dorothy and Solomon live." Ledent, " 'Of, and not of, this Place': Attachment and Detachment in Caryl Phillips' A Distant Shore," Kunapipi 26.1 (2004): 157.
} 
Many passages in the book actually give the impression that, mutatis mutandis, English citizens act as custom officers would - they scrutinize their border attentively so as to spot and quickly remove possible threats to the nation. Almost all the characters of the novel are in one way or another under close scrutiny and, should they show deviant behaviour, then they are likely to receive advice on how to get back onto the right path. For example, Dorothy is warned by her colleague Sally that " "tongues are wagging" " about her and that the other teachers are beginning to think that she feels " "too grand" " to mix with them (227), meaning that Dorothy really ought to change her attitude. Again, this brings us back to the connections between Conrad and Phillips, insofar as Heart of Darkness is concerned with man's response to chaos when he is "released from the moral order of society," whereas A Distant Shore is committed to the alienated other's response to civilization, when $\mathrm{s} /$ he is administered heavy doses of the procrustean treatment pertaining to any oppressive moral order.

The weight of people's eyes (which Solomon clearly feels the night he encounters Mike, 274) is so omnipresent in the sections of $A$ Distant Shore set in England that it is, to start with, no wonder if many characters feel compelled to find places, refuges, where there is no need "to watch [one's] p's and q's," as Dorothy's father puts it (13). Solomon's bungalow in Stoneleigh obviously represents for him this kind of refuge from society's watchful eyes, hence his insistence that people should not be able "to look in at [him]" and his satisfaction with the "further protection" that the "plastic window blind" gives him (283). However, despite the new window blind, passers-by are still able to take a peep at the interior of Solomon's bungalow (14), which indicates that the protections sought by the characters against the weight of people's eyes are illusory. To find a sense of peace, what choice is there left for individuals under scrutiny but to reject all societal norms? If becoming homeless is one possible manifestation of such resistance, one understands why Dorothy's staring at a homeless man prompts him to burst out: “'you can't hurt me anymore [...] you can't hurt me" (12). As we know from the context of the novel, Dorothy had never seen, let alone mistreated, this man before in her life, which means that his cry is directed less at Dorothy as an individual than at the rules of oppressive society, which she at times enforces even though she also falls victim to them. The irony here is that if the homeless man had truly

${ }^{7}$ Caryl Phillips, "Introduction," xvi. 
become indifferent to society's ways and judgments, then he would not cry out against Dorothy.

In Solomon's and Dorothy's cases, the close scrutiny to which they are exposed obviously results in their being labelled as 'Other' (Solomon for his skin colour and Dorothy for her eccentric behaviour), and eventually both are wiped off the landscape: Solomon is killed, while Dorothy is put away in a mental institution. But of course, the inhabitants of Weston will not readily acknowledge that their keenness to erase otherness actually reveals their darkness; that they can be oppressors or even murderers. A closer look at the pub landlord's views concerning the treatment of the Epstein family makes it clear that villagers are not to blame for making their lives a misery, but that the real culprits are the family themselves, since "they weren't even trying [to adapt]" (9). As for Solomon's murder, the landlord's reaction is one of denial. As he explains to Dorothy, her friend's death

'must have been an accident because there's nobody in Weston who would do anything like that. [...] If you've lived here as long as I have, love, and you've grown up with folks like these, you'd understand that there's not one among them capable of harming anybody. That's just how they are. Decent folk committed to their families and their community [...].' (48-49)

But there is no denying the fact that Solomon has been murdered, which means that some of the villagers, particularly the youths who had been harassing Solomon, cannot qualify as "decent" Westonians. The question we might ask ourselves here is whether or not the 'arrival of darkness', of persecution and murder in England, can be attributed to a loss of decency on the part of these young people, which would be in keeping with Dorothy's statement that "without manners we're no better than animals" (311). Yet the text itself undermines the pub landlord's and Dorothy's belief that decency is a safeguard against savagery. It is, for instance, crucial that, despite her very decent behaviour, Dorothy should end up in jail for attacking a homeless woman. As for Solomon, the only gentleman Dorothy ever knew, he committed crimes in Africa when he was still known as Gabriel, notably against his former employer and friend Felix. Although Felix belonged to the ruling tribe, he "never displayed any prejudice against those, like Gabriel, whose blood marks them off as the nominal enemy" (89). Moreover, he did not hesitate to provide Gabriel/Solomon with money to leave the country. But, since what Felix offered was not enough for his friend, Gabriel brutally killed and then robbed him (89-92). These examples suggest that good manners can function as 
masks hiding one's real past or one's prejudices. This implies, too, that the rejection of any civilized pretence by the younger generations cannot be said to coincide with any 'arrival of darkness' in England. As I pointed out earlier, darkness has always been there, but it is simply more visible without the decorum of good manners. That a shift from covert to openly expressed racism - or, more generally, to vindications against established rules or social changes - has occurred in English society becomes apparent when comparing Solomon's first passenger as a volunteer driver, "an elderly man [...] [whose] body exudes an unfortunate odour" (298), with the "abusive youngster" (241) making a fuss to be allowed to take his bike aboard a bus while Dorothy waits for its departure. When Solomon's elderly passenger is forced to accept the help of a black man, he stares at his driver but says nothing (298). The man's brooding silence stands in stark opposition to the flow of insults that the young man directs at the bus driver. But, whether or not frustration or racist feelings are voiced or enacted, they exist regardless of any generational gap.

Up to this point I have focused on Phillips's representation of England as a dead end, wanting no cultural or class mixing. Even though the characters of the book remain on the whole very passive, as if overwhelmed by a society marginalizing them, it might be suggested that the author himself, in many ways, offers textual resistance to society's crushing force and in so doing redeems his characters' passivity. In the first section, any information relating to Solomon's skin colour is conspicuously un-salient (Dorothy, indeed, puts more emphasis on his good manners), perhaps as should ideally be the case that is, if society were colour-blind. Further, his English is impeccable, he has never had the habit of "sweating away" (186) his problems through dancing or singing, and he is said to "[fit] in with how he behaves about everything" (14). Solomon's lack of exoticism arguably functions to blur the division between the typical English gentleman and the 'colourful' stranger, so that the character resists classification into the latter category. Dorothy, for her part, is obsessed with maintaining her respectability and dignity, which, however, she flouts, without even realizing it, when she harasses Geoff or patronizes Mahmood's wife. For all her flawless manners, Dorothy is clearly an unreliable narrator, but as it is only gradually revealed that she suffers from mental problems, her classification as an atypical Englishwoman is rendered rather complicated. By focusing on an immigrant man and a mentally ill woman, Phillips casts light on the lives of those whom society usually leaves aside, those who "may as well have been living on the dark side of the moon" (59). Thus, not only does the author problematize the marginalization of Dorothy and Solo- 
mon, but he also counters it by making their lives central to his narrative - in Petra Tournay's words, "Phillips pursues the project of re-writing and recreating 'hidden histories',",

Of course, it will not do to discuss the strategies of textual resistance to society's ostracizing force in A Distant Shore without mentioning the novel's universal quality. The many similarities between the fates of a black immigrant, a (mentally ill) woman, Jews, homeless people indeed suggest that all these characters share a common history, a history of suffering. This, in fact, is a typical feature of Phillips's fiction, perhaps because, as Helen Thomas points out, the author

concentrates upon the intersecting histories of [Africa, Europe and America], and responds creatively and critically to the psychological effects of fragmentation, cultural dispersal, racism and economic exploitation. ${ }^{9}$

So, in A Distant Shore, suffering not only links the disparate patterns of Dorothy's music but also links together people coming from different places or backgrounds who, at first sight, may not seem to have much in common. Arguably, Phillips's all-inclusiveness contrasts starkly with the claustrophobic society depicted in the novel, but also redeems it: England is connected to the rest of the world, if only because suffering is universal and knows no class, gender or racial boundaries. The other common point between immigrants, Jews, the homeless, and the sick is that a society's response to their presence, if this society is predominantly violent or ostracizing, has the effect of unmasking its otherwise hidden darkness.

When listing the type of events that epitomize man's, or society's, inner predisposition to darkness, warfare automatically comes to mind. Even though the England described in the novel is not literally at war, the point is that there are similarities between a conflict-ridden country in Africa and an England confronted with immigration. As Paul Gilroy observes,

the process of black settlement has been continually described in military metaphors which offer war and conquest as the central analogies for immigration. The enemy within, the unarmed invasion, alien encampments, alien territory and new commonwealth occupation have all been used to describe the black presence in this way. ${ }^{10}$

\footnotetext{
${ }^{8}$ Petra Tournay, "Re-Telling the Past: Metafiction in Caryl Phillips's Diasporic Narratives," in Bridges Across Chasms: Towards a Transcultural Future in Caribbean Literature, ed. Bénédicte Ledent (Liège: L3 - Liège Language and Literature, 2004): 91.

${ }^{9}$ Helen Thomas, Caryl Phillips (London: Northcote, 2006): 2.

${ }^{10}$ Paul Gilroy, 'There Ain't No Black in the Union Jack' (London: Routledge, 1992): 45.
} 
The dangerousness ascribed to black settlers, however, is at odds with the emphasis that is laid on Solomon's meekness in the sections of $A$ Distant Shore set in England. In moving from Africa to England, Solomon does not become a conqueror; on the contrary, he loses all agency. That much becomes clear if one looks at the image of the bird in the novel. According to Carla, Dorothy's pupil, Solomon's last words are " "how he was a bird that could fly'" (54). These words may not at first sight appear to make much sense, and they seem to corroborate Carla's hypothesis that Solomon went mad when he was attacked - unless, that is, one relates them to Solomon's past as a soldier, his past as Gabriel. In his country of origin, Gabriel was quite literally a bird. The soldiers under his command had indeed nicknamed him 'Hawk', perhaps because of his capacity to observe and attack efficiently. The image of the bird is clearly associated with war. Another element suggesting this is the fact that, in military terms, being ready to fly means being ready to attack. While awaiting the order to recapture a village from the enemy, Gabriel's soldiers significantly say " "Hawk, we are ready to fly"” (147). But Gabriel, who "did not have the heart for this savagery," refuses to give the order, hence Captain JuJu's reaction: "“you are a coward, Hawk. Somebody has clipped your wings and you cannot fly. This is war and in war you must kill'" (148). Subsequently, Gabriel runs away from the army and eventually emigrates illegally to England, where he becomes Solomon, but many passages echoing JuJu's statement indicate that Solomon still senses that he is no better than a coward with clipped wings, as he recounts: "in truth, only one half of me was alive and functioning" (291):

I was a coward who had trained himself to forget. I accepted from people.

From $\mathrm{Mr}$ and Mrs Anderson. I was no longer 'Hawk'. I was no longer my mother's Gabriel. (297)

In Africa, Solomon was indeed a very powerful man, used to giving orders, but in England his fate depends on others - the prison officer, the lawyer, the Andersons - and he has to "[accept] from people."11 However, Solomon's violent reaction to the skinheads who harass him and his final claim that he is a bird that can fly (or fight) indicate that he has at last unclipped his wings, that he has after all reconnected with his past and recovered agency. Ironi-

\footnotetext{
${ }^{11}$ In fact, those who try to help Solomon in England (perhaps with the exception of Mike) have the tendency to treat him like a child, which he resents. A similar point is made in Bénédicte Ledent, "Family and Identity in Caryl Phillips's Fiction, in particular A Distant Shore," Commonwealth: Essays and Studies 28.2 (2007): 70-71.
} 
cally, Gabriel, who had wanted to escape the savagery of the war in Africa and had as a result lost his status as 'Hawk', finds himself confronted with savages in England and ultimately has no choice but to resort to violence and become a 'Hawk' again.

When comparing Phillips to Conrad, one is tempted to argue that the former has entrusted a black Marlow with the impossible mission of civilizing uncouth English people. However, insisting on reading A Distant Shore as simply reversing the usual dichotomy between, on the one hand, black and evil and, on the other, white and pure would amount to oversimplification. If, as Chinua Achebe maintains, "Heart of Darkness projects the image of Africa as 'the other world', the antithesis of Europe and therefore of civilization,"12 then Phillips, who does not share Achebe's uncompromising views, refrains from taking a literary revenge of sorts on Conrad by arguing the contrary. Respectively confronted with war or immigration, Africa and England both reveal the darkest sides of their nature. The only difference is perhaps that English people tend to display a deceitful refinement, thereby allowing their country to pose as a civilized nation. As argued above, the younger generations are shown to be rather unwilling to maintain this illusion, so that, by valuing politeness and respectability, Dorothy and Solomon are clearly going against the current trend. Yet, Dorothy's assault on the homeless woman, Solomon's "hidden history" (300), and his final struggle against the skinheads are in keeping with the idea that dignified behaviour is sometimes no more than a civilized pretence.

\section{WORKS CITED}

Achebe, Chinua. "An Image of Africa: Racism in Conrad's Heart of Darkness" (1975), Hopes and Impediments: Selected Essays 1965-1987 (Oxford: Heinemann, 1988):

1-20. Originally in Research in African Literatures 9.1 (Spring 1978): 1-15.

Conrad, Joseph. Heart of Darkness (1902), in Heart of Darkness and Selections from the Congo Diary, intro. Caryl Phillips (New York: Modern Library, 1999): 1-96.

Gilroy, Paul. 'There Ain't No Black in the Union Jack' (London: Routledge, 1992)

Ledent, Bénédicte. "Family and Identity in Caryl Phillips's Fiction, in particular $A$ Distant Shore," Commonwealth: Essays and Studies 28.2 (2007): 67-73.

\footnotetext{
${ }^{12}$ Chinua Achebe, “An Image of Africa: Racism in Conrad's Heart of Darkness" (1975), in Achebe, Hopes and Impediments: Selected Essays 1965-1987 (Oxford: Heinemann, 1988): 3 .
} 
. " 'Of, and not of, this Place': Attachment and Detachment in Caryl Phillips' $A$ Distant Shore," Kunapipi 26.1 (2004): 152-160.

Phillips, Caryl. A Distant Shore (London: Vintage, 2003).

"Introduction," in Joseph Conrad, Heart of Darkness, xi-xviii.

. A New World Order: Selected Essays (London: Secker \& Warburg, 2001).

Thomas, Helen, Caryl Phillips (London: Northcote, 2006).

Tournay, Petra. "Re-Telling the Past: Metafiction in Caryl Phillips's Diasporic Narratives," in Bridges Across Chasms: Towards a Transcultural Future in Caribbean Literature, ed. Bénédicte Ledent (Liège: L3 - Liège Language and Literature, 2004): 89-99. 
RACE AND MASKS 


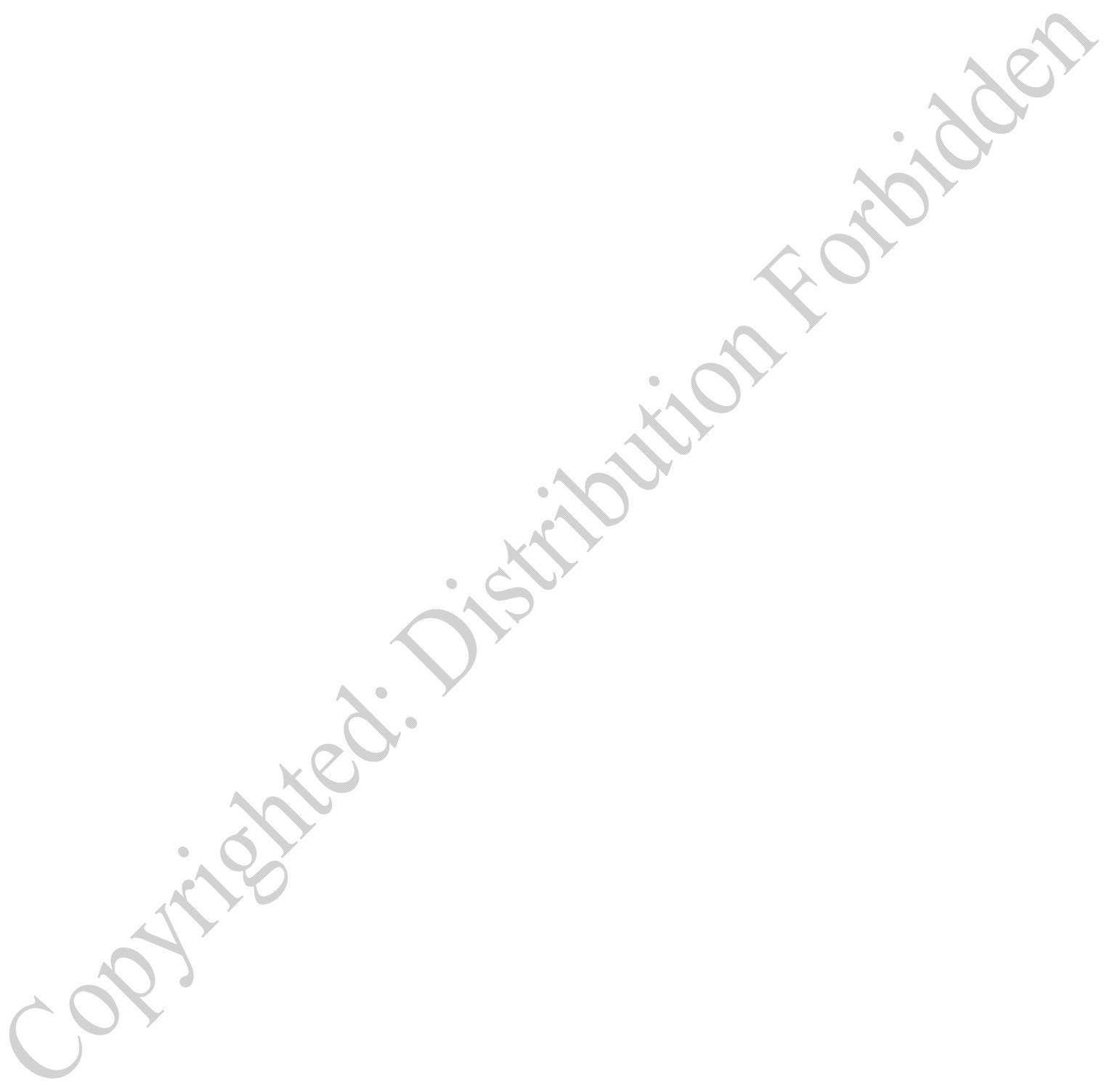




\title{
Omnipresent and Everlasting Imperialism Race and Gender Oppression in Caryl Phillips's Cambridge and A Distant Shore
}

\author{
LUCIE GILLET
}

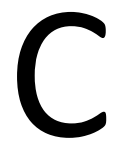

ARyl Phillips published CAMbridge IN 1991 and A Distant Shore in 2003. Twelve years and two novels separate these two books, whose stories also take place almost two centuries and two thousand kilometres apart. Yet these narratives may be viewed as strikingly similar in many respects. In what follows, I wish to examine how the similarities and differences between Cambridge and A Distant Shore operate to convey the idea that imperialism - the dominion of one nation or group of people over another - has lived on from the nineteenth century depicted in Cambridge to the twenty-first century of $A$ Distant Shore.

Cambridge recounts the stories of Emily Cartwright, a white Englishwoman who travels to her father's plantation in the Caribbean, and of Cambridge, a black African slave who ends up on Mr Cartwright's plantation after going through two middle passages. The narrative unfolds at the beginning of the nineteenth century, between the abolition of the slave trade and that of slavery. A Distant Shore follows Dorothy Jones, a white Englishwoman, and Solomon Bartholomew, an African political refugee who has fled to England. The two characters meet in Weston, a small village in the north of England, and eventually become friends. The novel is set in contemporary England, about twenty years after "Mrs Thatcher clos[ed] the pits."

Because of their different settings, Cambridge and A Distant Shore may at first sight appear to be very dissimilar. But, like their main characters, they

\footnotetext{
${ }^{1}$ Caryl Phillips, $A$ Distant Shore (London: Secker \& Warburg, 2003): 4. Further page references are in the main text after " $D S$. ."
} 
have significant features in common. Both novels discuss racial and gender oppression by presenting a black man from Africa and a white Englishwoman, two protagonists "separated by gender [...] and ethnicity"2 but nonetheless both subjected to "white male supremacy."3 Moreover, both novels can be read as allegories for "the late twentieth-century human condition everywhere in the world." I hope to demonstrate that, when examined side by side, these works convey an even stronger message about how imperialism has evolved since the nineteenth century.

The protagonists of each novel bear a strong resemblance to their counterparts in the other book. In Cambridge, Emily does not have any kind of influence or power over the men she encounters, not even the slaves, for, as Evelyn O'Callaghan writes, nineteenth-century English and plantation society "confined and silenced women." In the same way, in A Distant Shore, Dorothy's life is marked by female insignificance: she was brought up in a family where her mother's "voice didn't count for much with Dad" $(D S, 11)$, which is why "Mum ultimately fell silent" $(D S, 10)$. In her adult life, Dorothy reproduces the same pattern, first with her husband Brian, whom she allowed "to look through and beyond her, until he finally convinced himself that she did not exist" ( $D S, 199)$, and then with her lover Mahmood, with whom she often keeps silent, "being concerned to make sure that the dominant narrative is male" $(D S, 203)$.

The two black protagonists of Cambridge and A Distant Shore are also similar in terms of alienation. While Cambridge stands for the oppressed and the downtrodden in a predominantly racist society, the twenty-first-century political refugee Solomon has to endure racism every day, first in his African country, where he was a member of an ethnic minority, then in England, where nearly all the white people he meets reject him because he is black. But Solomon's likeness to Cambridge also comes from the suggested association of his situation with that of a slave. In Stoneleigh, where he is "the only coloured" $(D S, 45)$, he works as a "handyman-cum-night-watchman" ( $D S$, 14); just like the slaves who served their white masters, he is a black man in

\footnotetext{
${ }^{2}$ Sylvie Chavanelle, "Caryl Phillips's Cambridge: Ironical (Dis)empowerment?" International Fiction Review 25.1-2 (1998): 78.

${ }^{3}$ Bénédicte Ledent, Caryl Phillips (Contemporary World Writers; Manchester: Manchester UP, 2002): 100.

${ }^{4}$ Ledent, Caryl Phillips, 80.

${ }^{5}$ Evelyn O'Callaghan, "Historical Fiction and Fictional History: Caryl Phillips's Cambridge," Journal of Commonwealth Literature 29.2 (June 1993): 40.
} 
the service of an all-white community. His "great desire to learn" $(D S, 277)$ echoes Cambridge's Christian education in England. As for Solomon's dependence on $\mathrm{Mr}$ and Mrs Anderson during the first year of his stay in England, it reminds one of the slaves who, according to Emily, "are in our charge and must be provided for." Like the "black Hercules of a brute" $(C, 41)$ who was forced to abandon his real name Olumide to become Thomas, then David Henderson and eventually Cambridge, Solomon also undergoes "abusive multi-naming.", $\mathrm{He}$ was originally called Gabriel, but his soldiers in Africa prefer to address him as Hawk. Solomon is a name that he chooses later, but only because he knows that it is dangerous to be recognized as Gabriel in England.

The echoes of Cambridge in A Distant Shore become even clearer when we focus on Phillips's use of language. Indeed, Dorothy's and Solomon's narratives contain clear textual references to some of Cambridge's sections; Phillips, then, seems to be encouraging the reader to draw a parallel between the two novels, thereby stressing their characters' similarities. If Dorothy's situation reminds one of Emily's in terms of gender oppression, the use of the word "sacrifice" in the two texts reinforces their resemblance. The term clearly defines Dorothy's relation to men $(D S, 212)$, and equates her predicament with that of Emily, who lives in a society that is characterized by "daughters sacrificed to strangers" ( $C, 3$, my emphasis).

In the same way, Solomon's story echoes Cambridge's narrative. Both abound with sentences taken from The Interesting Narrative of the Life of Olaudah Equiano, or Gustavus Vassa, The African, Written by Himself. This common reference to Equiano's text and the ensuing association of the two black protagonists with the famous slave confirm the analogy between Solomon's predicament and that of Cambridge and of African slaves in general.

\footnotetext{
${ }^{6}$ Caryl Phillips, Cambridge (London: Bloomsbury, 1991): 72. Further page references are in the main text after " $C$."

${ }^{7}$ Françoise Charras, "De-Centering the Centre: George Lamming's Natives of My Person (1972) and Caryl Phillips's Cambridge (1991)," in Mapping African America: History, Narrative Formation and the Production of Knowledge, ed. Maria Diedrich, Carl Pedersen \& Justine Tally (Hamburg: LIT, 1999): 74.

${ }^{8}$ This fact is mentioned in relation to Cambridge in O'Callaghan, "Historical Fiction and Fictional History," and in relation to A Distant Shore in Bénédicte Ledent, "Family and Identity in Caryl Phillips's Fiction, in particular A Distant Shore," Commonwealth: Essays and Studies 29.2 (2007): 71, and is explored in the context of other colonial 'pre-texts' by Lars Eckstein in Re-Membering the Black Atlantic: On the Poetics and Politics of Literary Memory (Cross/Cultures 84; Amsterdam \& New York: Rodopi, 2006): esp. 74-96.
} 
This parallel is even more striking when one realizes that Phillips sometimes uses almost exactly the same words from Equiano's narrative in the two novels. While Cambridge says about the white traders that "their most constant practice was to commit violent depredations on the chastity of female slaves, as though these princesses were the most abandoned women of their species" $(C, 138)$, Solomon describes Denise (the teenager who secretly brings him food when he arrives in England) as a "poor girl, who was one of the most abandoned of her species" (DS, 278).

The likeness between the protagonists of the two novels might, then, indicate that the subjection of black people and of women - which may be considered as two different forms of imperialism - has not disappeared in contemporary England, an idea which is certainly reinforced by Phillips's use of Equiano's narrative in the two texts. As Maria Lourdes López Ropero remarks, Phillips "alters the conventional teleology of the slave narrative, wherein the slave progresses from bondage to freedom," his protagonists' passage - literal for Cambridge and symbolic for Solomon from freedom to bondage. By doing so, Fernando Galván observes, Phillips is "trying to write $[\ldots]$ a new history of slavery,"10 and refutes the notion that the end of colonialism coincides with the disappearance of imperialism.

Allegedly, Dorothy and Solomon's situation cannot be simply equated with that of Emily and Cambridge, if only because they live in different centuries. Still, the differences between the characters are mainly superficial: both women enjoy a comfortable social standing, but while Emily owes her situation to "her genteel upbringing and status as a lady in English society,"11 Dorothy has secured it for herself by working as a teacher. Dorothy is divorced and has lived alone since her husband left her, a position that was not in the least conceivable for a nineteenth-century woman like Emily. However, things change for Dorothy when she is forced to take early retirement because of a colleague's complaint against her for sexual harassment. Quite significantly, it is a man who deprives her of what partly embodies her relative in-

${ }^{9}$ Maria Lourdes López Ropero, "Irony's Political Edge: Genre Pastiche in Caryl Phillips's Cambridge," in Beyond Borders: Re-Defining Generic and Ontological Boundaries, ed. Ramón Plo-Alastrué \& María Jesús Martínez-Alfaro (Heidelberg: Winter, 2002): 135.

${ }^{10}$ Fernando Galván, "Between Othello and Equiano: Caryl Phillips' Subversive Rewritings," in Refracting the Canon in Contemporary British Literature and Film, ed. Susan Onega \& Christian Gutleben (Amsterdam \& New York: Rodopi, 2004): 200.

${ }^{11}$ Gail Low, “ "A Chorus of Common Memory': Slavery and Redemption in Caryl Phillips's Cambridge and Crossing the River," Research in African Literatures 29.4 (Winter 1998): 127. 
dependence: i.e. her job. So her new single life is not really synonymous with emancipation. Unlike Emily, who preferred leaving England to marrying Thomas Lockwood, Dorothy did not choose the lonely life that started with rejection by a man who, at the end of their relationship, no longer noticed her. After her divorce, she episodically sleeps with married men like Mahmood and her colleague Geoff Waverley, a situation reminiscent of Emily's romance with $\mathrm{Mr}$ Brown. In this respect, it is interesting to consider what Evelyn O'Callaghan calls "the indeterminacy of the title "mistress", 12 for Emily, "one in which the powerlessness of the mistress of the Great House overlaps with the illegitimacy of the mistress of the overseer,"13 as Jenny Sharpe observes. While Emily's status as the plantation-owner's daughter should confer a form of authority on her, she turns out to be powerless. Her helplessness is reinforced by her position as Mr Brown's mistress, an illegitimate relationship evocative of those the white men on the plantations often had with their female slaves. Though not openly expressed, Dorothy also appears as a powerless 'mistress': she is, indeed, a dismissed school 'mistress' before becoming the illegitimate 'mistress' of married men. In the end, the differences between Emily's and Dorothy's lives appear to be counterbalanced by their similarities, which suggests that the condition of women has only undergone superficial changes.

On the surface, too, Solomon's situation looks different from Cambridge's. Solomon is a free man who acquires legal status in England. But this does not guarantee fuller acceptance into British society, since he is soon murdered by local skinheads. Like Cambridge, he is killed by white people, and, like him, he too suffers from racism, which manifests itself in different ways. Indeed, the rise of neo-imperialism in contemporary Britain can be seen, for instance, in the recent development of far-right political parties and in the racial hatred that triggered off the murders of Stephen Lawrence and Anthony Walker, to mention but two examples. Another type of racial discrimination to which Phillips seems to allude in Solomon's story is the inequal treatment of black and white people in the legal system. Even though Solomon's homicide is officially considered to be a crime - therefore punishable by law - Dorothy is "not sure how hard [the police are] trying" $(D S, 47)$ to find the culprit when she observes the way they are enquiring about the murder. This might imply

\footnotetext{
${ }^{12}$ O'Callaghan, "Historical Fiction and Fictional History," 41.

${ }^{13}$ Jenny Sharpe, " 'Our History was Truly Broken': Writing Back to a Slave Past," in Sharpe, Ghosts of Slavery: A Literary Archeology of Black Women's Lives (Minneapolis \& London: U of Minnesota P, 2003): 108.
} 
that the killing of a black man is still regarded as less serious than that of a white person. Finally, in the second section of A Distant Shore, Phillips demonstrates that Solomon's migration is not so different from Cambridge's, in the sense that Solomon, too, is, in a way, forced to leave Africa. In fact, Solomon flees his country only to save his life after the government troops have massacred his family. He pays a fortune to travel in very precarious conditions in the hope of reaching England, which seems to be the country where "freedom is everything" $(D S, 78)$. Although Solomon's forced journey takes place in the twenty-first rather than the nineteenth century, it can be viewed as a consequence of imperialism. The second section of the novel in particular serves to underline the two main reasons for the massive migration that has taken place since the second half of the twentieth century: i.e. the idealization of the 'mother country' and the wish to flee the difficult life circumstances in the former colonies, both of which appeared in the wake of European colonization and were caused by it.

Here, the differences between Cambridge's and Solomon's situations are once again outweighed by their similarities, so that the reader of the two novels can better understand that Solomon's migration is actually one of the consequences of nineteenth-century imperialist ideology. In A Distant Shore, Phillips ironizes about the English people who are intolerant of the newcomers and who do not seem to be aware of the connection between colonization and immigration. This irony clearly appears when Mike talks to Solomon about 'blacks' in England:

'I'm an old traditionalist, Solomon. I want fish and chips, not curry and chips. I'm not prejudiced, but we'll soon be living in a foreign country unless somebody puts an end to all this immigration.' $(D S, 290)$

In saying this, he does not even realize that, at the time of colonization, the question of whether the colonized accepted the people, language, and culture of Britain could not even be considered. since these were imposed on them in their own country, without any possible discussion. Nor does Mike seem to understand that this new " "foreign country" is in great part the result of his nation's involvement in colonization.

The last - and most obvious - alleged difference between the two novels that I would like to examine can be found in the relationship between their characters. Franca Bernabei points out that in A Distant Shore, "Phillips re- 
peatedly shows the symbolic and literal act of knocking on someone's door," a pattern that also appears in Cambridge but does not prompt the same reaction on the characters' part. While, in Cambridge, Emily "quickly closed in the door" $(C, 93)$ in her black sentinel's face, Dorothy welcomes Solomon inside her bungalow when he knocks on her door for the first time. If it seems that Emily's "character makes evident that the shared oppression of white women and black slaves does not create the conditions for a common sisterhood," 15 Dorothy is conscious that, "like [her]," Solomon "is a lone bird" $(D S, 14)$, which is one of the reasons why she lets him enter her house and her life.

However, this friendship might not be indicative of much change in British society. The first reason for this is that the person who accepts Solomon in Weston is herself an outsider, also greatly in need of company. Like her African friend, Dorothy is rejected by the local people, who form "a village that is hardly going to give up its name and identity" $(D S, 3)$ and who are thus afraid of newcomers, as is made clear both by the hate-mail Solomon receives from his neighbours and by his eventual murder. The Westonians' rejection of newness reflects England's attitude as a whole, which is symbolized by Mrs Anderson's relation with Solomon. Mr and Mrs Anderson have always played the role of surrogate parents to Solomon and also to Mike, the Irish truckdriver: the two men call Mrs Anderson 'Mum' and she once tells Solomon that "Mike and [he] were like the sons that she had never had" $(D S, 287)$. Mrs Anderson becomes the 'mother' of two foreigners originating in former colonial territories; she might therefore be considered to be a metaphor for the 'mother country' that England was for the colonies in her imperial heyday. Even though Mrs Anderson is a very generous host, her endeavour to be a mother to two adult men in their thirties implies that they need to be taken care of. She thus adopts a patronizing stance that is reminiscent of England's relationship to its colonized 'children.' In A Distant Shore, Phillips associates Mrs Anderson's behaviour towards her adoptive sons with England's attitude to its former colonies, which suggests a wish on Britain's part to maintain power over foreigners. This testifies to a deep unwillingness to substitute the title of 'host country' for that of 'mother country', and thereby reveals that the acceptance of the 'Other' in British society remains partial.

\footnotetext{
${ }^{14}$ Franca Bernabei, "Guests, Strangers, and Non-Persons: Ius Migrandi and the Risks of Hospitality in a Circumatlantic Perspective," in Approaching SeaChanges: Metamorphoses and Migrations across the Atlantic, ed. Annalisa Oboe (Padua: Unipress, 2005): 42.

${ }^{15}$ Sharpe, “' Our History was Truly Broken'," 109.
} 
Dorothy's tolerance seems to apply only to her relationship with Solomon, for, if she finally accepts her African friend, she keeps rejecting and despising all the other outsiders. To her, homeless people are "disgusting, dragging themselves and the country down like this" $(D S, 65)$, and she views the other blacks in Britain with suspicion, even describing some of them as being "two steps removed from the jungle" $(D S, 265)$. As for homosexuals, embodied by her sister Sheila, she vigorously disapproves of their "lifestyle choices" ( $D S$, 25). The female protagonist of A Distant Shore can therefore be said to be in the ambivalent position of "alienating agent and [...] alienated subject," as Ledent puts it in another context. ${ }^{16}$ Such behaviour is reminiscent of Emily's in Cambridge, who feels superior to all the other subjected people on the island. Ambivalence also characterizes Cambridge's and Solomon's stance towards the others. In spite of Cambridge's deep alienation, the Christian instruction that he received informs his oppressive actions towards his black brethren, whom he tries to convert and dominate in the name of God and England. When he is enslaved again and sent to the Caribbean, he "reproduces on the domestic level the paternalism that is part and parcel of slavery" ${ }^{17}$ by demanding of Christiania that she obey him because "a Christian man possesses his wife" $(C, 163)$. Paradoxically, he does not see that his idealization of England and God supports the very system that subjugates him: i.e. imperialism. Solomon is not only an oppressed person, either. Although he explains that the massacre of a whole village in his country was not of his own making, he still feels extremely guilty about this incident and the ensuing tragedy, which might hint at the fact that he is not wholly innocent. Phillips leaves the reader in a state of uncertainty by shifting the perspective to the first person for this short passage about Gabriel's experience in the Liberation Army, thereby suggesting that what Gabriel says is subjective and only one version of reality. Solomon also becomes an oppressor of sorts in England, as testified, among others, by his irritation at women who do not have good manners. Significantly, Phillips chooses a black man and a white woman as the protagonists of Cambridge and A Distant Shore because each of the main characters is in this way made complicit in white male imperialist power. This is interesting, since it generates the ambiguities and paradoxes that I have underlined above, and it reveals that human relationships have always been complex.

\footnotetext{
${ }^{16}$ Bénédicte Ledent, "Voyages into Otherness: Cambridge and Lucy," Kunapipi 14.2 (1992): 53 .

${ }^{17}$ Ledent, Caryl Phillips, 102.
} 
This complexity also shows in Dorothy and Solomon's short-lived friendship, brutally interrupted by Solomon's murder, a tragic event which does not seem to be the only cause of their estrangement. I agree with Ledent when she writes that "Phillips also presents his protagonists' isolation as being [...] of their own making." $" 18$ Dorothy, for instance, is very ambivalent in her relationship with Solomon. She likes being in his company, but she decides to leave him for a few days, partly because she is afraid that he might "become a problem in [her] life" $(D S, 45)$ and partly because she believes that her departure will be "a means of attracting Solomon to her." 19 Ledent attributes the characters' fear of becoming too close to each other to "their experience of a world plagued by solitude"; ${ }^{20}$ a loneliness that results from oppression, and from the impact of several centuries of imperialism.

Finally, the endings of the two novels also illustrate this constant movement between a sense of community and one of detachment. In Cambridge, despite Emily's initial contempt for the slaves on the plantation, she eventually establishes friendly links with Stella, who even becomes "the legitimate substitute for Isabella," who used to be Emily's white servant. ${ }^{21}$ But Emily's baby, who represented what "Stella had hoped [...] they might share" $(C$, 178), is stillborn, which might indicate that the encounter with other oppressed people is not easy. The novel ends with a tension between the willingness to come together and the extreme difficulty of doing so, which also reappears in $A$ Distant Shore, where the protagonists long to open up to the other, but are soon confronted with the impossibility of such closeness.

In conclusion, the social evolution that takes place from Cambridge to $A$ Distant Shore seems to be mainly superficial. Society has changed on the surface but deep down imperialism still exists in the twenty-first-century, even if it emerges in different, perhaps less obvious ways. Just like Emily, for whom, as Gail Low puts it, "realization of her complicit relation to the institutions of slavery is a necessary step in her uneasy path to maturity," 22 contemporary Britain needs to look back on its past in order to understand its present situation. Setting A Distant Shore in England might be Phillips's way of prompting Britain and Western society to face the history they have been

\footnotetext{
${ }^{18}$ Bénédicte Ledent, " 'Of, and not of, this Place': Attachment and Detachment in Caryl Phillips' A Distant Shore," Kunapipi 26.1 (2004): 153.

${ }^{19}$ Ledent, "'Of, and not of, this Place'," 154

20 " "Of, and not of, this Place'," 153.

${ }^{21}$ Ledent, Caryl Phillips, 91.

${ }^{22}$ Low, "“A Chorus of Common Memory'," 127.
} 
trying to forget and to acknowledge that what is happening at the moment is only the logical continuation of some age-long imperialism, in the same way as $A$ Distant Shore may be read as a continuation, an echo of, Cambridge.

\section{WORKS CITED}

Bernabei, Franca. "Guests, Strangers, and Non-Persons: Ius Migrandi and the Risks of Hospitality in a Circumatlantic Perspective," in Approaching SeaChanges: Metamorphoses and Migrations across the Atlantic, ed. Annalisa Oboe (Padua: Unipress, 2005): 27-47.

Charras, Françoise. "De-Centering the Centre: George Lamming's Natives of my Person (1972) and Caryl Phillips's Cambridge (1991)," in Mapping African America: History, Narrative Formation and the Production of Knowledge, ed. Maria Diedrich, Carl Pedersen \& Justine Tally (Hamburg: LIT, 1999): 61-78.

Chavanelle, Sylvie. “Caryl Phillips's Cambridge: Ironical (Dis)empowerment?” International Fiction Review 25.1-2 (1998): 78-88.

Eckstein, Lars. Re-Membering the Black Atlantic: On the Poetics and Politics of Literary Memory (Cross/Cultures 84; Amsterdam \& New York: Rodopi, 2006).

Equiano, Olaudah. The Interesting Narrative of the Life of Olaudah Equiano, or Gustavus Vassa, The African, Written by Himself (1789), in The Interesting Narrative and Other Writings, ed. Vincent Carretta (New York: Penguin: 1995): 1-236.

Galván, Fernando. "Between Othello and Equiano: Caryl Phillips' Subversive Rewritings," in Refracting the Canon in Contemporary British Literature and Film, ed. Susan Onega \& Christian Gutleben (Amsterdam \& New York: Rodopi, 2004): 187-205.

Ledent, Bénédicte. Caryl Phillips (Contemporary World Writers; Manchester: Manchester UP, 2002).

- "Family and Identity in Caryl Phillips's Fiction, in particular A Distant Shore," Commonwealth: Essays and Studies 29.2 (2007): 67-73.

. "'Of, and not of, this Place': Attachment and Detachment in Caryl Phillips' $A$ Distant Shore," Kunapipi 26.1 (2004): 152-60.

. "Voyages into Otherness: Cambridge and Lucy," Kunapipi 14.2 (1992): 53-63.

López Ropero, Maria Lourdes. "Irony’s Political Edge: Genre Pastiche in Caryl Phillips's Cambridge," in Beyond Borders: Re-Defining Generic and Ontological Boundaries, ed. Ramón Plo-Alastrué \& María Jesús Martínez-Alfaro (Heidelberg: Winter, 2002): 131-37.

Low, Gail. " “A Chorus of Common Memory': Slavery and Redemption in Caryl Phillips's Cambridge and Crossing the River," Research in African Literatures 29.4 (Winter 1998): 122-40. 
O'Callaghan, Evelyn. "Historical Fiction and Fictional History: Caryl Phillips's Cambridge," Journal of Commonwealth Literature 29.2 (June 1993): 34-47.

Phillips, Caryl. Cambridge (London: Bloomsbury, 1991).

_. A Distant Shore (London: Secker \& Warburg, 2003).

Sharpe, Jenny. “' Our History was Truly Broken': Writing Back to a Slave Past,” in Sharpe, Ghosts of Slavery: A Literary Archeology of Black Women's Lives (Minneapolis \& London: U of Minnesota P, 2003): 87-119. 


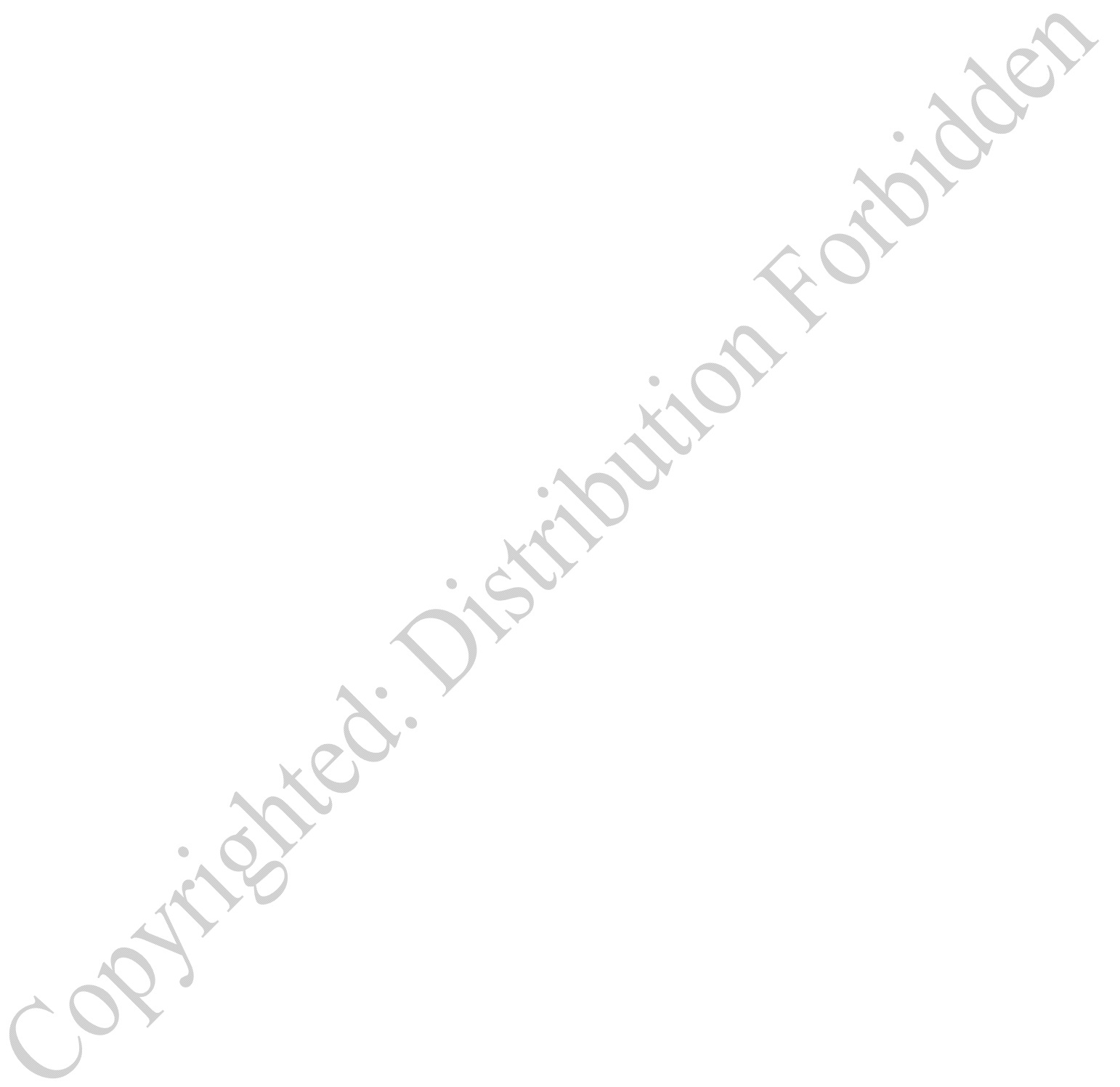




\section{The Dilemma of a Black Entertainer A Contextualized Reading of Caryl Phillips's Dancing in the Dark}

\section{TSUNEHIKO KATO}

$D$

anCing in the Dark, Caryl Phillips's eighth nOVel, is based on the life of Bert Williams (1874-1922), the black entertainer who won international fame on Broadway from the end of the nineteenth century to the early twentieth century, as well as in popular song. For all his success, Williams also became the target of accusations by members of his own community because of the minstrel shows in which he performed. Indeed, putting on 'blackface' makeup, he acted on stage as a "real coon," thereby mocking the inauthenticity of the long tradition of whites performing 'coon songs' while made up as blacks.

Phillips's books have often explored the lives of potentially controversial black figures who are likely to fall prey to criticism from within their own racial group. This tendency seems to date as far back as his first play, Strange Fruit, ${ }^{1}$ where Vivian, a Caribbean immigrant, is blamed by her two sons for not encouraging them to assert their racial identity and for acting like an 'Uncle Tom' by promoting their assimilation into white British society. We can also remember the African interpreter in "Heartland"2 who, thanks to his intelligence, is chosen by the governor of a slave-trading post to serve colonial interests in exchange for his personal security. Further, in Crossing the River, "The Pagan Coast" tells the story of a black slave who is the lover of

\footnotetext{
${ }^{1}$ Caryl Phillips, Strange Fruit (Ambergate: Amber Lane, 1981).

${ }^{2}$ Caryl Phillips, Higher Ground (London: Viking, 1989).

${ }^{3}$ Caryl Phillips, Crossing the River (London: Bloomsbury, 1993).
} 
his former master and goes to Liberia as a Christian missionary. ${ }^{4}$ Then there is the Othello figure in The Nature of Blood, ${ }^{5}$ who is employed on the basis of his achievements as a military commander to protect Venetian society from the attack of the Turks. He feels isolated and lonely in Venice because of his peripheral existence as a black man at the centre of the white world, and falls in love with the daughter of a Doge, thereby betraying his wife left behind in Africa. A modern black voice embedded in the text of the novel accuses him of being an Uncle Tom and a betrayer of his race. ${ }^{6}$ In this light, Dancing in the Dark can be regarded as yet another of Phillips's explorations of the 'Uncle Tom' figure. As will be demonstrated, Bert Williams's ambiguity is even more complex than that of all the other equivocal characters that the writer has dealt with hitherto. In an interview with Diane Rehm on the novel, ${ }^{7}$ Phillips says in effect that, this issue being very delicate in America, it took him fifteen years of living there to write about it.

Even if this essay will place Phillips's novel in the context of the USA, it is important to keep in mind that the author's interest in multifaceted black characters partly originates in the British cultural and political context of the late 1980 , when the issue of black identity and representation was widely debated. In this respect, Phillips's works seem to echo Stuart Hall's views in the wake of the latter's disagreement with Salman Rushdie about the critical assessment of Handsworth Songs, ${ }^{8}$ a documentary on the race riots that took place in the suburbs of Birmingham in $1985 .{ }^{9}$ Hall argued against the policy of representing black people as 'authentic' models, and called for a more nuanced depiction of such figures in various historical conditions. Dancing in the Dark can thus be read as another example of Phillips's stance against the uninformed and ahistorical judgments denounced by Hall. Phillips presents

\footnotetext{
${ }^{4}$ For a detailed analysis of such 'Uncle Tom' figures in Higher Ground, Cambridge, and Crossing the River, see John Ford, "Representations of Deference and Defiance in the Novels of Caryl Phillips," The Society for Caribbean Studies Annual Conference Papers 3, ed. Sandra Courtman (2002), http://www.caribbeanstudies.org.uk/papers/2002/olv3p2.pdf (accessed 22 December 2009).

5 Caryl Phillips, The Nature of Blood (London: Faber \& Faber, 1997).

${ }^{6}$ Phillips, The Nature of Blood, 181.

${ }^{7}$ Caryl Phillips, "Caryl Phillips: Dancing in the Dark," interview with Diane Rehm, The Diane Rehm Show: WAMU 88.5 FM (28 October 2005): http://www.wamu.org/pro grams/dr/05/10/28.php (accessed 31 July 2009).

${ }^{8}$ Handsworth Songs, dir. John Akomfrah (Black Audio Film Collective, 1986).

${ }^{9}$ Stuart Hall, "New Ethnicities," in Black Film/British Cinema (IC A Document 7; London: Institute of Contemporary Arts, 1988): 27-31.
} 
Bert Williams as a courageous man ${ }^{10}$ who fought alone to prove the artistic capacity of black people in an unfavourable historical context, where he had to face both the racist views of white spectators and the accusing glare of his fellow blacks.

It is therefore important to specify the conditions under which Bert Williams had to work. For instance, it should be pointed out that racism was still the order of the day in the USA at the turn of the twentieth century, and that the Jim Crow system was deeply entrenched in Southern society, where terror in the form of lynching by white mobs was still rampant. Furthermore, in the wake of the Great Migration of black people from the South to the northern industrial cities and the emergence in Harlem of what was called the New Negro', there was a race riot in 1900 in New York City in which blacks were attacked by thousands of white mobs - an incident mentioned in Phillips's novel. ${ }^{11}$ So, when Booker T. Washington said that "Bert Williams had done more for the Negro race than any other black of his period," ${ }^{, 12}$ he was well aware of the difficulties with which the entertainer had to cope, and of what he had achieved in spite of it all.

The history of the minstrel show reveals to us that the genre itself reflects the atmosphere of the period. According to Dale Cockrell, what we now call black minstrel shows started at the beginning of the nineteenth century ${ }^{13}$ and took the form of musical performances with white actors putting on "black makeup and more or less mock[ing] black people through song, dance, and speech." ${ }^{\prime 14}$ It was a cultural as well as a political act, for, by making fun of the assumed foolishness of black slaves, it drew the line between the African Americans and the immigrants from Europe, Irish ones among others, who had newly arrived in the northern American cities in large numbers during the 1840 s and 1850 s. The racism found in the minstrel show was in line with the strategy of the Democrats, who tried to obtain the votes of immigrants from European countries under the flag of patriotism and white supremacy to sup-

${ }^{10}$ Caryl Phillips, "Dancing in the Dark: Caryl Phillips in Conversation with John McLeod," Moving Worlds 7.1 (2007): 104-05.

11 Darryl Pinckney, "Blacking Up," New York Review of Books 51.12 (13 July 2006): 2729, http://www.nybooks.com/articles/article-preview?article_id=19136 (accessed 31 July 2009).

${ }^{12}$ Darryl Littleton, Black Comedians on Black Comedy: How African-Americans Taught Us to Laugh (New York: Applause Theatre \& Cinema, 2006): 32.

${ }^{13}$ Dale Cockrell, Demons of Disorder: Early Blackface Minstrels and Their World (Cambridge \& New York: Cambridge UP, 1997): xii.

${ }^{14}$ Cockrell, Demons of Disorder, ix. 
port slavery in the South. ${ }^{15}$ Between that time and the moment when Williams joined the minstrel circuit, there had been no basic change to the ritual framework of the minstrel show, particularly not in its racial and ethnic implications - except that black actors could now also participate. This became possible because they were considered to be more authentic than white actors. Artistically talented black people were thereby provided with opportunities to act on stage but, at the same time, they were only allowed to perpetuate stereotypes.

It was at such a critical juncture in the tradition of the minstrel show that Bert Williams and George Walker started to perform. What white audiences wanted to see on stage were reflections of the stereotypical image of the Southern black, with which Williams had nothing in common. Thus Williams made an art out of his routine by creating a character who was completely different from himself - he was, in other words, an artist, and he wanted to be respected as such. The irony of this is that the white audiences who took great pleasure in watching his performances did not make any distinction between Williams and the role he was playing, because his onstage persona corresponded to their preconceived idea of what a black man was. Herein lies the dilemma facing the entertainer. What Phillips does in his novel is to delve into the life of Williams as a minstrel performer to see how he negotiates this situation, how he constantly lives the contradiction of trying to prove his artistic ability by playing a character that denies his real self. This struggle confers some dignity on him, but it is also one of the major causes of the difficulties he encounters in his life.

By exercising artistic licence, Phillips tries to sound the complexities of Williams's inner conflict. For the novelist, the character's malaise seems to originate partly in his family background. Indeed, Phillips puts great emphasis on the fact that Bert was not born in the USA but was the son of proud West Indian parents ${ }^{16}$ with "a quiet authority." grants who were prepared to remake their life in the new American world" (23), but when they arrive in Florida they are, to their dismay, "encouraged to see themselves as inferior" (23). Later, after moving to California, the "eleven-

${ }^{15}$ Michael Rogin, Blackface, White Noise: Jewish Immigrants in the Hollywood Melting Pot (Berkeley \& Los Angeles: U of California P, 1996): 40.

${ }^{16}$ Phillips, "Caryl Phillips in Conversation with John McLeod," 106-107. Phillips says that "because Bert Williams was a West Indian immigrant, this was central to his dilemma" (106).

${ }^{17}$ Caryl Phillips, Dancing in the Dark (New York: Alfred A. Knopf, 2005): 23. Unless otherwise indicated, further page references are in the main text. 
year-old Bert begins to learn the role that America has set aside for him to play" (25). It could be suggested that, for the Williamses, who are not used to being treated as inferior, to adopt the attitude expected of black people in a racist environment is all the more humiliating and hard to accept. Ironically, it might be during this process of consciously imitating how members of his race are supposed to behave that Bert becomes aware of his talent for impersonating others.

Although young Williams is doing well in school, he betrays his father's expectations by joining a medicine show at the age of sixteen. As a child he is "inseparable" (83) from his dad, and he has interiorized the latter's values so deeply that he tends to see whatever he does as his father would. So although the son decides to follow his artistic calling and see where his talent leads $\mathrm{him}$, he is destined to judge what he is doing in terms of paternal values. The consequence of this, as Phillips describes it, is that the higher he steps up the ladder of success as an entertainer, the more ashamed of himself he becomes.

How exactly, then, does Phillips depict the manner in which his protagonist's fame paradoxically comes to be the cause of his humiliation as well? One of the ways this is achieved is by contrasting Williams's dilemma with his partner George Walker's apparently less reflexive, more instinctive approach to life. Williams meets Walker in 1893, when the latter is looking for someone whose talent would "complement his own" (28). Initially, Williams plays the straight man and Walker the clown, but it is only when they decide to change roles that "the laughs came" (35). Williams's fame is thus inextricably linked with the humiliation of playing the buffoon. As a result of sacrificing their dignity, the duo make their way to New York City and become "The Two Real Coons," achieving such great success in the world of vaudeville that they even form their own theatrical group and hire black comedians who will later become successful in the field. Furthermore, in 1904, their company is invited to make a tour of England and play at Buckingham Palace in the presence of the Royal family.

In spite of their similar experience of show business, the two men display contrasting attitudes to race. Walker is a militant who wishes to challenge the existing status quo of racial relations, whereas Williams is more cautious in his assessment of social realities and essentially tries to survive. For example, in Phillips's novel, when a race riot erupts outside the New York theatre where the two men are playing, Walker, "refusing to exercise any caution" (67), recklessly goes out and is beaten up by angry whites, while Williams, in compliance with the advice of the theatre manager, stays in until he is in- 
formed "that America is ready to receive him. Ready to make his entrance without his makeup" (68) - an interesting conflation of the Bahamian's artistic career with his position as an outsider in American society.

The difference between the two men also affects the way they perform on stage. Whereas Walker is "not afraid to bad eye the audience" (11), Williams is quite aware of the unspoken contract between white spectators and black performers and tries not to provoke the public by overtly crossing the invisible boundary. Rather than being confrontational, he shows his audience that black people, too, can be talented:

He can hold an audience like nobody else in the city. He knows when to go gently with them, and he carefully observes their mood; he knows not to strain the color line for he respects their violence. At other times, when he can sense something close to warmth, he might push and cajole a little, and try to show them something that they had not thought of before; he might try to introduce them to the notion that music and wit are the colored man's gift to America. (10)

Although the contrast between Williams's and Walker's outlooks on race does not cause any serious problem so long as they are struggling to earn fame and money, it leads them in different artistic directions when they achieve success on Broadway as well as in England. Walker thinks that "nothing seem[s] more absurd than to see a colored man making himself ridiculous in order to portray himself"' (120), while Williams believes that

it is through hard work and application that [he] has developed his timing to the point where he knows how to delay and hold back. The audience may think they are watching a powerless man but they are, in fact, watching art. [...] We must see the line. We cross that line, George, then who is going to pay to see us? [...] In time an alternative to the counterfeit colored culture that besmirches our stage will emerge, but only in time. Right now nobody

will pay to see the colored man be himself, so we must tread carefully. (121)

Williams emphasizes the artistic aspect of their performance because, unlike Walker, who talks as if there were an "alternative" way, he cannot be so optimistic. To him, the "counterfeit colored culture" is the only way to survive and show his talent.

This is not new to him; it has worried him since the beginning of his career and has been the source of his pride as well as his humiliation. In other words, the tension experienced by Williams is the result of his attempt to make the 
best of the "ambiguous hand" that history has dealt him. ${ }^{18}$ What is more, this dilemma is the key to understanding how Williams's life as a performer comes to affect his relationship with other people, starting with his own father and his wife. This inner conflict starts when he first puts on blackface makeup:

Detroit, 1896: And the first time he looked at himself in the mirror he thought of the embarrassment and distress that this would cause his father and his heart sank. [...] How could a West Indian do such a thing to himself? (57)

Here Phillips emphasizes that Williams is looking at what he is doing from the standpoint of his West Indian father. And the latter is indeed bitterly disappointed when he at last sees his son on the Broadway stage:

[His father] sits in nigger heaven and looks down at his West Indian son. At first he does not recognize him, and then, when he does, his stomach moves. This bewildered creature with a kinky wig, long ill-fitting white gloves, a shabby dress suit, oversized shoes, a battered top hat, sleeves and trousers that are too short, a mouth exaggerated by paint, this real funny nigger is his son? This coon with big eyeball-poppin' eyes is his child? [...] this is not his son. (83)

To his father, it does not matter that the character his son is playing is not the real Bert but the product of his artistry. The father's unexpressed wish is that his son should play a respectable black man with dignity, but what can be seen on the stage is quite different. Significantly, the price Bert Williams has to pay to achieve success in show business is also what alienates him from his father.

Williams's uneasy compromise also has a decisive effect on his interaction with women, particularly his wife Lottie. Here again we can compare Walker's and Williams's contrasting personalities, this time in terms of their attitudes to gender relations. Whereas Walker, even after marrying Aida, cannot stop flirting with other women, Williams is depicted as being sexually inept, recoiling from close physical contact with his wife and women in general. One might be tempted to think that he is gay, in spite of his romantic courting of Lottie. Ultimately, Williams seems be only interested in finding a woman whom he can trust and with whom he can talk about anything, including his predicament. Paradoxically, the malaise he wants to share becomes the very

\footnotetext{
${ }^{18}$ This phrase is used in a different context by Phillips to describe his own situation. See Caryl Phillips, A New World Order: Selected Essays (London: Secker \& Warburg, 2001): 4.
} 
cause of the growing rift between Williams and his wife. For example, even at the time Williams is courting Lottie, he talks about his artistic success but is unable to share his feelings about using blackface makeup:

He pauses as if he had suddenly revealed too much, and she looks at him but says nothing. His mind is still full and he has not finished. They both know that there is something else. (35)

Lottie understands his reluctance to speak. She knows that Bert is in reality a dignified person, but also "a man who is playing a part" (35). Thus she does not push him further to reveal what his problem is, and "decides that the less they talk about Detroit the better it will be for both of them" (35). But she unconsciously knows that ignoring Bert's dilemma will crucially affect their relationship; at this early stage, she "already understands that this man's heart is likely to remain a deep ocean of jeweled secrets" (37). When Lottie watches Bert perform, she also feels that her husband-to-be is beyond her emotional reach:

This is not the dignified man that she knows, and so she too is permitted to laugh. However, the sight of her suitor in corkface disturbs something in her soul. But there is nobody to whom she might turn and quietly confess her anxieties, sitting high up in the balcony with the colored folks. (18)

Lottie's inability to confide in Bert is fully revealed when they are married. Their intimacy is not that of a couple and, quite significantly, her husband soon starts calling her "Mother." A similar lack of communication mars Williams's friendship with Walker:

And George does not understand, brimming as he is with a brashness that makes white men angry and causes colored men to move a little closer to him in the hope that some of his confidence might ease its way out of his short dark body and into their own cautious hearts. But me, they look at me and wonder, Mother - they look at me and wonder why I am what I am. (52)

Again the difference in their personalities seems to be the cause of the divide between them. Whereas Walker is confident, Williams is not. As we have seen, Williams believes in himself as an artist, but his confidence is always undermined by the accusing eyes of his proud West Indian father. Unable to share his burden with anybody, Williams is left alone with his dilemma:

At the end of the day, Williams needs time to think about what he is doing.

He needs time to consider and reconsider everything that he has done, and to turn his short life over in his mind and think and drink and drink and 
think for there is nobody with whom he cares to talk. Not George. Not Mother. (62).

Towards the end of his career, Williams's isolation is compounded by the changing situation of black artists. After Walker falls ill in 1909, Williams joins the Ziegfeld Follies in the face of much protest by white actors. He nevertheless continues to perform as the only black player in the company. One day a group of affluent black people in Harlem visit him to admonish him to stop perpetuating the stereotypical black man's image, which the increasingly race-conscious people of the time regard as degrading. This visit is a shock to Williams as well as an indication that the times are changing and that the artist's "old-fashioned imitation of a nigger coon" (136) is felt to be an insult to the 'New Negro'. He tries to defend himself, but the argument that he is just "impersonating a particular type who does not exist except in [his] imagination" (179) does not convince his interlocutors. Their perspective is that Williams's acting only reinforces the prejudices that "exist in their [white people's] imagination" (179).

These exchanges seem to confirm that Williams's dilemma is not understood, and they raise a number of questions, most of which are significantly not directly answered in the book - a lack of explicitness that contributes to building up the intricacy of Bert's character. For example, should Williams be held responsible for what he perceives as an absence of alternatives, considering the circumstances of the time? What would happen if Williams were to offend the white audience by forsaking the role assigned to him? Has he not contributed to the advancement of black people by paving the way for a new generation of black actors? This last question is addressed in a typically ambiguous way towards the end of the novel, when Williams is interviewed by a young reporter. In the course of their discussion, it becomes clear that Williams has indeed helped to launch the career of black actors such as Charles Gilpin, who had a small part in his production Abyssinia. However, Williams realizes that, unlike Gilpin, he himself will always be regarded as a performer as opposed to an actor, a "term which suggests a certain dignity" (199). This episode brings home to him that he is now considered a figure of the past, including by the journalist, who constantly refers to him in the past tense.

As this essay has attempted to make clear, Dancing in the Dark depicts the life of a great entertainer whose career took place at a moment when black comedians were unable to cast aside the stereotypes deeply embedded in the national imagination. These constraints could hardly be avoided at the time, and Phillips subtly shows that they were the foundations of Williams's painful 
dilemma, which dramatically affected both his professional and personal life. Admittedly, the novel suggests that mentalities were slowly starting to change at the end of Williams's career and that some improvements took place for black artists even during his lifetime - as with Gilpin, for example. Still, the book also intimates that black entertainers in the USA had, and still have, a long way to go before practising their art in total freedom.

\section{WORKS CITED}

Cockrell, Dale. Demons of Disorder: Early Blackface Minstrels and Their World (Cambridge \& New York: Cambridge UP, 1997).

Ford, John. "Representations of Deference and Defiance in the Novels of Caryl Phillips," The Society for Caribbean Studies Annual Conference Papers 3, ed. Sandra Courtman (2002): http://www.caribbeanstudies.org.uk/papers/2002/olv3p2.pdf (accessed 22 December 2009).

Hall, Stuart. "New Ethnicities," in Black Film/British Cinema (IC A Document 7; London: Institute of Contemporary Arts, 1988): 27-31.

Handsworth Songs, dir. John Akomfrah (Black Audio Film Collective, UK 1986; 61 $\min$.).

Littleton, Darryl. Black Comedians on Black Comedy: How African-Americans Taught Us to Laugh (New York: Applause Theatre \& Cinema, 2006).

Phillips, Caryl. "Caryl Phillips: Dancing in the Dark," Interview with Diane Rehm, The Diane Rehm Show: W AMU 88.5 FM (28 October 2005): http://www.wamu .org/programs/dr/05/10/28.php (accessed 22 December 2009).

- Crossing the River (London: Bloomsbury, 1993).

. Dancing in the Dark (New York: Alfred A. Knopf, 2005).

. "Dancing in the Dark: Caryl Phillips in Conversation with John McLeod," Moving Worlds 7.1 (2007): 103-114.

Higher Ground (London: Viking, 1989).

The Nature of Blood (London: Faber \& Faber, 1997).

A New World Order: Selected Essays (London: Secker \& Warburg, 2001).

Strange Fruit (Ambergate: Amber Lane, 1981).

Pinckney, Darryl. "Blacking Up," New York Review of Books 51.12 (13 July 2006): 27-29, http://www.nybooks.com/articles/article-preview?article_id=19136 (accessed 22 December 2009).

Rogin, Michael. Blackface, White Noise: Jewish Immigrants in the Hollywood Melting Pot (Berkeley \& Los Angeles: U of California P, 1996). 


\title{
The Mask and the Unheimlich in Caryl Phillips's Dancing in the Dark
}

\author{
ITALA VIVAN
}

If you walk down Seventh Avenue today he is a man who never existed. [...] If you walk down this broad Harlem avenue today it will soon become clear that old-fashioned dignity and civic pride have long fled the scene, and this would have broken his stout heart. [...] Today, if you walk down this broad Harlem avenue $[\ldots]$, and then continue walking through the park to midtown, he is a man who never existed. ${ }^{1}$

B

ERT Williams enters THE BOOK, THE STORY OF HIS LIFE, as if he were walking onto a stage now gaping empty, so that one wonders if such a man ever existed. Ambiguity marks the incipit of Dancing in the Dark with a mixture of presence and absence that will be the trademark of the character throughout the narrative. Presence and absence, reality and mask, face and 'blackface', life and performance grow alongside one another as the plot/biography develops, and intertwine inextricably in the individual tragedy of Bert Williams, the last 'darky' and the first great artiste of black American modernism.

Insistent repetitions create an immediate rhythm of dance and suggest the melancholy of bygone events, introducing a character whose individual history, shaped out of conflicts and complexities, will become a culturally determined destiny and embody a collective predicament, a fall into an interstice between worlds. His fictional role as a trickster, bound to be comic but also to be the dupe of life, is the result of what he in fact is, the son of blacks and at the same time of whites, a descendant of African slaves but also of free men,

\footnotetext{
${ }^{1}$ Caryl Phillips, Dancing in the Dark (London, Secker \& Warburg, 2005): 3-4. Unless otherwise indicated, further page references are in the main text.
} 
placed at the heart of a racialized society. The novel takes up the form of a masquerade from its very beginning, blending story and history, fiction and biography in the 'adventure' of a hero who has a double who existed in 'real' life.

Born in Nassau, in the Bahamas, of mixed descent (his grandfather was white and his grandmother a quadroon), the historical Egbert Austin Williams moved to the USA with his family as a child, and as a young man fled his father's house in Riverside, California, to tour the USA as a travelling performer. From 1896 he adopted the black mask of minstrelsy and performed in cork face till the end of his short life. He died aged forty-six in 1922, the year Marcus Garvey was arrested and his Black Star Line confiscated. Before his death, he had tried to abandon the black mask that had made him famous and brought him onto the Broadway scene and beyond, in the great tour of the Ziegfeld Follies where he performed without cork face. Among his admirers were Buster Keaton and the King of England, Booker T. Washington and Florenz Ziegfeld in person. He was in every way a real star.

\section{From the historical Bert Williams to his mirror reflections}

Caryl Phillips takes up this historical figure and instructs him to perform a new and dramatic role before the readers' eyes. The character's task is ambiguous and startling, his gestures organized in such a way as to frighten and move, to create perplexity and anxiety - in a word, to plunge us into the uncanny. We know we are never alone with Bert Williams, for he is never alone with himself. He is a lonely man and talks very little, but when he enters the scene, something else enters along with him, and frightens us: is it a shadow, a ghost, or merely a reflection in a mirror? Sigmund Freud, and Otto Rank, would identify this unfathomable presence as a doppelgänger; Lacan would acknowledge it as a lack, a stunned gaze, a specular image of the manque often revealed by a mirror. In his seminal essay "Das Unheimliche," ${ }^{2}$ Freud describes his own uncanny experience of being startled by the image of a stranger in his railway cabin: a stranger who turns out to be Freud himself reflected by a mirror. Bert Williams introduces us to several disturbing experiences of this kind, where the mirror allows no recognition and induces uneasiness, fear, and even angst. The best example of such a situation seems to be

\footnotetext{
2 Sigmund Freud, "The Uncanny" ("Das Unheimliche,” 1919; tr. under the supervision of Joan Rivière [incl. in Collected Papers, 1925], repr. in On Creativity and the Unconscious, New York: Harper Torchbooks, 1958): 109-10, Note 1.
} 
the unsettling scene where he recalls the first time he put on his black mask in Detroit in 1896:

And the first time he looked at himself in the mirror he thought of the embarrassment and distress that this would cause his father and his heart sank. [...] How could a West Indian do such a thing to himself? The first time he looked in the mirror he was ashamed [...]. He kept telling himself, I am no longer Egbert Austin Williams. As I apply the burnt cork to my face, as I smear the black into my already sable skin, as I put on my lips, I am leaving behind Egbert Austin Williams. [...] As he looked at himself in the mirror he knew that he had disappeared, and he understood that every night he would have to rediscover himself before he left the theatre. The first time he looked at himself in the mirror the predicament was clear, but just who was this new man and what was his name? Was this actually a man, with his soon-to-beshuffling feet, and his slurred half speech, and his childish gestures, and his infantile reactions? [...] However, the audience never failed to recognize this creature. That's him! That's the nigger! He looks like that. And that's just how he talks. And he walks just like that. I know him! I know him! [...] And the first time he looked in the mirror his heart sank like a stone for he knew that this was not a man that he recognized. This was somebody else's fantasy, and unless he could make this nobody into somebody, then he knew that eventually his eardrums would burst with the pain of the audience's laughter. The first time he looked at himself in the mirror his heart sank. In Detroit in 1896. (57-58, emphases in boldface mine)

Bert Williams's anguished recollections include the theme of racial otherness, in his case complicated by intraracial differences. Bert Williams is coloured, but not a black American. His West Indianness is one more mask that he wears or sheds, depending on the occasion, both visually (the blackface of minstrelsy) and linguistically (his Caribbean accent, though this aspect is not directly treated in Phillips's reconstruction). When the reviewers describe him as a typical black coon, Bert recoils and takes refuge in the isolation of his dressing room, the secluded and private place where he dresses and undresses and puts on his cork face ${ }^{3}$ and takes it off, always in secrecy:

${ }^{3}$ In the world of minstrelsy, 'to put on the cork face' means - or, rather, meant - to paint one's face black before going on stage. In fact, originally the minstrel's face was painted black with a burnt cork, hence the expression 'cork face.' At the end of the show the minstrel would take his cork face off, that is, clean his face of the black makeup. In Dancing in the Dark the process of putting on his cork face and taking it off is for Bert Williams a slow ritual, always performed in a secluded situation of absolute secrecy required by the sacred (or devilish) nature of the process itself. 
The dressing room is the one place where he is able to think clearly [...] where he can sit alone and remember all that has gone before, and imagine all that is still to unfold. The mirror is the most important part of the room. The mirror and the lightbulbs. [...] Every evening, having washed his face and applied the towel, a despondent Bert stared into the mirror but he failed to see the amiable coon with the cavernous mouth whom the influential critic had described. (89-90, emphases in boldface mine)

The most unsettling experience of this kind takes place on his deathbed, and not by chance, for the doppelgänger is an image of death and his apparition an intimation of mortality, and is perceived as such by Bert's wife Lottie, who assists him and provides him with the mirror, focus of the strategy of identity and repetition displayed through various masks and based on a geometric game of doubles and reflections:

I offer him the mirror, which he holds by the handle, and I watch as he is shaken into panic by the puzzled face in the glass. He eventually absorbs the initial distress of recognition, [...] but I know that once the mirror is in his hands my husband is no longer with me. I know that my husband will spend the whole day staring into the mirror, $[\ldots]$ but his well-disciplined countenance will betray but little of his inner drama. [... I I can hear mortality, like dull thunder, continuing to rumble its merciless way toward him and I take this quaking as a signal that I should withdraw for my husband's daily performances with the handheld mirror require no audience (207, emphases in boldface mine).

In counterpoint to Lottie's thoughts, we hear Bert's delirious monologue, culminating in a definition subverting Hamlet's famous statement ${ }^{4}$ and establishing the centrality of darkness with a beautiful sliding effect:

I truly lost sight of myself many years ago when my tightly shod young feet touched the shore of the powerful country to the north. I followed my father, [..] but I lost him on that New York night when [...] he sat upstairs in nigger heaven and looked down on me. [...] I am alone in the darkness. [...]. Father, do you really understand what they want from us in this American world? Do you? We are being held hostage as performers, and those who imagine that they are engaged in something other that entertainment should ask my wife to pass them the handheld mirror. But I must not complain for

\footnotetext{
${ }^{4}$ In his best-known monologue, Hamlet concludes that "conscience does make cowards of us all" (Hamlet III.i.85). This idea is subverted by Bert when he speaks of "this darkness that makes human beings of us all" (208), where the element of reason and light (i.e. conscience) is replaced with darkness (i.e. the absence of light).
} 
my time has been spent, $[\ldots]$ and I wander in this darkness that makes human beings of us all. (208, emphases in boldface mine)

For Hamlet, of course, it was consciousness and not darkness which made us all human beings, but what is darkness for Bert Williams, what role does darkness have in the gripping tragedy of his life? Is it the prison of race that forces upon him a mask he has to accept in order to entertain his audiences? Or, rather, is it the limit he cannot transcend, an enigmatic liminality, an unknown terrain that compels him to dance the cakewalk rather than perform an art free from stereotypes? Maybe he is doomed to dance in darkness because his racialized world prevents him from playing in the dark, as Toni Morrison puts it, ${ }^{5}$ that is, from being a full artist. His acting is on the threshold of art because it is not recognized as such. Bert is not accepted by whites when he appears on stage without blackface, and at the same time he is vilified by his own coloured people because he is known for his performances in cork face. Not only so: in fact, he does not even have 'his own coloured people', for he does not perceive himself as black American, and Harlem, although he likes it, is not his home. A dead-end issue, a predicament which offers no other way out but dancing to one's death.

In the very last moments of his life, Bert becomes prophetic and envisions the future of the racialized world he lives in:

Others will come after me to entertain you, and they will happily change their name and put on whatever clownish costume you wish them to wear, and dance, and sing, and perform in a manner that will amuse you, and you will mimic them, and you will make your money, but know that at the darkest point of the night, when no eyes are upon them, these people's souls will be heavy, and eventually some among them will say no, and you will see their sadness, and then you will turn from them and choose somebody else to place in the empty room, or nudge into your empty stage [...]. (208-209)

\section{Double-consciousness and multiple identities}

In the novel, Bert Williams is positioned close to the "double-consciousness" theorized by W.E.B. Du Bois as a topos of black America, ${ }^{6}$ and therefore far from the compromised mediation accepted by Booker T. Washington. Yet the

\footnotetext{
${ }^{5}$ Toni Morrison, Playing in the Dark: Whiteness in the Literary Imagination (Cambridge MA: Harvard UP, 1992).

${ }^{6}$ W.E.B. Du Bois, The Souls of Black Folk (Chicago: A.C. McClurg, 1903).
} 
latter - who knew Bert Williams, and wrote on him appreciatively - saw him as a champion of accommodationism:

Bert Williams is a tremendous asset of the Negro race. He is an asset because he has succeeded in actually doing something, and, because he has succeeded, the fact of his success helps the Negro many times more than he could help the Negro by merely contenting himself to whine and complain about racial difficulties and racial discriminations. The fact is that the American people are ready to honour and to reward any man who does something that is worth while, no matter whether he is black or white, and Bert Williams's career is simply another illustration of that fact. ${ }^{7}$

The agonizing duplicity in Williams's predicament, its tragic irony, was obviously lost on Washington, but not so in Phillips's novel, where the character is plunged into anguish and bent on a downward path of destruction - he is, in fact, doomed. It is as though Phillips had extracted from the historical Bert Williams all his hidden potentialities, made him walk on a new stage, and developed his personal and cultural predicament to the extreme conclusions of a total isolation followed by tragic death.

Bert's personality, structured around a conflictual - or, rather, oppositional - dynamic tension, is in fact bent on self-destruction, as his wife Lottie understands very well, albeit through a process of sorrowful discovery. Lottie perceives the presence of the other inside Bert himself, and the tragic need to perform through a rigid persona, the black mask. Lottie resonates with Bert's tensions and perpetual grief, for she is herself a compulsive personality driven by extreme forces, and also a repressed artiste: she has her own mask, a hat which conceals her kinky hair.

Lottie is, just like Ada, the wife of Bert's on-stage partner George Walker, deeply involved in the artistic life of her time, the black Harlem of Paul Laurence Dunbar and Claude McKay, both of whom were West Indians and friends of Bert's, but who are not represented in the novel. As the tragedy develops, we see a wider and richer picture emerge of that Harlem that has often been represented as a marvellous world, but is no paradise to Bert Williams.

The narrative explores the complexity of a society that is not only racialized but also marked by intraracial tensions, as Caribbean Bert Williams's

\footnotetext{
${ }^{7}$ Booker T. Washington, "Bert Williams," in Booker T. Washington Papers, vol. 10, 1909-11, ed. Louis R. Harlan \& Raymond W. Smock (Urbana: U of Illinois P, 1981): 391.
} 
loneliness in Harlem suggests. This environment is seen from the viewpoint of an extremely gifted individual straitjacketed by the power of pervasive stereotypes he cannot avoid, since his art cannot do without society, nor exist outside it. The emergence of the Unheimlich is unavoidable, part and parcel of Williams's position, and is represented with cruel determination in the novel. It becomes his destiny, thereby creating a inescapable tragedy.

\section{Dancers and automatons, Bert and Olimpia}

Freud hints at the mechanical nature of the Unheimlich when he analyzes E.T.A. Hoffmann's Der Sandmann and touches on the figure of Olimpia - a mechanic doll, an automaton, a replica (or doppelgänger) of a real woman. The fascination for Olimpia is a marvellous scene in Hoffmann's novella, and is identified by Freud as a fascination for duplicity, for she is the feminine side of the masculine character Nathaniel, who is obsessed by her - a narcissistic drive, for Olimpia is part of himself. There is an interesting scene in Dancing in the Dark that seems close to Freud's observation on the matter, and which occurs when Bert Williams acts in a movie (something that really happened with Darktown Jubilee) and then sees the short film in a dark room:

\footnotetext{
the images begin to flicker against the wall. For eleven minutes he sees himself performing an act he has never before witnessed, moving easily, the hand gestures perfect, the timing flawless. He watches himself and in the darkness he is quietly moved. [...] As the film thunders through the projector for a second time, Bert looks at the moving picture and he feels proud of it $[\ldots]$. Between his needs and his audience's expectations he walks a tightrope, but with only a black box for guidance he now knows that he is always liable to miscalculate. He understands the nature of the problem - he needs to see, hear, feel his audience - but they too must understand that there is, on his part, no desire to cause offense. (191-92)
}

This is a startling scene. For the first time Bert watches his double, or doppelgänger, in action; he is, in a way, reunited with one of his multiple selves while he, as spectator, is not wearing a cork face: i.e. he is in a way detached from his own performance. He is in darkness, he watches himself play, and he knows he is just perfect. The mechanical nature of the movies - the flickering of images on a wall - has enhanced the performer's qualities and allowed him to see his own talent. But he walks a tightrope, and his audiences will turn 
down his performance in a film because it betrays the stereotype. Bert Williams will make no other films in his career. ${ }^{8}$

If we were to adopt Freud's suggestions on the split personality of the automaton, we might reach the conclusion that Phillips's Bert Williams suffered from a complex of castration that might explain his differences with his father and his own sexual block (he recoils from physical contact with women). But Phillips's novel was probably not written to suggest conclusions of this kind, nor do we believe in the effectiveness of psychoanalyzing literary characters. Yet Freud helps us to detect the enigmatic nature of the fascination exerted by a multiple and conflictual personality who lives in a social and cultural context whose racial stereotypes generates high levels of aggressiveness and violence. A time-honoured tradition of forced submission on the part of blacks, descendants of slaves, had long compelled them to hide their own selves and act as entertainers of the dominant classes in order to survive and cover up their true feelings, thus avoiding retaliation, punishment, and hatred. Hence the need to use a mask, many masks. Frantz Fanon wrote unforgettable words on black skin and white masks, and the destructive function of role-playing in a racialized context. ${ }^{9}$

\footnotetext{
${ }^{8}$ A brief passage from Darktown Jubilee is included or, rather, quoted in Bamboozled, the film Spike Lee made in $\mathbf{2 0 0 0}$ - a satirical comedy pivoting on a minstrel show produced in contemporary times as a television serial. Lee's film introduces characters obsessed with the black mask and explores the racial undertones in the world of show business, but not only that. The act of putting on blackface makeup, so powerfully and painfully evoked in Phillips's novel, is repeated over and over again in the film, with disturbing connotations of disgust and compulsion. Finally, one cannot help noticing that the intriguing title, Bamboozled, refers back to trick and therefore to trickster - and the film shows a situation of tricked tricksters playing with the black mask. The African-American tradition has kept alive the presence and role of the trickster of African origin, whose prototype may be considered the ambiguous god Exu from the Yoruba pantheon. The trickster is also a familiar figure in Caribbean culture. The trickster figure is meant here not as "an archetypal idea, but rather as a symbolic pattern": see Robert D. Pelton, The Trickster in West Africa: A Study of Mythic Irony and Sacred Delight (Berkeley, Los Angeles \& London: U of California P, 1980): 3. On the other hand, Jung's intuition of the unavoidably comic nature of the trickster, his dissembling impulse and the many masks in his very self, constitutes a fundamental insight into the nature of the trickster. See Carl Gustav Jung, "On the Psychology of the Trickster Figure," tr. R.F.C. Hull, in Paul Radin, The Trickster (New York: Greenwood, 1969): 195-211.

${ }^{9}$ Frantz Fanon, Black Skin, White Masks, tr. Charles Lam Markmann (Peau noire, masques blancs, 1952, tr. 1967; London, Pluto, 1982).
} 


\section{The birth of "a shuffling, dull-witted, watermelon-eating Negro"}

Bert Williams's predicament throws a bright light on a destiny of self-destruction. The forces that lead to Bert's demise may be psychological, but they are first and foremost products of American society's reliance on racial stereotypes - in this respect, the psychical violence to which Williams subjects himself may be a metaphoric evocation of the lynching and burning of black people in the USA. Phillips's re-creation of Williams's inner turmoil makes for an emotionally vivid reading experience, where tenderness and irony blend with the hard facts of life. The pages where the twenty-six-year-old Bert courts Lottie and tells her the story of his life - in the classic manner of oldtime heroes, from Ulysses and Nausicaa to Aeneas and Dido downwards - are enchanting in their gracefulness. He tries to explain to her how it was that he came to adopt the mask and tricks of the 'darky' while he was working with his partner George Walker:

it made more sense to both George and myself that we exchange roles, so I became the clown and he became the straight man, and right away the laughs came more easily $[\ldots]$. His mind is still full and he has not finished. They both know that there is something else. [...] And the makeup. George was not happy but I tried the makeup and became somebody else. [...] She understands that her suitor is a man who is playing a part. He is playing a shuffling, dull-witted, watermelon-eating Negro of questionable intelligence. $\mathrm{He}$ is playing a character. He is a performer who applies makeup in order to play a part. [...] I have not talked about the cakewalk, he says. It was George's idea to add the cakewalk to the act [...]. Only Williams and Walker possess such a high sense of themselves. [...] this man's heart is likely to remain a deep ocean of jeweled secrets [...]. (35-37)

Again, a final Shakespearean-like touch, "jeweled secrets" sunk in the "ocean" $" 10$ is added to sprinkle with classic beauty the delicate relationship between Bert and Lottie. Yet this very relationship, its inability to develop further, is among the elements that precipitate Bert's downfall and tragedy. The man ends up frozen under a glass bell which isolates him completely from sights and sounds and locks him in final mutism and remoteness. And we notice, with a shudder, that the evocative reference to Ariel's song includes a hidden, implicit image of death by drowning.

\footnotetext{
${ }^{10}$ Cf. Ariel's song in The Tempest (I.ii.396-401): "Full fathom five thy father lies, / Of his bones are coral made; / Those are pearls that were his eyes; / nothing of him that doth fade, / Both doth suffer a sea-change / Into something rich and strange."
} 
But let us not be beguiled by the ambiguous hint at Shakespearean beauty. It might, rather, be relevant to observe, at this point, that the insistence on secrets, secrecy, hiding, and related words does not seem to happen by chance or be just a decorative element in the context of Phillips's narrative. The whole story of the performer Bert is organized on two levels, on and off the stage, in and out of visibility. The pivotal element of the dividing line is the missing home. Bert has no home, and when Lottie tries to give him one by buying an apartment on Seventh Avenue with her own money, he recoils and feels threatened by her generous move. The homeless hero seeks a home inside himself, in the secrecy of his existence, in the unfathomable depth of his silences and loneliness. Freud remarks that the German word for 'secret' is 'geheim', philologically connected to the Unheimlich through the common root Heim (home). Although the linguistic link is lost in English, the semantic values of the two words are connected, for a secret is something which is not or should not be known, an element cut off and removed from the area of that which is known, and the Unheimlich is the unfamiliar, the unknown (and therefore frightening, startling). ${ }^{11}$ The division marked by secrets and secrecy is not territorial, but metaphoric, and works powerfully in Bert's life-span, governed by a dramatic alternation of secret and public life, between a phantasmatic home and the stage where he actually dwells. This narrative strategy hints at a hidden and incurable wound caused by the loss of home. An unspeakable loss.

\section{Masks, jokes, and racial stereotypes}

The historical Bert Williams as a cultural representative of his times was placed between the nineteenth and the twentieth century. The second part of his life developed in the lively climate of the Harlem Renaissance, where the wind of modernism brought a whiff of fresh air, but its first part was rooted in the provincial atmosphere of late-nineteenth-century America. Those times, still close to slavery, saw white people's relationships with blacks and col-

${ }^{11}$ In his 1919 essay on das Unheimliche, Freud remarks that it is only in German that the word expresses the different shades of meaning connected to heimlich and derived from the word Heim (home). In English, the word commonly used is 'uncanny', in Italian 'perturbante'. The German definition hints at an object that used to be familiar and reappears as unfamiliar, thereby creating an uncanny effect, but the most important element is its duplicity, for it is connected to the concept of home, out of which there is estrangement ('spaesamento'): "the uncanny is that class of the terrifying which leads back to something long known to us, once familiar" (Freud, "The Uncanny," 123-24). 
oureds ('Negroes', as they were then called) dominated by racism and very little knowledge of the black world. Intraracial relationships were not directly discussed, and Bert Williams, as well as his friends Dunbar and McKay, were exceptions in their ability to portray and express cultural differences among blacks. Knowledge of Africa was practically non-existent among whites, ${ }^{12}$ so much so that towards the end of the nineteenth century and in the early-twentieth century there developed the fashion (in both the USA and Europe) of mounting exhibitions and expositions of ethnological specimens brought from Africa. Gradually this became a real branch of exoticizing show business, where frauds were often exhibited: ${ }^{13}$

The use of 'ordinary niggers' in the place of authentic Africans in fact became so widespread that even naturalists had to declare the authenticity of their specimen. In 1885 , one had defensively to prove that the Africans on display were actually Africans, not, "as some of the journalists have wickedly insinuated, Irish immigrants, cunningly painted and made up like savages. They are genuine Zulus."14

African authenticity, then, became a relevant issue, and it is in this context that the historical Bert Williams presented his show In Dahomey, which also travelled to London's West End theatres and in 1903 was performed at Buckingham Palace for the family of King Edward VII. There Bert Williams inserted a song which became a hit, "Every Darkey Is a King":

Evah darkey is a king!

Royaly is jes' de ting.

If yo' social life's a bungle,

Jes yo' go back to yo' jungle,

And remember dat your daddy was a king. ${ }^{15}$

Bert Williams and George Walker's approach articulated a diversified gaze on African and African diasporic expressions and, while aiming to create popular shows, it tried to bring innovations to the discourse of African-American cul-

12 Although, of course, much knowledge was gathered and made available by African Americans (such as Martin Delany) and their activist abolitionist sympathizers in the nineteenth-century missionary and colonization movements.

${ }^{13}$ Africans on Stage: Studies in Ethnological Show Business, ed. Bernth Lindfors (Bloomington: Indiana U P, 1999).

${ }^{14}$ Louis Chude-Sokei, The Last 'Darky': Bert Williams, Black-on-Black Minstrelsy, and the African Diaspora (Durham NC \& London: Duke UP, 2006): 123.

${ }^{15}$ Cited in Chude-Sokei, The Last 'Darky', 122. 
ture. It would not be long before Garveyism and Rastafarianism launched new versions of diasporic pan-Africanism, but this interesting song is in itself evidence of a new sensibility.

On the other hand, if we are to consider Bert Williams as a fictional character, we notice that Phillips's novel retells the curious but not infrequent condition of a couple of black young men - in this case, Bert and George themselves - hired to play the role of African 'savages' whose arrival from the dark continent had been delayed. It seems that the two friends went on with their performance even after the arrival of the 'real' Africans, who apparently did not look savage enough to the impresario of the 1894 Ethnological Show in San Francisco. Such episodes, far from being funny, tint the novel with a strange melancholy, for they confirm the centrality of otherness in the highly racialized American context. Bert was in a constant state of exile, both from the white and from the black world, being not even an 'authentic' African.

Black performers were accepted in America only if they were acting to create a comic effect and presented themselves as funny, clumsy, and idiotic. This show of pretended stupidity confirmed the feeling of superiority of white audiences, in a strategy of affect pointedly analyzed by Freud:

it is possible to produce the comic in relation to oneself in order to amuse other people - for instance, by making oneself out clumsy or stupid. In that way one produces a comic effect exactly as though one really were these things [...], by fulfilling the condition of the comparison which leads to the difference in expenditure. But one does not in this way make oneself ridiculous or contemptible, but may in some circumstances even achieve admiration. The feeling of superiority does not arise in the other person if he knows that one has only been pretending; and this affords fresh evidence of the fundamental independence of the comic from the feeling of superiority. ${ }^{16}$

Freud seems to suggest that the comic mask should never betray the underlying personality and should therefore stick to the impersonator and be the same as the impersonator in the consciousness of the viewer. This analysis fits the tragedy of our fictional hero Bert Williams and his ambivalent, complex, and dangerous relationship to his own blackened face. For Bert, the black mask is not a masquerade, it is one more self that he takes up when performing for his audiences, an identity he adopts in order to communicate. His tragedy cannot be understood by his contemporaries, and in the novel there is a

\footnotetext{
${ }^{16}$ Sigmund Freud, Jokes and Their Relation to the Unconscious (Der Witz, 1905; tr. \& ed. James Strachey, New York: W.W. Norton, 1960): 199.
} 
meaningful episode that occurs when Bert is met by six affluent coloured gentlemen who try to convince him to abandon his grotesque minstrel's face, a travesty they see as degrading for the whole black race:

Why, Mr Williams, do you choose to play the shambling, pathetic dupe? [...] The Negro I portray is not any man in this room so there is no need for any among you to behave defensively. [...] I am impersonating a particular type who does not exist except in my imagination. [...] And in their imagination, Mr Williams. We exist in their imagination as you portray us, and you reinforce their low judgement of us as dull and pitiable. An exasperated Bert opened his arms wide. Am I responsible for the coarse imagination of some few among my audience? Am I responsible for how the Negro is viewed in America? I am an entertainer, what would you have me do? Stop performing? [...] We do not know, and have never known, this man who you impersonate. [... ] It would appear that the Negro is only acceptable on the American stage as long as he is singing idle coon songs and dancing foolishly. In other words, as long as he is a close approximation to the white man's idea of a nigger. [...] Bert [...] looked from one well-groomed colored face to another, unable to comprehend why these six supposedly intelligent men could not understand that he was merely playing a character. His darky was clearly not representative of them or their worlds. His coon was a very particular American coon as seen by a man from the outside. (179-80)

This impossible dialogue between Bert Williams and the group of well-off African Americans is simply agonizing. They cannot understand the actor whose acting appears degrading in their eyes - while he cannot explain to them the multi-faceted reality of his own role and the essential nature of his multi-layered mask, nor can he make them see the other lurking behind his cork face.

The world of black minstrelsy has been widely analyzed by historians and cultural critics, and offers a partial basis for the development of Bert's character in the novel. Bert, in fact, was "the last darky,"17 a late impersonator of the coon type that had gained so much favour and success both in America and in Britain, and that had travelled as far as South Africa, where it still survives in the New Year's Coon Carnival in Cape Town. It is, in fact, in carnivals that black minstrelsy now continues to exist, in South Africa as well as in Trinidad, where it displays its subversive role in a climate of accepted transgression reminiscent of those festivals where slaves were allowed to wear

\footnotetext{
${ }^{17}$ See Chude-Sokei, The Last 'Darky'.
} 
their travesty in public and entertain everybody while unleashing verbal revenge on their masters.

But our - and Phillips's - Bert Williams might also be interpreted as a champion of the double voice theorized by Henry Louis Gates, ${ }^{18}$ and be placed "in that undertheorized 'third space' of postcolonial discourse evoked by both Gates's attention to 'trinary' forces and Houston Baker's investigation of Caliban's 'triple play' of signification." ${ }^{, 19}$ It is, in fact, tempting to read Bert's acting as 'signifying' in an area placed between America and Britain and thus to see him not as a mere product of Anglo-American racism but as a representative of the double-voicedness coming from Africa and manifesting the sinister and invisible presence of the Yoruba god Exu - a powerful figure who travelled to the Americas with the transatlantic diaspora of slavery.

Phillips's character is rooted in the historical role of black minstrelsy, but uses it as a powerful metaphor for his own complexities. By adopting the socalled cork face as a comic device, Bert is allowed to walk the tightrope, as he himself says, on the intraracial terrain he is addressing. His playing on stereotypes offers him ready-made materials for the construction of multiple identities and the organization of his compulsive ambiguity. The angst that inhabits his psyche and grows worse with the passing of time might be interpreted as the result of a condition of not feeling at home or, as Heidegger would say, of Unheimlichkeit. ${ }^{20}$ In sum, Bert is a character who is at first introduced as an historical figure but who, under Phillips's guidance, ends up walking out of history and emerging again as metaphor.

\section{WORKS CITED}

Baker, Houston A., Jr. Modernism and the Harlem Renaissance (Chicago: U of Chicago P, 1987).

Bamboozled, dir. Spike Lee (New Line Cinema, US A 2000; 135 min.).

Berto, Graziella. Freud, Heidegger: Lo spaesamento (Milan: Bompiani, 2002).

Chude-Sokei, Louis. The Last 'Darky': Bert Williams, Black-on-Black Minstrelsy, and the African Diaspora (Durham NC \& London: Duke UP, 2006).

Darktown Jubilee (Protective Amusement Company and Biograph, 1914).

Du Bois, W.E.B. The Souls of Black Folk (Chicago: A.C. McClurg, 1903).

\footnotetext{
${ }^{18}$ Henry Louis Gates, Jr., The Signifying Monkey: A Theory of African-American Literary Criticism (New York: Oxford UP, 1988).

${ }^{19}$ Chude-Sokei, The Last 'Darky', 107.

${ }^{20}$ Graziella Berto, Freud, Heidegger: Lo spaesamento (Milan: Bompiani, 2002): 148-49.
} 
Fanon, Frantz. Black Skin, White Masks, tr. Charles Lam Markmann (Peau noire, masques blancs, 1952, tr. 1967; London, Pluto, 1982).

Freud, Sigmund. Jokes and Their Relation to the Unconscious (Der Witz, 1905; tr. \& ed. James Strachey, New York: W.W. Norton, 1960).

. "The Uncanny" ("Das Unheimliche," 1919; tr. under the supervision of Joan Rivière [incl. in Collected Papers, 1925], repr. in On Creativity and the Unconscious, New York: Harper Torchbooks, 1958), 122-61.

Gates, Henry Louis, Jr. The Signifying Monkey: A Theory of African-American Literary Criticism (New York: Oxford UP, 1988).

Hoffmann, Ernst Theodor Amadeus. Der Sandmann, in Nachtstücke, Erster Teil (Berlin: Realschulbuchhandlung, 1817).

Jung, Carl Gustav. "On the Psychology of the Trickster Figure," tr. R.F.C. Hull, in Paul Radin, The Trickster (New York: Greenwood, 1969): 195-211.

Lindfors, Bernth. Africans on Stage: Studies in Ethnological Show Business (Bloomington: Indiana UP, 1999).

Morrison, Toni. Playing in the Dark: Whiteness in the Literary Imagination, Cambridge MA: Harvard UP,1992).

Pelton, Robert D. The Trickster in West Africa: A Study of Mythic Irony and Sacred Delight (Berkeley, Los Angeles \& London: U of California P, 1989).

Phillips, Caryl. Dancing in the Dark (London: Secker \& Warburg, 2005).

Washington, Booker T. "Bert Williams," in Booker T. Washington Papers, vol. 10: 1909-11, ed. Louis R. Harlan \& Raymond W. Smock (Urbana: U of Illinois P, 1981). 


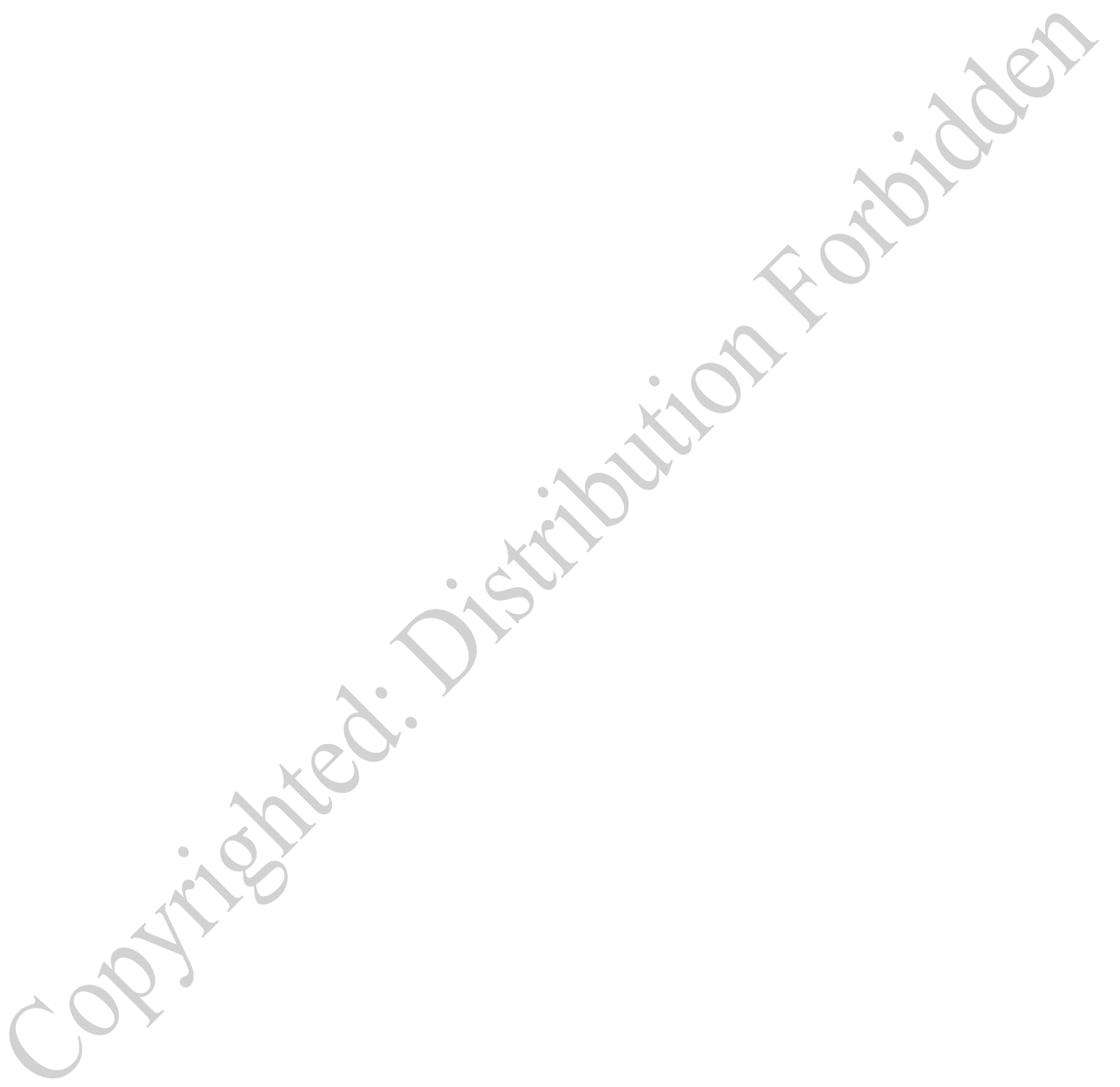




\section{Concentric and Centripetal Narratives of Race Caryl Phillips's Dancing in the Dark and Percival Everett's Erasure}

\section{Dave GunNing}

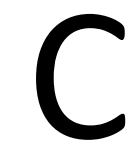

ARYL PHILlips's DANCING IN THE DARK (2005) provides a prolonged and sensitive exploration of the dilemmas faced by the stage performer Bert Williams (1875-1922). In an interview with Phillips that took place shortly after the novel's release, John McLeod ventures a question on how the book explores the personal experience of race, "the ways in which race can complicate and problematize some of the most intimate aspects of a person's life." Phillips responds by reflecting on the difficulties of asserting and retaining individual agency in response to the 'bigger' problematics of race:

It is not an easy thing for anybody to do, to have to balance out the difficulties of personal responsibility with one's loyalties to a group. But to have to play that out in the public glare and to have to grapple with a stereotype which is imposed upon you, which can stifle you as an artist or stifle you as an individual, is a tremendously difficult thing to do. And he dealt with it. I mean he dealt with it and he didn't deal with it. But he did the best he could in the circumstances. ${ }^{2}$

It is in that final qualification that we find an invaluable way into reading the novel. Phillips offers two contradictory ways of reading Bert Williams, but they are offered at the same time: "He dealt with it and he didn't deal with it." The moment of contradiction is registered as of crucial importance but Phil-

\footnotetext{
${ }^{1}$ John McLeod, in Caryl Phillips, "Dancing in the Dark: Caryl Phillips in Conversation with John McLeod," Moving Worlds 7.1 (2007): 105.

${ }^{2}$ Phillips, "Caryl Phillips in Conversation," 106.
} 
lips's concern is to preserve, rather than attempt to resolve, this conflict. The reader of Dancing in the Dark is asked to confront and negotiate this opposition; the only way we can attain an understanding of Bert's situation is by first finding a way to locate ourselves in a position of contradiction, from which more effectively to identify the equivalent position that Bert himself was forced to occupy. We must be able simultaneously to see Bert both coping with the inconsistencies of his predicament and yet failing to endure the pressures exerted on him. In order to allow for this difficult readerly stance, the novel must embrace dichotomies; it searches out a form to embody them and retains a consistent tension between seemingly incommensurable ways of being in the world. It recognizes how contradiction might sometimes be made inevitable by circumstance and become the condition within which one's life is plotted.

In exploring how Phillips portrays Bert's lived experience of incompatible realities, the primary image I wish to employ as a focal point is that of erasure. The first time Bert decides to wear blackface makeup, in Detroit in 1896 , his experience is rendered through reference to this concept:

he drew on his lips so that they grew beyond his own, swimming out towards his cheeks and down his chin. His lips were the final touch. He erased himself. Wiped himself clean off the face of the earth so that he found himself staring back at a stranger. ${ }^{3}$

Within Derrida's famous use of the concept of erasure, the trace that precedes and remains after erasure is "not only the disappearance of origin" but simultaneously reveals "that the origin did not even disappear, that it was never constituted except reciprocally by a nonorigin, the trace." ${ }^{, 4}$ My use of the term is intended to allow for a broader definition, which encompasses both the sense of an absolute annihilation and that of the removal that nonetheless preserves a remnant. Contra Derrida, in each of the senses of erasure I present it is the nature of the transformation of the origin that interests me, rather than the revelation of its prior and continuing non-existence. Dancing in the Dark offers us a view of negation which can be comprehended either as complete or as partial; the perspective from which judgment is arrived at seems to be the crucial factor. As Bert applied the cork, "he erased himself. Wiped himself

\footnotetext{
${ }^{3}$ Caryl Phillips, Dancing in the Dark (London: Secker \& Warburg, 2005): 58. Further page references are in the main text.

${ }^{4}$ Jacques Derrida, Of Grammatology, tr. \& ed. Gayatri Chakravorty Spivak (De la grammatologie, 1967; Baltimore MD \& London: John Hopkins U P, 1976; corrected ed., 1997): 61.
} 
clean off the face of the earth so that he found himself staring back at a stranger." The action seems to demonstrate, if anything, the impossibility of auto-annihilation: Bert does not enact his absolute departure but remains as a witness, tracking this disappearance in the mirror. As Darryl Pinckney has observed, Bert is "very much the observer" in this novel and this role of witness seems here to eclipse that of agent, ${ }^{5}$ what we see is something very like a splitting of the cogito ergo sum, as Bert as observing subject and Bert as observed object hurtle in radically different directions. However, within this complicated division of the contemplating self into perceiver and perceived, the reader is asked to be present at both viewpoints, to bear witness both to the dissolution of Bert's unified identity and to its inevitable persistence.

The specificity of Phillips's engagement with some of the impositions and deductions demanded by the mobilization of racial ideas and his development of a particular formal strategy for the representation of radical dissociation can be profitably illuminated by reading Dancing in the Dark alongside a novel that deals with a similar set of themes: Percival Everett's Erasure (2001). The thematic similarities between these two texts are in many ways profound, although it is in comparing their differences that we can perhaps locate some of the most important things they have to say on contemporary issues of racialization. The concentration in both novels on the construction and marketing of racial identity seems to speak to an important concern in the new millennium. Phillips himself has identified ways in which his novel relates to questions of "responsibility" in terms of representations, echoing some of Paul Gilroy's concerns about the frameworks of signification in which black public figures are located, particularly in the USA. ${ }^{6}$ Relevant here are debates concerned not so much with 'who speaks' as with how they are constructed as particular kinds of speaking subjects. Each of these novels draws attention to the frameworks that make expression possible, but also determine how the articulations of the racialized person are received. However, each text presents an opposing model of how this limiting dissemination of representations of selfhood might affect the subject who offers up their enunciation of identity to be inevitably misrecognized in such discursive frameworks.

The narrator and protagonist of Everett's novel is Theolonius Ellison (nicknamed 'Monk' after the jazz pianist Thelonious Monk), a college professor

\footnotetext{
${ }^{5}$ Darryl Pinckney, "Blacking Up," New York Review of Books 51.12 (13 July 2006): 26.

${ }^{6}$ Phillips, "Caryl Phillips in Conversation," 106-107; Paul Gilroy, Against Race: Imagining Political Culture beyond the Color Line (2000; Cambridge MA: Harvard U P, 2001): esp. 135-237.
} 
and an experimental novelist: he is working on a re-telling of Gaius Petronius' Satyricon. Introducing himself on the first page of the novel, Monk tells us:

I have a dark brown skin, curly hair, a broad nose, some of my ancestors were slaves and I have been detained by pasty white policemen in New Hampshire, Arizona and Georgia and so the society in which I live tells me I am black; that is my race. ${ }^{7}$

For Monk, race is an external imposition; a categorization from outside. It is not an integral part of his experience. He simply does not wish to live his life according to this socially constituted 'fact' of race. "The hard, gritty truth of the matter is that I hardly ever think about race," he tells us (4).

Monk is increasingly riled by the success of a novel written by a young woman called Juanita Mae Jenkins. His dislike of the novel, We's Lives in Da Ghetto, is partly due to his opinion of its limited literary worth, but perhaps even more because of the way in which it is valorized in the cultural marketplace as an 'authentic' account of a 'real' black experience. For him, the novel is "an idiotic, exploitive piece of crap" (213). While his own novels are castigated for not being 'black' enough, Jenkins's book achieves acclaim precisely because of its adherence to a version of vernacular authenticity. Monk refuses to acquiesce to the view that "only the vernacular can confer the medal of representativeness upon a range of other, less obviously authentic, cultural activities." ${ }^{\prime 8}$ In refusing to contribute to a 'black' literature, Monk limits his own saleability, an act in which, he recognizes, "the irony was beautiful. I was a victim of racism by virtue of my failing to acknowledge racial difference and by failing to have my art be defined as an exercise in racial self-expression" (238).

As the novel progresses, Monk finds himself in financial difficulties and eventually writes a parody of the 'ghetto fiction' that so upsets him. The novel he writes, My Pafology, is largely a twenty-first-century revision of Richard Wright's Native Son - though here the central figure, Van Go Jenkins, is more alienated, more violent, and less articulate than even Bigger Thomas. Monk takes his "piece-of-shit novel" (159) to his agent and they set about publishing it under the pseudonym of Stagg R. Leigh. ${ }^{9}$ Predictably, the novel is received

\footnotetext{
${ }^{7}$ Percival Everett, Erasure (2001; London: Faber \& Faber, 2003): 3. Further page references are in the main text.

${ }^{8}$ Gilroy, Against Race, 179.

${ }^{9}$ This improbably transparent pseudonym is a humorous variant of Stagger Lee, Stagolee, and their own variant spellings, as attached to the murderous black protagonist of a
} 
without irony and soon lands a six-hundred-thousand-dollar book deal, followed by three million dollars for the movie rights. Monk finds himself having to impersonate Stagg, both over the telephone and behind a screen on a daytime talk show. Increasingly, though, he seems to suffer a breakdown under the stress of this deception. This mental decline is partly rendered through persistent returns to a seminal work by Monk Ellison's namesake: Ralph Ellison's Invisible Man. Early in his impersonation of Stagg, Monk contemplates the possibility of "becom[ing] a Rhinehart"; later, as his condition continues to deteriorate, he meets a Dr H. Bledsoe $(184,241)$. The success Monk achieves with Stagg's novel, which by this point has been renamed Fuck, leads him not just to recognize the force of race as a lived experience, but also to confront the more troubling idea that race may also be a performance, and one in which the script is determined by others. The novel culminates in a revisiting of the lines spoken by Brother Jack during the Invisible Man's nightmarish vision of castration, "Now you're free of illusion [...] how does it feel to be free of one's illusions?" (293). ${ }^{10}$ It is suggested that, for Monk as for Ellison's narrator, the loss of the illusion of autonomy is a loss of self: an erasure which is perhaps total and suggestive of negation and annihilation.

Everett's use of Wright's and Ellison's seminal works is significant for working through the comparison between Erasure and Dancing in the Dark, and not only because Caryl Phillips has written of the importance of these two novels to his own development as a writer. ${ }^{11}$ Everett's text develops an understanding of how the literary might be seen to delimit the possibilities of the experience of race; how race is created, manipulated, and preserved in the textual record. This is something also achieved by Phillips in much of his fiction. In Cambridge, for example, the narratives of slaveholders like Lady Mary Nugent and slaves such as Olaudah Equiano are each explored and meanings drawn from their inevitable assumptions and omissions, while in The Nature of Blood Shakespeare's Othello and Anne Frank's Diary are

well-known blues ballad whose first versions were composed in Mississippi around 1895 . The legendary (but factually based) figure fits in perfectly with the themes adumbrated in the present essay.

${ }^{10}$ See Ralph Ellison, Invisible Man (1952; Harmondsworth: Penguin, 2001): 569.

${ }^{11}$ Caryl Phillips, The European Tribe (1987; London \& New York: Faber \& Faber, 1999): 7-8. 
crucial source texts. ${ }^{12}$ Phillips's novels can be read as a consistent readerly exploration of the limits of literary possibility, sounding out what can be said within the constraints of the form.

However, in Phillips's more recent writing there is a shift away from this forensic engagement with the literary archive. While $A$ Distant Shore retains traces of Phillips's engagement with earlier texts, ${ }^{13}$ the written word to some extent surrenders its privilege to the spoken as conversation becomes a central focus of the novel (the literal conversations between Solomon and Dorothy seem as important as the dialogue that takes place between their narratives on the level of form and perhaps further develop the tentative straining toward communication we find in The Nature of Blood).${ }^{14}$ In Dancing in the Dark, the dominant structural motif is neither the written text nor the conversation, but an articulation that exists somewhere between the two: the performance on a stage.

It is this adoption of the staged performance as the central organizational pivot in the novel that allows it to offer a different perspective on the notion of the erasure that may take place in the construction of a racialized identity. The staged performance occupies a specific and limited moment of time. This contrasts strongly with the modes of public self-representation examined in Phillips's earlier novels. In Cambridge, for example, the eponymous slave is required to articulate his story within the fixed codes of representation allowed by eighteenth- and nineteenth-century literary conventions; in doing so, he inevitably presents another fixed text and is unable to mount a challenge to the networks of representation that have conditioned him. The performances that Bert provides in Dancing in the Dark gesture beyond such fixity; they are provisional texts open for re-editing and revision. Very early in the narrative, we are informed of Bert's ability to catch the mood of his audience and to shape his routine accordingly. The performance of race does not necessarily

2 Caryl Phillips, Cambridge (London: Bloomsbury, 1991); Caryl Phillips, The Nature of Blood (London: Faber \& Faber, 1997). See also Lars Eckstein, "Dialogism in Caryl Phillips's Cambridge, or the Democratisation of Cultural Memory," World Literature Written in English 39.1 (2001), and John Thieme, Postcolonial Con-Texts: Writing Back to the Canon (London \& New York: Continuum, 2001): 155-69.

${ }^{13}$ Bénédicte Ledent has noted the "oblique linguistic resemblance" that parts of Solomon's story bear to Equiano's Interesting Narrative. Ledent, "Family and Identity in Caryl Phillips's Fiction, in particular A Distant Shore," Commonwealth: Essays and Studies 29.2 (2007): 71.

${ }^{14}$ Ledent has recently suggested that the idea of "conversation" provides a useful motif for looking at all of Phillips's writing. Ledent, "Editorial," Moving Worlds 7.1 (2007): 1. 
have to pander at all times to the same negative essentialized version of blackness; it is, rather, a tailored and variable presentation. In his later years, it is precisely the fixity of images and one-sidedness of contact that turns Bert away from film: "he needs to see, hear, feel his audience" (191).

The idea of reciprocity operates through Bert's carefully controlled use of movement. Bert's performance is predicated on motion, and this has interesting implications for his experience of race:

Before they see me they see my gloved hands twisting and turning, and then they make out the rest of me as I carefully edge my way between the heavy velvet drapes and stand still and slowly look all around. They do not know what to do. It is only when I move that the problems begin. I shuffle and they laugh. I show them that I am clumsy and they laugh. I stand still and they do not know what to do. Until I move I might be pitiable. It is only when I move that they recognise me. (94)

This moment embodies a complicated sense of racial identity that is explored in the novel. While Hegel famously summarizes the self/other dialectic by noting that "self-consciousness exists in and for itself when, and by the fact that, it so exists for another; that is, it exists only in being acknowledged,"15 in Dancing in the Dark the processes of recognition and acknowledgement are often played out upon the stage, on a level at least partly removed from Bert's personal experience of self. The processes of self-formation are not operating in the usual Hegelian sense. The misrecognition enacted in the performance of race before an audience with the potential to turn hostile is hardly healthy for Bert, and the novel does not offer these blackface performances as unproblematical assertions of agency, but the reaction of the audience is nonetheless a response which Bert has the ability to elicit or suppress. They recognize him when he moves; it is a misrecognition, and a damaging one, but one in which he retains the power of causation. The distortion of himself as racial object is nonetheless an assertion of his status as acting subject, though certainly not in circumstances of his own choosing: "He dealt with it and he didn't deal with it."

Bert's ability, or failure, to offer this surrogate self to the audience and manipulate the moment of recognition is the key struggle explored in the novel. It is in this development of an alternative self, which gets sacrificed nightly to the racist expectations of the paying crowd, that he must find the means to control his erasure, to make it temporary and retain an independent sense of

\footnotetext{
${ }^{15}$ G.W.F. Hegel, Phenomenology of Spirit, tr. A.V. Miller (Phänomenologie des Geistes, 1807; Hamburg: Felix Meiner, 1952; tr. Oxford: Oxford U P, 1977): 111.
} 
self that can be reclaimed when the show ends. In Judith Butler's seminal study of the effects of 'faked' performance in the hegemonic discourse of gender, she suggests that the simulacra of femininity offered by the drag artist's act

destablizes [sic] the very distinctions between the natural and the artificial, depth and surface, inner and outer through which discourse about genders almost always operates. ${ }^{16}$

However, in Phillips's novel the disjunctive effects of Bert's contrived performances upon the operation of racializing signification in early-twentiethcentury America are less important than the effects of such impersonation on the performer. Butler's heuristic of whether such mimicry destabilizes the categories of discourse that make it possible is not taken up by Dancing in the Dark. The focus is instead on the fact that the conditions in which this mimicry is expected are not only sustained throughout the duration of Bert's lifetime but seem to offer the only possible platform for public articulation.

Central to Bert's attempts to preserve self-regard in the novel is his development of an alternative persona - the one who is to perform on the stage. This distinct self comes into being at the moment when Bert first applies the makeup. Reading this novel in the context of Phillips's earlier work, it is significant that the alternative character appears while he is looking in the mirror. Mirrors are important throughout Dancing in the Dark, but elsewhere Phillips has also used mirrors and mirroring to suggest troublesome constructions of the self. These earlier deployments of the trope of mirroring allow us to locate Bert's difficulties in establishing self-identity across a spectrum of reactions to the simultaneous experiences of recognition and difference that reflection may allow. Stephen Clingman describes The Nature of Blood as marked by "mirrorings, refractions, reflections," the two moments in the novel when physical mirrors become integral to its design. As part of this novel that offers visions of European racism across parallel times, the death-camp survivor Eva Stern looks at herself in the mirror of her dormitory in a displaced persons camp. She is unable to relate to the image she sees there:

\footnotetext{
${ }^{16}$ Judith Butler, Gender Trouble: Feminism and the Subversion of Identity (New York \& London: Routledge, 1990): viii.

${ }^{17}$ Stephen Clingman, "Forms of History and Identity in The Nature of Blood," Salmagundi 143 (Summer 2004): 158.
} 
A stranger's face, with large puffy eyes. I do not want this anguished expression. How can this stranger be me? [...] I begin to laugh at this mask. I smear the lipstick around my mouth. A jagged slash, red like blood. ${ }^{18}$

During her previous torment on arriving at the camp, she had tried unsuccessfully to forget her name and "to put Eva away in some place for safe-keeping until all of this is over. ${ }^{, 19}$ The act of dissociation does not in fact fully take place for her until after the liberation of the camp. It is now, as she attempts to come to terms with her survival, that she feels unable to see herself as complete. The reflection which she finds unrecognizable takes on an existence independent of Eva's sense of herself as a unified subject. The "girl with the swathe of red around her mouth" becomes a haunting presence that "follow[s] [her] across the water" even after her migration to England. ${ }^{20}$ The existence of two parallel identities is indicative of the extent of Eva's trauma, and it is suggested that her eventual suicide is predicated on a wish to resolve this existential schism:

The other girl is looking at me with sadness in her eyes, so I reach over and take first one hand and then the other. Don't worry, I say. Everything will be fine. $^{21}$

However, while for Eva the mirror triggers the dissociation that will lead to her death, another of the central characters in the novel, the Othello figure, has an experience before his mirror which is quite distinct. Throughout the novel, he is a keen observer of Venetian customs, but his seduction of Desdemona contains an important moment of self-scrutiny when he stares in his mirror and recognizes that "the wooing of this lady did indeed threaten the very foundations upon which my life was constructed. ${ }^{22}$ For Othello, however, the reflected image is refused the power of definition: "I abandoned the mirror and made my way towards the door., ${ }^{23} \mathrm{He}$ rejects "the culture of narcissism" in favour of an active search for personal alliances and individual growth. ${ }^{24}$

${ }_{18}$ Phillips, The Nature of Blood, 48.

${ }^{19}$ The Nature of Blood, 165 .

${ }^{20}$ The Nature of Blood, 188.

${ }^{21}$ The Nature of Blood, 199.

${ }^{22}$ The Nature of Blood, 144.

${ }^{23}$ The Nature of Blood, 144.

${ }^{24}$ Bryan Cheyette, "Venetian Spaces: Old-New Literatures and the Ambivalent Uses of Jewish History," in Reading the 'New' Literatures in a Postcolonial Era, ed. Susheila Nasta (Cambridge: D.S. Brewer, 2000): 65. 
The division of personality and the possible harm this may cause are not an option for the general.

Bert's experience before the mirror is neither the fatal splitting suffered by Eva nor the Othello figure's easily overcome doubt. Instead, when the stage performer looks into his glass, he willingly dissociates his self, but nonetheless insists on retaining the capacity for reclamation:

I am leaving behind Egbert Austin Williams. However, I can, at any time, reclaim this man with soap and water and the rugged application of a coarse towel. (57)

The character created in the act of masking is one he feels he can step back from, but also one over which he, unlike Eva, maintains control. Bert recognizes as much as George that the shambling "real coon" persona is "created by the white man" (123), but he makes this template inhabitable by endowing it with a deeper theatrical meaning and elevating the demeaning portrayal to the status of an art. He understands that "unless he could make this nobody into somebody, then [...] eventually his eardrums would burst with the pain of the audience's laughter" (58). In order for the act of dissociation to fulfil its defensive purpose, the mask must be granted an autonomous integrity that serves to distance it from the performer. This is not always easy for Bert: his invention of the great pantomimist Pietro as an imagined external point of origin for some of his performances seems to suggest the need for a validation of the fact that the actor and character remain separate (141-42). His unhappiness at the public's unwillingness to grant him the accolade of "actor," rather than "performer," has similar roots:

'Actor' is a term that suggests a certain dignity, and it implies a necessary distance between the performer and the character to be interpreted. This one word, 'actor,' if properly applied to him, might have spared his soul much misery. (199)

Bert's difficult work of attempting to ensure the separation between himself and his racial performance is captured in Phillips's epigraph to the book, which quotes from Williams's own recorded words: "Nobody in America knows my real name and, if I can prevent it, nobody ever will." Ralph Ellison argues that, for black Americans particularly, names "must become our masks and our shields." ${ }^{, 25}$ The suggestion is that the will to unite one's identity may

\footnotetext{
${ }^{25}$ Ralph Ellison, "Hidden Name and Complex Fate: A Writer's Experience in the United States" (address, 6 January 1964), in Shadow and Act (1964; New York: Vintage, 1972):
} 
best be mustered when it can be encompassed within a name. Self-naming especially seems to bolster this sense of agency. Bert "seems to have no desire to rename himself" (17) but nonetheless recognizes the importance of preserving a part of himself separate from the version that is sent out into the world on the theatre stage. His name becomes less a barrier behind which he might seek protection than an emblem of his need to hold an essential something back during his performances.

In Erasure, Monk Ellison finds it difficult to preserve a sense of himself distinct from his imposture as Stagg R. Leigh. Monk also spends several important moments in front of mirrors. He often contemplates his reflection to allow himself to identify his real self, apart from his pretence. However, it is not always easy to reclaim his true identity from behind the parts he is playing:

I have often stared into the mirror and considered the difference between the following statements:

(1) He looks guilty.

(2) He seems guilty.

(3) He appears guilty.

(4) He is guilty. (233)

The question here is not only how the relationship between appearance and reality is to be perceived, but whether there are any meaningful differences between various kinds of appearances. In the novel, Monk often searches for proof that there are different ways of reading through façades to find the reality that lies behind. However, he increasingly finds that such a distinction between outward form and inner essence becomes untenable.

Once Monk has written My Pafology/Fuck, it is important for him to consider it as parody, and he even at one point offers the suggestion that it functions as a work of art through such irony $(151,247)$. But the enthusiastic reception the novel continues to receive in all quarters works to disallow this interpretation. In failing to find any external point of validation for the parodic reading, it becomes increasingly difficult for Monk to posit its possibility. The novel continually functions to remind us that "language never really effaces its own presence" and that meaning may always depend more on the contexts

148, repr. in The Collected Essays of Ralph Ellison, ed. \& intro. John F. Callahan, preface by Saul Bellow (New York: Modern Library, 1995): 192. The phrase is a perhaps unconscious borrowing from an address delivered by William Hamilton in 1864 on the first anniversary of abolition. 
in which it is constructed by the receiver, than on the machinations of the originator (51). Late in the novel, Monk recounts an old joke:

I'm reminded of the parrot in the house, which when he hears a knock at the door says, "Who is it?" The man knocking answers, "It's the plumber." The door remains closed and so he knocks again. "Who is it?" the parrot asks. "The plumber." Knock, knock. "Who is it?" "The plumber!" This goes on until the crazed knocker breaks through the door, falls onto the carpet below the parrot's perch, has a heart attack and expires. The residents of the home return to find the man stretched out on their floor. "Who is it?" the wife asks. The parrot says, "The plumber."

The question is of course, does the parrot answer the woman's query?

And of course he does and he doesn't. He's a parrot. (253)

This tale serves as another instance of Monk's uncomfortable realization that the intentions that motivate an utterance are "of course" immaterial when it comes to evaluating its truth. Truth is seen as a mere function of language and there are no valid criteria for distinguishing the real from that which simulates it. Faced with this, Monk is playing a fatal game in his literary impersonation. Without the means to distinguish between performance and performer, total erasure is inevitable.

As a precocious college student, Monk impresses his father with his reading of Finnegans Wake. He argues that Joyce's novel "actually conforms to conventional narrative" and that its techniques are essentially traditional, with the only significant difference being that it always "calls attention to [its own] devices." Ultimately, "the work really reaffirms what it seems to expose. It is the thing it is, perhaps twice" (210). Monk's criticism serves as an insightful metafictional comment on the nature not only of Fuck but, in its recognition of doubling, of the narrative of Erasure itself. Fuck is never able to establish itself as parody, and remains "the thing it is," while, despite Monk's resolution to escape the binds that racialization might exercise upon him, Erasure bleakly suggests that race will have the final determining power. Margaret Russett argues that "the double narrative of Erasure might [...] be understood as a dialectical reading of 'the African-American novel'," presenting this construction both in its avant garde and vernacular forms. ${ }^{26}$ Significantly, however, Erasure begins to suggest equivalence in these forms; implying that when readings of diverse texts are filtered through a lens of race, it is race it-

\footnotetext{
${ }^{26}$ Margaret Russett, "Race under Erasure: For Percival Everett," Callaloo 28.2 (Spring 2005): 365 .
} 
self that will inevitably make the greatest final impression. In the last pages of the novel, Monk again imagines himself before his reflection: "I had caught myself standing naked in front of the mirror and discovered that I had nothing to hide and that lack was exactly what forced me to turn away" $(E, 285)$. It is the realization that there is nothing he can conceal behind the façade of performance, and that the appearance is the essence, that precipitates Monk's erasure.

Bert Williams's partial and provisional erasure within the mode of staged performance and the more complete dissolution experienced by Monk Ellison as he becomes trapped by the parody he creates can be characterized by a pair of metaphors which straddle the spatial and the temporal: I want to suggest that the narrative of Everett's Erasure can be read as centripetal and that of Phillips's Dancing in the Dark as concentric. Monk's story traces out an awareness of the limitations open to the character as it becomes apparent how he is expected to occupy a racially determined position. His initial refusal to subscribe to the limiting and detrimental discourses of race becomes untenable as he increasingly has to recognize the limited ways in which his expression may be comprehended. His descent into mental instability is paralleled by his awareness of this loss of possibilities and his gradual metamorphosis into the caricature of Stagg R. Leigh. The form of his erasure is centripetal because, as he moves forward in time, he finds less and less space to manoeuvre. The narrative of Dancing in the Dark, however, is concentric: while we are clearly presented with an imposed and destructive notion of a core identity, the narrative does not progress towards this inexorably, as in the other novel. Rather, we have to read the staged performance of the degraded identity as contained within Bert's wider personhood. At times he fears the possibility of becoming confined in the limited and humiliating narrative of the performance but, unlike Monk, Bert does not have to accept this as inevitable.

These centripetal and concentric patterns are also echoed in the forms used by each of the novelists. Erasure is confined to Monk's first-person perspective, although it is peppered with extracts from his writing and his ideas for stories. This confinement within Monk's prism of experience allows Everett to enforce the sense of inevitability of the ending towards which he moves. Throughout the novel, metafictional commentary is used to reinforce the certainty of the conclusion. In their imagined conversation, Joyce tells Wilde that story is "just a way to announce the last page" (211). The erasure that gives the novel its title and culminates in the indecisive "hypotheses non fingo" of 
the last page cannot be avoided (294). Elsewhere, it is noted that "narrative always travels in the same direction," so "never are we dropped into a space and returned to the previous narrative position or into nothingness" (60). However, while the narrative of Erasure is largely chronological, allowing for the gradual centripetal restriction of possible meaning to Monk's struggle, the refusal of strict linearity in Dancing in the Dark makes it difficult to read this novel simply as a story of decline. Events are often returned to more than once, and the episodes of Bert's career are not always presented in the order of their occurrence. The meanings of these events are, then, denied fixity of meaning and are open to continual reinterpretation. A distance between appearance and reality can be sustained in the novel though the multiplicity of interpretations offered of the moving figure on the stage.

Typically for Phillips's writing, our reading of the narrative is crucially informed by the use of multiple perspectives. In this case, we are able to see Bert not only through his own eyes as he struggles to understand and negotiate the problematic of erasure, but also through the eyes of those around him. We are provided with the opinions of those who would see him primarily in terms of the negated object-self (such as George and Aida), and, importantly, also through the eyes of his wife Lottie, who continues to interpret Bert as an autonomous subject. While George begins to suspect that "Bert's unfortunate blackface performance and his disturbingly accommodating personality are becoming somewhat confused," Lottie always "understands that her suitor is a man who is playing a part" $(110,35)$. As each of these versions of Bert is preserved throughout the novel, the concentric circles of meaning are left intact and, while we may not be able to fully separate Bert from the performances he enacts, neither can we accept the final reduction of his personality to the performance alone.

At the end of the novel, Bert expresses a sickbed desire to contemplate his reflection in Lottie's handheld mirror. When he first regards his unpainted face he is "shaken into panic." But, Lottie tells us, "he eventually absorbs the initial distress of recognition" (207). Bert has certainly been damaged by his many years of "performative bondage" (6) and the stresses of continual misrecognition by his audience, but unlike Eva Stern in The Nature of Blood, the failure to acknowledge his reflection is only temporary, and he can redeem his selfhood. This actor is never wholly and finally erased by the caricature. 


\section{WORKS CITED}

Butler, Judith. Gender Trouble: Feminism and the Subversion of Identity (New York \& London: Routledge, 1990).

Cheyette, Bryan. "Venetian Spaces: Old-New Literatures and the Ambivalent Uses of Jewish History," in Reading the 'New' Literatures in a Postcolonial Era, ed. Susheila Nasta (Cambridge: D.S. Brewer, 2000): 53-72.

Clingman, Stephen. "Forms of History and Identity in The Nature of Blood," Salmagundi 143 (Summer 2004): 141-66.

Derrida, Jacques. Of Grammatology, tr. \& ed. Gayatri Chakravorty Spivak (De la grammatologie, 1967; tr. Baltimore MD \& London: Johns Hopkins UP, 1976; corrected ed., 1997).

Eckstein, Lars. "Dialogism in Caryl Phillips's Cambridge, or the Democratisation of Cultural Memory," World Literature Written in English 39.1 (2001): 54-74.

Ellison, Ralph. "Hidden Name and Complex Fate: A Writer's Experience in the United States" (address, 6 January 1964), in Shadow and Act (1964; New York: Vintage, 1972): 144-66, repr. in The Collected Essays of Ralph Ellison, ed. \& intro. John F. Callahan, preface by Saul Bellow (New York: Modern Library, 1995): 189-209.

—. Invisible Man (1952; Harmondsworth: Penguin, 2001).

Equiano, Olaudah. The Interesting Narrative of the Life of Olaudah Equiano, or Gustavus Vassa, The African, Written by Himself (1789), in The Interesting Narrative and Other Writings, ed. Vincent Carretta (New York: Penguin: 1995): 1-236.

Everett, Percival. Erasure (2001, London: Faber \& Faber, 2003).

Frank, Anne. The Diary of a Young Girl, tr. Susan Massotty, intro. Elie Wiesel (1947; Harmondsworth: Penguin, 2000).

Gilroy, Paul. Against Race: Imagining Political Culture beyond the Color Line (2000; Cambridge MA: Harvard UP, 2001).

Hegel, G.W.F. Phenomenology of Spirit, tr. A.V. Miller (Phänomenologie des Geistes, 1807; Hamburg: Felix Meiner, 1952; tr. Oxford: Oxford U P, 1977).

Ledent, Bénédicte. "Editorial," Moving Worlds 7.1 (2007): 1.

—. "Family and Identity in Caryl Phillips's Fiction, in particular A Distant Shore," Commonwealth: Essays and Studies 29.2 (2007): 67-74.

Phillips, Caryl. Cambridge (London: Bloomsbury, 1991).

1. Dancing in the Dark (London: Secker \& Warburg, 2005).

. "Dancing in the Dark: Caryl Phillips in Conversation with John McLeod,"

Moving Worlds 7.1 (2007): 103-14.

. The European Tribe (1987; London \& New York: Faber \& Faber, 1999).

- The Nature of Blood (London: Faber \& Faber, 1997).

Pinckney, Darryl. "Blacking Up," New York Review of Books 51.12 (13 July 2006): 26-29.

Russett, Margaret. "Race under Erasure: For Percival Everett," Callaloo 28.2 (Spring 2005): 358-68. 
Thieme, John. Postcolonial Con-Texts: Writing Back to the Canon (London \& New York: Continuum, 2001).

Wright, Richard. Native Son (1940; New York: New American Library, 1964).

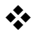




\title{
The Dynamic of Revelation and Concealment In the Falling Snow and the Narrational Architecture of Blighted Existences
}

\author{
GORDON COLLIER
}

$\mathrm{R}$

EVEALING AND CONCEALING: THE NOVEL begINS IN THE IMPERFECT and in media res, "He is walking in one of those leafy suburbs of London where the presence of a man like him still attracts curious half-glances." The reader who thinks he knows, from past reading experience, where Phillips 'is coming from' will fill in the subjectivized identity of this male ("he," but no name) with ethnic history. He may be a "non-European' in a middle-class, Hampsteady or Chelsean neighbourhood where, even now in an ostensibly wholly multiculturalized London ("still"), there is a covert ("half-glances") alertness to ethnic difference where those looking have 'liberal' reasons not to admit to their curiosity. In turn, the walker is himself analytically alert, as the next sentence indicates - but the opening is a leurre or false clue (in the Barthesian sense), as it is his 'middle-class' clothing ("jacket and tie") that relaxes "a few of the passers-by." But wait a second: if his clothing fits the neighbourhood, it can't be class indices that set him off. The rest of the sentence tells us that "others" are seeing beneath or past the attire, "actively suppressing the urge to cross the road." How can the "he" know this? (Or is an omniscient narrator at work? but no: "he can see," so that's all right, then.) If a reflex (mental, inward) is "actively" resisted, how does this emerge beyond concealment? The male walker must have developed an extraordinarily refined set of antennae for body language. Or is he, extra-

\footnotetext{
${ }^{1}$ Caryl Phillips, In the Falling Snow (New York: Alfred A. Knopf, 2009): 3. Further page references are in the main text. All quotations in my first two paragraphs are from this opening page of the novel.
} 
polating from his own phenotype awareness in this human context, simply projecting paranoically? The closing sentence of the opening paragraph seems to move us, in its summative deduction, into an impersonal, generalizing zone where subjective emotion ("It is painfully clear") is half-concealed as a mere adverbial intensifier and the walker stands outside, or on the edge of, his immediate context (no 'painfully clear to him'); "as far as some people are concerned, he simply doesn't belong in this part of the city." By the end here, we have not been moved an inch towards clarification of the walker's status; what we do have, however, is an almost serenely neutral style beneath which some kind of animus, and some kind of detached subjectivity, flows. Revelation and concealment, which will constitute the systole and diastole of the whole of the narrative that follows.

We are, it seems to me, teased further when the walker removes the sunglasses he is wearing - on a sunless late-autumn day. Reason enough - not skin colour, then - for passers-by to experience cognitive dissonance: jacket and tie and sunglasses: a spiv or a crim in suburbia? "The dark glasses make him feel more comfortable [...] he is able to look at people without them being able to see his eyes." What is concealed here - some kind of 'racial supplement' (fear or diffidence or resentment or challenge in his eyes, over and above skin colour)? Or perhaps not... perhaps his psychological constitution demands that he be able to observe intently without drawing attention to the act or offending the objects of his attention. Such a supposition will bear fruit. We accompany the "he" in the present tense - somewhat unnerving, this tense; in English-language narrative of events and thoughts, we are unaccustomed (as we would not be in, say, French) to an overdetermined implementation of immediacy (the classic temporal mode being the safer remove of preterity or past-tenseness, where the 'story' is already 'history'). Until we get accustomed to the rhythms of the narrative, and are granted relief and perspective by the occasional emergence of passages in the recollective past tense, we are in uneasy suspension (and, even then, may remain that way) about what this present-tense narration is aiming at. As we accompany the "he," the objects itemized, the actions and sensations and reported thoughts denoted, seem to be under surveillance. The term 'description' is conventionally applied to phases or segments of narrative that are more or less (contrastively) static 'pauses' in or interruptions of actional sequences - for example, what a house looks like, or a group of trees on a hillside. Here, everything reads as description, as though the "he" is himself registering it all in a continuum, and at a slight remove. Added to this is another vexing feature of the 
present tense, which is its tendency to universalize rather than particularize the 'feel' of what is described (or, perhaps better, mentally noted or noted down). The "he" is, as it were, pulled in two directions: both immediately 'in' the self-initiated or registered action and outside the temporal plane of subjectivity. In French, the present tense sounds 'natural'; here, we could begin to wonder whether it might be somehow pathological, or, at the very least, an index to a "painfully" attuned sensibility. And this in a novel whose gestural rhetoric is moderated, levelheaded, dispassionate, not given to the ideological excurses of, say, a Saul Bellow or the passionate explosiveness of, say, a Philip Roth. And, it turns out, certainly not a barrel of laughs - something that applies to all of Phillips's fiction, always on good grounds, yet often with tiny and highly significant exceptions.

I think that what the present tense 'points to' is existentially different in this novel. I mean, it's not the fact of the present tense itself that should command attention, for it is nothing new in Phillips's novels. With the exception of The Final Passage (1985) and A State of Independence (1986), there have been little outcroppings of present-tense narration in all of Phillips's fiction: the whole of Part I in Higher Ground (1989), followed by the often near-obligatory present-tense reporting of the epistolary middle section; in Cambridge (1991), via near-imperceptible shifts from past imperfect to present perfect, to characterize sundry observations of a social or anthropological nature (in a kind of journal annotations); intermittent observations in Joyce's journal in Crossing the River (1993) and, in a kind of tour de force of inverted logic, present tense in Martha's traumatic memories in her section of that novel. It is in the same novel that we experience how the narrative, at the close, levitates into a kind of dispassionate apotheosis of anguish, which is conveyed beyond historical time and space and in a brilliant confection of all tenses. The firstperson narrative sections of the African general ('Othello') in Venice, in The Nature of Blood (1997), ${ }^{2}$ are in the present tense, and at one late point he is shouldered aside, so to speak, by a bitter, accusatory narrator's voice in the universal present; in the same novel, with very few historical, past-tense segments concerned with her family, Eva's narrative is in a present tense that is coping with trauma and the cold breath of mortality. The fates of a range of

\footnotetext{
${ }^{2}$ Bénédicte Ledent has brief, astute observations on tense in this novel in her book Caryl Phillips (Contemporary World Writers; Manchester: Manchester U P, 2002): 148.
} 
central, alternating protagonists in A Distant Shore (2003) are overwhelmingly narrated in the present tense in such a way (to judge from the existential arcs described) as to intimate not so much immediacy as provisionality, hesitant process.

The most consequential deployment of present-tense narration is to be found in Dancing in the Dark (2005), the immediate precursor of In the Falling Snow. In a mode inflected delicately with Free (In)Direct Discourse, the narrator shifts from character to character - Bert Williams, George Walker, Eva, Ada, Lottie. Part of this present-ness has surely to do with Bert's "hot Caribbean past" being "undermined by cold American anxieties," 3 partly to do with the temporal suspension of consciousnesses in isolation, partly intimating the now well-rehearsed timelessness of Bert and George's artistic routines. At any rate, the reader feels quite comfortable in this flow of present-ness - which is, however, less a flow than flux and fluctuation, as there are also irruptions of past-tense narration that repay examination, particularly because these shifts are not at all self-evident. There is no space here to explore the details of the significance of tense in Dancing in the Dark; suffice it to say that the novel is highly complex and subtle in its persistencies and juxtapositions, and serves a multiplicity of purposes beyond any 'simple' representation of narrative immediacy or 'simple' representation of the past recollected.

It is chiefly against the background of this review of tense that I propose to consider the 'time-zones' of In the Falling Snow, which, I will be arguing, seem to be more straightforward in their arrangement or sequencing, but which, when taken together with other narrative indices, serve to shape a central personality who is far more disconcerting than any Phillips has so far created.

But first, back to the hunt (or back at the ranch, or the text). After the inceptive uncertainties discussed above, our walker is admitted to a house by a woman who is clearly nervous about the prying eyes of passers-by. What follows is a tryst that is ostensibly sexual yet profoundly anhedonic, an actional sequence that is masterly in its compact relaying of necessary background circumstance and acutely freighted attitude and consciousness on the part of the male character. What do we learn, plot-summary-wise? Keith (so addres-

\footnotetext{
${ }^{3}$ Caryl Phillips, Dancing in the Dark (New York: Alfred A. Knopf, 2005): 23.
} 
sed, at last), forty-seven, is meeting Yvette (so identified by him in thought), twenty-six, for sex in her small north-west London terraced house, and has been doing this for some time now. He has been separated from his wife Annabelle for three years, kicked out by her after confessing to a one-night stand (well, a three-nighter, actually, at a conference retreat in the New Forest) with a co-worker. Keith is Yvette's boss. While he is going through the erotic rituals, his ex-wife leaves messages on his cell-phone about difficulties with their seventeen-year-old son Laurie - a problem from Keith's domestic past that flits in and out of his thoughts and helps shape the remainder of the narrative. He also reflects on mundane differences between Yvette and himself (she likes reality TV shows, he can't stand them; she likes northern indie bands, while he - and this becomes of consequence later - is immersed in 1970 s soul and would like to write on it; as a couple, "they have shared nothing" except bed, 11). By the end of this present get-together, Keith has intimated to Yvette via thin rationalizations that there's no future in their relationship; this after two bouts of copulation.

It unnerves somewhat to realize just how much factual circumstantial exposition there is here in the space of very few pages; it's unnerving because it doesn't come across as exposition, despite all those meticulous and sometimes redundant mentions of precise ages (at one point, when Keith recalls how Annabelle kicks him out, Laurie is referred to as "their fourteen-year-old son," 7, which we could have computed for ourselves). Nor, until we look back, are we likely to register the fact that the present-tense narration is broken four times by passages of past-tense recollection. Because these latter passages have comparative relevance to the immediate scene, they come across very much as part of the flow of Keith's current perceptual sensorium. We do not get the feeling that an omniscient third-person narrator is active outside the characters, even though Keith's observation of external action (Yvette's movements and behaviour) is intensively indexed to inward cognition. ${ }^{4} \mathrm{We}$ are with a 'personal' or self-referential third-person narrator, yet with no explicit coloration of Free (In)Direct Discourse.

This Keith, this 'central protagonist' of what can be safely termed an uncomfortable and sometimes agonizing agon, appears at many moments to have stepped out of the skin of Meursault in Camus' L'Étranger, for he has a

\footnotetext{
4 "He knows," "try as he might," "He may not have found a way to talk to her... but he has been forced to tell her," "he notices," "he hears what he imagines is...," "he resigns himself to the fact...," "He watches as she loses herself in what he imagines is....," "he is fully aware that...."
} 
weirdly affectless side to him. 'Side' only, though, because another part of him is moved by, or offended by, aesthetic irritants whose ultimate meaning is hard to plumb. On one level he would seem to be a sexual opportunist, only in it for the bunny. He is aware of his continuing interest in women but is reluctant to go hunting at his age. On his first pub encounter with Yvette, he realized that she "could solve a problem" (9); she is attractive, energetic, spontaneous. Yet, although this is convenient for him, he is troubled that she is the leader and he the led. In the narration and the action, he seems to get out of this situation through a kind of passive-aggressive double-consciousness: physically docile, even inert, and obeying all of Yvette's now-too-familiar erotic cues, he is inwardly, mentally, actively resistant and judgmental. There is some suggestion that Keith is weighed down by his potential jeopardizing of his relationship with his son, and that this is partly responsible for his current attitude towards Yvette and for his resolve to "end their arrangement" as (in a nice, sly touch) he imagines the "thin, wispy trails of departure" left in the wake of an aeroplane passing overhead (8). At the same time, always been "keen to avoid" intimacy, he is determined to play a "detached role" $(4,5)$.

What is the catalogue of poor Yvette's shortcomings? Keith feels "disdain for the crass vulgarity" of her red thong, "this silly piece of string," a "tart's uniform"; her "scented candles make him gag"; her sexual "enthusiasm is almost theatrical" (5). After the sex and her retreat into self-involvement, "he is untroubled by her temporary plight" (6). Yvette's post-shower vanityrituals are "a performance"; she dresses "like a music hall performer escaping from a sack" (10). Keith is starting to sound like an up-tight cad, wanting something 'better' but not admitting it. What makes the aesthetic embarrassment all the keener is the revelation (after an evanescent hint about Yvette's ankles being "cocoa butter smooth," 5) that his assiduously and theatrically 'sexy' lover is a non-tragic mulatto, with 'relaxed' (i.e. de-kinked) hair:

her heritage is most evident in the battle between Europe and Africa that is being waged on her face where full lips and emerald green eyes compete for attention. Under the most intense scrutiny she could easily pass for white and suntanned, but her penchant for kente cloth scarves and wooden beads speaks eloquently to the fact that she has never tried to deny her mixed background. (6)

This belated descriptive acknowledgement of Yvette's ethnic identity has a compromised ring about it, as filtered through Keith's gauging, distancing awareness. The first sentence is not neutral but almost mock-heroic, with 
"Europe and Africa" as emblems or allegories, the attributes of lips and eyes linked by exquisitely careful zeugma. "Under the most intense scrutiny" is a subtly monitory gesture at the racialization of surfaces (and at the trope of 'passing'), but even here Yvette is not let off the hook: her 'leaning toward' her 'African' side is equally encoded, and with semantic, etymological wit, as a merely modish "penchant" for scarves and beads (where, too, the latter can't help but evoke slave-traders' trinkets). When this passage and stock eurocentric expectations about mulatto women are sized up against Keith's view of Yvette's sexual behaviour, it becomes eminently clear that he is not inclined to endorse these expectations, which turn on irresistible 'natural' sexuality rather than the artificiality he registers. We are left wondering where the truth lies, and whether Keith's mind-set might not be in some profound way distorted or damaged. What Phillips seems to be setting us up with is a character of as yet inexplicable complexity. Perhaps a history of psychic wounding with its blossoming, livid scar-tissue will gradually emerge. Revealing and concealing: the narrative allows us to 'read' Yvette ethnically; but an interest in soul music doesn't allow us to 'read' Keith. Is it we who are challenged, or is it Keith?

There is a chink of light near the start of the next, double sequence, where, first, Keith is on his way back from Yvette by train to Shepherd's Bush, and where, second, the third-person (past-tense) perspective shifts to Annabelle. Both sequences are suffused with different kinds of generational tension, and both turn on race. In the train sequence, three "partly white" (13) teenagers, two boys and a girl, fight over the latter's iPod and react with aggressive obscenity when an elderly white lady intervenes civilly. The teenagers are mixed-race, "like his son Laurie" (13), who is bullied at school for being a "halfie" (16). Keith keeps uncomfortably apart from the iPod affair and the kids, and finds "their ill manners mystifying" (13). We learn, from a passage of recollection, that Keith's (step-)mother Brenda, when his father was "readmitted to the hospital" (15), instilled good manners in him, along with an ethic of scholastic achievement, both of which he tried to pass on to Laurie as a timid child. This 'middle-class' ethos contrasts with Keith's observation that the teenagers on the train "identify themselves as black" (14) - thus picking up, in a different class nexus, generation, and clothing code, from Yvette's ethnic self-identification.

We are challenged to read unarticulated codes: who is black, Keith or Annabelle? Who is black, Brenda or Keith's unnamed father, or both, or neither? If Keith, is he black or "partly white," or, if Annabelle is black, is 
Keith then white? We are also challenged to ask: Does it matter? Will it matter? We are teased by the names "Annabelle" and "Brenda," which sound so .... English - so .... white?

I mentioned earlier Phillips's intercalation of tenses. In the train sequence, Keith "peers" through the window (present). Then he "changed" trains (past: i.e. before he "peers"). Then present tense again, but this time embedded as universal-habitual in the train-changing action (the way he dresses "only serves" to invite a mugging), which continues on the King's Cross escalator (when "he called Annabelle") until the train arrives and he "squeezed through the carriage doors." Immediately, "Three teenagers sit opposite him" - a recursion to present tense, but we cannot be certain what this links up with; we are prompted or forced to take all of the present-tense narration as post-dating the change at King's Cross and continuing, westwards, until the teenagers get off at Westbourne Park and Keith, thinking about the elderly white lady, is given an isolated scrap (finally) of Free Direct Thought ("Does she understand and maybe pity them, or does she simply feel contempt?" 15$).^{5}$ There follows a block of past-tense recollection about his mother, about Laurie at school, about Annabelle's resistance to his suggestion that Laurie defend himself, and about her father, with his "military background" (16), agreeing with him.

The next paragraph opens: "The subject of Laurie and bullying came up on the only occasion that Annabelle's father actually met his grandson" (16). This is a deceptive, neutral fulcrum - we assume that we are still within the radius of Keith's awareness, but it is actually the incipit for a long sequence from Annabelle's perspective, in which there are subjective descriptive details that Keith could not be privy to, not even if Annabelle had recounted to him the circumstances of her meetings, in the park and over lunch, with her mother and with both her parents at their country home. Facts are skirted around: Annabelle keeps "something about her relationship with her parents a secret from Keith" (16); when Annabelle tells her mother she is pregnant, the reaction is, on repeated occasions, tears, not happiness; Annabelle is told she must "make up" with her father (we are not told why); she tells Keith she hasn't been at a play (as she had said) but with her father, then says that this isn't true, and that she has been seeing her mother. At this point, when Keith

\footnotetext{
${ }^{5}$ Free Direct Thought - "Who the hell could it be at this hour?" (195); "This stupid book will never be written" (199) - is sparsely but effectively encountered elsewhere to convey emotions that might lose their force if encoded otherwise.
} 
storms angrily out of the house, we ourselves wonder why she should claim that she has been seeing her father, because there has been nothing in the narrative beyond her mother's urging. Concealing and revealing: it is only now, as Annabelle sits alone, that she goes back over the visit to her father - a recollective sequence which, significantly, also opens with a train journey, this time to Wiltshire, via Annabelle's memories of student days, drugs, theatre acting, loss of virginity. Here there is verbal violence of a different sort, which comes after tense affability, tea-taking, and questions about the sex of the baby-to-come: her father casually tells her he has received an anonymous note smearing his daughter for being a "nigger-lover" (24). The result is estrangement. Her mother begins to visit Annabelle and "her husband" (in Annabelle's narration, he is, significantly, almost always so referred to; at a certain distance, as it were) to see them and her grandson. After Laurie starts asking awkward questions about why Grandma visits but never his grandfather, Keith is prompted to suggest that they travel to Wiltshire with the boy to see him. The old man is gaunt with cancer, and converses listlessly before a "cheerless silence" (29) descends. He is unaware of the significance to Keith of why Laurie was named after Laurie Cunningham, "“a footballer who I used to like a lot'" (28). ${ }^{6}$ Shifts in perspective are subdued: Annabelle, clearly signposted by name, is with her mother in the kitchen, and then suddenly there is "Annabelle's father" speaking and being answered by "he" (Keith), followed by stiff, untagged dialogue. The recollection of the visit is truncated by a return to Keith's present on the train, which is leaving Ladbroke Grove; he is almost home. While he walks through the streets after leaving the tube station, the recollective architecture of his thoughts gravitates back towards race. He remembers Yvette's displeasure, on an early date at the cineplex he passes, when, just as the film is starting, he falls asleep, exhausted with all the work he had to do in his job with the local authority, where his "Race Equality" unit has been merged with "Disability and Women's Affairs" (31). It is, finally, at this point that we learn his full name, Keith Gordon, that he must now grapple with the spelt-out irony "of being an able-bodied black man

\footnotetext{
${ }^{6}$ We must work out for ourselves that Cunningham, who played for West Bromwich Albion, was the second black footballer to play for England (1979-80), after Vivian Alexander Anderson (1978-88) - see Phillips's "Colour Me English" above (18); cultural distance, then, between father-in-law and Keith. The naming of Laurie after a footballer connects up later (61) with the fact that Keith played football in his student days, and Laurie himself is keen on the game.
} 
speaking on behalf of disabled white people" (31), and that he can no longer take time off work to attend soul gigs and take notes.

I am endeavouring to make the shape of this essay more analytical than synthesizing, as well as inversely apical in the sense that the perhaps sometimes barely tolerable attention to densities of local detail so far forms a broad baseline from which I can gradually move towards a summative tip of the iceberg. What I just termed 'recollective architecture' can be expanded as a trope to apply to Phillips's overall handling of the intimate connections between tenseshifts, the perspective from which thought and action are captured, the tacit patterning of analogies, the way in which data on personal and ethnic identity are 'dosed' out to the reader in fragments. This architecture creates a Palladian façade of ostensibly sober and 'open' social detail (always a strong feature of Phillips's fictions against which he mounts pitched battles of subversion) which withal keeps concealing, or only reluctantly revealing, a creeping crisis of identity. From now on, central existential irritants emerge as ghostblips on the screen of the action - the experiencing and recollecting of incident as slowly cumulative accretions that buck against the telos of narrative linearity through their spirallings and circlings. ${ }^{7}$

\footnotetext{
${ }^{7}$ We are back here, of course, with concealment and revelation - which, I should belatedly hasten to say, is no more 'new' to Phillips's fiction than his deployment of tenses. In a long-ago essay of mine which did some detective work on the 'Jewish connection' in Crossing the River, I noted - and here I permit myself the indulgence of quoting at some length - how Phillips's structured obliquity was early acknowledged:

Galen Strawson expresses well the effect of the way in which, in Crossing the River generally and, by extension, in Phillips's fiction as a whole and increasingly, "crucial information is introduced in oblique fashion, or revealed late in the story, so that earlier oddities suddenly acquire sense, the moral pitch is altered and the reader is tipped into reinterpretation" [...]. This isn't, however, so much a narrative 'device' in the novel as an index to Phillips's narratorial interiorization of the character as subject, for whom the subjectively self-evident 'fact' can often remain unmarked outside the bounds of the description or introspection for which the selfevident is the first or prime cause. [...].The structural fragmentation and doublingback of the various narratives may involve a fugaciousness or volatility that has to do with a skirting around the edges of the unspoken. It is also quite possible and valid to see the narrative fragmentations as indices of diasporic scattering. Equally possibly, one can view this as reflecting (or, indeed, conveying) something just as fundamental about the essential interiority (rather than social exteriority) of humanity and the way the mind copes with experience.

— Gordon Collier, "Serene Surface, Secret Depths? Joyce's Section in Crossing the River,"

in Postcolonial Knitting: The Art of Jacqueline Bardolph, ed. Richard Corballis \& André
} 
One example at this juncture concerns a network of correspondences: regarding social background, Keith's thoughts in connection with his job summarize the mutually hostile racial climate of Thatcher's Britain $(38,42-44){ }^{8}$ we have already had the train journeys; Annabelle's memories of student days are later matched by Keith's; the botched meeting between Annabelle and her father, with the anonymous "nigger-lover" letter, is matched by the equally botched occasion when Annabelle, just before graduation, introduces her boyfriend Keith to her father, only for the latter to globally criticize Keith's "people's 'ill manners"” (42). If the occasion on which Keith is identified as "Keith Gordon" has to do with perspectival projection of an 'official public role', there is an analogous maintenance of distance at this stiff and ominous 'family' meeting, when Keith's prospective father-in-law is identified as "Mr. Johnson." The 'colonial' echo in Yvette's scarves and beads (6) has a bitter metaphoric counterpart in Keith's reflection about his job, where he finds himself "marooned [...] after all these years of white collar bondage" (44). An earlier gnomic memory of Annabelle's where she finds herself "sitting in the next seat but one to an awkward-looking boy at a semi-professional production of Sweet Bird of Youth" (21) finds its completion only eighteen pages later when Keith recalls how a girl leans across to speak to him "during the interval of Sweet Bird of Youth" (39).

All the while, there is the absent presence of Keith's father, which makes itself felt slantwise. We earlier had mention of his re-hospitalization. In his first year at university, Keith resists his mother's urging to build a "relationship with his father" (40); he gets a letter from Brenda which compels him to cancel his plans to backpack round Europe with Annabelle: "this woman had pretty much raised him by herself" (41). When Keith discusses with Annabelle where they might take jobs after graduation, “he didn't see any reason to go north and back in the direction of his father, particularly as he no longer had Brenda" (43). As readers, we eavesdrop, as it were, on the subjectively self-evident and already half-buried. We can piece together circumstances (Keith's father has 'deserted' his mother or is somehow out of the parental reckoning; his mother falls ill and is dead three years later; the father is still

Viola (Hamilton, New Zealand: School of English and Media Studies, Massey University \& Nice: CRELA, Université de Nice-Sophia Antipolis, 2000): 186.

${ }^{8}$ The novel is saturated with impassively relayed indices to racism (see, for example, 118, $157,163,168,186,190)$, all preparatory to explosive treatment of this topic at the end of the novel. 
living, and 'up north' somewhere), but not ultimate causality. I shall return to the father in due course.

In this architecture, the character constellations are generally, and oddly, nucleated one-on-one affairs, like a billiard table with just the white ball and one red, and nothing more to allow the playing-out of the Newtonian physics normal on the oblong expanse of baize. Knock-on effects are subterranean, despite the ranging back and forth of the characters' thoughts and memories. I have been putting great emphasis on the presence of present-tense narration, and shall do so here again: the past emerges solely from the characters' restricted and sometimes constricted physical rangings through or portation within physical spaces (trains; streets; domestic, office, pub or public-library interiors; Keith leaving Yvette's house vs. storming out on Annabelle). Particularly in the case of Keith, the past, distant or near, seems to have no independent validity but instead subjectively subtends his present. Small details of present circumstance (e.g., a fridge door swinging closed, 44) lead directly into associated chains of past circumstance. ${ }^{9}$ Without the intermittent coursing of the present-tense narrative, there would be no past. The past is almost an embarrassment, a concatenation of barely registered small pleasures erased by equally inconspicuous creeping failure.

For instance, after leaving Yvette and returning home by tube, Keith stops off for a pint at his local pub, a comfort-zone offering musty, shabby resistance to the new (even the jukebox stocks the old, soul-allied songs that he likes). Here, "he is in control, which is precisely what Yvette accused him of needing to be" (35). This is the cue for his past-tense recollection of the remainder of the scene in Yvette's flat, in which, though she makes it clear that she wants to keep on with their relationship, he is determined to sidle out of it. As throughout the book, the narrative fabric contains thematic 'hooks' which serve to tighten connections: one such, tiny 'hook' between the pub where Keith is sitting and Yvette's home is the presence in the latter of living-room barstools (37). Of greater consequence, "control" is hooked up to. Yvette hotly points out that it was Keith who approached her in the first place, whereas, a few lines later, when he reflects on how it was she who asked him out on the disastrous cinema date and, a week later, asked him to her home (36-37), he is trying to fend off any implication that he is "in control." To be

\footnotetext{
${ }^{9}$ There are very few occasions on which these hingeings are explicitly cued - e.g., "His mind revisits the problems of work" (38); or "He remembers standing at his own front door" (47) - and when they are we are likely to experience a twinge of disappointment at a lapse into pre-modernist technique.
} 
"in control," for Keith, seems to be okay in an impersonal environment like a pub or a library reading-room (or in his job), but not something he wants to admit to in personal relationships. This is part of an ethical nexus of evasion and acceptance centering on personal responsibility. It seems that it is potentially (so far, in thought) only with regard to his son Laurie that Keith even contemplates the shouldering of responsibility; but this will be hard, as it is a situation in which he cannot be "in control," for, as has already been adumbrated, Laurie is increasingly inaccessible emotionally; besides, Keith is now a distant father, distanced through his own unexplained (albeit probed, 45, 46) momentary infidelity.

After the break-up with Yvette, the next day he finds 'exposure mails' from her on all the office computers (49-51). There is a skilful intercalation here of a conversation between Keith and Clive Wilson, his boss, about these 'revenge' emails and Yvette's evident disappointment, on the one side, and, on the other, the icy presence in the office of his deputy, Lesley, whom he had 'dropped' after the New Forest escapade. Chapter I closes with a pub scene in which Clive amiably suggests that Keith, to avoid further friction, go off on paid leave (56-57). There is a double-whammy of irony here. As Keith has been unable to contact Yvette to talk her down, Clive suggests that Lesley (of all people) "sit down and talk to her" (56). It seems that Keith's 'race disability' has been trumped by 'women's affairs'.

In Chapter II, Keith, for his book, shifts his base of operations from his flat to a shabby local public library that can offer him no research resources ${ }^{10}$ but, like his local pub, lets him "see who is coming through the door" (64). It is significant that his sense of writer's impotence here is immediately followed by his move, on his second day in the library, to pick up a young woman whom he has been observing carefully. Note the contrastive segue from paragraph to paragraph, from his faltering 'soul research' to his escape into controlled 'public privacy':

[...] were he to be brutally honest, his advice to himself would be to give up. At four o'clock she comes in, and again she sits at his table [...] (64)

\footnotetext{
${ }^{10}$ This is not just a bland fact about under-resourced public facilities but an index to the marginalization of an area of music born of the culture of an 'ethnic minority' (yet an interest of the broad masses); it echoes an observation that Phillips made about how he couldn't find the material in the libraries at Oxford to pursue his interest in African-American literature; see "Caryl Phillips" (1995), interview with Pico Iyer, in Conversations with Caryl Phillips, ed. Renée T. Schatteman (Jackson: U P of Mississippi, 2009): 41.
} 
This is, once again, interiorized perspective (the non-identifying "she" for a person already 'known' to him but specified en passant only seven pages later, when Keith has taken her via the pub to his home, as "this girl called Danuta," $70 ;{ }^{11}$ onomastic distantiation is found here as earlier, with the elusive, ironical girl always addressing him as "Mr. Keith"). This narrative architecture without mediation is maintained at the next point of juncture:

He wonders if she is hungry. Perhaps she would like to go for an Indian, or maybe to his flat for another drink if she doesn't like this pub? He thinks carefully about how to pose the question for he doesn't want to come across as tacky. [...] She has to know that he likes her [...] then again here in the pub, $[\ldots]$ the girl will already have anticipated both his question and his uncertainty as to how to frame it.

He opens the front door and steps to one side $[\ldots]$ (67)

The "question" - the action - is not actually asked, but represented only as Free Direct Thought, as a projected tactic, and the 'response' is not specified but only inferrable from the minimally deictic signposting in the new paragraph. This characteristic suppression of explicitness reflects an inner state of resistance by Keith to the import of his own actions, a resistance that cannot withstand upsurges of family associations, as when Keith examines the calligraphy of the woman's addition to the note he slips across to her in the library: it reminds him of how Annabelle's mother tried to make Laurie's handwriting, itself also "a child's first attempt at joined-up writing" (65), more 'middle-class'.

Part of the function of the episode with Danuta - with its frantic thoughtscenario of Keith rehearsing all the possible stages of sexual encounter, ending in an admission of "indecision" (71) that echoes his writer's-block thoughts earlier - is her status as a mercilessly clear-sighted reflector-character who poses questions he must answer. Asked by Danuta about whether he might be bisexual, Keith answers: "'I have enough trouble with women'” (73); he immediately wants to retract this admission, associating it with the fateful "urge

${ }^{11}$ Naming gradient is employed diegetically to signal Keith's inward projection of increasing intimacy with the woman: she becomes "this Danuta" (71), then "Danuta" (73) just before he makes his first physical move and cups her face in his hands. When she rejects his clumsy kiss, reference reverts to "she." This is correlated with the "control' motif - here his sense that she has been put off by what he suspects is his "stupidly" "taking charge" (75). In a McDonald's with Danita the next day, he reflects that he "has to take charge, yet be sensitive, otherwise he realises that the whole encounter will quickly descend into argument and she will leave" (88). 
to confession" about his New Forest escapade that led to the break with Annabelle. The 'editing control' Keith would like to exercise but cannot may be a conditioned passivity that link up with the fact that he has been raised by Brenda, and it is significant that Danuta asks about a photo "tucked away" on the windowsill and Keith replies that "She's my father's wife"” (72). Whereupon Danuta acutely summarizes the nest of relationships: " "you do not have a picture of your mother, and you do not have a picture of your father, but you have a picture of your father's wife?'" (72).

When Danuta leaves to go to her office-cleaning job, Keith is prompted by the sight of the photo into an extended set of nested episodes in recollective past tense centering on Brenda and his father. Earlier, after Keith hears what sounds like a car backfiring, we are made privy to his memory of visiting his father up "north"12 and noticing that the latter just shrugged when his son mentioned London's "gun violence" (48). Keith finds it hard to muster sympathy for his exhausting, unpredictable, judgmental father, who has "been either hospitalised or struggling in his mind" with "his demons" (49). In the first segment of the later sequence, Keith, late in his first year at university, takes Annabelle to introduce her to Brenda, who, though "suddenly aged" and showing signs of terminal illness, receives his girlfriend warmly. Keith recalls his father's long-term hospitalization and the West Indian landlord throwing the woman and the boy out of their accommodation: "she had better take her white arse out of his place" (77); at last we have, via reverse racism, clarity about Brenda's ethnicity. This, of course, may make Keith's father black, but we still can't be sure; after all, there seems (from the exchange with Danuta) to be a 'blood mother', of unspecified race, hidden deep in the background revealing and concealing. While Annabelle is in the kitchen making tea, it is clear from Brenda's conversation with Keith that his father, after he was released from hospital and was hired as a janitor, took him away from Brenda, and that this remains a source of resentment for Keith (79). We then discover that Keith's "grieving stepfather" has to deposit him, at the age of six, "with the man who was his real father. At this time his father and Brenda were living in a small back-to-back whose door opened directly on to a cobbled street" (81). The subjectified narration here is so radical as to be wholly opaque and confusing; there has been no prior reference to Keith's being with foster

\footnotetext{
${ }^{12}$ We gradually gather enough hints to guess that the place involved is modelled on Sheffield in the Midlands - close to York (explicitly mentioned as a museum-visit destination of Keith's), and near enough, also, to the town of Phillips's own childhood, Leeds, and triangulated with Manchester and Bradford.
} 
parents or with a "stepfather," and, although Keith's father has, it was claimed, taken him away from Brenda, he is here living with her and his father. So we must wait for clarification. Meanwhile, by the time Keith is eight, his father shuts himself off in his books or rants "at nobody in particular" (81). He is taken away by the police and consigned to a mental institution (though Keith only senses that this is not a regular hospital), and is in such a state of mute catatonia that Brenda stops taking her frightened son on visits to him. In the next, one-page, segment, "“Earl'," a "stranger," pays a visit to Keith, now thirteen years old, and warns Brenda that he'll be returning soon for his son (83-84). The closing segment returns us to the visit of Annabelle and Keith to Brenda, and confirms that his father was granted custody, with permission for Keith to visit Brenda on the weekends. By this stage we are left with an overall image of familial dysfunctionality: a close bond between mixed-race Keith and Brenda, his white foster-mother; a broken bond between Keith and his black, mentally damaged blood father; the flitting ghost of a "grieving stepfather"; and unarticulated biological presences further down the line.

The remainder of Chapter II deals efficiently with two narrative topics in discrete sequence. The first concerns Keith's few successful attempts to meet with the enigmatic Polish girl, in whom he seems to have only a superficial interest ("what a strangely pleasant distraction the girl was," 91) yet a compulsion to explore in her class-less, non-British otherness, down to his secretly tracking her movements and finding out that she has a platonic but increasingly and problematically demanding boyfriend called Rolf - all this culminating in a surge of embarrassed remorse at his middle-aged obsession with a young girl and his determination to immerse himself in his research (at his flat now, not in the library); "with the work there is no awkwardness to negotiate and no guilt to absorb" (101). The second is a meeting with Annabelle to discuss the behavioural problems of their son Laurie - a meeting that is indeed tinged with awkwardness and guilt; and, not only that, also with design on Keith's part, as we can suspect from the richly ambiguous closing sentences of this chapter, when Annabelle phones in distress because Laurie has gone temporarily missing:

The line goes dead, but he continues to hold the mobile to his ear. As long as he holds this pose there is still some communication between himself and Annabelle and their son. He just has to hold the pose. (114)

Keith seems to get along okay with his seventeen-year-old son on their outings together, although Annabelle simmers with repressed anger at him 
when he tries to assure her that everything is "fine" with Laurie (125); after all, the hate-mail 'sexual harassment' blog on which Yvette has blurted out her now finished relationship with Keith has been drawn to Annabelle's attention, and she is afraid Laurie will find out. There are occasions that betray a certain irony, as when Keith suggests that, as an exam present, Laurie and he go to the Caribbean because his "grandparents come from there" (120). This is clearly a kind of attempt at dynastic conditioning on Keith's part, but, despite his own footballing past, he is deaf to Laurie's preference for going to Barcelona to see Europe's best team play. One can understand Laurie's resistance: for him, his grandfather is just a "weirdo" (120). The only time Keith went north to present his grandson to the old man, the latter simply walked out of his own house muttering to himself and went to the pub. (This memory is so sharply etched that it gets 'cubistically' repeated in narrow compass from a slightly different angle, 120, 121.) Twelve years earlier, the pregnant Annabelle had also been given the silent treatment by Keith's father.

With the exception of a few brief passages of past-tense narrative in which Keith recalls scenes from his childhood $(168-72,178-80)$, the failed visits to his father with Laurie and Annabelle (120-21), and a couple of immediately antecedent events (146-47), the seventy-five pages of Chapter III are in the present tense and in resolutely forward-marching chronological sequence. I have already mentioned some of the scenes; by and large, the third chapter, after the fragmented circlings of the first two, is a linear catalogue of ineluctable failure on Keith's part (but with two tiny, and revealing, bright spots). Keith tries to 'bond' with Laurie and has a face-off with the hostile Annabelle. After calling for a pub meeting with his boss, Clive, and finding that the latter is taking the side of Yvette, Keith tells him to get lost (another 'storming out', 120) before buying a shirt for Laurie. Danuta turns up after a bust-up with Rolf and seems to be asking for help and shelter, but ends up 'storming out' of his flat (140). Keith meets Lesley in a Starbucks after she phones and asks to talk, and he finds out that Yvette intends to press charges for harassment in the workplace and that Clive is planning to get rid of him. After arranging to meet Laurie at a stadium for a lesser-league football match, Keith waits in vain for his son to turn up. His phone-call to Yvette ends with her hanging up on him. Calling on Annabelle to find out why Laurie didn't turn up for the match, Keith is told that he can't see the boy, and that Laurie and his gang have got into trouble. With an intermittently sullen Laurie in tow, 
Keith roams central London, the London Eye, and the South Bank, trying unsuccessfully to awaken a sense of history and personal responsibility in his son. Keith texts Lesley, asking her to keep him in touch with developments in the office, and leaves London by train for a few days. He is interrupted in his stay out of town by Annabelle, who phones to say Laurie is in trouble with the police because of involvement in a stabbing; Keith returns to London by bus, and he and Annabelle wait in the police station and a Kentucky Fried Chicken until Laurie is released without charges. It is interesting that these last few pages start in the present tense and then, after a surreptitious indication of how long he has been away from London ("He lies in his own bed for the first time in three days," 190) - and via a motival association between the present (Annabelle standing under the light of a lamppost before they return to pick up Laurie from the police station) and the distant 'whole' past (how the way she looks under the light reveals the same beauty he saw when he first met "the posh teenager" at the theatre performance, mentioned earlier, and referred to briefly one last time on page 205) - returns to the 'finality' of the past tense as Keith goes over the remainder of the scene with Laurie, with Annabelle packing the sleepy boy in her car and driving away, leaving Keith to walk home to his flat through the windy, wintry night. The last image given us is a projectively 'post-coital' one of Keith's own thwarted desire: that of a laughing young couple across the street, "still naked although they were now fully dressed" (192).

The three days Keith spends away from London, a stretch of narrative at the very centre of the book, open up, and half-promise to clarify, the archive of Keith's disjunctive family past. Although the destination is kept under wraps, Phillips sets out mundane, familiar aspects of train travel so that they assume, in retrospect, symbolic significance (161): it is a night journey of the soul, or a birthing, where the journey itself is unimportant and undescribed (the "ticket inspector wakes him"); it is Keith's journey alone (he "looks around at the empty carriage," having overslept the stop); and it is terminally decisive (" "Look, mate, you better get off unless you're ready to go back to London" "). Keith has returned to "his city" (162) to visit his father. What he gets is an 'on the ground' view of the kind of thing he is in charge of at work: the house and his father are in a state of chaotic neglect, a condition that must have been getting worse over the five years since the old man was made redundant from his university janitor's job. Keith's inward analysis, ironically enough, seems to be blind to the symptoms of poor mental health that his father has always exhibited; instead, his social-welfare gaze is directed not at 
the past of what he sees but at a future deduced from current social circumstances: "it now appeared to him that his father was in danger of embracing a premature inertia that was laced with a hint of reclusive bitterness" (167). It becomes clear that Keith has the diffident intention of trying to persuade his father to quit his house and move in to a care facility called the Mandela Centre, where, apart from habitual sessions in his "cheerless" pub, he spends a lot of his time anyway, with a group of old West Indian friends (from, it appears, the migrant generation of 1960) who are denizens of the Centre. After fairly fruitless exchanges with his father in the house, the pub, and the park, Keith ends up with him and his friends at the Mandela Centre, where his father's hostile and dismissive reaction to the topic of Brenda earlier in the day, as well as Keith's admission to him of the problem that Yvette is causing him, "does not fill him with hope that his father will ever talk honestly with him on any subject" (185).

This business about Keith's wanting to "talk honestly" and meeting with resistance is actually a revealing, recurrent pattern in his dealings with certain persons - his father, Laurie, Danuta, occasionally also Annabelle. These responses by no means account for the whole fabric of Keith's attempts at communication, but they are characteristic of a level of passive-aggressive behaviour that is not so much inherent in the persons addressed as elicited by something in his discursive manner - rational, conciliatory - that signals he is not 'in control', hence not worthy of empathy. He explains, he justifies; but his good intentions are not acknowledged. Somehow, this dynamic intercalates with the other features I have drawn attention to - the anhedonic, the absence of engaged passion, the lack of humour.

With his father, however, Keith is in a quite different zone from elsewhere in the book; there is, for one thing, less evasiveness on the part of his father, despite his resistance to Keith's attempts to remedy his living conditions. His father's directness, too, is unlike the discourse patterns found elsewhere, and his speech, and that of his mates at the Centre, stands out with its creoleinflected grammar and idiom. Keith is tempted to use some old photographs he finds to coax his father to talk about the past, but this doesn't eventuate; Keith does notice that his father and his friends seem, in these snapshots, taken "shortly after his arrival in England," to be "surprisingly content" (165), and he seems aware of the possible presence of a Caribbean cultural nexus (as when he imagines his father watching cricket on television, 167). Every other index in the narrative up to this point has been to bitterness and reclusive resentment. At the community centre, Keith is amused to see his father and his 
friends revelling in "what he imagines to be the spirit of their Caribbean youth" (175), and, after joking with the men about not needing Keith to look after him, "his father winks playfully at his son" (175). When the old man arrives back home from the Centre, he can laugh and chuckle at Keith's suggestion that he make his father something to eat (178), and, earlier, Keith looks at his father's "surprisingly soft eyes" (168). The residual vital spirit intimated here is matched by indications that, far from being incurious about his son (as he had been at the disastrous meetings narrated earlier), his father is alert to his interests (e.g., asking him about the progress of his book, 166) and, somewhat sceptically, to his line of work (167-68).

There are two ways in which these positive indices are offset, and explained: first, by two of Keith's past-tense sets of flashback memories; second, and, summatively, by exchanges Keith has with one of the Centre's residents, "Uncle Baron," the most sensible of his father's drinking pals when Keith was growing up, and the only one who ever remembered the boy's birthday (175). After the pub visit, Keith lies in the same bed he slept in as a child, and remembers Brenda's motherly attentions, and the day on which, as a six-year-old, he comes home from school to find his "mother," "the slender lady," gone (he assumes she has "left"), then the train journey to another town, where he is introduced to "a woman named Brenda" and a man "introduced to him as his father" (169). Half a year later, the boy is still thinking of his mother, though we never learn anything more about her, and his father intimates that she has died. Brenda and his father eventually marry, in the absence of Keith, who now remembers how the marital arguments culminate in the police arriving to take his father away and how, after his return from the hospital, he claimed custody. These recollections of boyhood constantly involve Keith's awareness that his father has always been upset at Brenda's treatment of him. Further, Keith still finds his father a "mystery" (172), and the reader will perhaps find here a slight hint that the same scenario is being played out in reverse between Keith and Laurie. Keith as a boy resents the "strange women" (178) that pass through his father's house and prompt him to go and stay overnight at Brenda's. It is also possible that Brenda is entertaining other men friends, but this is something Keith actively avoids exploring. Once again, this connects up with Laurie, in that Annabelle was anxious that Keith's extramarital affairs not get back to their son. In Keith's memories, the narrative indications earlier that Keith's father liked immersing himself in his books are explicitly confirmed by Brenda (179), who also admits to Keith that his father underwent electroshock treatment during hospitalization 
- which finally explains for us those earlier details about his mute, catatonic posture and what Brenda here suggests is his altered personality. These memory fragments are not contiguous; Keith visits Brenda's grave while his father is playing dominoes at the community centre (178), and it is only after other recollections that we are returned briefly to the scene narrated elaborately earlier on where Keith takes Annabelle to visit the ailing Brenda, and we learn that, after Annabelle has left to start a summer job at a newspaper, Brenda confides in Keith that she has cancer (180). Six weeks later she is dead, and his father does not attend the funeral. Micro-patterns are established (Keith absent from the wedding, his father absent from the funeral), but - and this must be Phillips's understanding of how to represent the workings of memory - the same scenes are revisited, but in an almost amnesiac fashion, with different inflections of detail, different additions that ultimately do not provide resolution. We are led to believe that, although Brenda causes Earl to be 'sectioned', she resists a doctor's proposal that he be permanently committed and Keith to be placed in foster care (181). What results, albeit not spelt out or adduced by Keith, is an attachment to Keith on the part of his 'second mother' that is so fierce that she is willing to give the boy up to his father, in a permanently fractured marital arrangement, in order not to lose him. Revelation and concealment; an architecture of circular returning and departure, and a vista of the past and its legacy as one of broken relationships yet covert loyalties.

For his part, "Uncle Baron," in conversation with Keith, clarifies several important issues. First, Earl's personality, his philandering, his reading, and his attachment to his son:

"Your father is difficult like a mule, and lonely too. He long ago finished messing around with the ladies." Baron smiles a broad and toothless grin. "[...] it's not good for him sitting alone in the house. [...] at least we can keep each other company. He can even go back to pretending he's still reading plenty of books and nobody will laugh at him like in the old days. [...] I always understand your father better when I see how he is around you."

"What do you mean how he is around me?"

"Well, Earl likes your company. The man is always boasting off about you, and how you're doing this big job and in charge of all kinds of people in London."

He looks closely at Baron to see if he is making some kind of a joke, but Baron's eyes narrow and his face becomes increasingly serious. (183-84) 
Baron, the man who has accompanied Earl through the whole of his immigrant life and who, it turns out, himself becomes self-defensively taciturn, is the character who at last gives us the 'heart of the matter': Keith's mother, apparently after giving birth to him (though this assumption is corrected much later), leaves Earl and marries another man, the "grieving stepfather" who, when she dies, delivers Keith "like a parcel" (184) to his blood father and Brenda. And suddenly the whole social perspective broadens through Baron's quiet words to Keith. Those who came to Britain from the Caribbean have no pride in having achieved anything, and: " ' When your mother and father come to this country, you really think that either one of them expect to die here?" (182). The migrants, and Baron doesn't blame them, are alienated from their children, who, if they have succeeded at all, have done so " in spite of us" " (185). This is a crushingly depressing summary, and it will be interesting to see if Keith takes these insights with him through the remainder of the narrative.

In chapter IV, immediately after his return from up north, Keith mentions to Annabelle that he has been thinking about his mother a lot (this after the visit to his father and the mother-related flashbacks) (206), which prompts another ploughing of the memory-field of childhood (206-209), this time with slightly more detail on Keith's early boyhood before and after he is taken away to Brenda. We have the boy's attitude towards the "unshaven" man with his mother, whom the boy instinctively regards only as "the man" and not as kin, despite his kindness. The entrapment adumbrated by Baron can be felt in family life, with his mother and "the man" working, alternately, to the point of exhaustion, with his mother playing the pools in the hope of getting enough money to take them back to the West Indies, and with the rise of blatant racism and "the man," much like Earl, subsiding into silence and his mother, much like Brenda, declining into (terminal) illness. For most of this memorytranche, as befits the boy Keith's level of unfamiliarity, Brenda is still "the new woman" (208), but she warmly confides in the boy, offering clarifying elaboration of earlier motifs: for example, that "England had hurt" his father's head, that he "prefers books to people," that his memories of the West Indies upset him. There is also a flash of the coming interracial tension that was stacked on top of the white racism of the time, with Brenda's mention of "the Pakis" (209) taking all the jobs. 
Like chapter II, chapter IV is largely a straightforward present-tense progression over a narrow temporal compass. Indeed, the novel's action in the present occupies only a very few days altogether, which is one reason why the present tense suits. But chapter IV, after the 'dynastic' revelations of the previous chapter, is occupied with fairly uninteresting and unmemorable events which may, however, be part of Phillips's design, inasmuch as Keith is represented as having to come to terms with the quotidian despite the frustrations that are making themselves felt in impulsively considered or effected action, or in further revelations to his passive consciousness. The plot thickens, but at low temperature. The high point is the aforementioned brief phase of childhood memory, prompted by Keith's experience with his father up north. There is also Keith's suggestion to Annabelle that they go and live abroad (206), which links in with Keith's suggestion to Laurie that they visit the West Indies, and with what Baron told him about Caribbean men getting stranded in the UK. And there is one other, epiphanic exception to Keith's reluctance to connect up the past explicitly with the present - significantly in a present-tense section of dialogue with Annabelle - when we learn that she and Keith finally did get to tour Europe in their second student year, a time Annabelle tenderly admits was " the best holiday of my life" (210), and when Keith experiences an overwhelming desire, as the ferry approaches Dover, to be quit of England and to stay in France.

In chapter V, Keith takes the train up north; his father, he learns on the way, is seriously ill. When he visits Baron at the Centre after seeing his father in intensive care, Baron essentially rehearses all that he and Brenda have already imparted; but it probably needs to be drummed into Keith, particularly Baron's lesson that he must help his father whether he loves him or not - this, just after Keith has felt tempted to catch a train back to London, probably never to return (248).

In the hospital there is an ambiguous exchange when Earl says he wants to go home, and Keith takes him to be referring to the house; "'You don't understand me, Keith" " (251) - it may be that pre-death instinct to return 'home', this here meaning the Caribbean. This is soon disambiguated in the first of the most moving passages in the whole book, in which Earl explains to his son, in a coherent flow over thirteen pages, how he came to England in 1960 (252-64). I hate to have to say this, but the first time I read the novel, I felt tempted, after Earl had his say here and the narrative returned to Keith's 
perspective - and however improbable it might be for an old man, weakened and drugged in a hospital bed and with fluid-filled lungs, to deliver such an extended Saramago-like last testament or summa vitae -to close the book and walk away. It was though the novel had become Earl's story, or, indeed, that it had been his story all along, and that any empathy for Keith had been pressed out of me by the weight of his dispassionate wellmeaningness. But no: there was a small gesture by Keith as he sat by his father: when he reaches out and holds his father's hand, we realize that this is the very first physical sign in the whole book of Keith's suppressed affection for him. And I asked: is Keith redeemed? Will he hearken to his father's story? And so I read on.

In none of his novels has Phillips hitherto made a character the mouthpiece for an indictment of cultural and/or political institutions, although, of course, his themes constantly imply such indictments, as does the narrative action. In the present novel, Phillips has come the closest so far to being on home ground, whereby I am certainly not suggesting that the action and characters have an autobiographical basis. But the 'historical' and cultural period, and the geographical locations, are those that Phillips himself grew up in. Although he has acquired a cosmopolitan's clarity of vision, this has come from a deep awareness of the value of his Caribbean 'roots' (this is almost a cliché, given that the 'rhizomatic' cultures of the Caribbean are always already postmodern, global, and cosmopolitan in their intense allegiance to the local). With Earl as (finally) his mouthpiece, Phillips returns to those roots to take stock of the Caribbean-British or periphery/metropole nexus.

Phillips's representation of Earl's account of his traumatic arrival in England matches up in every respect to the now classic accounts we are familiar with from Sam Selvon, George Lamming, and V.S. Naipaul, whereby one is tempted to say that Phillips, by choosing to have this account rendered almost without interruption in verisimilar direct-speech creole, leads by half a nose. Interestingly enough, the flashback architecture employed in the main narrative line throughout the novel is also found here, but with the grammar of creole eliding the boundary between present-tense experience and past-tense recollection; everything here is 'present ${ }^{13}$. What we have is a young man

\footnotetext{
${ }^{13}$ Earl's memory narrative is to some extent perhaps artificial, inasmuch as he displays the fully detailed powers of description and atmosphere one might, rather, attribute to Phillips, and as he has no difficulty in replicating verbatim the 'correct' speech of white people. But we accept this convention; it is, indeed, as though the inner subjective form of Earl's memories were being articulated immediately, with all their frank anxiety and patina of failure, rather than as paraphase.
} 
with a preternaturally nervous but certainly not naive sensibility, and the sights that assail him, all those indices we have absorbed from earlier migrant fiction and poetry, are rendered fresh by the power of Earl's anatomizing. The stevedores working at the dock look shockingly shabby and poor, unlike the dapper white colonials back home. Already on board the ship, Earl has absorbed the usual handy hints for dealing with the English: understand 'doubletalk' (they always mean the opposite of what they politely say), never make noise or boast, or mill around for service (all good Caribbean traits), never reveal that you know far more about their culture and history than they do themselves, never talk about your islands, because they haven't a clue about them, and never call them racially prejudiced; indeed, match their stupidity by playing the innocent stranger. ${ }^{14}$

Earl then casts his mind back to when Ralph, his close friend since schooldays, is on the point of leaving for the UK in 1959, but firmly resolved to return rich in five years to open a garage. Earl's mother is dead and he is left to look after his ailing father. The roots of gender divisions already found in the novel are intimated here, with Earl's sister responsibly married and Earl and Ralph exploiting the stoicism of women. There is a memory-shunt backwards ten years to when Earl's brother Desmond, who has got a married woman with child, flees the island to go orange-picking in Florida. Here another theme (already adumbrated by Baron) is revisited: the scant attention paid to parents by their children once they have set out on their own distant lives. And another, Earl's preoccupation with books, which is there already when he is a schoolboy carting around his law-book and dictionary like a Roquentin, ${ }^{15}$ studying in a failed effort to get the cherished overseas scholarship and alienating his father in the process. We re-emerge into the scene of Ralph's leavetaking, and two months later Earl's father dies (this episode, with the boy facing up to death and burying his father, is superbly rendered). It is Earl's sister Leona who urges him to escape entrapment in his sugar-factory job by following Ralph to England (we find out later that her husband has left her and she wants to move into their father's house with her two children).

We are returned interstitially to Keith's present, and it is clear that, back from the hospital and in his father's musty, disordered house, he has turned in on himself, unable to bring himself to phone Annabelle or text Laurie, regis-

\footnotetext{
${ }^{14}$ Cf. Phillips's remarks in "Colour Me English" above, 19.

${ }^{15}$ Cf. Jean-Paul Sartre's La Nausée (1938), with the main character's linear progression through his encyclopedia, his obsession with a jazz motif, and his 'project' to write a book that might give meaning to his hollowed-out existence.
} 
tering that his father must have looked again at the box of photos Keith came across (perhaps the trigger for his reminiscences) but able neither to put them away nor "to pick them up, or even touch them" (266). He seems blind to the import of his father's sudden access of confidences:

It's not going to happen, is it? The moment when his father's anger turns to tenderness and a touching acceptance of his situation. He's wasting his time hoping that the man's face might be transfixed by the gentlest hint of a reconciliatory smile. After all these years, why now? [...] His father's silence has meant that his son has never been able to properly explain himself to anybody. (266)

This last insight must, to judge from Keith's modes of reasoning and communication, be true. But the rest - why this expectation of external signals, given Earl's traumatized life, precisely now when the essential part of him is opening up? When Keith goes to pick up forms at the Mandela Centre (where he wants to rent his father a flatlet, to get him out of the house), he finds the poster there reading "Have a Positive Encounter With Yourself" crass; the irony of its needful application to him escapes him. On Keith's return to the hospital, what he encounters is his father's apparent partial blindness, and he considers consulting a nurse or doctor about Earl's sudden lapses into sleep (268; symptoms of stroke rather than a heart attack), this latter perhaps a metatextual clue to why the spoken memory flow seems cut short in midstream. That there is now no "silence," that there is a kind of "reconciliatory" process going on, is revealed in the reproach his father levels at Keith that he 'abandoned' him the previous night (268). Another, twelve-page tranche of reminiscence now follows (268-79), with Earl clear in his determination about what he is communicating to his son, and clear about chronology, taking up as he does where his 'arrival' details had left off.

Once again we have a train journey north, the destination of which turns out to involve Earl linking up with Ralph in the hope of getting a job at the same iron foundry where his friend works. There is a strange encounter on the train with a cultivated ex-Army Englishman who shares his sandwiches with the cautious Earl and makes backhanded remarks about ethnic tolerance. Arrived in the northern city, Earl is directed to a pub crowded with West Indians and meets up with a still lively but decidedly down-at-heel Ralph and his older friend Baron, who came to England from Jamaica much earlier and seems not to be interested in this young man fresh off the boat. When the drunk Ralph finally gets back to his flat with Earl, the former expresses nos- 
talgia for home and impotently defiant, bitter resentment at the active "niggerhunting" Teddy-Boy racism of which he is constantly a victim $(274,276)$. In terms of narrative architecture, there are interesting unheralded transitionjumps as in Keith's narrative, such as when Earl is suddenly being introduced by Ralph to the foreman at the iron foundry (275). It is here that we learn that Earl has already quit two jobs because of the barely concealed racism of white union operatives. This memory-tranche closes with Earl's disastrous attempt to talk to a kind-enough but self-absorbed and infantilizing lecturer about the possibility of taking evening classes, or at least the university entrance exams. This theme of eternal intellectual self-improvement is tragically present throughout the book and serves as Earl's shield against the world.

In the next interstitial 'break' centred on Keith, there is an echo of his earlier train journey north for the three-day visit to his father, when Keith is similarly awakened, this time having fallen asleep in the hospital cafeteria; now it is late evening and his father is calling for him. It turns out that Earl is determined to continue his narrative from where he left off, and Keith must follow him on this journey. This third and longest (seventeen pages) tranche of recollective testimony (281-97) is at once the most harrowing and the most epiphanically reconciliatory. Ralph continues his ineffectual ranting against racists, and (himself paying 'extra rent' via sex with his married landlady) encourages Earl to have stand-up sex with white prostitutes in parks, something that, in its abdication of self-respect, fills him with disgust. In a scuffle with some white racists, Ralph is beaten up and hospitalized, and Earl fetches Ralph's sister Shirley from Manchester and invites her to stay at his place. There are crucial facts that Earl elides in the telling - that Ralph has died of his wounds (the scene of the funeral is recounted only later, 291-92) and that Earl and Shirley sleep together (what Earl later terms "the confusion," 292) before she returns to Manchester after the funeral, without taking leave of Earl. When Earl has to leave Ralph's flat (he had already contemplated doing so before the racist attack) and has to roam the streets looking for new accommodation, we get a flavour of the 'housing problem' so memorably recorded by Selvon and Soyinka. And then he is summoned by phone to Manchester and confronted with the fact that Shirley is pregnant: "'she look across the table at me. "Well?"," (292).

At this point there is another of those unheralded narrative jumps: " 'It take me nearly a year before I find the courage to ask out Brenda" (292). They talk in Earl's pub - or, rather, Brenda talks, because, as Earl significantly says, "'I don't have no story to offer in return"” (293). Increasingly, the 
voices in his head "'making all kind of loud noise"" (293), and when he takes Brenda to an Indian restaurant and senses the same kind of racist attitude he felt on an earlier visit alone, he explodes, is hospitalized, and is subjected to drug therapy and electroshocks. Brenda visits him regularly. He finds out from a doctor that he has been in the facility for five years now. Just before he is released from care, he asks Brenda to marry him: " "then she start to smile" (295). Occlusions here (what about the pregnant Shirley?), which we must endeavour to prise open. Final clarification comes with another 'jump' (this time astonishing us, because such an unexpected closing of an enigmatic circle, as it were) involving Earl's directly addressing Keith: "'I don't see you till you was six"” (295). We get another replay of the scene where Keith is handed over to his father - this time not by the "grieving stepfather" but, more illuminating from another perspective, by some "coloured man" who is Shirley's husband. It is clear now that Shirley is the "slender woman" Keith remembers as his blood mother, and that it was Shirley's wish, before she died of a lung disease, that her son be entrusted to the care of his blood father. Brenda tries to convince Earl that he needs to look after his son, but he knows it will be hard, as he admits to Keith in his closing words, remembering how he tiptoed in to watch the sleeping boy:

I am thinking to myself that nobody can say that I don't do nothing with my time in England. I lose my best friend, and then I get fooled off by a woman, and then I find myself living with an English girl, but at least I have you. But I'm not ready for this. It's not you that I don't want, son. I just don't want this life, because England already hurt me enough as it is. (297)

$\mathrm{He}$ is lost. He wants to be back in his island bar with Ralph, to have his books, to have his father and siblings. It is the agon of life-defeating nostalgia, the agony of countless Caribbeans who are strangers in a strange land.

What can Keith do with this knowledge? We next find him on a bus returning to London (the bus - rather than train - journey yet another doubling, this time of his previous return from seeing his father). "All he can think about" (298) is the time his father came to Brenda's, when he was thirteen, and took him to a Disney cartoon. When they leave the cinema in the dark, snow is falling as they trudge home, "his hand tight and safe in his father's hand." Fascinated at the snow, Keith looks back and sees "two sets of footprints where they had walked, a large pair and his own smaller ones." I don't know 
why, but every time I read this whole passage I find it epiphanically moving, sometimes so much that it provokes tears. The topos of England's snow is tried and true (as in Naipaul's Mimic Men), but, for me, never so affectingly represented as here; it has, of course, to do with the hushed closeness of father and son, and Phillips rounds off the motif with equal power on the next page when the boy sees the "single set of footprints" and how "the falling snow steadily erased all evidence of his father's presence." It is clear that Phillips is telling us to pay attention to broader implications: perhaps, among other things, that familial warmth, coherence, and shared experience are the only way for the Caribbean immigrant legacy to withstand the social 'cold' of England, to celebrate the country's small miracles.

The bus trip -which might have prompted us to wonder why Keith was leaving his father behind in hospital - has occluded a final fact. There is a flashback, once again with Keith being woken, only to see that the hospital bed is empty and that his father died in intensive care half an hour before. He locks the door of his father's house, not yet wanting to begin "the process of sifting through the evidence of his father's life" (302). We suspect that it is not just the detritus and scant memorabilia that Keith will have to 'sift through', but the rich evidence of all that his father recounted to him in the hospital. In mundane ways, continuity persists: when he phones Annabelle from the bus, she informs him that Laurie has got his girlfriend Chantelle pregnant. When he reaches London, he contemplates the area where Annabelle lives, and there is an echo of his father's desire to turn back the clock in his preference for the 'old days' - not the days of his obligation, before London, to engage in factitiously positive black-oriented culture-work, but the days before Annabelle's part of London became gentrified. There is an intimation that Keith, now that his father is gone, feels trapped in immaturity or a kind of persisting childhood:

So that's it then? His father has gone and now there's nobody ahead of him. Nobody higher than him on the tree. The traffic suddenly dies down for a moment, and he stares across the common and finds himself enveloped in a pocket of silence. He feels exposed and vulnerable. Small. That's it. Small. An accelerating lorry blasts by, and then another. So that's it then? (304)

This is a rich, highly ambiguous passage: there is silence (his father's silences, his absence) and there is sound and fury, yet a kind of inanition, and a revisiting of his father's own feelings upon reaching England. There is that telltale "ahead," which for Keith signifies the robbed comfort of his genetic 
past, not the "ahead" of the new life, and familial continuity, co-created by his son Laurie. As he later lies in bed at Annabelle's, having slept the sleep of the emotionally exhausted, he tells himself that it is "not his bedroom" (308); despite Annabelle's tender ministrations and what looks like her desire for him to return to the fold, he does not want to stay here "with all these people" (meaning: Annabelle, Laurie and Chantelle, and the placidly confident dressing-table photo of Annabelle's parents). He resolves to tell Annabelle that he will go "home" to Wilton Road (he is "not ill or incapable"). It seems that the cycle of reclusion is about to repeat itself, possibly including (to judge from many behavioural clues throughout the narrative) depression. But who's to tell, as Annabelle ascends the stairs to the bedroom?

Despite this present-time conclusion, we are left in our thoughts with the music of Earl's terminal 'project' of accounting for his life. It overshadows Keith's own existence, which, it is intimated, will continue to suffer from 'writer's block', stopping and starting, attempts to impose solitary self-discipline and control hijacked by abortive, diversionary reachings-out to other souls. Amid his own personal 'home listening' to disciplined, 'cool', 'controlled' jazz, Keith's own project to impose the music of sense devolves, via hesitancy, inconsistency, and contradiction, into nothingness. Starting ambitiously with the long historical reach of antecedents and a commitment to examining 'black' racial factors, it moves away from its basis in soul music, towards deracialized globality and loose contiguity rather than cultural coherence. ${ }^{16}$ In its own way, this is thematically central to the plot, being the counterpart in Keith of his father's books and failed project of self-enlightenment. The theme sputters and then peters out, like the to-and-fro hesitancies of Keith's relationship with Danuta, to be replaced by the unmediated black testimonio of his father, a chronicle of a recuperated past that Keith must somehow learn to live with and, perhaps, through.

In the Falling Snow is the most 'contemporary' and least 'historical' of Phillips's novels - indeed, the only one so far apart from A Distant Shore, whereby the two books pursue distinct diasporic trajectories (present-day

${ }^{16}$ It is interesting to see how music is, for Phillips himself, particularly in his travel writings, the object of quiet, unswerving allegiance. Music is, indeed, so essential a feature of his cultural identity and 'project of enlightenment' that, for all the seriousness of The Atlantic Sound, and for all the challenges the title's ambiguities pose, that same title derives ultimately, and with a certain levity on Phillips's part, from the name of a record label notable for its cross-cultural origins and its catholic and historically significant coverage of (more recently) jazz and (particularly in its early 'roots' years) soul and black r\&b. It's almost as though Phillips hijacked what could well have been the ideal title for Keith's book. 
African in A Distant Shore, recollectively - and thus indeed 'socio-historically' - Caribbean in In the Falling Snow). It is as though Phillips, in these two narratives, were being increasingly impelled along a similarly urgent, fluid course as in the essays of his commandingly inclusive 'travelogue' nonfiction. Here, in In the Falling Snow, we do not find ourselves in a poisonous provincial enclave as in $A$ Distant Shore, but squarely in two spatial zones (London and the Midlands) that happen to possess linchpin valency in Phillips's own biography. Although I have already tried to distance myself from speculations about biographical intertextualities, there is often such an overwhelming degree of 'match' with Phillips's earlier stations in life that one is perforce tempted to commit the fallacy of adducing too narrow a fit between fiction and fact. This resolutely aside, there are in the novel - and this is central to all of the contributions to Songs in the Key of Life so far - the same magisterial and magical culinary reworking of the ingredients of diasporic, 'islanded' identity that we find right from the beginning of Phillips's oeuvre the mother-son relationship; fragmented familial lineage; the foster-status of children; the Othello topos of black man/white woman; racial mixing; the existential theme of migrant arrival in England; the iconic magic of snow; the xenophobic and racist climate of Britain, to the point of murderous violence; the maintenance of civility and the need for self-improvement; painful awareness of the gaze of 'different' (non-black) others; protagonists as distanced, if involved, observers of the social scene with its covert histories; the difficulty for non-white children of navigating through their schooldays; descent into mental instability as a refuge from an intransigent environment; even (this time from Phillips's biographical writings) such adversions to creativity as football, theatre, and black music ... the list can go on. The urban is a more central focus of In the Falling Snow than it is in A Distant Shore, and, despite the geographical specifics of the north of England being withheld, there is an almost dogged adherence, at times, to named (and almost villageois) and linearly plotted areas of London. This is a form of postmodern realism that distinguishes In the Falling Snow from A Distant Shore, where, save for the potent immediacy of genocidal Africa and the claustrophobia of Sangatte, the chief actional site is strongly fictionalized and generalized in order to intimate the persistence into the future of a Britain caught in its historical hypocrisies. ${ }^{17}$ In the Falling Snow tensely explores its own range of 'hypocrisies'

\footnotetext{
${ }^{17}$ In the Falling Snow does not have the allegorical dimension of $A$ Distant Shore, the sites of whose 'English action' have speaking names: the name of the village of Weston, particularly once the African Solomon enters the picture, cries out to be construed as 'the
} 
or false double-consciousness - but is ultimately, if diffidently, washed clean by the purity of its title image.

\section{WORKS CITED}

Camus, Albert. L'Étranger (1942; Paris: Gallimard, rev. ed. 1953). Tr. by Matthew Ward as The Stranger (tr. 1946; new tr. 1988; New York: Vintage, 1989).

Collier, Gordon. "Serene Surface, Secret Depths? Joyce's Section in Crossing the River," in Postcolonial Knitting: The Art of Jacqueline Bardolph, ed. Richard Corballis \& André Viola (Hamilton, New Zealand: School of English and Media Studies, Massey University \& Nice: CRELA, Université de Nice-Sophia Antipolis, 2000): 185-96.

Ledent, Bénédicte. Caryl Phillips (Contemporary World Writers; Manchester: Manchester UP, 2002).

Naipaul, V.S. The Mimic Men (1967; Harmondsworth: Penguin, 1969).

Phillips, Caryl. The Atlantic Sound (New York: Alfred A. Knopf, 200o).

—. Cambridge (London: Bloomsbury, 1991).

- Crossing the River (London: Bloomsbury, 1993)

—. Dancing in the Dark (New York: Alfred A. Knopf, 2005).

The Final Passage (London: Faber \& Faber, 1985).

- Higher Ground: a novel in three parts (London: Viking, 1989).

In the Falling Snow (New York: Alfred A. Knopf, 2009).

The Nature of Blood (London: Faber \& Faber, 1997).

. A State of Independence (London: Faber \& Faber, 1986).

Sartre, Jean-Paul. La Nausée: roman (Paris: Gallimard, 1938). Tr. by Robert Baldick as Nausea, intro. James Wood (tr. as The Diary of Antoine Roquentin, 1949; new tr. 1963; Harmondsworth: Penguin, 2000).

Strawson, Galen. "Children of the Ever-Rolling Stream," Independent on Sunday (16 May 1993).

West', not least because of its post-industrial degeneracy; the nearby 'new' development bears, like artificial medieval wainscoting and half-timbering, the 'old' name of Stoneleigh, its inhabitants unwelcome 'stones' in the once pastorally idyllic 'meadow' (Anglo-Saxon 'leigh') of Weston. 


\section{Notes on Contributors}

Thomas Bonnic is Full Professor of Literatures in English in the Departamento de Letras, Centro de Ciências Humanas Letras e Artes, State University of Maringá, Brazil. His research and teaching areas focus on postcolonialism, postmodernism, feminism, and literary theory. His books include $O$ pós-colonialismo e a literatura: Estratégias de leitura (2000), Conceitoschave da teoria pós-colonial (2005), and Resistência e intervenção nas literaturas pós-coloniais (2009). He has published widely on African fiction (anglophone and lusophone), English literature (especially Graham Greene), white British colonial themes (Aphra Behn, Shakespeare, Marina Warner), black British writing (Andrea Levy, Ben Okri, Caryl Phillips), and fiction of the Caribbean diaspora (Jamaica Kincaid, Pauline Melville, Jean Rhys). He is the literature editor of the journal Acta Scientiarum: Language and Culture.

Fatim Boutros is the author of Revision als Illusion? Die Aufarbeitung der Sklaverei in neueren Romanen der anglophonen Karibik (2004). His booklength study 'Facing Diasporic Trauma: Representations of Slavery in the Novels of Fred D'Aguiar, John Hearne and Caryl Phillips' is forthcoming. A professional course leader for foreign-language training in international companies, he has been a university teacher and is currently an independent researcher and the drummer for the Nuremberg groove/soul band One Step Closer and the indie band Mio Myo.

Gordon COLlier has taught postcolonial literature, film, and cultural studies at the universities of Mannheim (1970-76) and Giessen (1977-2008). He has published articles on postcolonial film, Caribbean literature, narratology, and iconography, and books on translation and on Patrick White (The Rocks and Sticks of Words, 1992). He is the editor of US/THEM: Translation, Transcription and Identity in Post-Colonial Literary Cultures (1992) and Spheres 
Public and Private: Western Genres in African Literature (2011), and of a retrospective essay collection by John Kinsella, Spatial Relations: Essays, Reviews, and Commentaries (2011), and has co-edited the critical anthologies Shuttling Through Cultures Towards Identity/Vers une identité interculturelle (with Judith Bates, 1996), A Talent(ed) Digger (with Hena Maes-Jelinek and Geoff Davis, 1996), Postcolonial Theory and the Emergence of a Global Society (with Dieter Riemenschneider and Frank Schulze-Engler, 1998), Crabtracks: Progress and Process in Teaching the New Literatures in English (with Frank Schulze-Engler, 2002), A Pepper-Pot of Cultures: Aspects of Creolization in the Caribbean (with Ulrich Fleischmann, 2003), and Spheres Public and Private: Western Genres in African Literature (2001). He is co-general editor and technical editor of the book-series Cross/Cultures: Readings in Post/Colonial Literatures and Cultures in English and of the journal Matatu: A Review of African Literature. His co-edition (with Chris Balme) of Derek Walcott's earlier criticism, 'The Journeyman Years: Occasional Journalism 1959-1974', is forthcoming. He is currently compiling a comprehensive bibliography and filmography of the African diaspora.

SANDRA COURTMAN is the programme coordinator for Literature with Creative Writing in the Institute of Lifelong Learning, University of Sheffield. She previously taught at Staffordshire University and the University of Birmingham. Sandra researches Caribbean and black British (particularly West Indian migrant) writing and culture of the post-Second World War period and the sociology and politics of publishing. Since 2000 she has been active on the organizing committee of the Society for Caribbean Studies. She is the author of Beyond the Blood, the Banana and the Beach: New Perspectives in Caribbean Studies (2004) and an edition of Joyce Gladwell's Brown Face, Big Master (2003), as well as numerous articles on Caribbean and West Indian diasporic writing (including essays on Beryl Gilroy, Joyce Gladwell, and Andrea Levy) as well as the Caribbean connections with Birmingham's photographic collections.

STEF CRAPS is a lecturer in English literature at Ghent University, where he directs the Centre for Literature and Trauma (LITRA). He is the author of Trauma and Ethics in the Novels of Graham Swift: No Short-Cuts to Salvation (2005) and has served as guest editor for special issues of Studies in the Novel (2008; with Gert Buelens) and Criticism: A Quarterly for Literature 
and the Arts (2011; with Michael Rothberg) on the topics of, respectively, postcolonial trauma novels and transcultural negotiations of Holocaust memory. He has also published numerous articles on these themes, including studies of David Dabydeen, Fred D'Aguiar, Caryl Phillips, J.M. Coetzee, Graham Swift, Jean Rhys, Salman Rushdie, Virginia Woolf. Holocaustrelated studies of Anita Desai and Caryl Churchill are in preparation.

Alessandra Di Maio teaches postcolonial and diasporic literature with a focus on Africa at the University of Palermo. She has translated works by Nuruddin Farah and Wole Soyinka, and is the author of Tutuola at The University: The Italian Voice of a Yoruba Ancestor (2000) and Wor(l)ds in Progress: A Study of Contemporary Migrant Writings (2008), and editor of the collection An African Renaissance (2006).

Malik Ferdinand studied French creole language and culture at AntillesGuyane University and obtained his doctorate from the Université Paris III Sorbonne Nouvelle. His research has a trans-Caribbean focus on such writers as Derek Walcott, Aimé Césaire, Reinaldo Arenas, Wilson Harris, Édouard Glissant, Antonio Benitez-Rojo, Léon-Gontran Damas, and Caryl Phillips. He currently teaches creole in secondary schools.

Cindy Gabrielle is a doctoral student in the English Department, University of Liège. Her fields of research include postcolonialism and graphic novels. She has published several articles on Janet Frame, the subject of her doctoral dissertation, on the 'graphicization' of fictional prose and poetry, and on contemporary African American theatre.

Lucie Gillet teaches in the English Department, University of Liège. Her fields of research are black British literature, contemporary English fiction, and multiculturalism in literature. Publications include "Representations of Multicultural Society in Contemporary British Novels," in Multi-Ethnic Britain 2000+, ed. Lars Eckstein, Barbara Korte \& Eva Ulrike Pirker (2008).

Dave GunNing is a lecturer in English at the University of Birmingham, where he teaches British literature since 1945, contemporary Irish writing, 
and recent postcolonial literature. His chief research focus has been black British, British Asian writing, contemporary Irish and early-twentieth-century Caribbean literature, and the literatures of South Asia (especially Pakistan). $\mathrm{He}$ is the author of Race and Antiracism in Black British and British Asian Literature (2011) and the co-editor, with Abigail Ward, of Tracing Black America in Black British Culture, a special issue of the journal Atlantic Studies (2009). His numerous journal and reference articles include studies of John Agard, James Berry, Fred D'Aguiar, Bernardine Evaristo, Amitav Ghosh, S.I. Martin, and Caryl Phillips.

Tsunehiko Kato is a professor in the Graduate School of International Relations, Ritsumeikan University, Kyoto. He is the author of The World of Caryl Phillips (2008) and of articles on Phillips and African American literature. His other books are The World of Toni Morrison (1997), The Study of African-American Literature: Alice Walker, Toni Morrison, and Gloria Naylor (1991), and The World of African-American Women Literature (1987). His stay at the University of Leeds as a visiting scholar in 2009 led him to Indian literature in English, and he is currently preparing a new book in this field. All his books are in Japanese.

Wendy Knepper now teaches at Brunel University, West London, after working at Queen Mary and Berlin's Humboldt University and for several years as a marketing consultant and IT entrepreneur. Her teaching areas are twentieth-century literature and theory, and her research interests include postcolonial and modernist literatures with a focus on Caribbean and diasporic writing as well as theory relating to transnational poetics, postcoloniality, globalization, and gender studies. Her longtime interest in the francophone Caribbean includes the forthcoming Patrick Chamoiseau: A Critical Introduction). She is currently working on a book-length project on Caribbean literature in an age of globalization.

Bénédicte Ledent teaches English language and Caribbean literature at the University of Liège (Belgium). She is the author of Caryl Phillips (2002) and of numerous articles on contemporary Caribbean fiction. She has edited Bridges Across Chasms: Towards a Transcultural Future in Caribbean Literature (2004), a special issue of the journal Moving Worlds on Caryl Phillips 
(2007), and (both with Kathleen Gyssels) The Caribbean Writer as Warrior of the Imaginary/L'Écrivain caribéen, Guerrier de l'imaginaire (2008) and Présence Africaine en Europe et au-delà/African Presence in Europe and Beyond (2010). Bénédicte is co-editor of the book-series Cross/Cultures: Readings in Post/Colonial Literatures and Cultures in English.

John MCLEOd is Professor of Postcolonial and Diaspora Literatures at the University of Leeds. His teaching and research areas centre on postcolonial studies (particularly Caribbean writing), postcolonial representations of London, and twentieth-century British writing. He is the author of the highly influential book Beginning Postcolonialism (2000, second edition 2010) and of Postcolonial London: Rewriting the Metropolis (2004), the editor of the Routledge Companion to Postcolonial Studies (2007), and co-editor of The Revision of Englishness (2004). He has also published a study of the novelist J.G. Farrell (2007) as well as guest-editing two issues of the journal Kunapipi (1999, 2003).

Peter H. MARSDEn was educated at the universities of Oxford, London, and Manchester. He recently retired from the Department of English Studies at the University of Aachen after many years as a lecturer there. His research interests continue to embrace both linguistics (e.g., varieties of English and translation studies) and literature, with a particular focus on Australian and New Zealand poetry. His publications include studies of individual authors such as Peter Bland, Peter Goldsworthy, Les Murray, Robert Sullivan, and, most recently, Hone Tuwhare. He is currently working on a study of the literary relations between New Zealand and Germany.

JoAN MILLER POWELL, born in Jamaica, obtained her doctorate on Caryl Phillips from the University of the West Indies, Mona Campus, in 2005. She has taught at both the University of the West Indies and the University of Botswana. She is now a lecturer in the Department of English at Walter Sisulu University, in South Africa.

IMEN NAJAR teaches in the English Department, University of Liège. Her teaching and research areas are postcolonial literature, Caribbean literature, and Carnival and carnivalesque literature. Her most recent publication is 
"Conrad's Kurtz in Heart of Darkness and Phillips's Nash in Crossing the River: A Discursive Approach," in Présence africaine en Europe et au-delà / African Presence in Europe and Beyond, ed. Kathleen Gyssels \& Bénédicte Ledent (2011).

CARYL Phillips was born in St Kitts, spent his childhood in the north of England, and now lives in New York, where he is professor of English at Yale University. He is the author of nine novels, four stage plays, and three books of non-fiction, in addition to several scripts and numerous essays. All of his writing, for which he has received numerous awards, testifies to a heightened historical consciousness and an empathic attention to human suffering, combined with a highly original approach to literary form. His latest publications are In the Falling Snow (2009) - a novel mostly set in contemporary England and focusing on a middle-aged man of Caribbean descent and Colour Me English (2011), a collection of essays. See http://www.caryl phillips.com/

Renée Schatteman is an associate professor in the English Department, Georgia State University, where she teaches postcolonial literature. She is the editor of Conversations with Caryl Phillips (2009). Her interest in Phillips' work grew out of her dissertation "Caryl Phillips, J.M. Coetzee, and Michael Ondaatje: Writing at the Intersection of the Postcolonial and the Postmodern." Her other publications include articles on Tsitsi Dangarembga, Sindiwe Magona, Zakes Mda, J.M. Coetzee, and Nadine Gordimer; interviews with Sindiwe Magona and Zakes Mda; and a three-volume curriculum guide to African literature entitled Voices from the Continent (2003-2005) which she co-wrote with Sara Talis O'Brien. She is currently working on a study of Phillips' oeuvre entitled 'Caryl Phillips: Cosmopolitanism and the Ethics of Sympathy'.

KIRPAL SINGH taught at the National University of Singapore and the National Institute of Education Prior before joining the newly established Singapore Management University, where he facilitated the core university module in creative thinking and is director of the Wee Kim Wee Centre for CrossCultural Studies. He has also taught and researched in several universities around the world, and in 1997 was Distinguished International Writer at the 
Iowa International Writing Program. Many of his creative works have been dramatized, choreographed, and set to music. For ten years Kirpal edited the postcolonial critical journal WLWE (World Literature Written in English), and he is the author of, among other books, the bestseller Thinking Hats and Coloured Turbans: Creativity Across Cultures (2004).

Petra tournay-Theodotou is an associate professor of English at European University, Cyprus, where she teaches postcolonial, British, African-American, and women's literature. Her publications include journal articles and book chapters on nineteenth- and twentieth-century Spanish (Gustavo Adolfo Bécquer, Manuel Rivas), Latin American (Carlos Fuentes, Jorge Luis Borges), and British (John Banville, Lawrence Durrell, Zadie Smith, Caryl Phillips, Leone Ross, Eve Makis) literature and a monograph on Bécquer.

DARIA TUnCa works as a postdoctoral researcher in the English Department of the University of Liège, under the auspices of the Fonds de la Recherche Scientifique - FNRS. Her research focuses on stylistic approaches to African literatures, with a particular emphasis on contemporary Nigerian fiction. She has published articles and reviews in such international journals as African Literature Today, Postcolonial Text, Wasafiri, and the Journal of Postcolonial Writing. She maintains bibliographical websites on Chimamanda Ngozi Adichie (http://www.L3.ulg.ac.be/adichie) and Ben Okri (http://www.L3.ulg.ac.be/okri).

ChikA UNIG We, born in Enugu, Nigeria, now lives in Turnhout, Belgium. She studied at the University of Nigeria, Nsukka (BA), the Catholic University of Leuven (MA), and the University of Leiden (PhD). Her first novel, De Feniks, was published in Dutch in 2005, and is the first book of fiction written by a Flemish author of African origin. Her second novel, On Black Sisters' Street (2009), also appeared in Dutch as Fata Morgana (2008). Her prize-winning short stories have been widely broadcast (including by the B BC), and her fiction for children (including A Rainbow For Dinner, 2003, and Ije at School, 2003) enjoys great popularity. 
ItAla ViVAn is a professor emerita of the Faculty of Political Science, Institute of Foreign Languages, at the University of Milan, where she specialized in anglophone African literature. She is the author of Flawed Diamond: Essays on Olive Schreiner (1991), Alf Kumalo: South African Photographer (1998), Corpi liberati in cerca di storia, di storie: Il nuovo Sudafrica dopo l'apartheid (2005), Dalla englishness alla britishness 1950-200o: Discorsi culturali in trasformazione dal canone imperiale alle storie dell'oggi (with Claudia Gualtieri, 2008), and Dalla lambretta allo skateboard: Teorie $e$ storia delle sottoculture giovanili (1950-2000) (2009), and the editor of Il nuovo Sudafrica: Dalle strettoie dell'apartheid alle complessità della democrazia (1996). She is currently engaged in research on cultural museums.

ABIGAIL WARD is a lecturer in postcolonial studies in the School of Arts and Humanities, Nottingham Trent University. Current or previous teaching and research includes black writing in Britain, Caribbean and twentieth-century literature, gender studies, and literary theory. She is the co-editor, with Dave Gunning, of Tracing Black America in Black British Culture, a special issue of the journal Atlantic Studies (2009), and the author of Caryl Phillips, David Dabydeen and Fred D'Aguiar: Representations of Slavery (2011).

Louise Yelin is Kempner Distinguished Professor of Literature and Chair, School of Humanities, Purchase College, State University of New York, where she teaches postcolonial studies, the novel, autobiography and selfportraiture, feminism, and twentieth-century British culture. She is the author of From the Margins of Empire: Christina Stead, Doris Lessing, Nadine Gordimer (1998) and essays on feminism, postcolonial literature, and globalization. She is also Adjunct Curator, Neuberger Museum of Art at Purchase College, SUNY. Her essay "Callin' Out Around the World: Isaac Julien's New Ethnicities" (Atlantic Studies 6.2 [2009]: 239-53) is a companion piece to the essay in this volume. She is currently working on a book, 'British Lives: Windrush to Parekh', about autobiography and self-portraiture in Britain since the Second World War. 


\section{Index}


